Universidade de São Paulo

Escola de Engenharia de São Carlos

Departamento de Arquitetura e Urbanismo

\title{
Desenho Industrial e Arquitetura no Ensino da FAU USP (1948-1968)
}
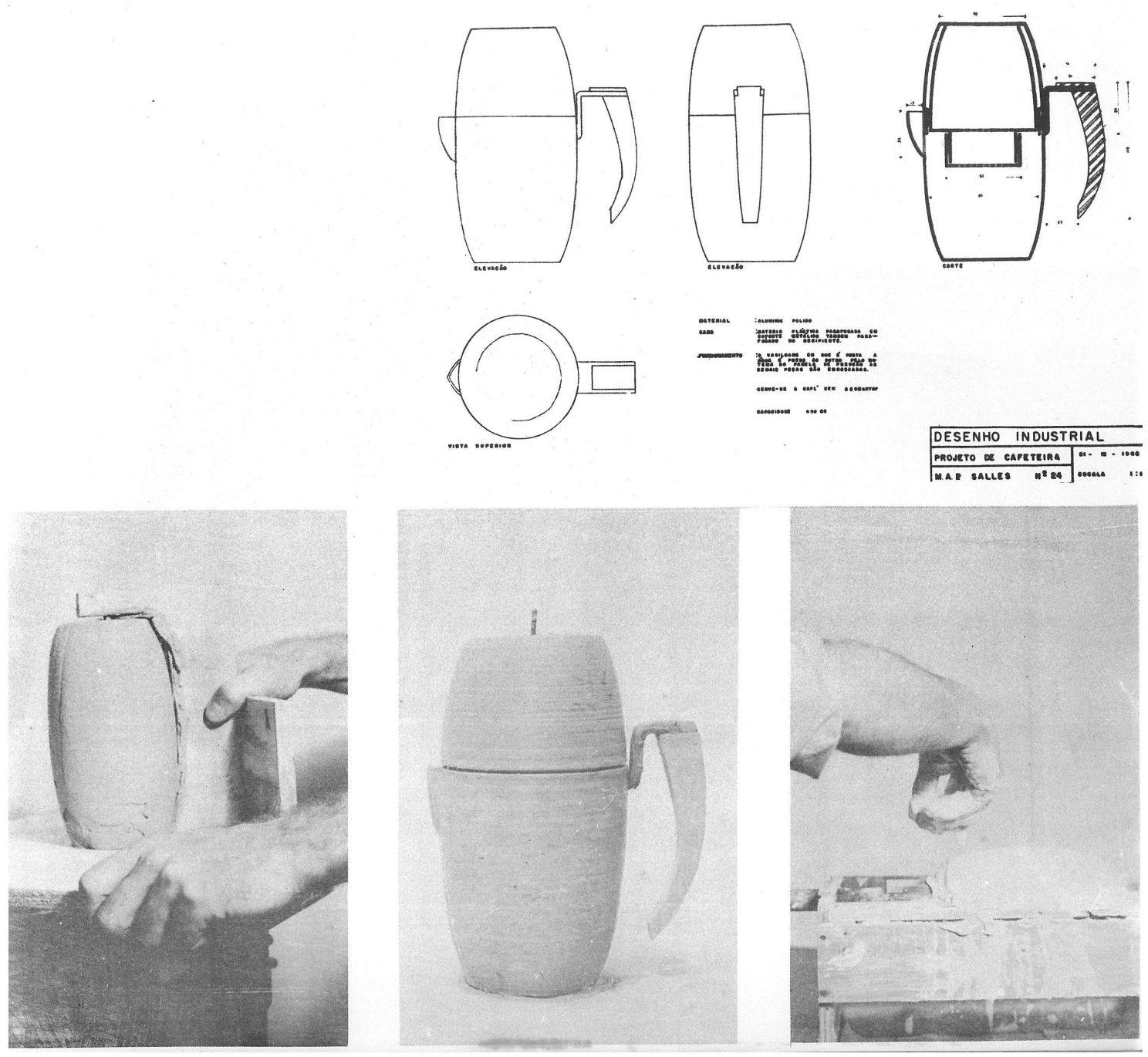

Tese de Doutorado

\section{Juliano Aparecido Pereira}

Orientador: Prof. Dr. Renato Luiz Sobral Anelli

São Carlos Junho 2009 


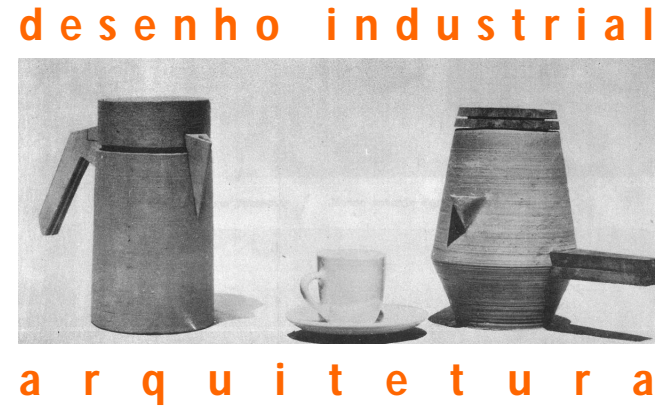




\author{
Universidade de São Paulo \\ Escola de Engenharia de São Carlos \\ Departamento de Arquitetura e Urbanismo
}

\title{
Desenho Industrial e Arquitetura no Ensino da FAU USP (1948-1968)
}

\begin{abstract}
Tese de Doutorado
Tese apresentada ao Programa de Pós-Graduação em Arquitetura e Urbanismo do Departamento de Arquitetura e Urbanismo, Escola de Engenharia de São Carlos, Universidade de São Paulo. Área de concentração: Teoria e História da Arquitetura e do Urbanismo.
\end{abstract}

\section{Juliano Aparecido Pereira}

Orientador: Prof. Dr. Renato Luiz Sobral Anelli

São Carlos

Junho de 2009 


\section{AUTORIZO A REPRODUÇÃO E DIVULGAÇÃO TOTAL OU PARCIAL DESTE TRABALHO, POR QUALQUER MEIO CONVENCIONAL OU ELETRÔNICO, PARA FINS DE ESTUDO E PESQUISA, DESDE QUE CITADA A FONTE.}

\section{Assinatura:}

e-mail: pjuliano_ufu@yahoo.com.br

\section{Ficha catalográfica preparada pela Seção de Tratamento} da Informação do Serviço de Biblioteca - EESC/USP

Pereira, Juliano Aparecido

Desenho industrial e arquitetura no ensino da FAU-USP (1948-1968) / Juliano Aparecido Pereira ; orientador Renato Luiz Sobral Anelli. -- São Carlos, 2009.

Tese (Doutorado-Programa de Pós-Graduação em Arquitetura e Urbanismo e Área de Concentração em Teoria e História da Arquitetura e do Urbanismo) -- Escola de Engenharia de São Carlos da Universidade de São Paulo, 2009 .

1. Arquitetura. 2. Desenho industrial. 3. Faculdade de Arquitetura e Urbanismo da Universidade de São Paulo. 4. Reforma de 1962. 5. Industrialização da Arquitetura. 6. João Batista Vilanova Artigas. I. Título. 
FOLHA DE JULGAMENTO

Candidato: Arquiteto e Urbanista JULIANO APARECIDO PEREIRA.

Tese defendida e julgada em 07/10/2009 perante a Comissão Julgadora:

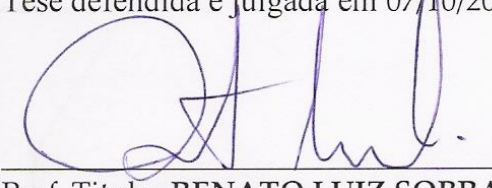

Prof. Titular RENATO LUIZ SOBRAL ANELLI (Orientador)

Aprovado

(Escola de Engenharia de Săo Carlos/USP)

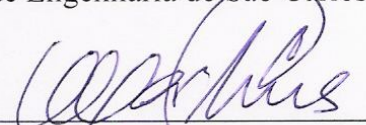

Prof. Titular CARLOS ALBERTO FERREIRA MARTINS

(Escola de Engenharia de São Carlos/USP)

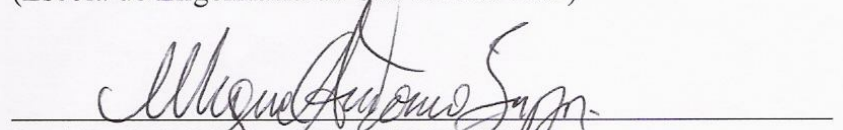

Prof. Dr. MIGUEL ANTONIO BUZZAR

(Escola de Engenharia de São Carlos USP)
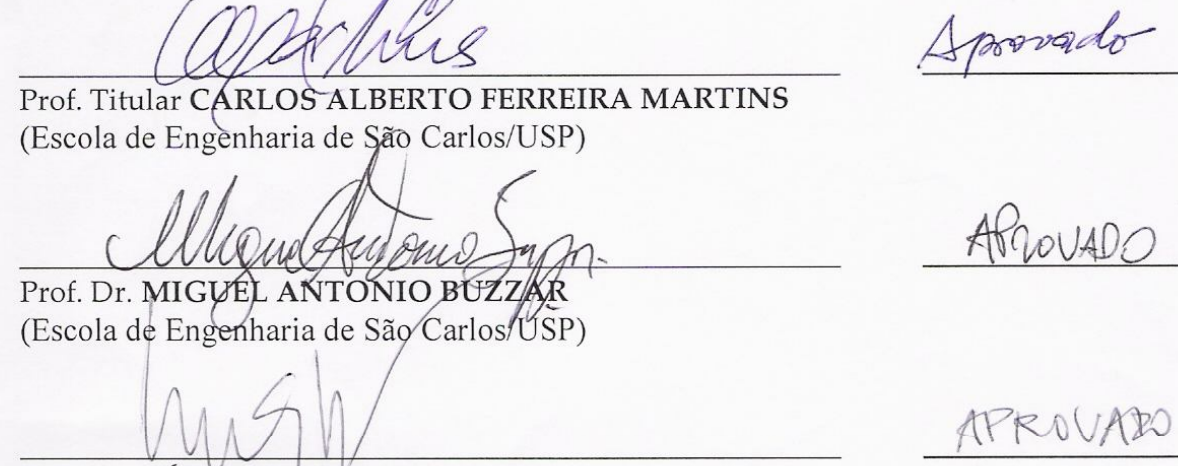

Prof. Dr. LÚCIO GOMES MACHADO

(Faculdade de Arquitetura e Urbanismo/USP)
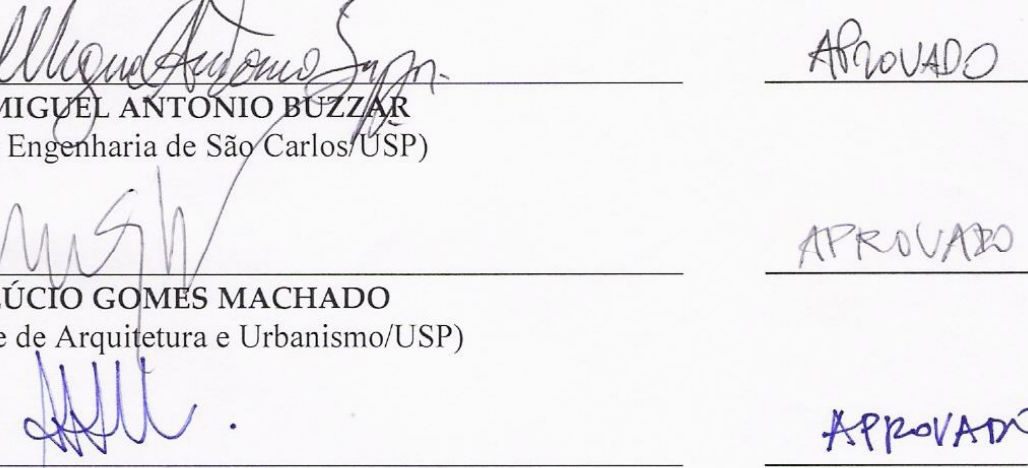

APROUADO

APROVADO

Prof ${ }^{\mathrm{a}}$. Dra . ANA LUIZA DE SOUZA NOBRE

(Pontifica Universidade Católica/campus Rio de Janeiro)

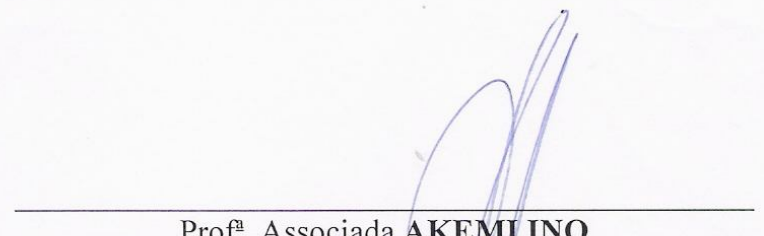

Prof ${ }^{\mathrm{a}}$. Associada AKEMI INO

Vice - Coordenadora do Programa de Pós-Graduação em Arquitetura e Urbanismo, em exeercicio.

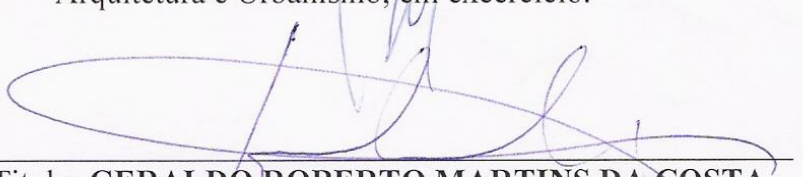

Prof. Titular GERALDO ROBERTO MARTINS DA COSTA

Presidente da Comissão da Pós-Graduação da EESC 


\section{Agradecimentos:}

A realização desta tese contou com a contribuição de muitas pessoas e instituições, entre as quais sou particularmente grato à:

Renato Anelli pela orientação que, mesmo diante das dificuldades surgidas, sempre incentivou o desenvolvimento da tese e a quem agradeço muito especialmente.

Lúcio Grinover, Julio Roberto Katinsky e Alessandro Ventura pela gentileza de seus depoimentos, compartilhando detalhes de uma história da FAU USP que ajudaram a construir.

Lúcio Gomes Machado que, na banca de qualificação, orientou de forma decisiva 0 prosseguimento deste trabalho, indicando caminhos a serem investigados e compartilhando informações de uma história da FAU USP a qual ajudou a construir e também pelo compartilhamento da memória profissional de seu pai, Lourival Gomes Machado.

Carlos Alberto Ferreira Martins que, na banca de qualificação, orientou de forma decisiva o prosseguimento deste trabalho, agradeço também a toda a formação em arquitetura recebida desde o período de meu curso de graduação.

Maria Cecília Loschiavo do Santos pelo grande incentivo ao desenvolvimento deste trabalho, pelas orientações dentro do campo do design e da arquitetura, pelo espírito crítico com que sempre recebeu meus trabalhos.

Marcos da Costa Braga pelas informações e discussões sobre temas relacionados a essa pesquisa.

Lara Leite Barbosa pelas interlocuções em nossas pesquisas nas áreas de arquitetura e de design. 
Juscelino Humberto Machado Cunha Machado Junior pelas interlocuções, em nossas pesquisas nas áreas de arquitetura e de design, e pelo auxílio na diagramação das imagens.

Ana Luiza Nobre (PUC - RJ), Ana Paula Koury (Universidade São Judas Tadeu - SP), Elaine Pereira da Silva, Luis Eduardo Santos Borda (FAURB UFU - Uberlândia, MG), Luiz Carlos De Laurentiz (FAURB UFU - Uberlândia, MG), Marcelina Gorni (Universidade Estadual de Goiás), Maria Beatriz Camargo Cappello (FAURB UFU Uberlândia, MG), Maria Cecília Vidal Magalhães Lara (FAUeD); Maria de Lourdes Pereira Fonseca (FAURB UFU - Uberlândia, MG), Roberto Portugal de Albuquerque (FAU USP) e Vera Alves Cepêda (Departamento de Ciências Sociais UFSCAR - São Carlos, SP).

Maria do Socorro Dias Novaes de Senne pela revisão do texto desta tese.

CAPES pela bolsa de doutorado concedida durante o primeiro ano de desenvolvimento desta pesquisa.

FAURB UFU pelo apoio recebido, nos dois últimos anos de realização deste doutorado.

Departamento de Projeto da FAU USP e Departamento de História da FAU USP pela liberação na realização de pesquisas junto aos seus arquivos.

As Bibliotecas da EESC USP, FAU USP e da UFU. 


\section{RESUM 0}

\section{Desenho Industrial e Arquitetura no Ensino da FAU USP (1948-1968)}

Esta tese apresenta as relações, entre desenho industrial e arquitetura, que se estabeleceram no ensino da Faculdade de Arquitetura e Urbanismo da Universidade de São Paulo, FAU USP, de 1948 até 1968. São discutidas as questões relativas à evolução do ensino de arquitetura e do desenho industrial (DI) até 1962. No plano da arquitetura, são observadas a reforma da Escola Nacional de Belas Artes, ENBA, a partir da direção de Lucio Costa (RI, 1930), e a FAU USP, com a sua criação, em 1948, por Anhaia M ello, independente da Escola Politécnica (SP) e dos engenheiros-arquitetos. Sobre o desenho industrial, são estabelecidas algumas das influências das experiências internacionais - Bauhaus (1919-33), VKhUTEM AS (1917-30), HfG de UIm (1947-68) - que, diretamente, ou reformuladas nos Estados Unidos, chegaram ao Brasil. São consideradas as interlocuções entre as primeiras experiências de ensino de DI no país, entre estas, o IAC-MASP, (SP, 1951-1953), a ESDI (RJ, 1963) e a FAU USP (SP, 1962), objeto central desta investigação. A partir da Reforma de 1962, liderada por Vilanova Artigas, é estudada a intenção manifesta de criação de uma Universidade do Projeto, em que, pela prática do ateliê, o profissional da FAU USP estaria apto a atuar em qualquer área de projeto: arquitetura, urbanismo, design de produto e design gráfico, constituindo assim uma escola de formação de designers de produto diferente da contemporânea ESDI. Outras questões abordadas dizem respeito à importância da cultura arquitetônica e da cultura geral nacional, para a realização da identidade do desenho industrial brasileiro, e à adoção de métodos do desenho industrial como recurso para uma produção arquitetônica em uma quantidade capaz de suprir as demandas sociais nacionais, sem perder de vista a sua qualidade.

\section{Palavras-chave:}

Arquitetura; Desenho Industrial; Faculdade de Arquitetura e Urbanismo da Universidade de São Paulo; Reforma de 1962; Industrialização da Arquitetura; João Batista Vilanova Artigas. 


\section{ABSTRACT}

Industrial Design and Architecture in the teaching of FAU USP (1948-1968)

This thesis presents the relations between industrial design and architecture that were established in the teaching of Faculdade de Arquitetura e Urbanismo da Universidade de São Paulo, FAU USP, between 1948 until 1968. The questions about the evolution of the architecture and industrial design teaching until 1962 are discussed. In the architecture plan, the reform of Escola Nacional de Belas Artes, ENBA, from the direction of Lucio Costa (RI, 1930) and FAU USP, its foundation in 1948, by Anhaia Mello independent of Escola Politécnica (SP) and the architectural engineers. About the Industrial Design, some influences of international experiences are established - Bauhaus (1919-33), VKhUTEM AS (1917-30), HfG of Ulm (1947-68) - that directly or reformulated in the United States arrived in Brazil. The interlocutions between the first teaching experiences of Industrial Design (ID) in the country are considered, among them, IAC-MASP, (SP, 1951-1953), ESDI (RJ, 1963) and FAU USP (SP, 1962), main object of this research. From the Reform of 1962, led by Vilanova Artigas, the intention of creation of a Project University is studied, which using the practice of the atelier the professional of FAU USP would be able to act in any project area: architecture, urbanism, product design and graphic design, constituting a school of product designers formation different from the contemporaneous ESDI. Other questions are related with the architectonic culture importance and national general culture for the execution of the identity of the brazilian industrial design and the adoption of methods of the industrial design as a resource for an architectonic production in a quantity able to supply the national social demands, without losing its quality.

\section{Keywords:}

Architecture; Industrial Design; Faculdade de Arquitetura e Urbanismo da Universidade de São Paulo; Reform of 1962; Industrialization of Architecture; João Batista Vilanova Artigas. 
Desenho Industrial e Arquitetura no Ensino da FAU USP (1948-1968)

\section{Sumário}

\begin{tabular}{|l|l|l|}
\hline & Apresentação & 1 \\
\hline
\end{tabular}

\section{Parte 1: Elementos Precursores da Reforma de 1962}

\begin{tabular}{|l|l|c|}
\hline Capítulo 1 & Arquitetura e Ensino & 9 \\
\hline Capítulo 2 & Desenho Industrial e Ensino & 41 \\
\hline
\end{tabular}

\section{Parte 2: 1962-1968}

\begin{tabular}{|l|l|c|}
\hline Capítulo 3 & Desenho Industrial na FAU USP a partir de 1962 & 89 \\
\hline Capítulo 4 & A contribuição do Departamento de História da FAU USP & 169 \\
\hline Capítulo 5 & Desenho Industrial e Arquitetura na FAU USP & 221 \\
\hline
\end{tabular}

\begin{tabular}{|l|l|c|}
\hline & Considerações Finais & 269 \\
\hline
\end{tabular}

\begin{tabular}{|l|l|l|}
\hline & Anexos & 279 \\
\hline & Bibliografia & 401 \\
\hline
\end{tabular}




\section{Relação de Imagens}

01. José Maria da Silva Neves. Residência Oscar da Cunha Vasconcelos. Revista Politécnica, n.100, entre PP.226 e 227, ago./set. 1930. [fonte: FICHER, 2005, p. 213].

02. José Maria da Silva Neves. Grupo Escolar do Bosque da Saúde. Novos Prédios para Grupo Escolar. [fonte: FICHER, 2005, p. 211].

03. José Maria da Silva Neves. Grupo Escolar Vila Moreira. Novos Prédios para Grupo Escolar. [fonte: FICHER, 2005, p. 211].

04. Caetano Fraccaroli. Mãe, escultura à praça Buenos Aires, 1965. Foto de Ennio Brauns e M arco Antônio de Moraes. [fonte: FICHER, 2005, p. 268].

05. M anifesto Bauhaus e programa com xilogravura de Lyonel Feininger. 1919. Walter Gropius. [fonte: DROSTE, 2001, p. 18].

06. Vista da exposição de Max Bill no MASP. São Paulo, 1951. [fonte: MAM-SP. Concreta '56: A raiz da forma. Catálogo. 2006]

07. Unidade Tripartida. 1948-1949. Autor: Max Bill. [fonte: BRITO, 1999, p. 38].

08. Lina Bo Bardi. Exposição Nordeste. Ao fundo a nova escada do Solar do Unhão. 1963. [fonte: Pereira, 2008].

09. Lina Bo Bardi. Exposição Nordeste. Piso superior do Solar do Unhão: Objetos expostos como em feiras populares. 1963. [fonte: Pereira, 2008].

10. Lina Bo Bardi. Exposição Nordeste. Carrancas, ao fundo objetos miúdos. 1963. [fonte: Pereira, 2008].

11. Ari Antonio da Rocha. Carro Aruanda. 1964. [fonte: PRODUTO E LINGUAGEM . 1ㅇ․ trimestre de 1965. Ano 1, número 1.]

12. Ari Antônio da Rocha. Protótipo automobilístico Aruanda. Prêmio Lúcio Meira, 1964. [fonte:http://www.redetec.org.br/inventabrasil/aruanda.htm, visitado em 21 de junho de 2009].

13. Ari Antonio da Rocha. Carro Aruanda. 1964. [fonte: PRODUTO E LINGUAGEM . 1ㅇ․ trimestre de 1966. Ano 1, número 3.]

14. Ari Antônio da Rocha. Protótipo automobilístico Aruanda. Prêmio Lúcio Meira, 1964. [fonte: http://www.redetec.org.br/inventabrasil/aruanda.htm, visitado em 21 de junho de 2009].

15. Ari Antônio da Rocha. Protótipo automobilístico Aruanda. Prêmio Lúcio Meira, 1964. [fonte: http://www.redetec.org.br/inventabrasil/aruanda.htm, visitado em 21 de junho de 2009]. 
16. Michel Arnoult e Norman Westwater. Poltrona estruturada em madeira maciça com fio de nylon no assento e encosto e almofadas soltas. 1964. [fonte: SANTOS, 1995, p. 140]

17. Geraldo de Barros (Bioni e Cia. Ltda. Indústria e Comércio de Móveis). Cama Beliche. 1965. [fonte: PRODUTO E LINGUAGEM, 2‥ trimestre de 1965. Ano 1, número 2.]

18. Geraldo de Barros (Bioni e Cia. Ltda. Indústria e Comércio de Móveis). Cama Beliche. 1965. [fonte: PRODUTO E LINGUAGEM, 2ํ. trimestre de 1965. Ano 1, número 2.]

19. Geraldo de Barros (Bioni e Cia. Ltda. Indústria e Comércio de Móveis). Cama Beliche. 1965. [fonte: PRODUTO E LINGUAGEM, 2º. trimestre de 1965. Ano 1, número 2.]

20. Geraldo de Barros (Indústria Hobjeto). Mesa. 1966. [fonte: PRODUTO E LINGUAGEM . 1‥ trimestre de 1966. Ano 1, número 3.]

21. Geraldo de Barros. Cartaz para o IV Centenário de São Paulo. 1954. [fonte: MUSEU DE ARTE MODERNA (São Paulo, SP). Concreta '56: A raiz da forma. Catálogo. 2006. p.229]

22. Michel Arnoult (Mobília Contemporânea). Linha de Escrivaninhas Residenciais. 1965. [fonte: PRODUTO E LINGUAGEM , 2‥ trimestre de 1965. Ano 1, número 2.]

23. Michel Arnoult (Mobília Contemporânea). Linha de Escrivaninhas Residenciais. 1965. [fonte: PRODUTO E LINGUAGEM , 2º. trimestre de 1965. Ano 1, número 2.]

24. Michel Arnoult (Mobília Contemporânea). Linha de Escrivaninhas Residenciais. 1965. [fonte: PRODUTO E LINGUAGEM , 2․ trimestre de 1965. Ano 1, número 2.]

25. Alcindo R. Moritz e Arno Schindler (Indústria de Refrigeração Cônsul). Geladeira. 1966. [fonte: PRODUTO E LINGUAGEM . 1‥ trimestre de 1966. Ano 1, número 3.]

26. Setor de Desenho Industrial Walita S.A.. Ferro Elétrico Automático. 1965. [fonte: PRODUTO E LINGUAGEM , 2‥ trimestre de 1965. Ano 1, número 2.]

27. Setor de Desenho Industrial Walita S.A.. Ferro Elétrico Automático. 1965. [fonte: PRODUTO E LINGUAGEM, 2o․ trimestre de 1965. Ano 1, número 2.]

28. Setor de Desenho Industrial Walita S.A.. Ferro Elétrico Automático. 1965. [fonte: PRODUTO E LINGUAGEM, 2o. trimestre de 1965. Ano 1, número 2.]

29. Setor de Desenho Industrial Walita S.A.. Ferro Elétrico Automático. 1965. [fonte: PRODUTO E LINGUAGEM, 2․․ trimestre de 1965. Ano 1, número 2.]

30. Gustave Adolphe Martin (Cerâmica Sanitária Porcelite). Conjunto de peças sanitárias Suspensas. 1965. [fonte: PRODUTO E LINGUAGEM, 2ํ․ trimestre de 1965. Ano 1, número 2.] 
31. Norman Westwater (Indústria Ideal Standard). Conjunto de Louça Sanitária. 1966. [fonte: PRODUTO E UNGUAGEM . 1ํ. trimestre de 1966. Ano 1, número 3.]

32. Antonio Gundemaro Lizarraga (São Marco Vidros de Arte Ltda.). Linha de Copos Trópico. 1965. [fonte: PRODUTO E LINGUAGEM, 2o. trimestre de 1965. Ano 1, número 2.].

33. Exercício: análise do objeto e sua representação [primeiro ano DI FAU USP, 1962] [fonte: FAU USP, 1963].

34. Exercício: análise do objeto e sua representação [primeiro ano DI FAU USP, 1962] [fonte: FAU USP, 1963].

35. Exercício: análise do objeto e sua representação [primeiro ano DI FAU USP, 1962] [fonte: FAU USP, 1963].

36. Exercício: análise do objeto e sua representação [primeiro ano DI FAU USP, 1962] [fonte: FAU USP, 1963].

37. Exercício: análise do objeto e sua representação [primeiro ano DI FAU USP, 1962] [fonte: FAU USP, 1963] [fonte: FAU USP, 1963].

38. Exercício: análise do objeto e sua representação [primeiro ano DI FAU USP, 1962] [fonte: FAU USP, 1963].

39. Exercício: projeto e produção - ferramentas manuais [primeiro ano DI FAU USP, 1962] [fonte: FAU USP, 1963].

40. Exercício: projeto e produção - ferramentas manuais [primeiro ano DI FAU USP, 1962] [fonte: FAU USP, 1963].

41. Exercício: projeto e produção - ferramentas manuais [primeiro ano DI FAU USP, 1962] [fonte: FAU USP, 1963].

42. Exercício: projeto e produção - ferramentas manuais [primeiro ano DI FAU USP, 1962] [fonte: FAU USP, 1963].

43. Exercício: abridor de garrafas. [segundo ano DI FAU USP, 1962] [fonte: FAU USP, 1963].

44. Exercício: apagador de quadro negro [segundo ano DI FAU USP, 1962] [fonte: FAU USP, 1963].

45. Exercício: cortador de papel. [segundo ano DI FAU USP, 1962] [fonte: FAU USP, 1963].

46. Exercício: cortador de papel. [segundo ano DI FAU USP, 1962] [fonte: FAU USP, 1963].

47. Desenho de um jogo de xadrez. [Terceiro ano DI FAU USP, 1962] [fonte: FAU USP, 1963]. 
48. Desenho de um jogo de xadrez. [Terceiro ano DI FAU USP, 1962] [fonte: FAU USP, 1963].

49. Jogo de xadrez. [Terceiro ano DI FAU USP, 1962] [fonte: FAU USP, 1963].

50. Jogo de xadrez. [Terceiro ano DI FAU USP, 1962] [fonte: FAU USP, 1963].

51. Jogo de xadrez. [Terceiro ano DI FAU USP, 1962] [fonte: FAU USP, 1963].

52. Jogo de xadrez. [Terceiro ano DI FAU USP, 1962] [fonte: FAU USP, 1963].

53. Jogo de xadrez. [Terceiro ano DI FAU USP, 1962] [fonte: FAU USP, 1963].

54. Jogo de xadrez. [Terceiro ano DI FAU USP, 1962] [fonte: FAU USP, 1963].

55. Jogo de xadrez. [Terceiro ano DI FAU USP, 1962] [fonte: FAU USP, 1963].

56. Jogo de xadrez. [Terceiro ano DI FAU USP, 1962] [fonte: FAU USP, 1963].

57. Jogo de xadrez. [Terceiro ano DI FAU USP, 1962] [fonte: FAU USP, 1963].

58. Jogo de xadrez. [Terceiro ano DI FAU USP, 1962] [fonte: FAU USP, 1963].

59. Jogo de xadrez. [Terceiro ano DI FAU USP, 1962] [fonte: FAU USP, 1963].

60. Jogo de xadrez. [Terceiro ano DI FAU USP, 1962] [fonte: FAU USP, 1963].

61. Isqueiro. [Terceiro ano DI FAU USP, 1962] [fonte: FAU USP, 1963].

62. Cafeteira. [Quarto ano DI FAU USP, 1962] [fonte: FAU USP, 1963].

63. Cafeteira. [Quarto ano DI FAU USP, 1962] [fonte: FAU USP, 1963].

64. Cafeteira. [Quarto ano DI FAU USP, 1962] [fonte: FAU USP, 1963].

65. Cafeteira. [Quarto ano DI FAU USP, 1962] [fonte: FAU USP, 1963].

66. Cafeteira. [Quarto ano DI FAU USP, 1962] [fonte: FAU USP, 1963].

67. Cafeteira. [Quarto ano DI FAU USP, 1962] [fonte: FAU USP, 1963].

68. Cafeteira. [Quarto ano DI FAU USP, 1962] [fonte: FAU USP, 1963].

69. Cafeteira. [Quarto ano DI FAU USP, 1962] [fonte: FAU USP, 1963].

70. Cafeteira. [Quarto ano DI FAU USP, 1962] [fonte: FAU USP, 1963].

71. Cafeteira. [Quarto ano DI FAU USP, 1962] [fonte: FAU USP, 1963].

72. Cafeteira. [Quarto ano DI FAU USP, 1962] [fonte: FAU USP, 1963].

73. Cafeteira. [Quarto ano DI FAU USP, 1962] [fonte: FAU USP, 1963].

74. Heinz Nösselt. Mesa para jogo de xadrez de Josef Hartwig. 1924. [fonte: Droste, 2001]. 
75. Josef Hartwig [mestre artesão da Bauhaus]. Jogo de xadrez. 1924. [fonte: Droste, 2001].

76. Jogo de xadrez. [Terceiro ano DI FAU USP, 1962] [fonte: FAU USP, 1963].

77. Jogo de xadrez. [Terceiro ano DI FAU USP, 1962] [fonte: FAU USP, 1963].

78. Exercicios de DI FAU USP [fonte: Lucio Grinover in: revista O Dirigente Industrial. 1966.]

79. Carro Aruanda. Ari Antônio da Rocha (1964). Capa de abertura do Capítulo 11: Desenho Industrial de Julio Katinsky no livro História Geral da Arte no Brasil de Walter Zanini [São Paulo: Instituto Walther Moreira Salles, 1983] [fonte: ZANINI, 1983].

80. Fazenda Floresta, Itu, São Paulo, 1870 [fonte: ZANINI, 1983].

81. Fazenda Floresta, Itu, São Paulo, 1870 [fonte: ZANINI, 1983].

82. A fachada da rua com um nariz postiço ainda mantém certa aparência carrancuda, mas ao lado do jardim, que liberdade de tratamento e como são acolhedoras; e tão modernas puro Le Corbusier (nota do autor acompanhando o croqui). [citação extraída por Julio Katinsky de Lucio Costa. Documentação Necessária, in Alberto Xavier, org., Sobre arquitetura Lucio Costa] [fonte: ZANINI, 1983].

83. Cadeira e mesa art nouveau da Vila Penteado [fonte: ZANINI, 1983].

84. Cristaleira art nouveau da Vila Penteado [fonte: ZANINI, 1983].

85. Eliseu Visconti, vaso de cerâmica com decoração fitomorfa, 19 x 19 coleção SPHAN, em depósito no M NB-A, Rio de Janeiro [fonte: ZANINI, 1983].

86. Projeto de Cadeira. Gregori Warchavchik, 1932 [fonte: ZANINI, 1983].

87. Mesa secretária para Paulo Prado, projeto de Gregori Warchavchik, 1930, compensando com estrutura de cedro maciça [fonte: ZANINI, 1983].

88. Caixa d'água em Recife, cobogó, projeto de Luiz Nunes [fonte: ZANINI, 1983].

89. Elemento vazado, Parque Guinle, projeto de Lucio Costa [fonte: ZANINI, 1983].

90. Caixilhos do Ministério de Educação e Saúde, fachada sul, 1936 [fonte: ZANINI, 1983].

91. Elemento vazado, projeto de Franz Heep [fonte: ZANINI, 1983].

92. Brises móveis. Obra do Berço, projeto de Oscar Niemeyer, 1937, Rio de Janeiro [fonte: ZANINI, 1983].

93. Poltrona do antigo Ministério da Educação e Saúde, hoje palácio da Cultura, Rio de Janeiro [fonte: ZANINI, 1983].

94. Mesa do antigo M inistério da Educação e Saúde, hoje palácio da Cultura, Rio de Janeiro [fonte: ZANINI, 1983]. 
95. Ante sala do gabinete do ministro do antigo M inistério da Educação e Saúde, hoje palácio da Cultura, Rio de Janeiro [fonte: ZANINI, 1983].

96. Cadeiras de Zanine Caldas, 1948 [fonte: ZANINI, 1983].

97. Cadeira de Zanine Caldas, 1950 [fonte: ZANINI, 1983].

98. Cadeira inspirada em rede caipira, projeto de Lina Bo Bardi e Giancarlo Palanti, 1948 [fonte: ZANINI, 1983].

99. Poltrona, projeto de Lina Bo Bardi e Giancarlo Palanti, 1948 [fonte: ZANINI, 1983].

100. Cadeira de Zanine Caldas, 1950 [fonte: ZANINI, 1983].

101. Poltrona, projeto de Carlos Millan, 1954 [fonte: ZANINI, 1983].

102. Cadeira Ovo, projeto de Lina Bo Bardi, 1954 [fonte: ZANINI, 1983].

103. Poltrona, projeto de Lina Bo Bardi e Giancarlo Palanti, 1948 [fonte: ZANINI, 1983].

104. M esa de Centro, projeto de Joaquim Tenreiro, 1950 [fonte: ZANINI, 1983].

105. M esa para escritório, projeto de Carlos Fongaro, 1956 [fonte: ZANINI, 1983].

106. Cadeira Mole, projeto de Sergio Rodrigues, 1957 [fonte: ZANINI, 1983].

107. Luminárias, projeto de Lívio Levi, 1970 [fonte: ZANINI, 1983].

108. Implantação urbana e elevação do orelhão, projeto de Chu Ming Silveira, 1970 [fonte: ZANINI, 1983].

109. Implantação urbana e elevação do orelhão, projeto de Chu Ming Silveira, 1970 [fonte: ZANINI, 1983].

110. Móveis para escritório, projeto de Jorge Zalszupin e Marcelo Resende [fonte: ZANINI, 1983].

111. Minicomputador Cobra, terminais remotos, projetista desconhecido [fonte: ZANINI, 1983].

112. Bomba da Petrobrás, projeto de Aloísio Magalhães [fonte: ZANINI, 1983].

113. Aparelho de precisão para uso médico, Coretron, projeto de Bergmiller [fonte: ZANINI, 1983].

114. Aparelho de precisão para uso médico, Coretron, projeto de Bergmiller [fonte: ZANINI, 1983].

115. Jorge Zalszupin [Móveis de I'Atelier]. Poltrona com estrutura de madeira jacarandá e acabamentos de latão. Assento e encosto de borracha esponjosa. Revestimento com tecido de lã [legenda do artigo]. [fonte: Revista Acrópole, no 265, 1960]. 
116. Julio Katinsky [M óveis de I'Atelier]. M esa de centro baixa. Estrutura desmontável de jacarandá e tampo de cristal [legenda do artigo]. [fonte: Revista Acrópole, no 265, 1960].

117. Julio Katinsky [M óveis de I'Atelier]. Mesa de centro baixa. Estrutura desmontável de jacarandá e tampo de cristal [legenda do artigo]. [fonte: Revista Acrópole, no 265, 1960].

118. Jorge Zalszupin [Móveis de I'Atelier]. Três mesinhas auxiliares, entrando uma dentro da outra. Executadas com sistemas de madeira moldada. Os pegadores facilitam o manejo [legenda do artigo]. [fonte: Revista Acrópole, № 265, 1960].

119. Jorge Zalszupin [M óveis de I'Atelier]. Poltrona estofada com estrutura baixa de jacarandá e corpo de borracha esponjosa. Revestimento com tecido de lã. [legenda do artigo]. [fonte: Revista Acrópole, № 265, 1960].

120. Jorge Zalszupin [Móveis de I'Atelier]. M esa de Centro, combinando numa junção de tipo malhetada dois materiais diferentes: jacarandá da Bahia e mármore. Pontas de apoio de latão [legenda do artigo]. [fonte: Revista Acrópole, no 265, 1960].

121. Jorge Zalszupin [M óveis de I'Atelier]. Carrinho de chá: estrutura de ferro pintada a duco, rodas de latão polido. Bandeja superior removível e dupla face: de um lado fórmica lisa, de outro com pequenos rebaixos que servem para colocar caju, chocolate, etc. a roda giratória torna o móvel muito manejável [legenda do artigo]. [fonte: Revista Acrópole, no 265, 1960].

122. Jorge Zalszupin [Móveis de l'Atelier]. Mesa moldada de madeira com furo no tampo para receber um porta-revista de metal ou madeira, de cor contrastante [legenda do artigo]. [fonte: Revista Acrópole, no 265, 1960].

123. Julio Katinsky [M óveis de I’Atelier]. Poltrona para ambiente de bar, jardim de inverno, terraço, etc. Estrutura metálica em travessas de jacarandá. Os botões de latão polido formam as pontas dos esticadores [legenda do artigo]. [fonte: Revista Acrópole, 으 265, 1960].

124. Julio Katinsky [M óveis de I'Atelier]. Banquinho leve de estrutura de ferro pintada a duco e quadro de jacarandá com acento de couro natural costurado com linha grossa [legenda do artigo]. [fonte: Revista Acrópole, no 265, 1960].

125. Jorge Zalszupin [Móveis de I'Atelier]. Cadeira para sala de jantar. Concha de plástico armada com fibra de vidro, revestida com tecido de lã. Pés de jacarandá e ferro permitindo variar a inclinação da concha. Uma almofada solta no acento [legenda do artigo]. [fonte: Revista Acrópole, № 265, 1960].

126. Alessandro Ventura. Objetos de Pia de Cozinha. s/d. [fonte: LEAL, 2002.]

127. Alessandro Ventura. Porta Talheres Split, Tok\&Stok. s/d. [fonte: LEAL, 2002.]

128. Alessandro Ventura. Conjunto de Tigelas Línea, Tok\&Stok. s/d. [fonte: LEAL, 2002.] 
129. Alessandro Ventura. Balde e Bacia de Plástico, Hydrus, Tok\&Stok. s/d. [fonte: LEAL, 2002.]

130. Julio Katinsky, Helio Penteado e Hélio Pasta. Usina Hidrelétrica de Xavantes. Rio Paranapanema [divisa geográfica entre os estados de São Paulo e do Paraná], 1968 [fonte: arquivo Julio Katinsky].

131. Julio Katinsky, Helio Penteado e Hélio Pasta. Usina Hidrelétrica de Xavantes. Rio Paranapanema [divisa geográfica entre os estados de São Paulo e do Paraná], 1968 [fonte: arquivo Julio Katinsky].

132. Julio Katinsky, Helio Penteado e Hélio Pasta. Usina Hidrelétrica de Xavantes. Rio Paranapanema [divisa geográfica entre os estados de São Paulo e do Paraná], 1968 [fonte: arquivo Julio Katinsky].

133. Julio Katinsky, Helio Penteado e Hélio Pasta. Usina Hidrelétrica de Xavantes. Rio Paranapanema [divisa geográfica entre os estados de São Paulo e do Paraná], 1968 [fonte: arquivo Julio Katinsky].

134. Escritório Rino Levi. Edifício FIESP / CIESP / SESI. Av. Paulista, São Paulo, SP. 1969. [fonte: ANELLI, 2001].

135. Escritório Rino Levi. Estrutura Metálica Geométrica. Fachada da FIESP. 1969. [fonte: LEAL, 2002].

136. Vilanova Artigas. Estação Rodoviária de Jaú. Jaú, SP, 1973. [fonte: FERRAZ, 1999.]

137. Vilanova Artigas. Estação Rodoviária de Jaú. Plantas. Jaú, SP, 1973. [fonte: FERRAZ, 1999.]

138. Vilanova Artigas. Estação Rodoviária de Jaú. Corte. Jaú, SP, 1973. [fonte: FERRAZ, 1999.]

139. Vilanova Artigas. Estação Rodoviária de Jaú. Jaú, SP, 1973. Vista interna. [fonte: FERRAZ, 1999.]

140. Vilanova Artigas. Estação Rodoviária de Jaú. Jaú, SP, 1973. Rampa. [fonte: FERRAZ, 1999.]

141. Vilanova Artigas e Carlos Cascaldi. Ginásio de Utinga. Santo André, SP, 1962. Vista Externa. [fonte: FERRAZ, 1999].

142. Vilanova Artigas e Carlos Cascaldi. Ginásio de Utinga. Santo André, SP, 1962. Implantação. [fonte: SEIXAS, 2003].

143. Vilanova Artigas e Carlos Cascaldi. Ginásio de Utinga. Santo André, SP, 1962. Pavimento Superior. [fonte: SEIXAS, 2003].

144. Vilanova Artigas e Carlos Cascaldi. Ginásio de Utinga. Santo André, SP, 1962. Corte. [fonte: FERRAZ, 1999]. 
145. Vilanova Artigas e Carlos Cascaldi. Ginásio de Utinga. Santo André, SP, 1962. Pátio. [fonte: FERRAZ, 1999].

146. Vilanova Artigas e Carlos Cascaldi. Ginásio de Utinga. Santo André, SP, 1962. Detalhe da quadra de esportes. [fonte: FERRAZ, 1999].

147. Vilanova Artigas e Carlos Cascaldi. Ginásio de Utinga. Santo André, SP, 1962. Banheiro masculino. [fonte: FERRAZ, 1999].

148. Vilanova Artigas, Fabio Penteado, Paulo Mendes da Roche e Escritório Técnico CECAP. Conjunto Habitacional CECAP Zezinho Magalhães Prado. Guarulhos, SP, 1967. [fonte: FERRAZ, 1999.]

149. Vilanova Artigas, Fabio Penteado, Paulo Mendes da Roche e Escritório Técnico CECAP. Conjunto Habitacional CECAP Zezinho Magalhães Prado. Guarulhos, SP, 1967. [fonte: FERRAZ, 1999.]

150. Vilanova Artigas, Fabio Penteado, Paulo Mendes da Roche e Escritório Técnico CECAP. Conjunto Habitacional CECAP Zezinho Magalhães Prado. Guarulhos, SP, 1967. [fonte: FERRAZ, 1999.]

151. Vilanova Artigas, Fabio Penteado, Paulo Mendes da Roche e Escritório Técnico CECAP. Conjunto Habitacional CECAP Zezinho Magalhães Prado. Implantação Geral. Guarulhos, SP, 1967. [fonte: FERRAZ, 1999.].

152. Vilanova Artigas, Fabio Penteado, Paulo Mendes da Roche e Escritório Técnico CECAP. Conjunto Habitacional CECAP Zezinho Magalhães Prado. Elevação do Bloco. Guarulhos, SP, 1967. [fonte: FERRAZ, 1999.]Implantação Geral. Guarulhos, SP, 1967. [Fonte: FERRAZ, 1999.].

153. Vilanova Artigas, Fabio Penteado, Paulo Mendes da Roche e Escritório Técnico CECAP. Conjunto Habitacional CECAP Zezinho Magalhães Prado. Estudo da Unidade Habitacional. Guarulhos, SP, 1967. [fonte: FERRAZ, 1999.]

154. Perspectiva axonométrica demonstrando a montagem dos elementos préfabricados. Conjunto Habitacional Zezinho Magalhães Prado. Arquitetos: Vilanova Artigas, Fábio Penteado e Paulo Mendes da Rocha. Guarulhos, 1967, CECAP. [fonte: FICHER, Sylvia. Subsídios para um estudo do Conjunto Habitacional Zezinho M agalhães Prado. Pesquisa FAU USP, s/d.]

155. Fogão. Conjunto Habitacional Zezinho Magalhães Prado. Arquitetos: Vilanova Artigas, Fábio Penteado e Paulo Mendes da Rocha. Guarulhos, 1967, CECAP. [fonte: FICHER, Sylvia. Subsídios para um estudo do Conjunto Habitacional Zezinho Magalhães Prado. Pesquisa FAU USP, s/d.]

156. Armário dos dormitórios. Conjunto Habitacional Zezinho Magalhães Prado. Arquitetos: Vilanova Artigas, Fábio Penteado e Paulo Mendes da Rocha. Guarulhos, 1967, CECAP. [fonte: FICHER, Sylvia. Subsídios para um estudo do Conjunto Habitacional Zezinho Magalhães Prado. Pesquisa FAU USP, s/d.] 
157. Forno. Conjunto Habitacional Zezinho Magalhães Prado. Arquitetos: Vilanova Artigas, Fábio Penteado e Paulo Mendes da Rocha. Guarulhos, 1967, CECAP. [fonte: FICHER, Sylvia. Subsídios para um estudo do Conjunto Habitacional Zezinho Magalhães Prado. Pesquisa FAU USP, s/d.]

158. Geladeira. Conjunto Habitacional Zezinho Magalhães Prado. Arquitetos: Vilanova Artigas, Fábio Penteado e Paulo Mendes da Rocha. Guarulhos, 1967, CECAP. [fonte: FICHER, Sylvia. Subsídios para um estudo do Conjunto Habitacional Zezinho Magalhães Prado. Pesquisa FAU USP, s/d.]

159. Armário do balcão de serviços. Conjunto Habitacional Zezinho M agalhães Prado. Arquitetos: Vilanova Artigas, Fábio Penteado e Paulo M endes da Rocha. Guarulhos, 1967, CECAP. [fonte: FICHER, Sylvia. Subsídios para um estudo do Conjunto Habitacional Zezinho Magalhães Prado. Pesquisa FAU USP, s/d.]

160. Paulo M endes da Rocha. Residências Paulo M endes da Rocha e Luiz Gonzaga Cruz Secco. São Paulo, 1964. [fonte: XAVIER, LEM OS E CORONA, 1983].

161. Paulo M endes da Rocha. Residências Paulo M endes da Rocha e Luiz Gonzaga Cruz Secco. São Paulo, 1964. [fonte: XAVIER, LEM OS E CORONA, 1983].

162. Paulo M endes da Rocha. Residências Paulo M endes da Rocha e Luiz Gonzaga Cruz Secco. São Paulo, 1964. [fonte: PIÑóN, 2002].

163. Paulo M endes da Rocha. Residências Paulo M endes da Rocha e Luiz Gonzaga Cruz Secco. São Paulo, 1964. [fonte: PIÑÓN, 2002].

164. Paulo M endes da Rocha. Residências Paulo M endes da Rocha e Luiz Gonzaga Cruz Secco. São Paulo, 1964. [fonte: PIÑóN, 2002].

165. Paulo M endes da Rocha. Residências Paulo M endes da Rocha e Luiz Gonzaga Cruz Secco. São Paulo, 1964. [fonte: PIÑÓN, 2002].

166. Paulo M endes da Rocha. Residências Paulo M endes da Rocha e Luiz Gonzaga Cruz Secco. São Paulo, 1964. [fonte: PIÑÓN, 2002].

167. Paulo M endes da Rocha. Residências Paulo M endes da Rocha e Luiz Gonzaga Cruz Secco. São Paulo, 1964. [fonte: PIÑÓN, 2002].

168. Paulo M endes da Rocha. Residências Paulo M endes da Rocha e Luiz Gonzaga Cruz Secco. São Paulo, 1964. [fonte: PIÑóN, 2002].

169. Paulo M endes da Rocha. Residências Paulo M endes da Rocha e Luiz Gonzaga Cruz Secco. São Paulo, 1964. [fonte: PIÑÓN, 2002].

170. Paulo M endes da Rocha. Residências Paulo M endes da Rocha e Luiz Gonzaga Cruz Secco. São Paulo, 1964. [fonte: PIÑóN, 2002].

171. Paulo M endes da Rocha. Residências Paulo M endes da Rocha e Luiz Gonzaga Cruz Secco. São Paulo, 1964. [fonte: PIÑóN, 2002]. 
172. Paulo M endes da Rocha. Residências Paulo M endes da Rocha e Luiz Gonzaga Cruz Secco. São Paulo, 1964. [fonte: PIÑON, 2002].

173. Paulo Mendes da Rocha. Residência Gerassi. São Paulo, 1988. [fonte: PIÑóN, 2002].

174. Paulo M endes da Rocha. Residência Gerassi. São Paulo, 1988. [fonte: ARTIGAS, Rosa; 2002].

175. Paulo Mendes da Rocha. Residência Gerassi. São Paulo, 1988. [fonte: PIÑóN, 2002].

176. Paulo Mendes da Rocha. Residência Gerassi. São Paulo, 1988. [fonte: ARTIGAS, Rosa; 2002].

177. Paulo M endes da Rocha. Residência Gerassi. São Paulo, 1988. [fonte: ARTIGAS, Rosa; 2002].

178. Paulo M endes da Rocha. Residência Gerassi. São Paulo, 1988. [fonte: ARTIGAS, Rosa; 2002].

179. Paulo Mendes da Rocha. Residência Gerassi. São Paulo, 1988. [fonte: ARTIGAS, Rosa; 2002].

180. Paulo M endes da Rocha. Residência Gerassi. São Paulo, 1988. [fonte: ARTIGAS, Rosa; 2002].

181. Paulo Mendes da Rocha. Residência Gerassi. São Paulo, 1988. [fonte: PIÑóN, 2002].

182. Paulo Mendes da Rocha. Residência Gerassi. São Paulo, 1988. [fonte: ARTIGAS, Rosa; 2002].

183. Paulo M endes da Rocha. Residência Gerassi. São Paulo, 1988. [fonte: ARTIGAS, Rosa; 2002]. 


\section{Relação de Tabelas}

01. Cadeiras de ensino dos conteúdos de projeto até 1962, FAU USP.

02. Conteúdos distribuídos nos quatro períodos do Curso de Arquitetura do Departamento de Arquitetura da HfG de Ulm.

03. Disciplinas do IAC MASP ministradas em 1951. Origem: Livro de Chamada - Cursos Regulares do IAC MASP. In: LEON, 2006, p.45.

04. Distribuição por cidades dos associados da ABDI em 1966

05. Distribuição por categoria profissional dos associados da ABDI em 1966.

06. Comissões Julgadoras do Prêmio Roberto Simonsen e os produtos industriais premiados entre 1964 e 1966.

07. Sequência de Desenho Industrial. Departamento de Projeto. FAU USP (1963-1967).

08. Professores e exercícios de projeto da Sequência de Desenho Industrial da FAU USP em 1962.

09. Sequência de Desenho Industrial. Docentes entre 1966 e 1967. Departamento de Projeto. FAU USP (1963-1967). 


\section{Apresentação $^{1}$}

O ensino de desenho industrial na FAU USP insere-se em um conjunto mais amplo de preocupações relativas às delimitações, ou atribuições, profissionais do arquiteto. Entre outros objetivos, caracterizar o exercício profissional do desenho industrial como campo da arquitetura faz parte da transformação curricular proposta pela Reforma de 1962 da FAU USP, de maneira inovadora. Entretanto não se pode negar que o estabelecimento desta relação entre o campo da arquitetura e o do desenho industrial se faz presente desde os primeiros modelos de escolas ligados à formação para a atuação neste segundo campo. Apenas referindo-se aos modelos de escolas que se estabeleceram já num contexto de maior desenvolvimento e penetração do modo de produção industrial no universo das relações sociais, podem ser citadas escolas como a Bauhaus, os VKhUTEMAS, a HfG UIm, no plano internacional, e o IACMASP, a ESDI, a própria FAU USP, além de uma experiência de escola abortada no seu nascedouro em Salvador, elaborada pela arquiteta Lina Bo Bardi e pouco referida em nossa historiografia de arquitetura ou de design. Todas essas escolas, ao pensar o ensino de desenho industrial, não prescindiram da relação deste com a própria arquitetura, mesmo que seja pela exclusão, como no caso da ESDI.

Ainda que se considere a relativa proximidade temporal

1. Esta tese foi revisada de acordo com a Ortografia da Língua Portuguesa (1990), em vigor a partir de 1 ㅇ de janeiro de 2009. entre essas experiências didáticas, iniciadas nos anos de 1920, com o estabelecimento da Bauhaus (1919) e dos VKhUTEMAS (1917) até as escolas brasileiras criadas nas 
décadas de 1950 e 1960, as relações propostas entre arquitetura e a produção do objeto seriado, embora em todas elas permaneça a indústria como elemento de intermediação entre ambas, irão em cada escola assumir abordagens conceituais distintas.

Nesse sentido, um dos primeiros requisitos para a compreensão do ensino de desenho industrial estabelecido com a Reforma de 1962, na FAU USP, é aquele de desvendar que possíveis diálogos conceituais foram estabelecidos entre a FAU USP e as demais experiências de ensino congêneres constituídas nesse período histórico.

Não menos importante também é considerar nesse período as reformas curriculares que aconteciam no Brasil no campo do ensino restrito e convencional da arquitetura. Como ponto de partida, buscavam um distanciamento das conhecidas e tradicionais matrizes de formação do arquiteto, qual seja o modelo da Escola de Belas Artes ou da Escola Politécnica. E, como ponto de chegada, objetivava uma dupla aproximação com a arquitetura moderna: estabelecê-la como novo paradigma arquitetônico no campo estético e adotar a sua definição de uma nova espacialidade para o edifício e para a cidade, o que corresponderia às novas realidades sociais. E, também, é importante considerar, que essas reformas do ensino de arquitetura eram contemporâneas à própria discussão da regulamentação e da garantia do exercício profissional da arquitetura e, nesse contexto, se retroalimentavam. Assim sendo, estabelecer o campo da produção do edifício, da cidade e do objeto como prerrogativas exclusivas do profissional arquiteto era, ao mesmo tempo, uma discussão de currículo escolar e de debate de arquitetos atuantes profissionalmente e que, então, se organizavam como classe profissional por meio, por exemplo, do Instituto de Arquitetos do Brasil, o IAB.

Dessas reformas curriculares, entre as duas mais emblemáticasequemaistardesecolocariamcomomodelos 
2. Ver o relatório $O$ Ateliê na Formação do Arquiteto, do relator Carlos Barja Millan (São Paulo, 15 de janeiro de 1962) in: Sinopses FAU USP, 1993. a serem absorvidos por outras Faculdades de Arquitetura brasileiras, deve-se citar aqui aquela empreendida por Lucio Costa, em 1930, na Escola Nacional de Belas Artes, a ENBA, quando então foi diretor desta instituição no Rio de Janeiro, por um breve período. E, em segundo lugar, mas não menos importante, a anteriormente referida Reforma de 1962 da FAU USP, que empreendida por um conjunto de professores e já ensaiada em 1957, a ela não se nega a liderança do arquiteto Vilanova Artigas.

Relativamente à Reforma de 1962 sobre o currículo da FAU USP, neste momento é importante ressaltar as duas proposições fundamentais por essa comissão estabelecida. A primeira delas refere-se à implantação da prática do ateliê como elemento para a informação e, sobretudo, para a formação do arquiteto. Uma proposta pedagógica anteriormente indicada, como se verá mais adiante, numa comissão de professores montada, em 1957, dentro da FAU USP para uma reforma do ensino que, naquele momento, não consegue se efetivar integralmente ${ }^{2}$. Outro ponto-chave diz respeito à organização dos campos de conhecimentos curriculares por meio dos Departamentos, em 1962, ainda que estes coexistam com o sistema de Cátedras das universidades brasileiras, as quais só serão extintas com a reforma universitária do Governo Federal, em 1969. Por intermédio desta nova proposta de 1962, são organizados dentro da FAU USP quatro Departamentos de ensino e pesquisa: 1. Composição (pouco depois, Projeto); 2. Histórico-Crítico; 3. Ciências Aplicadas e 4. Disciplinas Técnicas.

Com essa Reforma, ficou o Departamento de Projeto com a responsabilidade pela administração da prática do ateliê onde o exercício de projeto compreenderia quatro escalas distintas, mas entendidas como complementares: edifício, cidade, desenho industrial e programação visual. O sentido que deveria ter o Departamento de Projeto e suas quatro Sequências, na conceituação do professor 
3. Entrevista concedida em 04 de março de 2009 (ver anexo). Durante a entrevista, Grinover caracteriza a ideia de uma Universidade do Projeto, como uma espécie de escola que, voltada ao ensino globalizante do projeto total, pudesse somar e superar aquilo que pretendia tanto a Escola de Design da Guanabara quanto a Faculdade de Arquitetura de São Paulo.
4. Para se ter uma ideia, Julio Katinsky foi professor do Departamento de História, e, de dentro deste departamento, contribuiu para a elaboração de uma nova abordagem da história da arquitetura, por meio de disciplinas de graduação e de pesquisas envolvidas com o universo da técnica dentro da arquitetura. Também é considerável a sua participação em discussões e publicações sobre o ensino de desenho industrial, ao longo da década de 1960 e 1970. Além disso, Katinsky é autor de um número relevante de projetos no campo do mobiliário.
Lúcio Grinover, seria o diferencial do ensino de desenho industrial da FAU USP se comparada, por exemplo, à sua contemporânea Escola Superior de Desenho Industrial, a ESDI, implantada um ano depois, em 1963, no Estado da Guanabara, no Rio de Janeiro. Enquanto na experiência carioca, a atividade de projeto recaía e limitava-se, grosso modo, à produção do objeto e à programação visual, o que se desejava na FAU USP, nas palavras de Grinover, era a constituição de uma Universidade do Projeto $^{3}$.

Por outro lado, é importante considerar que o ensino de desenho industrial na FAU USP não se caracteriza como ponto de interesse único e exclusivo do Departamento de Projeto. Lembrando que, dentro desta Escola, o desenho industrial, entre outros objetivos, cumpriria também o papel de industrializar o projeto e o processo de produção da arquitetura, é necessário entender como outros departamentos participaram e contribuíram para uma definição do que deveria ser o ensino e a prática do desenho industrial dentro da FAU USP. É necessário olhar, também, para os departamentos que dentro do curso de arquitetura centravam sua atenção em conteúdos que embasariam a atividade de projeto, seja, por exemplo, os conteúdos de História ou de Tecnologia da Arquitetura ${ }^{4}$. Assim sendo, a compreensão do desenho industrial, por vários segmentos da FAU USP, revela em certa medida uma conceituação da própria arquitetura e do urbanismo, focando os três, juntamente com a programação visual como campos complementares e relativos a um mesmo exercício profissional.

A evolução dessa proposta pedagógica e a definição de conteúdos de ensino ligados à formação do arquiteto na FAU USP estão ligadas a três acontecimentos fundamentais que marcaram a Escola. A primeira delas é a própria criação do curso de Arquitetura e Urbanismo em 1948, como um curso independente do curso de Engenheiro-Arquiteto da 
5. Como será detalhado mais à frente, inclusive a Reforma Universitária imposta pelo Governo Militar apontava para uma direção política oposta à proposta dominante no Fórum de 1962, da FAU USP.
Escola Politécnica da USP. Os outros dois acontecimentos são destaques de uma prática comum de autoavaliação da FAU USP, isto é, os Fóruns de Debates sobre o Ensino que reuniam professores, alunos e funcionários. Uma prática de caráter anual, mas que, nos anos de 1962 e 1968, estabeleceu grandes avanços no ensino da FAU USP. A primeira data foi aquela da implantação da Reforma curricular que estabeleceu as sequências e departamentos de ensino, e a segunda significou um amplo balanço dessas mudanças estabelecidas dentro da FAU USP, em 1962. Este Fórum de 1968, é importante lembrar, antecedeu a Reforma Universitária do Governo Federal, de 1969, que pôs fim definitivo ao antigo sistema de cátedras que balizava a organização do sistema de ensino universitário brasileiro. Um sistema acusado pela FAU USP desde 1962, mas não exclusivamente por esta Faculdade, como responsável por determinadas características retrógradas do sistema universitário do país ${ }^{5}$.

Considerando este arco temporal das datasacontecimentos citadas, diante desse período histórico que se estende de 1948 até 1969, é necessário um olhar para o contexto econômico, político e social do país, para se compreender o sentido de todo esse conjunto de preocupações e de respostas intencionadas pela FAU USP no intuito de justificar a sua existência como instituição de ensino na sociedade brasileira. Nesse período em questão, no mínimo, do ponto de vista político e econômico, é possível estabelecer dois momentos históricos distintos: 1945 até 1964 e, depois de 1964 até 1985. Adotando a terminologia de Boris Fausto (2008), respectivamente, o Período Democrático e o Regime Militar. A denominação de cada um é suficiente para lembrar o país no plano político. Com relação ao período que se estende de 1945 até 1964, Carlos Martins o caracteriza como a maior década do século 20 brasileiro, lembrando a condição oposta que o texto do historiador Eric Hobsbawm indica 
6. Argumento apresentado pelo professor Carlos Alberto Ferreira Martins em minha banca de qualificação deste doutorado. Para Eric Hobsbawm, o século 20 foi breve e extremado, foi inaugurado pela Primeira Guerra Mundial, em 1914, e se encerra com a crise desencadeada com a queda do Muro de Berlim, no ano de 1989. Para Martins, a democracia brasileira, vivida entre 1945 e 1964, é caracterizada como um hiato entre duas ditaduras (do Estado Novo e do Golpe Militar). Ainda que possam ser ressaltadas certas particularidades dos diferentes governos desse período, o mesmo teve, ao longo de seus 19 anos, como características comuns, a liberdade democrática no campo da política e, no plano econômico, o desejo comum de um desenvolvimento econômico nacional independente.

As características desse período também gestaram particularidades no plano social, artístico e cultural brasileiros. para o século 20, em Era dos Extremos: o Breve Século XX: 1914 - $1991^{6}$. Diante desses dois períodos históricos apontados, é importante relacionar que a FAU USP é criada e conceitualmente estruturada entre os anos de 1948 e 1962. Um período de democracia e de determinadas esperanças quanto a um futuro de desenvolvimento econômico e social nacional. Mas é importante ressaltar que tudo aquilo que é gestado no plano teórico pela Escola nesse período democrático irá fazer se tornar uma prática num período de restrição de liberdade política e de incertezas quanto ao futuro econômico do país. 
Parte 1: Elementos Precursores da Reforma de 1962 



\section{Arquitetura e Ensino}

1. MACHADO, Lourival Gomes. A renovação da Arquitetura Brasileira (1947). In: XAVIER (2003, pp.75-78).
O ensino institucional de arquitetura no Brasil, na primeira metade do século 20 , passaria por um processo de reestruturação tanto de seus conteúdos quanto da sua forma de transmissão. As mudanças ora gestadas são reflexos de uma prática arquitetônica que se via transformada, seja por novos pressupostos técnicos da produção ou por uma redefinição daquele profissional a quem caberia o exercício do projeto. Em outras palavras, houve uma nova definição de uma prática arquitetônica e de uma garantia da exclusividade do profissional habilitado para exercê-la.

No que diz respeito ao estabelecimento inicial dessas transformações no campo da prática, Machado (1947), em $A$ renovação da arquitetura brasileira ${ }^{1}$, descreve um processo evolutivo de desenvolvimento da arquitetura moderna no Brasil que se inicia em São Paulo, ao longo da década de 1920, precisamente com Gregori Warchavchik e Flávio de Carvalho, por meio de seus escritos na mídia, ou por suas primeiras realizações arquitetônicas. Mais tarde a liderança desse processo se transfere para o Rio de Janeiro, durante a década de 1930 com o grupo de arquitetos encarregados da construção do Ministério da Educação e Saúde. E, posteriormente, no início dos anos de 1940, uma terceira etapa de desenvolvimento da arquitetura moderna ocorreria em São Paulo, algum tempo após o retorno de Rino Levi de sua formação na Itália, pela passagem de Bernard Rudofsky ou por novos arquitetos formados no Brasil e, com um olhar de 
interesse, também pela arquitetura moderna produzida nos Estados Unidos, como o caso de Vilanova Artigas.

Considerando essa linha evolutiva de início e de desenvolvimento da arquitetura moderna em nosso país e o eixo geográfico em que ela se dá, também é possível afirmar um processo de rebatimento das transformações dessas práticas profissionais no campo do seu ensino. Quando de uma segunda etapa do desenvolvimento da arquitetura moderna cujo centro passa a ser o Rio de Janeiro, temos contemporaneamente, isto é, entre 1930 e 1931, a presença do arquiteto Lucio Costa, como diretor da Escola Nacional de Belas Artes, ENBA, e a sua reforma pedagógica no sentido de afirmar uma opção pela formação de arquitetos dentro de princípios estabelecidos pelo desenvolvimento da arquitetura moderna até aquele momento e contra o ensino tradicional que era até então a orientação desta Escola, naquilo que diz respeito à formação do arquiteto. Por outro lado, anos mais tarde e de volta a São Paulo, em 1948, marcaria a criação do Curso de Arquitetura da Faculdade de Arquitetura e Urbanismo da Universidade de São Paulo (FAU USP) como um curso independente e em substituição àquele de engenheiroarquiteto oferecido pela Escola Politécnica de São Paulo. Este novo curso, desde sua criação, buscou em sua afirmação, no que concerne a uma visão de arquitetura, também se aproximar da produção da Arquitetura Moderna. Desde sua criação, o seu primeiro diretor, o professor Anhaia Mello, procurou estabelecer, em seu quadro docente, professores ligados a esta concepção e

2. Entre os novos professores da recém-criada FAU USP, contamse: Alcides da Rocha Miranda (arq. ENBA 1932), Antonio Paim Vieira, Abelardo Riedy de Souza (arq. ENBA 1932), Hélio Queiroz Duarte (arq. ENBA 1931) e, posteriormente, Eduardo Corona (arq. FNA 1946). Ver FICHER (2005, pp.151-152). para tal procurou contar com arquitetos formados no Rio de Janeiro, já dentro do espírito de renovação proposto pela reforma de Lucio Costa dentro da ENBA, isto é, arquitetos de formação carioca e de orientação moderna ${ }^{2}$.

Para a compreensão dessas novas propostas didáticas ou pedagógicas, é importante que se caracterize qual era o ensino arquitetônico que preconizava tanto a 
3. Como dito na nota anterior, parte dos professores contratados por Anhaia Mello para a recém-criada FAU USP se formou arquitetos no ambiente de mudanças proposto na ENBA por Lucio Costa a partir de 1930. Isto comprova a existência de uma visão comum perpassando as duas escolas e relacionadas à opção pela arquitetura moderna.
Escola de Belas Artes carioca quanto a Escola Politécnica paulista e suas visões de arquitetura ou, melhor dizendo, do profissional ligado ao universo da construção civil. Ambos os modelos são descendentes de concepções francesas para o ensino institucionalizado de formação do profissional da construção. A École des Beaux-Arts, como sendo a matriz de origem da ENBA do Rio de Janeiro e o curso de arquitetura civil da École Polytechnique, como sendo o modelo de origem do curso de engenheiroarquiteto da Escola Politécnica de São Paulo. Para caracterizar um e outro sistema de ensino, Ficher (1988, p. 129), em seu ensaio $O$ ensino da construção no domínio da arquitetura, afirma que, na tradição acadêmica estabelecida com a École des Beaux-Arts, a forma correta resulta da aplicação da teoria da composição, a qual determina o emprego dos elementos arquitetônicos $e$ de composição. Tal técnica de projeto está sistematizada em Eléments et Théorie de l'Architecture (1901-04) de Guadet. Quanto ao sistema politécnico, este adotado por diversas escolas de engenharia a partir do curso de arquitetura civil da École Polytechnique, a forma correta está associada à racionalização da distribuição pela composição segundo traçados regulares e ao estudo dos diversos tipos de edificação. Este modelo foi estabelecido por Durand em Précis des leçons d'Architecture Donnés à I'École Polytechnique (1802-05).

Apesar dos objetivos em muito semelhantes entre as reformas do ensino de arquitetura na ENBA, proposto por Lúcio Costa em 1930 e, 18 anos depois, em 1948, com a criação por Anhaia Mello do curso de arquitetura da FAU USP ${ }^{3}$, como referido acima, as duas escolas das quais tais mudanças partiram eram distintas em suas origens e, em consequência, ocasionaram diferentes vitórias a cada empenho pretendido, a reforma carioca e a paulista.

Isso porque a experiência do modelo Beaux-Arts da ENBA significava para Lucio Costa um modelo ultrapassado e a 
4. SOUZA, Abelardo de. A ENBA, antes de depois de 1930 (1978). In: XAVIER (2003, pp.63-70).

5. SANTOS, Paulo. A Reforma da Escola de Belas Artes e do Salão (1966). In: XAVIER (2003, pp.60-63).

6. COSTA, Lucio. A Situação do Ensino das Belas Artes (1930). In: XAVIER (2003, pp. 57-58). ser substituído, sobretudo pelo choque de compreensão entre aquilo que a escola acreditava e a nova visão de Lucio Costa sobre arquitetura, enquanto processo de produção e produto. De acordo com Souza (1978) ${ }^{4}$, a posse de Lucio Costa na direção da ENBA, em 12 de dezembro de 1930, é fruto da presença de Gustavo Capanema à frente do recém-criado Ministério da Educação pelo governo de Getúlio Vargas. Apesar da formação de Lucio Costa na ENBA, a sua presença, por esta indicação de Capanema e pela adesão de Costa à arquitetura moderna, o colocava em confronto com os velhos professores desta Escola que ensinavam arquitetura com base nos princípios tradicionais, conforme indica Santos $(1966)^{5}$ :

A posse de Lucio Costa na direção da Escola Nacional de Belas-Artes (ENBA) deu-se em 12 de dezembro de 1930. No dia 29 dava ele uma entrevista a Gerson Pompeu Pinheiro (...) O Globo, a qual caiu como uma bomba, pulverizando a arquitetura de estilos da década de 1920-1930, que tinha constituído a base do ensino na ENBA. Arrasou com o Salão de Belas-Artes e com a orientação da pintura que, a seu ver, ignorava tudo depois de Cézanne.

Recuperando a entrevista de Lucio Costa $(1930)^{6}$, sobre estas questões, ele assim avaliaria a ENBA quando assume a sua direção:

Fazemos cenografia, estilo, arqueologia, casas espanholas de terceira mão, miniaturas de castelos medievais, falsos coloniais, tudo, menos arquitetura. (...) Acho indispensável que os arquitetos deixem a nossa Escola conhecendo perfeitamente a nossa arquitetura da época colonial, não com o intuito de transposição ridícula de seus motivos, ou de mandar fazer falsos móveis de jacarandá - os verdadeiros são lindos -, mas de aprender as boas lições que ela nos dá 
de simplicidade perfeita, a adaptação ao meio e à função, e conseqüente beleza.

De fato, o embate de Lucio Costa na ENBA será o de uma oposição à permanência da maneira de pensar em que, para a arquitetura, a forma correta resulta da aplicação da teoria da composição, a qual determina o emprego dos elementos arquitetônicos e de composição, ou seja, a matriz da École des Beaux-Arts. Uma visão a ser superada e para a qual, Costa, na condição de um arquiteto externo à Escola, sendo indicado diretor, procuraria contar em sua empreitada com mais professores sem vínculos diretos com a ENBA e a sua tradição a ser superada, como Gregori Warchavchik, à época com 34 anos, e seu assistente Affonso Eduardo Reidy, então com 20; Alexander Buddeus, jovem arquiteto alemão, autor de vários bons projetos na Europa e no Brasil (...); Emílio Baumgart, grande inovador do processo do cálculo estrutural no Brasil (SOUZA, 1978).

A essa enorme disparidade de entendimento sobre a arquitetura e o seu ensino, entre Lucio Costa e os antigos professores da ENBA, está relacionada a curta duração da gestão de Costa à frente da Escola. Entretanto um movimento que, medido de outra forma, sairia vitorioso, pois somado à passagem de Le Corbusier pelo Rio de Janeiro na década de 1930 e à realização do prédio do Ministério da Educação e Saúde, motivo da vinda do arquiteto franco-suíço ao Brasil, indicaria um decisivo passo a mais no caminho a ser trilhado pela nossa nascente arquitetura moderna e para o ensino da mesma.

Em São Paulo, a situação foi diferente. Ficher (1988, p.129), ao delimitar a relação entre projeto e construção no sistema beaux-arts, apontará que para este sistema construir é uma atividade banal em que o projeto arquitetônico acrescenta prováveis qualidades estéticas ou simbólicas, no sentido de que o projeto qualifica 
7. Entrevista concedida ao autor em 05 de março de 2009. Julio Katinsky estudou na FAU USP entre os anos de 1952 e 1957.

8. De fato o argumento de Katinsky parece ter bastante sentido pelo menos no discurso de um grupo de professores ao longo da história da FAU USP, sobretudo para uma parte daqueles da área de História da Arquitetura e alguns outros de Projeto. Textos como O Desenho de Vilanova Artigas e Desenho e Emancipação de Flávio Motta, em certa medida, reafirmam tal esperança no desenho e na técnica. O primeiro texto trata de uma aula inaugural da FAU USP, em 1967, e o segundo foi publicado pela primeira vez no Correio Brasiliense, em Brasília, 1967. Juntamente com um terceiro texto de Mário de Andrade, sob o título Do Desenho, foram todos republicados, em 1975, pelo Centro de Estudos Brasileiros do Grêmio da Faculdade de Arquitetura e Urbanismo, o GFAU USP. a construção. Num ponto de partida oposto, parte considerável daquilo que a Politécnica entendia como sendo requisito para a correta construção se identificava e antecipava alguns dos princípios da arquitetura moderna. A valorização do domínio da melhor e mais adequada técnica construtiva que sempre norteou a pesquisa e o ensino dentro da Escola Politécnica de São Paulo, por exemplo, se converteu em sua tradição. E desta forma, o modelo de ensino de arquitetura defendido por Anhaia Mello e identificado com os pressupostos da arquitetura moderna, mais que encontrar um ponto de contraposição na escola paulista que the deu origem, como foi o caso de Costa na ENBA, encontrou em São Paulo na tradição desenvolvida pela Politécnica um de seus pontos de apoio ao seu desenvolvimento.

No ponto de vista defendido pelo professor Julio Katinsky ${ }^{7}$, com um olhar não apenas em 1948, mas durante a década de 1950 até 1962, prevalece na FAU USP uma transição:

\begin{abstract}
Apesar de se falar que nós não queríamos nem curso da Poli nem o curso da Belas Artes; historicamente, as duas grandes escolas que existiram, foram a Escola de Belas Artes, que é uma criação renascentista, que baseava todo o ensino no desenho e a Escola Politécnica que centrava todo seu ensino no desenvolvimento da ciência da tecnologia. Então o que a FAU USP fez, na realidade, neste período, que vai de 1957, digamos, antes de se corporificar em 1958 (...) o que na realidade a Faculdade de Arquitetura fez foi a síntese das duas Escolas ${ }^{8}$.
\end{abstract}

Ainda considerando este ponto de vista da existência de um contexto de implantação do Curso de Arquitetura da USP muito mais como um processo de evolução do que de radical ruptura com uma visão conceitual do ensino de construção e da arquitetura, ao contrário da condição 
de Lúcio Costa, Anhaia Mello, como responsável pela criação da FAU USP e na condição de seu primeiro diretor, já era um membro, professor catedrático, da própria instituição que Ihe deu origem, a Escola Politécnica, e não um membro externo. Nos primeiros anos de existência da FAU USP, o curso encontrava-se instalado na própria Escola Politécnica, no bairro da Luz, sendo transferido por volta de 1949 para sua sede própria, a Vila Penteado, à rua Maranhão 88. É ainda importante ressaltar o nascimento da FAU USP com uma orientação conceitual identificada com os preceitos desenvolvidos pela arquitetura moderna, devido à presença da visão de Anhaia Mello relacionada a tais pressupostos:

Quanto ao ensino na FAU, esse iria se caracterizar pela manutenção de certos ideais politécnicos ligados ao conhecimento técnico da construção e ao racionalismo arquitetônico, pela preocupação quase exclusiva de Anhaia com o urbanismo e pela orientação do debate estético para o modernismo. No que se refere ao último aspecto, novamente seu papel foi ímpar, na medida em que, como diretor, era o responsável pela contratação de novos professores para complementar o corpo docente advindo da Politécnica. E foi por seu intermédio que para ela entrou uma série de arquitetos de formação carioca e orientação moderna, tais como Alcides da Rocha Miranda (arq. ENBA 1932), Antonio Paim Vieira, Abelardo Riedy de Souza (arq. ENBA 1932), Hélio Queiroz Duarte (arq. ENBA 1931) e, posteriormente, Eduardo Corona (arq. FNA 1946). Por sua iniciativa, em 1950 José Zanine Caldas foi contratado, como assistente de Rocha na disciplina de Plástica, para organizar a oficina de maquetes da Escola. Em 1951, chegou a convidar Oscar Niemeyer (arq. ENBA 1934) para lecionar, porém como a reitoria vetou o contrato, alegando a afiliação comunista daquele arquiteto em junho se exonerou da direção (Ficher, 2005, pp. 151-152).

Se na caracterização dessas duas visões pioneiras e exemplares de reforma do ensino de arquitetura, no que diz respeito à orientação dos seus diretores, Lucio Costa 
e Anhaia Mello, havia em comum uma identificação com a defesa dos postulados da arquitetura moderna, também será marca dessas duas transições, por que passavam o ensino nestas escolas, que tais mudanças fossem engendradas em um contexto social marcado por uma defesa dos claros limites para atuação do arquiteto enquanto classe profissional, com a garantia de tal exercício da profissão expresso em legislação específica. Sobre este ponto, Ficher (1988, P.130) explica:

\begin{abstract}
A questão legal refere-se à organização do trabalho na área da construção após a regulamentação profissional. Além de ter valorizado, de maneira inédita no passado, o ensino institucional, criando a médio prazo uma reserva de mercado para os diplomados pela exclusão daqueles construtores inscritos na convenção, a regulamentação profissional ampliou ainda mais a separação entre a atividade prática da construção e o método técnico de sua transmissão.
\end{abstract}

9. Como será apresentada, mais adiante, a própria determinação do desenho industrial como conteúdo a ser ensinado em escolas de arquitetura ou em escolas específicas também terá o seu correspondente no âmbito do debate da regulamentação do exercício profissional, quando o Conselho Regional de Engenharia e Arquitetura, o CREA, irá se posicionar sobre o assunto, não ficando a discussão restrita apenas ao círculo das comissões nacionais de ensino, estabelecidas para determinar os currículos mínimos das escolas de arquitetura.
Aqui se apresenta clara esta relação possível e vantajosa entre ensino e regulamentação da profissão9. Para ilustrar esse contexto, pode-se indicar que é de 1933 o Decreto Federal número 23.569 que regulamenta a profissão do arquiteto, do engenheiro e do agrônomo, criando o Conselho Federal de Engenharia, Arquitetura e Agronomia, o CONFEA, e o Conselho Regional de Engenharia, Arquitetura e Agronomia, o CREA. Este decreto-lei, valorizando a titulação, iria afetar não apenas o desempenho da profissão, como também o seu ensino institucional, transformado então em caminho único para a obtenção da competência profissional.

Quando se discute esse processo de determinação legal da profissão e do profissional de arquitetura, neste contexto histórico, é necessária a atenção para uma questão de extrema relevância a este trabalho. Tal questão refere-se 
10. Rino Lei forma-se na Itália, em Milão e Roma, entre 1921 e 1923, retorna ao Brasil no segundo semestre de 1926, iniciando a sua trajetória profissional em São Paulo a partir de 1927. Ver ANELLI ( 2001, pp. 24-35). à determinação exclusiva do exercício do projeto como a atividade que irá caracterizar e diferenciar o arquiteto em relação aos demais profissionais ligados à construção. Um princípio que mais uma vez caracteriza, nesse período histórico, um movimento único, mas que cumprirá dois objetivos complementares, quais sejam, tanto a regulamentação profissional quanto a constituição da arquitetura moderna em nosso país.

Se, antes de tal regulamentação profissional, poderiam exercer a profissão tanto aqueles com uma formação institucional (arquitetos, engenheiros, engenheirosarquitetos, de origem das Escolas de Belas Artes ou das Politécnicas) ou ainda aqueles formados no ofício, como mestres de obras e todos estes pudessem responder pelo projeto ou pela construção, após 1933 os papéis profissionais se tornam mais claros. $E$, nesse contexto anterior a 1933, não é menos importante a informação de que o projeto até então não tinha nenhum valor comercial. Fossem escritórios de engenheiros, arquitetos, ou a atividade dos mestres de obras, o projeto era algo sem valor econômico para o mercado, e assim sendo a sua percepção como valor intelectual a ser remunerado era mínina para o contratante. Os escritórios sobreviviam economicamente da construção. Como marco na mudança desta condição profissional, nos parece da maior importância a lembrança de Ficher (2005) com relação ao escritório do arquiteto Rino Levi ${ }^{10}$ como sendo o primeiro em São Paulo a sobreviver economicamente e exclusivamente do projeto de arquitetura (projeto e fiscalização de obra). É o primeiro a dedicar-se somente ao projeto arquitetônico e não mais à sua construção. Assim sendo o que se opera também é que o arquiteto deixa de ser um profissional do comércio para se tornar um profissional liberal. Acerca desta condição, Ficher (1988) assim a descreve: 
Após a década de 30 (e, portanto, fenômeno extremamente recente), com a regulamentação profissional, ficou legalizada tal separação (entre a concepção e a construção de um edifício), porém com a introdução de mais um fator de mediação: como diferenciar engenheiros e arquitetos - ambos diplomados e, portanto, legítimos - e, mais grave ainda, como distinguir projetistas e construtores? Através de outra adjetivação: projetar edifícios, em todos os seus aspectos (projeto arquitetônico, estrutural e das diversas instalações), seria uma atividade liberal, enquanto construir edifícios seria uma atividade comercial. Esquematicamente, a parcela liberal fica sob responsabilidade dos arquitetos ou engenheiros encarregados da solução formal do problema arquitetônico e dos diversos arquitetos ou engenheiros especializados: calculista, hidráulicos, eletricistas, etc. A construção, identificada como a parcela comercial da transação, fica por conta dos empreendedores, os quais, além de mestres e operários, contam com profissionais diplomados na execução da obra.

Essa delimitação da exclusividade do projeto atribuída ao arquiteto, discutida sob o ponto de vista do exercício profissional, é da maior importância ser aqui considerada. Na evolução do ensino de arquitetura no Brasil e no caso da FAU USP, objeto desta investigação, determinar a prática do projeto (e construir uma base teórica que o sustente) e substituir as tradicionais disciplinas de Composição Arquitetônica pela prática do ateliê caracteriza o processo de evolução do ensino de arquitetura na FAU-USP, desde a sua criação em 1948.

Mas esse processo não se fará de uma forma imediata à criação da FAU USP em 1948. Pois apesar de se ter apontado a visão do fundador da Escola, o professor Anhaia Mello, alinhada a três pressupostos fundamentais da arquitetura moderna (valorização da técnica, do urbanismo e a identificação à própria estética moderna em arquitetura), o currículo que será estabelecido desde 1948 até 1962 será, como dito anteriormente, uma soma de disciplinas com uma dupla origem: a matriz da Belas 
Artes e a da Politécnica. Entretanto é necessário ressaltar esse momento como de uma transição que desaguaria na Reforma de 1962, onde então a noção do projeto, cujo estabelecimento será defendido como atividade única e exclusiva do arquiteto, abarcaria todas as escalas de sua realização, tal qual preconizado pela arquitetura moderna ao longo do século 20.

Considerando esse período referido como de transição, a tabela abaixo lista as disciplinas ligadas ao novo curso de arquitetura da FAU USP que, não estando ligadas aos conteúdos da técnica ou da história da arquitetura e da arte, preconizava a realização do projeto e, como originadas no modelo da Belas Artes, vinham prescritas sob o título Composição:

\begin{tabular}{|l|l|l|}
\hline Cadeira & Disciplina & Ano \\
\hline 16 & Composição de Arquitetura. Pequenas Composições I. Desenho Arquitetônico & 1o e 2o \\
\hline 21 & Desenho Artístico & 1o e 2o \\
\hline 17 & Composição de Arquitetura. Pequenas Composições II. Plástica II & 3o \\
\hline 22 & Composição Decorativa & 3o e 4o \\
\hline 18 & Composição de Arquitetura. Grandes Composições I. Plástica III & 4 o \\
\hline 23 & Urbanismo & 5o \\
\hline 28 & Arquitetura Paisagística & 5o \\
\hline
\end{tabular}

Tabela 01: Cadeiras de ensino dos conteúdos de projeto até 1962, FAU USP.

11. Artigas foi interino de Anhaia Mello na Politécnica, de agosto de 1941 a novembro de 1943. Entre 1946 e 1947, ficou afastado da Politécnica para viagem de estudos aos Estados Unidos, com o apoio do próprio Anhaia que ressaltou na ocasião: $A$ imensa vantagem para a nossa escola, nesta emergência de reorganização do curso de Arquitetura e Urbanismo, aproveitar a ida do arquiteto Artigas aos Estados Unidos para estudar os cursos de arquitetura daquele país, de vez que estão hoje ensinando
A despeito dessa grade adotada, desde o início do ensino de arquitetura na FAU USP, a Escola contou com professores, graças a Anhaia Mello, com uma orientação moderna, como foi o caso de Vilanova Artigas ${ }^{11}$ que como auxiliar de Anhaia Mello, ao lado do também professor da FAU USP, Zenon Lotufo, foram precursores de um ensino de orientação moderna na cidade de São Paulo. Por outro lado a FAU USP contou também com professores que, apesar de uma formação nos modelos tradicionais, ligados à arquitetura eclética, sem abrir mão totalmente destes princípios, somaram a esta formação inicial os conteúdos da arquitetura moderna, como foram os professores que merecem destaque nesse início da FAU USP: José Maria da Silva Neves e Caetano Fraccaroli. A presença na Escola 
nas escolas de arquitetura norte-americanas os expoentes mundiais da arquitetura: Gropius, Saarinen, Mendelsohn, Behrendt, Frank Lloyd Wright (FICHER, 2005, p.297).

12. Apesar da informação de Ficher $(2005$, p. 212) de que Silva Neves foi responsável pela cadeira Desenho Artístico do primeiro ano do novo curso da FAU USP, localizamos no Departamento de Projeto da Escola, o nome de Ernest Robert de Carvalho Mange como responsável por esta disciplina. Ficher (2005, p. 212) informa também que no antecessor curso de engenheiroarquiteto da Politécnica, Silva Neves era responsável, desde maio de 1934, pela cadeira de Composição Geral, lecionando Desenho Arquitetônico e Esboço do Natural e Desenho e Perspectiva.

13. Ver: FAU USP. Desenho Industrial 1962. Ficher (2005. p.212) informa que Jacob Mauricio Ruchti (arq. Mackenzie, 1940) também foi auxiliar do catedrático Silva Neves, sem informar precisamente a data. Por outro lado, Leon (2006) informa que Jacob M. Ruchti foi também professor no IAC-MASP (19511953), sendo responsável pela disciplina Composição (de interiores).

14. Fichas da cadeira 22: Composição Decorativa, ministrada até 1962.

15. Argumento apresentado na banca de qualificação deste doutorado. destes dois professores, de reconhecido valor profissional à época entre seus pares, ilustra bem o processo de transição por que passava a Escola naqueles anos de 1948 a 1962, oscilantes entre o abandono completo das matrizes tradicionais e a opção definitiva pela arquitetura moderna.

O professor José Maria da Silva Neves foi responsável pela cadeira Composição Decorativa ${ }^{12}$ até 1962. Com a implantação da Reforma de 1962, passa a ser responsável pela disciplina Desenho Industrial III, tendo como auxiliares Abrahão Velvu Sanovics (arq. FAU USP, 1958) e Luiz Gastão de Castro Lima (arq. FAU USP, 1954) ${ }^{13}$. Silva Neves se aposenta em 1966.

Silva Neves, responsável pela cadeira número 22, Composição Decorativa, realizava uma abordagem que transitava entre a arte e a arquitetura decorativa até o industrial design ${ }^{14}$. O primeiro item indicado corresponde ao ensino da arquitetura de interiores e, quanto ao industrial design, uma das abordagens propostas é aquela da arte decorativa no setor industrial. O professor Lucio Gomes Machado, da FAU USP, argumenta, a partir de uma abordagem da produção prática de Silva Neves, assim como a do professor Bruno Simões Magro, que seria impossível eles terem abordado em suas disciplinas o desenho industrial. Porque eram acadêmicos, de formação acadêmica. O objeto para eles era entendido como uma questão de estilo. Nada a ver com o método de desenho industrial, ainda que fossem objetos. Porque não é o problema da escala, é o problema do método ${ }^{15}$. Por outro lado, ainda que de fato seja muito pertinente o ponto de vista defendido pelo professor Lucio Gomes Machado sobre esta impossibilidade de uma abordagem mais clara do desenho industrial por Silva Neves, não se pode negar 


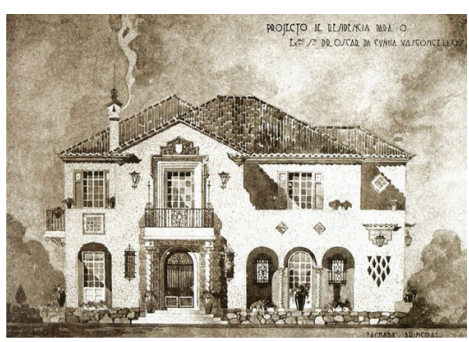

Fig.01. José Maria da Silva Neves. Residência Oscar da Cunha Vasconcelos. Revista Politécnica, n.100, entre PP.226 e 227, ago./set. 1930. [fonte: FICHER, 2005, p. 213]

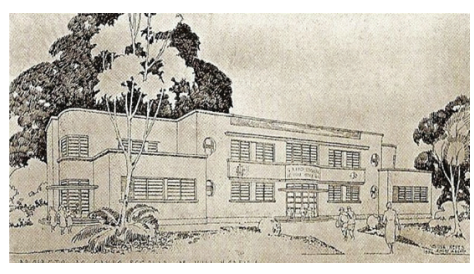

Fig.03. José Maria da Silva Neves. Grupo Escolar Vila Moreira. Novos Prédios para Grupo Escolar. [fonte: FICHER, 2005, p. 211]. no trabalho de José da Silva Neves uma determinada assimilação de certos princípios modernos em algumas de suas arquiteturas, ainda que outras permanecessem comprometidas com uma estética eclética. Para se ter um exemplo, considerando a sua atuação profissional, em janeiro de 1931, Silva Neves ingressa na Diretoria de Obras Públicas de São Paulo, sendo então comissionado na

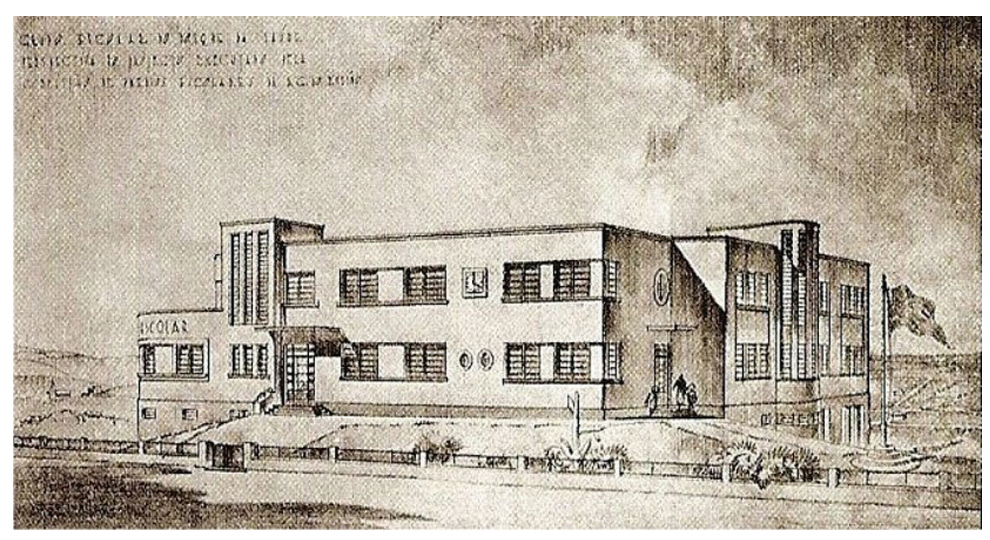

Fig.02. José Maria da Silva Neves. Grupo Escolar do Bosque da Saúde. Novos Prédios para Grupo Escolar. [fonte: FICHER, 2005, p. 211].

Secretaria de Educação e Saúde Pública, de 1935 a 1937. Esta Seção foi criada para estudar um novo tipo de prédio escolar e construir 40 grupos escolares na cidade. Esses projetos ficam sob a responsabilidade de Silva Neves que adota para a tarefa arquitetônica uma aproximação com a arquitetura moderna. Apesar de sua formação eclética, Silva Neves desde a década de 1930 estava identificado com o modernismo. Segundo Ficher (2005), talvez sejam estas escolas de José da Silva Neves o primeiro exemplo do emprego de uma estética moderna em obras públicas na cidade de São Paulo. Neste contexto, ainda que, como informa o professor Lucio Gomes Machado, Silva Neves não estivesse absorvido e optado pela arquitetura moderna enquanto um método de projeto, não se pode negar o ponto de vista de Ficher (2005) sobre a assimilação da mesma arquitetura moderna em sua proposição estética. Uma visão que auxiliaria este processo de transição na 
16. Entrevista concedida ao
FAU USP para se estabelecer a arquitetura moderna na sua integridade como modelo da Escola. Julio Katinsky que foi aluno na FAU-USP entre 1952 e 1957, tendo sido, portanto, aluno de Silva Neves, comenta:

Ele (Silva Neves) fez diversas obras de arquitetura do período Art Deco. E ele já tinha preocupações marcadamente funcionalistas nas obras dele. Uma das escolas está aqui perto, aquela escola Marina Franco, que era uma escola que se chamava José de Anchieta, por isso tem aquele horrível azulejo do padre Anchieta com um indiozinho. Esse projeto é dele. Ele fez vários projetos. Você pode pegar um livro da FDE sobre o Convênio Escolar. Há uma série de projetos que são dele. Os que antecedem o Convênio Escolar. Preocupação com o ensino, com a construção de edifícios escolares, foi uma preocupação constante da República Paulista, desde 1890, e o José Maria da Silva Neves era um arquiteto, um engenheiroarquiteto muito respeitado. Eu fui aluno dele. Ele era muito simpático, ele nos deixava fazer tudo que queríamos, uma beleza! Nós trabalhávamos muito com ele ${ }^{16}$.

Esta é a imagem com a qual Julio Katinsky busca identificar Silva Neves e a justifica também como sendo decorrente de sua própria formação, pois, tendo estudado na Politécnica em 1922, se identificava com esse ideal de valorização do domínio da técnica no campo da arquitetura.

17. Entrevista concedida ao autor em 04 de março de 2009.
O ponto de vista do professor Lúcio Grinover ${ }^{17}$ sobre a atuação de Silva Neves, analisando a ficha da disciplina Composição Decorativa, aponta que a mesma fala em organização e equipamentos de ambientes comerciais, religiosos, mas do ponto de vista da decoração. Para Grinover, o desenho industrial entrava como início, numa discussão que poderia ter sido e que depois ficou muito mais ampla. Grinover lembra que, após a Reforma de 1962, a discussão em relação a equipamentos de ambientes comerciais, ou de quaisquer outros ambientes, passou a 
ser feita em função de certos tipos de equipamentos que podiam ser produzidos industrialmente. Isso foi a partir de 1962, 1963, quando se implantou a Sequencia de Desenho Industrial. Ainda para Grinover, Silva Neves era preocupado em termos com a relação entre a indústria e a arquitetura, pois estava muito mais vinculado à composição decorativa dos ambientes, no sentido tradicional, que propriamente do desenho do produto, como definido pela arquitetura moderna. Grinover termina afirmando que, no caso do industrial design presente na ficha de Composição Decorativa, sob responsabilidade de Silva Neves, o desenho industrial entrava como algo que tentava quebrar um pouco as velhas estruturas.

Como indicado, ao lado de José Maria da Silva Neves, outro professor desse mesmo período que, apesar de sua formação eclética, exerceu papel importante na evolução do ensino da FAU USP foi o professor Caetano Fraccaroli.

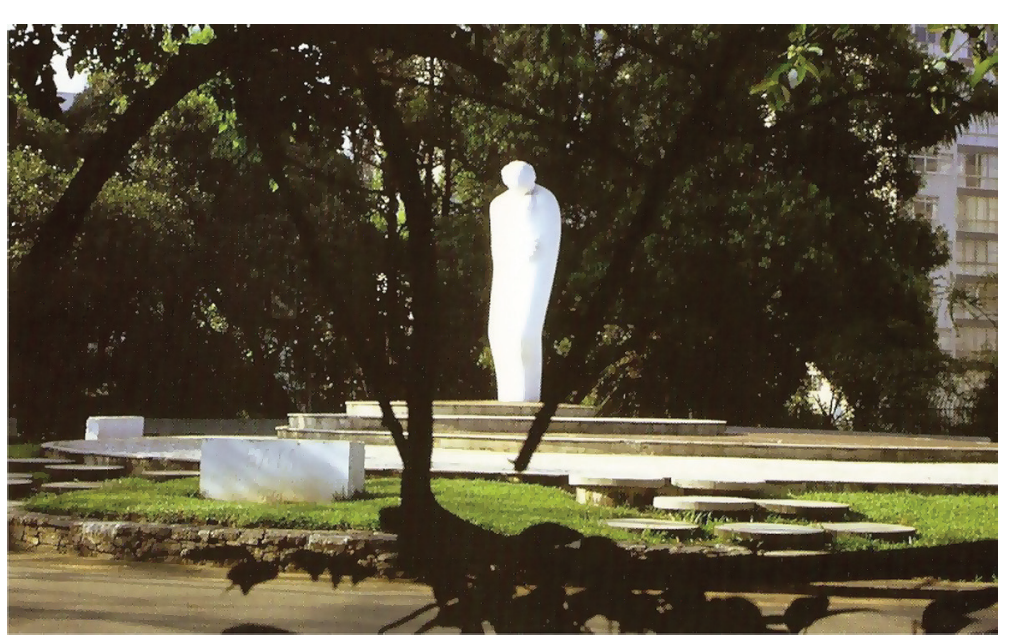

Fraccaroli estudou na

Fig.04. Caetano Fraccaroli. Mãe, escultura à praça Buenos Aires, 1965. Foto de Ennio Brauns e Marco Antônio de Moraes. [fonte: FICHER, 2005, p. 268]
Escola de Belas Artes de Verona. Veio para São Paulo em 1929. Como escultor, dedicou-se sempre ao ensino de plástica. Em 1944, foi contratado como auxiliar de Felisberto Ranzini na aula de Composição Decorativa - Modelagem do Curso de Engenheiro-Arquiteto da Escola Politécnica. Permaneceu na Politécnica até maio de 1949, quando foi transferido para a FAU USP. Entretanto, em 1951 retornou à Politécnica para lecionar novamente Composição Decorativa até 1954, ano da extinção do Curso de Engenheiro-Arquiteto da Poli. Na FAU USP, lecionou a cadeira de Plástica até 1969. De 1969 a 1985, foi professor da Sequência de Comunicação Visual do Departamento de 
Projeto; e, em 1969, iniciou a implantação do Laboratório de Modelos e Ensaios, o LAME, o qual dirigiu de 1971 a 1985.

Sobre Fraccaroli é interessante notar a longevidade de sua atuação docente na FAU USP, onde apesar de todas as mudanças por que passou a Escola, nesta conseguiu permanecer como elemento importante desde a sua criação em 1948 até 1985. Em que pese a ambiguidade de suas posturas políticas e também com relação à sua visão sobre arquitetura, em particular, e artes, no geral, a sua importância dentro da FAU USP é reconhecida por diversos outros professores da Escola que foram seus alunos ou docentes colegas de ensino. Entre todos aqueles entrevistados, é consensual o espanto causado pela ambígua postura de Fraccaroli que, sendo aquele que primeiro introduziu na FAU USP as teorias da Gestalt, mostrando-se consciente e sensível ao pensamento de vanguarda europeu no campo da produção da forma artística, na contramão disto tudo, ao mesmo tempo se identificava politicamente com determinados ideais políticos tidos como retrógrados e antiquados, como o fascismo naqueles anos.

Nesse sentido, Fraccaroli, responsável pelas disciplinas de plástica e, mais tarde, pelo início do Laboratório de Modelos e Maquetes na FAU USP, apresentava nesses dois campos a sua contribuição à formação do arquiteto, a partir de sua formação no campo da escultura e da pintura, ou seja, a sua formação no modelo da Escola de Belas Artes italiana (diferente da formação politécnica de Silva Neves). E dessa formação de Fraccaroli, Julio Katinsky destaca a sua contribuição:

O Fraccaroli já é um caso diferente, é um artista, sabia fazer, acadêmico, e que foi apanhado de repente por essa bruta transformação do Ministério da Educação, Arte Moderna, etc. Ele então tentou se adequar. Se aggiornare, como dizem os 
18. Entrevista concedida ao autor em 05 de março de 2009. Infelizmente, ainda não consegui localizar a imagem de tal escultura, e a data da mesma, que o professor Katinsky diz ter recebido como presente de Fraccaroli. Considerando a produção mais acadêmica a que se dedicou, é instigante a ideia de uma escultura produzida por Fraccaroli a partir da fita de Moébius. Ainda mais se considerando que a fita de Mébius é uma referência importante para a realização da escultura Unidade Tripartida de Max Bill, escultura esta consagrada com o primeiro prêmio da I Bienal Internacional de São Paulo, em 1951.

19. Entrevista concedida ao autor em 04 de março de 2009 italianos, e então ele introduziu várias propostas de ensino. Uma delas foi, todo mundo, durante certo tempo, fazer Mondrian, depois ele passou para a Gestalt, estudo da Gestalt. Ele era um homem difícil, porque ele era, a visão dele era uma visão meio fascista, mas ele foi um apaixonado pela Faculdade de Arquitetura, e ele morreu na Faculdade de Arquitetura. Ele tem bustos espalhados por aí, tem busto até aqui na FAU USP. Ele fazia todos os bustos, enfim, ele nunca foi bem tratado, aliás, como nunca as pessoas são bem tratadas no Brasil. Ele não foi bem tratado porque brigou com muita gente. Ele era muito... ele se considerava o maior artista do mundo, claro, mas isso não tinha muita importância. Ele acabou um pouco solitário (...). Eu até defendi, no fim da vida, defendi muito ele, apesar de saber que ele era um tremendo fascista. Ele brigava feio. Acabei defendendo tanto o Fraccaroli que ele me deu de presente uma escultura dele, por sinal muito bonita, uma figura de Moébius, uma fita de Moébius. Mas ele sempre foi um homem, na realidade, muito ligado ao ensino acadêmico. ${ }^{18}$

Esta dupla condição de Fraccaroli também é descrita por Ficher (2005, pp.267-268) que afirma que, como professor, (...) procurou sempre transmitir os princípios do neoplasticismo. Contudo em suas obras de esculturas, em geral encomendas comissionadas por instituições oficiais para logradouros públicos, seguiu uma orientação bem mais conservadora. Dessas, a mais conhecida é o Monumento à Mãe, à praça Buenos Aires, selecionado em concurso organizado pelos Diários Associados em 1965.

Para se compreender melhor o sentido da presença de Fraccaroli dentro da FAU USP, como professor de plástica ou dentro do Laboratório de Modelos e Maquetes, vale retomar o depoimento do professor Lúcio Grinover ${ }^{19}$.

(...) tínhamos artesões fabulosos. Eram artesões, inclusive quem orientava tudo isso era o Fraccaroli, Caetano Fraccaroli, que foi professor de plástica, etc. Eles eram artesões fantásticos em uma série de materiais. Inclusive, as primeiras coisas em 
plástico que foram levadas lá para a Faculdade, foram levadas por esses artesões. Então, seja do ponto de vista do objeto em si, seja do ponto de vista gráfico também, havia artesões e havia professores gráficos fabulosos, que ajudaram os laboratórios, usaram os laboratórios e influenciaram outros trabalhos para o mesmo laboratório. (...) O Fracarolli trouxe alguns deles, outros não vieram via Fracarolli, vieram por outro lado, por outros professores.

E, ao ser perguntado sobre os materiais trabalhados por esses artesãos, Grinover complementa:

\begin{abstract}
Com madeira, com metais, com gesso, com plástico. Mais tarde a Marlene (professora Marlene Picarelli) começou a fazer trabalhos em termos de elementos construtivos da arquitetura pré-fabricada, com concreto. Eram caras que estavam em bom momento. Estavam trabalhando, estavam contribuindo, ajudando de alguma maneira fantástica.
\end{abstract}

20. Na ocasião da banca de qualificação deste doutorado, os professores Carlos Martins e Lucio Gomes Machado comentaram que Caetano Fraccaroli, apesar desta sua importância para FAU USP, ainda não recebeu nenhum estudo específico. Em entrevista, o professor Julio Katinsky também comenta e lamenta tal situação.
Ao que se pode constatar, a despeito da ambiguidade de suas visões, esses dois professores significaram uma importante contribuição à evolução do ensino dentro da FAU USP ${ }^{20}$, no sentido de uma aproximação deste ensino à visão da arquitetura moderna, da industrialização da arquitetura e do próprio desenvolvimento das disciplinas ligadas ao ensino do desenho industrial. Por outro lado, dentro desse mesmo período que se estende de 1948 até 1962, é necessário considerar a organização de um movimento de professores dentro da Escola que, estabelecendo uma rotina de discussão sobre o ensino de arquitetura e a profissão, por intermédio de comissões ou grupos de trabalho, irão estabelecer uma evolução mais radical da estrutura do curso e dos conteúdos disciplinares adotados pela FAU USP. A evolução deste processo provocará por um lado o abandono definitivo das estruturas sob as quais se assentou o curso inicialmente 
21. A hegemonia a que se faz referência é aquela de imposição de uma nova forma de se conceituar e se produzir arquitetura, partindo da adoção da arquitetura moderna como um modelo que substitui todos aqueles que a precederam. Não estão sendo consideradas as diversas particularidades pelas quais, mais tarde, a arquitetura moderna irá se definir no país.

22. FAGGIN, Carlos. O Ateliê na Formação do Arquiteto: Uma análise Crítica do Documento Apresentado por Carlos Millan na FAU USP, em 1962. In: Revista Sinopses, Edição Especial, 1993, p.130. em 1948. Este processo trará como consequência a afirmação de outro modelo de ensino, identificado com a arquitetura moderna, enquanto processo e produto, e fará também uma decisiva contribuição à hegemonia desta mesma arquitetura moderna no Brasil $^{21}$. E, assim sendo, com relação a esta questão, essas mudanças terão uma dupla e complementar consequência ao desenvolvimento do ensino de arquitetura e à prática da arquitetura brasileira. Com relação ao primeiro, isto é, ao ensino, servirá de modelo aos demais currículos de outras escolas surgidas no país após transcorrer esse processo de reforma da FAU USP entre 1948-1962 na FAU USP. Sob esse ponto de vista, Faggin ${ }^{22}$ defende que:

\begin{abstract}
A partir de 1962 a FAU USP deu início a profundas reformas estruturais e pedagógicas no ensino de arquitetura. Sem dúvida nenhuma podemos afirmar, hoje, que a estrutura didática de todos os cursos de Arquitetura ministrados no Brasil segue, com pequenas diferenças, a chamada Reforma de 62 .
\end{abstract}

Como consequência, e não menos importante, ainda que se considere uma não total confluência e coesão de pontos de vistas sobre arquitetura entre os professores da Escola, o amadurecimento deste currículo, com uma determinada visão de arquitetura mais ou menos unificada, ao servir de modelo às demais escolas, contribuiu também para que muito da arquitetura produzida pelos idealizadores das mudanças da FAU USP fosse tomada também como paradigmas a serem seguidos e evoluídos por outros arquitetos em suas atuações profissionais.

Indicadas tais consequências futuras que a Reforma iria ocasionar, é importante também, ao se intencionar um olhar para esse processo que se estende de 1948 
até 1962, ter claro que não foi algo que ocorreu dentro dos limites do pensamento da FAU USP somente, pois o pensamento que nesses anos evoluía dentro da Escola se fazia com interlocuções entre os debates nacionais de regulamentação da profissão e também considerando os modelos de ensino de arquitetura existentes fora do país, particularmente da América do Sul, como será descrito mais adiante. Inicialmente, sobre a relação entre ensino e regulamentação profissional, vale ressaltar que muitos daqueles que estavam envolvidos com a evolução do currículo da FAU USP eram também protagonistas do debate sobre a regulamentação profissional, como Vilanova Artigas e Rino Levi, entre tantos outros.

Nesse período há um entrelaçamento de objetivos comuns discutidos em ambas as esferas: ensino e regulamentação da profissão. De uma maneira pioneira, em 1944, é realizado em São Paulo o 1 o Congresso Nacional de Arquitetos, organizado pelo Instituto de Arquitetos do Brasil, núcleo São Paulo, o IAB-SP. Com relação ao papel de arquitetos e do $I A B$, o próprio Artigas em relatório apresentado e aprovado em Reunião da Comissão de Ensino Superior da Organização das Nações Unidas para a Educação, a Ciência e a Cultura, a UNESCO, em Zurique, em 1974, assim iria se reportar à existência de um desejo comum entre a recém-criada organização profissional e os debates no campo do ensino naquele período:

O segundo pós-guerra encontrou os arquitetos brasileiros suficientemente prestigiados para começarem a planejar a educação e a formação de novos quadros de arquitetos. Para isso foi muito importante a reorganização a partir de 1944 do Instituto de Arquitetos do Brasil. Entidade nacional e a única agremiação de todos os arquitetos brasileiros, o IAB desde o 1ㅇ Congresso Nacional de Arquitetos, realizado em 1944, em São Paulo, dedicou-se a incentivar o aperfeiçoamento do ensino da Arquitetura e a fundação de novas Faculdades de Arquitetura dentro das Universidades, separadas das Escolas 
23. ARTIGAS, Vilanova. Contribuição para o relatório sobre o ensino de Arquitetura UIA-UNESCO (1974). In: Revista Sinopses, Edição Especial, 1993, p.134.

24. In: Revista Sinopses, Edição Especial, 1993, p.149. de Engenharia. ${ }^{23}$

Com relação à defesa e ao apoio do $I A B$ à criação de novas Faculdades de Arquitetura a partir de um modelo autônomo, é importante considerar nesse período a criação das seguintes Faculdades de Arquitetura que se separavam das Escolas de Engenharia ou já nasciam independentes: A Faculdade Nacional de Arquitetura, oriunda da Escola Nacional de Belas Artes, nasceu em 1945; a Faculdade de Arquitetura Mackenzie, separada da Escola de Engenharia Mackenzie, apareceu em 1947; a Faculdade de Arquitetura e Urbanismo, separada da Escola Politécnica em 1948; A Faculdade de Arquitetura de Universidade do Rio Grande do Sul, oriunda do Instituto de Belas Artes de 1952; A Faculdade de Arquitetura da Universidade Federal da Bahia, originária da Escola de Belas Artes da Bahia, em 1959; juntamente com a Faculdade de Arquitetura da Universidade Federal de Pernambuco ${ }^{24}$.

Pontuando este duplo processo de regulamentação do ensino e do exercício da profissão, em 1958, dois acontecimentos marcam tal evolução. Nesse ano, as reivindicações por uma nova regulamentação profissional são apresentadas na forma de projeto de lei ao então presidente Juscelino Kubitschek (MILLAN. In Sinopses, 1993, p. 130) e, ao mesmo tempo, acontece o 1o Encontro Nacional de Estudantes de Arquitetura que examinou a relação do ensino acadêmico e da prática profissional (FAGGIN. In Sinopses, 1993, p. 130).

Outro evento não menos importante para a evolução deste processo de discussão do ensino-prática profissional para a arquitetura, aconteceu em 1960. Foi a realização, em São Paulo, pelo Serviço Social da Indústria, o SESI, sob o patrocínio do Ministério da Educação, do Encontro 
25. MILLAN, Carlos Barja. $O$ Ateliê na Formação do Arquiteto (15 de janeiro de 1962). In: Revista Sinopses, Edição Especial, 1993, p.167.
Regional de Educadores Brasileiros. No que diz respeito à comissão que analisou o ensino de arquitetura, esta foi formada pelos professores arquitetos Vilanova Artigas, Roberto Cerqueira César, Hélio Duarte, Joaquim Guedes, Carlos Millan, Lúcio Grinover, Roberto Coelho Cardozo, Luiz Roberto Carvalho Franco, Rubens Maister, Miranda Maria Martinelli Magnoli. Millan, no documento O Ateliê na Formação do Arquiteto, de 1962, afirma que este encontro promovido pelo SESI, em 1960, e que teve como seu relator o professor Roberto Cerqueira César se caracteriza até então (isto é, até 1962) como o documento mais completo, fazendo deste relatório um documento extremamente útil quando pretendemos apresentar sucintamente o problema e paralelamente dar um balanço e encolunar, para a soma, as contribuições existentes. ${ }^{25}$

Este relatório, elaborado por Cerqueira César, concentra o ponto de vista de um conjunto considerável de arquitetos professores da FAU USP que estavam empenhados na reestruturação do ensino na Escola. Mas também é interessante de outro ângulo, pois mostra como, naquele período, encontrava-se organizado o ensino e o exercício da profissão no país e, sobretudo, a visão e o estímulo do Governo Federal e seus órgãos competentes para a evolução deste quadro. Conforme cita o documento, - exercício da arquitetura era, até aquele período, regulamentado pelo Decreto no 23.569, de 11 de dezembro de 1933. E, de acordo com tal decreto, as atribuições definidas como inerentes aos arquitetos, também chamados engenheiros-arquitetos, eram: 0 projeto, direção e fiscalização de obras de construção $e$ de serviços urbanísticos, além de paisagismo, da grande decoração e das obras de caráter essencialmente artístico e monumental.

De acordo com o relatório de Cerqueira César, sobre o encontro de educadores promovido pelo SESI, as atribuições relativas ao urbanismo eram também 
26. Como foi o caso em 1944, do já citado 1을 Congresso Nacional de Arquitetos, realizado em São Paulo pelo IAB-SP.

27. Relatório do professor Roberto Cerqueira César sobre O Ensino da Arquitetura e do Urbanismo - Encontro Regional de Educadores Brasileiros (promovido pelo SESI-SP, 1960). In: Revista Sinopses, Edição Especial, 1993, p.167.

28. Idem. partilhadas pelos engenheiros civis, ocasionando uma superposição de atribuições profissionais. Essa superposição era decorrência, como afirma Cerqueira César no relatório, de uma visão da arquitetura como uma das várias especializações da engenharia. Assim sendo, se no contexto de criação de tal regulamentação, isto é, 1933, tal visão fosse justificável pela própria situação do ensino no país, agora com a evolução do mesmo, seria necessária uma rediscussão deste ponto de vista e a sua redefinição e, como contribuição a esta transformação, o IAB, por exemplo, como órgão de classe, procuraria se mobilizar $^{26}$.

Nesse contexto, o relatório de Cerqueira César irá caracterizar uma ambígua postura por parte do Governo Federal no que diz respeito à dupla questão ensinoexercício profissional no campo da arquitetura. Se nesse período o governo reconhecia a necessidade de criar Faculdades de Arquitetura, inteiramente separadas das Escolas de Engenharia, com a função específica de formar arquitetos, isto não se traduzia até o momento em diploma legal, caracterizando a Arquitetura como atividade própria e com características perfeitamente definidas cujo exercício é privativo daqueles que receberam formação especializada ${ }^{27}$.

Ao encerrar tal relatório, após expor as principais atribuições indicadas pela Comissão de professores arquitetos, no Congresso do SESI, Cerqueira César conclui o relatório: Na realidade, da forma como está organizado o ensino de Arquitetura no Brasil, as escolas não estão aparelhadas para dar ao jovem profissional a formação adequada a este amplo campo de ação que deverá enfrentar $^{28}$.

Diante de tais desafios apontados como necessários de serem superados, a FAU USP, por intermédio de 
29. GUNN, Philip. $O$

Departamento de Tecnologia e o Currículo da FAU USP. In: Revista Sinopses, Edição Especial, 1993, p.77.

30. Desde a criação da FAU USP, em 1948, até a Reforma de 1962, a Escola teve os seguintes diretores: Anhaia Mello (19481951), Bruno Simões Magro (1951-1952), Luiz Cintra Prado (1953-1954), Lysandro Melo Pereira da Silva (1954-1956), Pedro Bento José Gravina (1956-1959), Anhaia Mello (1959-1961) e Lourival Gomes Machado (1961-1964).

31. De acordo com informação concedida por Lucio Gomes Machado, na banca de qualificação deste doutorado, Lourival Gomes Machado é diretor da FAU USP entre 1961 e 1964. Até esse período, segundo Lucio, a FAU USP não tinha Congregação, por não ter catedráticos suficientes. Os catedráticos eram da Politécnica. Em consequência, todos os diretores da FAU USP eram catedráticos da Politécnica que tinham sido designados pelo Conselho Universitário para exercer o cargo. Lucio afirma que havia nesse período um movimento dos estudantes, dos arquitetos, de dentro da Faculdade e, também de fora, para que a FAU USP conseguisse uma independência maior da Politécnica e então foram procurar um professor catedrático que pudesse ser diretor da FAU USP, mas que não fosse da Poli. Lucio afirma que seu pai, que era professor catedrático e que já dera aulas na FAU-USP entre 1950 ou 1951 é, em função disto, indicado para ocupar tal cargo. uma parcela de seus professores, irá, nesses anos que transcorrem de 1948 até 1962, apresentar uma contribuição decisiva. Entretanto é necessário pontuar que o desenvolvimento desse processo não se fez apenas a partir de um processo de diálogo entre a Escola e a sociedade, mas, sobretudo, a partir de um processo de resolução de seus próprios conflitos internos para a construção de um determinado senso comum sobre a arquitetura e o seu ensino. Nesse sentindo é que se pode compreender que a Reforma implantada em 1962 é antes ensaiada sem total êxito em 1955 e, depois novamente em 1957, por comissões de professores que naquele momento a despeito de não conseguirem implantá-la, terminam ao menos por estabelecer ideais de um modelo de ensino que seria recuperado e implantado em 1962. Contribuindo para esclarecer esta situação, Gunn ${ }^{29}$, recuperando o ponto de vista de Artigas, um dos principais articuladores da Reforma de 62, aponta que a mesma só foi possível graças ao trabalho do então diretor da FAU USP nesse período, o professor Lourival Gomes Machado que ocupou este cargo entre 1961 e $1964^{30}$. De fato como lembra o professor Lúcio Gomes Machado ${ }^{31}$, seu pai, isto é, Lourival Gomes Machado foi o primeiro diretor da FAU USP que não havia se formado dentro da Escola Politécnica e, não pertencendo a esta tradição, abriu espaço em sua direção da FAU USP para a implantação desses novos ideais que desvinculariam e emancipariam a FAU USP da Escola Politécnica. Aracy Amaral informa que o início da presença do professor Lourival Gomes Machado na FAU USP ocorre entre 1952 e 1953, quando o professor sociólogo e crítico de arte é convidado pelos alunos da FAU USP para ministrar cursos informais sobre arte, ilustrados com palestras e filmes sobre arte. Para esse fim, nesse período, foi convidado a dar essas aulas no quinto ano da Faculdade ${ }^{32}$. 
32. AMARAL, Aracy A. História da Arte na Formação do Arquiteto. In: Revista Sinopses, Edição Especial, 1993, p.84.

33. YURGEL, Marlene. Arquitetura Paulista - 1952-92. 40 anos de contribuição dos arquitetos formados na FAU USP. In: Revista Sinopses, Edição Especial, 1993, p.126.

34. Conforme informação do professor Lucio Gomes Machado, concedida durante a banca de qualificação deste doutorado, a origem do Departamento de História da FAU USP está ligada ao Centro de Estudos Folclóricos organizados pelo GFAU na década de 1950. Este centro depois se tornou Centro de Estudos Brasileiros. Lucio Gomes Machado acrescenta ainda que a primeira coleção de slides sobre arquitetura brasileira foi produzida pelo Centro de Estudos Folclóricos do GFAU, e que foi depois transferido para a biblioteca da FAU USP, antes da Reforma de 1962.

35. Idem.

36. Idem.
Marlene Yurge ${ }^{33}$ descreve a importância do Grêmio da Faculdade de Arquitetura e Urbanismo, o GFAU, entre as décadas de 1950 e 1960, envolvido com o desenvolvimento de atividades extracurriculares, como cursos, pesquisas e documentações, publicações, exposições e concertos. Destaca ainda dentro deste papel ativo assumido pelo GFAU na construção do conhecimento sobre arquitetura, artes e cultura dentro da FAU USP, também, a criação do Centro de Estudos Folclóricos ${ }^{34}$, a montagem de uma slidoteca de arquitetura e dos exemplares do Patrimônio Paulista, além de viagens às cidades históricas e a obras de arquitetura contemporânea. O GFAU também teve uma presença importante como representação discente nas comissões e fóruns da FAU USP para a reformulação do ensino. Yurge ${ }^{35}$ informa ainda que com a Reforma de 62 , com a criação do Museum, este passa a gerenciar as atividades paralelas que já eram desenvolvidas pelo GFAU, assim como os laboratórios e oficinas. Yurgel ${ }^{36}$ esclarece que, em 1964, o Museum e o GFAU foram instintos.

E com relação à importância decisiva de Lourival Gomes Machado, na direção da FAU USP, para que afinal se concretizassem as mudanças ensaiadas em momentos anteriores, sistematizadas através da Reforma de 1962, Artigas, um dos principais articuladores da Reforma, assim se reporta ao papel de Lourival Gomes Machado:

É significativo o fato de a Reforma de 1962 ter sido possível quando a Faculdade era dirigida por Lourival Gomes Machado sendo vice-diretor o matemático Cândido Dias da Silva. Retomávamos a linha cultural nacionalista de 1922 através da Faculdade de Filosofia da USP. Voltávamos à autenticidade de algumas de nossas melhores raízes, enquanto arquitetos. Assim me parece. Basta conhecer a obra de Lourival Gomes Machado, o papel que desempenhou na cultura paulista, 
37. ARTIGAS, Vilanova. Contribuição para o relatório sobre o ensino de arquitetura UIA-UNESCO. In: Revista Sinopses, Edição Especial, 1993, p.135.

38. BIRKHOLZ, Lauro Bastos; NOGUEIRA, Brenno Cyrino.

A FAU USP, sua criação

e funcionamento na Vila

Penteado. In: Revista Sinopses, Edição Especial, 1993, pp.10-11. sua convivência com a crítica das artes, seus estudos sobre arquitetura barroca, para compreender a natureza do ambiente que nos permitiu as reformas de $1962 .{ }^{37}$

Retornando aos antecedentes da Reforma de 1962, o primeiro regimento da FAU USP, e que já apontava a necessidade de mudanças, no sentido de realizar uma maior autonomia da FAU USP, surgiu em 1955 e, conforme informa Birkholz e Nogueira ${ }^{38}$, sobre o regimento:

(...) além da regulamentação de todos aspectos relativos ao corpo discente, à organização do corpo docente e à administração da Faculdade, o regulamento então adotado trouxe a tão desejada organização em Departamentos, a serem definidos posteriormente por Regimento Interno.

E continua:

Quanto à organização pedagógica, não houve, entretanto, com o novo regulamento, apreciáveis modificações, embora a experiência de ensino tivesse se enriquecido grandemente, com influências especialmente nos programas e conteúdos das disciplinas. A denominação das disciplinas e a seriação permaneceram basicamente as mesmas, apenas com algumas modificações quanto à sua localização. Mas nessa época já se movimentavam forças que levariam à Reforma do Ensino de 1962.

As informações de Birkholz e Nogueira contribuem para demonstrar tal processo de evolução contínua por que passa FAU-USP, no período entre 1948-62, sobretudo quando apontam as mudanças dos conteúdos das disciplinas ainda que suas estruturas formais oficiais 
permaneçam as mesmas. E nesse contexto é também importante lembrar que apesar desta indicação da criação dos Departamentos dentro da FAU USP pelo regimento de 1955, estes iriam conviver com o sistema de cátedras, o qual seria extinto apenas em 1969 com a Reforma Universitária do Governo Federal.

Após este primeiro regimento, mais um avanço significativo seria dado com a Comissão de 1957. Por meio de um exame do relatório $O$ Ateliê na Formação do Arquiteto, de Carlos Millan, comprova-se que os ideais ora estabelecidos pela Comissão de 1957 serviram de base e foram incorporados ao relatório de Millan, de 1962. E este relatório, por sua vez, foi a base teórica para as realizações práticas da Reforma de 1962. Entretanto, com relação a tais ideais, que não tendo sido efetivados naquele período de sua realização em 1957, e que foram reabsorvidos em 1962, há que se considerar a ressalva do próprio Millan de que a ideia do ateliê no ensino de arquitetura não havia sido plenamente desenvolvida em 1957.

39. FAGGIN, Carlos. O Ateliê na Formação do Arquiteto: Uma análise Crítica do Documento Apresentado por Carlos Millan na FAU USP, em 1962. In: Revista Sinopses, Edição Especial, 1993, p.131.
Conforme descreve Faggin ${ }^{39}$, a Comissão de 1957 foi composta pelos professores Rino Levi, Vilanova Artigas, Abelardo de Souza e Hélio Duarte. Recuperando os registros das realizações da Comissão de 1957, descritas em 1962, no relatório de Millan, o seu ponto crucial foi a ênfase que, naquele momento, dava às disciplinas de composição (em 1962, redefinidas como disciplinas de projeto). No ponto de vista destes quatro professores integrantes da Comissão de 1957, as disciplinas de composição deveriam ter dentro da escola a importância que ela tem no exercício da profissão. E assim afirmavam de maneira clara a importância do ateliê dentro do Curso de Arquitetura da FAU USP. No mais, segundo o relatório de Millan, a Comissão de 1957 reunia e organizava as cadeiras existentes, estabelecendo distinções de natureza e de função educativa de cada matéria na formação do arquiteto; criava os grupos de matérias de formação 
40. MILLAN, Carlos Barjas. O Ateliê na Formação do Arquiteto. (15 de janeiro de 1962). In: Revista Sinopses, Edição Especial, 1993, p.167. científica, de aplicação técnica, de cultura apropriada e do ateliê. Mas como o próprio Millan ressalva, tais ideias foram incorporadas, mas ainda com a necessidade de se compreender com maior profundidade a natureza do papel do ateliê no novo curso:

O ateliê não foi suficientemente aprofundado em nenhum dos estudos e pronunciamentos até aqui citados; é agora, com o objetivo muito prático da operação, que nos defrontamos com a necessidade de conceituá-lo, estabelecendo sua organização, sua estrutura, seu método e seus programas de trabalho. ${ }^{40}$

Antes de se abordar o detalhamento da natureza do ateliê, é importante considerar que o próprio relatório de Millan de 1962, se por um lado afirma a mudança pretendida pela FAU USP como inovadora no plano nacional, no subtítulo A Experiência Estrangeira, o mesmo relatório vem demonstrar a situação da FAU USP, não tanto de pioneirismo, mas como um esforço para superação de um atraso e atualização de nossa experiência de ensino, se comparada a outros países da América do Sul, onde o ateliê já era pilar estrutural dos cursos de arquitetura:

Em geral, mesmo na América do Sul, muitas dessas medidas citadas estão já em uso há bastante tempo, o ensino em ateliês, com a integração das cadeiras técnicas no desenvolvimento dos trabalhos de projeto através de uma assistência efetiva dos professores dessas cadeiras; o contato contínuo com a planificação ampla em todo o curso, de forma a criar no futuro arquiteto uma mentalidade urbanística real; a formação técnica concentrada na fase inicial do curso são diretrizes assentes e normas habituais e já quase tradicionais nas faculdades uruguaias e chilenas. Na Argentina até dois anos a organização do ensino era semelhante à brasileira, na reforma então realizada foram adotadas diretrizes semelhantes às do Uruguai e do Chile, os primeiros resultados são animadores ${ }^{41}$.
41. MILLAN, Carlos Barjas. O Ateliê na Formação do Arquiteto. (15 de janeiro de 1962). In: Revista Sinopses, Edição Especial, 1993, pp.172173. 
42. GUNN, Philip. $O$

Departamento de Tecnologia e o Currículo da FAU USP. In: Revista Sinopses, Edição Especial, 1993, p.77.
No detalhamento da proposta do ateliê do relatório de Millan, as disciplinas ligadas ao ensino de projeto ainda são referidas como Composição, subdivididas em Pequenas Composições e Grandes Composições. Mas Millan ressalta como objetivos do ateliê: possibilitar ao aluno o domínio da expressão gráfica; desenvolver a sensibilidade e a capacidade criadora e relacionar o ensino da arquitetura com a realidade profissional.

Avançando além da descrição acadêmica do relatório, a visão de Gunn ${ }^{42}$ sobre a aplicação dos conteúdos deste relatório na Reforma de 1962 é extremamente importante para a problematização de um projeto ideológico presente na Reforma de 1962. De acordo com Gunn, a Reforma de 1962 é também definida como Reforma Artigas. E significou para a FAU USP o estabelecimento de um currículo modernista, segundo Gunn, justificando sua afirmação da seguinte maneira:
Esta reforma, iniciada em 1962, foi influenciada por um conceito de projeto altamente vinculado a uma visão social do arquiteto e a uma ideologia racionalista no trabalho de projetar. Neste conceito de prática do arquiteto, a comunicação visual e o desenho industrial do objeto, ambos introduzidos no currículo a partir de 1957, junto com o Planejamento Arquitetônico, Projeto do Edifício e Paisagismo não foram pensados como especializações distintas, mas como momentos do mesmo conceito abrangente de Arquitetura como o campo legítimo de atuação do Arquiteto.

De fato, ainda que se possa questionar esta possível liderança de Artigas dentro de uma FAU USP, sob o poder de outros professores catedráticos, e a despeito de Artigas ocupar diante destes professores apenas o cargo de auxiliar de ensino; conforme relatam as memórias 
43. Sobretudo os depoimentos concedidos por Julio Katinsky, Alessandro Ventura e Lúcio Grinover.

44. PICARELLI, Marlene. $O$ Departamento de Projeto AUP
45. Ver: Revista Sinopses, Edição Especial, 1993, pp.144-155. Este documento foi produzido em 1973, para a UIA, a partir de textos dos professores Vilanova Artigas e Flávio Motta. da época ${ }^{43}$, Artigas desde o início de sua presença na Faculdade ocupou um determinado posto de liderança entre os alunos e os professores mais novos, devido, sobretudo, a sua enorme capacidade de articulação e a seu discurso.

Assim sendo, esta tese de Gunn de tradução da Reforma de 1962, como sendo o estabelecimento de um currículo modernista para a FAU USP, anulando ao máximo possível os resquícios de um ensino tradicional, parece se confirmar se forem consideradas as mudanças adotadas dentro do ensino de projeto no período da Reforma de 1962. Essas mudanças referem-se à substituição do Departamento de Composição, que congregava as disciplinas de Pequenas Composições e Grandes Composições pelo Departamento de Projeto, o qual passaria a reunir as disciplinas de Projeto, Planejamento, Desenho Industrial e Comunicação Visual. De acordo com Picarelli ${ }^{44}$, em 16 de janeiro de 1963, acontece a primeira reunião do Departamento de Projeto sob a presidência de Artigas.

Ainda sobre esse alinhamento do currículo da FAU USP, a partir de 1962, ao extrato da arquitetura moderna, este ponto de vista é também presente no Relatório Sobre o Ensino de Arquitetura no Brasil / UIA-UNESCO, assinado pela FAU USP ${ }^{45}$ :

O que se pode chamar luta pela autonomia do ensino de arquitetura, teve sua fase mais intensa entre 1947 e 1960. (...) Os primeiros modelos de ensino evoluíram de uma posição acadêmica (tradição Belas Artes) e tecnocrática (tradição Politécnica) para uma posição modernista, no sentido estético, influenciada pela Bauhaus e por Le Corbusier e, ao mesmo tempo, voltada para uma compreensão mais ampla dos problemas da construção no país. 
46. Os escritos de Artigas desse período são: Le Corbusier e o Imperialismo (1951); A Bienal é Contra os Artistas Brasileiros (1951); Os Caminhos da Arquitetura Moderna (1952) e Considerações Sobre Arquitetura Brasileira (1954).
É importante lembrar que um dos coautores deste relatório encaminhado, em 1973, para a União Internacional de Arquitetos, a UIA, é o próprio Artigas, que por sua vez foi um dos articuladores da Reforma de 1962 e, nesse contexto, tal texto pode ser tomado como uma espécie de balanço do arquiteto uma década depois da Reforma de 1962, e, vale dizer, aproximadamente duas décadas após os textos de Artigas em que estabelece sua crítica à arquitetura moderna no geral e a Le Corbusier em particular ${ }^{46}$.

E ainda que o texto afirme a opção pela FAU USP de uma posição modernista, no sentido estético, não parece ser este o limite de tal opção. A nova maneira de entender a atividade de projeto e a produção da arquitetura caracteriza a amplitude da adoção de um currículo modernista, após 1962, recuperando a expressão de Gunn, como um conceito de projeto altamente vinculado a uma visão social do arquiteto e a uma ideologia racionalista no trabalho de projetar.

E será este binômio racionalidade do projeto e visão social da arquitetura que fará pertinente à Escola a aproximação do método da arquitetura ao método do desenho industrial. $\mathrm{O}$ que significa o abandono definitivo dos modelos Belas Artes ou Politécnico, a favor de um novo modelo postulado inicialmente pela Bauhaus, mas desenvolvido também por outras escolas em outros países.

Até o presente momento procurou-se demonstrar em que medida a evolução do ensino de arquitetura, paralelo à regulamentação de sua prática profissional no Brasil, entre a década de 1920 e meados da década de 1960, contribuiu para a configuração de um novo entendimento da prática de arquitetura, bem como da incorporação do desenho industrial como atribuição profissional do arquiteto. Se todo esse processo é importante para se 
entender como a Reforma de 1962 incorpora e implanta o desenho industrial como uma prática da arquitetura, para se entender o seu desenvolvimento dentro da FAU USP, durante a década de 1960, até a Reforma de 1968, é necessário um olhar também para outros caminhos percorridos em paralelo pela estruturação do ensino do desenho industrial, o que será tratado no próximo capítulo. 


\section{Desenho Industrial e Ensino}

As disciplinas ligadas ao ensino de desenho industrial dentro do curso de arquitetura da FAU USP têm a sua implantação e o seu início, dentro do currículo da Escola, no ano de 1962. Contudo é importante que se considere que durante a década de 1960, mais precisamente durante sete anos, entre 1962 e 1968, este será o período de amadurecimento para a própria Escola sobre a sua compreensão do desenho industrial, num plano teórico e também prático. As duas datas pontuadas no interior da década de 1960, dentro da história da Escola, têm como acontecimentos importantes a realização de dois Fóruns de discussões sobre o ensino praticado pela FAU USP. O primeiro deles, como referido anteriormente, é aquele que implanta a Reforma de 1962. E, o segundo, é o do Fórum de 1968, um momento de avaliação, de revisão e de indicação de possíveis correções necessárias na trajetória pedagógica adotada.

Com relação à importância desses anos dentro da década de 1960, considerados pioneiros para a experimentação e desenvolvimento da visão do ensino do desenho industrial praticado na FAU USP, Picarelli descreve o esforço coletivo do quadro docente nesse mesmo período:

Os professores, pioneiros e autodidatas, deslocados de outras disciplinas para atuarem na sequência de DI, programaram sua formação na área, com cursos de especialização em outros centros internacionais como: Veneza (Istituto Statale D’Arte

- Corso Superiore di Disegno Industriale), Florença, Estados 
1. PICARELLI, Marlene. O Desenho Industrial no Departamento de Projeto da FAU USP. In: Revista Sinopses, Edição Especial, 1993, p.47.
Unidos e Japão.

Essa medida visava sanar algumas falhas em seu próprio processo de formação profissional, e, criar dentro da FAU USP as condições necessárias para se criar os trabalhos didáticos pertinentes à área.

Esse período inicial se caracterizou por tornar o DI uma atividade específica e consequentemente ligado à necessidade de um processo de ensino mais estruturado e atualizado. Dentro desse contexto estão os primeiros trabalhos curriculares: jogos de xadrez, rádios portáteis, bandejas para alimentação em avião, talheres, louças, eletrodomésticos, brinquedos, relógios, etc.

(...) Esta etapa pioneira encerra-se no fim da década de $60 .{ }^{1}$

O depoimento da memória da professora Picarelli se mostra suficiente para comprovar que, ao longo de toda a cronologia do ensino de desenho industrial da FAU USP, a década de 1960 está inscrita, na história da Escola, como uma etapa pioneira. E isto se justifica no sentido de que a instituição, por intermédio de seus professores, se empenha na construção de um campo particular de conhecimentos sobre desenho industrial. Com este objetivo, um dos pontos privilegiados para a formação do quadro docente será aquele de um diálogo com outras experiências congêneres desenvolvidas por outras escolas, tanto brasileiras como em outros países, contemporâneas ou antecessoras.

No capítulo anterior, procurou-se demonstrar em que medida as mudanças sobre a forma de se compreender o projeto do produto e o projeto da produção em arquitetura, por meio de uma leitura que aproxima a mesma dos procedimentos do desenho industrial, também enquanto projeto e produção, ocasionam, como uma de suas principais consequências, a reivindicação e a incorporação do desenho industrial como atribuição profissional do arquiteto.

Esses anos corridos dentro da década de 1960 podem ser caracterizados para a FAU USP com um sentido 
complementar às transformações dos anos anteriores (desde 1948), a partir da intensa interlocução entre o quadro docente da Escola e as experiências gestadas em outras instituições. A intenção deste capítulo é caracterizar a construção de tal trama de diálogos. Entre os interlocutores diretos ou indiretos da FAU USP no campo do desenho industrial, é possível citar principalmente as escolas pioneiras no plano internacional, quais sejam, os VKhUTEMAS-VKhUTEIN (1917-1930), na URSS; a Bauhaus (1919-1933) e a HfG de Ulm (1953-1968), as duas na Alemanha e, no Brasil, o IAC-MASP (1951-1953) em São Paulo e a ESDI (início em 1963) no Rio de Janeiro.

No caso do Brasil, sobre essas interlocuções referidas, e naquilo que interessa à FAU USP, vale pontuar que alguns dos professores envolvidos com o Desenho Industrial na FAU USP, ou se formaram ou foram professores durante o curto período de existência do curso de Desenho Industrial do IAC-MASP (1951-1953). Por outro lado, no que diz respeito às relações entre a FAU USP e a ESDI experiências didáticas contemporâneas -, ainda que se considerem algumas diferenças decisivas no ponto de vista das duas escolas sobre a temática do desenho industrial, uma série de atividades foi desenvolvida solidariamente, como seminários, organização de concursos públicos de desenho industrial, palestras da área, a existência de professores que transitaram pelas duas escolas, e, o mais importante, a criação conjunta, em 1963, da Associação Brasileira de Desenho Industrial, a ABDI, órgão pioneiro em seu esforço para conscientizar industriais e a sociedade sobre a importância do desenho industrial e, consequentemente, dos profissionais que o realizam.

No que diz respeito às aproximações entre essas escolas brasileiras e as estrangeiras, não são poucos os episódios de presença de ex-professores da Bauhaus ou de professores da HfG de UIm no Brasil, por intermédio do IAC-MASP, da FAU USP ou da ESDI. O intercâmbio de alunos também 
não é uma constatação menos relevante, quando se objetiva avaliar as interlocuções entre estas experiências brasileiras de ensino e aquelas internacionais.

Entre as experiências internacionais de desenvolvimento do ensino de desenho industrial, historicamente, as duas primeiras escolas que passaram por um primeiro processo de sistematização de um campo disciplinar organizado sobre o tema em questão foram os VKhUTEMASVKhUTEIN, criados na URSS em 1920, e a Bauhaus, criada na Alemanha em 1919. As duas Escolas foram as primeiras a dar início à discussão sistematizada da produção do objeto, utilizando-se dos processos industriais em substituição aos métodos artesanais, sendo que, a proximidade temporal possibilitou certas interlocuções entre as duas Escolas. Estas Escolas, operando nesse sentido, deram início a um processo de transformação dos métodos de transmissão dos saberes artísticos, realizando novos modelos de escolas capazes de conciliar a esta dimensão artística uma dimensão utilitária para a produção de objetos. Em muito será dentro deste processo que evoluirá o conceito

2. A ideia é resgatar alguns conceitos teóricos e didáticos desenvolvidos por estas Escolas, cujos ecos são perceptíveis no ensino de desenho industrial da FAU USP. Não é objetivo do trabalho uma análise detalhada das mesmas. As informações, cujas referências bibliográficas não forem explícitas, foram retiradas de GARCIA, Hernan C W S (2001). de arte decorativa e de artes aplicadas para o conceito de desenho industrial ${ }^{2}$.

A primeira Escola que será abordada é VKhUTEMASVKhUTEIN, a qual concentrou a maior parte da vanguarda russa do início do século 20, o Construtivismo. Em um breve quadro histórico, na Rússia pós-revolução de 1917, são criados os Estudos Livres do Estado, em 1918, para formar o povo nas Belas Artes e em substituição à Academia Imperial pré-revolucionária. A evolução destes Estudos Livres do Estado é que dariam origem em 1920 aos VKhUTEMAS (sigla para Ateliês Superiores Artísticos e Técnicos do Estado). Nestes a opção pela formação, no campo das Belas Artes, seria substituída por uma preocupação em formar artistas-construtores, uma expressão que na língua russa estaria muito próxima ao que hoje se define como designer. Artistas-construtores 
3. As outras Faculdades eram: Artes Gráficas, Arquitetura, Têxtil, Cerâmica, Escultura e Pintura. em consequência de um aprendizado tanto no universo das artes quanto das técnicas e processos produtivos da indústria. Ao centralizar as preocupações da vanguarda construtivista russa do início do século 20, os VKhUTEMAS são a cristalização das inquietações artísticas decorrentes da época e a preocupação com a indústria, enquanto fenômeno próprio da modernidade e indispensável para a construção do socialismo, tudo isto respaldado por uma política governamental consciente de sua importância. São essas características que inserem a Escola como um elemento importante dentro de um processo político, e em consequência, com o apoio recebido do Estado, leva à criação de um curso de dimensões gigantescas, se comparada à experiência contemporânea da Bauhaus. Os VKhUTEMAS tinham inicialmente 2.000 alunos e, posteriormente, em torno de 1.500, ou seja, eram dez vezes maior que a Bauhaus, que contava à época com uma média de 150 alunos. Outro ponto importante de se assinalar é que, dentro da evolução de seu ensino, a partir de 1926, a Escola passa a ter uma orientação ainda mais industrial e tecnológica que artística, alterando-se da sigla original a palavra ateliês para institutos. E os VKhUTEMAS passam a ser VKhUTEIN (Instituto Superior Artístico $e$ Técnico do Estado), em 1927.

Com relação aos VKhUTEMAS-VKhUTEIN, três das características de sua estrutura têm para este trabalho um interesse particular, o seu Curso Básico e duas de suas Faculdades, a Derfak e a Metfak ${ }^{3}$.

O Curso Básico, com orientação tanto artística quanto tecnológica, tinha como intenção construir a base do futuro artista-construtor. Os objetivos eram proporcionar uma educação geral artística e prática, científica, teórica, social e política. As disciplinas dividiam-se em dois grupos: matérias artísticas e práticas e matérias teóricas de química, física, matemática, geometria, teoria das sombras, aprendizagem militar, teoria científica da cor, 
uma língua estrangeira e história da arte. O curso básico, com duração de um ano era obrigatório a todos os alunos e pré-requisito para qualquer Faculdade Específica.

Quanto às duas Faculdades mencionadas como de interesse ao trabalho, são a Derfak, ou Faculdade de Madeira, e a Metfak, ou Faculdade de Metal. A primeira é dividida em três seções: composição de mobiliário, composição de arquitetura em madeira e talhado. Entre as preocupações com o mobiliário produzido, estão, principalmente, o desenvolvimento de peças dobráveis para se economizar espaço e a possibilidade de duplas funções a partir de rebatimentos e articulações de peças, como requisitos importantes para solucionar a falta de mobiliário e espaços nas residências populares da URSS da época.

O programa da Metfak objetivava a construção de objetos, projetos e modelos e a composição, isto é, o estudo formal orientado à parte artística do objeto em metal. A preocupação era formar artistas-construtores ou artistasengenheiros (outra expressão utilizada) com competência para resolver problemas tanto na área técnica como na artística aplicada ao objeto industrial.

A partir de 1926, as duas Faculdades, Derfak e Metfak, são fundidas em uma só, originando a Dermetfak, unindo em uma só escola o trabalho com a madeira e o metal e constituindo uma Faculdade ainda mais próxima daquilo que algum tempo depois passou a ser designado como um curso de desenho industrial.

Com relação à Bauhaus, no que concerne à indicação de uma cronologia prévia, entre os seus anos de existência de 1919 até 1933, as fases distintas de sua estruturação podem assim serem divididas: entre 1919 e 1923, caracteriza-se uma fase de fundação; de 1923 a 1928, uma fase de consolidação; e de 1928 até 1933, a fase de desintegração da Escola. De sua localização dentro do 
território alemão, entre 1919 e 1925, sua sede foi em Weimar, entre 1925 e 1932 estabeleceu-se, em Dessau e, por último, entre 1932 e 1933, em Berlim. Seus diretores foram Walter Gropius (1919-1928), Hannes Meyer (19281930) e Mies van der Rohe (1930 a 1930). Entre os professores responsáveis pelo Curso Básico da Bauhaus, conta-se com Johannes Itten (1919-1923), Lazlo MoholyNagy (1923-1928) e Josef Albers (1928-1933). A partir da visualização deste quadro quantificador da Bauhaus, já é possível deduzir do ponto de vista qualitativo a existência de uma Escola como expressão de diferentes abordagens conceituais no seu interior sobre o mesmo tema. Foge ao escopo deste trabalho uma investigação total da Escola, mas assim como no panorama estabelecido sobre a experiência dos VKhUTEMAS-VKhUTEIN, considerase importante determinar um quadro de informações sobre dois aspectos da Bauhaus, quais sejam, a evolução da estrutura de seu Curso Básico e a qualificação que propunha dotar seu aluno para lidar com a produção do objeto pela indústria.

As concepções pedagógicas do período da direção de Walter

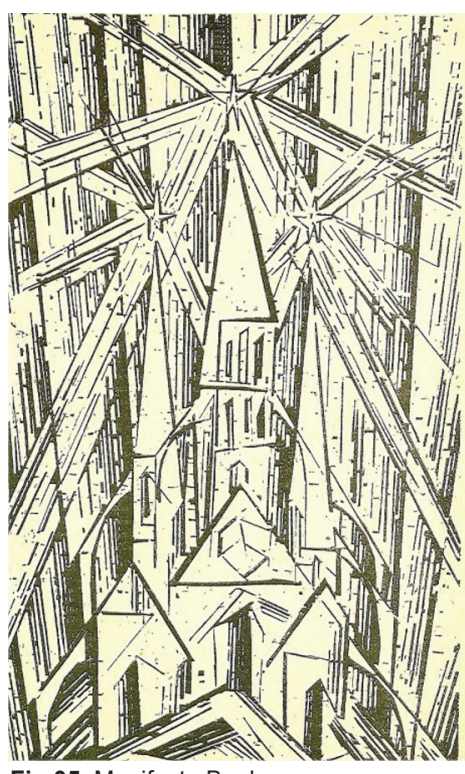

Fig.05. Manifesto Bauhaus e programa com xilogravura de Lyonel Feininger. 1919. Walter Gropius. [fonte: DROSTE, 2001, p. 18]
Gropius são importantes por representarem 0 ponto de vista do criador da Escola e por ser aquela do diretor que esteve mais tempo à frente da Bauhaus (1919-1928). O Manifesto de 1919, elaborado por Walter Gropius, ilustrado com a xilogravura Catedral, de Lyonel Feininger, apresenta as características do programa de ensino inaugural da Bauhaus de Weimar. 
Esta primeira fase do curso, a era Gropius, está baseada em uma proposta de união entre arte e artesanato. A partir deste ponto de vista, os docentes, em substituição à designação de professores, adotam uma autodefinição ligada à categoria profissional dos artesãos, que é a de mestre. Assim sendo, o corpo docente passa a se dividir entre mestres da forma (artistas) e mestres artesãos (conhecedores das técnicas artesanais). Sendo que em pouco tempo estabelece-se uma primazia dentro da Escola dos primeiros sobre os segundos. Ainda balizandose pelas categorias da organização do trabalho artesanal, os alunos passariam evolutivamente pelas categorias de aprendiz, oficial e, ao final, receberiam o título de mestre. Outro ponto não menos importante entre as definições propostas por Gropius, a partir do Manifesto de 1919, diz respeito à defesa de que, sob a supremacia da arquitetura, os ofícios deveriam ser organizados e desenvolvidos harmoniosamente, eliminando-se as diferenças entre artistas e artesãos:

4. WINGLER, Hans Maria. La Bauhaus. Barcelona: Gustavo Gili, 1980. p.41. Apud GARCIA (2001).
! A si pues formemos uma nueva corporación de artesanos, pero sin aquella arrogância que pretendia erigir um muro infranqueable entre artesanos y artistas! Aportemos todos nuestra inventiva, nuestra creatividad en la nueva actividade constructora del futuro, que será todo em una sola forma: arquitectura y escultura y pintura, y que milares de manos de artesanos elevarán hacia el cielo como sínbolo cristalino de una nueva Fe que está surguiendo. ${ }^{4}$

Após o manifesto inicial, Gropius, nas folhas seguintes, passa a apresentar as características programáticas do curso, partindo do conceito de arte unitária, que inclui a escultura, a pintura, as artes aplicadas e o artesanato e que tem como objetivo maior a realização da obra arquitetônica e que faz compreender entre as áreas de extensão do Ensino na Bauhaus: arquitetura, pintura 
e escultura, apesar de que a arquitetura, enquanto disciplina, só veio a acontecer em Dessau em 1928.

Ainda com relação ao Manifesto de 1919, o seu capítulo Subdivisão do Ensino caracteriza as três etapas já mencionadas por que passaria o aluno dentro da Bauhaus: Curso de Aprendizes, Curso de Oficiais e Curso de Jovens Mestres.

Estas são as bases que determinam o desenvolvimento pedagógico da era Gropius. Entretanto o Manifesto de 1919 não indica o Curso Básico que passará a existir seis meses mais tarde, após a contratação de Johannes Itten. Outro ponto de transformação ocorre em meados dos anos de 1920, quando Gropius começa a se distanciar da ideia de criação do novo estilo e a se ocupar da ideia do homem total, focando seu discurso sobre o indivíduo, isto é, o artista ou o projetista. Esta ideia é também compartilhada pelos professores do curso básico, Itten inicialmente, e o seu substituto, mais tarde, Moholy-Nagy. Este princípio defendia uma formação genérica em todos os campos do conhecimento, evitando o que Moholy-Nagy definia como o homem setorizado, em outras palavras, o especialista sem visão de conjunto.

O mesmo princípio será mais tarde, em 1937, mais uma vez defendido por Gropius, nos EUA:

5. GROPIUS, Walter. Bauhaus: Novarquitetura. São Paulo: Perspectiva, 1997. p.26. Apud GARCIA (2001).
(...) O nosso objetivo mais nobre é criar um tipo de homem que seja capaz de ver a vida sem sua totalidade, em vez de perder-se muito cedo nos canais estreitos da especialização. Nosso século produziu milhões de especialistas, deixemo-nos agora dar primazia ao homem de visão. ${ }^{5}$

Inserido nessa primeira direção da Bauhaus por Gropius, está o Curso Básico de Itten com uma orientação que evolui cada vez mais a aspectos intuitivos e esotéricos 
6. Walter Gropius se afasta da direção da Bauhaus em 1928. Devido ao empenho de Gropius em determinar para a Escola uma dimensão também social, $\mathrm{o}$ arquiteto é identificado no plano político com ideias supostamente bolchevistas, fazendo com que a imagem da Bauhaus passe por críticas na opinião pública. Para evitar tal situação de comprometimento da Escola, é que Gropius se afasta de seu cargo. (relacionados a religiões orientais), e, em consequência, se distanciando das concepções de Gropius. Tais diferenças levam Itten a se afastar do Curso Básico da Bauhaus em 1923, ocupando, a partir de então, o seu lugar MoholyNagy. Outro ponto de inflexão é que, a partir de meados dos anos de 1920, no mesmo período da mudança do curso para a cidade de Dessau, o foco subjetivo do curso passa gradualmente a ser substituído por uma abordagem mais objetiva e técnica. O curso começa a se estruturar de maneira mais realista na solução dos problemas da arquitetura e da indústria, começando a se tornarem mais relevantes disciplinas com orientação mais prática, técnica e cientificista, e que irão abrir caminho à direção de Hannes Meyer, onde essas disciplinas ocuparão lugar de destaque do curso 6 .

Como dito anteriormente, com a direção de Walter Gropius, a Bauhaus se orientava mais para os aspectos artísticos, à procura de soluções formais e considerando uma formação genérica para o aluno. Com Hannes Meyer, o curso se torna mais específico e prático, levando a Bauhaus ao seu período de maior produtividade e tudo isto a partir de um contexto em que a discussão estética fica em segundo plano, em favor do predomínio da visão da técnica e da ciência. A arquitetura, por exemplo, passar a ser redefinida em termos de construção, buscandose resolver a organização das funções do homem, materializadas por meio da opção pelas técnicas racionais. Neste novo contexto estabelecido, a forma, ao contrário do ponto de vista de Gropius, seria consequência das questões funcionais e construtivas apenas.

No período da direção de Hannes-Meyer, a Bauhaus se torna eminentemente uma escola de arquitetura com o seu ensino voltado à experiência prática aplicada a problemas reais e com ênfase ao trabalho em grupo. As matérias artísticas, julgadas no período Gropius como de grande importância, a partir de 1928, passam cada vez 
7. Como referido anteriormente, o tema da moradia popular na URSS dos anos de 1920, por meio dos VKhUTEMASVKhUTEIN, também adquire grande importância, e nesse ponto as duas Escolas são semelhantes. mais a assumir uma função secundária dentro da Escola. Disciplinas de acentuado caráter técnico e científico, tais como psicologia, sociologia, engenharia e economia, passam a ser as mais relevantes para o ensino.

Nesse contexto, as discussões sobre a moradia popular passaram a ter grande importância dentro da Bauhaus ${ }^{7}$. As oficinas e o departamento de arquitetura foram redimensionados a partir de um sentido, sobretudo social, e não mais sobre a primazia do sentido estético. Não eram mais incentivados os projetos conceituais ou simplesmente experimentais e mesmo a orientação das oficinas, antes para a aprendizagem, agora era dirigida à produção. Os professores ligados aos primeiros ideais estabelecidos durante a direção de Gropius (a formação mais artística e formalista determinada pelo conceito do homem total) vão aos poucos perdendo espaço dentro da Escola.

A presença de Hannes-Meyer na direção da Bauhaus, a qual também passa por problemas políticos, se encerra em 1930. Ocupa o seu lugar, na direção da Escola, o arquiteto Mies van der Rohe.

Como aconteceu com Hannes-Meyer, Mies van der Rohe foi indicado para novo diretor da Bauhaus por Walter Gropius.

Durante a direção de Mies, houve uma reorientação da Escola no sentido de que se, anteriormente, a mesma era dirigida à produção, agora se voltava para o ensino. 0 curso de arquitetura, anteriormente de nove semestres, agora passou a ser mais específico e foi reduzido para seis semestres, acentuando-se ainda mais a orientação técnica e prática. Relativamente ao Curso Básico, este deixou de ser obrigatório àqueles candidatos que comprovassem preparação prévia nos conteúdos deste curso. As oficinas, antes orientadas ao aprender fazendo, ou seja, com 
8. WICK, Rainer. Pedagogia da Bauhaus. São Paulo: Martins Fontes, 1989. Apud GARCIA (2001). objetivos na produção, agora se voltavam mais para assuntos didáticos e teóricos.

De acordo com Wick ${ }^{8}$, a crítica à pedagogia de Mies van der Rohe e que foi contrária ao espírito original da Bauhaus, que sempre procurou despertar e estimular as habilidades individuais dos alunos, foi que, com a direção de Mies, a Escola se volta para os moldes de um ensino mais acadêmico, repetindo a relação do aluno que aprende fazendo ao modo como o professor faz.

O Curso Básico da Bauhaus, ou Vorkus, tinha a intenção de preparar o aluno para enfrentar a especialização que desejasse cursar, bem como dar uma linguagem comum ao curso e criar uma formação básica comum a todos os alunos. Em grande medida, o Curso Básico é responsável pela determinação das características da Escola como um todo, e as mudanças de orientação de Bauhaus, muitas vezes, são consequência das próprias mudanças do Curso Básico. Os três responsáveis pelo Curso Básico foram: Johannes Itten (1919-1923), Lazlo Moholy-Nagy (19231928) e Josef Albers (1928-1933).

Considerando o Curso Básico de Itten, as divergências de pontos de vista com Gropius eram grandes. Itten não concordava com a ideia da primazia da arquitetura, sob a qual se organizariam todas as demais artes. Por outro lado, também discordava de Gropius sobre o uso da arte para fins alheios à arte, como por exemplo, submetê-la a serviço dos produtos industriais. A orientação do curso de Itten não era no sentido de dar ferramentas diretas para os alunos em seu futuro ofício, estava mais orientado à formação do homem total, a desenvolver a sua criatividade, mas não considerava a sua aplicação direta na arquitetura e no design como imaginava Gropius. Os ateliês de Itten não focavam os problemas construtivos e a sua industrialização, mas buscavam a produção de objetos com características de peças artísticas e de extração 
artesanal.

Gropius, em 1923, convida Moholy-Nagy para substituir Itten no Curso Básico da Bauhaus. O alinhamento das visões de Gropius e Moholy-Nagy leva alguns críticos a considerarem o início da era Gropius na Escola a partir de 1923, com o ingresso deste último.

Moholy-Nagy, formando-se de maneira autodidata, em sua vida profissional foi pintor, tipógrafo, escultor, fotógrafo, desenhista industrial e teórico de arte. Tal diversidade de atividades pode ser entendida como decorrência de sua filosofia do homem total e em oposição ao homem setorizado.

A presença de Moholy-Nagy na Bauhaus, entre outras questões, irá significar, por exemplo, uma contribuição importante à oficina de metal da Escola, quando esta oficina foi redirecionada da orientação artesanal, de Itten, a um trabalho artístico voltado ao produto industrial, incentivando-se a produção seriada e suas condicionantes

9. WICK, Op. cit., p. 200. Apud GARCIA (2001). de projeto e de meio de produção. Considerando, sobretudo a praticidade e o baixo custo, nesse período, é produzida uma série de protótipos aplicáveis à produção industrial. Apesar de neste período Moholy-Nagy não ter projetado pessoalmente nenhum produto industrial, a sua orientação dada à oficina de metais, relacionando-a com a produção moderna, irá influenciar o raciocínio das demais oficinas da Bauhaus.

Em seu ponto de vista pedagógico, para Moholy-Nagy a sua concepção de homem moderno se define em uma crítica ao que ele chama homem setorial (o homem especialista). Para Moholy-Nagy, a estrutura da sociedade e seu sistema moderno de produção é que criam a homem setorial, mas, segundo ele, a técnica jamais deve ser o objetivo, deve ser o meio e, acrescenta, o homem, e não o objeto, é o objetivo?. 
10. Id., p.175. Apud GARCIA (2001).
Esse ideal de desenvolver as diversas potencialidades do ser humano é comum a Itten e a Moholy-Nagy, com a diferença de que para o segundo a aposta nas técnicas e nos meios de produção modernos caracteriza o caminho para atingir tal objetivo:

\footnotetext{
A sociedade é a medida do pensamento humano. É através dela que nos orientamos no universo... E a realidade de nosso século é a tecnologia: a invenção, construção e manutenção de máquinas. Utilizar máquinas significa agir segundo o espírito do século. O espírito transcendente de épocas passadas está superado. Diante da máquina, todos são iguais... A tecnologia não conhece a tradição, nem tem consciência de classe. Cada um pode ser senhor da máquina, ou escravo dela. Reside aí a raiz do socialismo... Nosso século é isso: a tecnologia, a máquina, o socialismo... ${ }^{10}$
}

Com relação a Josef Albers (1928-1933), este foi o que mais tempo ficou responsável pelo Curso Básico. Albers, antes de ser professor, foi aluno da Bauhaus. Apesar da marca pessoal que conseguiu imprimir ao curso, aproveitou, sobretudo, a experiência de seus dois antecessores, de quem foi aluno, isto é, Itten e Moholy-Nagy. Antes de assumir individualmente o Curso Básico em 1928, a partir de 1925, quando passa a ser professor oficial, assume o primeiro semestre do Curso Básico (o segundo é de responsabilidade de Moholy-Nagy) e, antes de 1925, a partir de 1923, já trabalha como jovem mestre no Curso Básico sobre orientação de Moholy-Nagy.

Após essas duas experiências contemporâneas de ensino, isto é, os VKhUTEMAS-VKhUTEIN (1917-1930), na URSS, e a Bauhaus (1919-1933), na Alemanha, tem-se alguns anos mais tarde, no Segundo Pós-Guerra uma outra experiência de ensino de desenho industrial. Uma escola que se propõe inicialmente a ser uma nova Bauhaus. Trata-se da Hochschule Für Gestaltung, a Escola Superior da Forma, 
organizada na cidade de Ulm, na Alemanha. A HfG Ulm (1953-1968) tem a sua criação associada ao suíço Max Bill, que foi seu primeiro diretor, o qual pela divergência a outros professores, quanto a sua defesa de recriar a Bauhaus, o fez demitir-se do cargo de diretor, já em 1956. Assim como a Bauhaus e os VKhUTEMAS-VKhUTEIN, a HfG de Ulm também estrutura o seu Curso Básico que, a partir de 1962, é caracterizado como Primeiro Ano de Estudos, ministrado não dentro de um curso único, mas particularizado dentro de cada Departamento. Entre os Departamentos da Escola de Ulm, contavam-se: Design de Produto, Comunicação Visual, Arquitetura, Informação e Cinema. O último Departamento mencionado foi criado apenas em 1961. A duração de cada curso era de quatro anos.

Com relação ao ideal de Max Bill de repetir em Ulm a Bauhaus, um olhar sobre o que foi a nova escola, é possível afirmar que esta, mais que repetir a Bauhaus, pode ser lida a partir de um processo de evolução do ponto em que havia atingido a primeira. $O$ processo que se inicia com a direção de Gropius de reunir todas as manifestações artísticas sob a arquitetura (Manifesto de 1919) dentro da Bauhaus, até a sua extinção em 1933, evolui para uma visão não da arquitetura como a arte maior que congrega as demais, mais sim para um entendimento em que pelo procedimento de industrialização da produção arquitetônica, esta se iguala às demais artes. É, por exemplo, o que defende a direção da Bauhaus de Hannes Meyer, ao abandonar uma formação mais artística dos alunos da Escola em prol de uma raiz mais técnica. Em Ulm esta polêmica é reacendida entre Max Bill e os professores Otl Aicher e Tomás Maldonado, onde o primeiro defende, na HfG de Ulm, a retomada da ênfase da formação artística que predominava na Bauhaus da era Gropius, e os outros dois professores, questionando a validade de um modelo de ensino fixado há vinte anos passados, irão 
defender uma formação o mais possível ancorada em uma base técnica para Ulm. Ao longo do tempo, dentro de Ulm, predomina esta segunda visão. E, em substituição ao modelo de Gropius, ilustrado com a imagem da construção da catedral medieval que congrega todas as demais formas dos fazeres artísticos, no final da evolução e do amadurecimento desse processo Bauhaus-UIm, em Ulm tem-se a arquitetura unidade as demais artes, não por um conceito de superioridade de sua condição de produção, mas pela determinação de um denominador comum a todas as expressões artísticas envolvidas, qual seja aquele de redefini-las a partir de um novo processo comum de sua produção: o desenho industrial.

Sobre essa relação entre Bauhaus e Ulm, Aicher (1994, p.81) assim se posiciona:

cuando walter gropius nos propuso em ulm llamar a la hochschule für geltaltung la "bauhaus de ulm", no dudamos en rechazar la propuesta.

(...) y nuestra intención no era hacer uma segunda bauhaus, un remedo. nosotros deseábamos intencionadamente apartarmos de ella.

este "nosotros" pide una diferenciación. max bill pensaba a este respecto de otra forma que walter zeischegg, tomás maldonado, hans gugelot o yo mismo. Cierto que max bill tampoco quería um remedo, pero sí una suerte de nueva

11. O texto foi reproduzido de acordo com o que está no livro de Otl Aicher, sem uso de letras maiúsculas.

12. BÜRDEK, Bernhard E. Diseño: Historia, teoria y práctica del deseño industrial. Barcelona: Gustavo Gili, 1994 e LINDINGER, Herbert. UIm Design - The Morality of Objects. Massachusetts: MIT Press, 1991. bauhaus. se empeñó en que también em ulm hubiera, como em la bauhaus, estudios para pintores y escultores y telleres para trabajos de orfebrería em oro o plata. para walter zeischegg y para mí, esto era inimaginable (tomás maldonado e hans gugelot vinieron más tarde, pero compartían nuestro punto de vista. $)^{11}$

Sobre o desenvolvimento do ensino na HfG de Ulm, Garcia (2001, pp. 102-106), partindo das análises de Bürdek e Lindinger ${ }^{12}$, caracteriza seis fases por que passou a Escola. 
Por meio destas seis fases, o que se constata é um gradual processo de evolução da Escola no sentido de confirmar o acima mencionado abandono de uma formação de base mais artística em favor de uma mais técnica como suporte para o projeto do objeto.

A primeira fase, que se estende entre os anos de 1947 até 1953 , trata do processo de criação da Escola, tendo Max Bill como um dos principais organizadores da mesma e contando entre seus recursos financeiros, com doação feita pelos Estados Unidos, no contexto do Plano Marshall de reconstrução da Europa Pós-Segunda Guerra.

A segunda fase se estende entre 1953 e 1956. No ano de 1953, tem-se o início das aulas da HfG Ulm. É característica desse período o início dos conflitos metodológicos entre seus professores. De um lado Max Bill defendendo uma proximidade com a Bauhaus da fase Dessau e um curso onde os assuntos do design eram associados à arte. Outro grupo de professores, entre eles Otl Aicher e Tomás Maldonado, questionava o vínculo com a Bauhaus e defendia uma visão mais técnica e científica do design. Max Bill, que é diretor da Escola a partir de 1953, e reitor, a partir de 1955, na dissolução desse conflito abandona a Escola em 1956 e passa a prevalecer a segunda orientação.

A terceira fase, entre 1956 e 1958, se estabelece desenvolvendo na prática os princípios estabelecidos no final da segunda fase da Escola. Neste sentido, esta fase é caracterizada pela incorporação de disciplinas que orientam o ensino de design para uma dimensão mais tecnológica e científica, sobretudo pela orientação dada por Otl Aicher.

Durante a quarta fase, entre 1958 e 1962, são incorporadas ao currículo diversas matérias técnicas, e novos professores da área de ciências exatas passam a lecionar na Escola. Entre as novas disciplinas contam-se: ergonomia, técnicas matemáticas, economia, física, semiótica, sociologia e 
teoria da ciência. No Departamento de Design de Produto, onde Gui Bonsiepe passa a lecionar, passa a ter especial importância o desenvolvimento de metodologias de design e a preocupação com os sistemas modulares.

A quinta fase, entre 1962 e 1966, é a de reconhecimento da Escola de UIm, passando a mesma a servir de exemplo para a estruturação de várias outras escolas de design no mundo, como foi o caso da ESDI no Rio de Janeiro, por exemplo. A indústria passa a se interessar pela produção da Escola, e diversos projetos são desenvolvidos por equipes da Escola por solicitação dos industriais.

Por fim, a sexta fase, entre 1966 e 1968, trata do processo de fechamento da Escola desgastada por problemas econômicos e pressões políticas, somados ao próprio desgaste interno com assuntos pessoais e políticos.

Na HfG de Ulm, a existência do Curso Básico se faz inicialmente como uma herança do ensino da Bauhaus e, indiretamente, também dos VKhUTEMAS. Esta influência inicial é consequência do período em que a Escola esteve sob a direção de Max Bill, como dito anteriormente, exaluno da Bauhaus. O Curso Básico nestes moldes também é consequência da presença em Ulm, como professores convidados, de Josef Albers e Johannes Itten, excoordenadores do Curso Básico da Bauhaus.

Dentro da Escola de Ulm, o Vorkurs (Curso Preliminar) ou Grundlehre (Curso Básico), à semelhança de como era desenvolvido na Bauhaus e nos VKhUTEMAS, tratava de um período introdutório com um duplo objetivo. Um deles era familiarizar o aluno ingressante com o novo ofício por meio de um aprendizado gradual, do mais simples ao mais complexo. O outro objetivo era cumprir uma limpeza de certos preconceitos e vícios do ensino convencional ou da falta deste. É o que mais tarde Tomás Maldonado e Gui Bonsiepe definirão como a intenção do Curso Básico da Escola de eliminar a contradição entre o 
ensino convencional discursivo e o projetual próprio do ofício do projetista.

Os principais professores que fizeram parte do Curso Básico foram: Max Bill, Tomás Maldonado, Hans Gugelot, Friedrich Vordemberge-Gildewart, Claude Schnaidt, Walter Zeischegg e Abraham A Moles. Como professores convidados: Josef Albers, Johannes Itten, Willian S Huff, Helene Nonné-Schmidt, Walter Peterhans, entre outros.

O curso básico da HfG Ulm, ao longo do tempo, também passa por modificações, de acordo com as mudanças de coordenação do mesmo.

O Curso Básico sob a influência de Max Bill tinha a sua ênfase na análise visual e nas técnicas de representação. Um curso orientado aos aspectos formais do objeto, nos moldes da Bauhaus de Weimar. A partir de 1960, sob orientação de Tomás Maldonado e Otl Aicher, o curso se inclina para uma metodologia abstrata. E, em 1962, - Vorkurs (Curso Preliminar) passa a ser substituído pelo Primeiro Ano de Estudos. Neste novo formato, o ingressante já é direcionado a um dos departamentos específicos da Escola, tendo matérias básicas específicas dentro do próprio curso que escolheu.

Conforme foi referido, a HfG Ulm se estrutura para oferecer seus cursos, em cinco departamentos: Design de Produto, Comunicação Visual, Arquitetura, Informação e Cinema. Destes, interessa particularmente a este trabalho, os departamentos ligados ao ensino de Design do Produto e de Arquitetura.

Ao desenvolvimento do Curso de Desenho industrial, ou Design do Produto, também se faria presente o conflito inicial em Ulm entre a opção por uma visão mais artística ou mais técnica para o design. Um debate que acontecerá, sobretudo, no período relativo aos primeiros quatro anos do curso, ao final do qual se estabelecerá a segunda orientação. Max Bill, em seu desejo de seguir o ponto 
13. Wollner parte do Brasil em julho de 1954 para UIm. Por orientação de Max Bill, Wollner viaja seis meses antes do início do curso para se familiarizar com a língua alemã. de vista da Bauhaus de Weimar, caracteriza o designer como um artista e subordinados a ele devem estar todos os demais profissionais, como técnicos, engenheiros e outros que participam do processo de projeto. Na posição contrária, está Otl Aicher e, mais tarde, Maldonado e Gugelot, no desejo de desvincular a concepção da HfG de UIm da herança da Bauhaus, sobretudo naquilo que diz respeito a se considerar o design como um assunto basicamente de caráter artístico. 0 desfecho desta disputa se dá em 1956, com a saída de Max Bill da Escola de Ulm. O designer brasileiro, Alexandre Wollner ${ }^{13}$ estudou na HfG de Ulm. Foi selecionado por Max Bill, por ocasião da passagem do designer suíço pelo Brasil, no IAC-MASP em 1951. A partir de sua passagem por Ulm, em entrevista a Stolarski (2005, p. 41), Wollner ao ser questionado sobre as diferenças entre a Bauhaus e Ulm, e sobre uma possível inclinação de caráter mais científico para esta segunda, o designer brasileiro assim se posiciona referindo-se primeiro à Bauhaus e depois à UIm:

\footnotetext{
Não. Não havia curso de matemática, nem de física nem nada (na Bauhaus). O que é extraordinário para mim, que não pensava abstratamente, foi que comecei a perceber a relação que cada profissão estabelecia com o projeto. Aprendi que o projeto não era simplesmente uma ideia, que para fazer a forma era preciso informar-se ( $n a$ HfG UIm).
}

Um pouco antes em seu depoimento, Alexandre Wollner explica os conteúdos abordados nas disciplinas da HfG Ulm em confronto como o modelo Bauhaus:

\footnotetext{
Vieram professores de todo o mundo (para UIm) para ensinar coisas de todo tipo: ótica, percepção, comportamento humano. Vimos as necessidades das pessoas, vimos que todo mundo enxerga, mas que ninguém vê. Descobrimos que um
} 
curso relacionado somente à arte e ao artesanato, como da Bauhaus não resolvia nada.

Nesse sentido apontado por Wollner, o curso de design da HfG Ulm, ao contrário da Bauhaus que valoriza o projetista como um artista, irá definir o projeto em uma perspectiva de construção de respostas aos problemas de seu tempo, incorporando novas discussões, como ergonomia, ambiente e ecologia e o desenvolvimento técnico e científico.

Sobre o reequilíbrio desta relação dentro do desenho industrial, entre arte e ciência em Ulm, Garcia (2001, p.114) esclarece:

\footnotetext{
A relação crítica com a arte (na $H f G$ Ulm) não significa que a invalida, mas que agora não é prioritária. O projetista precisa de um lado intuitivo, com capacidade de dar uma boa aparência ao produto, ter visão geral de todas as variantes que envolve o processo projetual e ele não é absoluto, nem está sobre os engenheiros ou técnicos, a idéia é que esta discussão não exista, a não ser que no interesse e respeito mútuo, resolvam o problema.
}

Esta visão do projetista trabalhando em conjunto, dentro do Departamento de Design se torna uma característica didática do curso, incentivando-se o desenvolvimento dos trabalhos em grupos, bem como o seu processo de avaliação coletiva.

A condição de voltar os trabalhos desenvolvidos no Departamento de Design a uma orientação o mais prática possível, outra preocupação constante irá se concretizar pela aproximação da Escola ao contexto industrial: 
14. $\operatorname{GARCIA}(2001$, p. 114).

15. LINDINGER, Herbert. UIm Design - The Morality of Objects. Massachusetts: MIT Press, 1991, p.202. apud GARCIA (2001, p. 117). a problemas reais, passa-se a concretizar principalmente nas experiências que desenvolvem produtos encomendados pela indústria, passando alguns ateliês a funcionar como escritórios independentes, que recebem dinheiro por desenvolvimento dos projetos e protótipos para diversas indústrias como Braun e Kodak entre outras. ${ }^{14}$

Com relação à formação no campo da arquitetura, no Departamento de Arquitetura da HfG, muitas das vezes, no lugar do termo arquitetura, prefere-se a utilização da expressão Edificações Industrializadas. Isto mostra claramente o entendimento que a Escola tinha sobre esse tema. A HfG Ulm objetivou estruturar um curso orientado aos aspectos práticos e à produção, centrandose, sobretudo, nos estudos dos sistemas de produção industrial, como resposta a uma realidade que solicita respostas mais eficientes e econômicas para a construção do edifício. Assim Lindinger (1991) descreve essa orientação adotada:

O termo arquitetura não é muito usado. Usa-se construção. Isso significa que, a arquitetura não é nada mais do que a soma total das atividades presentes na construção, todos os pensamentos e decisões, todas as habilidades e produção dessas habilidades, todas entrelaçadas. Não dizemos apenas construção, dizemos construção industrial como uma descrição de arquitetura e, dessa forma, de construção em um contexto estritamente contemporâneo. Isto aparenta ser certo e necessário. $\mathrm{O}$ arquiteto deve perceber que as construções podem ser melhores produzidas pela indústria, com suas fábricas, máquinas e processos limiares e com materiais e formas que estão ligados a eles. E que, o que quer que aconteça, ele é uma parte desta construção industrial ${ }^{15}$.

Para Ulm, a produção convencional não mais seria capaz de atender às exigências da realidade, bem como se 
16. LINDINGER, Herbert. UIm Design - The Morality of Objects. Massachusetts: MIT Press, 1991, p. 204. apud GARCIA (2001, pp. 118 e 119). mostrava ultrapassado o processo de projeto centrado na figura do arquiteto. Para os professores de UIm, o projeto e a execução deveriam se realizar com a colaboração de diversos profissionais envolvidos no processo, sempre tendo em vista a alta produção e os baixos custos. Para se atingir esses dois objetivos, tal equipe deveria trabalhar com materiais novos e, sobretudo, com novas técnicas de fabricação e montagem.

O curso de Ulm institui disciplinas práticas e teóricas, dentro de um contexto em que as teóricas são preferencialmente associadas à realização de exercícios práticos. O curso busca capacitar um profissional para assumir encargos que envolvam a construção industrializada. A respeito do preparo do estudante para essa adequada e atualizada atuação profissional, como afirma Lindinger (1991):

O objetivo do departamento de construção é treinar os arquitetos capazes de solucionar os problemas provindos da industrialização de construções. Para esta finalidade, o departamento treina o aluno para identificar as tendências incorporadas nesse processo de industrialização e para tornálas a base de seu trabalho: o volume crescente e também o aumento do anonimato da demanda; as mudanças estruturais que ocorrem dentro da organização que projetam e constroem o prédio; a colaboração mais próxima entre todos os envolvidos na construção; maiores demandas de precisão e organização; a mecanização do trabalho de construção; a aplicação de novos materiais e processos; o crescimento de padronização ${ }^{16}$.

Nesse contexto, tem-se uma ênfase no estudo das estruturas pré-fabricadas, voltadas à construção industrial do componente com o menor desperdício, uso de técnicas de ponta, baixos custos e facilitando o trabalho na obra. Tem-se, também, o estudo do módulo (quadrados, cubos, formas triangulares, hexagonais, entre outros) como elemento repetitivo e formador de planos de curvaturas 
simples ou esféricas. Privilegiam-se os estudos das técnicas de montagem, dos elementos de conexão. Assim, com esses estudos, o que se tem em vista é caracterizar a produção arquitetônica à maneira como a indústria realiza a produção de objetos. E, em decorrência, grande parte das discussões do Departamento de Produtos e do Departamento de Arquitetura se equivale, e passam a ser as mesmas.

Tais preocupações estão expressas num Programa de Curso com clara orientação técnica e científica, conforme 17. Revista Ulm 12/13, de março apresentado a seguir ${ }^{17}$ : de 1965. p. 69 apud GARCIA (2001, pp. 119 e 120$)$. 


\begin{tabular}{|c|c|}
\hline período & conteúdo \\
\hline $\begin{array}{l}\text { Primeiro } \\
\text { ano de } \\
\text { estudos }\end{array}$ & $\begin{array}{l}\text { Introdução ao design (os exercícios têm a finalidade de informar o aluno com um sistema } \\
\text { geométrico, visual e construtivo de duas ou três dimensões); seminário (métodos de } \\
\text { produção, materiais de construção); geometria descritiva (polyhedra, plano); técnicas } \\
\text { de representação; teoria da topologia estrutural, análise combinatória, teoria da } \\
\text { probabilidade, teoria da informação; sociologia, economia, fisiologia, psicologia, história } \\
\text { (século XX). }\end{array}$ \\
\hline $\begin{array}{l}\text { Segundo } \\
\text { ano de } \\
\text { estudos }\end{array}$ & $\begin{array}{l}\text { Design e desenvolvimento: introdução à arquitetura de construções industriais (projetos } \\
\text { de baixa complexidade para as necessidades de massa empregadas em métodos de } \\
\text { produção em massa). Ênfase em materiais e métodos de construção industrial, novas } \\
\text { construções de prédios, instalações modernas, condições ambientais internas e externas, } \\
\text { e organização dos tipos de construção. Design técnico (engenharia, métodos de produção, } \\
\text { materiais); seminário de sociologia; seminário de ciência política, estatística (engenharia } \\
\text { mecânica) engenharia física (calor, umidade, acústica); instalações (aquecimento, condição } \\
\text { de luz, iluminação); história da arquitetura moderna; análise e crítica sobre arquitetura; } \\
\text { seminários especiais (coordenação modular, organização de construção, construção } \\
\text { econômica). }\end{array}$ \\
\hline $\begin{array}{l}\text { Terceiro } \\
\text { ano de } \\
\text { estudos }\end{array}$ & $\begin{array}{l}\text { Design e desenvolvimento. Construções industriais. Os projetos têm por finalidade a } \\
\text { definição e solução de problemas complexos em áreas socialmente e economicamente } \\
\text { críticas da arquitetura. Especialistas de ciências e indústrias são chamados para } \\
\text { colaboração (seminários); seminários especiais (coordenação modular, organização de } \\
\text { construção, economia da construção, construção de prédios modernos, planejamento de } \\
\text { padronização terrenos, administração industrial). }\end{array}$ \\
\hline $\begin{array}{l}\text { Quarto } \\
\text { ano de } \\
\text { estudos }\end{array}$ & $\begin{array}{l}\text { Pesquisa. Os projetos de tese de monografia procuram encontrar soluções básicas na } \\
\text { construção industrial e sua arquitetura. }\end{array}$ \\
\hline
\end{tabular}

Tabela 02: Conteúdos

distribuídos nos quatro períodos do Curso de Arquitetura do Departamento de Arquitetura da HfG de UIm.
Entre os principais professores desse Departamento de Arquitetura, conta-se com Max Bill, Rudolf Doernch, Herbert Ohl e Wagner Wirsing.

Ao apresentar as informações sobre os VKhUTEMASVKhUTEIN, a Bauhaus e UIm, não se objetivou uma análise detalhada e exaustiva sobre o assunto. Tal ocupação foge ao escopo deste trabalho. Antes, o que se pretendeu foi estabelecer alguns pontos-chaves necessários para se compreender que tipo de interlocuções será estabelecido entre estas e as escolas brasileiras pioneiras do ensino 
de desenho industrial, e, mais particularmente o caso da Sequência de Desenho Industrial da FAU USP.

O primeiro aspecto que se buscou demonstrar com relação a estas escolas internacionais é que cada uma delas tem um processo evolutivo interno próprio, fruto, sobretudo, das visões e dos conflitos de seus professores. Isto é necessário, pois a Bauhaus sob direção de Gropius não é exatamente a mesma de Hannes Meyer, assim como não é a mesma a HfG de Ulm sob direção de Max Bill e depois aquela orientada por Otl Aicher e Tomás Maldonado, apenas para citar dois exemplos explícitos.

Outro ponto importante foi a detecção da existência de um Curso Básico de caráter introdutório entre todas elas. Muitas vezes entender as afirmações e transformações desses Cursos Básicos significa entender boa parte da orientação conceitual de cada escola como o todo de um corpo doutrinário em si. No caso das escolas brasileiras, a adoção de Cursos Básicos, ou, de conteúdos básicos, sempre esteve presente. Estes cursos, ao se proporem o duplo objetivo de dissolver preconceitos trazidos pelos alunos e produzir uma nova base conceitual e intelectual comum para os conteúdos específicos, apresentam os próprios conceitos adotados pelas escolas na sua totalidade.

Evolui, dentro desse processo de análise dessas escolas internacionais, a caracterização do profissional egresso entre a concepção do generalista e do especialista. Gropius, Johannes Itten e Moholy-Nagy, o primeiro como diretor, os demais como professores do Curso Básico da Bauhaus, irão fazer a defesa do homem total contra o homem setorizado. Ainda que Moholy-Nagy, mais do que Itten, defenda uma maior proximidade do aluno da Bauhaus com a indústria, Nagy reafirma a sua crítica em seu discurso da sociedade de especialistas da era da indústria. Como apontando anteriormente, ele mesmo afirma: $O$ nosso objetivo mais nobre é criar um tipo de 
homem que seja capaz de ver a vida em sua totalidade, em vez de perder-se muito cedo nos canais estreitos da especialização. Ainda dentro da Bauhaus, com a direção de Hannes Meyer, a partir de uma caracterização do curso em favor do predomínio de uma visão técnica e mais científica, o próprio ensino de arquitetura passa a ser redefinido em função de uma ênfase na construção. Em Ulm, esta segunda opção se torna, então, muito clara. O desenhista industrial, não mais definido como um artista, é um profissional com conhecimentos específicos, um especialista que não está mais acima da equipe de trabalho na qual agora deve se integrar. A sua relação com engenheiros, técnicos ou demais especialistas é igualitária pela mesma importância que todos têm dentro do processo de trabalho, e particularizada em cada um pela contribuição específica de sua formação. Resumindo, a visão do desenhista industrial evolui nessas escolas de uma concepção do artista, e de formação generalista, que passa a dar lugar ao técnico, com conhecimentos específicos.

$\mathrm{Na}$ esteira da caracterização do desenho industrial, na trajetória VKhUTEMAS-VKhUTEIN, Bauhaus e UIm, o que se percebe é o amadurecimento histórico do significado do mesmo. Se considerarmos o discurso produzido para se justificar a existência dessas três escolas, é claro em todas elas a sua justificativa social. Desde os VKhUTEMASVKhUTEIN, em seu auxílio em atender às demandas de uma nova sociedade comunista na URSS até o caso da Bauhaus e de Ulm, implantadas no contexto de uma economia capitalista, mas sem perder o mesmo foco no atendimento das demandas sociais, se percebe que tal justificativa social se repete. $\mathrm{O}$ que evolui nesse processo é a visão conceitual do desenho industrial. Pois se nos VKhUTEMAS-VKhUTEIN e na Bauhaus, o desenhista industrial é formado entre o artista e o artesão, na HfG Ulm a sua base de formação é declaradamente técnica e científica. Nos VKhUTEMAS-VKhUTEIN e na Bauhaus, tem- 
se na formação do desenhista industrial, pode-se assim dizer, pelo caminho da arte e de artesanato, um modo de se aproximar da indústria, sem perder totalmente uma identidade inicial. Na segunda situação, com a HfG Ulm, pelo vínculo irrestrito à técnica e à ciência para se formar o desenhista industrial, tem-se um modo de se integrar à indústria. Tudo entendido dentro de um processo de evolução de um ponto de vista até o outro.

Por último, com relação à arquitetura, em uma análise a partir da mesma linha evolutiva VKhUTEMAS-VKhUTEIN, Bauhaus e HfG Ulm, o que se constata é uma evolução da ideia de arquitetura, onde também se mantém o seu papel social, mas se opera a sua ressignificação em dois aspectos: primeiro em sua relação com as demais artes e, segundo, com a sua maneira de ser produzida. Mas um e outro ponto são as duas faces de uma mesma moeda.

O Manifesto de 1919, de Walter Gropius, o qual fundamenta a criação da Bauhaus, não por acaso é ilustrado pela xilogravura de Lyonel Feininger de uma catedral medieval. Ela ilustra o conteúdo do texto. Pois Gropius idealmente propõe uma integração de todas as artes em torno de uma arte-mãe, ou de uma arte maior: a arquitetura. O símbolo desta afirmação? A catedral medieval significa que para a sua construção confluíam todos os saberes artísticos organizados nas corporações de ofício. Ou seja, todas as expressões artísticas, ou artesanais, se materializando a partir de uma manifestação arquitetônica. Como demonstrado, não por acaso, no início da Bauhaus, as designações e as relações que estas determinavam, professor e aluno, são substituídas por aprendiz, oficial e mestre. Com Hannes Meyer, dentro da própria Bauhaus, este conceito começa a ser substituído em função de uma reorganização do trabalho, não mais a partir do ideal das corporações de ofício medievais, mas em busca de uma organização de produção da arquitetura (e do objeto), considerando-se a nova estrutura produtiva 
instaurada pela máquina, isto é, a indústria.

Na HfG de Ulm, a oposição à Bauhaus não se faz no sentido de considerar a Bauhaus uma experiência inválida. O que se deseja é evoluí-la, considerando-se, sobretudo, os novos contextos sociais, culturais, econômicos e tecnológicos que se vive após a Segunda Guerra Mundial. Nesse quadro, para se entender o ensino de arquitetura dentro de Ulm, não significa pouco que a Escola declare preferir o termo Edificações Industrializadas em detrimento do secular termo Arquitetura. E Ulm irá desenvolver uma teoria de arquitetura baseada no seu processo de produção. E a relação aqui se inverte. Se no início, com o Manifesto de 1919, a arquitetura cumpriria o papel de tutelar as demais artes, no final desse processo, em Ulm, arquitetura, agora edificações industrializadas, abriria mão de uma áurea que Ihe fazia superior, e se integrava a todos os demais cursos ensinados em Ulm por compartilhar o mesmo processo produtivo. Em outras palavras, tudo isto equivale a dizer que, na HfG de Ulm, arquitetura se torna desenho industrial.

Essas todas são questões que nascem dentro dessas Escolas, mas que nas experiências brasileiras ressurgiram, contudo naturalmente ambientadas em nosso contexto histórico, político, econômico, social, etc. A historiografia de arquitetura e de desenho industrial no Brasil assinala entre as experiências pioneiras de Ensino de Desenho Industrial as seguintes Escolas: O Instituto de Arte Contemporânea do Museu de Arte de São Paulo, o IAC-MASP, Escola que existiu por um curto período de tempo, entre 1951 e 1953, onde além de outros cursos, era oferecido o de Desenho Industrial. Em São Paulo, a Sequência de Desenho Industrial da FAU USP, iniciada a partir de 1962. A criação da Escola Superior de Desenho Industrial, a ESDI, do Estado da Guanabara, RJ, em 1963. Entre estas Escolas, a regulamentação do ensino de desenho industrial pode ser caracterizada da seguinte 
maneira: No IAC-MASP como um curso de especialização (e não de nível universitário). A FAU USP será a primeira a oferecer dentro de um curso de graduação (de nível universitário) entre outras formações, a de desenhista industrial. E a ESDI será a primeira a criar uma graduação totalmente voltada ao ensino de Desenho Industrial.

Considerando a primeira dessas experiências de ensino de desenho industrial no Brasil, o Museu de Arte Moderna de São Paulo é criado em 1947. Na procura em atender a um dos seus objetivos mais importantes, que é o seu papel educativo no universo das artes e da cultura, os seus organizadores, em 1951, dão início ao funcionamento do seu Instituto de Arte Contemporânea. O objetivo principal da Escola era oferecer cursos, como apontado, no campo das artes e da cultura, com a duração de dois anos e estruturados em três etapas: Curso Preliminar (obrigatório), Cursos Especializados (livre escolha) e Cursos Complementares (Facultativos).

Em texto de apresentação do programa pedagógico do IAC, Pietro Maria Bardi, seu diretor, apresenta no plano de intenções a ideia de que a Escola pudesse funcionar, entre outros objetivos, como uma escola para a formação de desenhistas industriais:

Museu - Instituto de Arte Contemporânea

Programa

O Instituto de Arte Contemporânea é uma iniciativa do Museu de Arte de São Paulo. Tem por objetivo incrementar o estudo e as pesquisas no terreno das artes aplicadas. Adota uma orientação nitidamente contemporânea. Procura orientar a produção industrial, a fim de que os objetivos, de uso comum e de alcance coletivo, atinjam um nível estético elevado e em coerência com a época atual. Assim, o Instituto está convencido de contribuir, através das artes aplicadas, para a formação de uma consciência clara da função social da arte. ${ }^{18}$ 
Ostermos do discurso de PMBardiexpressos anteriormente e que nortearam o breve período de existência do IAC, ainda que este não tenha se caracterizado por um ensino de nível superior, buscaram formar quadros profissionais capazes de inserção no processo de produção industrial com o intuito de qualificar os seus produtos. Os termos adotados para definir os objetivos do Instituto de Arte são precisamente: contribuição ao desenvolvimento das artes aplicadas, no sentido de orientar a produção industrial e fazer cumprir uma função social da arte.

Como referido, o curso foi dividido em três etapas de formação: curso preliminar, cursos especializados e cursos complementares.

Sobre estas categorias, Leon (2006) informa que o curso preliminar era obrigatório a todos os alunos matriculados no curso, e visava a uma orientação básica ao bom aproveitamento dos cursos de especialização. Neste sentindo, aqui se reproduz um modelo semelhante ao dos Cursos Básicos da Bauhaus e dos VKhUTEMAS. Com duração de um ano, o curso abordaria as disciplinas História da Arte, Noções de Arquitetura, Teoria da Forma (com aulas sobre geometria, teoria do espaço, teoria da cor e da luz, estudo dos materiais, composição e teoria da construção), aulas práticas de Desenho da Natureza, Contato e Pesquisa com Materiais, Modelagem, Construção e Aplicação de Cores.

O Curso de Especialização, de livre escolha dos alunos, contaria, entre as especialidades oferecidas, com a possibilidade de se dedicar aos seguintes materiais, ou temas: Pedra, Madeira, Metal, Cerâmica, Vidro, Tapeçaria e Tecelagem e Artes Gráficas e Fotografia (composição tipográfica, técnica tipográfica, publicidade, layout, cartaz, gravura e fotografia). Aqui mais uma vez é clara a semelhança com os cursos da Bauhaus e dos VKhUTEMAS, 
19. Como se verá mais à frente do trabalho, dentro da FAU USP também houve uma bipolarização entre os professores sobre um método de ensino com foco ou no material ou na técnica (industrial). Alessandro Ventura, professor da FAU USP, em entrevista, usa como exemplo-limite dessa discussão a própria invenção do plástico usado pelos designers: trata-se de um material ou de uma técnica de produção? uma vez que nestes dois também o aprendizado nos ateliês era organizado de acordo com o trato específico com cada material. E também de certa forma, parece ressurgir a mesma problemática inicial da Bauhaus que depois evolui e amadurece em Ulm. Isto é, tratou-se de um esquema de ensino, ainda que a tônica do discurso oficial fosse a indústria, centrada muito mais no material que no processo produtivo ${ }^{19}$.

Como cursos complementares programados, estavam listados: Evolução do Concreto Armado, a ser ministrado por Pier Luigi Nervi, Arquitetura dos Jardins, por Roberto Burle Marx, e Acústica na Arquitetura, por Rino Levi.

A tabela abaixo apresenta as disciplinas do IAC MASP ministradas em 1951 e relaciona o nome dos professores responsáveis:

\begin{tabular}{|c|c|c|}
\hline professor & disciplina & meses \\
\hline Pietro Maria Bardi & História da Arte & março, abril, maio e junho \\
\hline Oswaldo Bratke & Materiais & março \\
\hline Lina Bo Bardi & Elementos de Arquitetura & março, abril, maio e junho \\
\hline Roberto Sambonet & Desenho à mão livre & março, abril e maio \\
\hline $\begin{array}{c}\text { Mansueto E. Koscinski e } \\
\text { Roger Bastide }\end{array}$ & Seminário & março, abril e maio \\
\hline Jacob Ruchti & Composição & março, abril, maio e junho \\
\hline André Osser & Representação gráfica maio \\
\hline Roger Bastide & Seminário (sociologia 2) & abril \\
\hline Oswaldo Bratke e Dudus & Materiais & maio e junho \\
\hline Zaltan & Materiais & abwaldo Bratke \\
\hline
\end{tabular}

Tabela 03: Disciplinas do IAC MASP ministradas em 1951. Origem: Livro de Chamada Cursos Regulares do IAC MASP. In: LEON, 2006, p.45.
Além dessa semelhança entre a estrutura curricular do IAC MASP e da Bauhaus, sobretudo, mas indiretamente também aos VKhUTEMAS, pela caracterização de um Curso Básico e pelos Ateliês organizados a partir dos materiais a serem trabalhados, outras foram as influências da Escola. Uma delas é a própria presença do designer suíço Max Bill. O IAC é inaugurado em 1 o de março de 


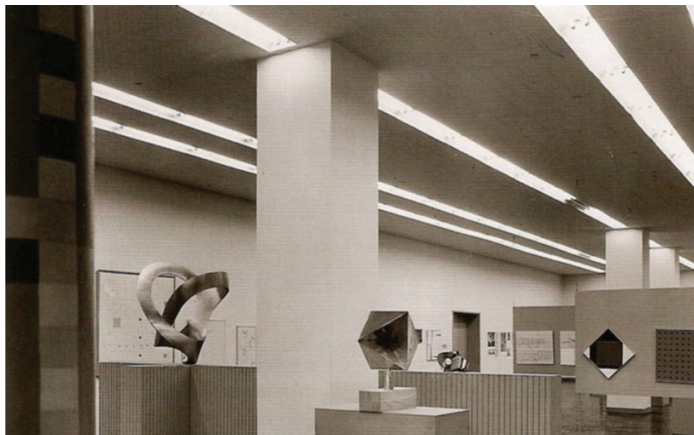

Fig.06. Vista da exposição de Max Bill no MASP. São Paulo, 1951. [Fonte: MAM-SP. Concreta '56: A raiz da forma. Catálogo. 2006]

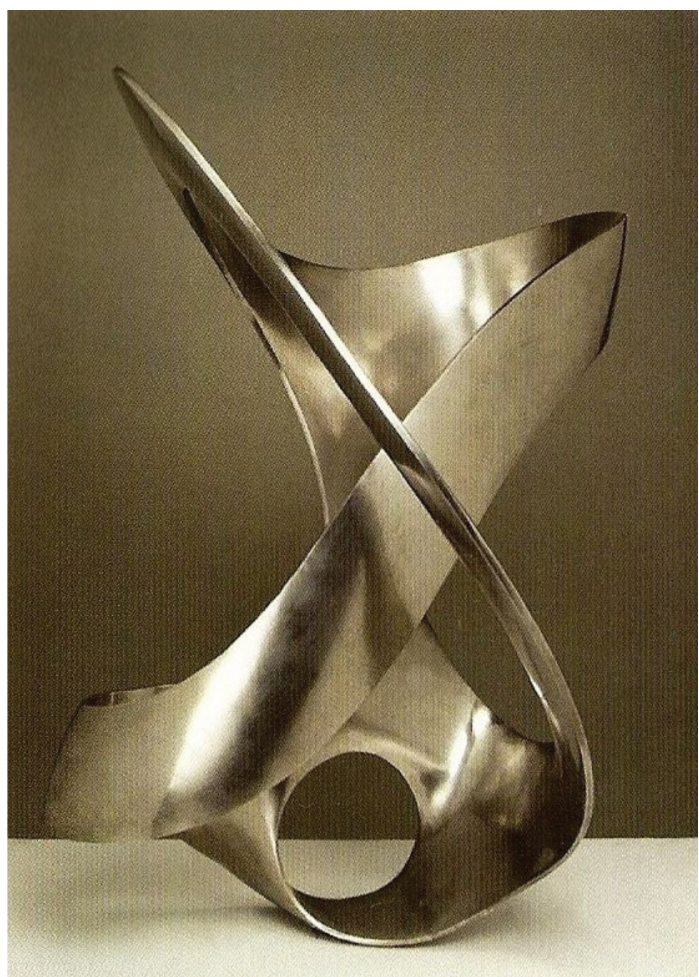

Fig.07. Unidade Tripartida. 19481949. Autor: Max Bill. [fonte: BRITO 1999, p. 38]

20. Depoimento de Wollner a STOLARSKI (2005, p. 37). A respeito desta polêmica de Max Bill e sua crítica à arquitetura moderna brasileira, a réplica de Lúcio Costa, a postura de Lina Bo Bardi na revista Habitat ver NOBRE (2008).
1951, mesma data da inauguração de Exposição de Bill no MASP. Também 1951 é o ano da I Bienal Internacional de São Paulo, quando Max Bill recebe o prêmio principal da I Bienal, pela realização de sua escultura Unidade Tripartida (1948-49). Entretanto é bom lembrar que Bill vem ao Brasil apenas em 1953, como júri da II Bienal de São Paulo e, apenas nesse ano, fala diretamente aos alunos da Escola. A divulgação de Max Bill nesses anos o apresenta como ex-aluno da Bauhaus, mas entre os anos de 1951 e 1953, Max Bill, na verdade desde 1947, já estava envolvido com a criação na Alemanha, da HfG UIm, a qual algum tempo depois contaria entres seus alunos com alguns brasileiros. Entre estes, o próprio Wollner, indicado por PM Bardi a Max Bill. Na ocasião da exposição de Bill no MASP em 1951, ainda que esta fosse realizada circunscrita apenas à obra do suíço, PM Bardi, no texto de abertura, já faz referência à futura Escola de UIm. E sobre a recepção desta exposição, Wollner recorda:

Ele (Max Bill) não pode vir porque já estava envolvido na criação da Escola de Ulm. Ele só veio ao Brasil em 1953. Nenhum crítico de arte, nessa época, falou ou escreveu nada sobre a exposição - mas todo mundo comentou a palestra que ele fez contra o Niemeyer ${ }^{20}$.

Ainda comentado a sua aceitação como aluno de Ulm, 
Wollner explica:

21. Depoimento de Wollner a STOLARSKI (2005, p. 38). Os outros brasileiros que estudaram na HfG Ulm foram Almir Mavignier, as irmãs Frauke e llse Koch-Weser (do Paraná) e Mary Vieira.
Quando Max Bill veio ao Brasil, perguntou a Bardi se algum brasileiro poderia ir à Escola de Ulm, ao que ele respondeu: Tem o Geraldo de Barros... - que trabalhava no laboratório de fotografia do museu, tinha mais envolvimento com projetos de design, tinha vencido o concurso de cartazes do IV Centenário - e tem o Alexandre aqui. O Geraldo foi escolhido, mas não pode ir: era recém-casado (...). Então o Bardi e o Geraldo me indicaram. Fiz uma pequena entrevista (...) e fui aprovado. ${ }^{21}$

Numa certa medida, esta presença de Max Bill, no Brasil e no IAC MASP, irá se caracterizar como um vetor da influência dos ideais da Bauhaus e de Ulm e será em muito pela presença de Bill que terá início o desenvolvimento da arte concreta no Brasil, influenciadora do desenvolvimento de um certo expoente do desenho industrial brasileiro.

Mas não são apenas estas as referências sobre as quais se fundamenta a experiência de ensino dentro do IAC MASP. A respeito da organização de sua Escola de Desenho Industrial em diversos documentos, fica clara uma relação da Escola não apenas com a Bauhaus de Dessau ou a Escola de UIm, mas também com o Institute of Design de Chicago, às quais se associam respectivamente os nomes de Walter Gropius, Max Bill e Moholy-Nagy. O que aponta também uma perspectiva de aproximação não apenas com a vertente do design desenvolvido na Europa, mas também com o transplante do mesmo para os Estados Unidos, tirando partido das características do avançado processo de industrialização deste país.

O arquiteto Jacob Ruchti, professor de Composição no IAC, em artigo para a revista Habitat, assim expressa a filiação da Escola de São Paulo: 
22. RUCHTI, Jacob. Instituto de Arte Contemporânea. Revista Habitat no 3. São Paulo, 1951 p.62. O Institute of Design de Chicago se estabelece como uma continuação da experiência Bauhaus nos EUA. MohoyNagy, ex-professor da Bauhaus, devido à ascensão do regime nazista alemão, migra para os Estados Unidos em 1937 e organiza a New Bauhaus. Em 1938, inaugura a sua própria escola, a School of Design que posteriormente se tornou um curso superior com o nome do Institute of Design em Chicago. $\mathrm{O}$ arquiteto Serge Chermayett substitui Mohoy-Nagy na direção da Escola, posto que Nagy falece em 1946.

23. RUCHTI, Jacob. Instituto de Arte Contemporânea. Revista Habitat no 3. São Paulo, 1951, p.62.

24. Loewy chegou a abrir nos anos de 1950, em São Paulo, uma filial de seu escritório norte-americano, tendo inclusive entre seus encargos a realização de trabalhos gráficos para as indústrias Matarazzo. Entretanto foi breve a existência desta filial no Brasil, que não chegou a ter a inserção prevista no mercado brasileiro e tampouco os lucros desejados.
O curso do IAC de São Paulo é uma adaptação às nossas condições e possibilidades do célebre curso do Institute of Design de Chicago, dirigido pelo arquiteto Serge Chermayett, e fundado em 1937 por Walter Gropius e Moholy-Nagy como uma continuação da famosa Bauhaus de Dessau. ${ }^{22}$

E complementa:

O IAC representa portanto em São Paulo - de uma maneira indireta - as principais idéias da Bauhaus, depois do seu contato com a organização industrial norte-americana. ${ }^{23}$

Além dessa proximidade do IAC MASP com a Bauhaus, Ulm e o Institute of Design de Chicago, o IAC realiza também uma aproximação com o desenvolvimento de outra vertente do design nos Estados Unidos. Se por um lado considerou a continuidade da corrente do design de matriz racionalista e funcionalista, que se desenvolve como desdobramento da Bauhaus a partir de seus ex-professores que migraram para os Estados Unidos em decorrência do nazismo alemão, também não passará despercebida ao IAC a outra corrente do design norte-americano, definida como o styling, cuja maior representação era o trabalho de Raymond Loewy ${ }^{24}$ e cujo formalismo era bastante criticado por aqueles ligados à corrente funcionalista.

Com relação ao styling e a sua crítica recebida dos funcionalistas, Cardoso (2004, pp.131-132) explica:

O termo styling, ou estilização, tem sido aplicado de maneira sistemática e quase sempre pejorativa aos trabalhos de uma série de designers americanos que se notabilizaram nas décadas de 30 e 40, dentre os quais cabe destacar não 
apenas (Raymond) Loewy como também Harold Van Doren, Henry Dreyfuss, Norman Bel Geddes e Walter Dorwin Teague. Acusados de praticar um tipo de design que consiste a dar a qualquer objeto um tratamento superficial de reformulação estética - ou seja, de reduzir o design a uma questão de projetar novas embalagens para velhos produtos - o seu trabalho tem sido constantemente menosprezado nos relatos escritos a partir de uma perspectiva modernista, quase na proporção exatamente inversa em que têm sido supervalorizados os esforços das vanguardas européias. (...) No caso de Raymond Loewy, por exemplo, é obviamente infundada e reducionista a acusação freqüentemente repetida de ser um mau designer ou um mero homem de marketing.

25. Com o fechamento em 1953 do IAC MASP, a sua Escola de Propaganda é transferida para a FAAP, caracterizando-se como a única escola do IAC a ter uma sobrevivência assegurada, após o fechamento da mesma.
O professor PM Bardi, como atestam os documentos produzidos quando de sua direção do IAC MASP, sempre explicitou a grande amplitude da conceituação de design que deveria contemplar a Escola. Pretendia a realização de objetos domésticos, móveis urbanos, a comunicação visual e o design gráfico, dentro deste último, o editorial, produção de cartazes, identidade visual e sinalização. Neste contexto, no IAC, além do curso de desenho industrial, somaram-se a este várias outras atividades, como cursos no campo da moda e o próprio início de uma Escola de Propaganda dentro do MASP25. Tais experiências e a forma de conduzi-las dentro da Escola atestam, além da herança manifesta por Bardi com relação à Bauhaus de Dessau, ao Institute of Design de Chicago e a UIm, que a Escola conseguiu estabelecer-se com determinadas características que não a filiavam apenas a esta herança funcional-racionalista declarada. O IAC MASP e PM Bardi, segundo depoimento de Luiz Hossaka, ex-aluno do IAC MASP e depois funcionário do MASP, a Leon (2006), caracterizam dentro do IAC a difusão da corrente do styling por meio do trabalho de Raymond Loewy: 
do professor Bardi sobre Raymond Loewy, via a importância do desenho bem planejado e isso me ajudou a formar essa idéia. O professor Bardi mostrou o slide do Studebaker. Na época, todos os carros que circulavam no Brasil eram americanos, da Ford ou da GM. Com o trabalho de Loewy ficou claro o que era design - o Studebaker, o cigarro Lucky Strike e também o desenho dos trens.

O IAC MASP teve duas turmas de alunos, uma em 1951 e outra em 1952. Entre 1952 e 1953, as duas turmas foram unificadas e, em 1953, quando a escola contava com 5 e 10 alunos apenas, fechou. PM Bardi objetivava uma aproximação do IAC com as indústrias paulistas no sentido de conseguir o apoio das empresas e a sobrevivência da Escola. Bardi tentou esta aproximação com várias indústrias, mas conseguiu muito pouco, em decorrência de que o IAC se viu obrigado a encerrar as suas atividades com as duas turmas de 1951 e 1952 reunidas em uma só classe.

Mas antes de se encerrar este foco sobre o ensino de desenho industrial no IAC MASP, cumpre destacar alguns profissionais que, sendo inicialmente professores ou alunos do IAC, algum tempo mais tarde dentro da FAU USP, dariam prosseguimento às discussões em torno do ensino e do ofício do desenho industrial em São Paulo.

O primeiro deles certamente é o professor Flávio Motta. Graduado em pedagogia pela FFLCH USP, em 1947, trabalhou no Instituto de Educação Caetano de Campos, no MASP e na FAU USP. Na FAU USP, foi professor a partir de 1954 e se tornou catedrático a partir de 1968. Sua participação no IAC MASP se fez como assistente de P M Bardi, inicialmente como monitor do Museu, dedicandose à montagem de exposições e à explicação das mesmas aos visitantes do Museu. No IAC, Flávio Motta ministrava cursos de História da Arte, segundo depoimento do exaluno da Escola, Ludovico Martino: O Pietro Bardi dava 
26. Entrevista concedida em 05 de março de 2009.

27. Na ocasião da banca de qualificação deste doutorado, Lucio Gomes Machado informou que o arquiteto Sérgio Ferro, por exemplo, também ministrava aulas nesse curso da FAAP. $\mathrm{O}$ arquiteto Vilanova Artigas escreve um texto sobre Desenho Industrial para uma exposição deste tema a ser inaugurada em 1962, na FAAP (ver anexo).
História da Arte paralelamente ao Flávio Motta. O Flávio Motta complementava o curso de História da Arte de forma muito viva. Ele empolgava os alunos. Flávio Motta, no início de sua carreira docente na FAU USP, no final da década de 1950, início da década de 1960, ministra também na Fundação Armando Álvares Penteado, a FAA, em São Paulo, um curso para educadores na área de desenho. Katinsky recorda sobre o sentido deste curso:

Ele (Flávio Motta) bolou uma coisa muito bonita para a época. Formar artistas no Brasil não dá, não tem mercado. Então a ideia dele, que, aliás, foi a própria história dele, ele é um excelente pintor, era formar professores de desenho ${ }^{26}$.

Esse curso existiu na FAAP ao longo do período de tempo transcorrido entre o fechamento do IAC MASP e os primeiros anos de funcionamento da Sequência de Desenho Industrial na FAU USP. Entre outras características, pelos professores que por ele passaram, pode ser entendido como uma espécie de ponte entre as duas escolas, o IAC e a FAU USP. Apesar de se tratar de um curso de habilitação em desenho, ou artes plásticas, havia dentro dele uma abordagem também de conteúdos do desenho industrial ${ }^{27}$.

Essa trajetória de formação e de ensino de Motta pelo IAC, pela FAAP e pela FAU USP, com uma olhar a partir da história para as questões do desenho, das artes e da arquitetura contemporânea, irá de maneira decisiva influir na constituição de uma determinada visão do desenho industrial gestada dentro da FAU USP a partir do seu Departamento de História. Uma visão em muito compartilhada, entre outros, por Julio Katinsky, conforme o seu próprio depoimento de vida. 
28. A cópia deste prospecto foi concedida pela professora Maria Cecília França Lourenço, do Departamento de História da FAU USP.

29. Escola Livre de Artes Plásticas. São Paulo, abril de 1949. (Folheto de propaganda).
O MASP é criado em 1947. Em 1948, ocorre a criação do Museu de Arte Moderna de São Paulo, o MAM SP. Outra informação que confirma a dedicação de Flávio Motta como educador no campo das artes pode ser extraída de um prospecto de criação de uma Escola Livre de Artes Plásticas do MAM SP ${ }^{28}$. Nesse período, Motta, que já estava envolvido com as atividades do MASP, aparece no referido prospecto como participante da comissão organizadora do curso, ao lado de Aldo Bonadei, Nelson Nóbrega, Alfredo Volpi, Waldemar da Costa e Valdemar Amarante.

O objetivo da Escola vem assim expresso:

\footnotetext{
Fundada na cidade de São Paulo, em abril de 1949, por um grupo de artistas e graças ao apoio prestado pelo Museu de Arte Moderna, é a Escola Livre de Artes Plásticas uma instituição que se destina a orientar as vocações artísticas, dentro de um ambiente de trabalho e de intimidade com os meios materiais de expressão. ${ }^{29}$
}

O folheto informa que já se encontram em funcionamento, com duração de três meses, os seguintes cursos: Gravura (a cargo do ilustrador e gravador Poty Lazaratto), Publicidade (a cargo do pintor e cartazista Danilo di Prete e do professor Waldemar Amarante), Desenho e Pintura (a cargo dos pintores Aldo Bonadei, Alfredo Volpi, Waldemar da Costa, Nelson Nóbrega e outros artistas convidados), Escultura (entregue aos escultores Victor Brecheret, Bruno Giorgi e Rafael Galvez) e História da Arte (a cargo do Sr. Flávio Motta).

O prospecto segue informando uma intenção futura da Escola: 
30. Escola Livre de Artes Plásticas. São Paulo, abril de 1949. (Folheto de propaganda).
Além dos cursos permanentes de Escultura, Pintura e Desenho, que já se acham em funcionamento, a Escola programou uma série de cursos para os alunos que demonstrarem aptidão para as chamadas artes aplicadas: Publicidade, Tecelagem, Fotografia, Cerâmica, Cenografia, Tapeçaria, Mobiliário, etc. ${ }^{30}$

A intenção da Escola de Artes Plásticas, na qual Flávio Motta estava inserido, aponta um dos caminhos, enquanto aposta, para se construir um ensino de design: das artes plásticas se chegar aos conteúdos das artes aplicadas e destas ao desenho industrial. Um caminho que irá pressupor uma intermediação de um aprendizado da história das artes e da arquitetura. Este ponto de vista, como afirmado, a partir da presença de Flávio Motta dentro da FAU USP, caracterizará uma contribuição do Departamento de História da Arquitetura e das Artes à reflexão e ao ensino do desenho industrial na formação dos arquitetos desta Escola.

Os alunos do IAC MASP não tiveram oportunidade de ser diplomados pelos cursos que fizeram, seja pelo fato de a Escola não ter sido organizada nos moldes universitários, ou por ter encerrado suas atividades de forma tão precoce. Entretanto, quando se olha a produção de desenhistas industriais ou de profissionais envolvidos no campo das artes e da arquitetura, sobretudo em São Paulo, a partir do início da década de 1950, constata-se que muitos dos que tiveram destaque nestas áreas iniciaram o seu aprendizado e a sua sensibilização para estas esferas de atuação a partir do próprio IAC MASP, pelas mãos do seu diretor Pietro Maria Bardi e demais professores envolvidos. Ao comentar o auxílio que prestou à montagem da Exposição de Max Bill no MASP, em 1951, o depoimento de Wollner é bastante esclarecedor do quanto a instituição balizou e deu sentido à formação dessa geração pioneira para compreensão do universo de transformação pelo qual passava o estatuto da produção artística naqueles anos: 
31. Depoimento de Wollner a STOLARSKI (2005, p. 37).
(...) Um dia o Bardi vem à sala de aula e me pergunta se eu estava disposto a ajudar na montagem de uma exposição. (...) Vamos fazer a exposição de um designer suíço famoso, ele disse. Um designer?, Perguntei. É, um designer, um sujeito que faz cartazes. (...). Foi a primeira exposição individual abrangente de Max Bill. Na montagem, comecei a perceber que o desenho tinha funções que não estavam muito claras para mim, que podia adaptar-se para criar produtos, formas novas. Fiquei paralisado. Foi um choque. Nesse momento, saí da idade das trevas. ${ }^{31}$

Nesse contexto, se por um lado destacamos a presença de Flávio Motta como professor do IAC MASP que, mais tarde, foi professor da FAU USP, cumpre destacar, entre os alunos do IAC que depois passaram pela FAU USP, os nomes de Ludovico Martino e Maurício Nogueira Lima.

Ludovico Martino, a partir de 1951, ao mesmo tempo em que cursava o IAC MASP, trabalhou no escritório de arquitetura de seu primo Plínio Croce, sócio de Roberto Aflalo. Martino estudou arquitetura na FAU USP em 1955, levando oito anos para se formar, concluindo o curso em 1962, ano em que a FAU USP implanta a Sequencia de Desenho Industrial.

Em 1964, Ludovico Martino, junto com Carlos Cauduro, abre o escritório de arquitetura, design de produtos e identidade corporativa, o Cauduro \& Martino. Entre outras realizações, Martino é autor do logotipo da FAU USP, que data de 1958. Além de ter sido aluno, Ludovico Martino também é docente na FAU USP.

Maurício Nogueira Lima estudou na primeira turma do IAC MASP. A partir de 1953, a convite de Waldemar Cordeiro, fez parte do Grupo Ruptura, dos concretistas de São Paulo. Entre 1953 e 1957, cursou arquitetura no Mackenzie. Lecionou na FAU USP, no Mackenzie, e nas 
FAU Santos e FAU Mogi das Cruzes.

Antes de abordar as experiências de ensino da ESDI (1963) e da FAU USP (1962), merecem destaque duas tentativas anteriores de institucionalização do ensino de desenho industrial, mas que ficaram limitadas apenas ao plano das intenções, sem poderem de fato se concretizar. Uma delas é a Escola Técnica de Criação do Museu de Arte Moderna, a ETC-MAM, do Rio de Janeiro. A outra se trata da tentativa da arquiteta Lina Bo Bardi de constituir em Salvador, Bahia, uma Escola de Desenho Industrial a partir de estudos da cultura popular do Nordeste do Brasil.

Relativamente à Escola Técnica de Criação do Museu de Arte Moderna, a ETC-MAM, do Rio de Janeiro, Lucy Niemeyer (1998, pp. 68-75) informa que Carmem Portinho, diretora Executiva Adjunta do MAM à época de sua criação, relaciona que a criação de uma Escola de Design no MAM RJ partiu de Max Bill, em 1953, quando ele passou pelo Rio de Janeiro no seu regresso à Europa, vindo ao Brasil integrar o júri de premiação da II Bienal de São Paulo. A ideia de Max Bill é que esta escola brasileira fosse criada nos mesmos moldes daquela que sob sua direção seria inaugurada na Alemanha em 1953: a HfG de Ulm. A proposta de inclusão no MAM de uma Escola Técnica de Criação, ETC, como assim ficou chamada, foi aprovada pelo Conselho do Museu e a inauguração de seu bloco-escola, em 1958, foi feita pelo presidente Juscelino Kubitschek, que em seu discurso afirmou:

Uma civilização que seja ao mesmo tempo técnica e industrial, cujo crescimento não esteja ligado a uma intensa atividade artística corre o risco de se deformar. 0 choque que a industrialização causa às atividades artesanais de características artísticas não saberia encontrar compensação sem a cultura de valores estéticos capazes de educar a mão do técnico e do operário, e assim assegurar a sobrevivência de características de beleza e de originalidade que sem isto 
33. Tomás Maldonado e Otl Aicher chegaram a vir ao Brasil entre 1959 e 1960, para ministrar alguns cursos breves.

34. Ver PEREIRA, 2008.
Para fundamentar a proposta didática do novo curso, foi encomendada a Tomás Maldonado ${ }^{33}$ uma proposta de currículo para a Escola. Ao mesmo tempo, sempre se manteve contato com Max Bill.

Entretanto apesar de todo esse empenho inicial, da existência do bloco-escola do MAM inaugurado, da estrutura curricular elaborada e do esboço do corpo docente, a Escola não pode ser inaugurada. O MAM não havia conseguido meios financeiros suficientes para a aquisição dos equipamentos necessários e para a folha de pagamento dos funcionários e professores da Escola.

Cardoso (2004, p. 170) explica que a Escola do MAM nunca vingou de fato, mas a sua experiência e os contatos lá firmados serviram de base para a organização da ESDI pouco tempo depois.

A outra Escola planejada, mas que não chegou a ser efetivada, mas que também merece destaque, é a experiência de Lina Bo Bardi em Salvador ${ }^{34}$. A arquiteta se deslocaria inicialmente para criar na capital baiana um Museu de Arte Moderna que se caracterizaria nos mesmos moldes que fora desde 1947 o MASP. Isto é, um museu não apenas como sinônimo de preservação do passado, mas como um centro-escola dinâmico e ligado à produção e reflexão sobre a cultura e a arte contemporânea. Desde a sua chegada a Salvador, em 1958, Lina toma contato com o extrato da produção manufatureira popular do Nordeste. Esta produção para a qual a arquiteta se coloca contra a denominação de artesanato, preferindo o termo pré-artesanato, passa a ser focada por Lina como uma herança material, um lastro cultural, para se pensar uma Escola de Desenho Industrial moderna, mas com uma 


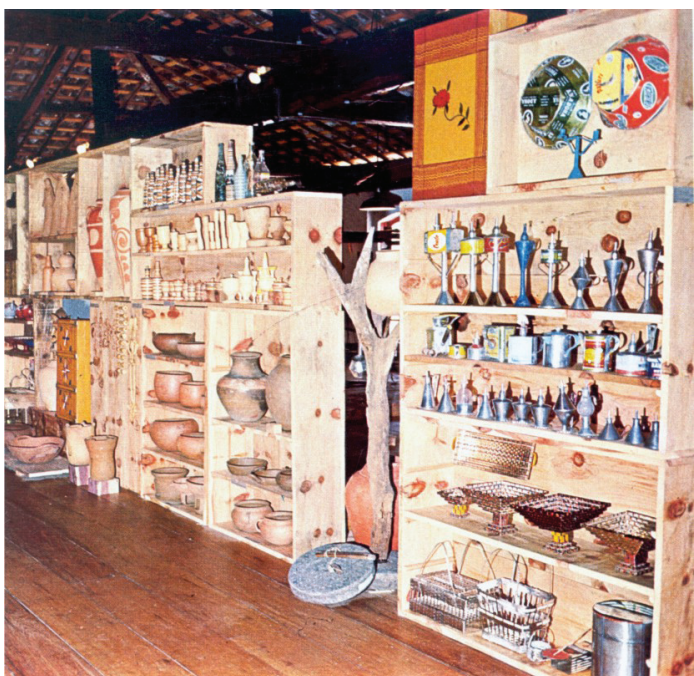

Fig.08. Lina Bo Bardi. Exposição Nor-

deste. Ao fundo a nova escada do Solar do Unhão. 1963. [Fonte: Pereira, 2008].

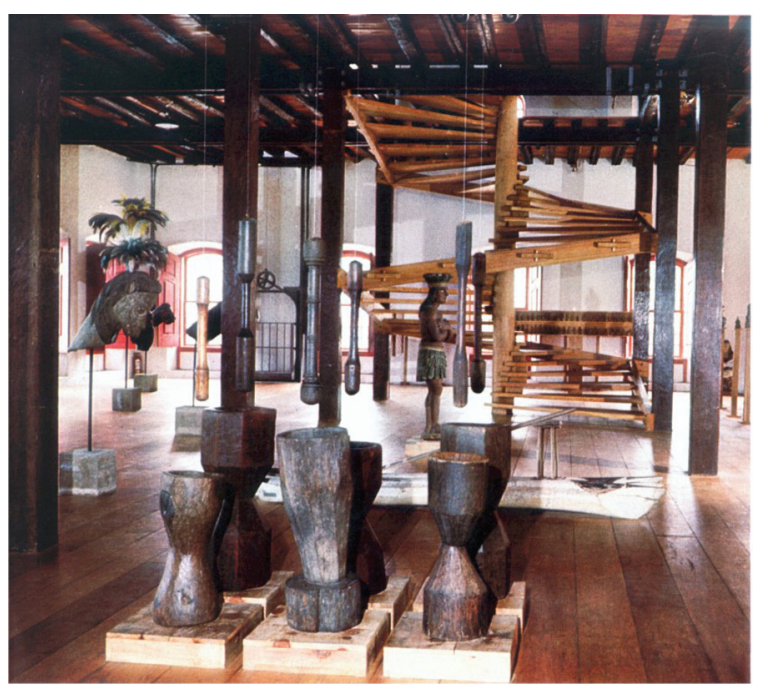

Fig.09. Lina Bo Bardi. Exposição Nordeste. Piso superior do Solar do Unhão: Objetos expostos como em feiras populares. 1963. [Fonte: Pereira, 2008].

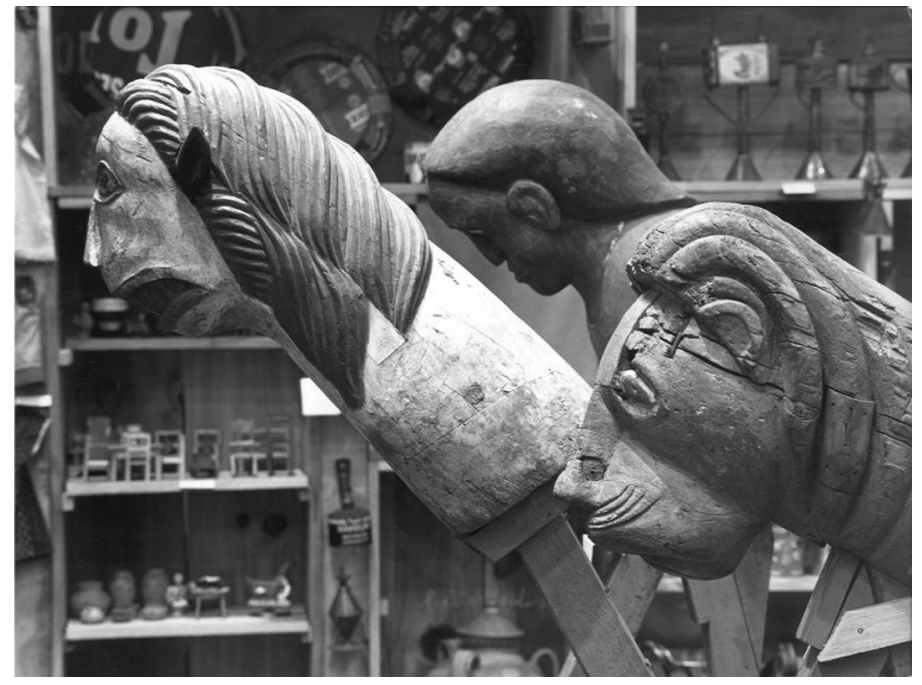

Fig.10. Lina Bo Bardi. Exposição

Nordeste. Carrancas, ao fundo objetos miúdos. 1963. [Fonte: Pereira, 2008].
35. BARDI, Lina Bo. Fôlder da Exposição Nordeste, 1963. Montada para a inauguração do Museu de Arte Popular no Solar do Unhão, 1963. In: PEREIRA, 2008, p.198. identidade própria. E assim sendo, Lina passa a se ocupar da estruturação da tal Escola que teria sua sede instalada em um antigo conjunto de arquitetura colonial denominado Solar do Unhão, na cidade de Salvador. A ideia de Lina era inicialmente constituir um acervo para um Museu de Arte Popular no Solar do Unhão, a partir de um levantamento da produção pré-artesanal, para usar os termos de Lina, do Nordeste Brasileiro. Assim por intermédio de um Museu de Arte Popular, seria constituído um acervo considerado como meio de estudo e ensino na Escola. E Lina afirma a necessidade de um estudo não do ponto de vista artístico, mas do ponto de vista técnico, mesmo se a palavra técnico define aqui um trabalho Primitivo $^{35}$. A Escola, cujo curso teria a duração de dois anos, tinha em vista como seus futuros alunos os artesãos, 
detentores dos conhecimentos práticos, e os alunos de cursos de arquitetura ou de engenharia. E a didática a ser adotada seria aquela de uma troca de experiência entre os dois segmentos matriculados. A estratégia de Lina era estabelecer a Escola de Desenho Industrial como um vetor de desenvolvimento econômico do Nordeste. Para isso a arquiteta intencionava estabelecer parceria entre o Solar do Unhão e a Superintendência para o Desenvolvimento do Nordeste, a SUDENE. Com o mesmo objetivo de impulsionar o desenvolvimento econômico regional, estava expressa, nos textos datilografados de Lina, a intenção de se montar uma Bienal de Design no Unhão com a intenção de se colocar à venda aos industriais visitantes os protótipos produzidos pelos alunos, a fim de que pudessem ser produzidos em escala industrial. Apesar da participação de Lina Bo Bardi nas duas experiências de ensino de desenho industrial em São Paulo e depois em Salvador, é necessário delimitar uma diferença entre as duas. O curso de Desenho Industrial do IAC MASP estava inserido em uma condição cosmopolita na qual São Paulo já estava se firmando no início da década de 1950. Nesse contexto, no IAC, o apelo se fez apenas em prol de um alinhamento e atualização da condição local com uma cultura internacional. Em Salvador, esse mesmo esforço de atualização se colocaria a partir de uma tensão com a cultura popular, não a desconsiderando, mas absorvendo-a como base para a constituição de uma cultura moderna com identidade própria.

Essa passagem de Lina por Salvador se concretizou no apoio recebido pelo governador do Estado naquele período, isto é, Juracy Magalhães, e pelo apoio inicial de Odorico Tavares, representante em Salvador da rede de jornais Diários Associados de Assis Chateaubriand. Terminado esse período democrático brasileiro, com o Golpe de Estado pelos militares, ocorrido em 1964, Lina Bo Bardi perde seu apoio em Salvador, da Escola de Desenho Industrial ficam apenas os seus registros nos 
36. A existência deste curso de Desenho Industrial é apenas citado no texto de STEPHAN, Auresnede Eddy Pires. Designers em Formação. In: LEAL, 2002, pp. 202-205. Infelizmente nosso trabalho não conseguiu dar conta de investigar esta Escola. Esta experiência não se encontra registrada em nossa bibliografia de arquitetura ou desenho industrial, merecendo um estudo específico.

37. Ponto de vista expresso por Marcos da Costa Braga durante o curso de extensão Design no Brasil, a formação do campo profissional, ministrado no Centro Cultural Maria Antônia da USP entre 03 e 05 de fevereiro de 2009. Braga é professor do curso de graduação em Design da FAU USP. papéis datilografados e o acervo popular coletado para a Exposição Nordeste, de 1963. Lina Bo Bardi retorna, então, de Salvador para São Paulo.

Antes da abordagem em capítulo específico da Sequência de Desenho Industrial da FAU USP e de suas relações com a sua contemporânea ESDI do Rio de janeiro, à guisa de conclusão deste capítulo, cumpre apresentar mais duas escolas brasileiras surgidas dentro da década de 1960 e também dedicadas ao ensino de desenho industrial. São os cursos da FUMA e da FAAP.

Em 1964, A Escola de Artes Plásticas da Fundação Universitária Mineira de Artes Aleijadinho, a FUMA, em Belo Horizonte, Minas Gerais, institui o ensino de desenho industrial ${ }^{36}$. A outra experiência ocorreu dentro da Fundação Armando Álvares Penteado, a FAAP, onde em 1967 é criado um Curso de Desenho Técnico e Artes Gráficas, dentro da área de Artes Plásticas. Em 1969, este curso é reformulado e passa a ser designado como curso de Desenho Industrial da FAAP. O professor e pesquisador Marcos da Costa Braga afirma que esses dois cursos, na elaboração de seus currículos, seguem o modelo desenvolvido inicialmente pela ESDI, como nas décadas subsequentes à década de 1960, o fariam as novas Escolas de Desenho Industrial constituídas no país, afirmando que, neste sentido, não é o modelo de desenho industrial vinculado ao ensino de arquitetura, como propõe a FAU USP o que se espalha pelo Brasil ${ }^{37}$. 
Parte 2: 1962-1968 



\section{Desenho Industrial na FAU USP a partir de 1962}

1. in Fórum de 1968. Prancha 2 - Projeto. Grupo 2: Desenho Industrial / Projeto de objetos industriais / Observações para Comunicação Visual Válidas.

2. FAU USP. Desenho Industrial 1962. São Paulo: Departamento de Projeto FAU USP, 1963.
Este curso (de Desenho Industrial da FAU USP) tem grande importância na etapa atual de desenvolvimento da indústria brasileira. Só isto caracterizaria um programa. (Vilanova Artigas) ${ }^{1}$

A publicação, no ano de 1963, dos exercícios dos estudantes da FAU USP, sob o título Desenho Industrial 1962², pode ser considerada uma importante ilustração daquilo que pretendia a recém-criada Sequência de Desenho Industrial do Departamento de Projeto da FAU USP. O breve texto de apresentação que antecede os trabalhos dos estudantes, organizados por período escolar, do primeiro ao quarto ano do curso, pontua, uma a uma, as metas as quais se desejava atingir com a incorporação do ensino de Desenho Industrial na formação do arquiteto.

Sinalizando o contexto que justifica tal esforço do curso de arquitetura da FAU USP, assim declara o texto introdutório:

Um país em fase de desenvolvimento amplia e torna mais e mais prementes as solicitações sobre novos e variados aspectos da produção. A formação do homem que toma parte nesse processo deve ser revista. A maneira acadêmica de enfoque dos problemas do planejamento, que condiciona o espaço do homem e os objetos que ele usa, deixa de responder àquelas solicitações e forçoso se torna uma nova colocação.

Para o arquiteto que toma a si a responsabilidade de uma 
3. FAU USP. Desenho Industrial 1962. (1963). resposta, não basta apenas a solução dos problemas no plano profissional de seu escritório. A colocação desses problemas no campo do ensino, livre das limitações da prática profissional, é forma decisiva de contribuição. ${ }^{3}$

O que se revela é a constatação de uma sociedade que se transformou e, em consequência, a afirmação de um novo compromisso de que o ensino também se modifique, para que possa continuar cumprindo seu papel social.

Essa transformação social, na verdade, é fruto de um conjunto de novas características que assumem a economia, mas também a política, no Brasil a partir de 1945. O desenvolvimento do ensino de Desenho Industrial na FAU USP se insere neste contexto, se forem considerados os anos que se estendem do período de sua gestação, entre 1948 e 1962, e, posteriormente, 1962, ano de seu início, até 1968, ano de avaliação ampla do modelo implantando pela FAU USP, em 1962.

No plano nacional, o ano de 1945 marca o final da ditadura Vargas e o início de um período político democrático que se estabelece desde 1945 até 1964. Posteriormente a 1964, o Brasil, no mesmo plano político, vê instaurado um regime militar que duraria até 1985 .

A industrialização brasileira que se inicia no período anterior a 1945 é impulsionada pelo processo de substituição das importações de bens de consumo e irá tomar novo fôlego nos anos que seguem, entre 1945 e 1985. A ideia de uma política de desenvolvimento econômico pela industrialização é um conceito que estará presente tanto nos discursos políticos do Período Democrático (1945 a 1964) quanto no Regime Militar (1964 a 1985), ainda que os métodos para atingi-los, no plano político e social, sejam radicalmente distintos em cada caso. E, nesses dois períodos, os dois ápices do empenho para o desenvolvimento econômico, via industrialização, para o período democrático e o militar 
podem ser considerados, respectivamente, o Plano de Metas do governo de Juscelino Kubitschek (1956-1961) e o período do Milagre Econômico Brasileiro (1969-1973).

O slogan da propaganda oficial do Governo JK era Cinquenta Anos em Cinco, e o seu Programa de Metas, uma política econômica delimitada como nacionaldesenvolvimentismo, estabelecia 31 objetivos distribuídos em seis grandes grupos: energia, transporte, alimentação, indústria de base, educação e a construção de Brasília, esta última considerada a metassíntese (FAUSTO, 2008).

O período do Milagre Econômico Brasileiro ocorre no governo militar do General Emílio G. Médici (1969-1973). Nesse período o país passou por um extraordinário crescimento econômico com taxas relativamente baixas de inflação. Um crescimento que, de acordo com Boris Fausto (2008, p.485), se fez, sobretudo, a partir de empréstimos externos e pela entrada de indústria e investimentos estrangeiros no país. Destas indústrias estrangeiras que aqui se instalaram cumpre destacar a automobilística que liderou o crescimento industrial com taxas anuais acima de $30 \%$. A ampliação do crédito ao consumidor e a revisão das normas de produção, autorizando a fabricação de carros de tamanho médio, atraíram fortes investimentos da General Motors, da Ford e da Chrysler.

Ainda que os dois modelos de desenvolvimento econômico conservem características distintas ou mesmo opostas, na esfera política e social, o ideal da industrialização do país é uma aposta comum para a superação da condição de seu subdesenvolvimento econômico. Uma questão importante sobre esta industrialização recai sobre o modelo a ser adotado, e que nesse período transitou entre duas opções: constituir e desenvolver uma indústria nacional ou importar e permitir a instalação da indústria estrangeira em nosso país. O trânsito das discussões políticas se estabelece em torno desses dois modelos. $\mathrm{Na}$ universidade, mais precisamente na FAU USP, em seu 
ensino de desenho industrial, a defesa será pela realização de uma indústria nacional, para a qual a Instituição teria uma contribuição específica, ainda que não fosse unificada a visão entre professores sobre o caminho e as características dessa indústria nacional.

Um importante acontecimento que comprova tal ponto de vista de contribuição é a criação da Associação Brasileira de Desenho Industrial, a ABDI. A instituição foi criada em 1963 e é considerada a primeira associação profissional brasileira da área. Foi uma associação da qual fizeram parte professores de desenho industrial da Sequência de DI da FAU USP, criada em 1962, e professores da ESDI, criada em 1963, desenhistas industriais, arquitetos, artistas plásticos, engenheiros, etc. com atuação na área, além de empresários ligados à indústria brasileira. Apesar de levar em seu título a definição associação brasileira, a atuação da entidade se deu, sobretudo, no eixo São Paulo- Rio de Janeiro, região mais industrializada do país e

4. A ABDI não pode ser considerada como um órgão de classe, inclusive porque contava entre seus associados com empresários industriais, e era uma das lutas da ABDI que se criassem instituições com caráter sindicalista para a profissão dos desenhistas industriais, uma vez que, por opção de seus associados, o próprio estatuto da Instituição impedia que a mesma se caracterizasse como instituto de classe. sede, respectivamente, dos cursos da FAU USP e da ESDI. $A A B D I$, é importante considerar, se estabeleceu com um caráter de associação cultural e não para cumprir funções classistas, pois mais amplos eram os seus objetivos que apenas a luta por um corporativismo profissional ${ }^{4}$. No seu início, entre os anos de 1963 e 1968, a ABDI esteve sob a presidência de Lúcio Grinover, arquiteto e professor da Sequência de Desenho Industrial da FAU USP desde 1962.

No ano de 1965, a ABDI lançou a revista Produto $e$ Linguagem. Apesar de ter durado apenas a edição dos seus três primeiros números, a publicação se constituiu como um importante veículo de divulgação das realizações e dos ideais a serem atingidos pela ABDI.

A edição número um de Produto e Linguagem, após estabelecer um breve panorama do contexto social e econômico que caracterizava o país, São Paulo e o Rio de Janeiro no início dos anos de 1960, assim declara o 
nascimento da $A B D I$ ligada à FAU USP e à ESDI:

5. PRODUTO E LINGUAGEM. 1‥ trimestre de 1965. Ano 1, número 1.
6. A lista publicada soma 60 associados, entretanto Lúcio Grinover, no artigo Desenho atende ao mercado em termos de produção, (revista $\mathrm{O}$ Dirigente Industrial. São Paulo, agosto de 1966. Número 12, vol.7.) afirma: A entidade ( $a$ $A B D I)$ tem atualmente (em 1966, isto é, mesmo ano da publicação dos 60 associados pela revista $\mathrm{PL}$ ) cerca de 120 associados e sua sede social se localiza na rua Augusta, 1.388, em São Paulo, onde são realizadas reuniões semanais de sua diretoria.
(...) Nessa conjuntura é que surgem a Sequência de Desenho Industrial da Faculdade de Arquitetura e Urbanismo da Universidade de São Paulo, a Escola Superior de Desenho Industrial da Guanabara e a Associação Brasileira de Desenho Industrial - as três entidades ora diretamente responsáveis pelos destinos do desenho industrial no Brasil, quer no que se refere à formação de profissionais, quer quanto às suas relações com os setores produtivos, quer ainda no que respeita a caracterização nacional e internacional do desenho industrial que aqui se começa a produzir ${ }^{5}$.

A apresentação presente na abertura da revista Produto e Linguagem informa por intermédio da ABDI um compartilhamento de ideais entre a FAU USP e a ESDI. Ao longo do tempo, foram se caracterizando algumas diferenças sobre a visão do desenho industrial entre ambas, mas de fato é inegável, como comprovam o conteúdo das três edições de Produto e Linguagem, a existência de um conjunto de ações em comum entre paulistas e cariocas.

Para se ter uma ideia dos professores e profissionais ligados à $A B D I$, basta recorrer ao último número da revista Produto e Linguagem que apresenta uma lista de seus associados $^{6}$.

Com relação ao grupo paulista, entre aqueles associados ligados ao ensino ou prática do desenho industrial, podem ser destacados: Abrahão Sanovics (arquiteto e desenhista industrial), Antônio Maluf (desenhista industrial), Ari Antônio da Rocha (arquiteto e desenhista industrial), Bramante Buffoni (desenhista gráfico); Cândido Malta Campos (arquiteto), Carlos Benvenuto Fongaro (arquiteto e desenhista industrial), Carlos Alberto Alexandre 
(desenhista industrial), Dario Imparato (arquiteto), Décio Pignatari (desenhista industrial), Eduardo Corona (arquiteto), Itiro lida (engenheiro), João Baptista Vilanova Artigas (arquiteto) e João Carlos Cauduru (arquiteto e desenhista industrial).

Em relação aos cariocas, também ligados ao ensino ou prática do desenho industrial no Rio de Janeiro, tem-se: Alexandre Wollner (desenhista gráfico), Aloísio Magalhães (desenhista industrial), Karl Heinz Bergmiller (desenhista industrial) e Edgar Duvivier (professor de desenho industrial).

\begin{tabular}{|c|c|c|c|}
\hline Cidade & Associados & Cidade & Associados \\
\hline São Paulo-SP & 53 & Brasilia - DF & 1 \\
\hline Rio de Janeiro - RJ & 4 & Recife - PE & 1 \\
\hline Porto Alegre - RS & 4 & Belo Horizonte - MG & 1 \\
\hline São Leopoldo - RS & 1 & Mauá - SP & 1 \\
\hline \multicolumn{4}{|c|}{ Total: 66 associados } \\
\hline
\end{tabular}

Tabela 4: Distribuição por cidades dos associados da ABDI em 1966

\begin{tabular}{|l|c|l|c|}
\hline Profissional & Associados & Profissional & Associados \\
\hline Empresa (Indústria e/ou comércio) & 16 & Crítico de Arte & 1 \\
\hline Desenhista Industrial & 10 & Desenhista & 1 \\
\hline Arquiteto & 9 & Estilista & 1 \\
\hline Arquiteto e Desenhista Industrial & 8 & Projetista Mecânico & 1 \\
\hline Desenhista Gráfico & 7 & Engenheiro Industrial & 1 \\
\hline Empresário Industrial & 5 & Engenheiro e Desenhista Industrial & 1 \\
\hline Arquiteto e Fotógrafo & 1 & Engenheiro & 1 \\
\hline Cenógrafo e Decorador & 1 & Estudante de Desenho Industrial & 1 \\
\hline Professor de Desenho Industrial & 1 & & \\
\hline & \multicolumn{3}{|l|}{ Total: 66 associados } \\
\hline
\end{tabular}

Tabela 5: Distribuição por categoraia profissional dos associados da ABDI em 1966.
As duas tabelas a seguir mostram a distribuição de associados, respectivamente, por cidades do país e por categorias profissionais:

Nessas tabelas apresentadas, é importante considerar que Alexandre Wollner e Karl Heinz Bergmiller eram residentes 
e atuantes profissionalmente em São Paulo, mas os dois exerceram atividades docentes no Rio de Janeiro, na ESDI.

Entre as empresas associadas merecem destaque: Alcantara Machado Comércio e Empresa Ltda. (São Paulo); Armações de Aço Probel (São Paulo); Brafor Fornecedor Escolar (São Paulo); Cia. Química Industrial de Laminados (São Paulo); Heinz Agte (Porto Alegre, RS); Indústrias Romi SA (São Paulo); Italma SA - Indústria de Mobiliário (São Paulo); Mobília Contemporânea SA (São Paulo); Mobilínea SA - Indústria e Comércio de Móveis (São Paulo); Multividro SA (São Paulo); Olivetti Industrial SA (São Paulo); Plásticos Plavinil (São Paulo); Play Arte Decorações Ltda. (São Paulo); SA Philips do Brasil (São Paulo); Spazio Móveis e Decorações SA (Rio de Janeiro, RJ); Walita SA Eletro Indústria (São Paulo) e Abel de Barros Lima, industrial (São Paulo).

Esse quadro apresentado aponta a enorme diferença de origem de formação entre todos os profissionais associados, mas todos eles com um ponto em comum e que era o de uma atuação profissional no campo do desenho industrial. Um quadro que coloca para a ABDI a defesa do desenho industrial, por outro a impediria de sair em defesa de uma definição e caracterização da regulamentação profissional atribuída a um único perfil profissional. Nesse aspecto é instigante ouvir o ponto de vista de Lúcio Grinover, presidente da ABDI, nos seus primeiros seis anos de existência:

7. Depoimento ao autor em 04 de março de 2009.
Mas tinha uma espécie de rivalidade entre São Paulo e Rio de Janeiro, quer dizer, eles nunca poderiam aceitar e nunca aceitaram que um arquiteto pudesse fazer Desenho Industrial, quando nós, se quer fazer desenho industrial, faz. A única coisa é que dentro da Faculdade de Arquitetura, talvez você pudesse ter um preparo teórico melhor do que se não fosse. Nós admitíamos que outros pudessem fazer desenho industrial, não era exclusivo. Eles não. Achavam que era exclusivo . 
O depoimento de Grinover aponta a visão de que qualquer profissional pudesse atuar na área, mas com a ressalva de que entre todos, o arquiteto, por sua formação mais ampla, teria as melhores ferramentas intelectuais e práticas para o exercício do desenho industrial. E ainda recorda sobre o desenvolvimento desse processo:

Pois é. Eu tentava amenizar esse tipo de conversa de discussão entre os vários... Todo mundo... Tinha os caras do Rio de Janeiro, tinha os caras de São Paulo... Então eu tentava amenizar isso e mostrar que a coisa não era essa briga que ia resolver os problemas de uma Associação Brasileira de uma futura e eminente profissão de Desenho Industrial. Tanto que quando nós, na Faculdade de Arquitetura colocamos claramente para o CREA (Conselho Regional de Arquitetura e Urbanismo) a questão da profissão do Desenho Industrial, e durante certo período o CREA aceitou a nossa ideia. Portanto dava a quem fizesse um curso de Desenho Industrial a possibilidade de ser configurado um desenhista industrial do ponto de vista profissional, inclusive, as escolas de desenho industrial caíram em si e depois de um ano, um ano e meio ou 8. Depoimento ao autor em 04 de março de 2009.

A hipótese de Grinover, como diretor da ABDI, procurava alargar a competência de atuação profissional, a tal ponto que, entre tantos profissionais, caberia uma fatia de tal competência aos arquitetos, os quais, como professor da FAU USP, na Sequência de Desenho Industrial, estava comprometido com a formação.

Se for considerado que, naqueles anos, a sociedade brasileira e as indústrias mal entendiam o que era o desenho industrial, talvez poderia ser um ponto de partida estratégico a direção de Grinover na ABDI: prioritariamente estabelecer uma consciência do que ele seja para depois definir a quem caberia exercê-lo. As 
9. Para detalhes sobre as discussões do seminário ver: PRODUTO E LINGUAGEM. 2‥ trimestre de 1965. Ano 1, número 2. e PRODUTO E LINGUAGEM. 10. trimestre de 1966. Ano 1, número 3. atividades da ABDI, divulgadas em Produto e Linguagem, comprovam tal aposta.

Nesses anos iniciais da ABDI, a instituição procurou exercer um papel formativo, mas também ligado ao reconhecimento de exemplos nacionais de ações profissionais ligadas à produção do desenho industrial. Para o primeiro objetivo, procurou organizar seminários temáticos e, para o segundo, concursos nacionais de objetos de desenho industrial.

É da $A B D I$ a primazia de realização do 10 Seminário de Desenho Industrial no plano nacional e também com relação à América Latina. Com um conjunto de temas indicados por Décio Pignatari, o Seminário foi promovido a partir de uma parceria estabelecida entre quatro entidades. A primeira delas, a própria ABDI. No âmbito acadêmico, participaram a FAU USP e a ESDI. E, por fim, contou também com o apoio das indústrias de São Paulo, representadas pela Federação das Indústrias do Estado de São Paulo, a FIESP.

O Seminário foi dividido em duas etapas. A primeira delas se realizou na FAU USP entre os dias 9 e 13 de novembro de 1964. A segunda etapa ocorreu na ESDI, no Rio de Janeiro, entre os dias 21 e 23 de junho de 1965. A etapa paulista abordou o ensino de desenho industrial em países estrangeiros e no Brasil. Enquanto na etapa carioca, o debate se deu em torno do projeto de uma escolapadrão de desenho industrial adequado às condições brasileiras. Ou seja, uma primeira etapa de estudo da arte sobre o tema, e uma segunda de proposições de ações transformativas 9 .

Um aspecto importante que se torna claro por ocasião da organização deste seminário é que se considerarmos a união, para a sua realização, de profissionais no exercício do desenho industrial, duas instituições de ensino e 
uma entidade de representação da indústria, tem-se a comprovação de um esforço de reconhecimento da importância do desenho industrial por todos os setores envolvidos em sua produção. E, mais interessante ainda, é que esses três setores (profissionais, escolas e indústrias) antes de se empenharem na discussão de uma regulamentação e definição de um estatuto do exercício profissional, se reuniram em torno da discussão do seu ensino institucionalizado. Nesse caso, os esforços se deram no sentido de primeiro formar o profissional e, depois, regulamentar a profissão. Algo que pode ser considerado consequência de uma dupla condição de seus associados: primeiro que a maior parcela deles eram professores, da FAU USP ou da ESDI, e, segundo, que entre esses professores não havia um consenso claro nem sobre o próprio ensino, quanto mais com relação à regulamentação profissional: a arquitetos ou desenhistas industriais caberia o desempenho desta nova profissão?

Ainda que não houvesse tão claro para a ABDI a quem caberia o exercício profissional, com a intenção de reconhecer contribuições reais de produtos com valor de desenho industrial, a entidade passou a colaborar na organização de dois concursos anuais. São eles, o Prêmio Lúcio Meira e o Prêmio Roberto Simonsen. O primeiro desses prêmios objetivava reconhecer o mérito de projetos de desenho industrial na área automobilística. Enquanto o segundo tinha como objetivo reconhecer projetos relevantes de desenho industrial no setor de utilidades domésticas.

A ABDI passou a colaborar com a empresa Alcantara Machado Comércio e Empreendimentos Ltda., na promoção do Prêmio Lúcio Meira a partir de 1964. De acordo com a apresentação veiculada em Produto $e$ Linguagem, o concurso Lúcio Meira era assim definido: 
10. PRODUTO E LINGUAGEM. 10. trimestre de 1965. Ano 1, número 1.
Este prêmio tem como objetivo incentivar a prática do Desenho Industrial, no campo especializado de carrocerias de automóvel. Estas podem estar situadas nas seguintes categorias: carros de passeio, carros de turismo, carros de esporte, carros de corrida, wagon-station, caminhões, camionetas, pick-ups, basculantes, etc. ${ }^{10}$

E com relação à seleção ocorrida em 1964, contando com a participação da $A B D I$, estabeleceu-se um júri composto por: Karl Heinz Bergmiller, Edmund Gold, Dario Imparato, Julio Katinsky e Lívio Edmondo Levy. O primeiro lugar na premiação de 1964 foi conferido a Ari Antônio da Rocha pela apresentação de seu protótipo Aruanda. Por extenso que possa parecer, vale citar na íntegra o parecer da Comissão Julgadora:

O projetista partiu da necessidade de conceber um veículo cujas características atendesse a uma parcela ponderável da população pelo seu baixo custo, maneabilidade e mínimo volume.

Consequentemente, propôs um carro popular que não viesse agravar os já severos problemas de congestionamento dos centros urbanos, cuja rede viária é na maioria das vezes, inadequada e obsoleta.

O projeto foi desenvolvido propondo uma estrutura monobloco (eliminando a dicotomia carroçaria-chassis)

Resultou um conjunto coerente ao qual não está ausente uma intenção estética, próxima do desenvolvimento contemporâneo em outros países.

Pormenores que suscitaram dúvidas, como o funcionamento das portas corrediças laterais, não diminuem o valor global do trabalho apresentado ${ }^{11}$.

Como se percebe, os méritos do desenho industrial premiado se relacionam diretamente ao atendimento às características e necessidades do usuário previsto, mas também representa uma contribuição à diminuição dos 
problemas de um trânsito já caótico na década de 1960, em algumas das grandes cidades brasileiras e, sobretudo, em São Paulo.

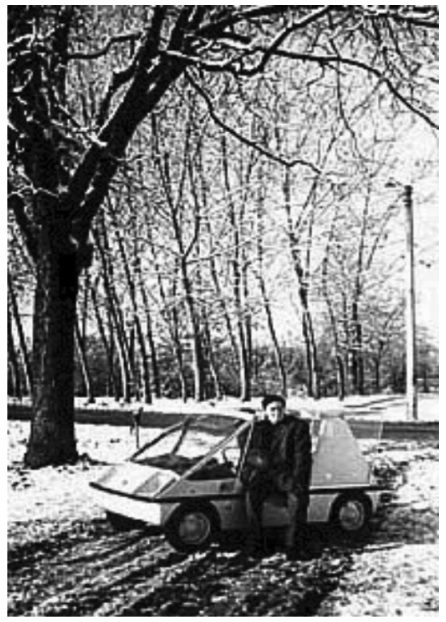

Fig.12. Ari Antônio da Rocha. Protótipo automobilístico Aruanda. Prêmio Lúcio Meira, 1964

[Fonte:http://www.redetec.org.br/

inventabrasil/aruanda.htm, visitado em 21 de junho de 2009].

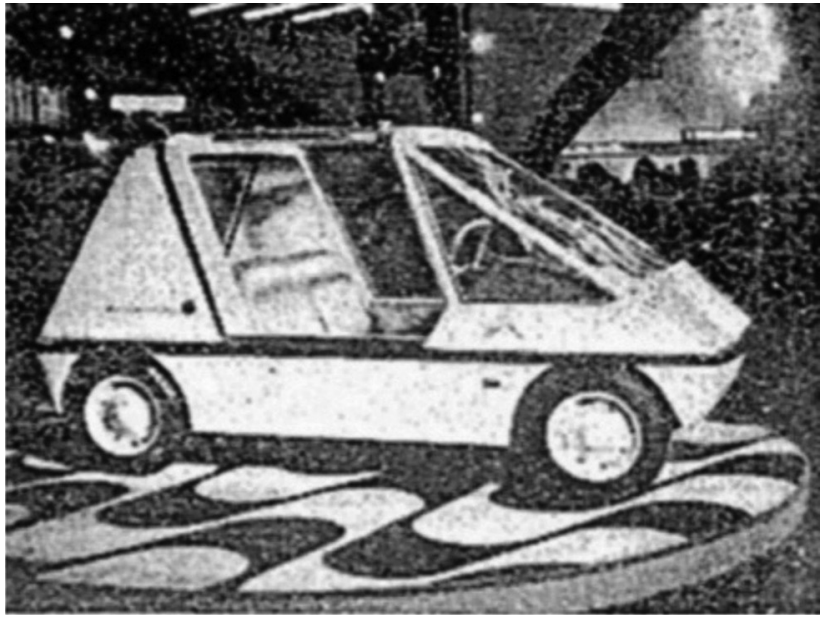

Fig.13. Ari Antonio da Rocha. Carro Aruanda. 1964. [fonte: PRODUTO E LINGUAGEM. ${ }^{\circ}$. trimestre de 1966. Ano 1, número 3.]

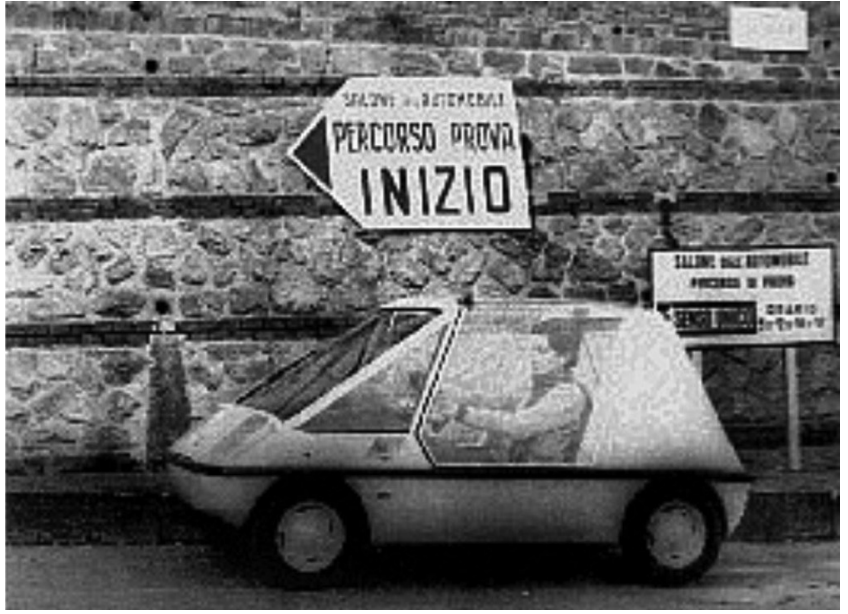

Fig.14. Ari Antônio da Rocha. Protótipo automobilístico Aruanda. Prêmio Lúcio Meira, 1964. [Fonte: http://www.redetec. org.br/inventabrasil/aruanda.htm, visitado em 21 de junho de 2009].

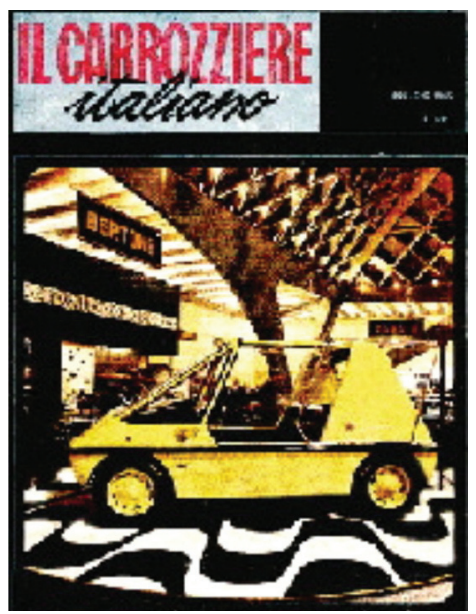

Fig.15. Ari Antônio da Rocha. Protótipo automobilístico Aruanda. Prêmio Lúcio Meira, 1964.

[Fonte:http://www.redetec.org.br/inventabrasil/aruanda.htm, visitado em 21 de junho de 2009].

Em 1983, no livro de Walter Zanini, História Geral da Arte No Brasil, ao apresentar uma história do desenho industrial brasileiro, com uma perspectiva de balanço de nossa produção, o autor do capítulo, Julio Katinsky, utiliza 
12. Depoimento ao autor em 05 de março de 2009. Infelizmente a pesquisa não conseguiu detalhar quem foram os demais ganhadores do Prêmio Lucio Meira após 1964. Entretanto este protótipo de Ari Antônio da Rocha recebeu uma grande divulgação na época, tendo inclusive sido exposto, em 1965, no Salão do Automóvel de Turim, na Itália, o que rendeu a seu autor uma bolsa de estudos nesse país.

13. Roberto Simonsen foi empresário, participante da vida política do país, a partir de 1933. Foi também presidente da Confederação Nacional da Indústria, CNI, presidente da Federação das Indústrias do Estado de São Paulo, FIESP e integrante do Conselho Superior da Escola de Sociologia e Política de São Paulo. No edital de apresentação do concurso, Simonsen é retratado como um líder da emancipação econômica e da assistência social no Brasil. os desenhos deste mesmo carro Aruanda na sua página de abertura.

O premiado Ari Antônio da Rocha tem formação de arquiteto pela FAU USP e sobre ele e demais profissionais de desenho industrial que receberam o Prêmio Lúcio Meira, assim Julio Katinsky informaria:

Por outro lado, esse processo (de industrialização brasileira) também teve os seus vícios, por exemplo, a indústria automobilística, um verdadeiro câncer na sociedade moderna. Num certo sentido, nós, a FAU USP, denunciamos isso. Tanto que os concursos inventados pelos grupos interessados em implantar a indústria automobilística no Brasil; eles fizeram um concurso de carro, o Prêmio Lucio Meira. Todos foram ganhos pela FAU USP, todos os primeiros lugares foram ganhos pela FAU USP. Todos. Por quê? Porque eram carros propostos corretamente. Anteciparam, num certo sentido, o que está acontecendo hoje. Apesar de na época os grandes carros ainda serem os americanos, Cadillac, principalmente os carros da Ford, enormes, gigantescos, todo mundo queria ter porque eram carros de 6 metros de comprimento (...)

Nós fizemos o contrário, em função de uma visão urbanística, todos os carros que o prêmio Lucio Meira concedeu, eram todos carros pequenos, carros muito adequados. Inclusive alguns têm circulado por aí, não iguais, mas projetos muito semelhantes àqueles que nós pensamos naquela época, porque aliávamos, não necessidades da indústria, da produção capitalista, mas as necessidades da própria cidade ${ }^{12}$.

O outro concurso, o Prêmio Roberto Simonsen ${ }^{13}$ para utilidades domésticas, passou a contar com a colaboração da ABDI também a partir de 1964. Considerando as instituições envolvidas com esse prêmio, pode-se ter claro o esforço da ABDI, assim como ocorreu no / Seminário de Desenho Industrial ou no Prêmio Lúcio Meira, no sentido de unir entidades ligadas ao desenho industrial para 
fortalecer o entendimento da importância do mesmo para a indústria.

O Prêmio Roberto Simonsen é patrocinado pela FIESP e pela ABDI e promovido pela empresa Alcântara Machado Comércio e Empreendimentos Ltda., como um evento ligado à Feira Nacional de Utilidades Domésticas de São Paulo, da qual também era promotora a Alcantara Machado, e possuía, como consultores que participavam da comissão julgadora, um representante de cada uma das seguintes instituições: Associação Brasileira de Desenho Industrial, ABDI; Instituto de Arquitetos do Brasil, IAB, núcleo São Paulo; Escola Superior de Desenho Industrial, ESDI; Faculdade de Arquitetura e Urbanismo da Universidade de São Paulo, FAU USP e Faculdade de Arquitetura Mackenzie, FAU Mackenzie.

Esse concurso de projetos e produtos de utilidades domésticas era destinado à participação tanto de desenhistas industriais quanto da própria indústria, numa situação em que a comissão definia como desenhista industrial o criador, individual ou em equipe, de projetos técnico-formais de objetos destinados à produção em série, tendo em vista a sua qualidade, o atendimento às necessidades sociais, econômicas e culturais da sociedade. Assim, caracterizava, na verdade, mais o desenho industrial que o profissional que o realizava, ficando aberto à participação de profissionais oriundos de formações distintas. Ainda o regulamento de julgamento e premiação informa que os objetos apresentados seriam avaliados, tendo em conta seus aspectos funcionais, construtivos e estéticos.

A tabela a seguir relaciona as comissões julgadoras e os produtos industriais premiados entre 1964 e 1966: 


\begin{tabular}{|c|c|c|c|c|}
\hline \multirow{2}{*}{ Edição } & \multirow{2}{*}{ Comissão Julgadora } & \multicolumn{3}{|c|}{ Premiados } \\
\hline & & objeto & autor & categoria \\
\hline \multirow{4}{*}{ 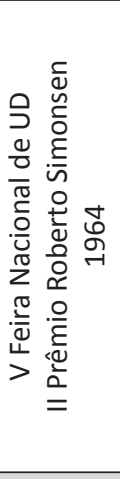 } & \multirow{4}{*}{$\begin{array}{l}\text { Lúcio Grinover (ABDI) } \\
\text { Giancarlo Palanti (IAB) } \\
\text { João Carlos Cauduro (FAU USP) } \\
\text { Karl Heinz Bergmiller (ESDI) } \\
\text { Eduardo Corona (FAU Mackenzie) }\end{array}$} & Poltrona (sem braços) & $\begin{array}{l}\text { Norman Westwater e } \\
\text { Michel Arnoult }\end{array}$ & $\begin{array}{l}\text { Prêmio } \\
\text { Roberto } \\
\text { Simonsen }\end{array}$ \\
\hline & & $\begin{array}{l}\text { Linha de Móveis para } \\
\text { Crianças }\end{array}$ & $\begin{array}{l}\text { Mânlio Rizzente e } \\
\text { Arnaldo Ruschioni }\end{array}$ & $\begin{array}{l}\text { Certificado } \\
\text { de Boa } \\
\text { Forma }\end{array}$ \\
\hline & & $\begin{array}{l}\text { Cadeira de Sala de } \\
\text { Jantar }\end{array}$ & $\begin{array}{l}\text { Mânlio Rizzente e } \\
\text { Arnaldo Ruschioni }\end{array}$ & $\begin{array}{l}\text { Certificado } \\
\text { de Boa } \\
\text { Forma }\end{array}$ \\
\hline & & Elementos de Vidro & Lívio Edmondo Levi & $\begin{array}{c}\text { Certificado } \\
\text { de Boa } \\
\text { Forma } \\
\end{array}$ \\
\hline \multirow{5}{*}{ 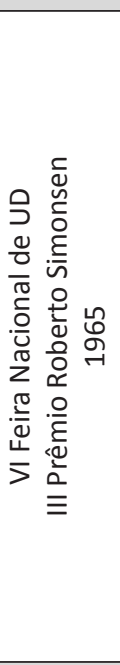 } & \multirow{5}{*}{$\begin{array}{l}\text { Fernando Lemos (ABDI) } \\
\text { João Carlos Cauduro (IAB) } \\
\text { João Rodolfo Stroeter (FAU USP) } \\
\text { Karl Heinz Bergmiller (ESDI) } \\
\text { Lívio E. Levi (FAU Mackenzie) }\end{array}$} & $\begin{array}{l}\text { Ferro Elétrico } \\
\text { Automático }\end{array}$ & $\begin{array}{l}\text { Setor de Desenho } \\
\text { Industrial da Walita } \\
\text { SA }\end{array}$ & $\begin{array}{l}\text { Prêmio } \\
\text { Roberto } \\
\text { Simonsen }\end{array}$ \\
\hline & & $\begin{array}{l}\text { Linha de } \\
\text { Escrivaninhas } \\
\text { Residenciais }\end{array}$ & $\begin{array}{l}\text { Michel Arnoult } \\
\text { (Mobilínea } \\
\text { Contemporânea) }\end{array}$ & $\begin{array}{l}\text { Certificado } \\
\text { de Boa } \\
\text { Forma }\end{array}$ \\
\hline & & $\begin{array}{l}\text { Conjunto de Peças } \\
\text { Sanitárias Suspensas }\end{array}$ & $\begin{array}{l}\text { Gustave Adolphe } \\
\text { Martin } \\
\text { (Cerâmica Sanitária } \\
\text { Porcelite) }\end{array}$ & $\begin{array}{l}\text { Certificado } \\
\text { de Boa } \\
\text { Forma }\end{array}$ \\
\hline & & Cama Beliche & $\begin{array}{l}\text { Geraldo de Barros } \\
\text { (Bioni e Cia. Ltda., } \\
\text { indústria e comércio } \\
\text { de móveis) }\end{array}$ & $\begin{array}{c}\text { Certificado } \\
\text { de Boa } \\
\text { Forma }\end{array}$ \\
\hline & & $\begin{array}{l}\text { Linha de copos } \\
\text { Trópico }\end{array}$ & $\begin{array}{l}\text { Antonio Gundemaro } \\
\text { Lizarraga } \\
\text { (São Marco Vidros de } \\
\text { Arte Ltda.) }\end{array}$ & $\begin{array}{l}\text { Certificado } \\
\text { de Boa } \\
\text { Forma }\end{array}$ \\
\hline \multirow{4}{*}{ 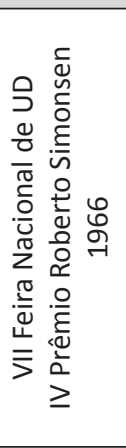 } & \multirow{4}{*}{$\begin{array}{l}\text { Michel Arnoult (ABDI) } \\
\text { Abrahão Sanovics (IAB) } \\
\text { Luiz R. Carvalho Franco (FAU USP) } \\
\text { Karl Heinz Bergmiller (ESDI) } \\
\text { Lívio E. Levi (FAU Mackenzie) }\end{array}$} & NÃO ATRIBUÍDO & NÃO ATRIBUÍDO & $\begin{array}{l}\text { Prêmio } \\
\text { Roberto } \\
\text { Simonsen }\end{array}$ \\
\hline & & $\begin{array}{l}\text { Conjunto de Louça } \\
\text { Sanitária }\end{array}$ & $\begin{array}{l}\text { Norman Westwater } \\
\text { (Indústria Ideal } \\
\text { Standard) }\end{array}$ & $\begin{array}{l}\text { Certificado } \\
\text { de Boa } \\
\text { Forma }\end{array}$ \\
\hline & & Geladeira & $\begin{array}{l}\text { Alcindo R. Moritz e } \\
\text { Arno Schindler } \\
\text { (Indústria de } \\
\text { Refrigeração Cônsul) }\end{array}$ & $\begin{array}{l}\text { Certificado } \\
\text { de Boa } \\
\text { Forma }\end{array}$ \\
\hline & & Mesa & $\begin{array}{l}\text { Geraldo de Barros } \\
\text { (Indústria Hobjeto) }\end{array}$ & $\begin{array}{l}\text { Certificado } \\
\text { de Boa } \\
\text { Forma }\end{array}$ \\
\hline
\end{tabular}

Tabela 6: Comissões Julgadoras do Prêmio Roberto Simonsen e os produtos industriais premiados entre 1964 e 1966. 
Fig.16. Michel Arnoult e Norman Westwater. Poltrona estruturada em madeira maciça com fio de nylon no assento e encosto e almofadas soltas. 1964 [fonte: SANTOS, 1995, p. 140]
Conforme consta no edital, o seu regulamento estabelecia a entrega de um Prêmio Roberto Simonsen e quantos Certificados de Boa Forma a comissão julgasse pertinente em cada edição do concurso. A seleção de 1964 contou com 16 projetos inscritos, em sua maioria, móveis. Dois anos mais tarde, em 1966, esse número apresentou um salto para 37 participantes.

Ainda vale uma menção à participação de Michel Arnoult e Lívio E. Levi. Arnoult recebeu o Prêmio Roberto Simonsen em 1964 e o Certificado de Boa Forma em 1965. Em 1966, passou a integrar a comissão julgadora, como representante da ABDI. No caso de Lívio E. Levi, este recebeu um Certificado de Boa Forma em 1964, passando a integrar a comissão julgadora, como representante da FAU Mackenzie, nos anos de 1965 e 1966.

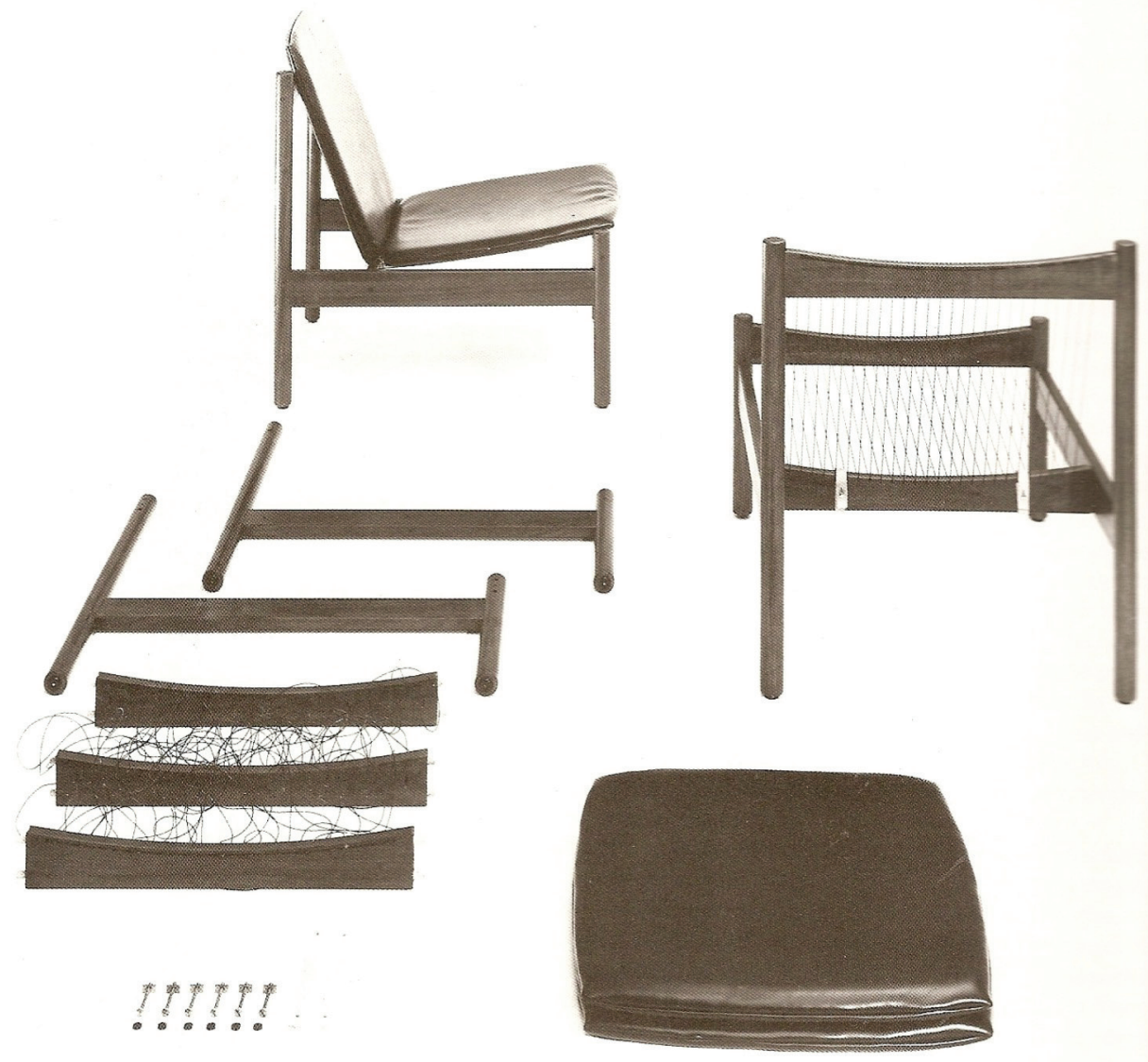


14. Parecer da Comissão Julgadora do /l Prêmio Roberto Simonsen em 1964. In PRODUTO E LINGUAGEM. 1‥ trimestre de 1965. Ano 1, número 1.

15. Ver revista PRODUTO E LINGUAGEM números 1 (ano: 1965), 2 (ano: 1965) e 3 (ano: 1966).
O parecer da comissão julgadora de 1964 assim justifica o Prêmio Roberto Simonsen conferido a Norman Westwater e Michel Arnoult pelo projeto de uma Poltrona:

Concebida em termos de produção em série, trata-se de uma poltrona desmontável, com um número reduzido de elementos padronizados compondo sua estrutura, estrutura esta perfeitamente visível e devassável. O sistema de fixação das peças componentes é simples e seguro. Destaque-se também a propriedade da utilização do fio de nylon como sustentação e molejo do assento e do encosto cujas almofadas iguais, de espuma de borracha revestida de plástico (e fixadas por dois cintos de couro), podem, por essa razão, ser bastante reduzidas em sua espessura. Isto quando aos aspectos construtivos. Quanto aos aspectos funcionais, caracterizam-se o conforto, a leveza e a facilidade de limpeza e conservação. Seu valor estético advém principalmente da estrutura aberta, clara, da unidade entre o externo e o interno, da fidelidade à natureza dos materiais e de sua adequada coordenação ${ }^{14}$.

O parecer ilustra os critérios adotados pela Comissão tanto desta edição quando das outras duas, conforme se pode constatar consultando as três atas de premiação ${ }^{15}$.

Entre os participantes premiados pelo concurso Roberto Simonsen, é importante destacar a presença de Michel Arnoult e Geraldo de Barros, destacando aqui a relevância das suas trajetórias profissionais e a importante contribuição que realizaram ao desenvolvimento do desenho industrial brasileiro.

Pautando seu trabalho pela racionalização e modulação dos móveis que projetou, Michel Arnoult, francês, chegou ao Brasil em 1951. Em sua formação europeia, estudou na Union Centrale des Arts Decoratifs, UCDA, a mesma onde estudou Charlotte Perriand. No Brasil, além de estagiar no escritório de Oscar Niemeyer, estudou na Faculdade 
Nacional de Arquitetura do Rio de Janeiro. Nesse período de estudante, associou-se ao arquiteto irlandês Norman Westwater, que trabalhava como cenógrafo, e começou a desenhar móveis. Durante a década de 1950, criaram a Mobília Contemporânea para a produção e comércio de seus móveis (Santos, 1995, p.137).

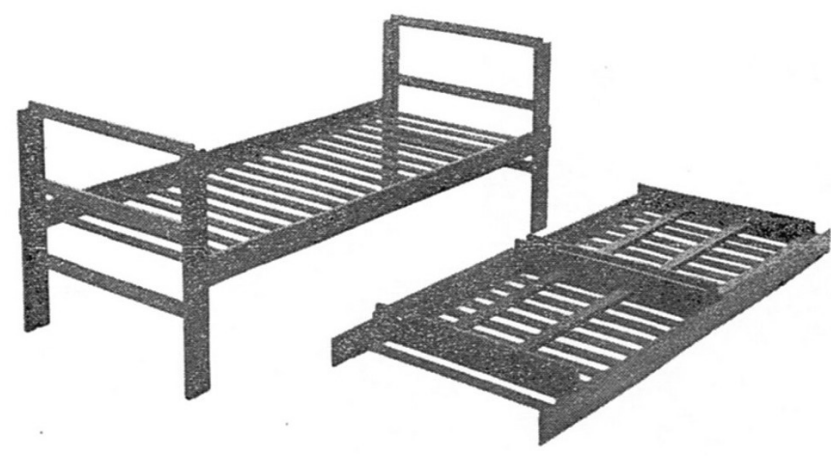

Fig.17. Geraldo de Barros (Bioni e Cia. Ltda. Indústria e Comércio de Móveis). Cama Beliche. 1965. [fonte: PRODUTO E LINGUAGEM, 2. trimestre de 1965. Ano 1, número 2.]

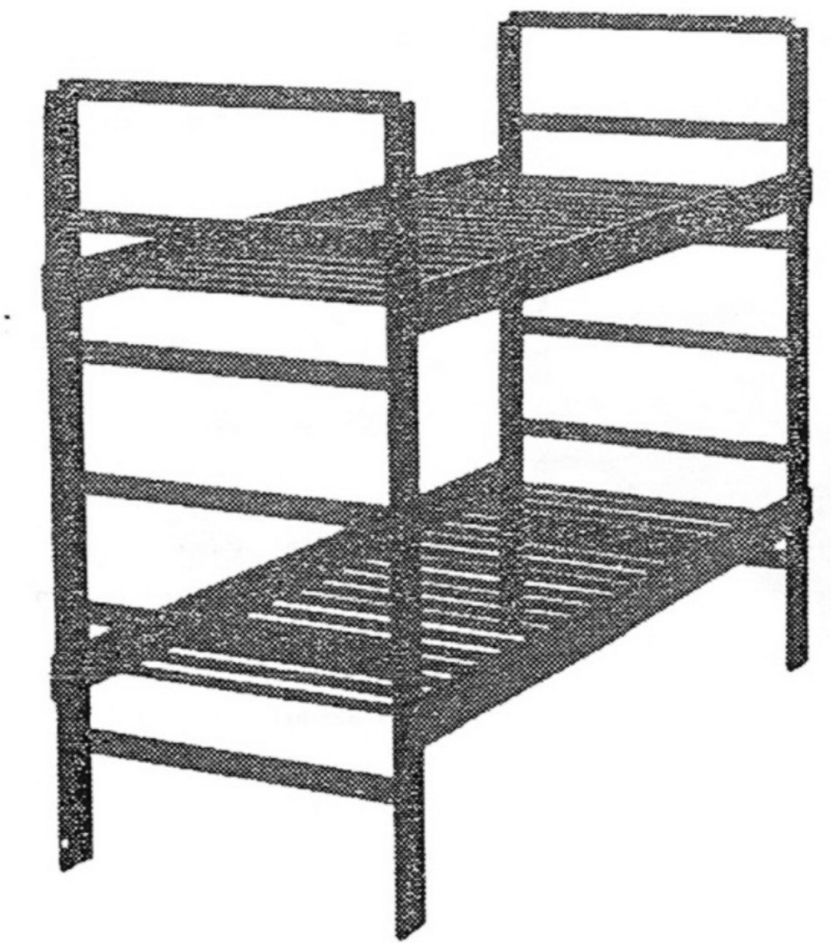

Fig.18. Geraldo de Barros (Bioni e Cia. Ltda. Indústria e Comércio de Móveis). Cama Beliche. 1965. [fonte: PRODUTO E LINGUAGEM, 2². trimestre de 1965. Ano 1, número 2.] 


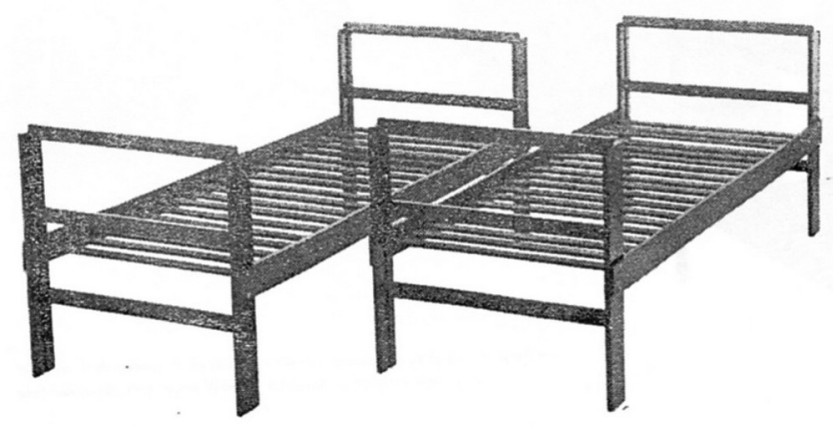

Fig.19. Geraldo de Barros (Bioni e Cia. Ltda. Indústria e Comércio de Móveis). Cama Beliche. 1965. [fonte: PRODUTO E LINGUAGEM, 2 ${ }^{\circ}$. trimestre de 1965. Ano 1, número 2.]

Pelo conjunto de sua atuação no campo do desenho industrial no Brasil, como indicado, merece destaque também a presença de Geraldo de Barros no concurso Roberto Simonsen, recebendo dois Certificados de Boa Forma. Um deles, em 1965, pelo projeto de uma cama

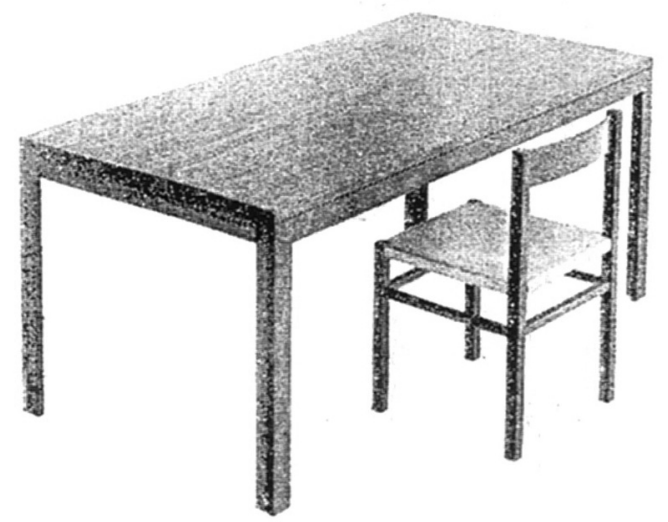

Fig.20. Geraldo de Barros (Indústria Hobjeto). Mesa. 1966. [fonte: PRODUTO E LINGUAGEM. $1^{\circ}$. trimestre de 1966 Ano 1, número 3.] beliche e, outro, em 1966, por uma mesa. Geraldo de Barros trabalhou no laboratório de fotografia no IAC MASP (1951-1953), e, ainda na década de 1950, por ocasião da montagem da Exposição de Max Bill no MASP, em 1951, fora indicado por Pietro Maria Bardi ao suíço Bill para estudar na futura HfG de Ulm. Na ocasião, não podendo aceitar a indicação, por motivos particulares, era recém-casado, é indicado em seu lugar o estudante do IAC, Alexandre Wollner. Barros foi vencedor do concurso para a comemoração do IV Centenário da Cidade de São Paulo em 1954. Em 1959, Geraldo de Barros participa da criação da Comunidade de Trabalho Unilabor, Indústria de Artefatos de Ferro, Metais e Madeira Ltda., ou apenas a Unilabor. Esta foi uma cooperativa de trabalho liderada pelo frei dominicano João Batista Pereira dos Santos, na qual Barros era responsável pelo desenho de toda a produção, pelo nome Unilabor (União no Trabalho), pela 


\section{Centenário de São Paulo}

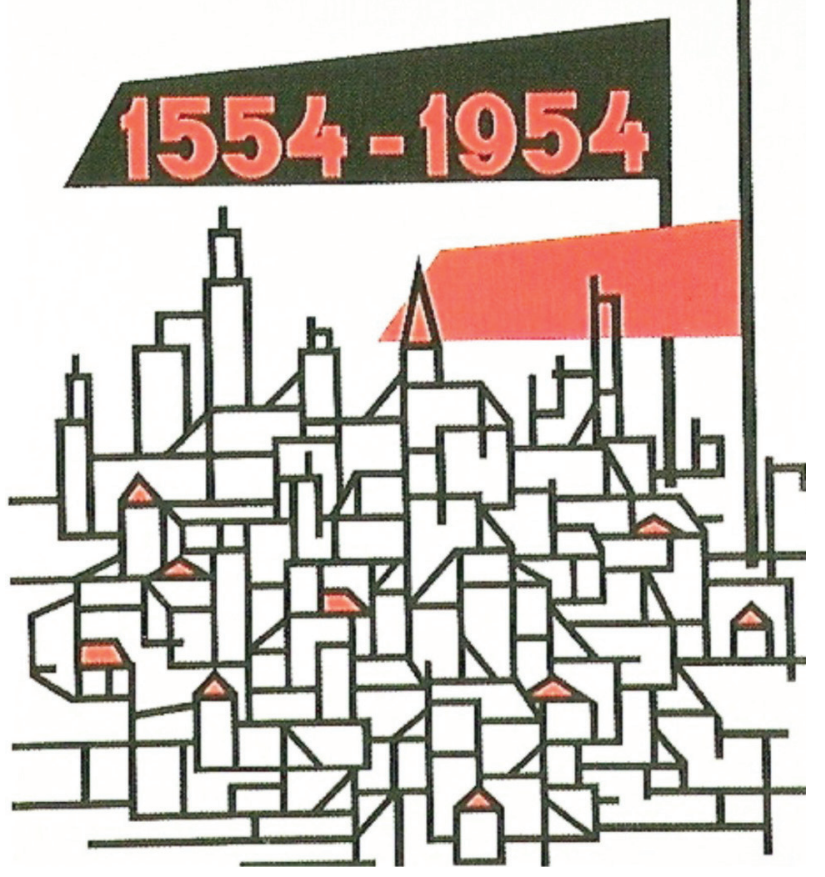

Fig.21. Geraldo de Barros. Cartaz para o IV Centenário de São Paulo. 1954. [fonte: MUSEU DE ARTE MODERNA (São Paulo, SP). Concreta '56: A raiz da forma. Catálogo. 2006. p.229]

16. Para maiores detalhes da trajetória profissional do pintor, fotógrafo e designer Geraldo de Barros, ver: Claro (2004) e Santos (1995).

17. Em depoimento, Julio Katinsky informa exatamente o contrário, afirmando na verdade uma falta de respeito e reconhecimento ao profissional Desenhista Industrial: Teve um estudante da FAU USP que foi trabalhar para a Walita. A Walita era tão ordinária, como empresa, que nunca publicou os trabalhos desse rapaz. Entrevista ao autor em 05 de março de 2009 marca e pela programação visual da empresa. Algum tempo mais tarde, juntamente com Aloísio Bione e alguns ex-participantes da Unilabor, no ano de 1964, criaria a Hobjeto Indústria e Comércio de Móveis S.A., onde produziu a cama beliche (1965) e a mesa (1966) premiadas com o Certificado de Boa Forma, do concurso Roberto Simonsen ${ }^{16}$.

Além dessas informações, não deixa de ser interessante notar que entre os objetos premiados, além de móveis feitos por arquitetos, estão também produtos realizados dentro das indústrias, como uma geladeira da marca Cônsul, e um ferro de passar roupas da Walita. No caso deste último, o mesmo é apresentado como de autoria do setor de desenho industrial da empresa, o que pressuporia por parte da Walita certo avanço na compreensão da importância da integração do processo de projeto do desenho industrial à linha de produção ${ }^{17}$.

Ainda com relação aos objetos premiados, além dos móveis de arquitetos e dos eletrodomésticos, é conferido Certificado de Boa Forma a produtos para a construção civil. Nas edições do terceiro e quarto Prêmio Roberto Simonsen, são selecionados dois conjuntos de peças sanitárias, respectivamente, um da Cerâmica Sanitária Porcelite, e outro da Indústria Ideal Standard. 


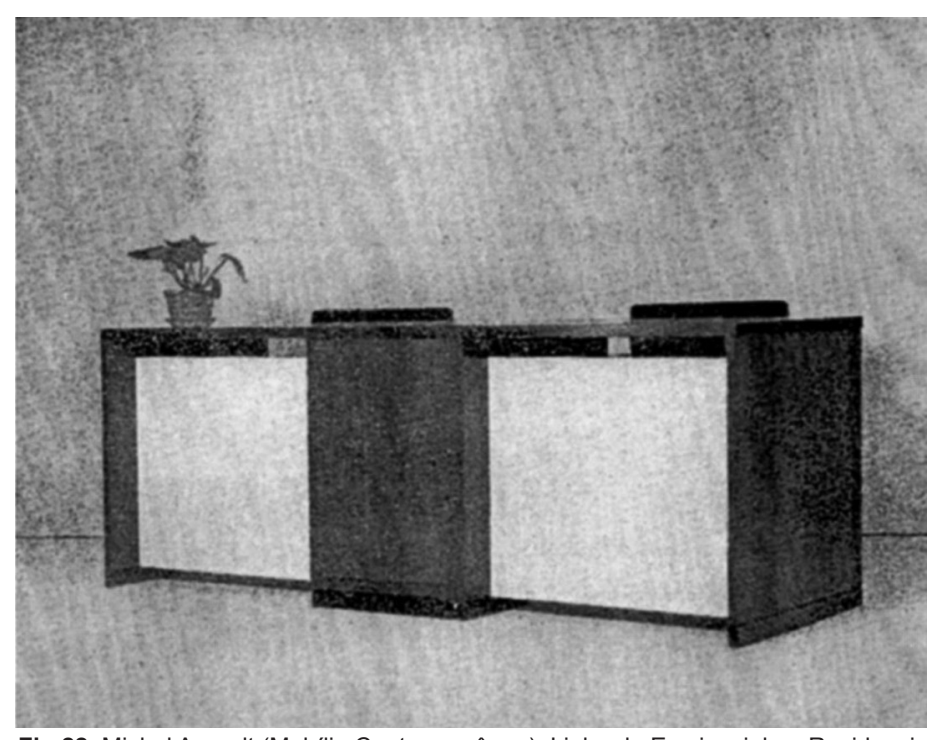

Fig.22. Michel Arnoult (Mobília Contemporânea). Linha de Escrivaninhas Residenciais. 1965. [fonte: PRODUTO E LINGUAGEM, $2^{\circ}$. trimestre de 1965. Ano 1, número 2.]

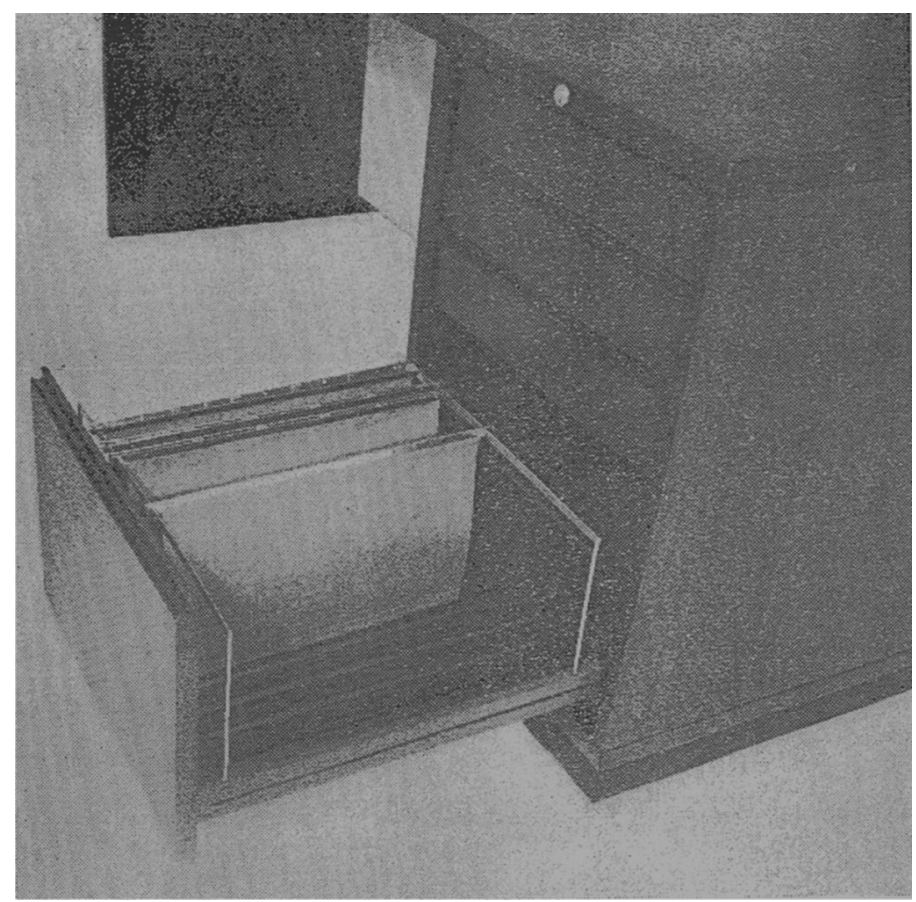

Fig.23. Michel Arnoult (Mobília Contemporânea). Linha de Escrivaninhas Residenciais. 1965. [fonte: PRODUTO E LINGUAGEM, 2². trimestre de 1965. Ano 1, número 2.] 


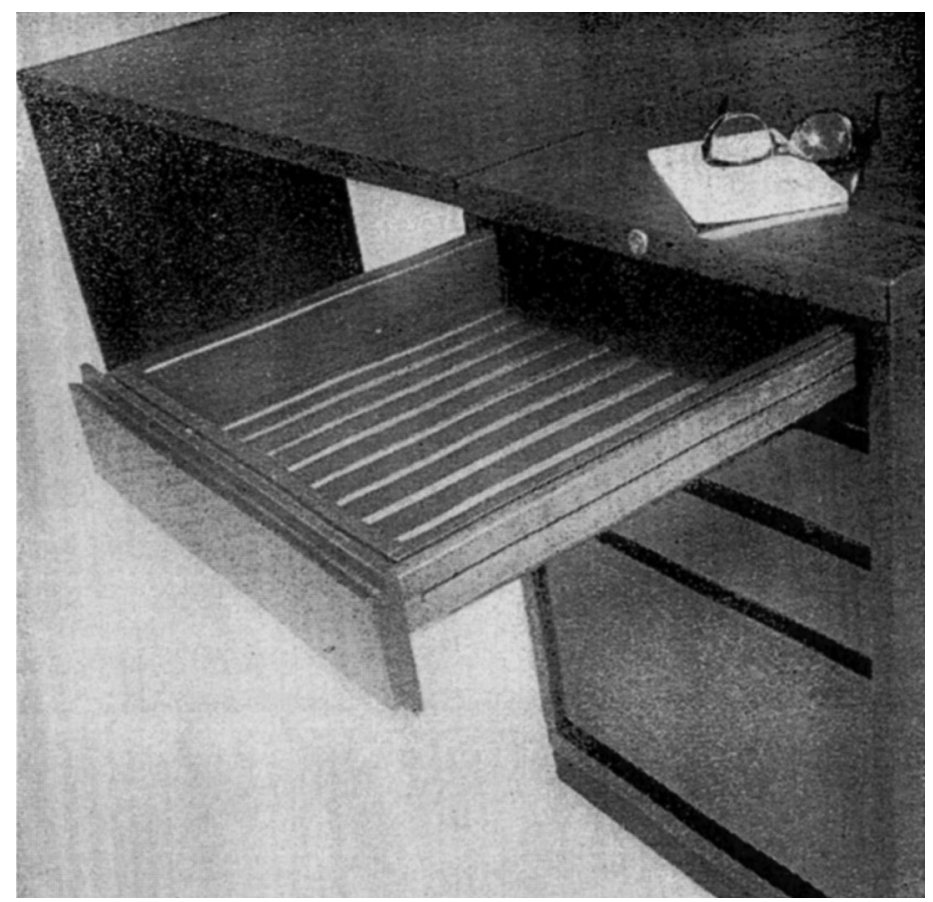

Fig. 24. Michel Arnoult (Mobília Contemporânea). Linha de Escrivaninhas Residenciais. 1965. [fonte: PRODUTO E LINGUAGEM, $2^{\circ}$. trimestre de 1965. Ano 1, número 2.]

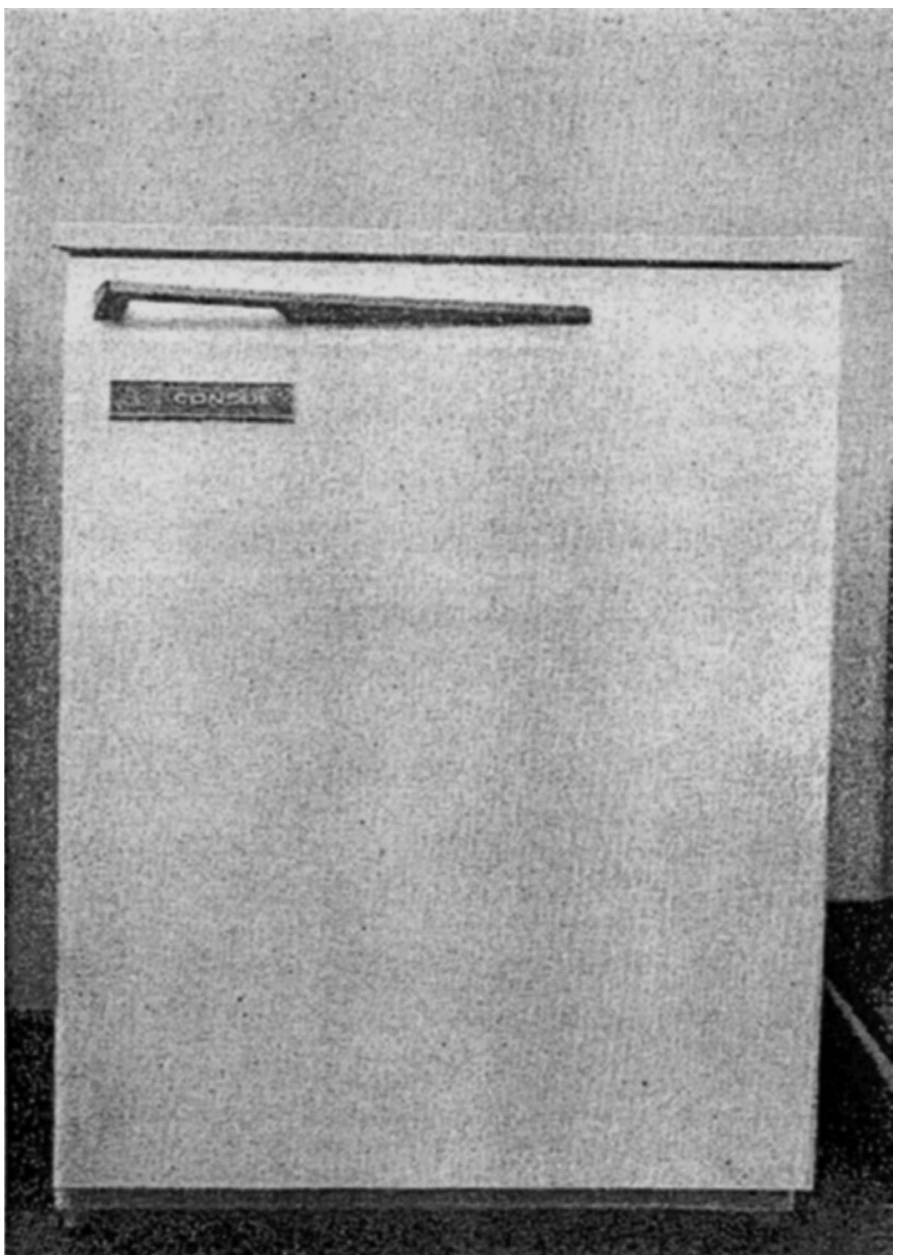

Fig.25. Alcindo R. Moritz e Arno Schindler (Indústria de Refrigeração Cônsul). Geladeira. 1966. [fonte: PRODUTO E LINGUAGEM. 1‥ trimestre de 1966. Ano 1, número 3.] 


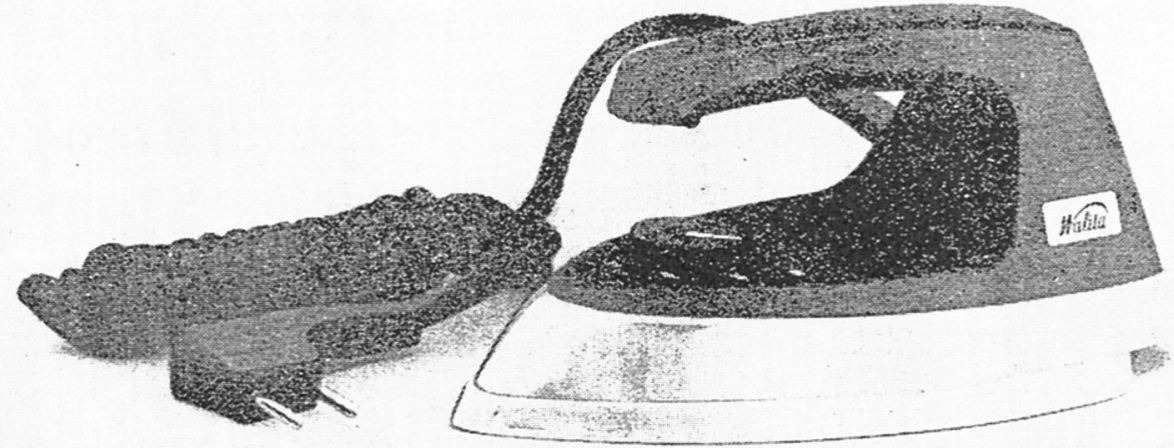

Fig.26. Setor de Desenho Industrial

Walita S.A.. Ferro Elétrico Automático.

1965. [fonte: PRODUTO E LINGUA-

GEM, $2^{\circ}$. trimestre de 1965. Ano 1 ,

número 2.]
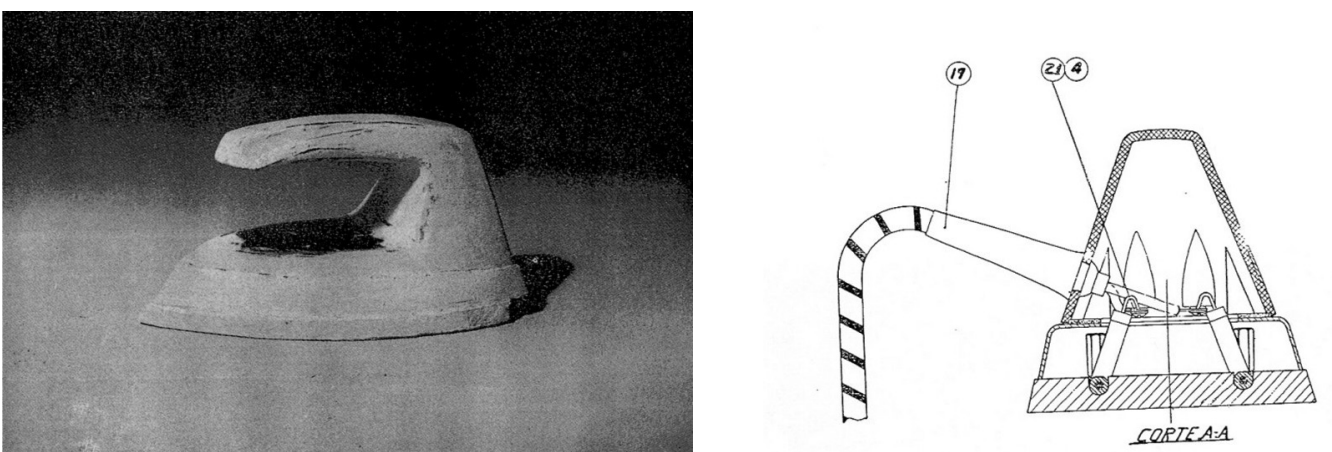

Fig.27. Setor de Desenho Industrial Walita S.A.. Ferro Elétrico Automático. 1965. [fonte: PRODUTO E LINGUA-

GEM, $2^{\circ}$. trimestre de 1965. Ano 1 número 2.]
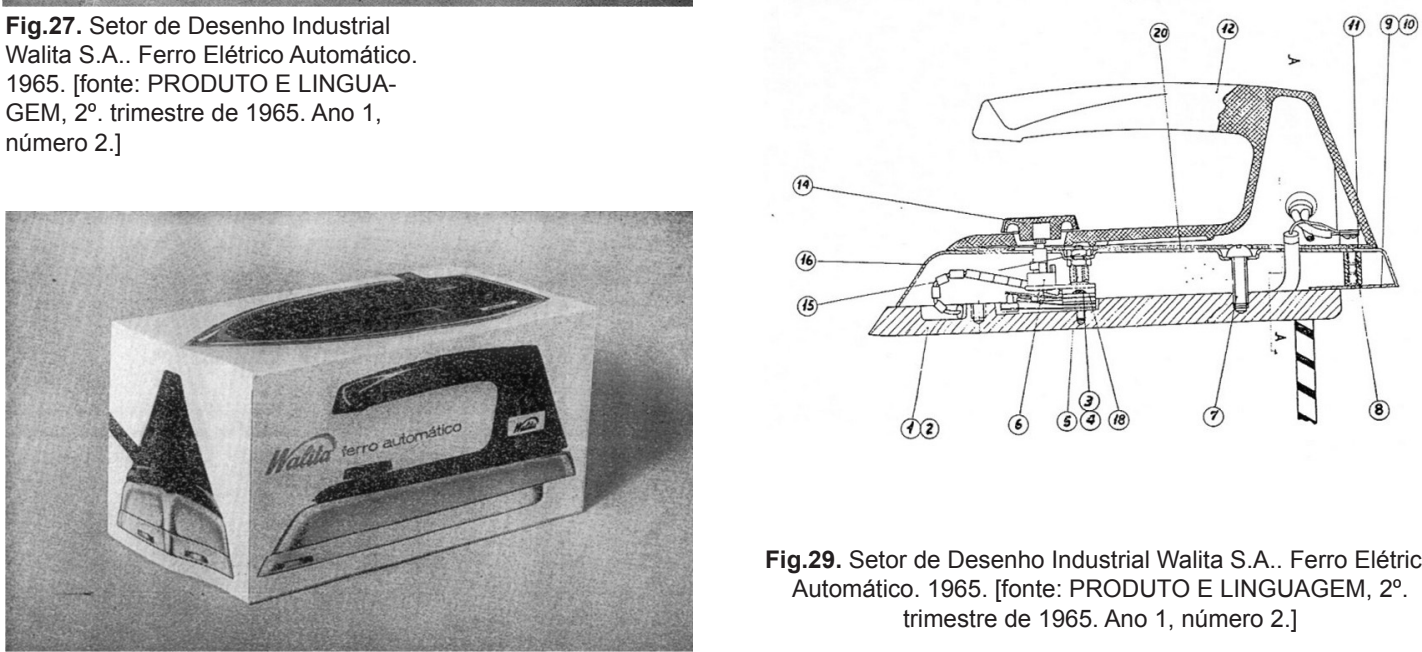

Fig.28. Setor de Desenho Industrial Walita S.A.. Ferro Elétrico Automático.

1965. [fonte: PRODUTO E LINGUA-

GEM, $2^{\circ}$. trimestre de 1965. Ano 1,

número 2.]

Fig.29. Setor de Desenho Industrial Walita S.A.. Ferro Elétrico Automático. 1965. [fonte: PRODUTO E LINGUAGEM, $2^{\circ}$ trimestre de 1965. Ano 1, número 2.] 


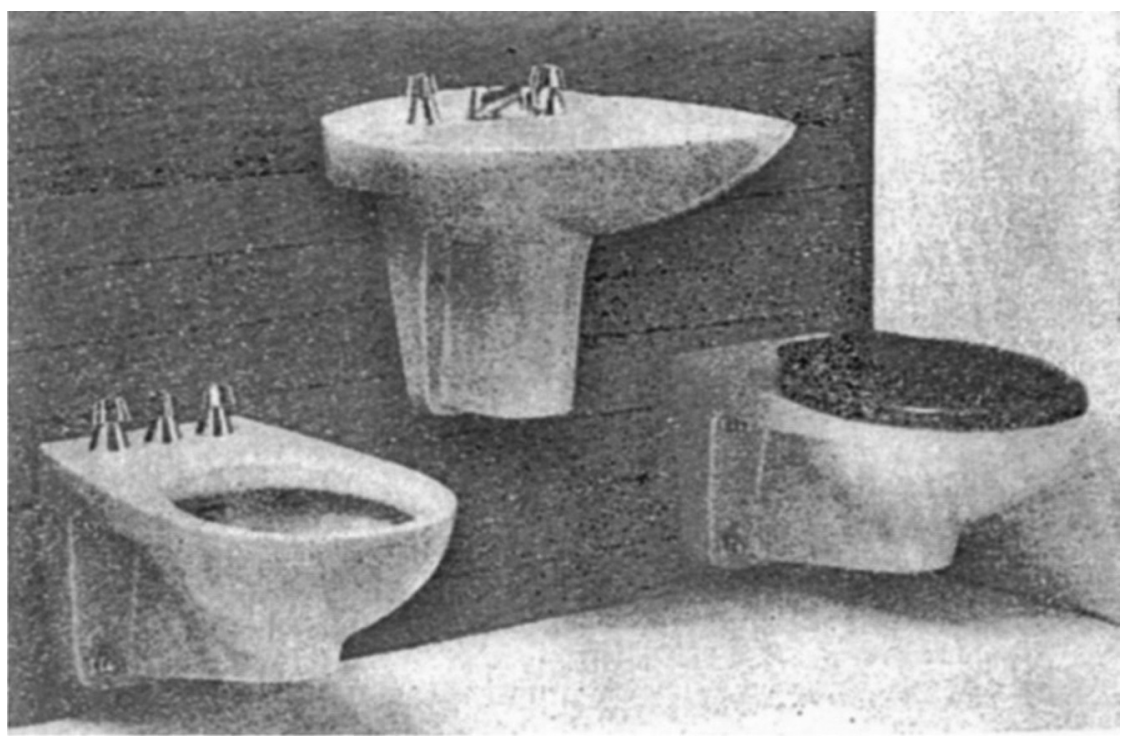

Fig.30. Gustave Adolphe Martin (Cerâmica Sanitária Porcelite). Conjunto de peças sanitárias Suspensas. 1965. [fonte: PRODUTO E LINGUAGEM, $2^{\circ}$. trimestre de 1965. Ano 1, número 2.]

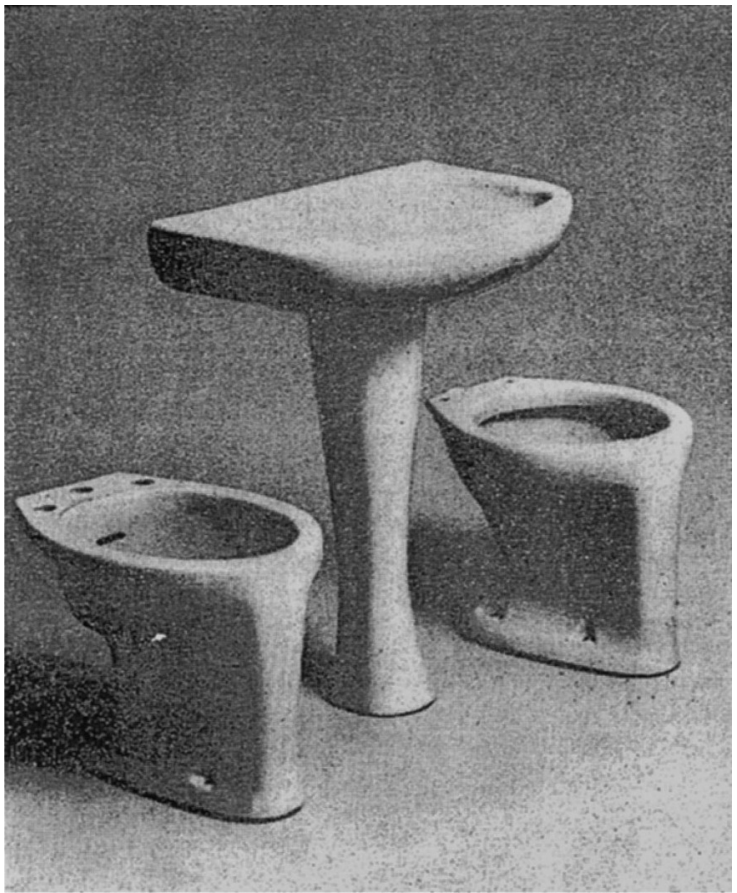

Fig.31. Norman Westwater (Indústria Ideal Standard). Conjunto de Louça Sanitária. 1966. [fonte: PRODUTO E LINGUAGEM. $1^{\circ}$. trimestre de 1966. Ano 1, número 3.]

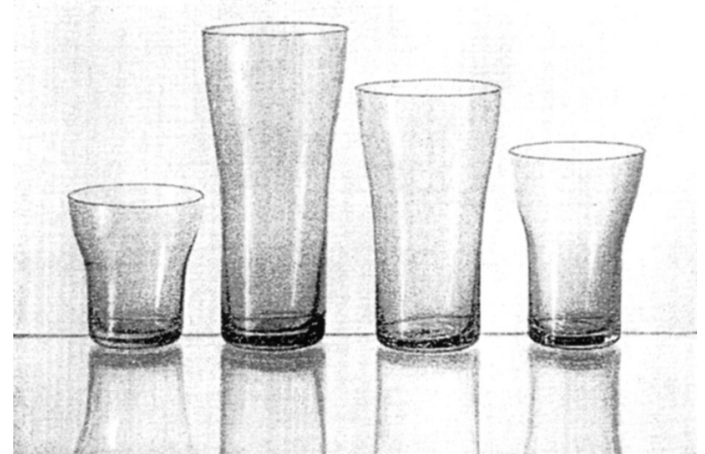

Fig.32. Antonio Gundemaro Lizarraga (São Marco Vidros de Arte Ltda.). Linha de Copos Trópico. 1965. [fonte: PRODUTO E LINGUAGEM, $2^{\circ}$. trimestre de 1965 . Ano 1, número 2.] 
No que foi exposto até aqui sobre a ABDI e a sua atuação, alguns dados podem ser tomados como esclarecedores do lugar do desenho industrial e do desenhista industrial dentro da industrialização brasileira. Em 1963, quando a $A B D I$ é fundada como a primeira e, até então, única entidade do gênero, o Brasil já possuía um considerável nível de industrialização, esforçando-se para superar sua entrada tardia nesse processo, seja pela participação do Estado, seja pela mobilização dos próprios industriais. Nesse período, a industrialização brasileira tinha como meta o incremento de sua produção de bens de consumo e, para realização desse contexto, as indústrias automobilísticas aqui transplantadas significaram uma decisiva contribuição. Nesse mesmo período, a $A B D I$, enquanto associação de nível nacional, com a participação da FIESP, contava entre seus associados com apenas 66 membros. Deste total, apenas 10 estavam inscritos como desenhistas industriais, 9 como arquitetos e 8 como arquitetos e desenhistas industriais. Se considerarmos esses números, indicando um total de apenas 27 designers (formados desenhistas industriais, arquitetos ou ambos) sócios da ABDI e, somando-se a este quadro, a participação no Prêmio Roberto Simonsen de apenas 16 projetos inscritos em 1964, e 37 participantes em 1966, tem-se a constatação de uma condição de descompasso entre a quantidade de indústrias e a de projetistas para os seus produtos. Diante deste quadro, parece totalmente justificado o empenho desta geração pioneira na constituição deste campo profissional. Para delimitá-lo com maior clareza, atuaram de três formas distintas, mas complementares. Empenharam-se em uma presença concreta e uma ação transformadora no mercado, como profissionais projetistas. Procuraram construir uma consciência social da relevância de tal profissão, por intermédio da ABDI. E, ao mesmo tempo, foram professores para formar esses profissionais. Mas, é necessário considerar que nem sempre o consenso foi o 
18. Conforme consulta ao seu Curriculo Lattes (www.lattes. cnpq.br, 11 de fevereiro de 2009), Grinover foi contratado em 1958 para o cargo de professor assistente da FAU USP. fio condutor desse processo.

Exemplo desse tripé de atuação, Lúcio Grinover, além de realizar projetos de desenho industrial e ser diretor da ABDI entre o ano de 1963 até 1968, realizou uma decisiva atuação à frente da implantação da Sequência de Desenho Industrial da FAU USP. Grinover estudou na FAU USP entre 1953 e 1957, se tornando docente na mesma a partir de $1958^{18}$. Tendo entrado para o quadro docente da FAU USP quatro anos antes da Reforma de 1962, colaborando intensamente para a sua implantação, após 1962, e ainda com um diálogo nesses anos com os docentes da ESDI, por intermédio de sua direção exercida na ABDI, toda essa trajetória profissional desenvolvida converte o seu depoimento sobre esses temas em um importante documento para a investigação daqueles anos.

Ao se reportar ao período, e procurando diferenciar o ponto de vista sobre a formação do desenhista industrial entre a ESDI e a FAU USP, informaria que, ao contrário da primeira, pensava na formação do especialista em desenho do produto ou em programação visual, e que a FAU USP pensava na criação de uma Universidade do Projeto:

As origens das duas Escolas são completamente distintas. Seja no desenho industrial aqui como no desenho industrial do Rio Janeiro. As grandes influências lá no Rio de Janeiro, naquela época, eram mais da Bauhaus e da Escola de (HfG) Ulm. Porque quando começou você tinha o (Karl Heinz) Bergmiller, você tinha o (Alexandre) Wollner que deram e começaram a dar aulas lá. Então realmente a origem da ESDI, no Rio de Janeiro, está mais relacionada com (HfG) Ulm, do que a FAU USP. A ideia era completamente diferente. Lá queriam fazer desenho de produto e nós queríamos, pensávamos que, além do desenhista de produto, esse indivíduo que saía da FAU USP, era um indivíduo que podia projetar em diversas áreas, ele escolheria a área na qual se aprofundaria, por isso que tinha as quatro sequências: de Projeto, Desenho Industrial, 
19. Depoimento ao autor em 04 de março de 2009.
Comunicação Visual e Urbanismo. A ideia da FAU USP era um pouco utópica, está certo, mas eu acho que continua uma ideia, ainda hoje, extremamente válida, de você ter praticamente uma Universidade do Projeto. Esse era o meu grande sonho quando garoto, de poder participar e colaborar na criação de uma Universidade do Projeto. Aí realmente as diferenças entre uma e outra geram nuanças. Certo, o que importava (no caso da citada Universidade do Projeto) era você ter como básico todo o ensino, todo o desenvolvimento de ensino, seja teórico ou prático, num projeto ${ }^{19}$.

Assim como é clara a Grinover, a Wollner, a Bergmiller, e a tantos outros, a filiação da ESDI à Escola de Ulm e também à Bauhaus, com relação à filiação desta ideia de constituição dentro da FAU USP de uma Universidade do Projeto, usando os termos do próprio autor, para Grinover esta surgia muito mais ancorada em um processo de discussões internas da própria Faculdade e dos debates entre os seus docentes. E, de acordo com Grinover, essa constituição de uma Universidade do Projeto seria um ideal compartilhado inclusive por Artigas, quando no exercício de sua liderança da Reforma de 1962:

O Artigas estava querendo dizer, acho eu, embora não tenha aparecido oficialmente em nenhum lugar, ele estava pensando também numa Universidade do Projeto, (...). Tudo me demonstra que ele estava pensando a mesma coisa. Talvez nós pensássemos maneiras diferentes para fazer isso, mas não me venham dizer que ele não tinha essa ideia, certo, de fazer alguma coisa, justamente uma ideia com várias possibilidades criativas e tecnológicas do arquiteto. Isso era aquilo que ele pregou durante muito tempo, sem dúvida nenhuma. Então, a importância dele, além de ser um carisma da arquitetura, a maneira de encarar os problemas todos... ele conduzia a turma para diversos lugares e nesse aspecto ele era muito bom e pioneiro. Depois disso, Artigas não faz mais nada que dissesse que ele estava apaixonado ou fizesse alguma coisa em termos de Desenho Industrial. Não, ele não fez. Ele desenvolveu algumas coisas em termos de arquitetura, depois 
21. Vale notar que muitos alunos da FAU USP, depois de formados, não definiram uma atuação profissional em apenas uma das quatro áreas, atuaram, sim, em várias delas e ainda em suas interfaces.

22. Grifo nosso.
E com relação a essa pretendida Universidade do Projeto, é importante ressaltar alguns pontos de método de ensino que afastam definitivamente este modelo dos outros. Se considerarmos as experiências de ensino de Desenho Industrial relatadas no capítulo anterior, sejam os VKhUTEMAS, a Bauhaus, a HFG de Ulm, e no caso brasileiro, o IAC MASP e a ESDI, todas essas escolas compartilhavam uma evolução metodológica do seu ensino, a partir de um modelo comum. Esse modelo dizia respeito a um processo em que o aluno entraria inicialmente em um Curso Básico, onde era ministrado um ensino introdutório comum a todos os alunos, e após a preparação neste Curso Básico, cada aluno escolheria uma única especialidade para seguir em frente em relação ao seu aprendizado. Na FAU USP, a situação era outra. Em primeiro lugar, a Escola nunca constituiu um curso básico nesses moldes descritos. E, em segundo, também ao contrário das Escolas supracitadas, o estudante da FAU USP não escolheria uma especialidade, mas estava obrigado a cursar todas elas: desenho industrial, programação visual, edificações e urbanismo. Então, depois de formado é que o estudante, agora profissional, escolheria qual área desejaria para desempenhar suas atividades ${ }^{21}$. Conforme indicado acima, de acordo com o depoimento do professor Grinover, o que importava era você ter como básico todo o ensino ${ }^{22}$, todo o desenvolvimento de ensino, seja teórico ou prático, num projeto.

Na defesa de seu ponto de vista, Grinover informa que durante a sua direção da $\mathrm{ABDI}$, frente à disputa da competência do exercício profissional do desenho industrial a arquitetos ou a designers, o primeiro defendido pelos membros da ABDI ligados à FAU USP, e o segundo, 
23. Depoimento ao autor em 04 de março de 2009.

24. E de fato pode-se considerar que a linguagem do desenho técnico para o desenho industrial guarda certas similaridades com o desenho mecânico, uma vez que esse se encarrega do desenho de peças da e para as máquinas. pelos membros da $\mathrm{ABDI}$ ligados à ESDI, defenderia que o mesmo fosse exercido por quem se sentisse capaz de tal tarefa, mas com a ressalva positiva com relação àqueles formados arquitetos: (...) dentro da Faculdade de Arquitetura, talvez você pudesse ter um preparo teórico melhor do que se não fosse. Nós admitíamos que outros pudessem fazer desenho industrial, não era exclusivo ${ }^{23}$.

Dentro dessa concepção de ensino, isto é, a ideia da Universidade do Projeto, os conhecimentos básicos estariam inseridos dentro do aprendizado de cada uma das quatro sequências de projeto, onde cada uma teria a autonomia para informar o que tem caráter introdutório para o seu aprendizado. Veja-se, por exemplo, o caso da Sequência de Desenho Industrial. Conforme relatos e o exame de documentos relativos ao ensino nesta área, sempre foi considerado importante que o estudante passasse por uma formação de caráter introdutório sobre representação e desenho técnico na escala do objeto que tem certas peculiaridades com relação ao desenho e representação na escala do edifício ou do urbanismo. E para a constituição desta formação aos estudantes, naqueles anos pioneiros, a FAU USP estabeleceu parcerias com as escolas do Serviço Nacional de Aprendizagem Industrial, o SENAl, que cedia para o ensino de desenho na FAU USP modelos de peças usadas para o ensino de desenho mecânico no SENAI ${ }^{24}$.

Para se entender esses conteúdos tratados como introdutórios na Sequência de Desenho Industrial da FAU USP, abaixo é apresentada uma tabela com a indicação das ênfases de aprendizado a cada ano do curso de DI da FAU USP: 


\begin{tabular}{|c|c|c|c|}
\hline & TEÓRICA & PRÁTICA & EXERCÍCIOS \\
\hline $\begin{array}{l}0 \\
\text { 2 } \\
\text { ol } \\
\text { ol } \\
-1\end{array}$ & $\begin{array}{l}\text { Importância do desenho } \\
\text { técnico como linguagem para } \\
\text { a realização formal. } \\
\text { Estudo de objeto de função } \\
\text { específica limitada, revelando } \\
\text { o aspecto anatômico. }\end{array}$ & $\begin{array}{l}\text { Desenho técnico - modelo } \\
\text { (sempre) } \\
\text { Individual - trabalho prático } \\
\text { Em equipe - análise do } \\
\text { problema }\end{array}$ & $\begin{array}{l}\text { Objetos existentes } \\
\text { Fazer desenho técnico } \\
\text { (relevo) } \\
\text { Projeto de objetos simples } \\
\text { de uso definido }\end{array}$ \\
\hline $\begin{array}{l}0 \\
\sum_{\alpha} \\
\text { ㅇ }\end{array}$ & $\begin{array}{l}\text { Os métodos de produção } \\
\text { industrial como definidores } \\
\text { das formas. Relação entre } \\
\text { desenho e materiais } \\
\text { (desenho de execução, } \\
\text { desenho de máxima). }\end{array}$ & $\begin{array}{l}\text { Em equipes pequenas para } \\
\text { estudo de métodos de } \\
\text { produção, sempre ligadas ao } \\
\text { exercício prático. } \\
\text { Resultados das pesquisas são } \\
\text { exprimidos por equipes } \\
\text { Projetos realizados } \\
\text { individualmente }\end{array}$ & $\begin{array}{l}\text { Aperfeiçoamento de } \\
\text { objetos existentes (parte } \\
\text { ou total) ou pequenos } \\
\text { projetos (definido) }\end{array}$ \\
\hline $\begin{array}{l}0 \\
\sum_{\alpha} \\
\text { ol } \\
\text { m }\end{array}$ & $\begin{array}{l}\text { A forma do ponto de vista } \\
\text { estético: textura, cor, forma, } \\
\text { etc. } \\
\text { A função da forma }\end{array}$ & $\begin{array}{l}\text { Em equipes pequenas para } \\
\text { estudo de métodos de } \\
\text { produção } \\
\text { Resultados das pesquisas são } \\
\text { exprimidos por equipes } \\
\text { Em equipe - trabalhos } \\
\text { práticos }\end{array}$ & $\begin{array}{l}\text { Projeto de grupo de } \\
\text { objetos relacionado a uma } \\
\text { só diretriz. }\end{array}$ \\
\hline $\begin{array}{l}0 \\
\text { 엉 } \\
\text { ol }\end{array}$ & Síntese & $\begin{array}{l}\text { Individualmente - trabalhos } \\
\text { práticos }\end{array}$ & $\begin{array}{l}\text { Objetos individuais } \\
\text { (acabados) }\end{array}$ \\
\hline
\end{tabular}

Tabela 7: Sequência de Desenho Industrial.

Departamento de Projeto. FAU USP (1963-1967).

A importância de capacitar o estudante com os conteúdos de um desenho técnico específico para o desenho industrial, enquanto linguagem para a realização formal, é relatada em vários documentos. E sobre essa questão, ainda que a tabela acima demonstre um crescimento gradativo, a cada ano, nos conteúdos de desenho industrial, é curioso notar que, após a Reforma de 1962, a Sequência de Desenho Industrial não foi implantada gradualmente, mas sim de uma vez só. E os alunos do segundo ao quarto ano da Faculdade cursaram, nesse 
25. Para detalhes, ver trabalhos dos alunos do primeiro ao quarto ano do curso em 1962, publicados em FAU USP. Desenho Industrial 1962. São Paulo: Departamento de Projeto FAU USP, 1963. ano de 1962, o seu respectivo ano de desenho industrial correspondente à tabela acima, sem passar pela préformação dos anos anteriores. A única atividade de ensino de embasamento que em 1962 foi ministrada igualmente aos quatro períodos foi a de desenho e representação na escala do objeto ${ }^{25}$.

Outro ponto que foi fundamental no curso de desenho industrial, e tratado como um conteúdo de caráter introdutório, foi a preocupação em capacitar o estudante do curso com um método de projeto. E nesse ponto por intermédio de alguns professores, como Lúcio Grinover e Marlene Picarelli, o ensino de DI na FAU USP realizou uma aproximação com o pensamento de um ex-estudante da HfG de Ulm, o desenhista industrial Andries van Onck. Como se pode comprovar pelos depoimentos e pesquisa aos documentos do período, a teoria de um método de projeto de desenho industrial definida como Metadesign foi bastante presente dentro do ensino de DI na FAU USP, ao longo da década de 1960. No Brasil, este método de projeto teve em Andries van Onck um grande propagador. Em passagem pelo Brasil, van Onck proferiu cursos de Metadesign tanto na FIESP quanto na FAU USP, e sua teoria foi publicada também na revista Produto e Linguagem da ABDI.

A respeito do seu curso ministrado na FIESP e a menção ao seu curso que realizou na FAU USP, ao nível de pósgraduação em 1965, veja-se a divulgação que recebeu nas páginas da Produto e Linguagem:

\section{Curso de Metadesign}

A ABDI concluiu as conversações com o professor Andries van Onck, que deverá estar em São Paulo nos fins deste mês para iniciar um curso de Metadesign na FAU USP (Faculdade de Arquitetura e Urbanismo da Universidade de São Paulo) e na FIESP (Federação das Indústrias do Estado de São Paulo). 
O curso a ser ministrado na FAU é limitado aos interessados no mesmo, que tenham diploma de nível superior. É, portanto, um curso de pós-graduação, a ser dado em 40 horas de aula, com um limite máximo de 40 inscritos.

O curso a ser ministrado na FIESP será de 8 aulas, num total de 16 horas, a partir do dia 2 de agosto.

Programa do Curso de Metadesign:

1a Aula: Introdução ao Metadesign como aproximação metodológica aos problemas formais do design; a evidência histórica do Metadesign; disciplinas afins; o conceito de estrutura.

2a. Aula: Combinatória matemática: a teoria que está à base da comunicação humana. Conceitos de standard, unificação, coordenação modular, sistemas e elementos componíveis.

3a. Aula: A teoria da informação e a cibernética. Introdução aos conceitos de medida da informação; e entropia e a redundância. O produto do Industrial Design como uma mensagem.

4a. Aula: A topologia e, em particular, a teoria dos graphs. 0 graph como modelo abstrato do problema e a conseguinte definição do programa do Metadesign.

5a. Aula: A teoria dos grupos e a simetria; a definição de uma estrutura como set de automorfismos. Estruturas cristalinas, corpos platônicos, retículas bi e tridimensionais; problemas de embalagem.

6a. Aula: A teoria dos movimentos como definida pela cinemática e pelas máquinas operatrizes; Mecanismos planos e espaciais, danificações das juntas, determinação de curvas por meio de mecanismo.

7ạ. Aula: Geometrias euclidianas e não-euclidianas conforme o programa Erlangen (Felix Klein); teoria das lignes, superfície mínima tensão, campo determinado por uma geometria específica.

26. PRODUTO E LINGUAGEM. São Paulo: 2‥ trimestre de 1965. Ano 1, número 2. 8a. Aula: Conclusão. Critérios para aplicação do Metadesign no basic design e no próprio design. Novos caminhos para o ensino do Metadesign programado ${ }^{26}$. 
27. Ciência que estuda comparativamente os sistemas de comunicação, controle e regulação nos seres vivos e nas máquinas. In: Houaiss (2009, p.157).

28. Ramo da física que estuda o movimento dos corpos, sem referência às forças que os produzem. In: Houaiss (2009, p.159).
Como indicado acima, o curso proposto por Andries van Onck procura estabelecer uma metodologia para o design, ou o desenho industrial, considerando entre os pressupostos para a sua realização, basicamente, os conteúdos da matemática e da geometria, da teoria da informação, da cibernética ${ }^{27}$ e da cinemática ${ }^{28}$. Isto é, propõe-se uma metodologia de desenhoindustrial baseada muito menos num processo criativo e mais amparado num conjunto de conhecimentos técnicos e científicos. Este método, percebe-se pela depuração dos fatos, teve grande influência no ensino da Sequência de Desenho Industrial da FAU USP. Quando se examina a primeira publicação de trabalhos de seus estudantes realizados em 1962, no campo de desenho industrial, e publicados no ano seguinte, é clara, nos textos de apresentação de cada ano curricular, pelos respectivos professores, a maneira como buscavam conceituar o desenho industrial. Neles é clara a antecipação da preocupação de van Onck de não caracterizar o desenho industrial como invenção. No texto dos professores Roberto Cerqueira Cesar, Luiz Roberto Carvalho Franco e Dário Imparato, responsáveis pelo 4ㅇ ano do Curso de Desenho Industrial da FAU USP, ao apresentarem a avaliação do exercício realizado pelos estudantes, cujo tema de projeto era uma cafeteira de uso doméstico, assim se posicionariam:

Partiu-se então para os estudos preliminares, com os primeiros croquis e as primeiras discussões em torno do projeto propriamente dito. Surgiu a essa altura, com bastante nitidez o problema da invenção dentro do design. Nas diretrizes do curso fizemos questão de deixar claro que design não é invenção. O nosso trabalho desse ano, porém, deixou patente que em muitos casos torna-se difícil impedir que se resvale no campo da invenção. Os objetos estudados permitiam inovações de funcionamento que traziam dúvidas quanto à sua legitimidade 
29. Relatório das Atividades do Quarto Ano. Professores Roberto Cerqueira Cesar, Luiz Roberto Carvalho Franco e Dário Imparato. In: FAU USP. Desenho Industrial 1962. São Paulo: Departamento de Projeto FAU USP, 1963.

30. De acordo com Albuquerque (2004, p.58), o Museum foi criado com a implantação da Reforma de 1962 para dar suporte aos quatro departamentos em que a FAU USP passava então a ser organizada. O Museum foi constituído como um órgão coordenador das atividades curriculares, extracurriculares e complementares de ensino, visando a estimular o interesse pelas artes gráficas, pela cenografia, pela miniatura de projetos, por meio de modelos de gesso e pela arte fotográfica. dentro do trabalho. Ora, na escola torna-se difícil controlar essa tendência natural do aluno em inventar, em resolver o quebra-cabeça de funcionamento. Isso o afasta do problema real do Designer. Além disso, dificilmente teremos na escola, possibilidade de construir protótipos e testar as inovações propostas, que acabam por isso no campo das suposições. É aconselhável, portanto, cercar a escolha dos temas de mais esse cuidado: usar de preferência, objetos em que o campo da invenção seja o mais restrito possível ${ }^{29}$.

\section{Esse tipo de comentário, onde explicitamente se fala contra} a ideia de invenção no projeto de desenho industrial, por sua vez se repete também nos demais textos dos outros professores, nas apresentações de trabalhos dos demais períodos escolares do ano de 1962.

A publicação desses trabalhos escolares relativos ao ano letivo de 1962 pelo Museum ${ }^{30}$ da FAU USP apresenta os seguintes professores responsáveis pelas disciplinas e os respectivos exercícios de projeto:

\begin{tabular}{|c|c|c|}
\hline $\begin{array}{l}\text { Período } \\
\text { Escolar }\end{array}$ & Professores & Exercícios \\
\hline 10 ano & $\begin{array}{l}\text { Hélio de Queiroz Duarte } \\
\text { Marlene Picarelli } \\
\text { Lúcio Grinover }\end{array}$ & $\begin{array}{l}\text { Resolver a pega de um dos objetos: ferramentas } \\
\text { manuais (cabos de lima, chave de fenda, alicates), } \\
\text { cabos de panela, pegadores de gaveta, alças de } \\
\text { mala, botões para rádio, botões para painéis de } \\
\text { automóveis, maçanetas, torneiras, talheres, etc. }\end{array}$ \\
\hline 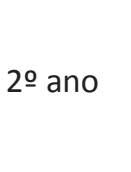 & $\begin{array}{l}\text { Ernest Robert de Carvalho Mange } \\
\text { João Baptista Alves Xavier } \\
\text { Cândido Malta Campos Filho }\end{array}$ & $\begin{array}{l}\text { Um dos três temas, com livre escolha dos alunos: Um } \\
\text { apagador de quadro negro para uso nas escolas em } \\
\text { geral; um abridor de garrafas para tampas metálicas } \\
\text { ou um cortador de papel para uso em escritórios. }\end{array}$ \\
\hline 3ㅇa ano & $\begin{array}{l}\text { José Maria da Silva Neves } \\
\text { Abrahão Velvu Sanovics } \\
\text { Luiz Gastão de Castro Lima }\end{array}$ & $\begin{array}{l}\text { Um jogo de xadrez (desenho das suas } 6 \text { peças, o } \\
\text { tabuleiro, a embalagem e a apresentação gráfica) e } \\
\text { o projeto de um isqueiro a partir de um mecanismo } \\
\text { existente fornecido ao estudante. }\end{array}$ \\
\hline 40 ano & $\begin{array}{l}\text { Roberto Cerqueira Cesar } \\
\text { Luiz Roberto Carvalho Franco } \\
\text { Dário Imparato }\end{array}$ & $\begin{array}{l}\text { Cafeteira: Propor uma solução para o preparo do café } \\
\text { doméstico brasileiro. }\end{array}$ \\
\hline
\end{tabular}

Tabela 8: Professores e exercícios de projeto da Sequência de Desenho Industrial da FAU USP em 1962. 
Relatório das Atividades do Primeiro Ano (1962)

Arquitetos professores: Hélio de Queiroz Duarte, Marlene Picarelli e Lúcio Grinover.

\section{Exercícios:}

1.Análise do Objeto e sua representação: Desenho técnico de objetos de madeira, aço e plástico (primeiro semestre).

2.Estudo e proposição de um objeto de uso: projeto e produção de um objeto à escolha do estudante: ferramentas manuais (cabos de lima, chaves de fenda, alicates, etc.), cabos de panela, pegadores de gaveta, alças de mala, botões para rádio, botões para painéis de automóveis, maçanetas, torneiras, talheres, etc.

[Fonte das imagens 33 até 42: FAU USP, 1963] 

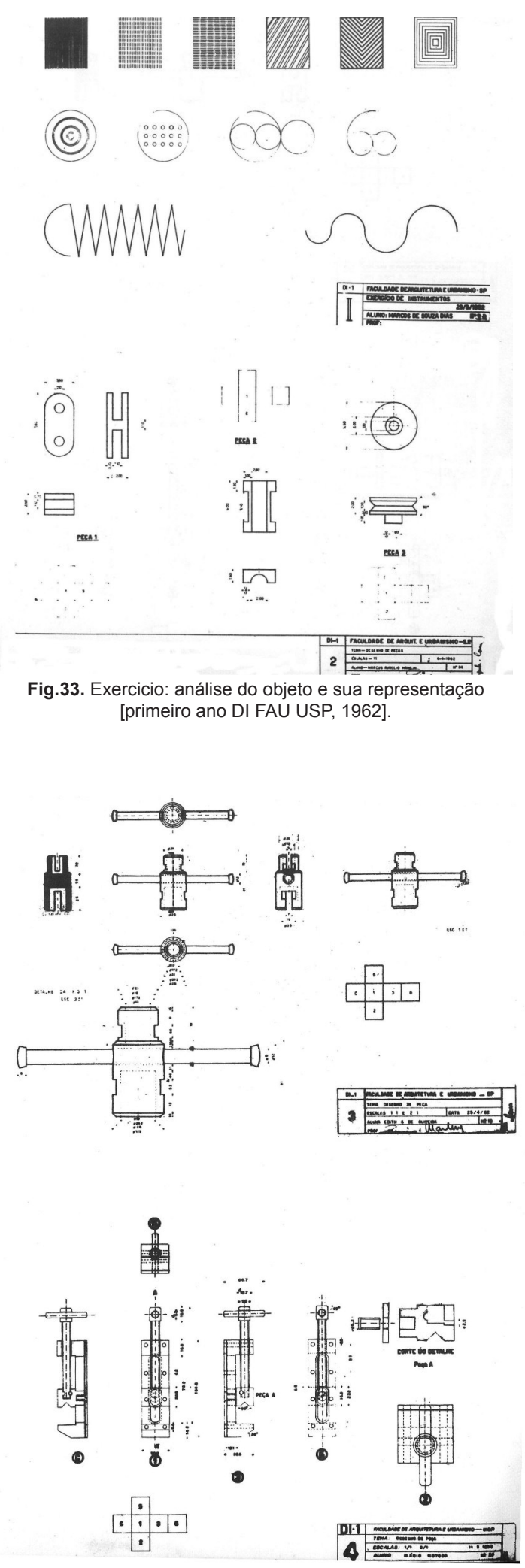

Fig.34. Exercicio: análise do objeto e sua representação [primeiro ano DI FAU USP, 1962]. 

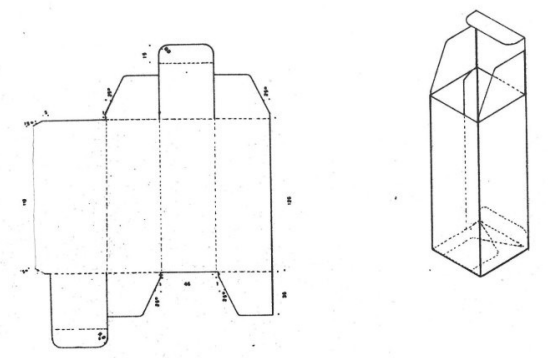

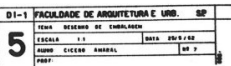
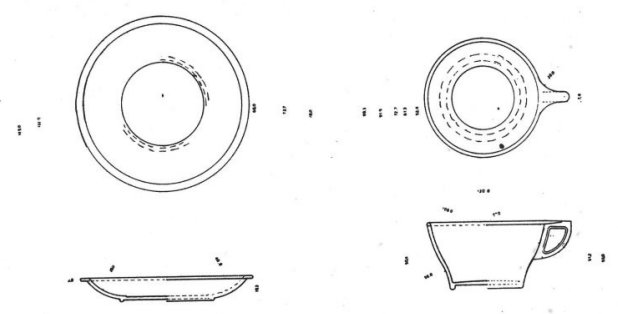

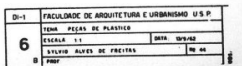

Fig.35. Exercicio: análise do objeto e sua representação [primeiro ano DI FAU USP, 1962].

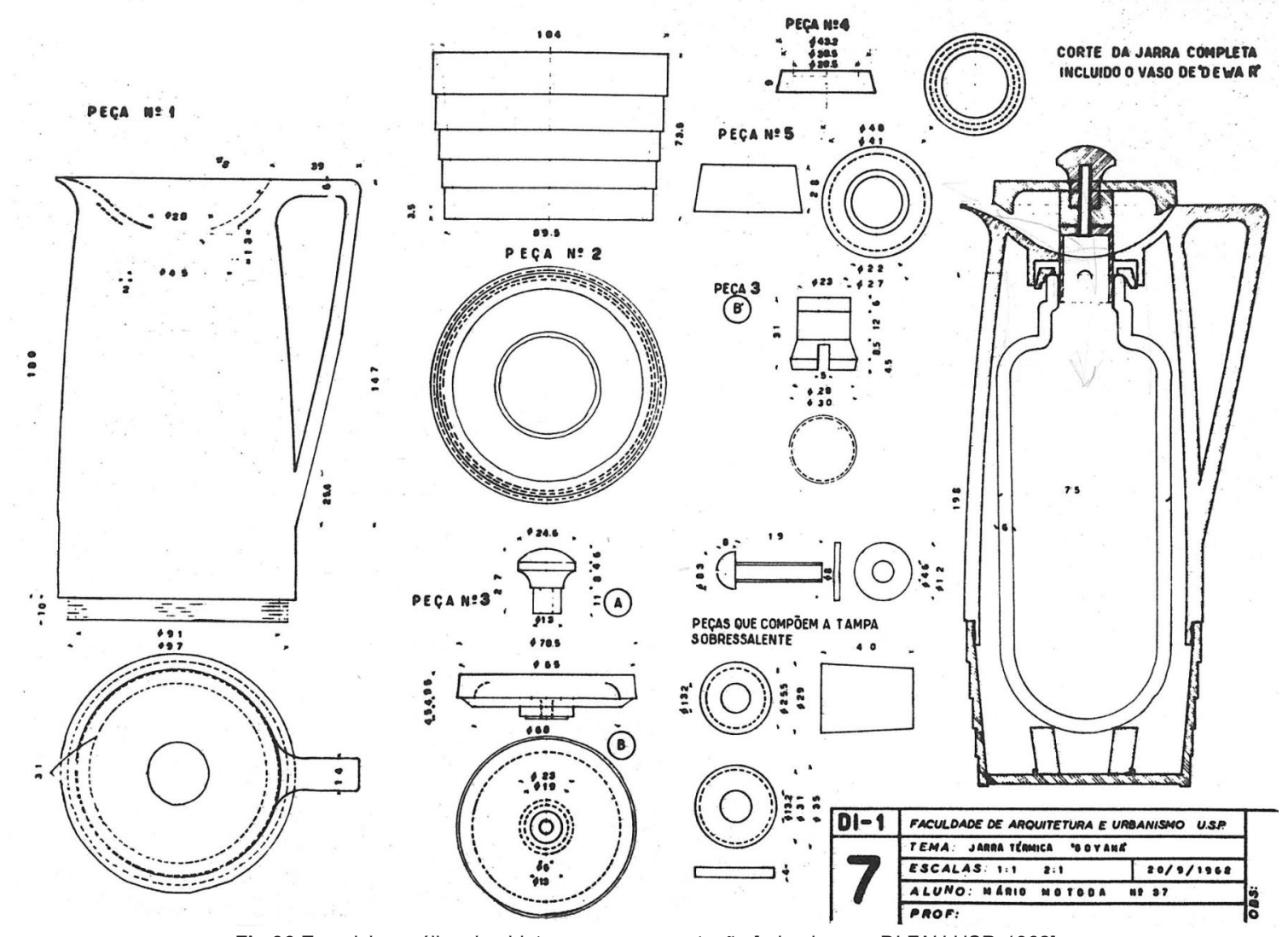

Fig.36 Exercicio: análise do objeto e sua representação [primeiro ano DI FAU USP, 1962] 

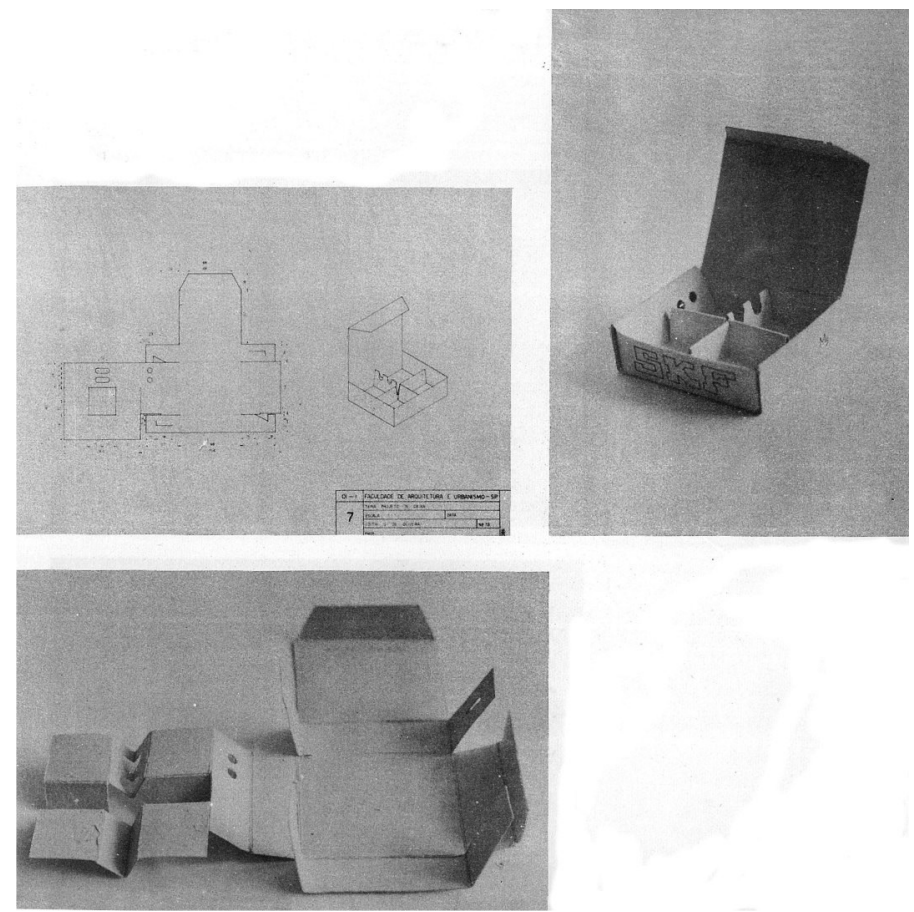

Fig.37. Exercicio: análise do objeto e sua representação [primeiro ano DI FAU USP, 1962].

\section{6}
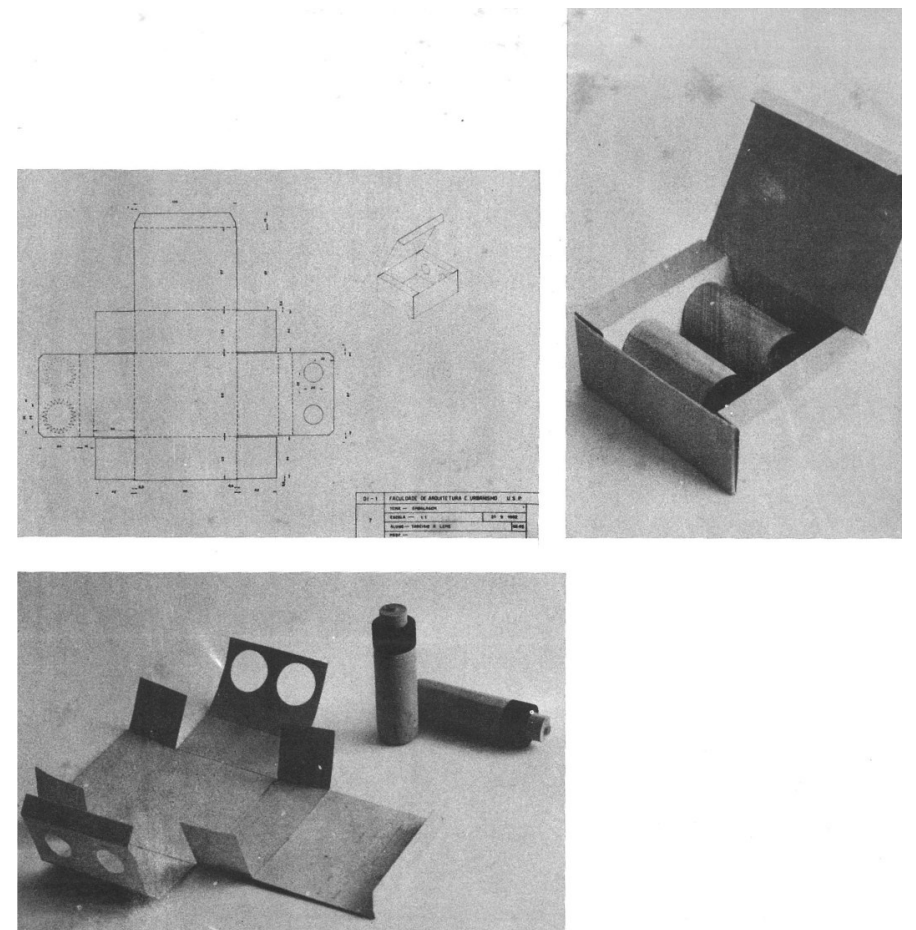

Fig.38. Exercicio: análise do objeto e sua representação [primeiro ano DI FAU USP, 1962]. 


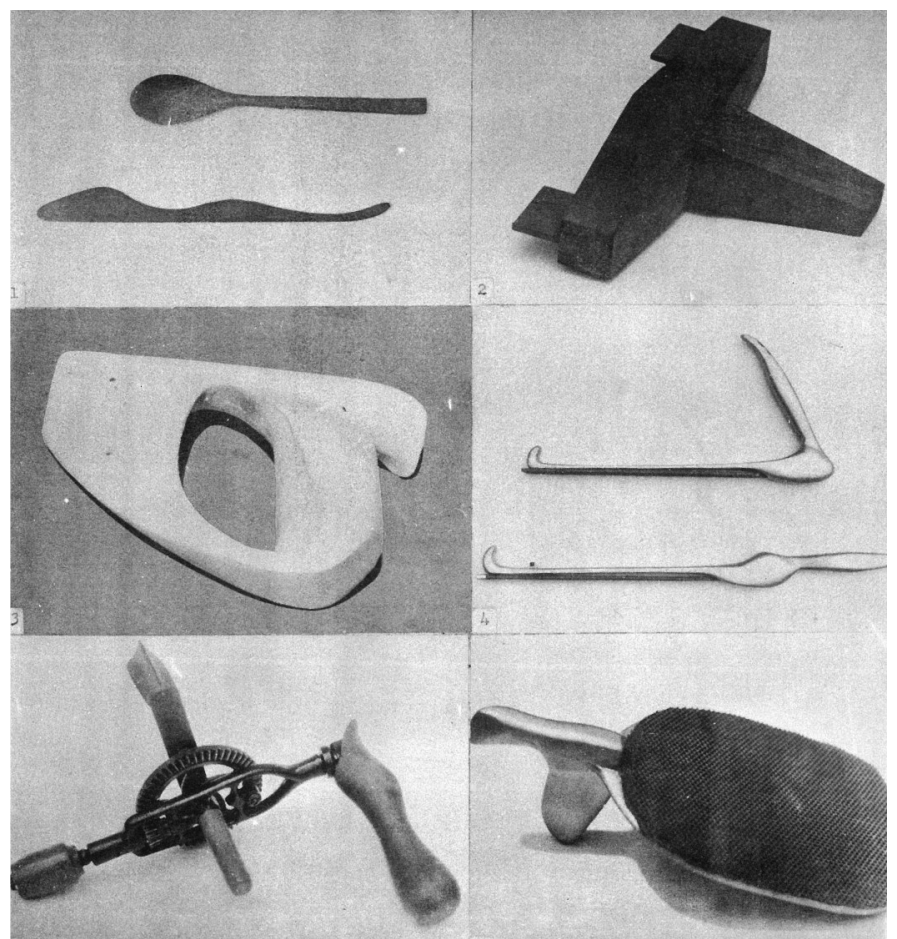

Fig.39.Exercicio: projeto e produção - ferramentas manuais [primeiro ano DI FAU USP, 1962].

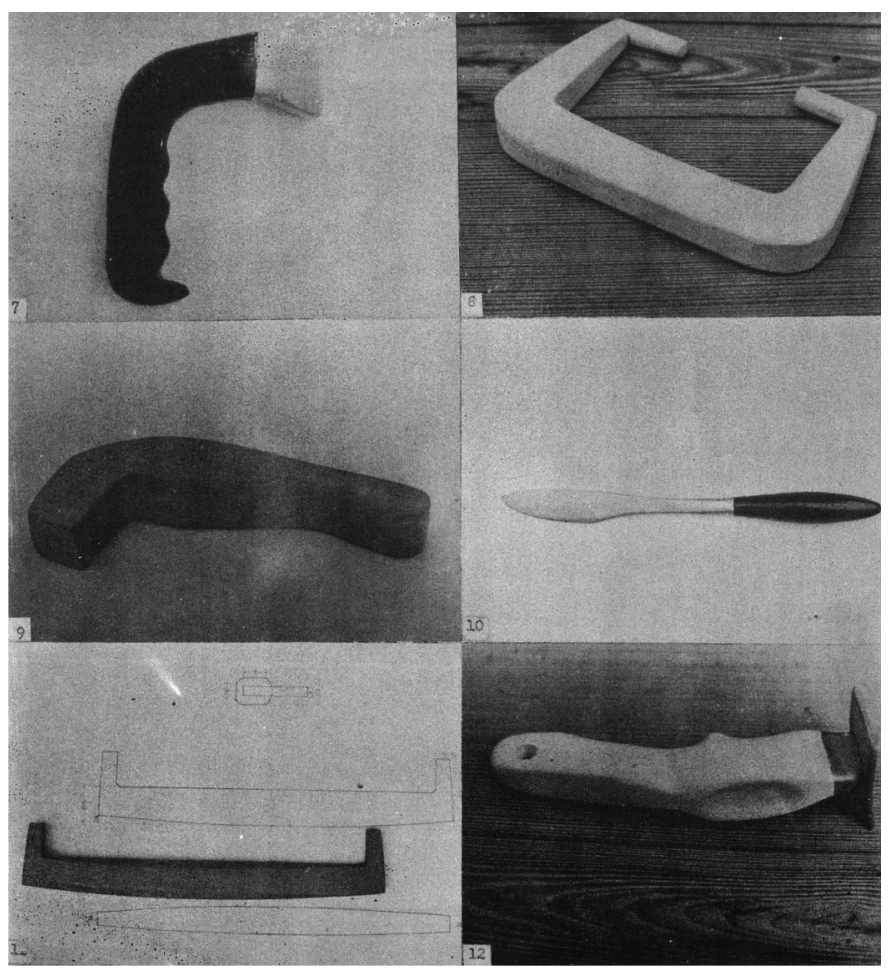

Fig.40. Exercicio: projeto e produção - ferramentas manuais [primeiro ano DI FAU USP, 1962]. 


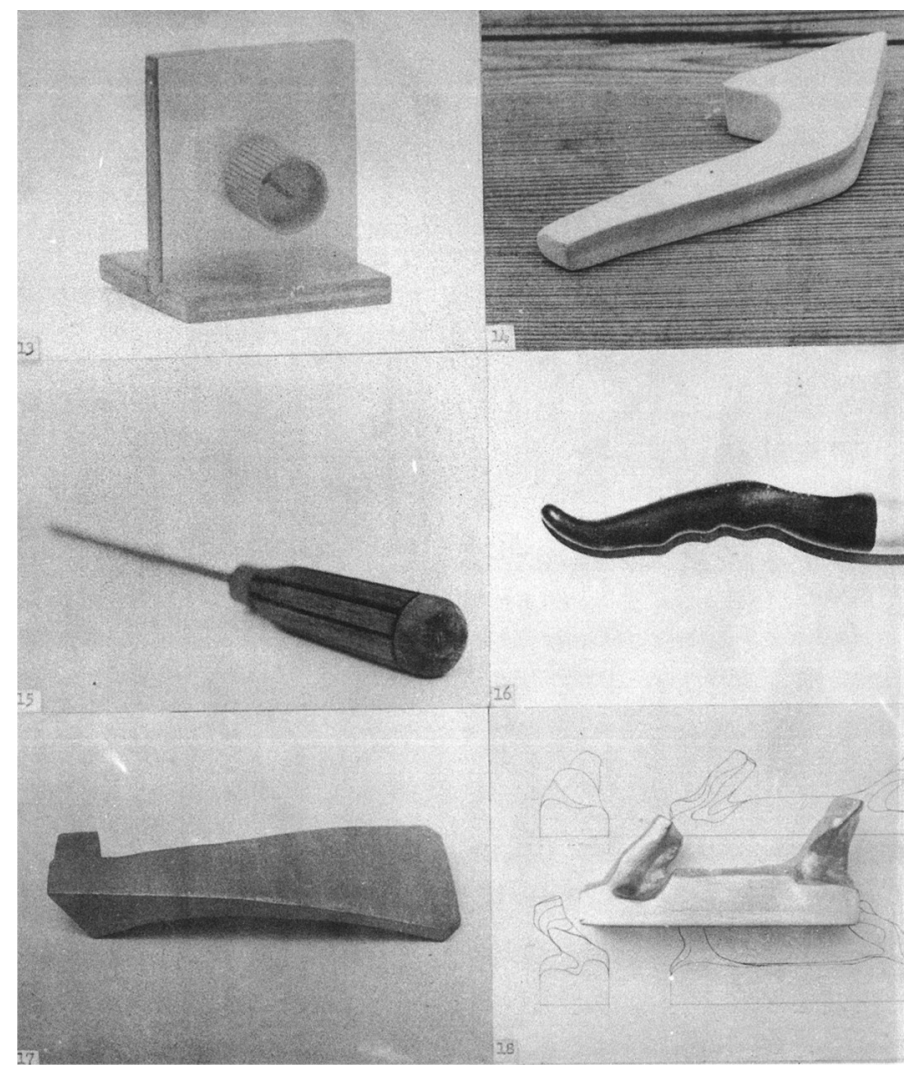

Fig.41. Exercicio: projeto e produção - ferramentas manuais [primeiro ano DI FAU USP, 1962]

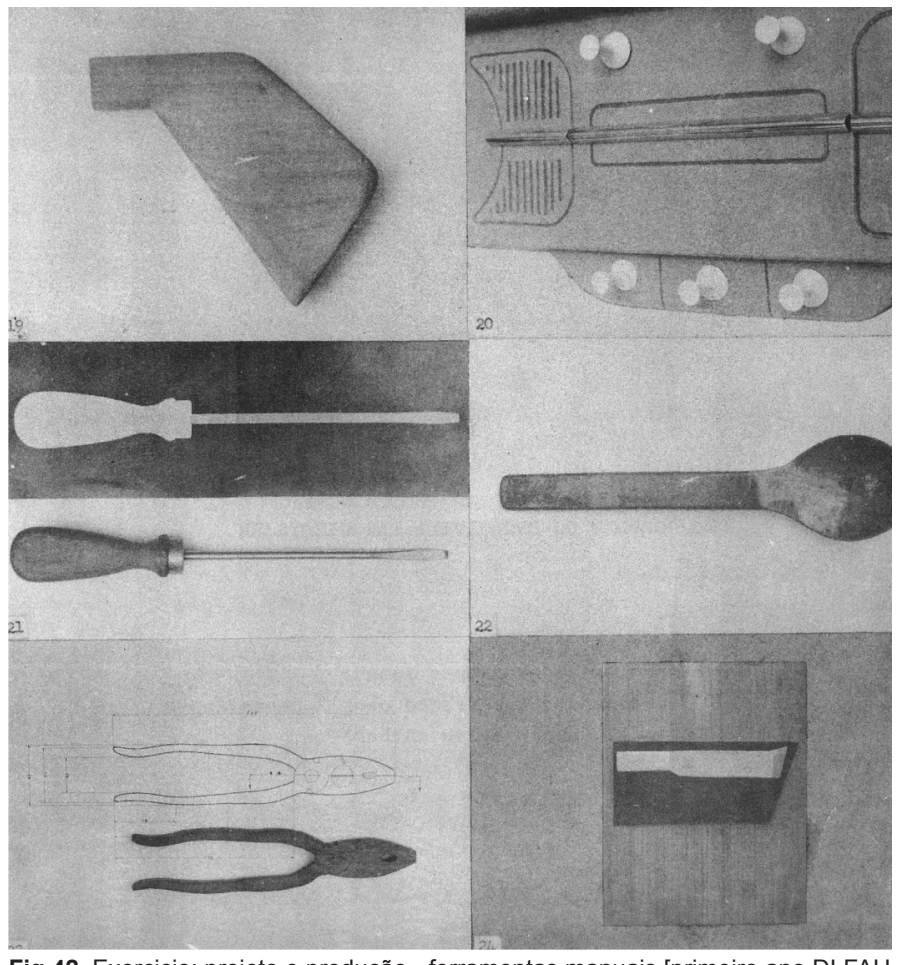

Fig.42. Exercicio: projeto e produção - ferramentas manuais [primeiro ano DI FAU USP, 1962]. 
Relatório das Atividades do Segundo Ano (1962)

Arquitetos professores: Ernest Robert de Carvalho Mange, João Baptista Alves Xavier e Cândido Malta Campos Filho.

\section{Exercícios:}

Escolha de um dos temas de projeto a serem desenvolvidos ao longo do ano letivo:

1. Um abridor de garrafas para tampas metálicas;

2. Um apagador de quadro negro, para uso nas escolas em geral;

3. Um cortador de papel para uso em escritórios.

[Fonte das imagens 43 até 46: FAU USP, 1963] 


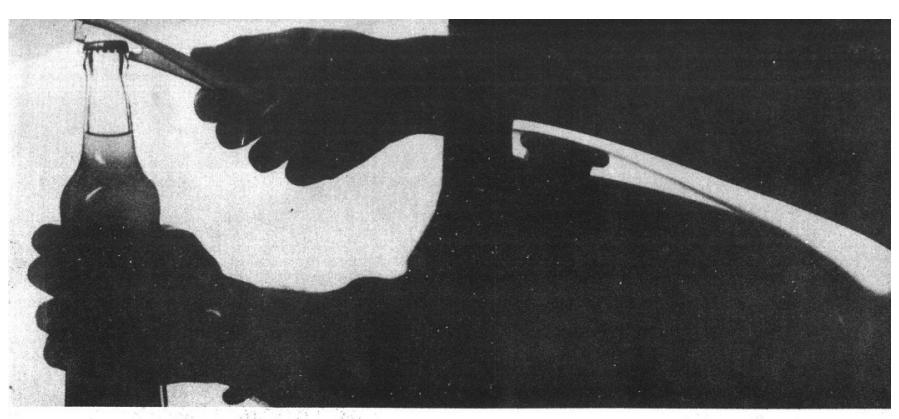

Garlos Nlberto Inécio Alexandre

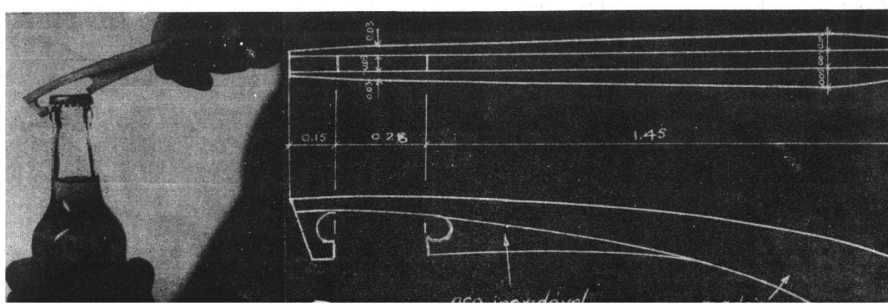

Fig.43. Exercicio: abridor de garrafas. [segundo ano DI FAU USP, 1962]

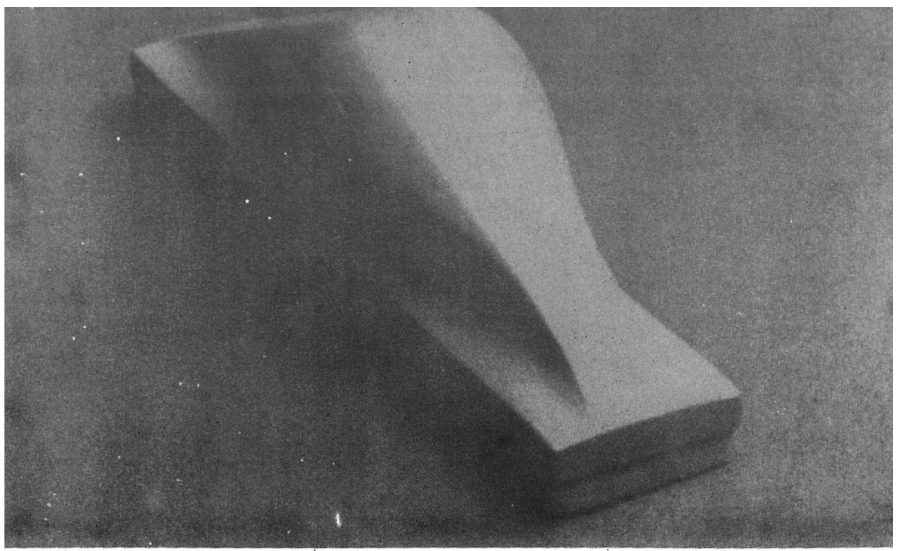

Cecilia Carmen Montei ro de Barn

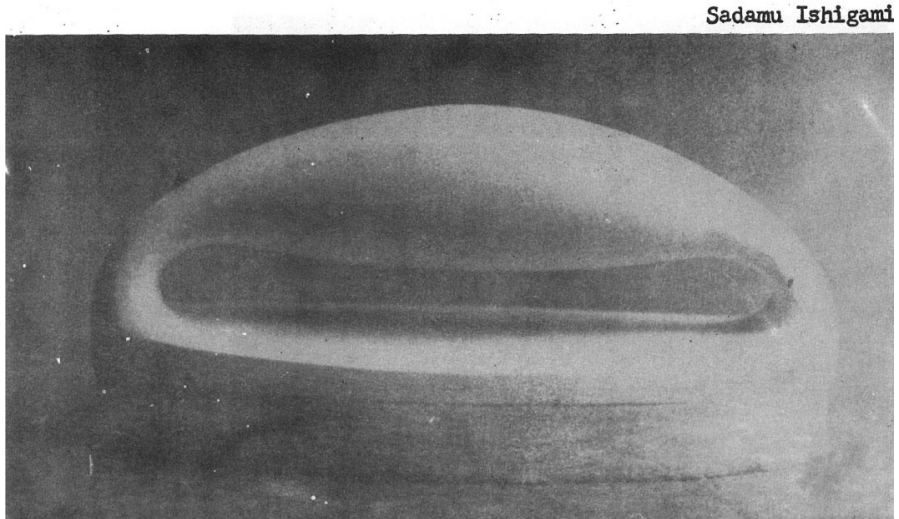

Fig.44. Exercicio: apagador de quadro negro [segundo ano DI FAU USP, 1962]. 


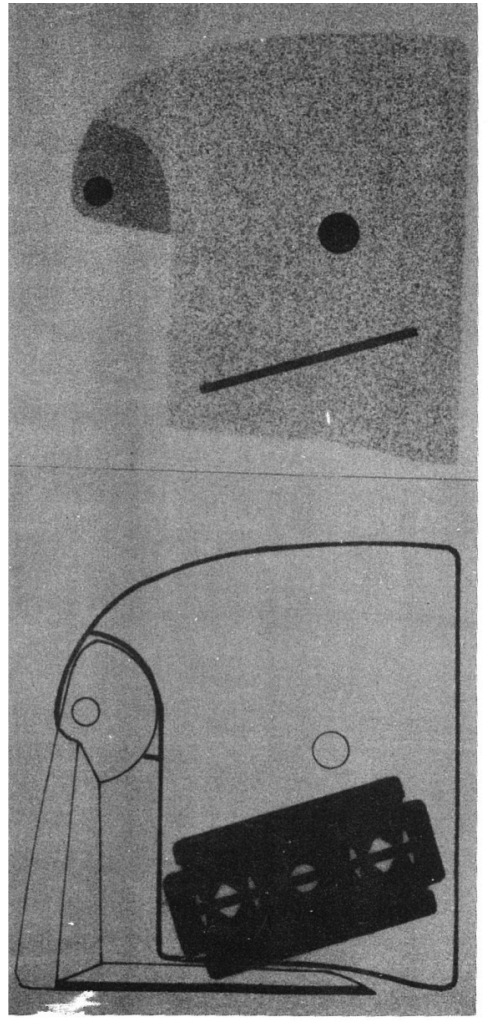

CORTADOR DE PAPEL

A função cortar é satf feita pela lâmina.cort te. Devido às facilida des de reposição, padr nisação e custo escolr. se uma lâmina do tipon" llete".

A LAMINA CORTANTE PREC SA DE UMA ESTRUTURA QUE SUPORTE.

Deve-se evitar que a 1 mina cortante risque $a$ prancheta de desenho. UMA PROTEÇX LIGADA A TRUTURA IMPEDE QUE A I MINA RISQUE A PRANCHET DE TRABALHO.

Proteção e suporte da

lete se adaptam formar um estojo metálico.

Fig.45. Exercicio: cortador de papel. [segundo ano DI FAU USP, 1962].

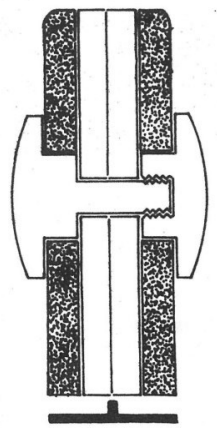

Um parfusoune to dos os elementos da estrutura: as 2 partes do esto jo metálico, fixando esse estojo à empunhadura PAULO MADEIRA RICARDO CHAHIN

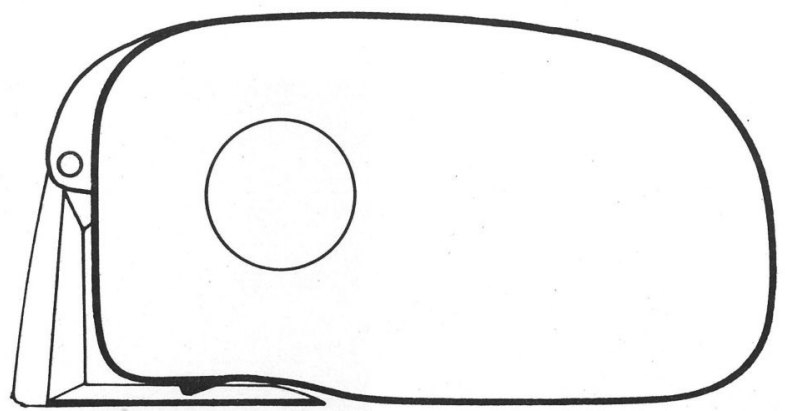

Fig.46. Exercicio: cortador de papel. [segundo ano DI FAU USP, 1962]. 
132 
Relatório das Atividades do Terceiro Ano (1962)

Arquitetos professores: José Maria da Silva Neves, Abrahão Velvu Sanovics e Luiz Gastão de Castro Lima.

\section{Exercícios:}

1. Re-estudo de um jogo de xadrez: Relevo e desenho, dentro das normas técnicas, de um jogo de xadrez existente; Projeto de seis peças; Projeto do Tabuleiro e Projeto do Estojo;

2. Projeto de um isqueiro a partir de um mecanismo existente dado.

[Fonte das imagens 47 até 61: FAU USP, 1963] 


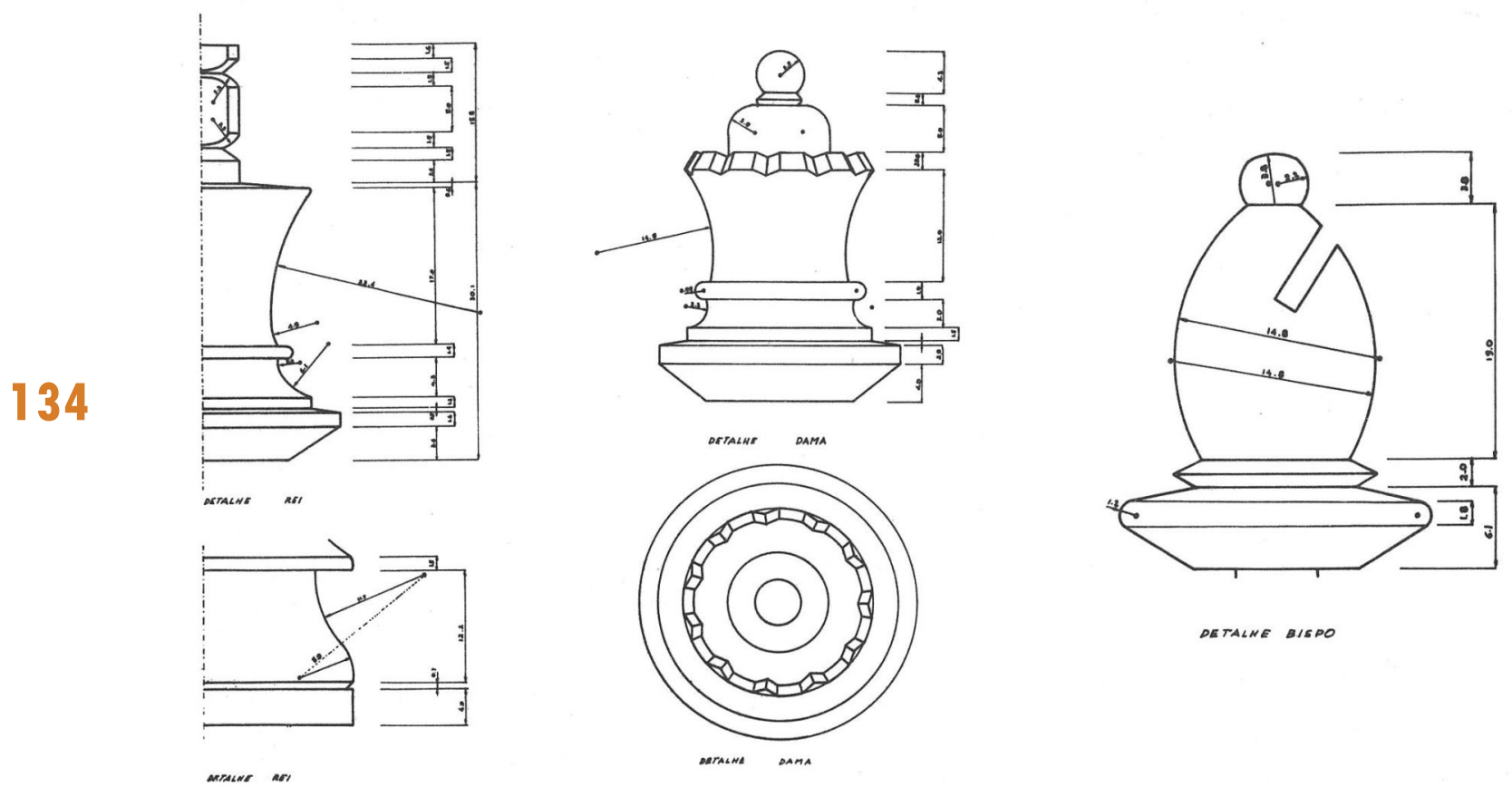

Fig.47. Desenho de um jogo de xadrez. [Terceiro ano DI FAU USP, 1962] 


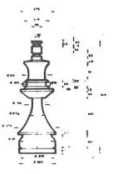

(9)

繁

迹

$\because$

㠊

(4)

(9)

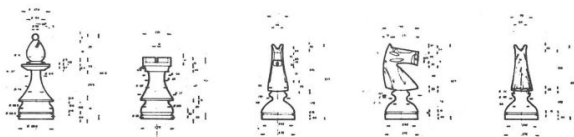

(0) 0

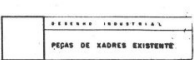

要:

E:

望:

(1)

(\$)

(I)

$\prod_{-1}^{2}$

党:

(a)

8

○

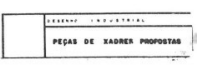

Fig.48. Desenho de um jogo de xadrez. [Terceiro ano DI FAU USP, 1962]
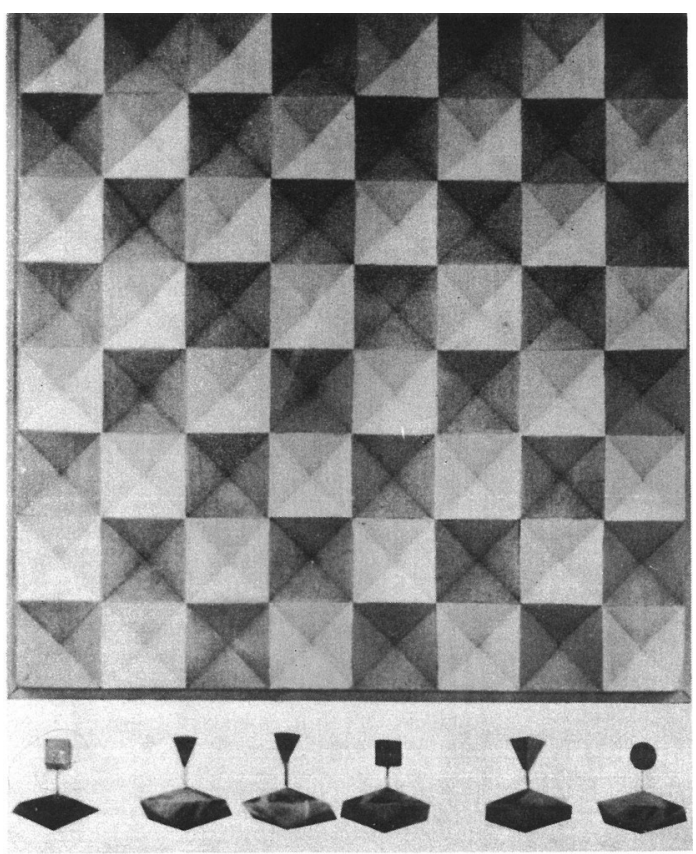

Alfredo Benito Parlato

Armenio Iranik Arakelian

Eurico João Salviati

Savério Henrique Castellano

Décio Verneck Moreira

Fig.49. Jogo de xadrez. [Terceiro ano DI FAU USP, 1962] 


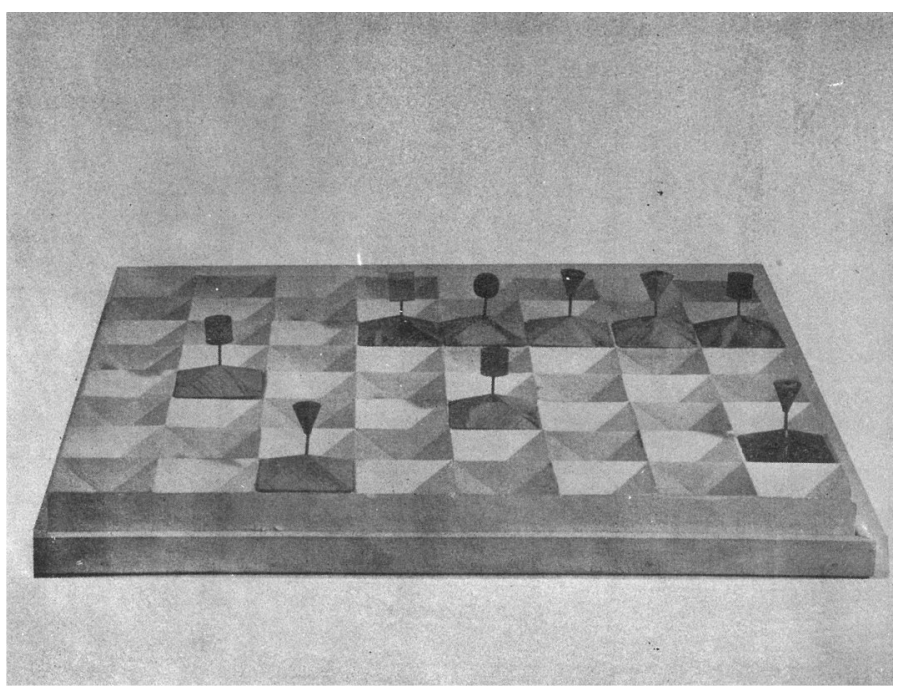

Fig.50. Jogo de xadrez. [Terceiro ano DI FAU USP, 1962]

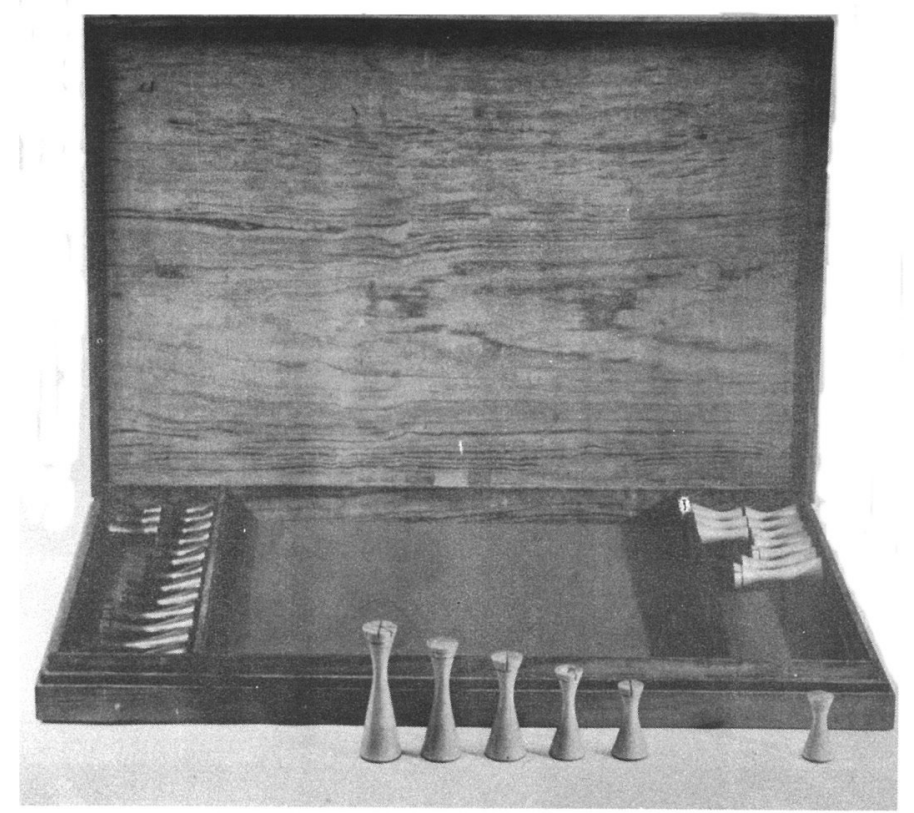

Adauto Ribeiro da Silva

Ivan Romano Batistic

Mutsutaka Shimizu

Paulo Rocha Queiroz

Wilson Rodrigues Netto

Yoiti Kataquiri

Fig.51. Jogo de xadrez. [Terceiro ano DI FAU USP, 1962] 

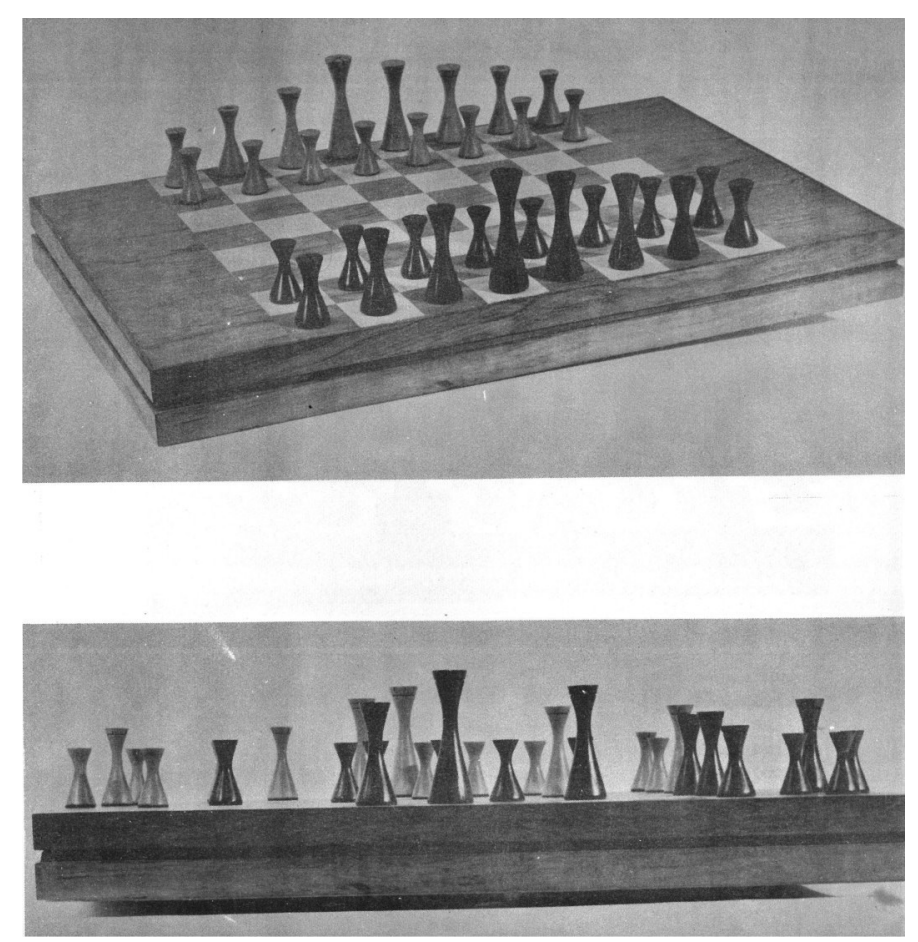

Fig.52. Jogo de xadrez. [Terceiro ano DI FAU USP, 1962]
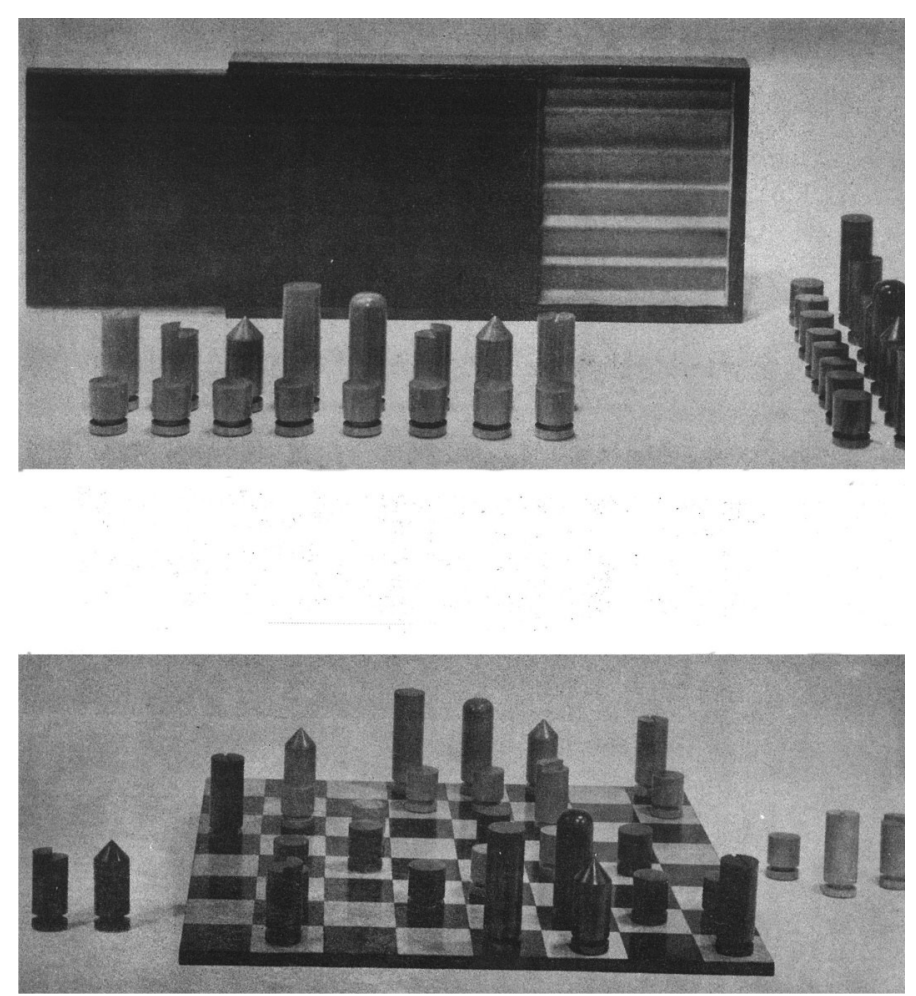

Fig.53. Jogo de xadrez. [Terceiro ano DI FAU USP, 1962] 


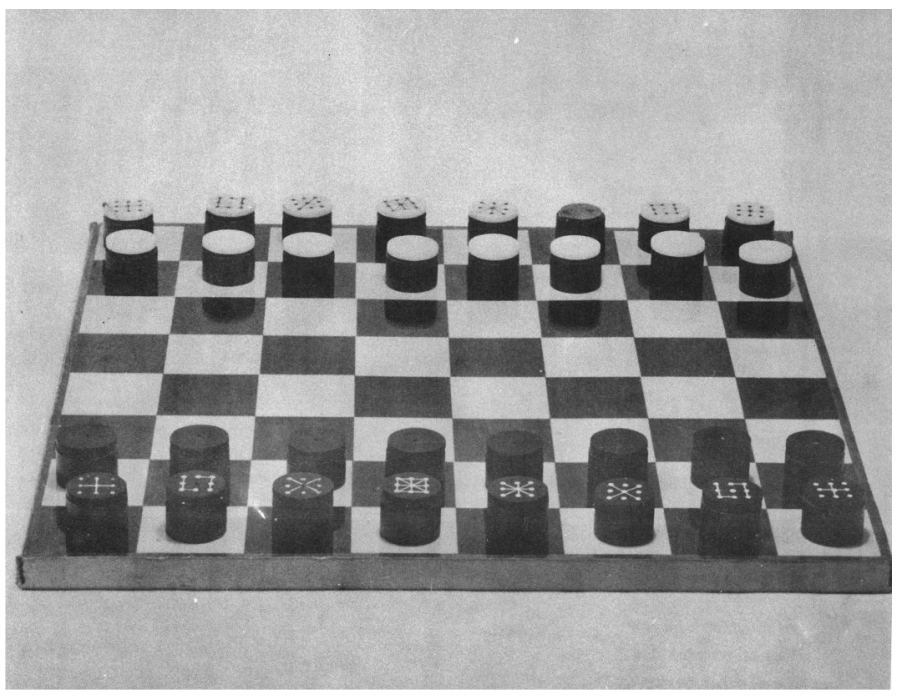

Fig.54. Jogo de xadrez. [Terceiro ano DI FAU USP, 1962]

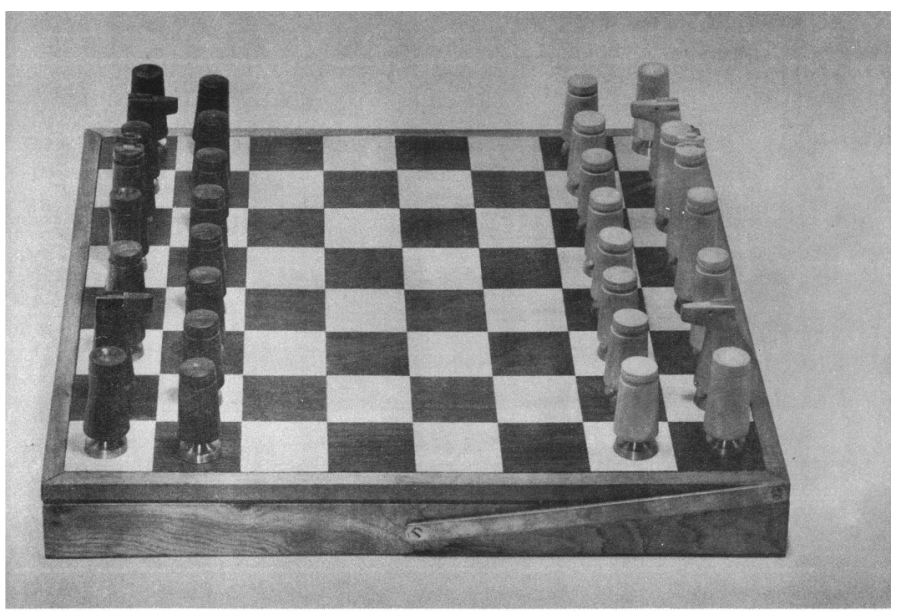

Antonío Célio Silve

Arí Antonto da Rocha

Arnaldo Antonio Martino

Carlos Henrique Heck

Conrado Jorge Heck

Fig.55. Jogo de xadrez. [Terceiro ano DI FAU USP, 1962] 

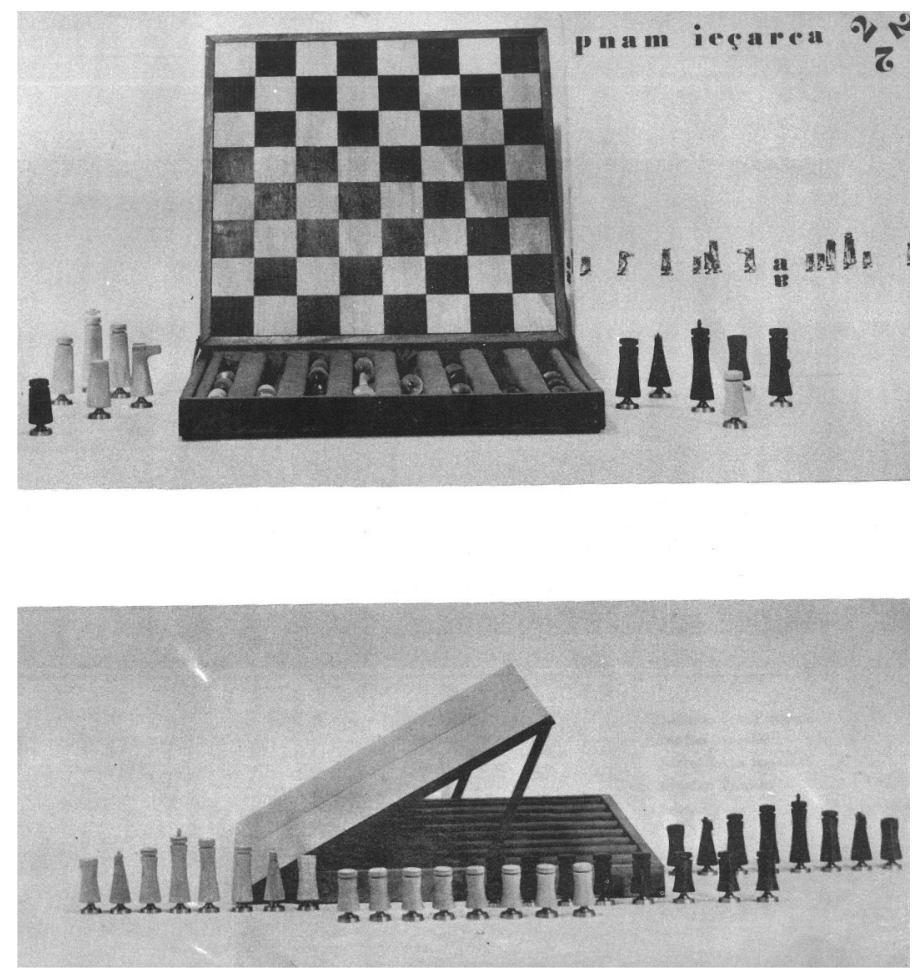

Fig.56. Jogo de xadrez. [Terceiro ano DI FAU USP, 1962]

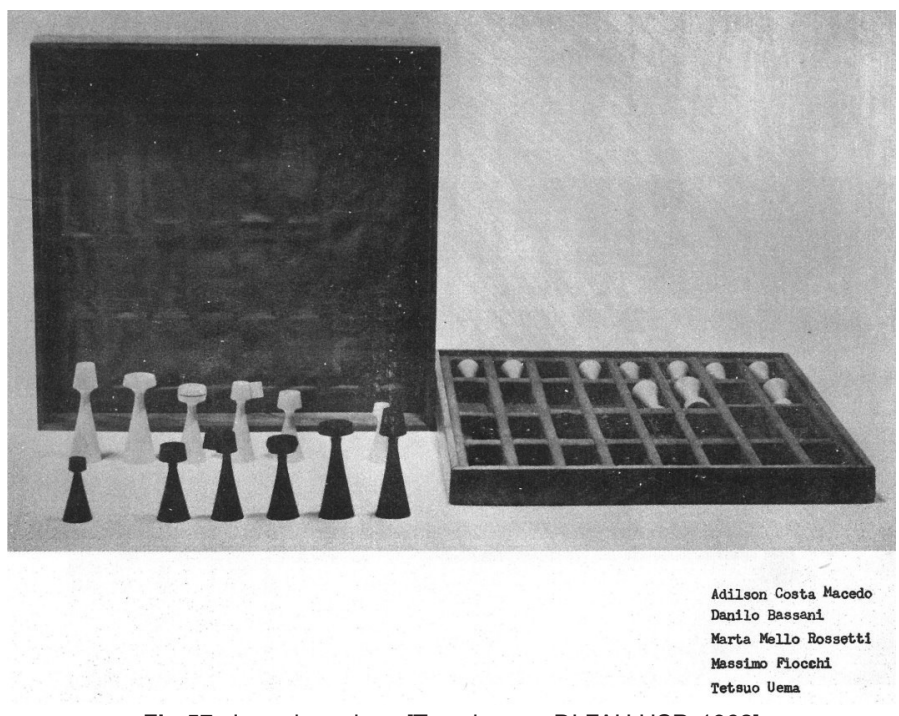

Fig.57. Jogo de xadrez. [Terceiro ano DI FAU USP, 1962] 


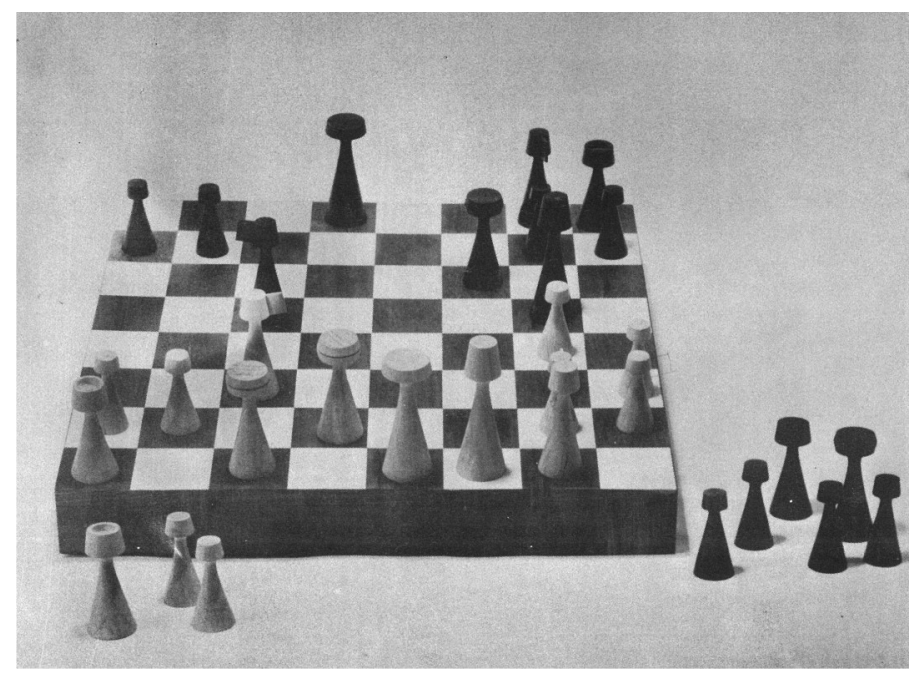

Fig.58. Jogo de xadrez. [Terceiro ano DI FAU USP, 1962]

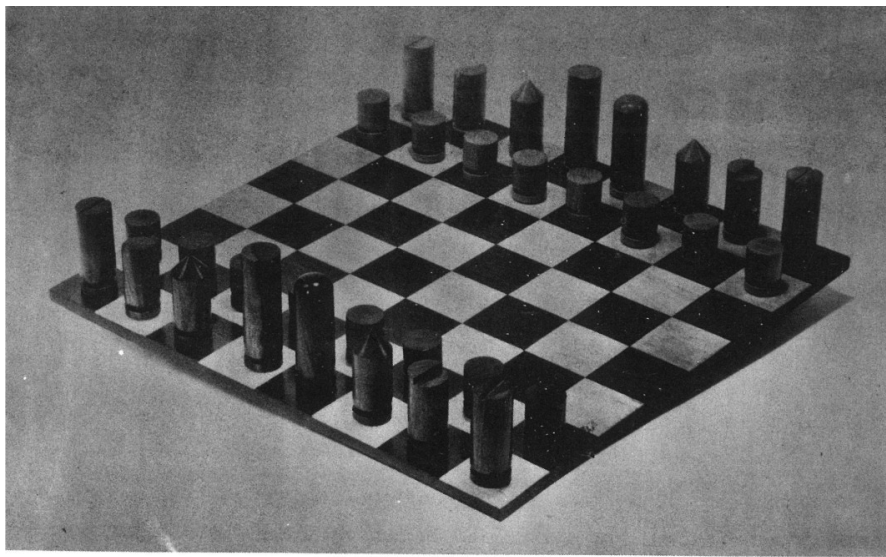

Carlos Augusto. Welker

CElio Pimenta

Luisa Toscano

Maria Helena C. de Abreu

Yasuko Tominaga

Antonio Domingos BattagI

Fig.59. Jogo de xadrez. [Terceiro ano DI FAU USP, 1962] 


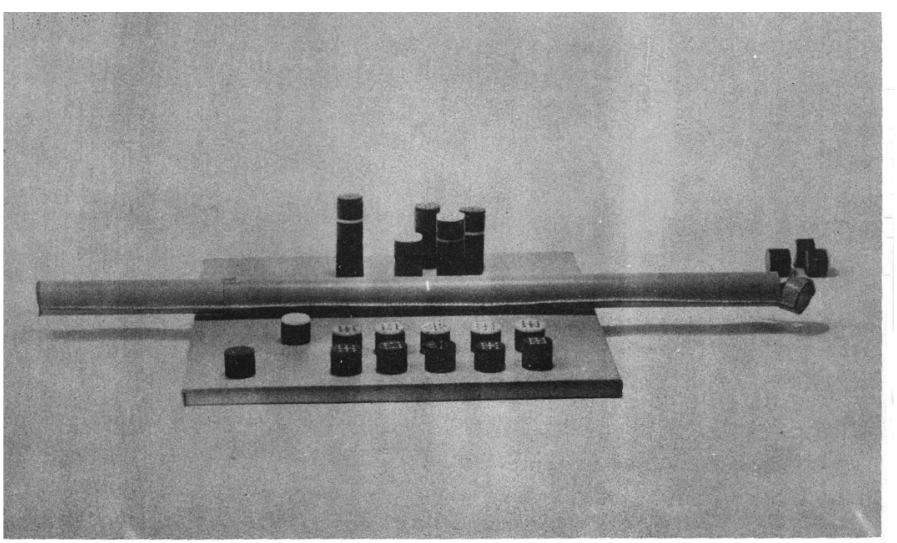

Ismael Gonzales

Jorge Alberto Silva Nove

José Ayrton Ferraz $†$

Mario Yoshinaga

Raul Guardia Sanchez

Vicente P. Borges Bicudo

Fig.60. Jogo de xadrez. [Terceiro ano DI FAU USP, 1962]
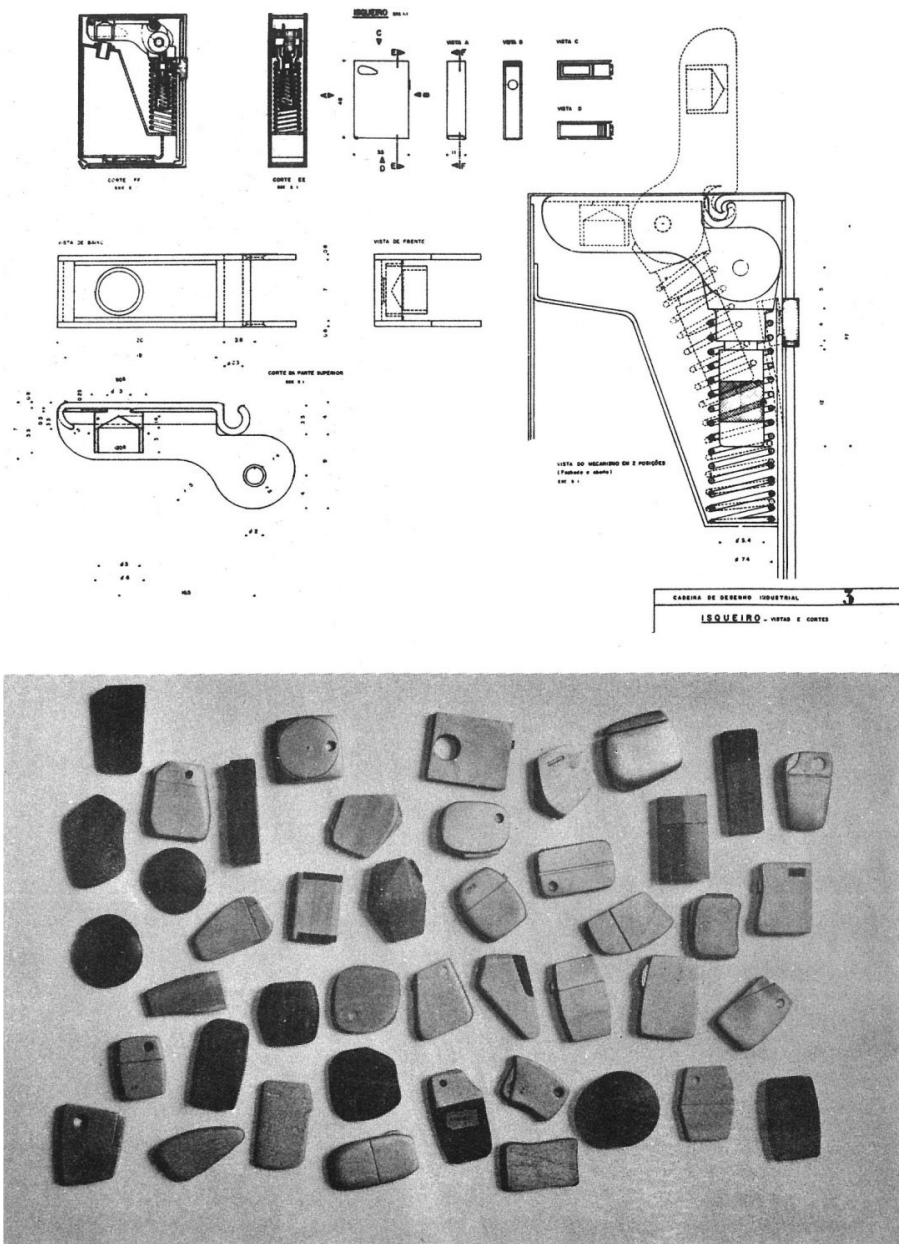

Fig.61. Isqueiro. [Terceiro ano DI FAU USP, 1962] 
Relatório das Atividades do Quarto Ano (1962)

Arquitetos professores: Roberto Cerqueira Cesar, Luiz Roberto Carvalho Franco e Dario Imparato

\section{Exercício:}

Propor solução para o preparo do café doméstico brasileiro (redesenho do simples bule tradicional até os sistemas mais elaborados de funcionamento a vapor ou pressão).

[Fonte das imagens 62 até 73: FAU USP, 1963] 

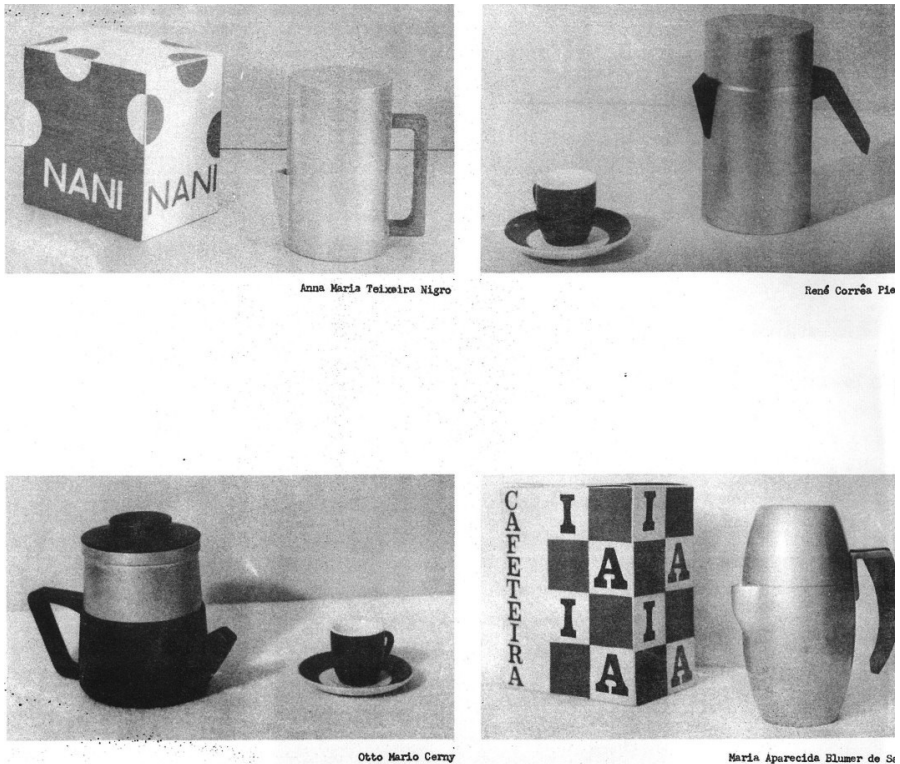

Fig.62. Cafeteira. [Quarto ano DI FAU USP, 1962]

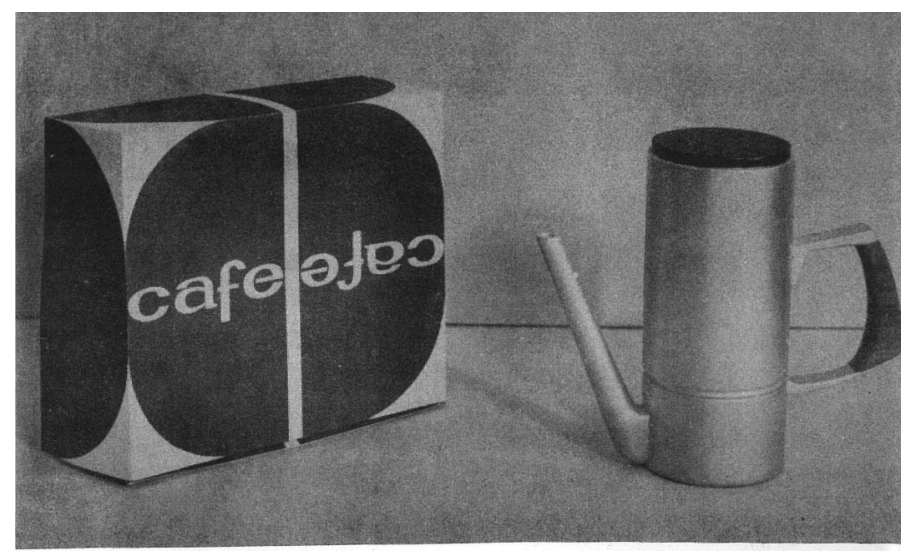

Antonio Sergio Bergamin / Juan Luiz Zuñiga Bustillos

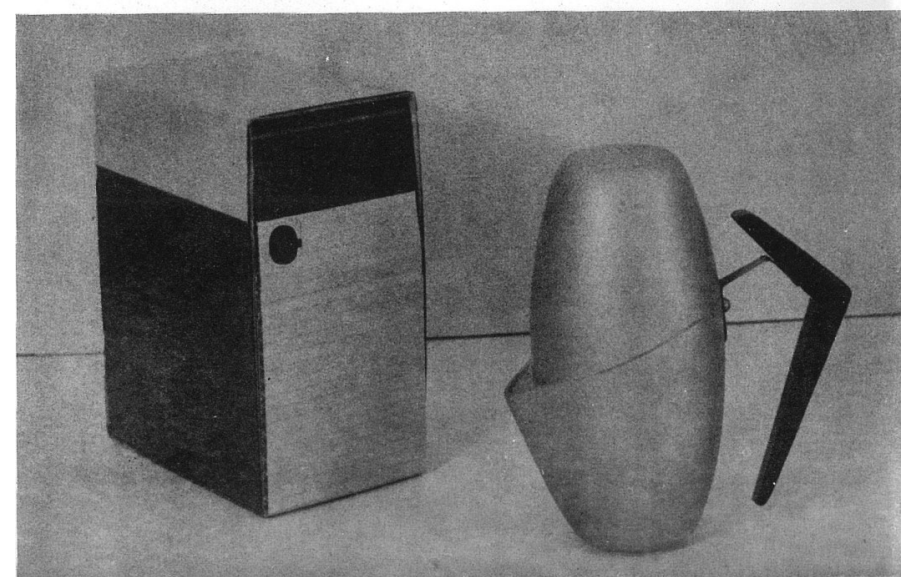

Fig.63. Cafeteira. [Quarto ano DI FAU USP, 1962] 

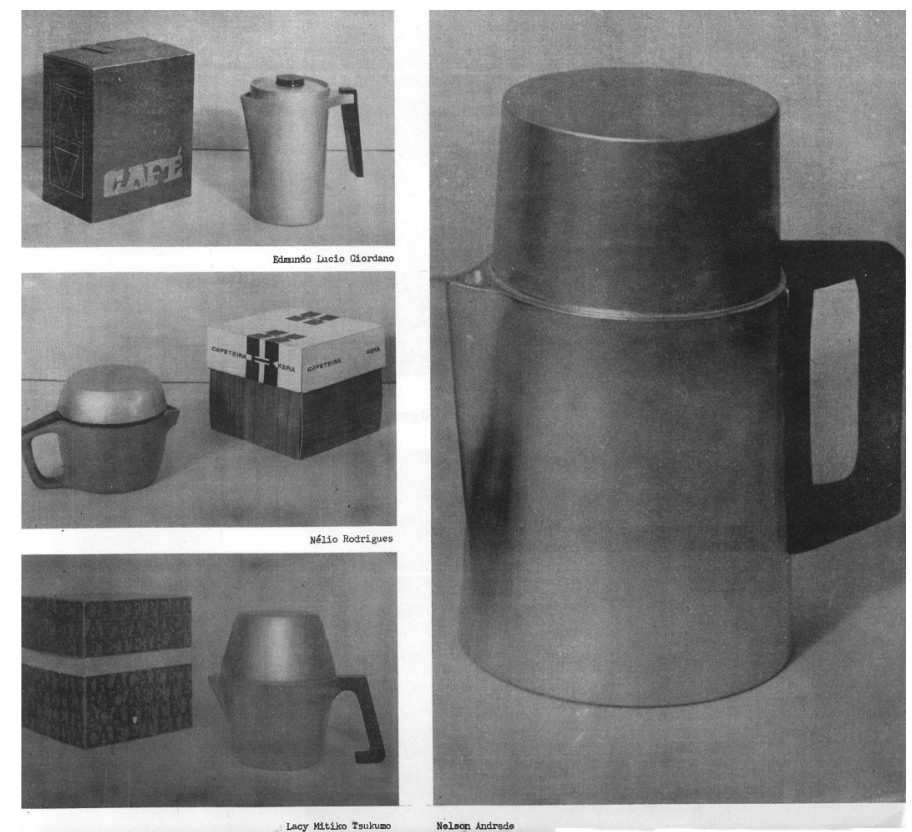

vielason ardro

Fig.64. Cafeteira. [Quarto ano DI FAU USP, 1962]

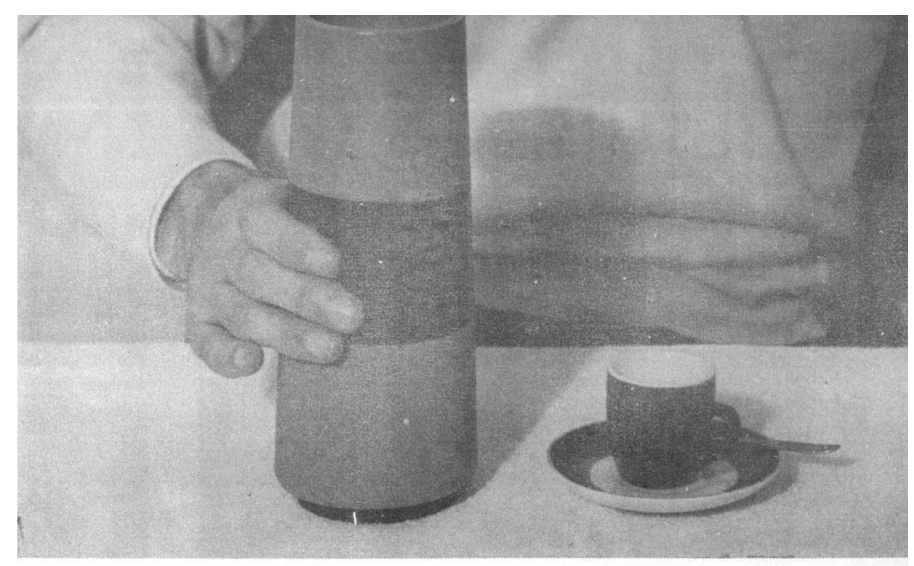

Willian Munford / Alfredo Osvaldo Gustavo Galles

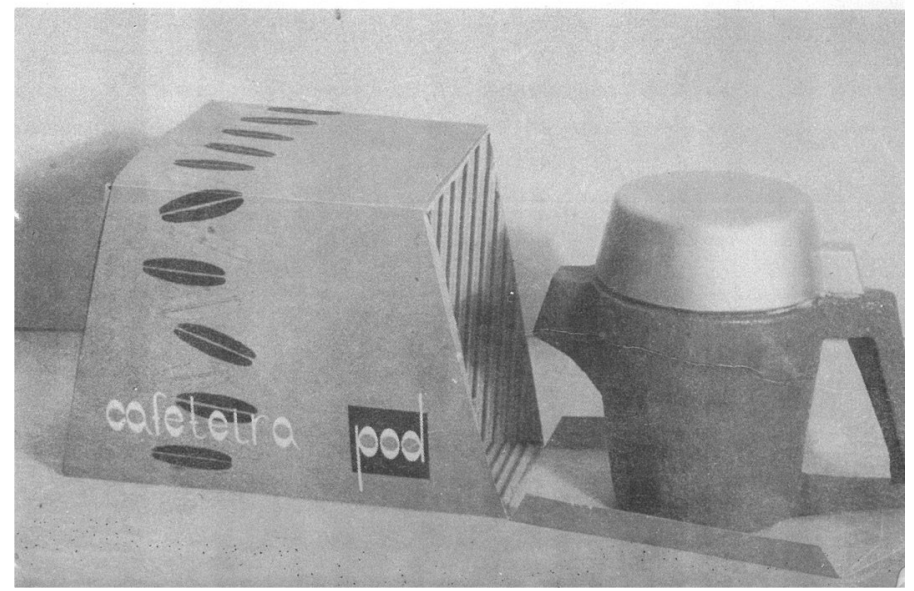

Fig.65. Cafeteira. [Quarto ano DI FAU USP, 1962] 


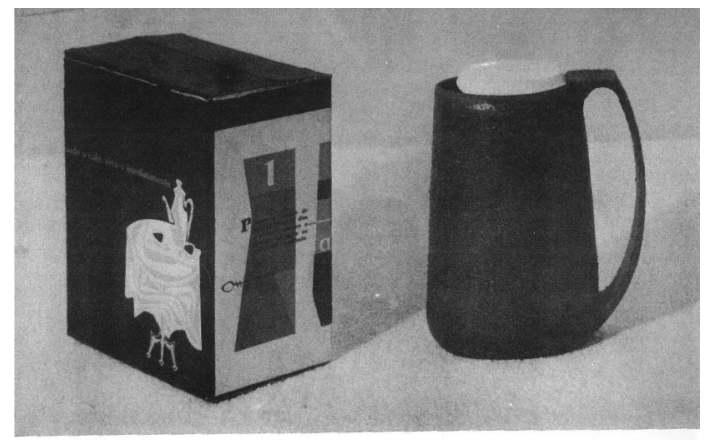

Paulo Julio Valentino Bruna / Zuraida Alexandre Arap

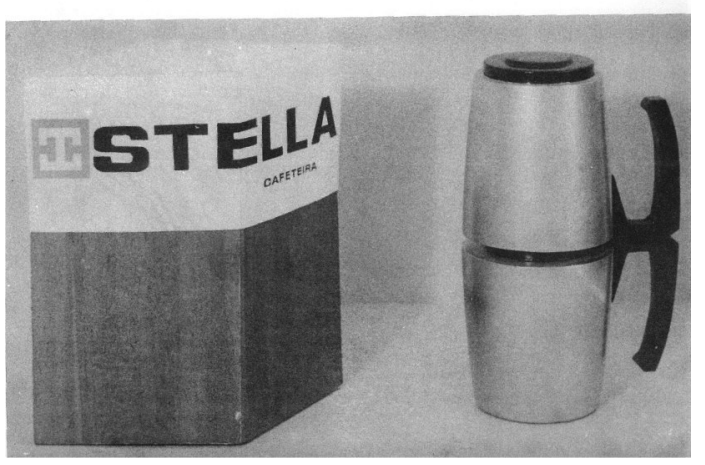

Fig.66. Cafeteira. [Quarto ano DI FAU USP, 1962]

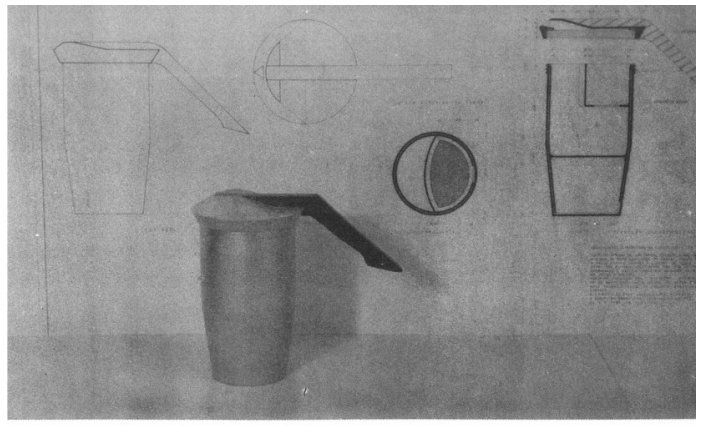

Hombuo Yamamoto / Jácono Antonio Frugis

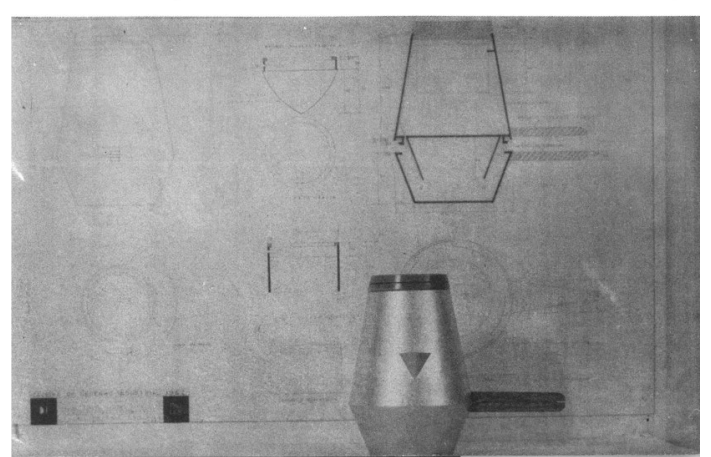

Fig.67. Cafeteira. [Quarto ano DI FAU USP, 1962] 


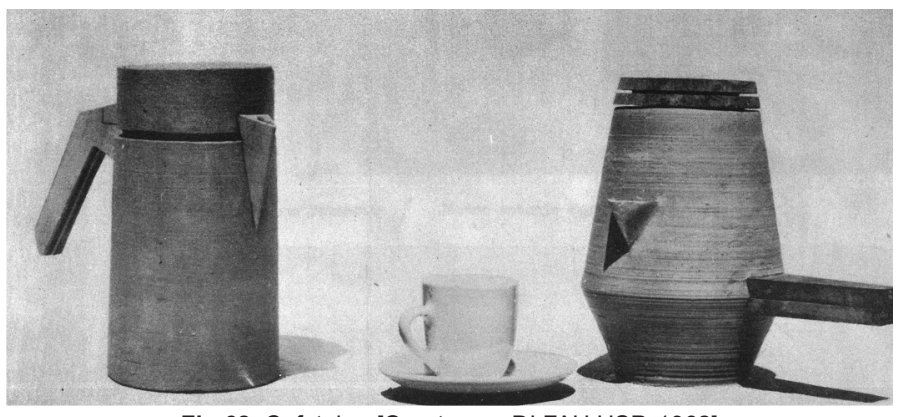

Fig.68. Cafeteira. [Quarto ano DI FAU USP, 1962]

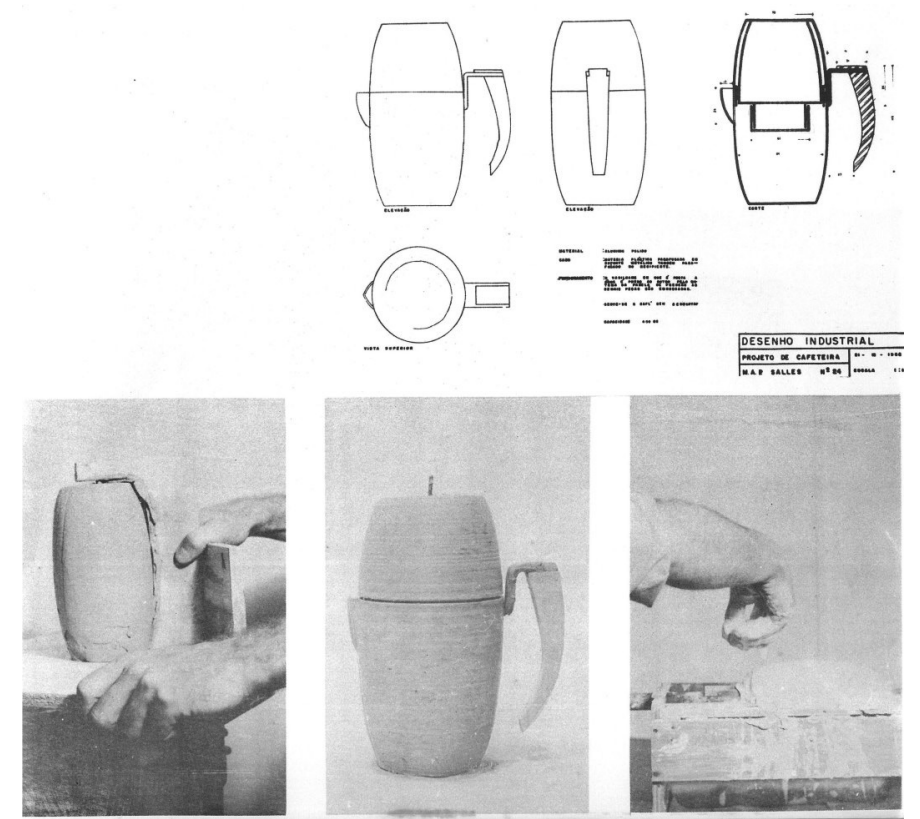

Fig.69. Cafeteira. [Quarto ano DI FAU USP, 1962]

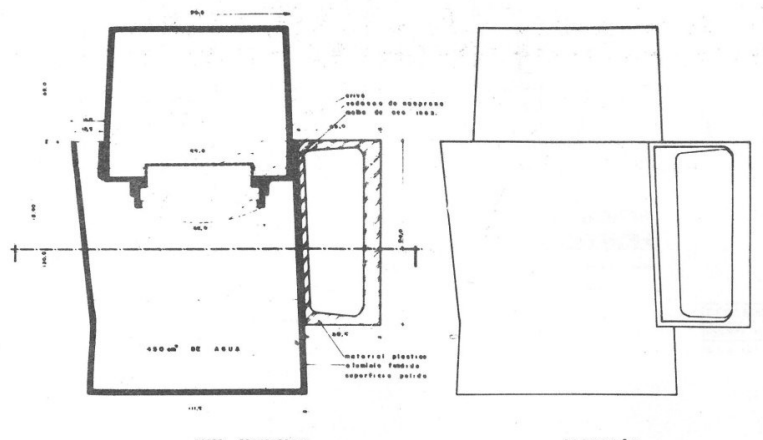

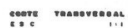

a.:.

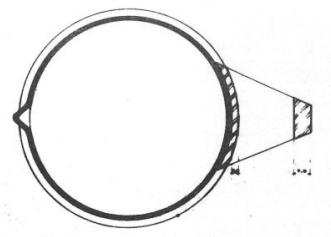

:::-: :

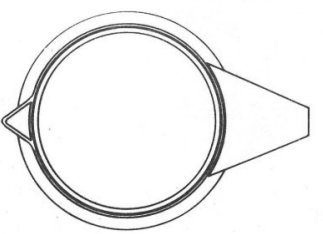

:a:: ………:

Fig.70. Cafeteira. [Quarto ano DI FAU USP, 1962] 


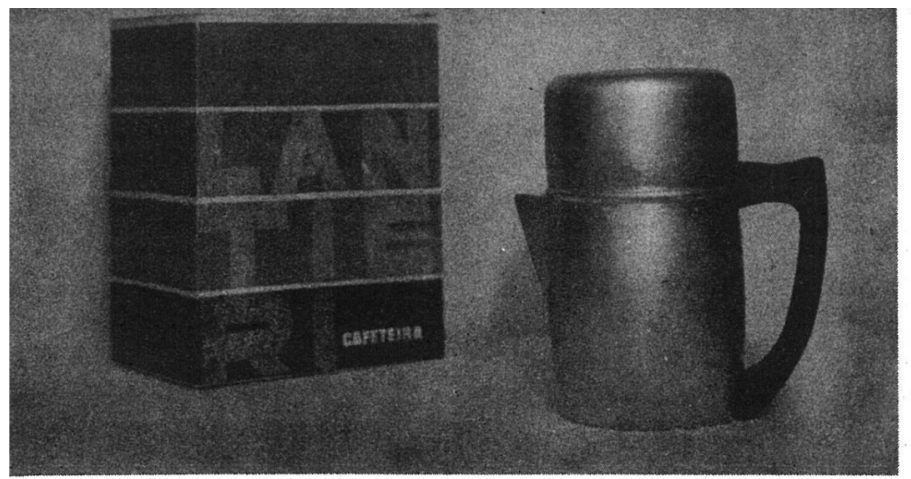

Kolleo Honde

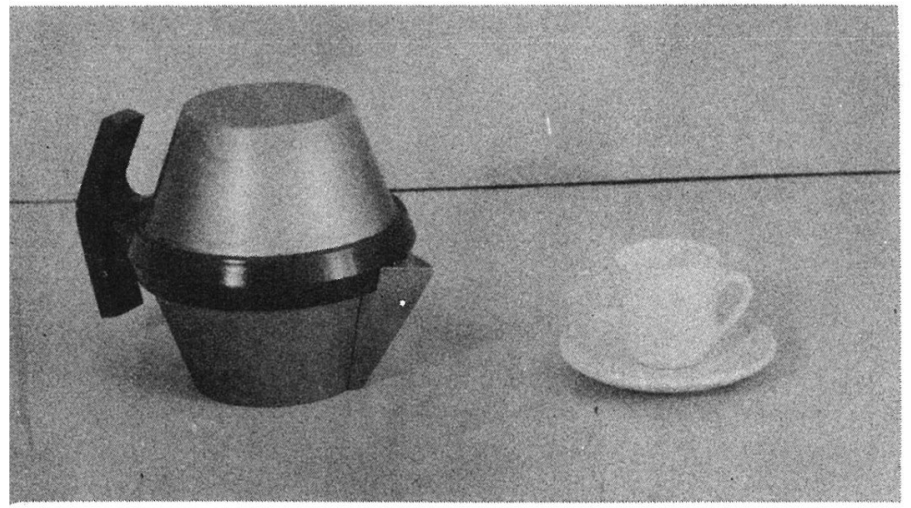

Nauricio Fridman

MLIve Lima Prado

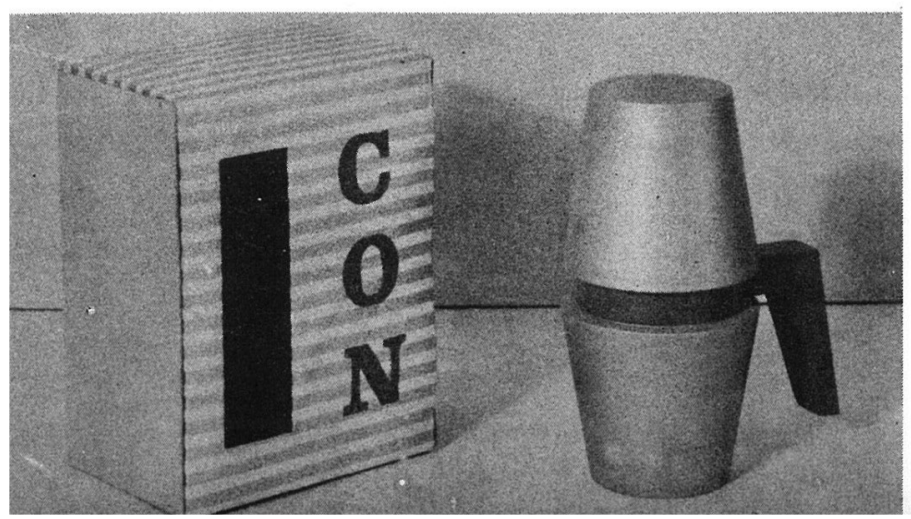

Fig.71. Cafeteira. [Quarto ano DI FAU USP, 1962] 


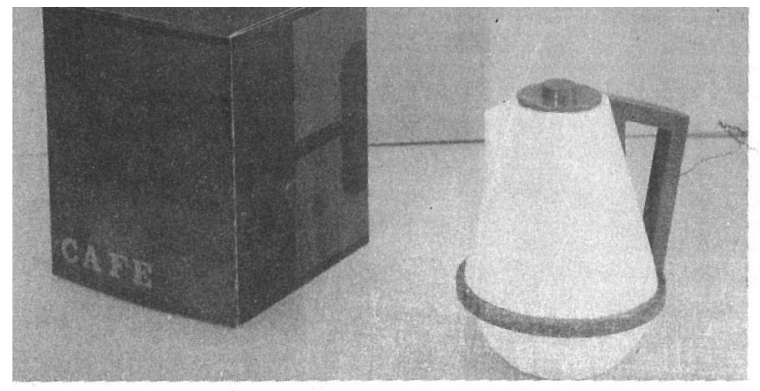

Angela Maria Apollinari

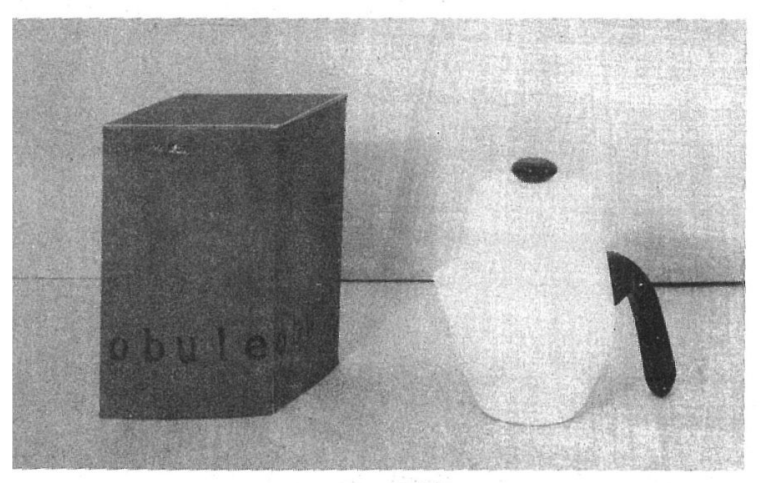

René Antonio Nusdeu

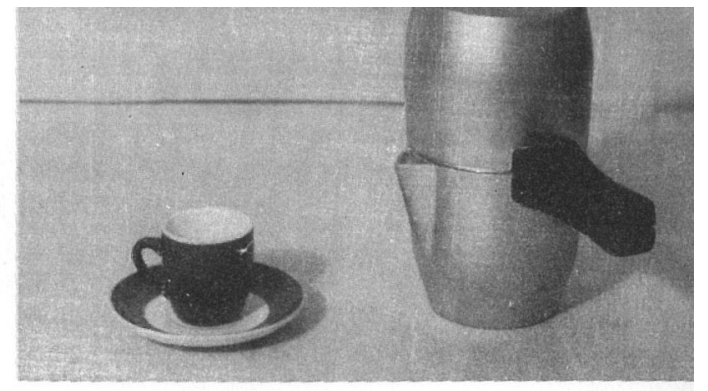

Yone Koseki

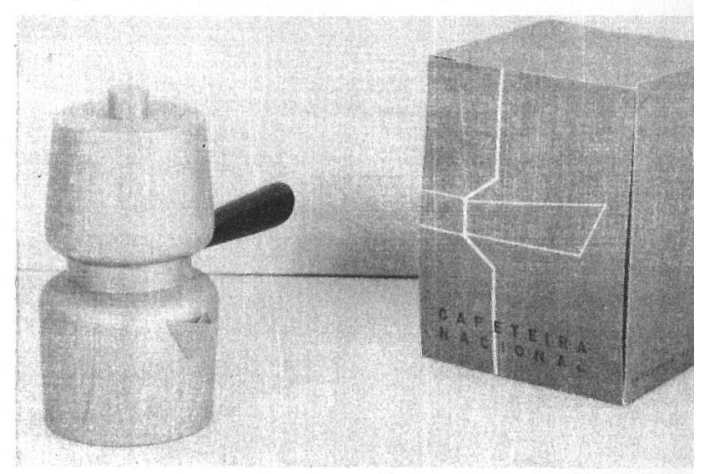

Moto1 Tsubouchi

Fig.72. Cafeteira. [Quarto ano DI FAU USP, 1962]

Luiz Fisberg

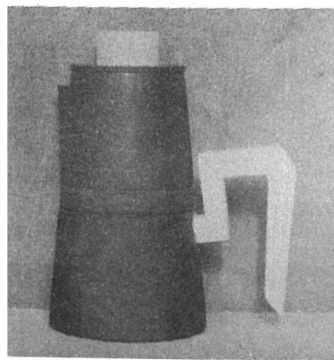

Newton Lapolla de Paula

Orly Lopes Querido
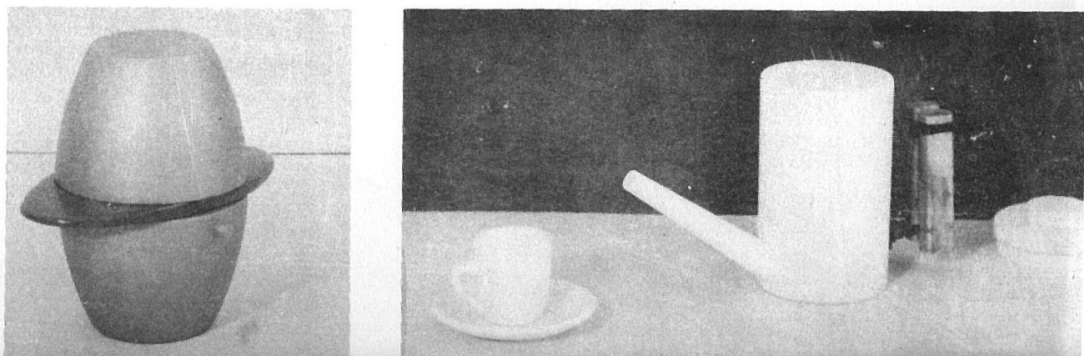

Fig.73. Cafeteira. [Quarto ano DI FAU USP, 1962] 
Com relação ao exercício de projeto do 3o ano de 1962, vale lembrar que o mesmo tema, isto é, o jogo de xadrez já fora proposto pela Bauhaus, em 1924. Entre alguns brinquedos criados dentro dos ateliês da Bauhaus, de acordo com Droste (2001, pp. 92-93), foi desenvolvido pelo mestre artesão Josef Hartwig um jogo de xadrez, onde didaticamente cada peça foi concebida segundo o tipo de jogada que poderia fazer. E no ateliê de carpintaria da Bauhaus, Heinz Nösselt projetou e executou uma mesa apropriada para esse jogo de xadrez.

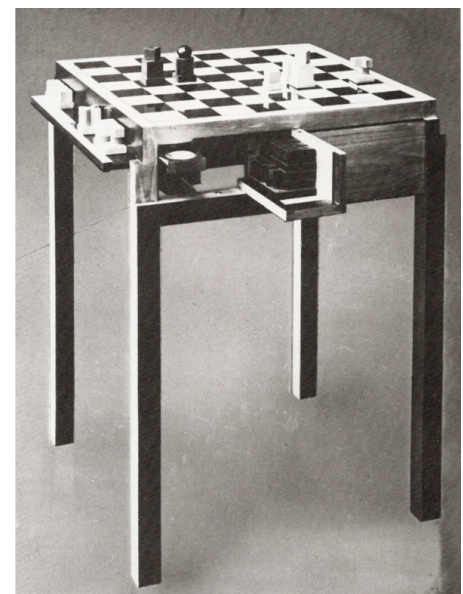

Fig.74. Heinz Nösselt. Mesa para jogo de xadrez de Josef Hartwig. 1924. [Fonte: Droste, 2001].

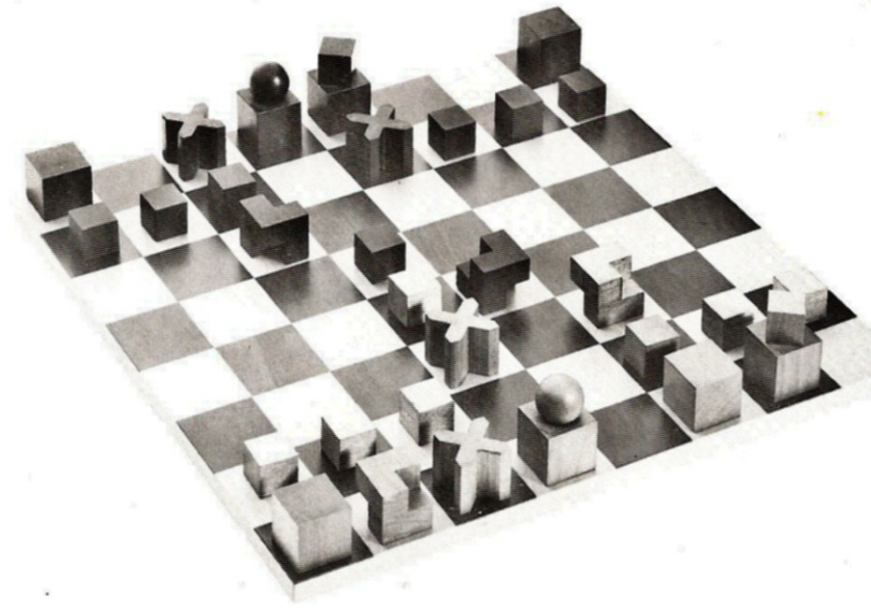

Fig.75. Josef Hartwig [mestre artesão da Bauhaus]. Jogo de xadrez. 1924. [Fonte: Droste, 2001].

Essa possível influência desse exercício da Bauhaus sobre o exercício da FAU USP, entretanto, não termina apenas na constatação da adoção de um mesmo objeto-tema comum, como exercício de investigação nos dois cursos. É importante considerar que a FAU USP compartilha de um mesmo ponto de vista conceitual que o proposto pela Escola alemã, a respeito da realização desse jogo de xadrez. Pois se na Bauhaus, ao invés de peças figurativas sobre o tabuleiro, optou-se pelo formato das peças lembrando o tipo de deslocamento que cada uma delas realizaria sobre o tabuleiro, na avaliação dos exercícios apresentados 
31. Relatório das Atividades do Terceiro Ano. Professores José Maria da Silva Neves, Abrahão Sanovics e Luiz Gastão de Castro Lima. In: FAU USP. Desenho Industrial 1962. São Paulo: Departamento de Projeto FAU USP, 1963. pelos estudantes da FAU USP, os três professores, José Maria da Silva Neves, Abrahão Sanovics e Luiz Gastão de Castro Lima, responsáveis pela disciplina, apresentariam a seguinte conclusão:

Como resultado final, constatou-se a tendência geral de abandono das reminiscências artesanais de dar às peças formas figurativas correspondentes aos seus nomes, completamente ultrapassadas pelos modernos conceitos de xadrez posicional deixando de considerá-lo como batalha e sim como jogo de relações.

Tomaram entre as peças características outras, como as de movimentação, apresentando maior coerência com as novas técnicas de produção. ${ }^{31}$

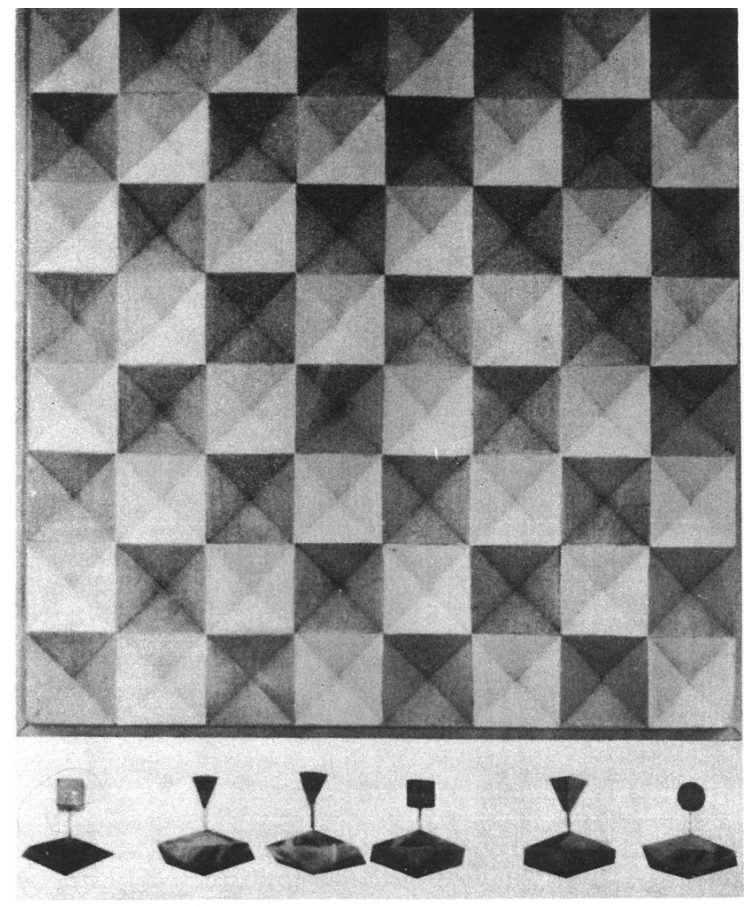

Alfredo Benito Parlato

Armenio Iranik Arakelian Eurico João Salviati Savério Henrique Castellano Décio Verneck Moreira

Fig.76. Jogo de xadrez. [Terceiro ano DI FAU USP, 1962] 


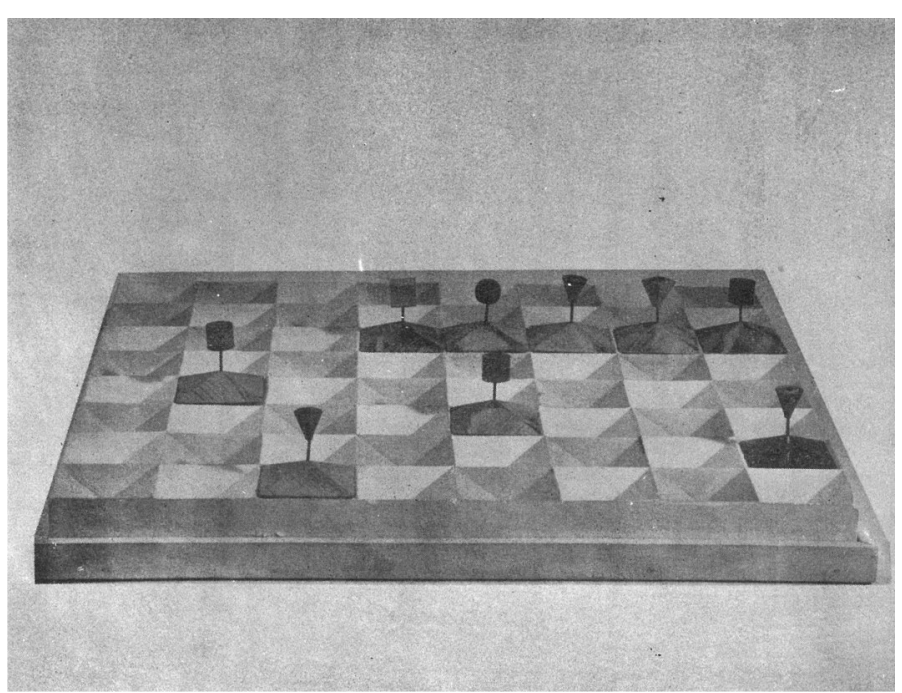

Fig.77. Jogo de xadrez. [Terceiro ano DI FAU USP, 1962]

É possível afirmar que, tanto no caso da Bauhaus como da FAU USP, para a determinação das formas das peças do jogo de xadrez, vale o postulado da arquitetura moderna: a forma segue a função, no sentido em que nesses dois casos a forma cumpre uma função didática. Mas no caso do discurso apresentado por esses professores da FAU USP, há uma informação adicional de que a forma deve ser também condicionada pelo modo como é produzida: industrial e não mais artesanal, evitando-se assim o velho e tradicional figurativismo das peças.

Mas retornando à discussão de um método de projeto para o desenho industrial dentro da FAU USP e às influências de Andries van Onck, Lúcio Grinover explica que a FAU USP, ao contrário da ESDI, não adotou como modelo de seu ensino de Desenho Industrial a HfG de Ulm. Contudo, Grinover considera que houve determinadas influências da mesma, sobretudo pela presença de van Onck no Brasil:

Não trouxemos e não implantamos modelos de (HfG) Ulm ou uma coisa parecida (na FAU USP). Quer dizer, se discutia ( $H f G$ ) Ulm. Então essas influências todas tiveram a sua consequência 
32. Lúcio Grinover. Depoimento ao autor em 04 de março de 2009.
33. Produto e Linguagem informa que o artigo foi traduzido da revista italiana Edilizia Moderna, número 85. com relação à gente, particularmente no que dizia respeito à metodologia de projeto, tanto que no começo do desenho industrial na FAU USP, nós convidamos um, também formado em (HfG) Ulm, o Andries van Onck, desenhista industrial formado em ( $H f G)$ Ulm. Se não me engano, contemporâneo de Bergmiller. Ele começou a trabalhar em diversas empresas italianas, tipo Rinasciente. E o van Onck veio para cá introduzindo, ou tentando introduzir uma metodologia para o projeto do desenho industrial. Tanto é que ele deu um curso chamado Metadesign.

(...) Tudo isso teve consequências muito fortes na parte de projeto, mas não só no projeto de produto. Também se começou por aí a fazer arquitetura industrializada, então essa mesma metodologia foi aplicada à arquitetura, em alguns aspectos ela se aplicava perfeitamente. Essa foi a importância dessa maneira de ver do Andries van Onck. ${ }^{32}$

De fato não é curta a presença direta ou indireta do pensamento de Andries van Onck na FAU USP ou entre seus professores de desenho industrial. Conforme indicado, o primeiro registro encontrado sobre a presença de van Onck nas discussões de desenho industrial no Brasil está associado à revista Produto e Linguagem, da $A B D I$, que realiza a divulgação dos dois cursos ministrados pelo exaluno da HfG de Ulm no Brasil: um curso de pós-graduação em Metadesign na FAU USP, com 40 horas, e um outro curso na FIESP, de 8 horas, ambos em 1965. No mesmo número da revista Produto e Linguagem, Lúcio Grinover traduz e publica extenso artigo homônimo de Andries van $\mathrm{Onck}^{33}$. O mesmo artigo é publicado em uma apostila do curso de pós-graduação da FAU USP, também em 1965. No ano seguinte, a professora da Sequência de Desenho Industrial, Marlene Picarelli em sua apostila Apontamentos de Aula para a graduação, publicaria o texto Anotações do Curso de Metadesign, prof. van Onck, com o seguinte conteúdo: Aula 1: Introdução à Teoria dos Grupos; Aula 
34. A apostila não informa as aulas de 3 a 5 .

35. Metadesign. Andries van Onck. Publicado em Edilizia Moderna, 1965. Traduzido por Lúcio Grinover e publicado em: PRODUTO E LINGUAGEM. 20. trimestre de 1965. Ano 1, número 2 e apostila de curso de pós-graduação da FAU USP (1965).
2: Teoria Combinatória, Aula 6: Geometrias ${ }^{34}$. Anos mais tarde, em 1971, novamente o método do Metadesign seria assunto de publicação da FAU USP. A publicação Estudos Ambientais 3, do laboratório de Artes Gráficas da FAU USP, apresentaria dois textos do professor Grinover: As Bases Filosóficas do Metadesign e Contribuições para a Leitura da Cidade. Nesse sentido pode-se considerar que o pensamento de Andries van Onck sobre Metadesign esteve em trânsito pela FAU USP pelo menos entre 1965 e 1971.

Mas consideremos os postulados dessa teoria sobre - Metadesign ao indicar as ferramentas que julgava corretas para o exercício de projeto no campo do desenho industrial. No artigo Metadesign, traduzido por Grinover de Edilizia Moderna no 85, van Onck aponta, em seu ponto de vista, uma perspectiva de compreensão do desenho industrial que deve ser superada pelas Escolas e qual outro entendimento do desenho industrial deveria ser tomado como o mais importante para a sua realização:

O aspecto ótico-formal do desenho industrial parece resistir mais à racionalização do que ao econômico, social, ergonômico, físico, tecnológico, psicológico, etc.

De fato, os programas das escolas de desenho industrial e os critérios para julgamento de vários prêmios de desenho industrial refletem essa condição. A supressão do aspecto visual racional cria uma predominância dos outros motivos que se evidenciam na forma dos objetos, incluídos aqueles de caráter formal intuitivo. Queria chamar a essa situação de tendência evasiva. A atitude evasiva se apresenta por isso, de um lado como tendência a ver o desenho como arte aplicada, onde a razão mais importante da forma deve ser procurada na livre expressão do designer $(. . .)^{35}$.

No discurso de van Onck, para a definição da forma 
36. Relatório das Atividades do Quarto Ano. Professores Roberto Cerqueira Cesar, Luiz Roberto Carvalho Franco e Dário Imparato. In: FAU USP. Desenho Industrial 1962. São Paulo: Departamento de Projeto FAU USP, 1963. dos objetos, é colocado um confronto entre duas possibilidades de sua realização. Uma delas reside na busca da racionalidade para caracterizar a forma, e a segunda, onde a forma é determinada pela livre expressão do artista. De acordo com van Onck, esta segunda visão liga o desenho industrial ao mundo das artes aplicadas, que ele critica ao delimitá-la como uma situação de tendência evasiva. Andries van Onck, nesse caso, está falando contra a forma dos objetos criados a partir de um caráter formal intuitivo.

Esse discurso de van Onck não é uma novidade para nós. É, na verdade, uma repetição da própria disputa presente na gênese da HfG de Ulm, onde de um lado Max Bill propunha uma orientação do curso onde os assuntos do design eram associados predominantemente à arte e, de outro lado, Otl Aicher e Tomás Maldonado, com a defesa de uma visão mais técnica e científica, questionando inclusive a defesa de Bill na adoção de uma orientação de Ulm muito próxima do que fora a Bauhaus (ver Capítulo 2).

Quando apresentamos nas páginas anteriores a discussão acerca dos trabalhos de desenho industrial realizados, em 1962, pelos estudantes da FAU USP e publicados em 1963, conforme atestam os textos de apresentação dos exercícios de cada ano do curso, era já um consenso, entre os professores naquele ano inaugural da Sequência de Desenho Industrial da FAU USP, explicar ao aluno que desenho industrial não é invenção: Nas diretrizes do curso fizemos questão de deixar claro que design não é invenção ${ }^{36}$.

Andries van Onck, assim como os primeiros professores da Sequência de Desenho Industrial da FAU USP procuraram, como ponto de partida, uma conceituação do desenho industrial que se distanciasse o máximo possível de um caráter predominantemente artístico, seja 
37. Esta expressão não é usada por Andries van Onck em seus escritos. Mas a adotamos neste trabalho como uma expressão para caracterizar a nossa interpretação de seu pensamento. desassociando-o de um possível grau de parentesco com as artes aplicadas ou com a ideia de invenção em si.

Mas se Andries van Onck preconiza, pelo caminho da busca da racionalidade, o abandono no campo do desenho industrial das características acima expostas, quais as ferramentas para se atingir tal racionalidade, em outras palavras, como funciona o Metadesign?

Se o método de produção industrial pede uma racionalização da forma do objeto que o desenho artístico, ou o trabalho do artista, não seria capaz de realizar, então o desenho da matemática ${ }^{37}$ poderia ser tomado como um caminho mais adequado. Esta parece claramente ser a opção para van Onck e para o curso de desenho industrial da FAU USP, pelo menos entre 1962 e 1968.

Considerando que a indústria opera não apenas com a produção seriada de um mesmo e único objeto, mas também com sistemas de elementos componíveis, que apesar de diferentes entre si, podem ter origem em uma mesma família, ou matriz, e que os objetos produzidos industrialmente podem constituir séries multiplicáveis ou subdivisíveis a partir de uma unidade-padrão, para van Onck o aprendizado do desenho da matemática e não mais do desenho artístico se mostra como o caminho mais correto para a formação do desenhista industrial, como técnico da indústria.

Em sua aula de matemática sobre Teoria Combinatória ministrada na FAU USP, van Onck assim ressaltaria a importância desses conceitos da matemática para o desenho industrial:

De fato não há ramo da ciência ou da tecnologia que não descubra, um dia ou outro, as inúmeras vantagens oferecidas pelos sistemas a elementos componíveis; esses elementos podem ser tubos, átomos, cristais, chapas metálicas, notas, 
38. Picarelli (1966). Apontamentos de aula do professor Andries van Onck. cores, linhas, números, movimentos, reações químicas, etc.

As vantagens para a indústria são evidentes. Os tipos de elementos que compõe o produto podem ser produzidos em grande série; o armazenamento se torna mais simples; e para satisfazer toda exigência do mercado são necessários só poucos tipos de elementos, de onde podem ser tiradas as várias combinações; a manutenção é facilitada, uma vez que os elementos podem ser trocados entre si; assim, aumentos e modificações são menos difíceis. Portanto, a possibilidade de satisfazer maior número de clientes em mais casos particulares vai em detrimento dos casos não contidos no sistema de elementos componíveis. A vantagem do sistema a elementos componíveis podem ser obtidas quando o sistema é estudado até o fim; disso vem que o projeto de um sistema de elementos componíveis é um trabalho delicado e longo ${ }^{38}$.

Alargando os limites de sua teoria, van Onck credita esta técnica de projeto não apenas como consequente de uma interpretação das novas possibilidades estabelecidas pela indústria, mas como um pensamento mais amplo com uma dimensão que é técnica, mas também cultural, pois teria se desenvolvido ao longo dos séculos. Cita como exemplo os sistemas de valores de moedas, sistemas de pesos, sistemas para medir tempo ou mesmo a linguagem humana, que van Onck caracteriza como um sistema componível (signo fonético, letras, palavras), etc. Mas naquilo que concerne ao campo do desenho industrial, ao caracterizar este método de projeto, Andries van Onck, estabelece um ponto de partida e um ponto de chegada para o projetista:

O projetista deve definir qual é o campo que ele quer cobrir e avaliar quais serão os tipos de combinações mais desejadas nos vários setores desse campo. Põe-se o problema: deve-se fazer um sistema só para cobrir a inteira gama de produtos, ou, então, se deve dividir o campo em um ou mais setores diferentes ${ }^{39}$.
39. Picarelli (1966).

Apontamentos de aula do professor Andries van Onck. 
E, enfim conclui:

40. Picarelli (1966).

Apontamentos de aula do professor Andries van Onck. Este ponto de vista retoma o pensamento de desenho industrial desenvolvido por Konrad Wachsmann, que colaborou com Walter Gropius na Bauhaus e Mies van der Rohe em estudos dos problemas da pré-fabricação. De acordo com Argan (1992), as pesquisas desenvolvidas por Wachsmann tinham por objetivo determinar o átomo construtivo: um, no máximo, dois elementos (um segmento e uma articulação nodal) que permitem qualquer combinação construtiva.

41. Ver anexo.

Aqui o projetista chega ao núcleo do problema do desenho dos sistemas a elementos componíveis, isto é, ao problema do dimensionamento e das juntas ${ }^{40}$.

A análise da listagem de exercícios de projeto, realizados dentro da Sequência de Desenho Industrial da FAU USP, entre os anos de 1965 e 1968, é suficiente para demonstrar que a disciplina do primeiro ano do curso realizava uma propedêutica muito próxima aos ensinamentos de van Onck, apoiando-se para tanto nos conteúdos da matemática:

Os primeiros trabalhos não são condicionados pela relação homem-objeto, mas sim por certas relações geométricas ou abstratas, conduzindo gradativamente para uma coordenação de determinados parâmetros que intervêm nos problemas de design.

A programação para o ano de 1965 obedece ao seguinte esquema:

1. Construção de curvas geradoras de figuras planas e espaciais;

2. Decomposição de elementos;

3. Sistemas de elementos componíveis;

4. Agrupamento de elementos bidimensionais no plano;

5. Agrupamento de elementos bidimensionais no espaço;

6. Agrupamento de elementos tridimensionais;

7. Projeto de um jogo (brinquedo) para armar ou construir ${ }^{41}$.

Com o intuito de ilustrar a importância que adquirem esses pressupostos, no primeiro ano do curso de desenho industrial da FAU USP, tomados para a construção 
das balizas teóricas sobre as quais se assentariam e se desenvolveriam os demais três anos de curso, vale mencionar ainda mais alguns exercícios desenvolvidos nesses primeiros anos do curso, entre 1965 e 1969, onde se verifica a realização de exercícios práticos ligados às prerrogativas teóricas propostas por Andries van Onck e seguidas por alguns professores da FAU USP.

Os temas sob os quais os exercícios de projeto do primeiro ano, istoé, da disciplina Desenholndustriall, do curso da FAU USP se desenvolviam eram: Simetria (1965); Coordenação Modular e Sistema de Elementos Componíveis (1965); Decomposição e Agrupamento Espacial de Elementos Tridimensionais (1967); Coordenação Modular (1967); Agrupamento Bidimensional de Elementos e Simetria (1968); Coordenação Modular e Projeto de um Sistema Componível (1968); Simetria e Coordenação Modular (1968). E mesmo quando os temas do primeiro ano estivessem ligados à realização de objetos com um uso específico determinado, estes não deixavam de discutir

42. Ver, no anexo, a listagem dos exercícios entre 1965 e 1968, do primeiro ao quarto ano do curso e a indicação dos professores responsáveis. os mesmos temas, mas agora com essa preocupação relativa ao uso: fosforeira de mesa (1967); Projeto de um sistema componível (estante, armário, etc.) destinado ao armazenamento ou sustentação de objetos e materiais, em um dos campos a ser escolhido pelo aluno: habitação, comércio ou educação (1968); Família de objetos (recipientes) que tenha por função receber ou conter elementos destinados ao atendimento de determinada necessidade de uso (1968); Conjunto de recipientes com elementos componentes de mesma estrutura formal, com três ou mais elementos, e dimensões variáveis de acordo com a sua utilização $(1968)^{42}$.

Lançadas as bases do primeiro ano, os demais anos seriam dedicados ao desenvolvimento de projetos de objetos que pudessem ser produzidos pela indústria, abarcando uma gama bastante variada de temas. A professora Marlene Picarelli, da Sequência de Desenho Industrial da FAU USP, 
43. PICARELLI, Marlene. O Desenho Industrial no Departamento de Projeto da FAU USP. In: Revista Sinopses, Edição Especial, 1993, p.47. nesses anos, relembra alguns trabalhos dos estudantes:

Esse período inicial se caracterizou por tornar o DI uma atividade específica e consequentemente ligado a necessidade de um processo de ensino mais estruturado e atualizado. Dentro desse contexto estão os primeiros trabalhos curriculares: jogos de xadrez, rádios portáteis, bandejas para alimentação em avião, talheres, louças, eletrodomésticos, brinquedos, relógios, etc.

Projeto de uma bandeja para o serviço padronizado a bordo dos aviões das linhas nacionais, com todos os acessórios necessários.

Projeto de uma linha de relógios a partir de um mecanismo existente a saber: relógio de parede, relógio de mesa, relógio de cabeceira.

Essa etapa pioneira encerra-se no fim da década de $60^{43}$.

Com relação aos professores responsáveis pelas disciplinas da Sequência de Desenho Industrial da FAU USP, além daqueles professores apresentados na tabela 8 , e que lecionaram entre 1962 e 1963, na referida Sequência, também foi possível recuperar a lista do professores entre os anos de 1966 e 1967, conforme apresentado a seguir: 


\begin{tabular}{|c|c|c|c|c|}
\hline \multicolumn{5}{|c|}{ CÁTEDRA 13: Sequência de Desenho Industrial. Docentes 1966 e 1967} \\
\hline ano & & disciplina & responsável & categoria \\
\hline \multirow{4}{*}{1966} & 133 & Desenho Industrial III & José Maria da Silva Neves & $\begin{array}{l}\text { Professor contratado } \\
\text { Doutor }\end{array}$ \\
\hline & 131 & Desenho Industrial I & João Carlos Cauduro & Instrutor designado \\
\hline & 132 & Desenho Industrial II & Lúcio Grinover & Instrutor designado \\
\hline & 134 & Desenho Industrial VI & Luiz Roberto Carvalho Franco & Instrutor designado \\
\hline \multirow{4}{*}{1967} & 133 & Desenho Industrial III & Lúcio Grinover & $\begin{array}{l}\text { Professor contratado } \\
\text { Livre-docente }\end{array}$ \\
\hline & 131 & Desenho Industrial I & $\begin{array}{l}\text { João Carlos Cauduro; } \\
\text { Eduardo Luiz Paulo Riesencampf } \\
\text { de Almeida }\end{array}$ & Instrutores designados \\
\hline & 132 & Desenho Industrial II & $\begin{array}{l}\text { Marlene Picarelli; } \\
\text { Manoel Kosciusko Pereira da Silva } \\
\text { Corrêa }\end{array}$ & Instrutores designados \\
\hline & 134 & Desenho Industrial VI & $\begin{array}{l}\text { Luiz Gastão de Castro Lima; } \\
\text { João Carlos Rodolpho Stroeter }\end{array}$ & Instrutores designados \\
\hline
\end{tabular}

Tabela 9: Sequência de Desenho Industrial. Docentes entre 1966 e 1967. Departamento de Projeto. FAU USP (1963-1967).
Nesses anos pioneiros, da década de 1960, de ensino de desenho industrial dentro da FAU USP, diante da proposta da Escola de uma formação completa a ser conferida ao arquiteto para atuar no campo profissional do desenho industrial, é importante ressaltar ainda mais duas características do curso.

Uma delas diz respeito ao último ano ser dedicado à realização de um projeto-tese, com tema de livre escolha do aluno, mas com a presença de um professor-orientador: do qual procurar-se-á utilizar todo o treinamento prático e a informação técnico-teórica sedimentada através dos 3 primeiros anos. Será desenvolvido em 3 etapas: Informações, 
44. Ver anexo.

45. GRINOVER, Lúcio. Desenho atende ao mercado em termos de produção. Revista $O$ Dirigente Industrial. São Paulo, agosto de 1966. Número 12, vol. 7.
Projeto, Apresentação. Observação: Os resultados serão submetidos à apreciação da indústria ${ }^{44}$.

Essa caracterização dada ao quarto ano demonstra o quanto a preocupação de formação do desenhista industrial não é tomada como algo secundário dentro da Escola, pois trata-se do desenvolvimento de um projeto nos mesmos moldes que o exigido para a conclusão do curso dentro na FAU USP, no campo da arquitetura ou do urbanismo.

A outra questão diz respeito a um processo de dupla avaliação dos exercícios, tanto pelos docentes quanto pela indústria, conforme demonstra a citação acima relativa ao projeto desenvolvido no quarto ano. E esta avaliação pela indústria não se limita apenas a esse ano, mas sim a todos os quatro anos da Sequência.

O professor Lúcio Grinover, no sentido acima exposto, de aproximar a produção da FAU USP da indústria brasileira, no ano de 1966, na condição de presidente da $A B D I$, apresenta um artigo sobre desenho industrial em uma revista do setor dirigida aos industriais. Trata-se do periódico O Dirigente Industria ${ }^{45}$. Em seu artigo, Grinover chama a atenção dos industriais para a necessidade de se pensar um desenho culturalmente brasileiro e incorporálo à nossa produção industrial. Para o diretor da ABDI, esta seria uma forma de se evitar a contínua e a incontrolada importação de desenhos, com a consequente evasão de divisas, que, ainda de acordo com Grinover, caracteriza a maior parte do grande desenvolvimento industrial brasileiro, por que passa o país no pós-Segunda Guerra Mundial. Em defesa de seu ponto de vista, Grinover lembra que o país já se encontrava em capacidade de produzir seu próprio desenho industrial, uma vez que este tinha seus méritos reconhecidos inclusive no 
exterior. Para comprovar sua tese, Lúcio Grinover cita dois prêmios internacionais recebidos pelo desenho industrial brasileiro. A Poltrona Mole, de 1957, de Sérgio Rodrigues, premiada em 1961 no Concorso Internazionale del Mobile, na cidade de Cantu, na Itália, e que estaria sendo produzida e comercializada na Europa. O segundo exemplo é o carro popular Aruanda, do ex-aluno da FAU USP, Ari Antônio da Rocha, vencedor do Prêmio Lúcio Meira em 1964, produzido por Fissore na Itália e chamariz do último Salão do Automóvel de Turim. Na mesma revista, o Dirigente Industrial, no intuito de ligar a produção da FAU USP à indústria brasileira, Grinover equipara a produção dos estudantes da Escola a esses dois exemplos de objetos do desenho industrial brasileiro, premiados no exterior. Em uma página completa do artigo publica protótipos de modelos de eletrodomésticos e equipamentos para a construção civil, no caso deste último, trata-se de paredespainéis com redes hidráulicas instaladas em seu interior. Todos esses são trabalhos de estudantes da FAU USP, realizados dentro da sua sequência de Desenho Industrial e assim os mesmos são apresentados por Grinover: Estes produtos são apenas uma pequena, mas eloquente amostra da capacidade criadora da geração de jovens desenhistas da Faculdade de Arquitetura e Urbanismo de São Paulo. 

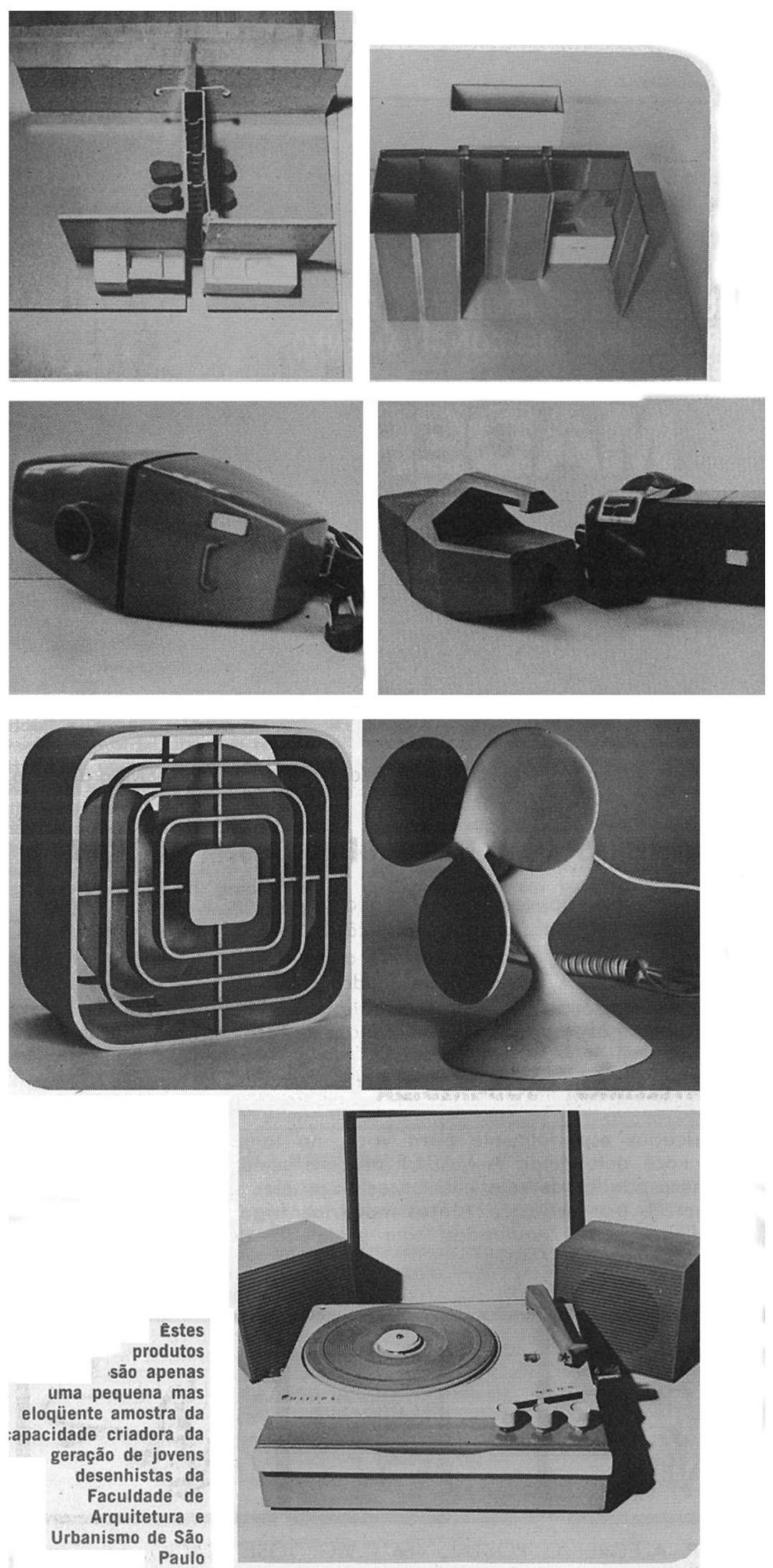

Fig.78. Exercicios de DI FAU USP [fonte: Lucio Grinover in: revista O Dirigente Industrial. 1966.] 
46. Lúcio Grinover. Depoimento ao autor em 04 de março de 2009.
Enfim, essas são as balizas que guiaram, ao longo da década de 1960, a instalação pioneira de uma Sequência de Desenho Industrial dentro da FAU USP. Num contexto em que, recuperando a expressão indicada por Lúcio Grinover, procurava-se constituir um ensino com um alcance muito mais amplo que os limites de uma escola restritiva de desenho industrial, pois que se desejava uma Universidade do Projeto. Nesta, o desenho industrial era enquadrado como apenas mais uma das possibilidades de realização dos projetistas que pretendiam formar. Um modelo que se desejou com uma autonomia no que diz respeito à reprodução de modelos de escolas gerados em contextos distintos. Um modelo que, na verdade, nasceu de um processo de discussões internas, como declara Grinover:

Eu não sei se tinha algum modelo na época e alguma Escola de Projetos, não sei. Acho que isso foi mais uma consequência das discussões que nós tivemos dentro da Escola. Discussões relacionadas a atividades de cada uma dessas áreas, certo, que estava lá dentro, embora não tivéssemos muito clara essa ideia, porque senão teríamos avançado muito, mas realmente começou a ter algum aspecto embrionário $(. . .)^{46}$.

E, como resultado desse processo de discussões internas, nem sempre foi uma Escola com um consenso único, sempre abrigou vozes apontando caminhos distintos, como se poderá depreender do capítulo seguinte, na abordagem da contribuição do Departamento de História da FAU USP para o ensino de desenho industrial. Uma condição que torna possível caracterizar o ensino de desenho industrial dentro da FAU USP muito mais como um processo que como um produto único e acabado.

Entretanto, é necessária a ressalva de que se a pretendida Universidade do Projeto, na busca de construir um ensino 
autônomo de modelos estrangeiros, procurou não reproduzir um modelo externo, como praticou a ESDI em relação à HfG de Ulm, todavia também não ignorou a existência e concretização de outras experiências. Antes, as avaliou criticamente e soube incorporar, entre suas perspectivas de ensino, aquelas experiências que julgava pertinentes por ir de encontro aos objetivos da FAU USP, no que se refere ao seu entendimento da prática do desenho industrial. Assim, como se pôde perceber, ainda que não tenha ocorrido a adesão total a um modelo externo único, são explícitas as suas referências ao que fora feito, ou ao que ainda se fazia, em outras Escolas de desenho industrial, como os VKhUTEMAS, a Bauhaus, a HfG de Ulm, ou mesmo as experiências brasileiras precursoras ou contemporâneas à FAU USP de produção ou ensino de desenho industrial, neste último caso, o IAC e a ESDI.

É também de se notar que a estruturação de ensino de desenho industrial na FAU USP, ao longo da década de 1960, nasce visceralmente ligada a um desejo de interpretação e colaboração à experiência de industrialização brasileira nesse período. Os professores da FAU USP, além de praticantes do desenho industrial, disputando o mercado, procuraram também estabelecer um diálogo direto com a indústria brasileira, objetivando conscientizá-la da importância para ela mesma da contribuição do desenhista industrial entre seus quadros profissionais. Para tanto, ao lado dos professores da ESDI e outros profissionais, constituíram a Associação Brasileira de Desenho Industrial, a ABDI, congregando, de um lado, todos aqueles que, diante da não regulamentação profissional, se outorgassem a prerrogativa de desenhistas industriais (fossem eles arquitetos, designers, artistas plásticos, decoradores, estilistas, engenheiros, etc.) e, de outro, os industriais. Ainda confirmando esta 
aproximação, como indicado acima, seja por meio da ABDI ou da FAU USP, esses profissionais desenvolveram várias atividades em parceria com a Federação das Indústrias do Estado de São Paulo, a FIESP. E naqueles anos, com a intenção de superar certos limites de um curso que vai sendo aos poucos implantado e construindo também aos poucos a sua infraestrutura, a FAU USP se aproximou de outra instituição-escola também voltada à formação de quadros profissionais para a indústria: o Serviço Nacional de Aprendizagem Industrial, o SENAI. Escola esta criada e mantida pela própria indústria brasileira. 



\section{A contribuição do Departamento de História da FAU USP}

O Departamento de História da Arquitetura e Estética do Projeto, o AUH, da FAU USP, desde a sua criação, congregou um determinado grupo de professores que realizaram uma contribuição particular ao ensino de Desenho Industrial e de Arquitetura na Escola. O surgimento regular deste Departamento remonta à Reforma de 1962, quando a Escola, pensando em reestruturar a sua organização interna, o que equivale a dizer minimizar o peso da estrutura das cátedras, organiza todo o seu ensino e pesquisa em três Departamentos: O Departamento de Projeto, AUP; o Departamento de História da Arquitetura e Estética do Projeto, AUH e o Departamento de Tecnologia da Arquitetura, AUT.

Analisando a trajetória de construção do Departamento de História da Arquitetura e Estética do Projeto, ou Departamento de História da FAU USP, é necessário um olhar além do ato que o afirma institucionalmente dentro da Escola, isto é, da sua definição oficial a partir das mudanças propostas com a implantação da Reforma de 1962. A gênese deste Departamento remonta ao ano de 1948, ano de criação da FAU USP. Está associada a estes anos iniciais a construção de um campo de preocupações sobre o passado de nossa arquitetura que surge fora da esfera docente, mas com o apoio desta, dentro do Grêmio da Faculdade de Arquitetura e Urbanismo, o GFAU, criado em novembro de 1948. 
O início das preocupações entre alunos e professores da FAU USP com a reflexão e o ensino de história da arquitetura e das artes se dá inicialmente no âmbito do GFAU com a criação de um grupo de estudos, em maio de 1949, designado Centro de Estudos Folclóricos, o CEF, e que algum tempo mais tarde foi renomeado como Centro de Estudos Brasileiros. Este grupo foi criado com o objetivo de conhecer e de documentar o passado da arquitetura e das artes brasileiras, mas também se ocupou das suas manifestações contemporâneas, isto é, a produção da arquitetura moderna. Nada deve causar estranhamento se for considerado que, no Brasil, o desenvolvimento da arquitetura moderna e a defesa do patrimônio histórico foram ações complementares de um mesmo evento.

A trajetória profissional do arquiteto Lucio Costa comprova a afirmação. A sua atuação institucional como diretor da ENBA, entre 1930 e 1931, como anunciamos anteriormente, tem, em sua proposta de reforma do ensino, o empenho em instituir uma nova orientação para a Escola ligada à arquitetura moderna, contra o ensino tradicional que significava um curso de arquitetura dentro de uma Escola de Belas Artes, naqueles anos. Por outro lado, a outra instituição também se dedicaria o arquiteto Costa. Alguns anos mais tarde, em 1937, é criado o Serviço do Patrimônio Histórico Nacional, o SPHAN. Neste, Costa passa a trabalhar como diretor da Divisão de Estudos $e$ Tombamento, DET, desde a sua fundação até 1972. Neste cargo, o arquiteto contribui para a definição de critérios e normas de classificação, análise e tombamento do patrimônio arquitetônico brasileiro. Outra contribuição do arquiteto à defesa do referido patrimônio está presente em textos de sua autoria em que estabelece relações entre a arquitetura colonial brasileira e a arquitetura moderna, os quais constituíram balizas para a atuação do SPHAN. Entre esses textos, cumpre destacar: Documentação Necessária (1937); Notas sobre o Mobiliário Luso-Brasileiro (1939) e 
1. Ver WISNIK (2001).
Arquitetura Jesuítica no Brasil (1941). ${ }^{1}$

Essa dupla atuação de Costa, isto é, à frente da indicação de uma orientação moderna para o ensino na ENBA e, ao mesmo tempo, sua participação no SPHAN na construção de critérios para a defesa do patrimônio arquitetônico colonial do país, irá ser repetida, guardadas as proporções dentro do Grêmio da FAU USP. Entre a criação do SPHAN, em 1937, e a criação do GFAU, em 1948, este segundo, a uma distância de 11 anos apenas, iria tomar para si a continuidade da empreitada de Lucio Costa: conhecer o passado de nossa arquitetura e documentá-la e, ao mesmo tempo, conhecer nossa arquitetura contemporânea.

Em depoimentos de suas memórias, arquitetos como Julio Katinsky e Lucio Gomes Machado, entre outros, é sempre confirmada a informação de que o GFAU, por meio de seu Centro de Estudos Folclóricos foi o primeiro a produzir materiais didáticos, como fotos e slides, sobre a arquitetura colonial e moderna brasileira. No final dos anos de 1950, durante uma viagem a Minas Gerais, documentaram as cidades de Sabará, Mariana, Ouro Preto e as obras de Oscar Niemeyer em Belo Horizonte. Segundo Bernardi (2008, p. 49), os cromos produzidos pelo grupo de estudantes envolvidos com esta viagem foram adquiridos por diversas instituições de ensino e muitos arquitetos brasileiros e estrangeiros na Argentina, Uruguai, Venezuela, Colômbia, Japão, Peru, Itália, Alemanha e Canadá, promovendo uma intensa divulgação da arquitetura nacional colonial e contemporânea.

O compartilhamento de ideais entre Costa e o CEF GFAU é expresso no depoimento de Abrahão Sanovics:

A partir de 1955 e nos anos seguintes, através do Grêmio da FAU, fizemos uma pesquisa da obra do arquiteto Lucio Costa, pois dizíamos: se tudo começou lá, vamos começar pelo 
2. Abrahão Sanovics em Depoimento ao IAB. Ver IAB-SP. Arquitetura e Desenvolvimento Nacional: Depoimento de Arquitetos Paulistas. Pini: São Paulo, 1979. p.57. Apud: BERNARDI (2008).

3. BERNARDI (2008, p.46). princípio. $^{2}$

O empenho desses estudantes, que passou a contar cada vez mais com o apoio de alguns docentes, entre outras atividades, se dedicou ao levantamento de construções de interesse histórico em localidades próximas à cidade de São Paulo:

Os alunos reunidos em torno do grupo (do Folclore) iniciaram um levantamento métrico arquitetônico nas casas da Aldeia de Carapicuíba, na Capela Jesuítica de São João Batista, na casa do Bandeirante e em várias casas do século XVII da periferia de São Paulo ${ }^{3}$.

Esse levantamento foi realizado ao longo do ano de 1949 e resultou em uma exposição que coincidiu com a inauguração do prédio da Vila Penteado, primeira sede da FAU USP. Mas o que interessa nesse levantamento é a constatação de que, apesar do grupo inicialmente se estabelecer em torno de discussões do folclore e patrimônio, gradualmente ele irá se aproximar também das questões ligadas à arquitetura. Um dos primeiros professores a se interessar por esses trabalhos de 1949, realizados dentro do CEF GFAU, é o arquiteto e professor Luis Saia. E vale lembrar que Mário de Andrade quando cria o Serviço do Patrimônio Histórico e Artístico Nacional, o SPHAN, conta com a colaboração de Saia. E é importante, também, pontuar que, em 1936, por intermédio do Departamento de Cultura de São Paulo, Mário de Andrade envia uma primeira missão de pesquisa folclórica ao Nordeste, missão esta que foi chefiada pelo arquiteto Luis Saia.

Nesse período inicial do GFAU, e ligado à criação do grupo 
do folclore, estiveram associados os nomes:

4. Testemunho fornecido pelo professor Gustavo Neves da Rocha ao professor Lucio Gomes Machado. s/d. in: BERNARDI (2008, p.41).
(...) (Antônio Alves) Carvalho (primeiro presidente do GFAU), o Marcílio, o (Roberto Pinto) Monteiro, o Plínio (Venanzi)... e outros que entraram no vestibular de 1949: o (Luiz) Gastão (de Castro Lima), o José (Claudio Gomes) e o Toshio Tone. Depois arrastaram outros como o Gustavo, o Flávio Motta, o (João Walter) Toscano, o Nestor (Goulart), o Julinho (Katinsky), o Benedito (Lima e Toledo). ${ }^{4}$

Entre os nomes listados cumpre destacar o seguinte: Luiz Gastão de Castro Lima foi professor do Departamento de Projeto, lecionando na Sequencia de Desenho Industrial da FAU USP, juntamente com Abrahão Sanovics, ambos como auxiliares do professor José Maria da Silva Neves, a partir de 1962. Flávio Motta foi professor do Departamento de História da FAU USP, a partir de 1954. Julio Roberto Katinsky estudou na FAU USP entre 1952 e 1957e se tornou professor pelo Departamento de História, a partir de 1962. Nestor Goulart, Benedito Lima e Toledo e João Walter Toscano foram professores do Departamento de História.

Considerando a designação desse grupo de estudos que se montou no GFAU, o Centro de Estudos Folclóricos, não deve passar despercebido o uso do termo folclore. Essa visão do folclore, ou melhor, do componente cultural tradicional, enquanto delimitador de uma identidade, contribui para a formação de uma determinada visão do desenho industrial dentro do Departamento de História, inclusive com um sentido de distanciamento ao da abordagem da ESDI. E como se verá mais adiante, entre os professores da FAU USP, alguns do Departamento de História se colocaram contra o modelo esdiano filiado à HfG Ulm, enquanto outros, os professores da Sequencia de DI dentro do Departamento de Projeto, se mostraram mais 
5. História da Arte na Formação do Arquiteto. In: Revista Sinopses, Edição Especial, 1993, p.84. afinados com o pensamento da Escola do Rio de Janeiro. Mas antes da abordagem desta questão, é necessário pontuar também alguns outros fatos estruturadores do Departamento de História da FAU USP.

O primeiro diretor da FAU USP, sem ligações com a Escola Politécnica, foi o professor Lourival Gomes Machado. Sob sua gestão (1961-1964), e graças a ela de acordo com depoimentos, foi possível se implantarem as diretrizes da Reforma de 1962. Conforme indica Amaral (1993) ${ }^{5}$, a presença do professor Lourival Gomes Machado na FAU USP se inicia entre 1952 e 1953, quando a convite do GFAU passa a ministrar cursos informais sobre história da arte para alunos do curso da FAU USP. Participa assim, também, o professor Lourival Gomes Machado do início da estruturação do núcleo da Escola que seria o embrião do seu Departamento de História.

No ano de 1954, Flávio Motta, após suas experiências iniciais dentro do IAC-MASP, do MAM SP e a sua presença na FAAP, inicia sua carreira docente na FAU USP, sendo contratado para dar regularmente aulas de História da Arte para as turmas do quinto ano de arquitetura, focando desde a pré-história até o impressionismo.

Julio Katinsky, por sua vez, inicia em 1962 sua contribuição à Escola, colaborando com a disciplina de Motta. E, por sua indicação, os alunos começam a realizar pesquisas dentro da FAU USP sobre artistas modernistas brasileiros, como Alfredo Volpi, Tarsila do Amaral, Anita Malfatti e outros. Na mesma disciplina, a partir de 1963, o arquiteto Sérgio Ferro passa a ser colaborador.

A partir de 1968, de acordo com depoimento de Julio Katinsky a Amaral (1993, p.84), o professor Flávio Motta percebe que a indústria cultural já está fazendo história da arte. Em consequência, cria a disciplina de título Arte e Vida Urbana. Motta permaneceria como professor do 
6. O registro mais remoto localizado junto aos arquivos do Departamento de História da assinado por Julio Katinsky. A partir de 2005, de acordo com a consulta, a mesma disciplina passou a ser AUH 412 Técnicas Retrospectivas. Estudo e Preservação dos Bens Culturais.

7. Depoimento ao autor em 05 de março de 2009. FAU USP data de 1972 e segue

curso de graduação da FAU USP até 1977.

Uma contribuição específica do Departamento de História da FAU USP à Sequencia de Desenho Industrial do Departamento de Projeto foi a criação, entre 1972 e 1973, da disciplina AUH 410 História da Técnica na Arquitetura, no Urbanismo e no Desenho Industrial ${ }^{6}$. O próprio professor Katinsky ${ }^{7}$ justifica o sentido da existência de tal disciplina:

O curso de Desenho Industrial da Faculdade, na realidade, começou como uma Sequência do Departamento de Projeto, porém com repercussões nos outros Departamentos, porque o Ministério da Educação exigia que houvesse uma disciplina de História da Técnica no Curso de Design (início da década de1970). Então, para se enquadrar na legislação em vigor, e o curso de Design (Sequencia de Desenho Industrial) da FAU USP ser reconhecido, era preciso que essa disciplina fosse da: História da Técnica.

Essa reformulação do Ministério da Educação, o MEC, de que fala Katinsky é citada por Picarelli como ocorrida em 1972, mesmo ano da instituição desta disciplina:

Decorridos 10 anos de implantação do DI no currículo, em fins de 1972, a diretoria da FAU USP, face à proposta de regulamentação da profissão do Desenhista Industrial, nomeia uma comissão de desenho industrial para estudo da situação apresentada e consequente elaboração de propostas visando a recolocar a FAU USP à frente do processo de formação de Desenhistas Industriais. ${ }^{8}$

8. PICARELLI, Marlene. O Desenho Industrial no Departamento de Projeto da FAU USP. In: Revista Sinopses, Edição Especial, 1993, p.49. Vale lembrar que até hoje a profissão do Desenhista Industrial ou do Designer no Brasil ainda não foi regulamentada. 
Sequencia de Desenho Industrial. Dez anos antes, em 1963, Julio Katinsky publica pela FAU USP a apostila Apontamentos sobre Arte e Indústria. O ponto de vista de Katinsky anunciado em 1963 com esta apostila é, na verdade, um elemento precursor da disciplina criada em 1973. Pois nesta primeira apostila já se encontra presente parte considerável de uma conceituação que se refere à arte, à indústria e à técnica e que são reformatadas para a sua aplicação dentro do curso da disciplina História da Técnica na Arquitetura, no Urbanismo e no Desenho Industrial. A apostila traz à capa uma escultura de Pablo Picasso, Cabeça de Touro, de 1943, em que para construir a imagem desta cabeça, o escultor reutiliza um guidom e um banco de bicicleta, fazendo as vezes do chifre e da cabeça, respectivamente. Com relação a esta apostila de 1963, em entrevista concedida ao autor em 2009, ou seja, quarenta e seis anos depois, a imagem da capa desta apostila é uma lembrança extremamente clara para Katinsky, que comenta sobre a mesma: Afinal de contas o que é projetar? O que é criar? Criar é o que fez o Picasso, pega um selim de bicicleta e um guidom e faz uma cabeça de boi. Como se verá mais à frente, aqui o autor já começa a enunciar uma diferença fundamental, que ele mesmo caracteriza, entre o seu ponto de vista (compartilhado por outros professores do Departamento de História da FAU USP) e o da ESDI sobre o Desenho Industrial. Esta diferença de pontos de vista reside no fato de que enquanto na ESDI, com sua origem na HfG de Ulm, o projetista é absorvido pela indústria como um técnico, para o pessoal da História da FAU USP, o projetista não abriria mão da manutenção de seu status de artista. Dois pontos de vistas radicalmente opostos e que fundam a mesma profissão com características em muito distintas em si.

Na breve apresentação, Katinsky assim declara a origem de tais apontamentos presentes na apostila de 1963: 
9. KATINSKY (1963).

10. Sob o título Cidade Contemporânea, o texto citado por Katinsky fui publicado originalmente por Oscar Niemeyer na revista Módulo, Volume 2, número 11, em dezembro de 1958.
Resultado de aula ministrada aos alunos da Faculdade de Arquitetura e Urbanismo, em 1962, reúne a presente publicação uma série de informações sobre as relações da arte com a indústria, bem como temas paralelos há muito motivos de constantes debates entre estudantes e arquitetos. É nosso intuito, ao divulgarmos estas notas, reavivar esses debates e aprimorar em novas contribuições, este trabalho preliminar. ${ }^{9}$

As informações sobre arte e indústria de que fala Katinsky na verdade objetivam, ao longo de todo o seu texto, uma narrativa a partir da história da organização do trabalho humano, mostrando como a evolução do domínio tecnológico repropõe por meio da reorganização do trabalho as relações entre os homens. Não por acaso, Katinsky no primeiro capítulo de seu escrito, sob o título Arquitetura e Opressão, apresenta um extenso trecho do texto escrito pelo arquiteto Oscar Niemeyer intitulado $A$ cidade Contemporânea ${ }^{10}$. O que este texto apresenta é o conceito condutor da narrativa da história da técnica de que Katinsky se propõe a tratar, e esse conceito estabelece a defesa de um ponto de vista em que à medida que evolui o domínio tecnológico humano, na mesma proporção, ocorre um reequilíbrio das relações de trabalho, e de uma nova solidariedade entre os homens, defendendo que o mundo inaugurado pelas revoluções industriais faz surgir um novo humanismo, afirmando ainda a (...) esperança no mundo contemporâneo, nas imensas possibilidades que se abrem diante de nós e das novas gerações, para a libertação do homem da opressão. É entre os marcos desse humanismo que devemos, agora e sempre, permanecer. Essas são as palavras de Katinsky. Em que pese certo nível de idealismo no texto do arquiteto, que o faz crer nessa capacidade emancipatória da técnica por si só, este é o ponto de vista que o arquiteto defende. Mas é por este viés que este arquiteto e professor da FAU USP procurará 
11. AUH 410 História da Técnica na Arquitetura, no Urbanismo e contar uma história da técnica, seja no plano internacional como também no brasileiro. $O$ que Katinsky estabelece em seu discurso é uma dimensão, um enquadramento histórico e cultural para técnica.

Aproximadamente dez anos mais tarde, Katinsky, expressando a continuidade do firmado na apostila de 1963, assim justificaria a disciplina ligada à História da Técnica:

A disciplina tem como objetivo explicitar as relações que se estabelecem entre os instrumentos disponíveis para atuar sobre o meio ambiente e as aspirações da sociedade ao longo da história, manifestas nas suas fixações territoriais. Torna-se, pois, necessário estabelecer um plano de investigação onde esse duplo aspecto se ache evidenciado. A disciplina pretende examinar, em forma de sumário, a história da técnica desde os seus primórdios conhecidos, até os dias de hoje. ${ }^{11}$

O conteúdo abordado pela disciplina é listado em: Técnicas Construtivas e de Implantação no Sítio, Transportes, Meios de Produção, Técnicas de Saúde e Técnicas de Representação. A prática da disciplina foi estruturada da seguinte forma, de acordo com o depoimento de Katinsky:

E eu fui encarregado de dar essa disciplina, e me recusei a dar uma disciplina típica brasileira, que é de leitura. Você lê, de preferência, meia dúzia de livros estrangeiros e fala para todo mundo aquilo que você leu. Quer dizer, as disciplinas no Brasil, até pouquíssimo tempo atrás, eram tão somente verborrágicas, eram de pura verborragia, os caras não tinham experiência nenhuma de nada e então eu propus uma disciplina dupla: História Geral da Técnica, claro, essa que existe nos livros de História da Técnica e que é uma disciplina que vem sendo feita pelos europeus desde meados do século XVIII, mas com sinais claros de organização nos séculos XVI e XVII. Essa é a grande proposta da Renascença. E eu propus 
12. Depoimento ao autor em 05 de março de 2009. uma segunda disciplina que seria História da Técnica no Brasil. Evidentemente, a História da Técnica no Brasil não podia ser dada como a tradição da História da Técnica Europeia. Porque a História da Técnica Europeia era baseada numa relação histórica, cronológica das invenções, e as invenções retornavam. Como então poderia haver uma História da Técnica brasileira? Isso pode parecer engraçado, mas essa pergunta me foi feita por um dos fundadores da Universidade de São Paulo, um professor importante, professor francês chamado August Bastide que veio a São Paulo para receber o título de professor emérito, se não me engano, na década de 1970. A essa altura já havia definido a disciplina História da Técnica no Brasil com bastante clareza, ao menos para mim. Disso resultou toda uma série de trabalhos de caráter crítico-histórico que foram em parte absorvidos pelos alunos e pelos professores. A característica fundamental da História da Técnica foi abandonar a idéia de invenção, mas fazer uma espécie de levantamento das técnicas que permitiram a ocupação territorial do Brasil. Esse foi um ponto de vista muito apoiado na Antropologia, na época, e na Economia e na Sociologia. Arcabouço teórico que serviu de ponto de apoio para montar a disciplina História da Técnica no Brasil. ${ }^{12}$

No transcorrer de seu depoimento, Katinsky explica que, para o reconhecimento e estudo das técnicas construtivas brasileiras, os alunos, acompanhados do professor, iniciaram um trabalho de levantamento dessas técnicas nas fazendas de açúcar e café em Itu, cidade próxima a São Paulo. Fizeram isto a partir com um caráter pioneiro que, em certa medida, retoma as preocupações originais de Lucio Costa e do próprio Centro de Estudos Folclóricos do GFAU.

Nesse sentido apontado acima, isto é, de delimitar uma dimensão, um viés cultural para técnica é que aqui entra em cena o uso da palavra folclore e o sentido pelo qual o mesmo é investigado por esses arquitetos. E a adoção deste termo é algo que se verifica não apenas no início de vida do GFAU, e dos professores do Departamento de História, como também compareceu no próprio discurso 
de Artigas por ocasião de um texto desse arquiteto, contemporâneo a esse período, para uma exposição de Desenho Industrial que se realizaria na FAAP em 1962, por intermédio do professor Flávio Motta. Esta exposição foi uma iniciativa do IAB SP em atender a uma solicitação das indústrias de São Paulo. Por meio de sua Comissão de Desenho Industrial, O IAB realiza, em 1962, um levantamento dos produtos industriais brasileiros, com a finalidade de realizar uma exposição do desenho industrial nacional com a colaboração da Fundação Armando Álvares Penteado, FAAP. Por falta de verba, a exposição não pode ser levada a cabo, mas como contribuição a este empenho do IAB e da FAAP, foi produzido pelo arquiteto Vilanova Artigas um texto de apresentação da mostra avaliando, no seu ponto de vista, as características dos objetivos a serem apresentados pela mesma. Discutindo as questões relativas à necessidade de construção de uma identidade própria para esses objetos, Artigas adota o termo folclore para delimitar uma tradição cultural popular nacional. Em seu texto, o arquiteto irá se dirigir à sociedade de forma geral, mas em particular aos industriais. Seu discurso apresenta a seguinte leitura das condições da indústria brasileira. De um ponto de vista tecnológico, esta já se encontrava, para o arquiteto, consideravelmente desenvolvida, o que Ihe faltaria é o desenvolvimento de uma identidade própria, que a particularize diante das demais produções industriais de outros países. Mas Artigas, em advertência, afirma que esta condição da indústria brasileira naqueles anos é uma condição compreensível, mas não aceitável:

A forma plástica dos produtos industriais fabricados no Brasil em sua grande maioria vem de fora. Isto porque, de um lado, os nossos produtores preocuparam-se, em virtude do rápido desenvolvimento industrial, antes com o reequipamento para atingir a expansão e a melhoria técnica requeridas pelo crescimento acelerado da produção manufatureira, do que 
com a forma plástica do objeto a produzir, de outro lado, as indústrias estrangeiras que aqui se instalaram, trouxeram conjuntamente com os equipamentos, o que é natural, o desenho dos produtos que iam produzir em nosso país. 0 resultado dessa dupla atitude, aliás, muito compreensível, frustrou o desabrochamento do desenho industrial brasileiro (ARTIGAS, 1962).

E para a constituição de um desenho industrial absorvendo nossa identidade cultural preexistente e contribuindo para a evolução e transformação desta identidade, Artigas apontará a necessidade de um olhar no sentido de que os projetistas de nosso desenho industrial reconheçam e absorvam tal herança:

No Brasil, a caracterização dos produtos segundo tendências estéticas nacionais impõe-se ainda pelo vasto repositório formal, constituído por um largo passado de criação artística, que se manifestou em todos os campos plásticos, desde o erudito ao folclórico, e por um presente muito rico de inventividade estética de alto mérito, cujo valor incontestável é fortemente demonstrado pelo apreço internacional de que tem sido alvo. Por esse motivo, não é admissível que a produção industrial brasileira conserve-se alheia a este vasto manancial de criações artísticas, passado e presente, erudito e folclórico.

$\mathrm{O}$ arquiteto Artigas afirma que esta absorção da tradição é algo comum nos países mais industrializados europeus, e este é na verdade um diferenciador de suas produções industriais, no sentido de criar produtos com qualidades únicas para a competição no mercado internacional.

Em princípio é de se causar um grande estranhamento que Artigas defenda a ideia de existência de um folclore nacional, e o seu resgate por aqueles com formação erudita, ainda mais considerando que dentro do PCB, 
13. Trecho de uma entrevista de Artigas a Aracy Amaral. Ver BUZZAR (1996). onde foi militante, o arquiteto, nas disputas por uma expressão artística e arquitetônica a ser defendida para o país dentro do $\mathrm{PCB}$, em uma disputa polêmica, se colocou contra o grupo de nacionalistas do Sul do país, assim delimitando-os: (...) era o pessoal do Rio Grande do Sul, que propunha uma arte regionalista, e que passaram a desenhar homem com laço e cavalo de fronteira. ${ }^{13}$

Para se entender essa polêmica, é preciso considerar que, para Artigas, essa aproximação e, preferencialmente, absorção do folclore pelo nosso desenho industrial, deveria ser feita a partir de outra perspectiva. Ele mesmo, no texto de abertura da Exposição de DI do IAB e da FAAP, em 1962, faz uma advertência:

Não fazem, porém, as duas instituições esse movimento com intenção demagogicamente nacionalista, mas porque entendem que as formas plásticas dos produtos constituem veículo importante de educação artística, assumindo assim relevante aspecto social.

Além disso, em todos os países, as formas plásticas dos produtos refletem os aspectos culturais de seu povo, particularmente as tendências estéticas que o gosto artístico aliados aos usos e costumes compuseram. Estes aspectos culturais não sintetizam apenas a tradição, mas resumem também a etnologia dentro das quais o povo se formou.

Muito claramente afirma um desejo de fugir a uma intenção demagogicamente nacionalista. Mas como não incorrer nesse risco ao abordar o folclore, que é uma categoria criada pela cultura erudita para enquadrar a cultura popular? Ainda mais considerando que os arquitetos, ou desenhistas industriais, pela sua formação institucionalizada, são naturalmente detentores de uma cultura erudita ${ }^{14}$. Tudo isto, que a princípio pode 
15. ARTIGAS, Vilanova. Contribuição para o relatório sobre o ensino de arquitetura UIA-UNESCO. In: Revista Sinopses, Edição Especial, 1993, p.135. parecer um paradoxo, deve ser compreendido pelo caminho com que Artigas se aproxima conceitualmente do folclore. O seu caminho de aproximação é o mesmo dos modernistas brasileiros da Semana de 1922, na tentativa de expressar uma arte moderna, alinhada com o pensamento das vanguardas europeias, mas sem deixar de lado a contribuição de uma cultura nacional brasileira, que eles reconheceram existir em nosso folclore. E esta é uma aproximação não apenas de Artigas, ela é perceptível também no discurso de outros professores. Para se ter uma ideia da importância que o arquiteto Artigas atribui a esse grupo de artistas da Semana de 1922, nesse sentido apontado, vale recuperar mais uma vez a afirmação de Artigas no sentido de valorizar a importância de Lourival Gomes Machado como diretor da FAU USP:

É significativo o fato de a Reforma de 1962 ter sido possível quando a Faculdade era dirigida por Lourival Gomes Machado, sendo vice-diretor o matemático Cândido Dias da Silva. Retomávamos a linha cultural nacionalista de 1922 através da Faculdade de Filosofia da USP. Voltávamos à autenticidade de algumas de nossas melhores raízes, enquanto arquitetos. Assim me parece. Basta conhecer a obra de Lourival Gomes Machado, o papel que desempenhou na cultura paulista, sua convivência com a crítica das artes, seus estudos sobre arquitetura barroca, para compreender a natureza do ambiente que nos permitiu as reformas de $1962 .{ }^{15}$

Esse será o viés pelo qual, para Artigas, é feito o uso da palavra folclore em sua construção ideológica de uma identidade nacional, isto é, uma retomada da linha cultural nacionalista de 1922. O arquiteto Julio Katinsky reafirma este ponto de vista:

Essa visão vem dos modernistas. Vem do Mário de Andrade, 
16. Depoimento ao autor em 05 de março de 2009. Esta explicação de Katinsky é uma resposta sobre uma questão em que foi pedido ao professor para comentar o uso do termo folclore por Artigas. Na ocasião, citamos a Katinsky o ponto de vista oposto da arquiteta Lina Bo Bardi quanto ao uso do termo folclore.
17. Esses professores tiveram um caráter pioneiro nesse início do Departamento de História da FAU USP, pois somente a partir de 1972 é que é contratada uma quantidade maior de professores para o Departamento: Aracy Amaral, Luiz Carlos Daher, Áurea Pereira da Silva, todos em 1972. Ana Maria Belluzzo (1978). Maria Cecília França Lourenço (1981, em substituição de Áurea Pereira da Silva). Nelson Alfredo Aguilar (1985, em substituição de Luiz Carlos Daher). Ricardo Marques de Azevedo (1989, em substituição de Nelson Aguilar). Ver AMARAL (1993, p.84), in: Revista Sinopses, Edição Especial, 1993. do Oswald de Andrade, etc. E por incrível que pareça, ela é muito incentivada por artistas que eram europeus, que tinham assim uma visão muito humanista da obra de arte. A exemplo de Blaise Cendrars que insistiu para os paulistas irem visitar Minas Gerais. Ele foi junto em 1924. Também o próprio Le Corbusier que recomendou que se colocasse azulejo no Ministério da Educação. Azulejo é um produto tradicional brasileiro. ${ }^{16}$

Como afirmamos no início do capítulo, o próprio professor Luis Saia, da FAU USP, foi colaborador do modernista Mário de Andrade junto ao SPHAN, e a pedido de Andrade chefiou, em 1936, uma missão de pesquisa no Nordeste brasileiro sobre o folclore desta região do Brasil. Também informamos que um dos exercícios didáticos iniciais de Julio Katinsky, ao entrar para o Departamento de História da FAU USP, era levar os alunos a pesquisarem a produção de artistas modernistas como Volpi, Tarsila, Anita Malfatti e etc.

Então se forem consideradas as atividades iniciais do GFAU, com o seu Centro de Estudos Folclóricos, a presença de Luis Saia; os pontos de vista dos professores que formaram o núcleo inicial que estruturou o Departamento de História, entre os quais cabe destacar os professores Lourival Gomes Machado, Flávio Motta e Julio Katinsky ${ }^{17}$ ou mesmo o empenho de Vilanova Artigas com a sua chamada de importância para uma dimensão históricocultural para o desenho industrial, presente em seu texto para a exposição da FAAP, pode-se caracterizar dentro da FAU USP um grupo de professores pensando um caminho para a prática do desenho industrial diferente daquela defendida pela ESDI, que se ligava à matriz da HfG de Ulm. Isto não significa que todo o pensamento da FAU USP sobre o Desenho Industrial optou por este caminho, fazendo crítica à escola carioca. Alguns professores da Sequencia de Desenho Industrial, no Departamento de 
Projeto, inclusive se colocaram céticos quanto a esta visão formulada a partir do Departamento de História da FAU USP.

Esta visão do Departamento de História da FAU USP procurou embasar uma prática do Desenho Industrial visceralmente ligada e legitimada por um passado cultural, ou seja, calcada na descoberta e invenção de uma tradição. E esse passado cultural onde se encontrava? Dois foram os focos para os quais esse grupo de professores lançou seus olhares: o folclore e o conjunto de técnicas construtivas do período colonial do Brasil. Um ligado à produção do objeto e, outro, à produção do edifício. No primeiro caso, com um olhar intermediado pelo ponto de vista de Mário de Andrade e dos artistas modernos da Semana de 1922 e, no segundo, pelo apelo de Lucio Costa a um olhar de nossa arquitetura moderna para um aprendizado com a nossa arquitetura colonial.

Para reforçar esse ponto de vista de distanciamento dos postulados da ESDI e busca de um caminho autônomo marcado pela identidade nacional, o arquiteto Julio Katinsky assim se colocaria com relação à escola carioca:

18. Depoimento ao autor em 05 de março de 2009.
(...) o pessoal do Rio de Janeiro, seguindo uma linha bem colonizada, eles inventaram de fazer uma escola de design específica, que era a ESDI, que acabou se transformando numa coisa diferente do que eles imaginavam, porque a Escola da ESDI era cópia de Ulm (Hochschule für Gestaltung - Escola Superior da Forma -, HfG UIm, na Alemanha) que foi pensada num universo industrial completamente diferente, além de ser uma política torta. E que existia naquela época, da Guerra Fria, e que queria caracterizar todo o trabalho criativo através do produto de mercado. ${ }^{18}$

O professor Katinsky irá fixar sua crítica negativa ao modelo de ensino da ESDI exatamente nesse enquadramento 
19. Depoimento ao autor em 05 de março de 2009.

20. Katinsky. Desenho Industrial. In ZANINI. História Geral da Arte no Brasil (1983). da Escola pela adoção de uma postura que ele define muito negativamente como colonizada, decorrência da implantação de um modelo gestado fora da realidade cultural brasileira, sem levar em consideração tal realidade e ao mesmo tempo por delimitar o trabalho criativo a apenas produzir produtos para o mercado.

No livro clássico de Walter Zanini, História Geral da Arte No Brasil, coube a Julio Katinsky o relato sobre a nossa produção nacional de desenho industrial. O livro data de 1983, e nesse sentido pode ser tomado já como uma perspectiva de avaliação histórica de um passado. Katinsky em depoimento afirma que intencionava escrever 100 páginas sobre o desenho industrial brasileiro, mas que Zanini limita seus escritos a apenas 35 laudas $^{19}$. Em que pese esse limite de texto imposto, dentro das 35 páginas de que dispõe, o autor dedicaria à ESDI apenas as nove linhas transcritas abaixo:

\footnotetext{
No Rio de Janeiro, o procedimento foi um pouco diferente (comparando o ensino de DI na FAU USP e na ESDI). Talvez devido à tradição mais antiga e mais sólida da Escola de Belas Artes, fundada no Império, por isso mesmo mais conservadora, a preocupação em incorporar a indústria moderna ao projeto conduziu a se organizar uma escola que rompesse radicalmente com os padrões existentes.

Assim fundou-se a Escola Superior de Desenho Industrial, tentando seguir o modelo de UIm. Este modelo alemão não foi totalmente implantado por razões óbvias: pensado para uma situação muito particular do pós-guerra europeu, num meio social totalmente diferente, já de início apresentava dificuldades de organização bastante penosas. ${ }^{20}$
}

A história do desenho industrial brasileiro, que Katinsky narra nas 35 páginas do livro de Zanini, se inicia com a abordagem da nossa arquitetura colonial, lida sob a ótica 
21. Os cobogós, do edifício caixa d água no Recife, do arquiteto Luiz Nunes; os elementos vazados do Parque Guinle, no Rio de Janeiro, do arquiteto Lucio Costa; os caixilhos do edifício do Ministério da Educação e Saúde e os brises móveis da obra do berço, do arquiteto Oscar Niemeyer.
22. REIS, José. Pesquisa científica e tecnológica, in Ciência e Cultura. Citado por Katinsky. Desenho Industrial. In ZANINI. História Geral da Arte no Brasil (1983). Na entrevista de 2009, 26 anos depois, Katinsky afirma, nos dias atuais, a persistência desta mentalidade em parte dos industriais do país. conceitual do texto Documentação Necessária (1937) de Lucio Costa. Apresenta a expressão do Art Noveau no Brasil, ilustrado, sobretudo, com imagens dos móveis da Vila Penteado, primeira sede da FAU USP. Sobre os anos de 1920, apresenta o mobiliário produzido pelo arquiteto Gregori Warchavchik para mobiliar suas casas modernistas. Nos anos de 1930, a partir da arquitetura moderna carioca, cita o desenho de objeto de alguns componentes arquitetônicos para fachadas ${ }^{21}$ e peças de mobiliário produzidas especificamente para os interiores do edifício do Ministério da Educação e Saúde. Entre os anos 1940 e 1950, apresenta um mobiliário produzido em sua maioria para uso doméstico, de autoria de Zanine Caldas (Fábrica de Móveis Z), Lina Bo Bardi e Gian Carlo Palanti (Estúdio de Arte Palma), Escritório Branco \& Preto, Joaquim Tenreiro, Carlos Fongaro e Sérgio Rodrigues. Ao acrescentar, paralelo ao desenvolvimento dessas experiências dos arquitetos, o desenvolvimento da indústria brasileira, Katinsky reproduz o argumento de José Reis:

Existe por outro lado, em nosso meio, uma longa tradição de indústria sem pesquisa própria, ávida de comprar tecnologia fora e revendê-la com lucro, sem o menor interesse em criar algo novo, ainda que tecnologia intermediária ou coisa parecida. ${ }^{22}$ 


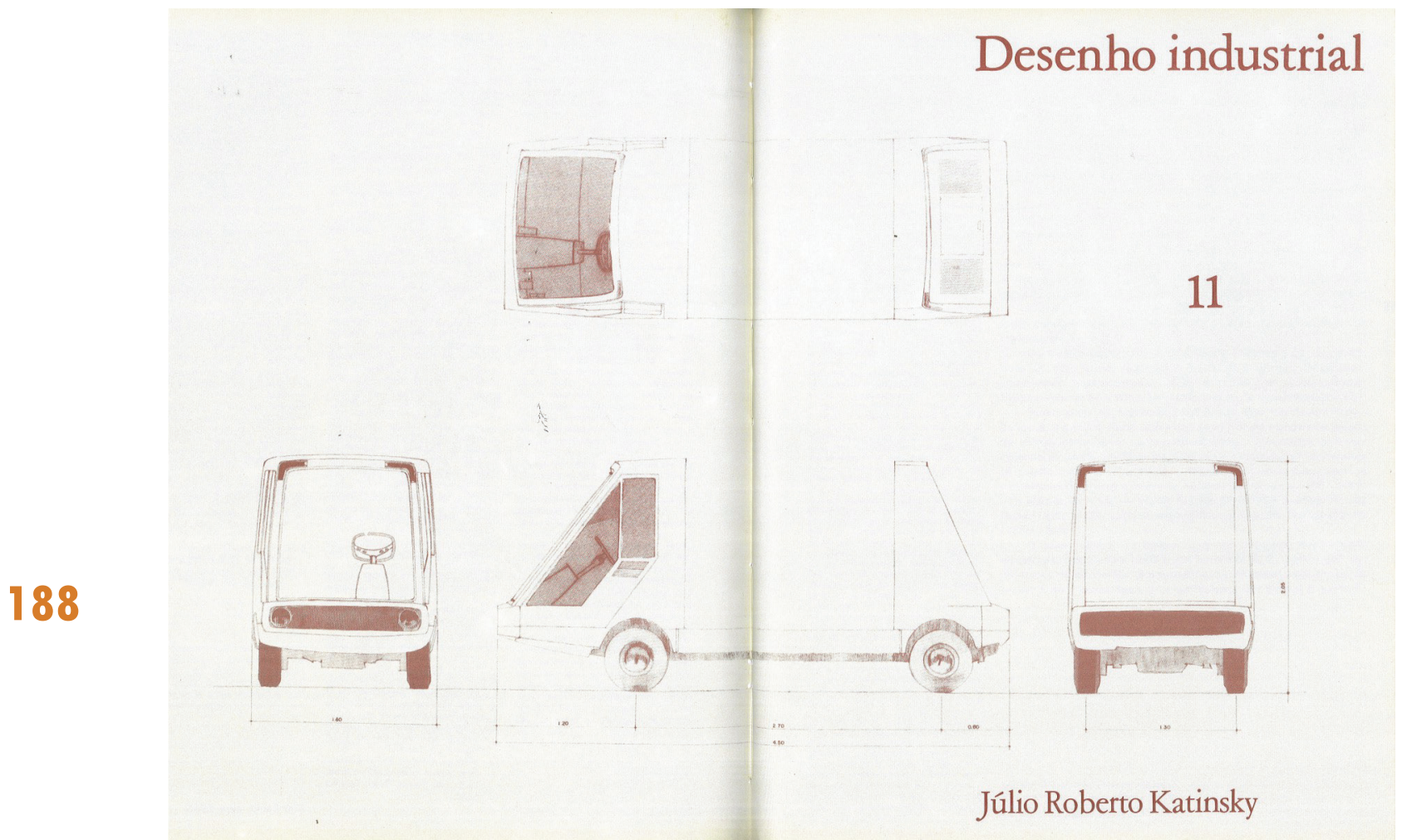

Fig.79. Carro Aruanda. Ari Antônio da Rocha (1964). Capa de abertura do Capítulo 11: Desenho Industrial de Julio Katinsky no livro História Geral da Arte no Brasil de Walter Zanini [São Paulo: Instituto Walther Moreira Salles, 1983] [Fonte: ZANINI, 1983]

[Fonte das imagens 79 até 114: ZANINI, 1983] 


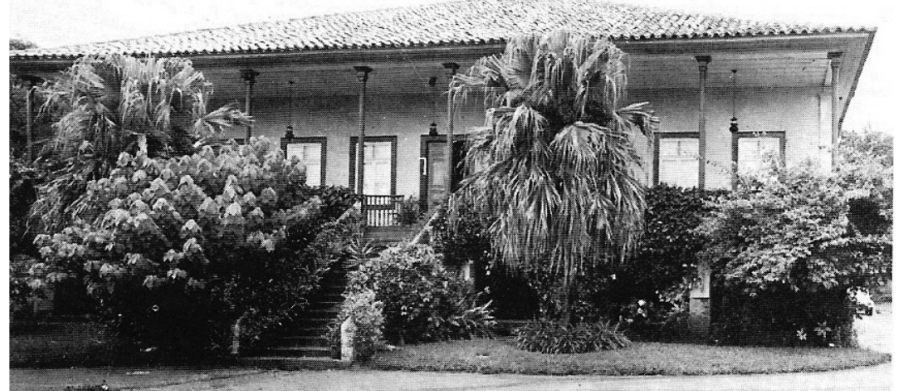

Fig.80. Fazenda Floresta, Itu, São Paulo, 1870.

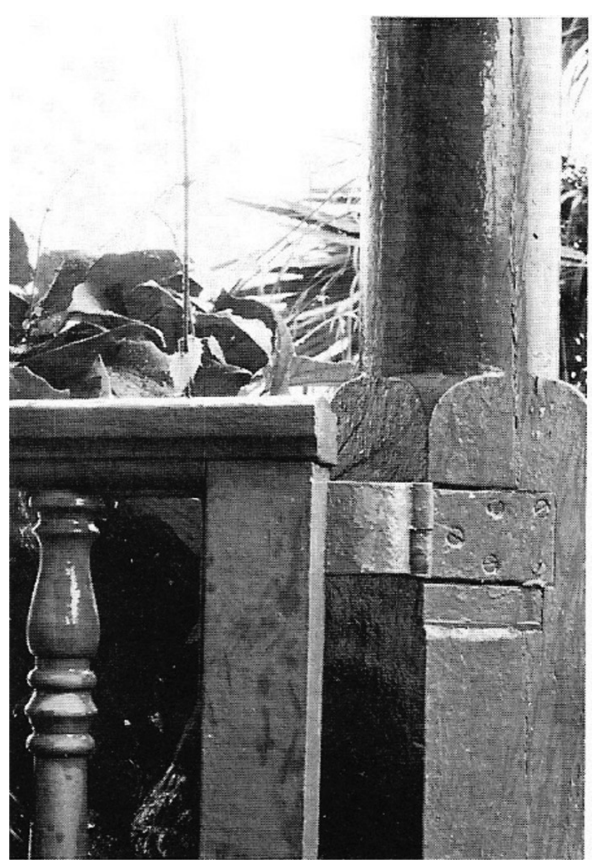

Fig.81. Fazenda Floresta, Itu, São Paulo, 1870

Os elementos pré-fabricados de ferro fundido ganharam tanta aceitação que, mesmo no interior longínquo de São Paulo, eles foram procurados. Esta casa é um testemunho eloqüente dessa preferência: o construtor não podendo obter colunas de ferro, construiu sua aérea varanda com coluna de peroba, imitando colunas de ferro (Comentário de Katinsky).

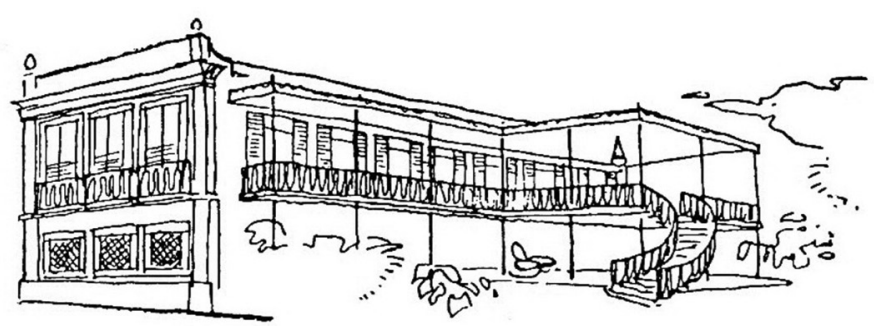

Fig.82. A fachada da rua com um nariz postiço ainda mantém certa aparência carrancuda, mas ao lado do jardim, que liberdade de tratamento e como são acolhedoras; e tão modernas puro Le Corbusier (nota do autor acompanhando o croqui). [citação extraída por Julio Katinsky de Lucio Costa. Documentação Necessária, in Alberto Xavier, org., Sobre arquitetura Lucio Costa] 


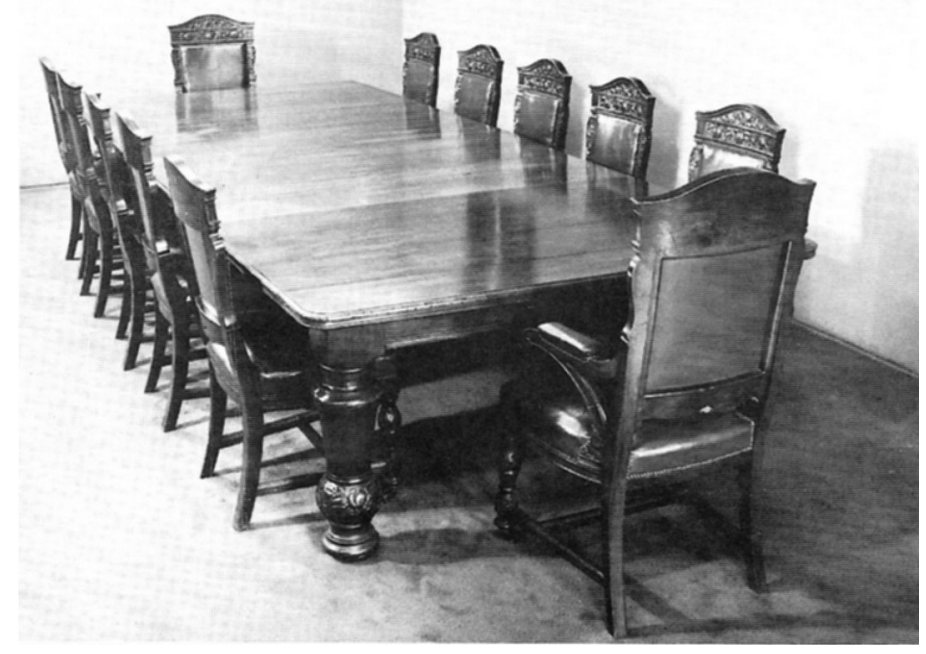

Fig.83. Cadeira e mesa art nouveau da Vila Penteado.

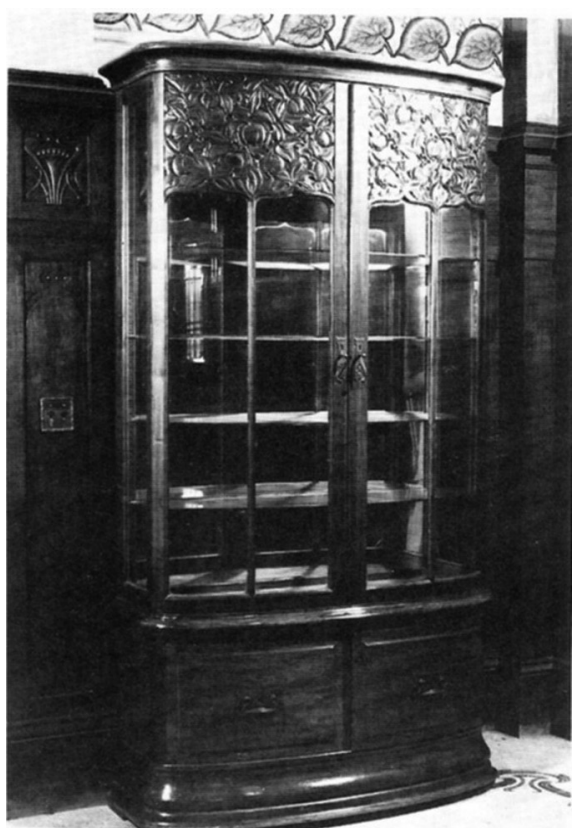

Fig.84. Cristaleira art nouveau da Vila Penteado.

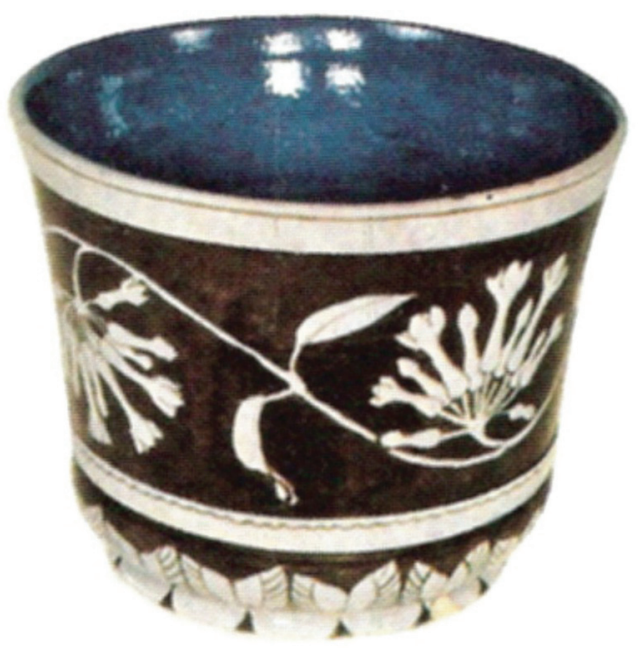

Fig.85. Eliseu Visconti, vaso de cerâmica com decoração fitomorfa, 19 x 19 coleção SPHAN, em depósito no MNB-A, Rio de Janeiro.

O crescimento vertiginoso de algumas cidades brasileiras, ocorrido nos fins do século 20, colocou em questão o equipamento destas cidades: a solução tradicional das camadas mais abonadas de importar bens manufaturados em troca de matérias primas (a cadeira Thonet é um exemplo e um símbolo dessa atitude) entrava em crise. O Art Nouveau surgido nessa época com suas preocupações de qualidade estética sobretudo, não foi mais que uma questão de modernidade patrocinada pelos barões do café (Comentário de Katinsky). 


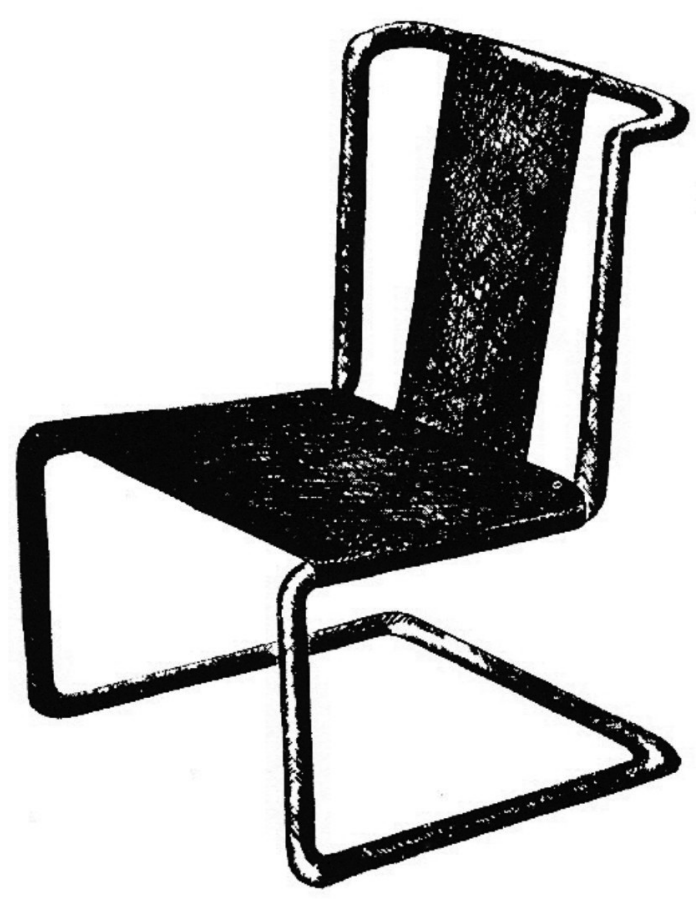

Fig.86. Projeto de Cadeira. Gregori Warchavchik, 1932

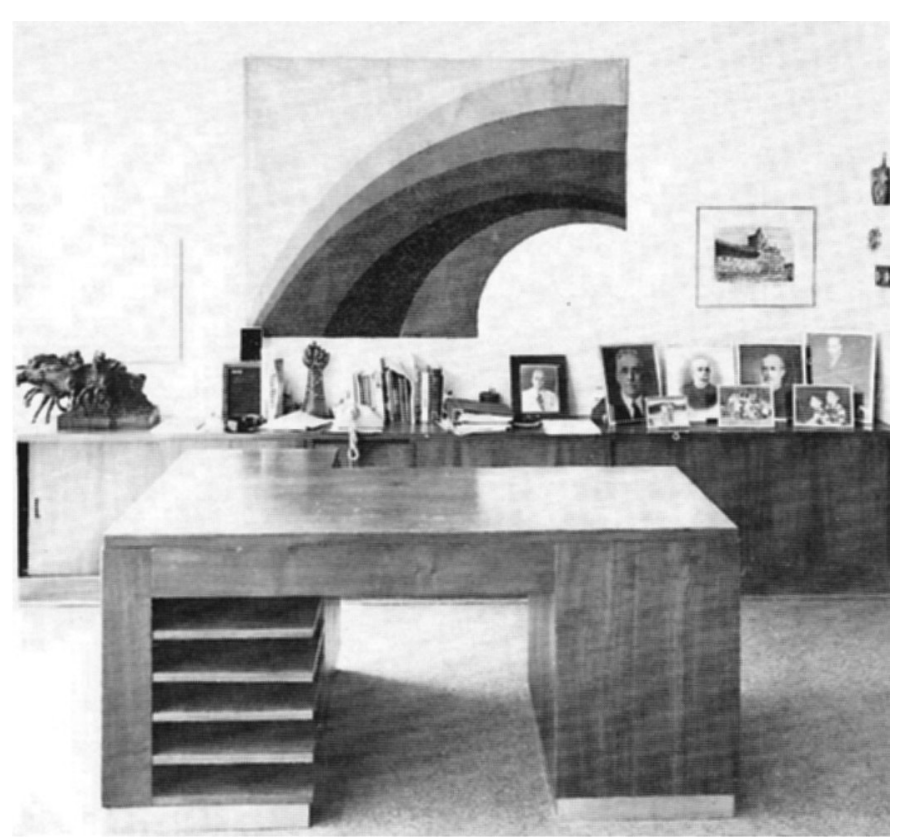

Fig.87. Mesa secretária para Paulo Prado, projeto de Gregori Warchavchik, 1930, compensando com estrutura de cedro maciça.

Impulsionado pelo Modernismo, o projeto de equipamentos, principalmente de móveis, seguem fielmente certas experiências vienenses e alemãs, especialmente as primeiras criações da Bauhaus (Comentário de Katinsky) 


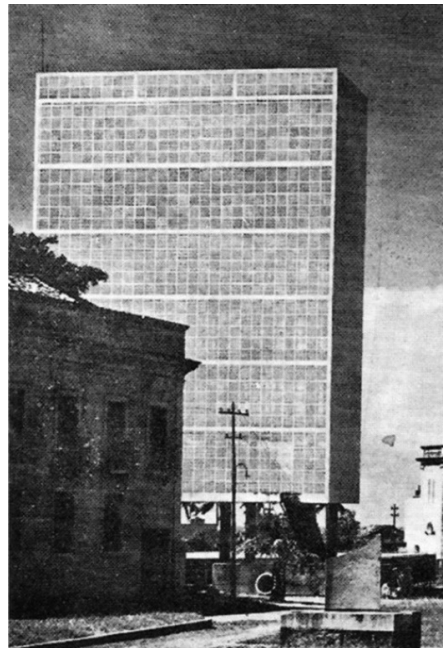

Fig.88. Caixa d'água em Recife, cobogó, projeto de Luiz Nunes.

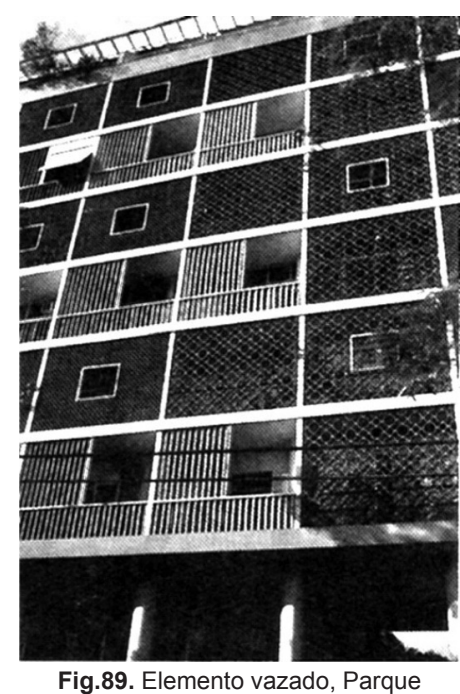

Fig.89. Elemento vazado, Parque
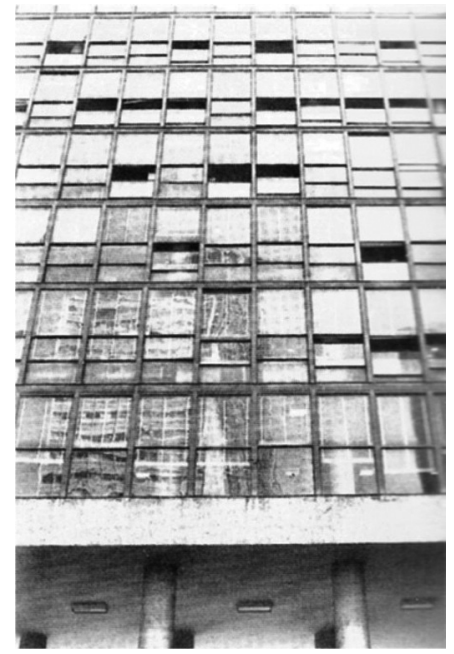

Fig.90. Caixilhos do Ministério de Educação e Saúde, fachada sul, 1936

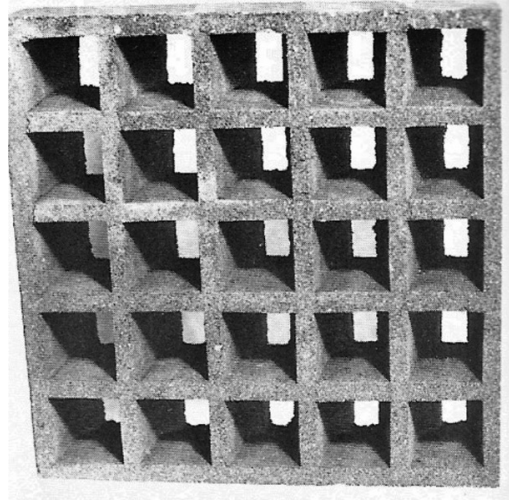

Fig.91. Elemento vazado, projeto de Franz Heep.

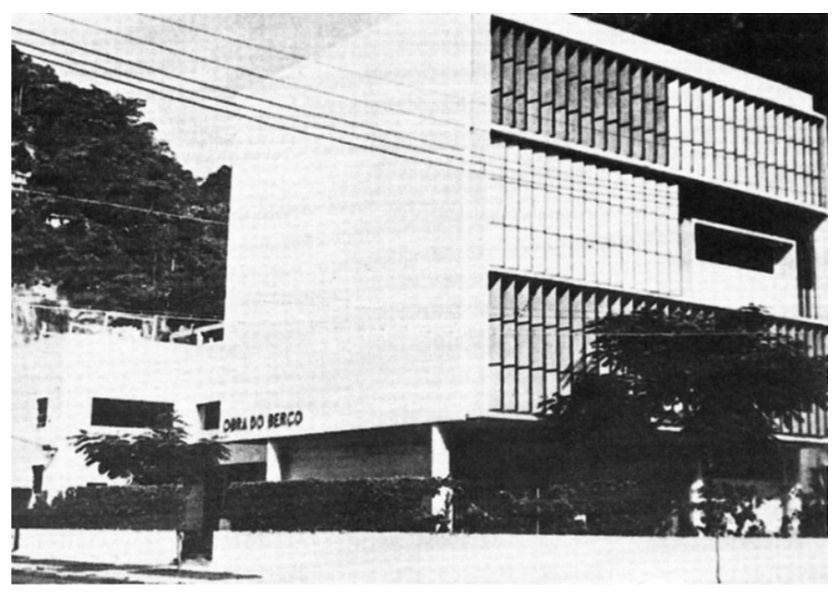

Fig.92. Brises móveis. Obra do Berço, projeto de Oscar Niemeyer, 1937 Rio de Janeiro.

Nas décadas de 1930 e 1940, pela primeira vez, os projetos de elementos da construção se destacam das lutas estéticas para ganhar a participação mais ampla da população. Em particular o elemento vazado (cobogó) de concreto ou cerâmica incorporou-se aos elementos usuais da construção no Brasil (Comentário de Katinsky). 


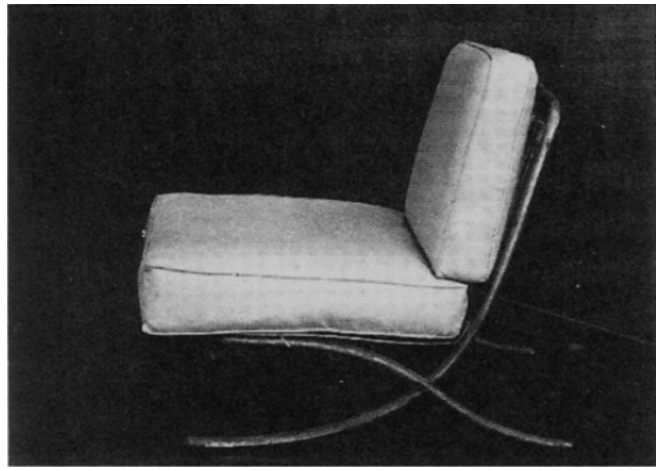

Fig.93. Poltrona do antigo Ministério da Educação e Saúde, hoje palácio da Cultura, Rio de Janeiro.

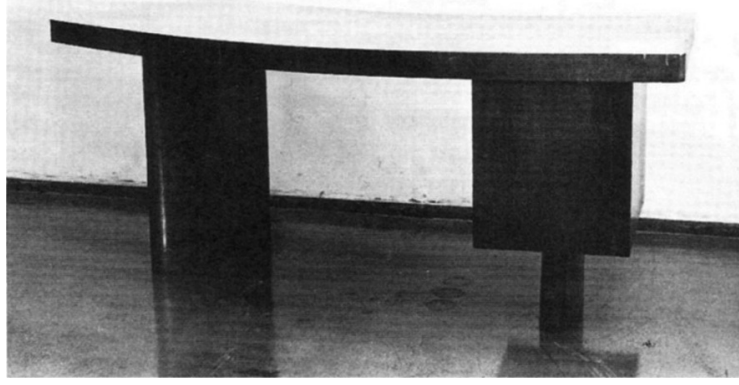

Fig.94. Mesa do antigo Ministério da Educação e Saúde, hoje palácio da Cultura, Rio de Janeiro.

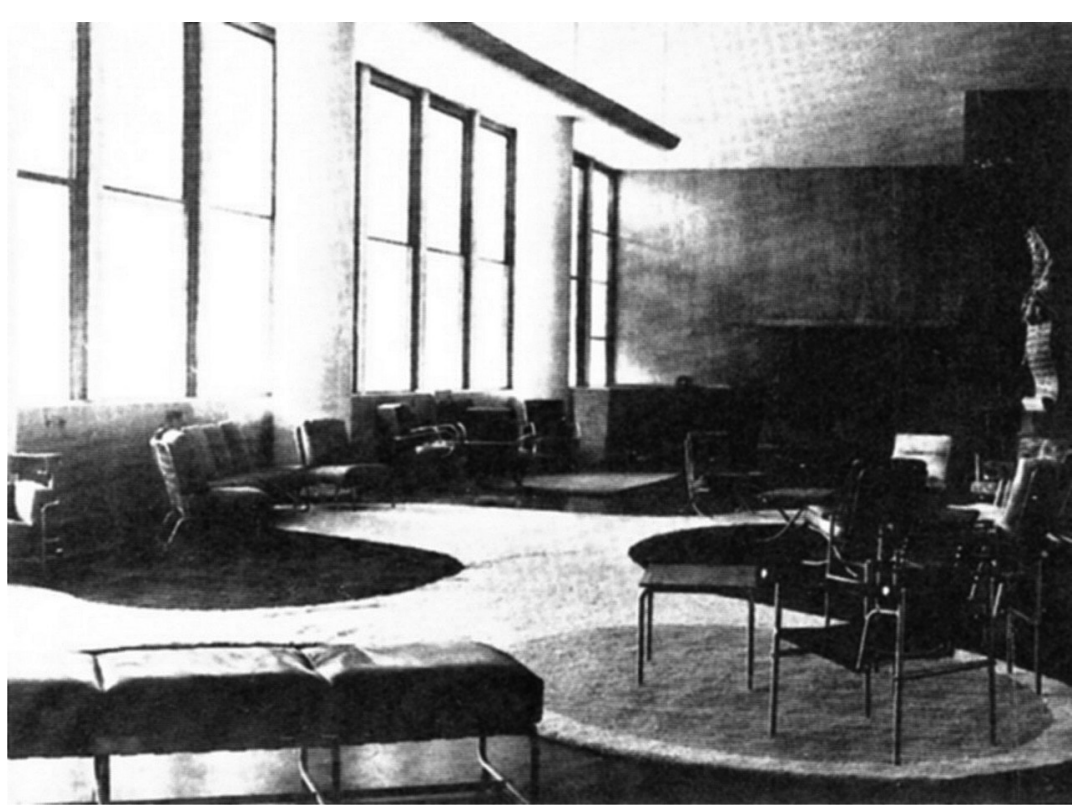

Fig.95. Ante sala do gabinete do ministro do antigo Ministério da Educação e Saúde, hoje palácio da Cultura, Rio de Janeiro.

Os arquitetos cariocas, reunidos no projeto do Ministério da Educação e Saúde, procuraram equipar os ambientes do novo prédio com mobiliário coerente com as intenções de valorização da indústria bandeira estética que os distinguia de outras correntes de arquitetos brasileiros. Assim, esses móveis seguem estreitamente modelos europeus muito admirados então: Le Corbusier e Mies van der Rohe (Comentário de Katinsky). 


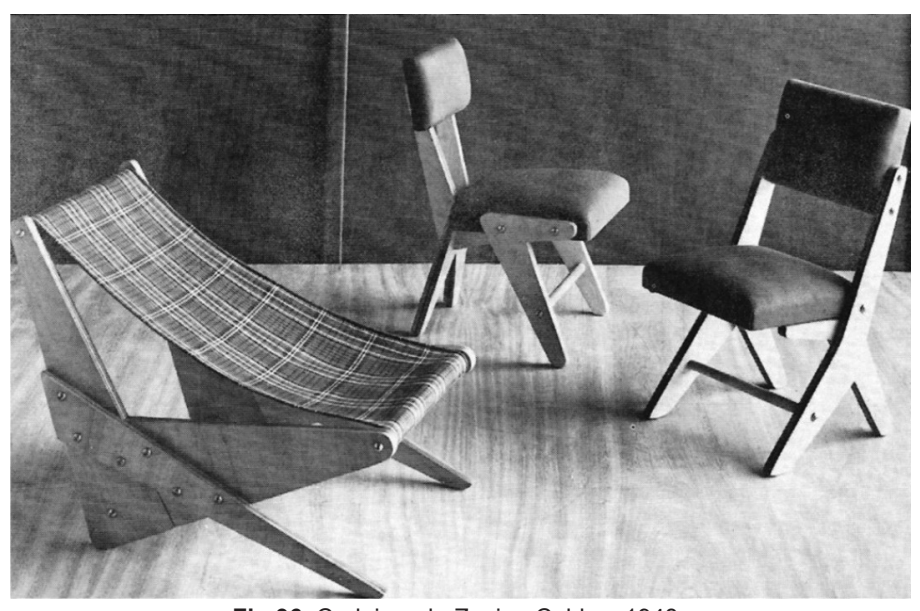

Fig.96. Cadeiras de Zanine Caldas, 1948

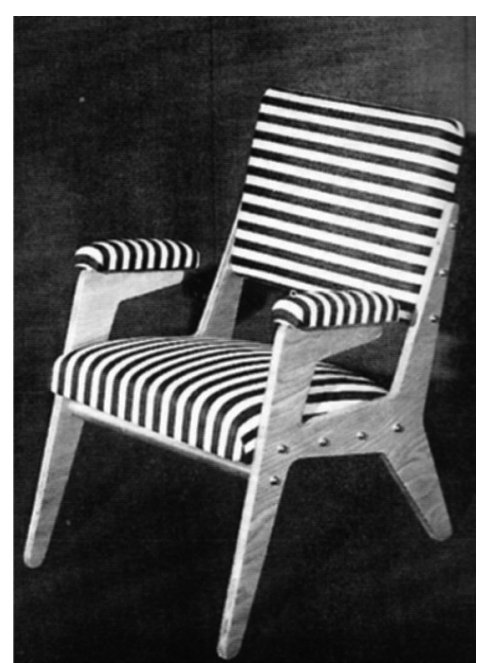

Fig.97. Cadeira de Zanine Caldas, 1950.
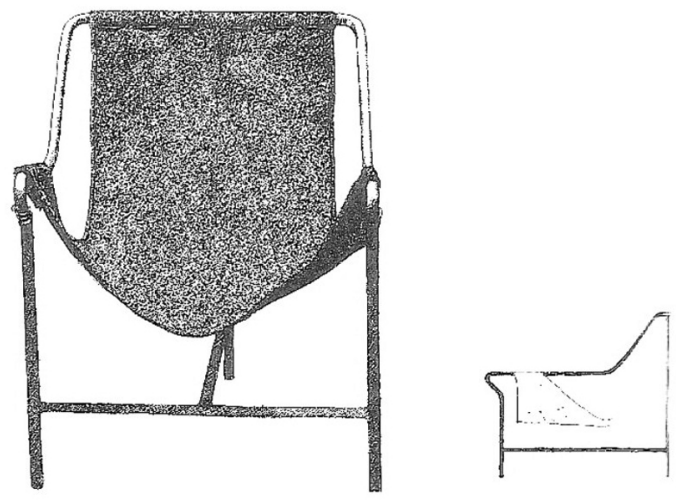

Fig.98. Cadeira inspirada em rede caipira, projeto de Lina Bo Bardi e Giancarlo Palanti, 1948.

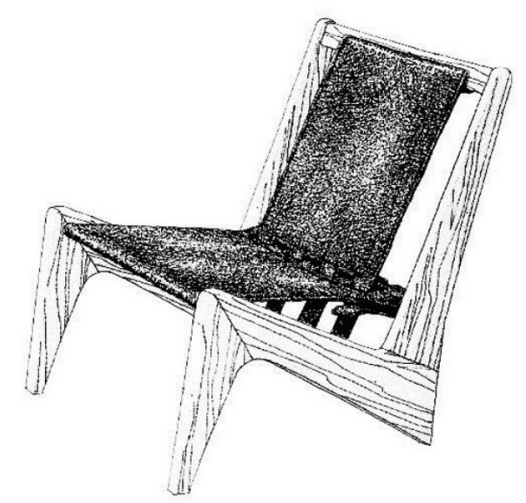

Fig.99. Poltrona, projeto de Lina Bo Bardi e Giancarlo Palanti, 1948. 


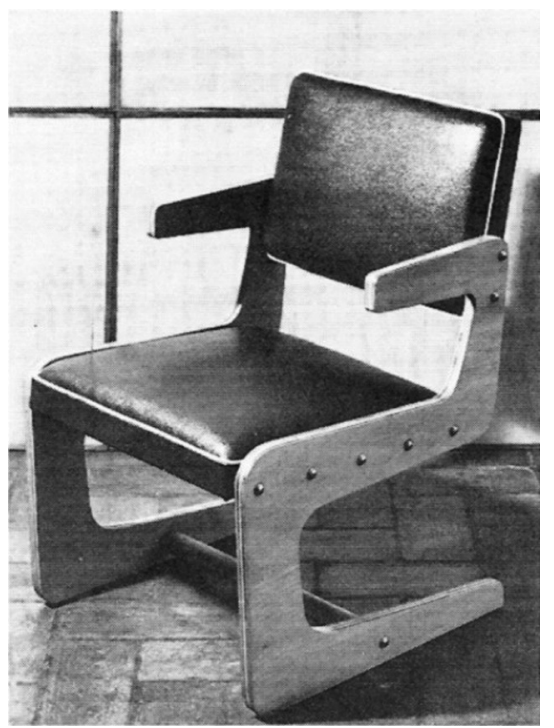

Fig.100. Cadeira de Zanine Caldas, 1950.

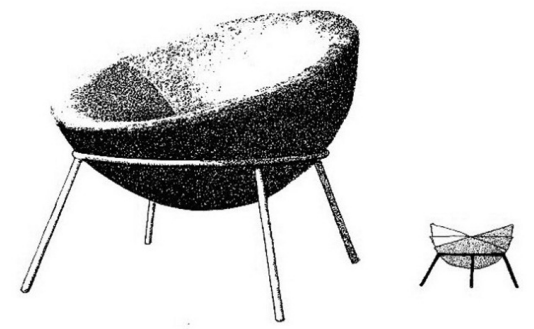

Fig.102 Cadeira Ovo, projeto de Lina Bo Bardi, 1954.

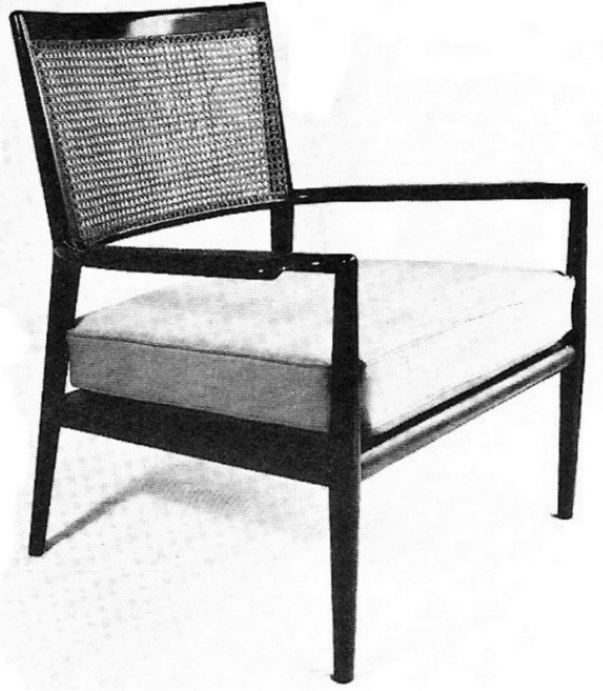

Fig.101. Poltrona, projeto de Carlos Millan, 1954

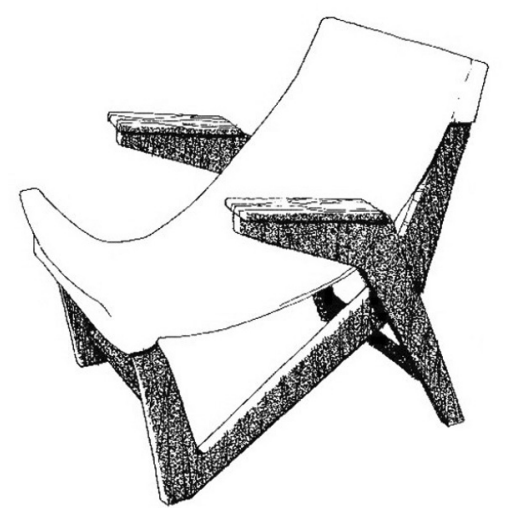

Fig.103. Poltrona, projeto de Lina Bo Bardi e Giancarlo Palanti, 1948. 


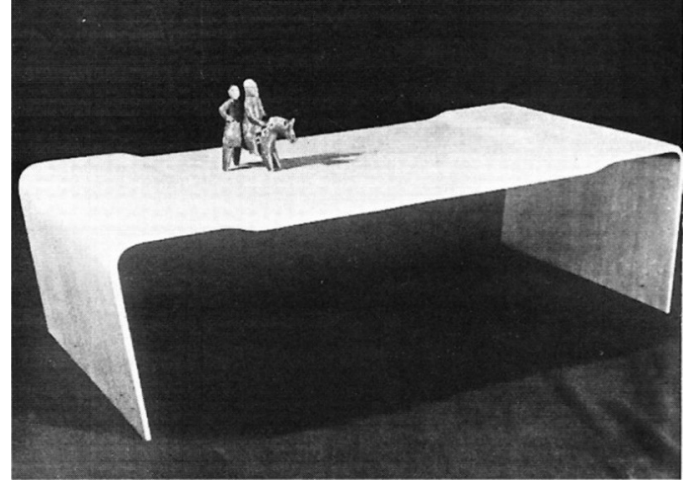

Fig.104. Mesa de Centro, projeto de Joaquim Tenreiro, 1950

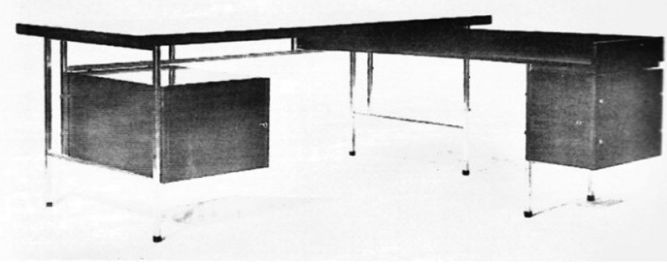

Fig.105. Mesa para escritório, projeto de Carlos Fongaro, 1956.

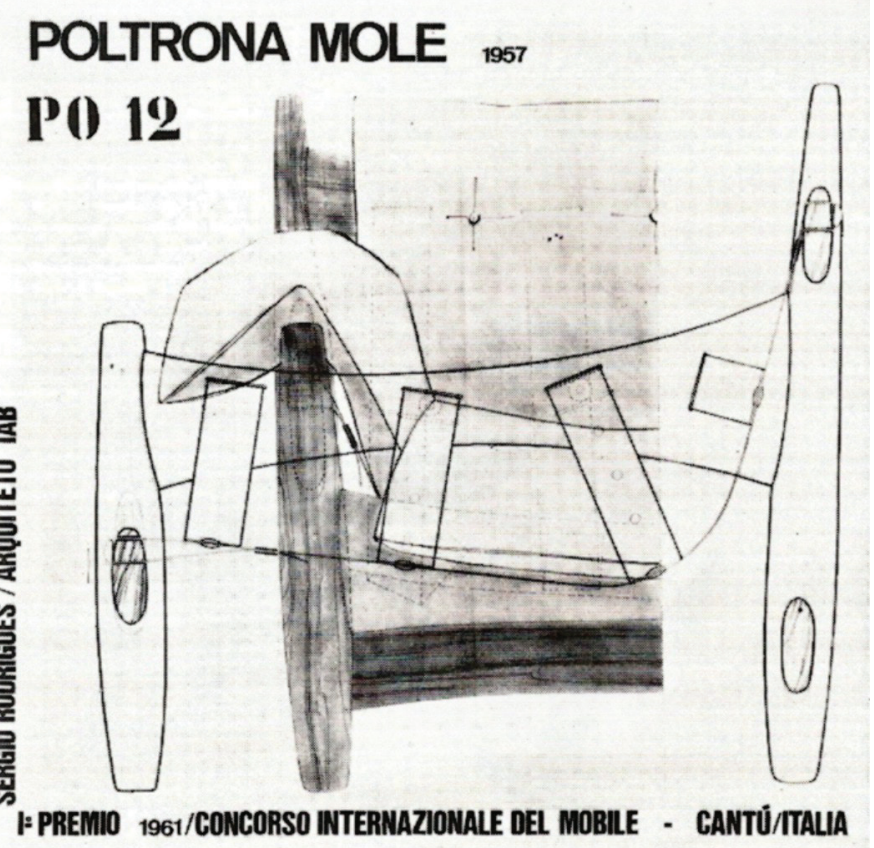

Fig.106. Cadeira Mole, projeto de Sergio Rodrigues, 1957.

Na esteira do êxito nacional e internacional da arquitetura moderna brasileira deu-se um florescimento do desenho industrial, principalmente, como já foi assinalado,emelementos de construçãoenomobiliário(ComentáriodeKatinsky) 

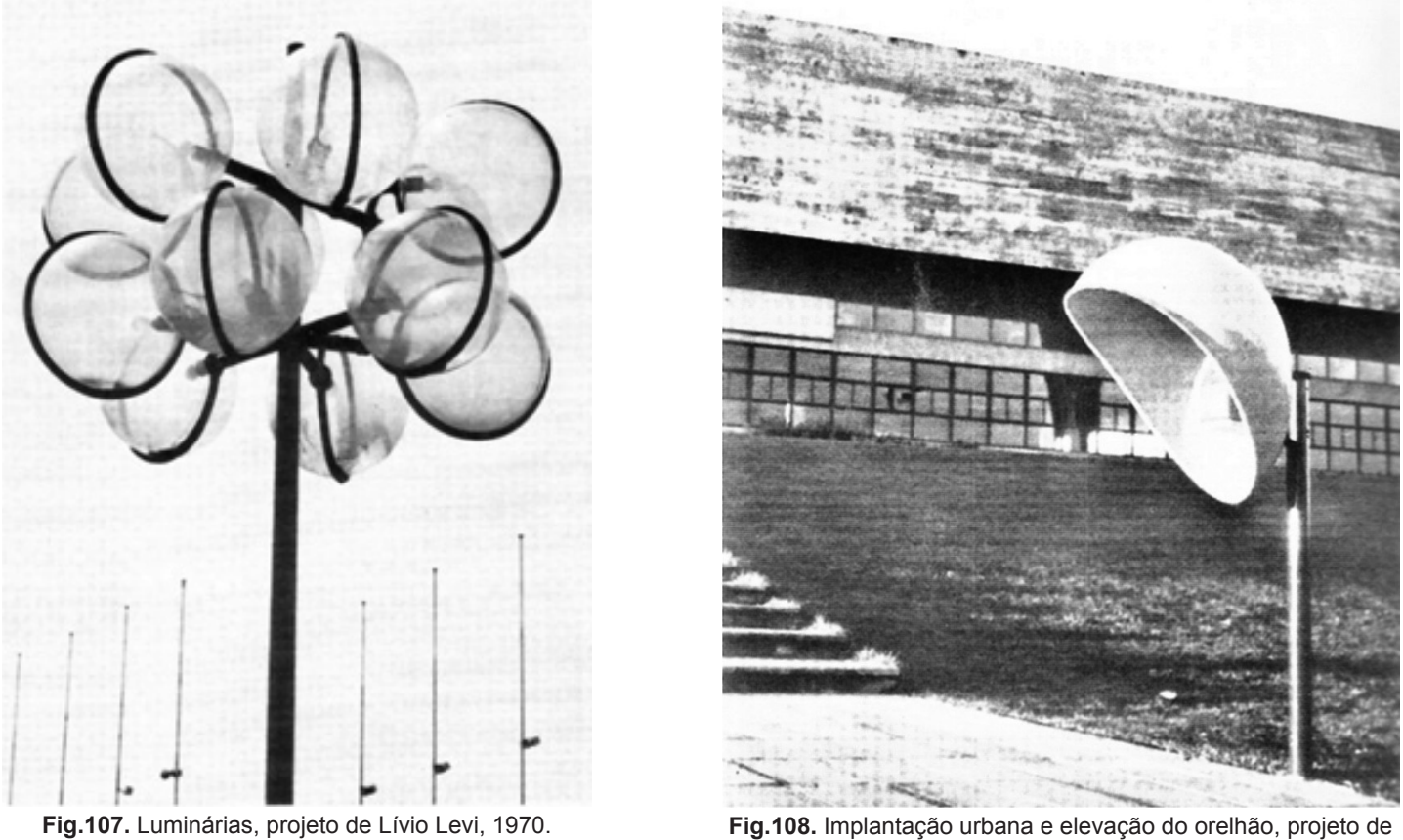

Fig.108. Implantação urbana e elevação do orelhão, projeto de Chu Ming Silveira, 1970

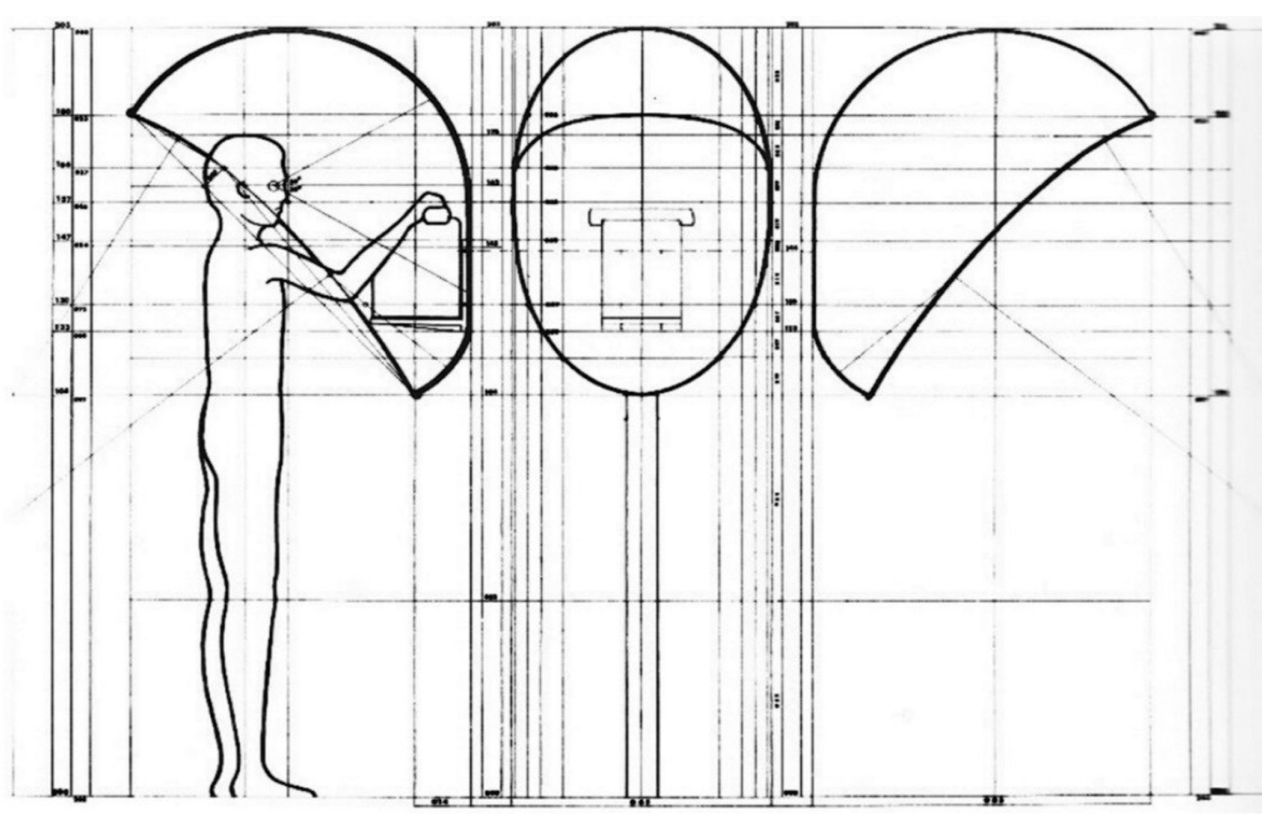

Fig.109. Implantação urbana e elevação do orelhão, projeto de Chu Ming Silveira, 1970. 


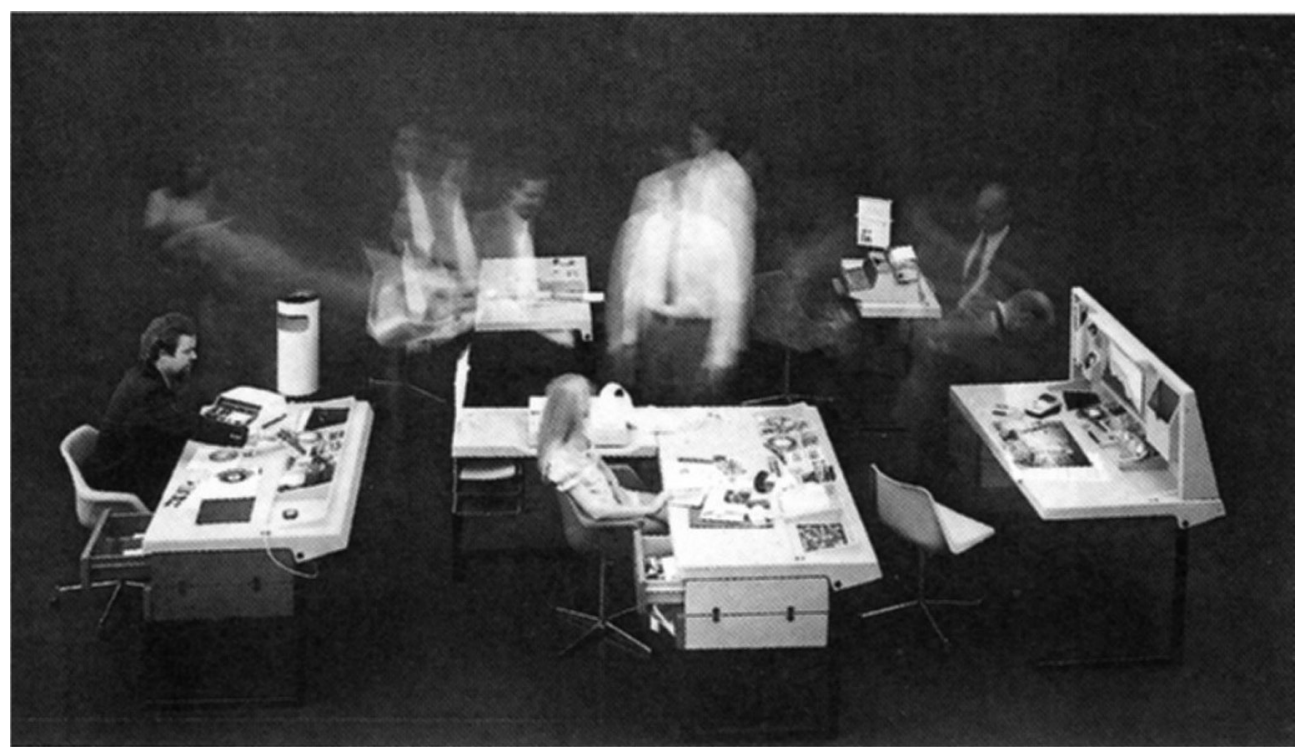

Fig.110. Móveis para escritório, projeto de Jorge Zalszupin e Marcelo Resende.

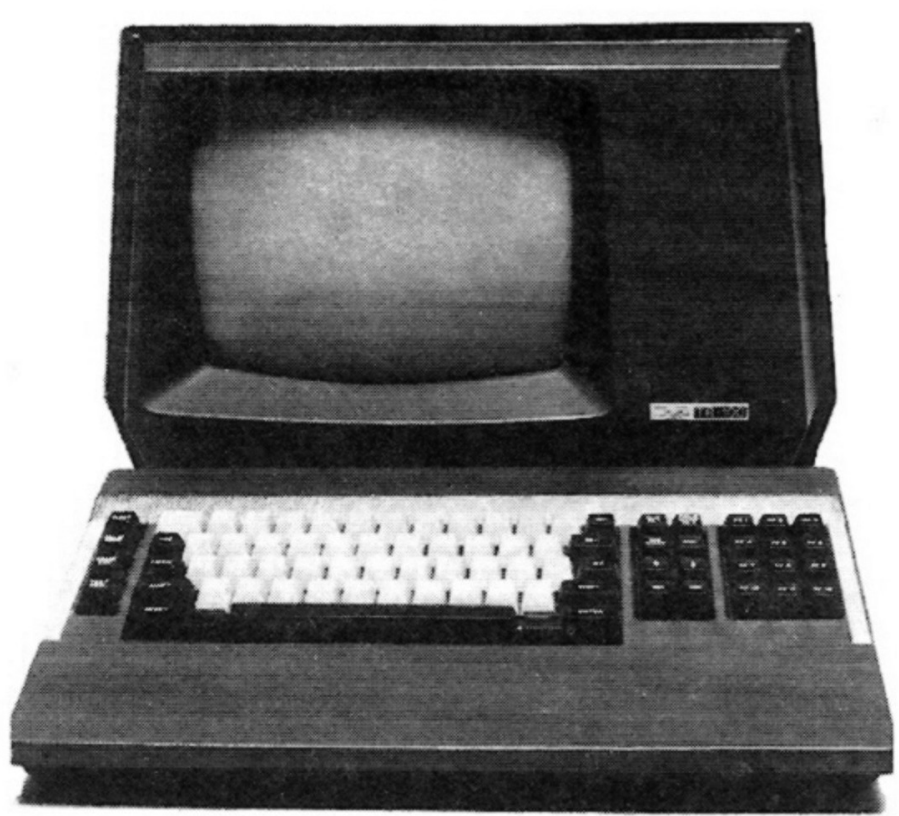

Fig.111. Minicomputador Cobra, terminais remotos, projetista desconhecido 


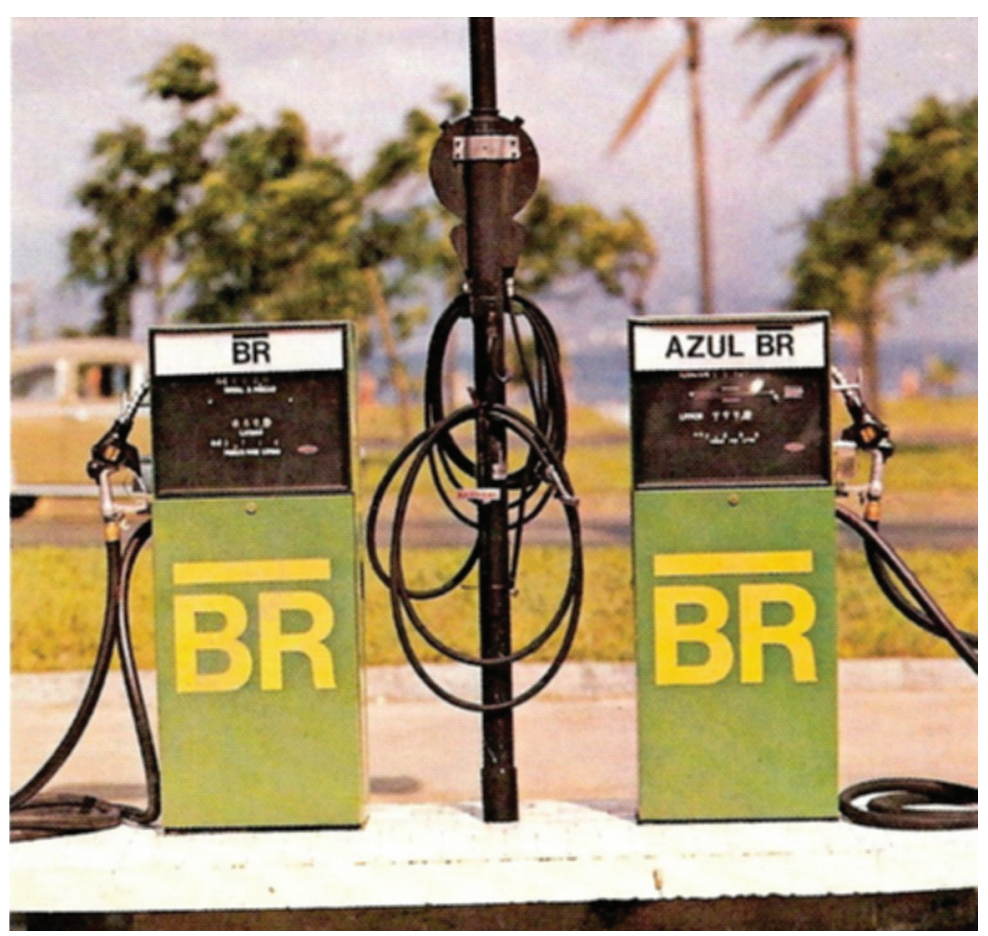

Figg.112. Bomba da Petrobrás, projeto de Aloísio Magalhães.

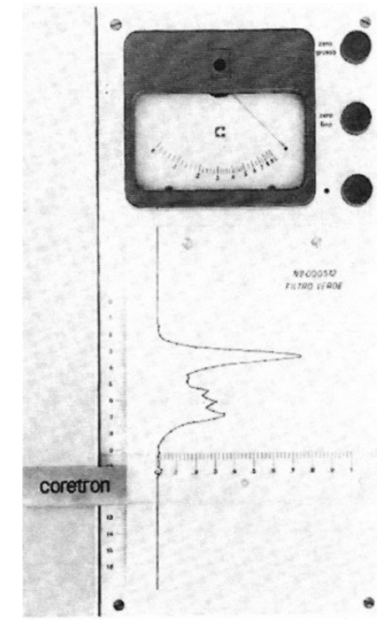

Fig.113. Aparelho de precisão para uso médico, Coretron, projeto de Bergmiller.

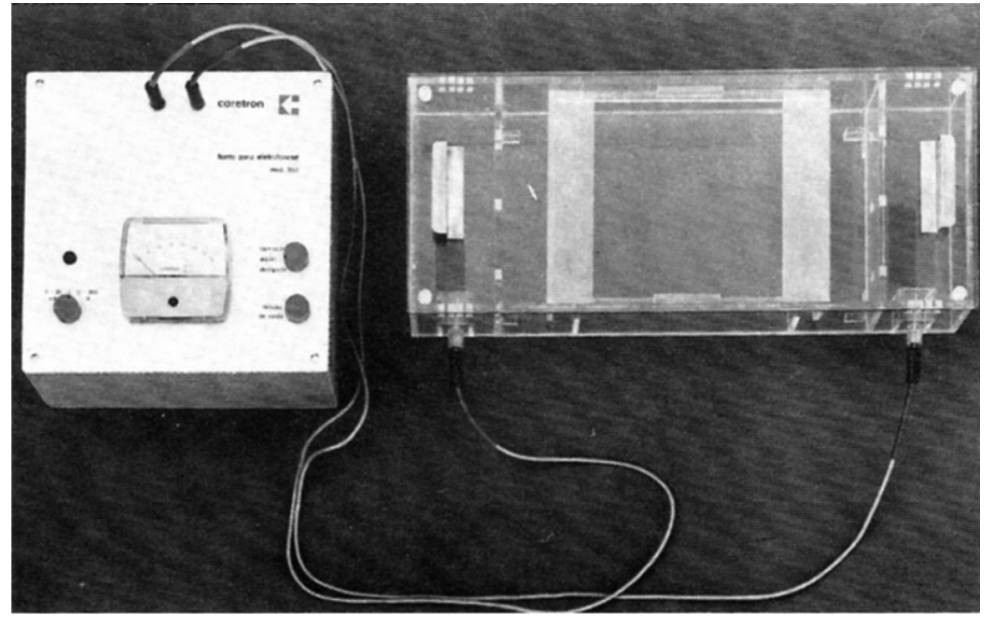

Fig.114. Aparelho de precisão para uso médico, Coretron, projeto de Bergmiller. 
23. Para detalhes dessa discussão da construção de identidade nacional do móvel moderno brasileiro ver: SANTOS, Maria Cecília Loschiavo dos. (1995).
Essa intenção de se produzir uma arte moderna aliada à construção de um projeto de identidade nacional é algo que perpassa os artistas modernistas da Semana de 1922, os arquitetos teóricos e/ou práticos de nossa arquitetura moderna e a produção de um possível desenho industrial ligado à nossa arquitetura, seja os componentes do edifício, seja o mobiliário de interiores. Com exceção da produção de Warchavchik, os demais exemplos de que Katinsky se vale para configurar a produção de um mobiliário nacional moderno, em seu texto sobre desenho industrial para o livro de Zanini, têm uma intenção manifesta de contribuírem para a construção da identidade nacional, recuperando valores do passado ${ }^{23}$.

No âmbito dessa discussão entre desenhistas industriais e os industriais acima apontados, se cristalizou um discurso que de um lado coloca os arquitetos ou desenhistas industriais como aqueles que produziram o móvel adequado no que diz respeito a novos padrões estéticos, de conforto, e condizentes com novas demandas da sociedade urbana e industrial, sem abrir mão de um vínculo com a identidade cultural. No outro polo se coloca a indústria, muitas vezes explicada como a vilã que não olha para os produtos nacionais, preferindo o retorno econômico rápido de uma produção baseada no transplante e, quando muito de adequação, de modelos estrangeiros ao país, ou seja, a ideia da cópia contra a da criação.

O ponto de vista desses arquitetos reforça a visão dos desenhistas industriais que não abrem mão do entendimento de seu trabalho enquanto expressão artística, sendo assim limitados a uma produção em escala 
24. Depoimento ao autor em 05 de março de 2009. artesanal. Por que agindo a partir desse ponto de vista, como artistas, não conseguem se integrar aos quadros de profissionais da indústria. O próprio arquiteto Julio Katinsky lamenta tal condição, ao comentar sua produção de móveis entre 1958 e 1959, dentro do escritório de Jorge Zalszupin:

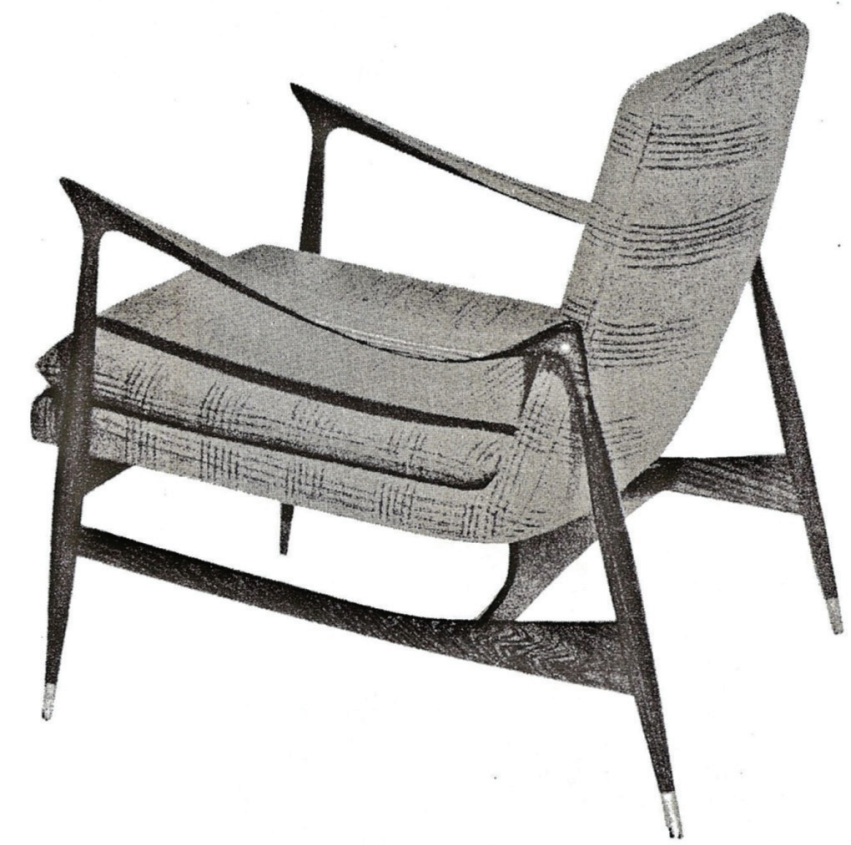

Fig.115. Jorge Zalszupin [Móveis de l'Atelier]. Poltrona com estrutura de madeira jacarandá e acabamentos de latão. Assento e encosto de borracha esponjosa. Revestimento com tecido de lã [legenda do artigo]. [Fonte: Revista Acrópole, $n^{\circ}$ 265, 1960].

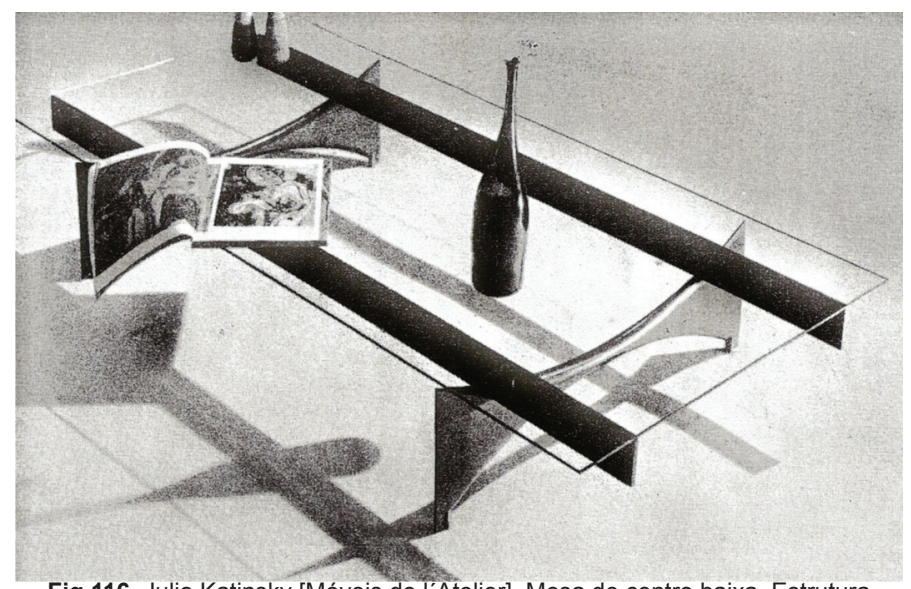

Fig.116. Julio Katinsky [Móveis de TAtelier]. Mesa de centro baixa. Estrutura desmontável de jacarandá e tampo de cristal [legenda do artigo]. [Fonte: Revista Acrópole, $\left.\mathrm{n}^{\circ} 265,1960\right]$. 

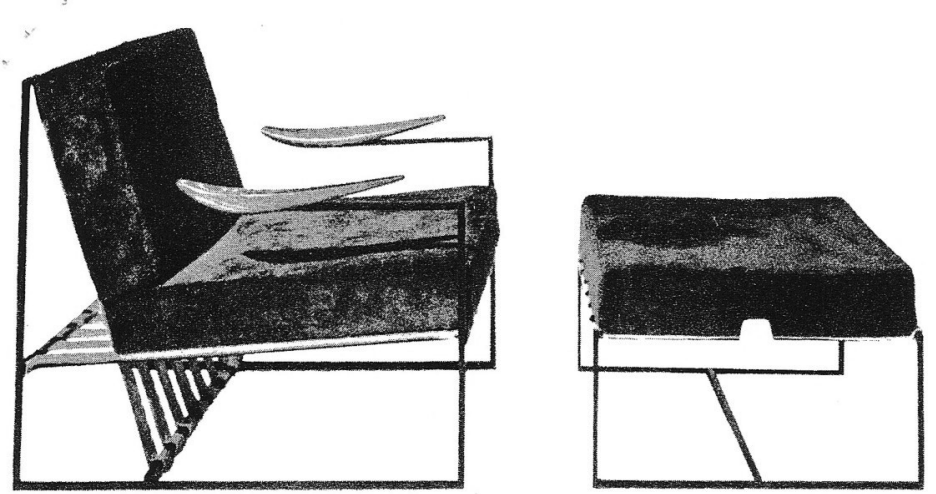

Fig.117. Julio Katinsky [Móveis de l'Atelier]. Mesa de centro baixa. Estrutura desmontável de jacarandá e tampo de cristal [legenda do artigo]. [Fonte: Revista Acrópole, $\mathrm{n}^{\circ} 265$, 1960].

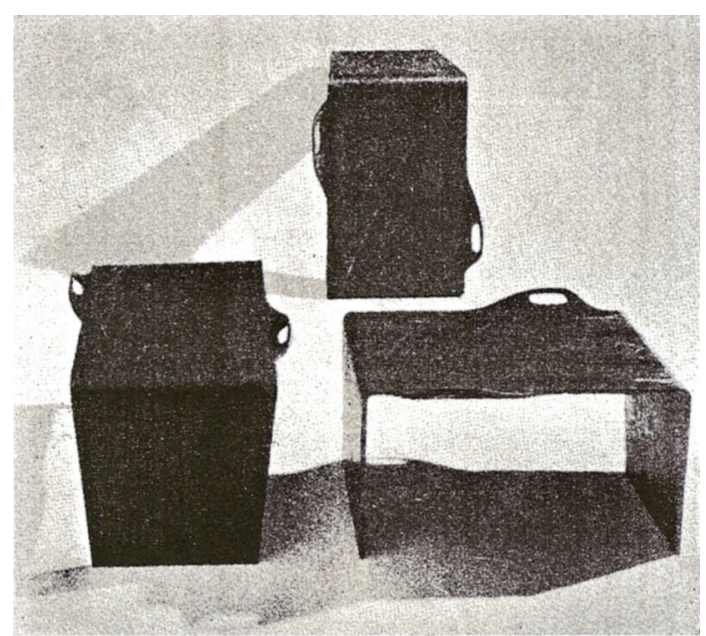

Fig.118. Jorge Zalszupin [Móveis de l'Atelier]. Três mesinhas auxiliares, entrando uma dentro da outra. Executadas com sistemas de madeira moldada. Os pegadores facilitam o manejo [legenda do artigo]. [Fonte: Revista Acrópole, $n^{\circ} 265$ 1960].
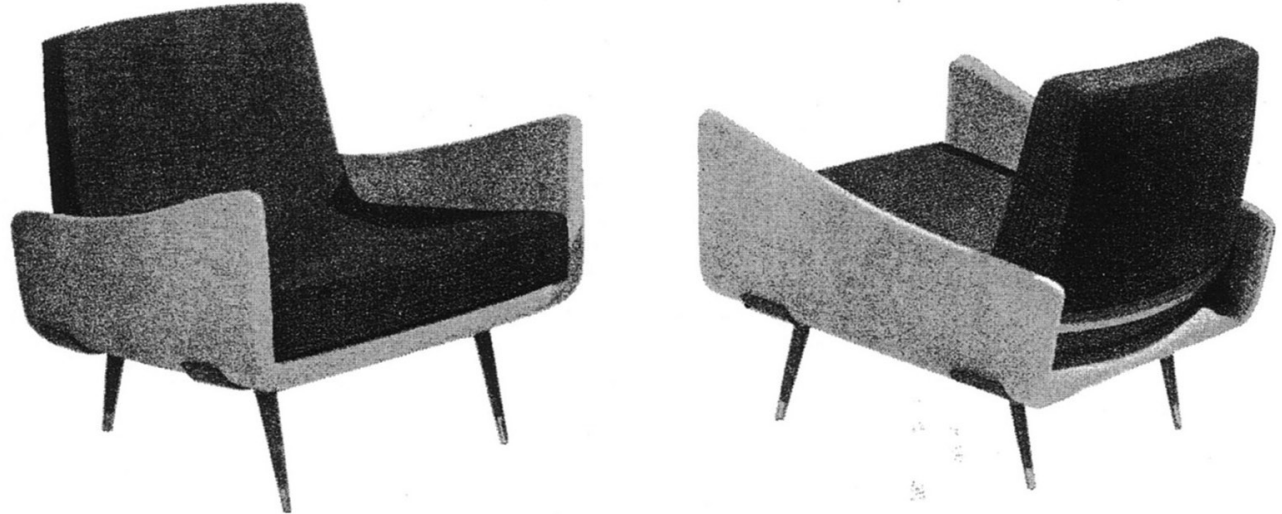

Fig.119. Jorge Zalszupin [Móveis de l'Atelier]. Poltrona estofada com estrutura baixa de jacarandá e corpo de borracha esponjosa. Revestimento com tecido de lã. [legenda do artigo]. [Fonte: Revista Acrópole, $\left.n^{\circ} 265,1960\right]$. 


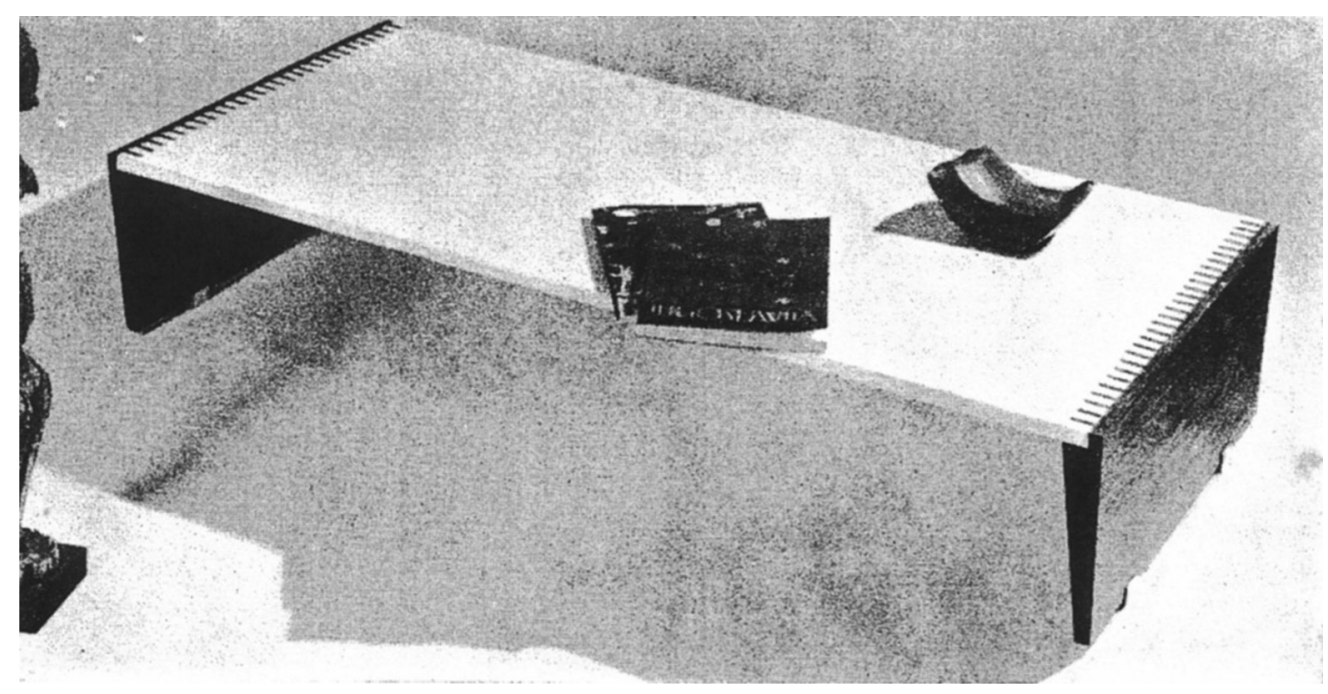

Fig.120. Jorge Zalszupin [Móveis de l'Atelier]. Mesa de Centro, combinando numa junção de tipo malhetada dois materiais diferentes: jacarandá da Bahia e mármore. Pontas de apoio de latão [legenda do artigo]. [Fonte: Revista Acrópole, $\left.n^{\circ} 265,1960\right]$.

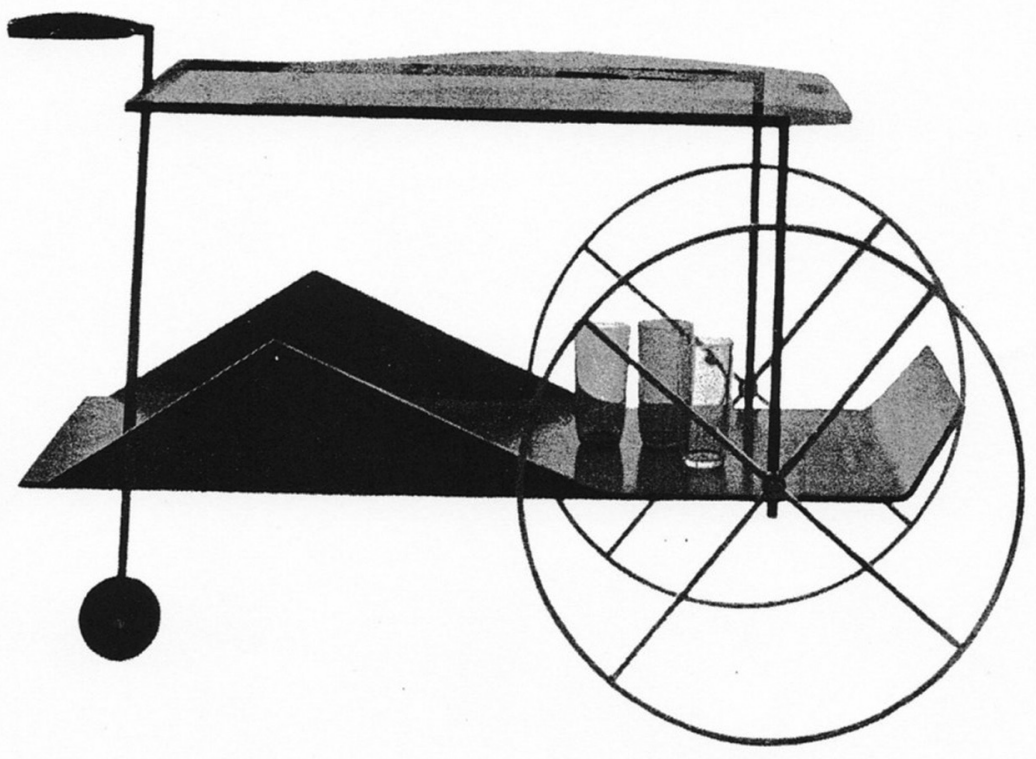

Fig.121. Jorge Zalszupin [Móveis de l'Atelier]. Carrinho de chá: estrutura de ferro pintada a duco, rodas de latão polido. Bandeja superior removível e dupla face: de um lado fórmica lisa, de outro com pequenos rebaixos que servem para colocar caju, chocolate, etc. a roda giratória torna o móvel muito manejável [legenda do artigo]. [Fonte: Revista Acrópole, n 265,1960$].$ 


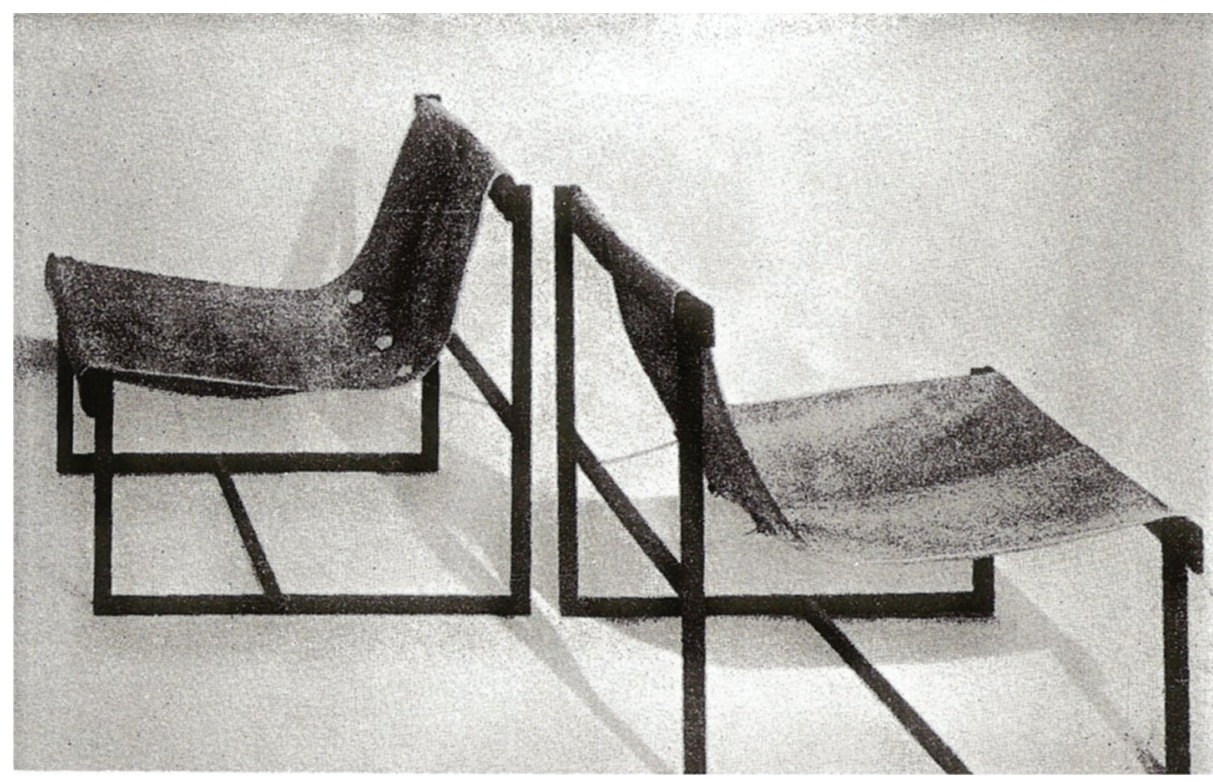

Fig.122. Jorge Zalszupin [Móveis de l'Atelier]. Mesa moldada de madeira com furo no tampo para receber um porta-revista de metal ou madeira, de cor contrastante [legenda do artigo]. [Fonte: Revista Acrópole, $n^{\circ} 265$, 1960].

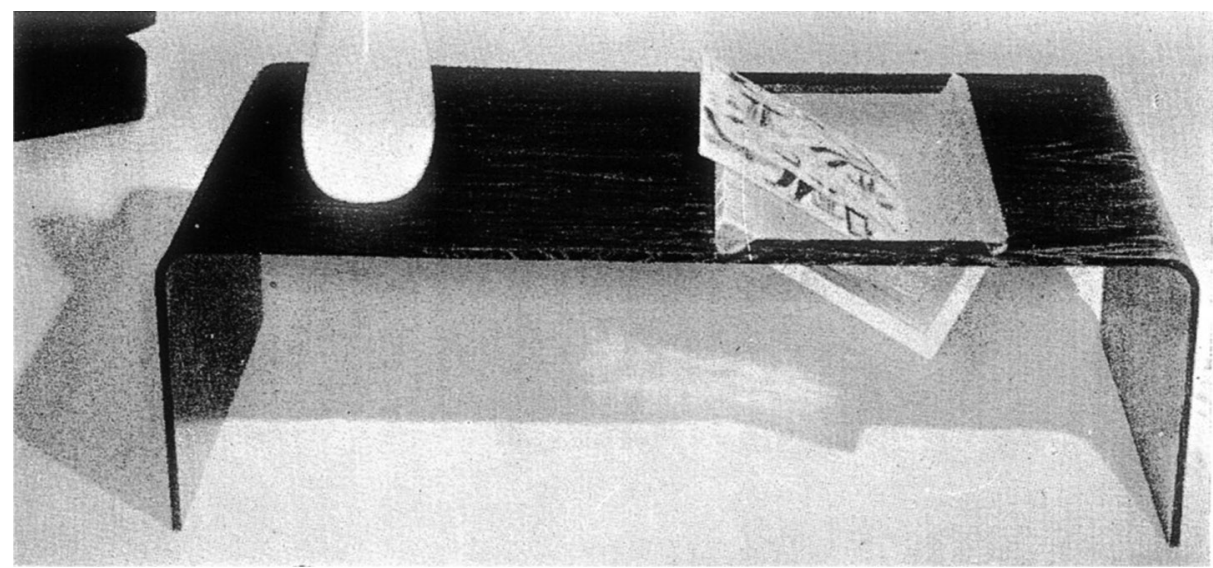

Fig.123. Julio Katinsky [Móveis de l'Atelier]. Poltrona para ambiente de bar, jardim de inverno, terraço, etc. Estrutura metálica em travessas de jacarandá. Os botões de latão polido formam as pontas dos esticadores [legenda do artigo]. [Fonte: Revista Acrópole, $\left.n^{\circ} 265,1960\right]$. 


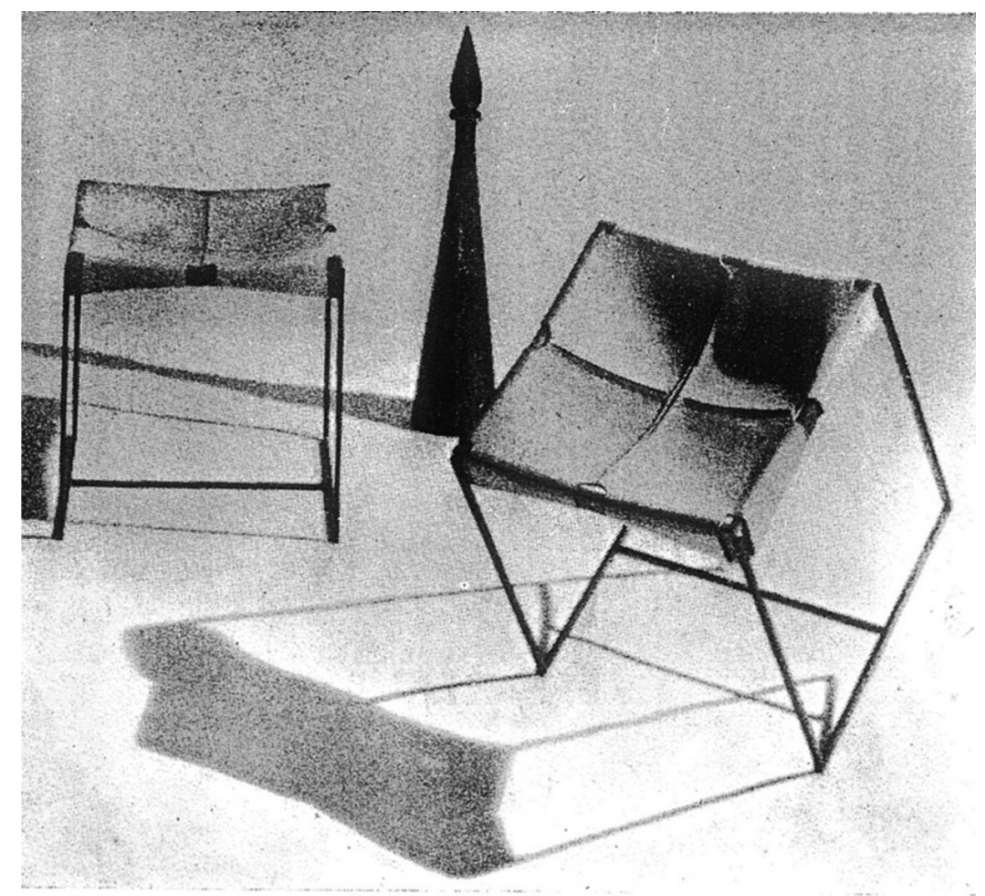

Fig.124. Julio Katinsky [Móveis de l'Atelier]. Banquinho leve de estrutura de ferro pintada a duco e quadro de jacarandá com acento de couro natural costurado com linha grossa [legenda do artigo]. [Fonte: Revista Acrópole, $\mathrm{n}^{\circ}$ 265, 1960].

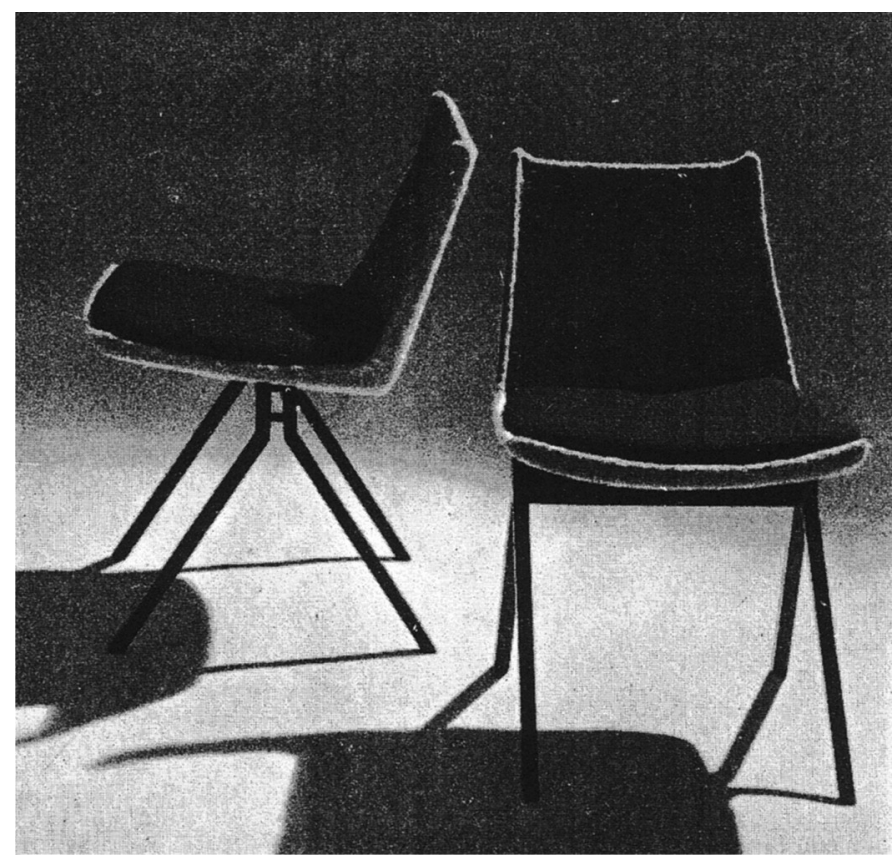

Fig.125. Jorge Zalszupin [Móveis de l'Atelier]. Cadeira para sala de jantar. Concha de plástico armada com fibra de vidro, revestida com tecido de lã. Pés de jacarandá e ferro permitindo variar a inclinação da concha. Uma almofada solta no acento [legenda do artigo]. [Fonte: Revista Acrópole, n² 265, 1960]. 


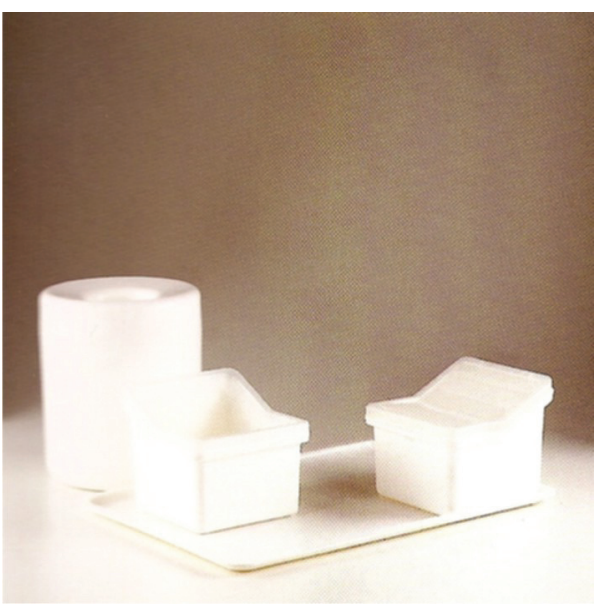

Fig.126. Alessandro Ventura. Objetos de Pia de Cozinha. s/d. [Fonte: LEAL, 2002.]

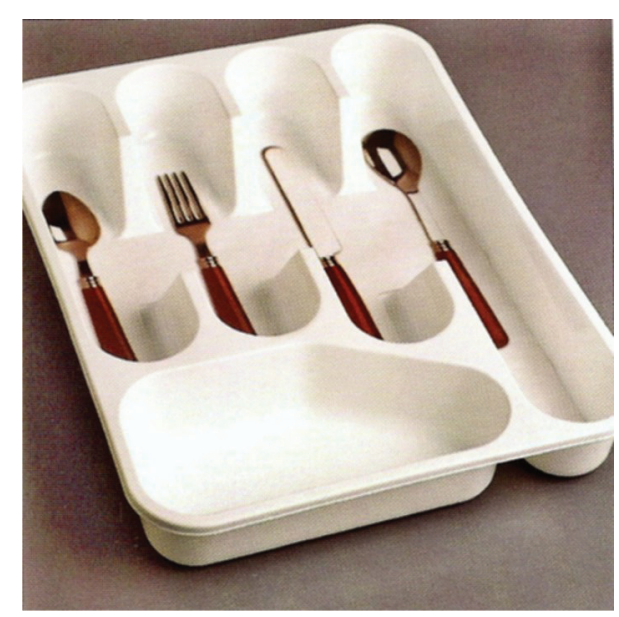

Fig.127. Alessandro Ventura. Porta Talheres Split, Tok\&Stok. s/d. [Fonte: LEAL, 2002.]

25. Depoimento ao autor em 19 de fevereiro de 2009
Não tão confiante no mesmo caminho desse grupo de arquitetos ou desenhistas industriais, no mesmo período Alessandro Ventura, arquiteto e professor do Departamento de Projeto da FAU USP em disciplinas da Sequencia de Desenho Industrial, apostava em outro caminho. Assim como ele, alguns outros professores desta área de projeto da FAU USP irão postular outro viés para o ensino e prática do desenho industrial. Esse caminho era o de uma ação não de fora para dentro da indústria, mas ao contrário: de dentro da própria indústria, integrando-se a ela em seus quadros técnicos. Nesse ponto, Alessandro Ventura e outros professores da Sequencia de Desenho Industrial da FAU USP, ao conceituarem assim as suas ações profissionais, estão se aproximando do modelo da HfG de Ulm, e, por consequência, da ESDI. Ventura estabelece seu ponto de vista sobre o desenho industrial ao comentar a sua trajetória profissional:

(...) Eu tive durante quinze anos escritório de desenho industrial, eu nunca fiz mobiliário, não é que eu não fiz porque eu não tive oportunidade, eu não quis, eu não quis trabalhar com madeira, eu quis trabalhar com técnicas mais sofisticadas, e a madeira, apesar de ser um material nobre, ela tem uma limitação tecnológica, (...) eu queria ter uma participação mais importante junto à indústria, eu achei que a indústria da madeira é uma indústria importante, sim, mas ela não significa avanço, eu queria avançar, com tecnologias novas, são opções estratégicas que você faz, é a tua visão. ${ }^{25}$

O professor Alessandro Ventura que trabalhou como desenhista industrial dentro da indústria, 


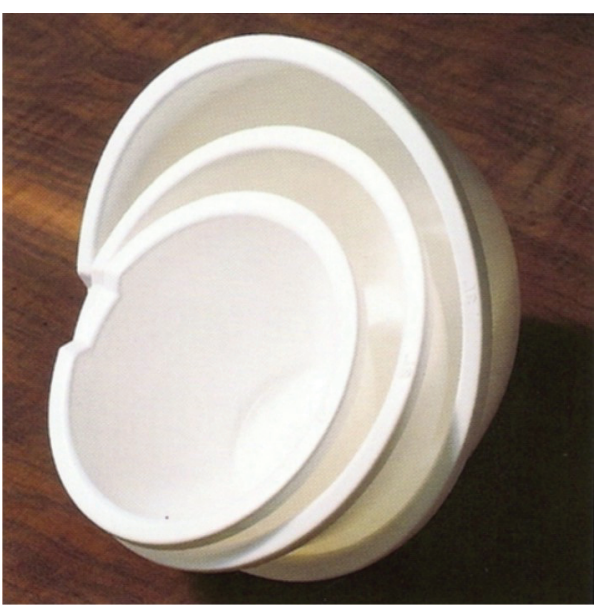

Fig.128. Alessandro Ventura. Conjunto de Tigelas Línea, Tok\&Stok. s/d. [Fonte: LEAL, 2002.]

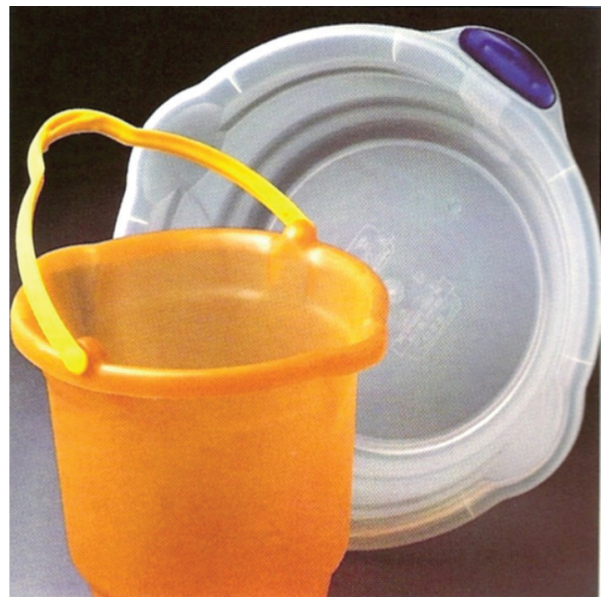

Fig.129. Alessandro Ventura. Balde e Bacia de Plástico, Hydrus, Tok\&Stok. s/d. [fonte: LEAL, 2002.]

26. Depoimento ao autor em 19 de fevereiro de 2009. tendo sido ele próprio por um tempo dono de indústria, entretanto inicia sua carreira trabalhando com projetos de edifícios de arquitetura e, como ele afirma em depoimento, trabalhou logo depois de formado no escritório de Artigas. O depoimento de Ventura talvez seja a melhor caracterização desta hesitação entre permanecer à margem ou se colocar dentro da indústria e perder o status de artista. Ele comenta que quando já estava trabalhando dentro da indústria, a respeito de suas atividades profissionais, em uma ocasião:

(...) eu me lembro que uma vez, em contato com o Artigas (...), eu passei a me dedicar à indústria, e ele me disse: poxa, eu nunca pensei que fôssemos chegar a este ponto, de ver alguém trabalhando na indústria! Porque a visão dele era outra, ele ficou surpreso em ter um profissional, um arquiteto, voltado para os problemas industriais. Ele não achou que fosse fazer isso, muito provavelmente achou que fosse ser outra coisa, mas ele achou surpreendente ter chegado a este ponto, quer dizer, tão longe, acho que o alcance que ele previa era mais curto. ${ }^{26}$

Ainda Alessandro Ventura, ao ser questionado sobre o ponto de vista do crítico italiano Giulio Carlo Argan (1993), que define o arquiteto moderno como aquele profissional capaz de projetar da colher à cidade e sobre a viabilidade desse modelo dentro da FAU USP, na medida em que seu Departamento de Projeto, após a Reforma de 1962, visava a capacitar seus alunos a se projetarem nos campos do desenho industrial, programação visual, edificações e urbanismo, assim se expressaria: 
27. Depoimento ao autor em 19 de fevereiro de 2009.
Quando você desenha a colher, nem sempre você está envolvido com a indústria, você pode estar vendendo a colher, se você quiser, mas com a visão cultural do que é a colher e não com a visão estratégica do que é a indústria. Essa é a diferença. (...) Eu acho que aqui (na FAU USP) o pessoal vê de uma forma mais livre, do ponto de vista cultural da discussão: A colher é importante para os pobres, então nós temos que fazer isso assim, assim... Sem se preocupar quem é que fabrica isso, qual é o custo disso, qual é o estado da arte para fabricar isso, é importante, não é importante... ${ }^{27}$
Com relação a este ponto de vista, ao ser questionado por García (2001, p.162) sobre a existência no Brasil de dois modelos de ensino de projeto e de desenho industrial, um deles ligado à tradição italiana em que os designers são todos arquitetos e, outro, ligado a uma visão alemã, em que designers têm formação de designers, assim o designer visual Alexandre Wollner se posicionaria:
28. Alexandre Wollner em entrevista a García (2001, p.162). Wollner, que estudou em Ulm, foi um dos professores fundadores da ESDI e, em certa medida, um tanto cético quanto a esta visão de desenho industrial como atribuição do arquiteto, sobretudo na forma como é caracterizado pelo Departamento de História da FAU USP.
É claro que seja arquiteto, por que lá na Itália a tendência ao artesanato é muito grande, e o arquiteto tem uma tradição artesanal, gostar das coisas artísticas, etc., que nem as escolas de arquitetura brasileiras em geral (...). ${ }^{28}$

Esses depoimentos de Alessandro Ventura e de Alexandre Wollner em muito contribuem no sentido de delimitar ainda mais a fronteira entre o pensamento de alguns arquitetos da FAU USP, sobretudo do seu Departamento de História, e o ponto de vista que balizou a ESDI em seu entendimento sobre o ensino e a prática do desenho industrial, considerando sua filiação direta desta segunda Escola ao modelo definido pela HfG Ulm.

E o discurso desses professores do Departamento de História da FAU USP, sintetizado nos escritos de Katinsky, 
29. Depoimento ao autor em 05 de março de 2009. em sua caracterização do Desenho Industrial, não deixaria de lado a própria análise que a HfG de Ulm faz da arquitetura, quando esta Escola faz a defesa da total industrialização da mesma. Com certa ironia, assim Katinsky descreve a situação:

\footnotetext{
Uma das coisas que mais se falava era que a Arquitetura ia acabar, porque as pessoas iam poder fazer as suas casas como (brinquedo de montar) lego: pegar pedaços de coisas produzidas e cada um ia ser arquiteto de si mesmo. Até agora não aconteceu isso, mas era uma ideia de que o futuro da Arquitetura seria esse. Aconteceu exatamente o contrário. Aconteceu que hoje tem mais arquitetos no mundo do que no tempo em que eu era estudante, inclusive em São Paulo. ${ }^{29}$
}

O desabafo de Katinsky de uma redução da prática da arquitetura a peças de montar como um brinquedo lego de fato tem mesmo conexão com um dos grandes objetivos da HfG Ulm, como citado no capítulo em que abordamos esta Escola, e que era de transformar a arquitetura em desenho industrial. $O$ que pode ser confirmado se for considerado que, no Departamento de Arquitetura da HfG Ulm, por uma questão de procura de uma nova definição para a prática arquitetônica, se opta pela expressão Edificações Industrializadas, ao invés da tradicional expressão arquitetura e também que as discussões desse Departamento eram muito próximas das realizadas pelo Departamento de Design. A diferença está apenas em se considerar não que a HfG de Ulm transforme a arquitetura em algo que qualquer pessoa possa realizar, como afirma Julio Katinsky, desconsiderando a relevância social do profissional arquiteto. O que a Escola de Ulm preconiza é uma ressignificação do profissional, agora enquadrado como um técnico da indústria.

$\mathrm{O}$ arquiteto Katinsky, com uma atuação na área de ensino 
e pesquisa, realização de projetos que se estendem da área do mobiliário ao edifício e à escala de transformação da paisagem, coloca outro ponto de vista sobre a produção da arquitetura e a redução desta a um objetotipo reproduzido ao infinito. Ele adverte que o significado do desenho industrial não é apenas o de reproduzir um mesmo objeto, seja em qualquer escala, em infinitas vezes. Para Katinsky um objeto único, produzido uma única vez, à semelhança das catedrais medievais, também pode ser considerado fruto do desenho industrial. Navios, aviões, submarinos, naves e estações de exploração espacial são, cada um deles, produzidos não aos pares, mas como peças únicas, mas cuja existência se tornaria impossível, acaso não pudesse contar com os componentes industriais. Assim Julio Katinsky se reporta à situação:

(...) a própria ESDI sempre classificou como um produto em série (o desenho industrial), como eles diziam. Desenho Industrial é o graneleiro de 120.000 toneladas, que é um barco feito por encomenda. Eu até gozava, porque o avião 737, o Boeing, que é o avião mais difundido no mundo, tem um igual ao outro (risos)? O fuso é igual, mas você entra dentro e é tudo diferente, porque no meio do caminho o banco muda, o puxador muda, aquele depósito de mala muda, vai mudando tudo, e as grandes obras de engenharia são tudo produto da indústria moderna, mas nenhuma delas é igual à outra. 0 Boeing é feito por encomenda, ninguém é louco de fazer um avião em série. Meu Deus, você vai fazer o que? Os americanos caíram nessa besteira, quando eles fizeram o módulo lunar. Eles fizeram 14, usaram 2. O resto serviu para que fizessem exposição no mundo. Nunca foram usados, eu vi um módulo lunar, nunca usado, numa exposição em Londres. Eu acho uma estupidez, não precisa. Módulo lunar, pô! Faz um.

Agora é instigante esta visão de Katinsky. Primeiro por que em nada ela pode ser considerada uma nota isolada e se realizando apenas num plano teórico. Se for considerada a produção de arquitetos formados ou professores da FAU 
30. Esta foi uma questão em torno da qual se estabeleceu boa parte da discussão da banca de qualificação deste doutorado.
31. Módulo-medida e Móduloobjeto in ARGAN ( 2000, p.96)
USP, o que predomina é esta mesma visão entre aqueles que se dedicaram à prática da prancheta. Pouquíssimos foram os arquitetos que de fato desenvolveram trajetórias profissionais exclusivamente dentro da indústria ${ }^{30}$. Em segundo lugar, por que esta visão parece fazer a manutenção do ideal do arquiteto como artista, a despeito do técnico. As técnicas e os materiais mudaram, mas há uma defesa de que a forma de agir profissional do arquiteto seja mantida inalterada. Argan, na coletânea Projeto e Destino, constrói uma imagem ilustrativa deste paradigma de ação profissional:

\footnotetext{
Quando contemplamos um simplíssimo muro de tijolos, devemos logo reconhecer que ele possui determinadas qualidades formais, resultantes da malha ou do retículo da alvenaria, isto, é, da dimensão, da forma e da combinação dos elementos. É inútil perguntar se um muro de tijolos pode ser ou não uma obra de arte: pode ser uma obra de arte, pode ser o mais banal dos artefatos. Mas, em todo caso, existe uma diferença estrutural entre as alvenarias dos vários períodos históricos ou das várias civilizações, e a diferença não depende de um grau diverso de progresso da técnica de alvenaria, mas da diversa concepção da forma arquitetônica. É claro, portanto que o tijolo não é matéria bruta, mas é já um valor de forma: empregando os tijolos que Ihe chegavam, fabricados em série pela olaria, o arquiteto assumiu, como matéria de sua construção, tipos elaborados através de uma longa experiência construtiva. E a sua própria obra contribuirá, de algum modo, para desenvolver ou modificar aquele tipo formal. ${ }^{31}$
}

Essa conceituação de Katinsky, certamente compartilhada por outros arquitetos projetistas da FAU USP, se assemelha em muito ao paradigma descrito por Argan, ao afirmar que a diferença não depende de um grau diverso de progresso da técnica de alvenaria, mas da diversa concepção da forma arquitetônica. E, no caso em questão, seria possível substituir os termos o progresso da técnica de alvenaria 
32. Em coautoria com os arquitetos Helio Penteado e Hélio Pasta. Construída no rio Paranapanema, que faz divisa geográfica entre os estados de São Paulo e do Paraná. pelo progresso da técnica industrial, e encontraríamos exatamente o mesmo discurso desses professores da FAU USP, capitaneados por Katinsky. É esta construção intelectual, por outro lado, que permite ao arquiteto do Departamento de História da Escola enquadrar o seu projeto que realizou em 1968, da Usina Hidrelétrica de Xavantes $^{32}$ como melhor exemplo de desenho industrial do que a própria linha de mobiliário projetada e produzida com Jorge Zalszupin entre 1958 e 1959. Assim ele analisa esta sua experiência de projeto:
33. Depoimento ao autor em 05 de março de 2009.
Por exemplo, eu fiz a arquitetura de uma usina (...) a Xavantes. Era uma das maiores usinas na época. E houve uma concorrência internacional para produzir um gerador. E esse gerador é enorme, tem 5 metros de diâmetro. Nunca ninguém tinha feito um gerador desse tamanho, o rotor. (...) Também os 4 rotores de Xavantes foram feitos especialmente, só que milhares de peças que entram nesses rotores foram feitas em série, claro. Você para entrar num navio de vela, você tem o mesmo interruptor que você tem na sua casa. Esse problema, infelizmente, está carregado de falsas, vamos dizer assim, proposições. Diante de todo problema do Desenho Industrial, devido a esse problema de luta de mercado, etc., é muito difícil de distinguir o que é avanço real e o que não passa de propaganda fraudulenta. ${ }^{33}$

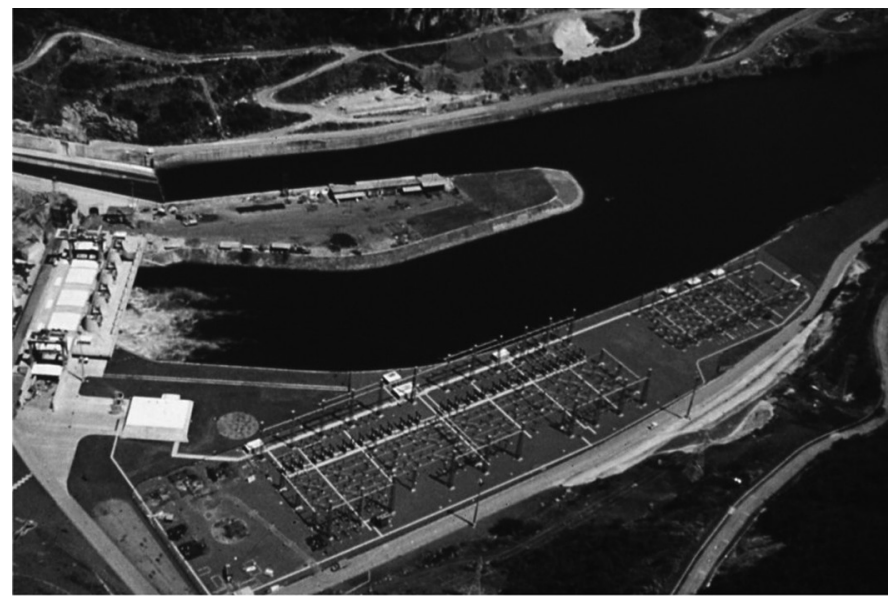

Fig.130. Julio Katinsky, Helio Penteado e Hélio Pasta. Usina Hidrelétrica de Xavantes. Rio Paranapanema [divisa geográfica entre os estados de São Paulo e do Paraná], 1968 [Fonte: arquivo Julio Katinsky]. 


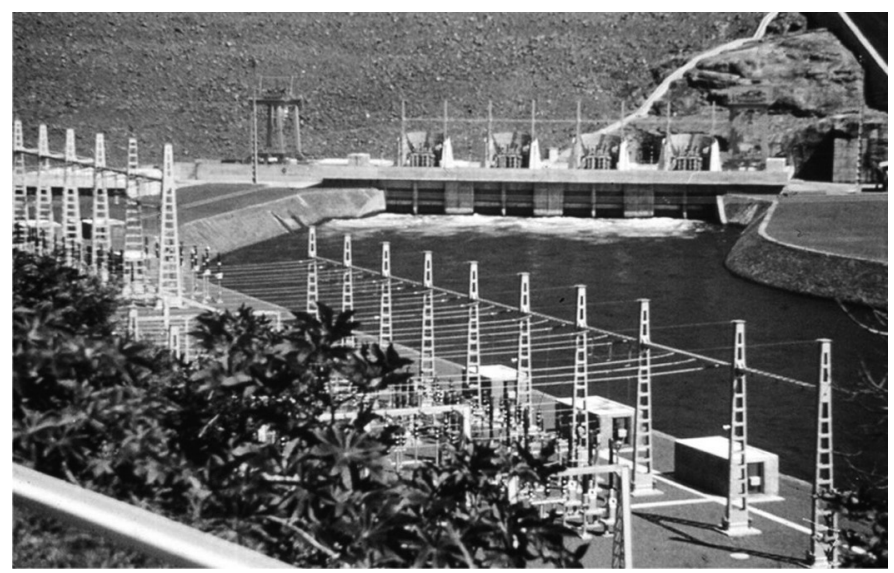

Fig.131. Julio Katinsky, Helio Penteado e Hélio Pasta. Usina Hidrelétrica de Xavantes. Rio Paranapanema [divisa geográfica entre os estados de São Paulo e do Paraná], 1968 [Fonte: arquivo Julio Katinsky].

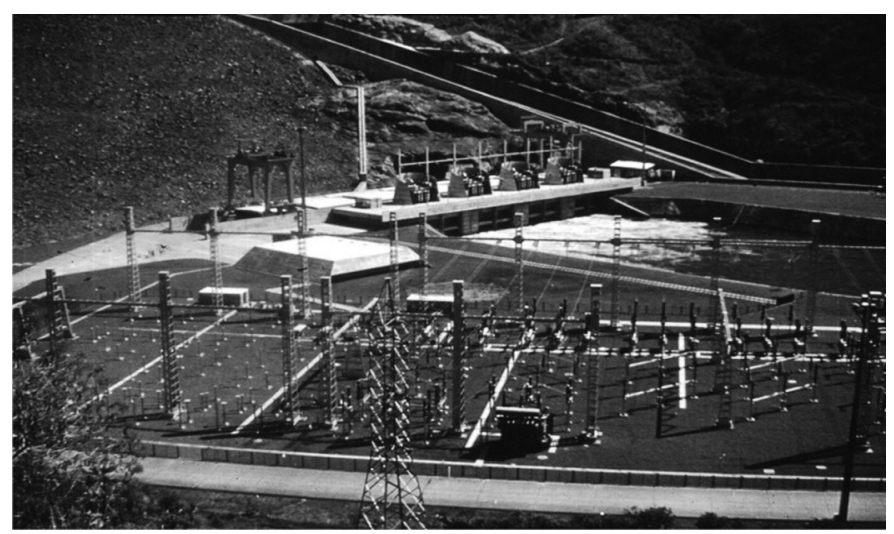

Fig.132. Julio Katinsky, Helio Penteado e Hélio Pasta. Usina Hidrelétrica de Xavantes. Rio Paranapanema [divisa geográfica entre os estados de São Paulo e do Paraná], 1968 [Fonte: arquivo Julio Katinsky].

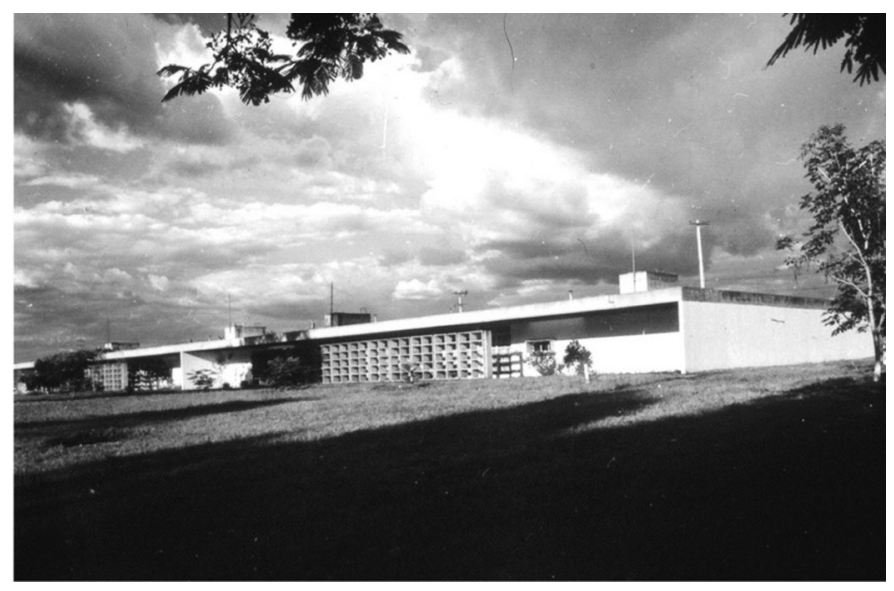

Fig.133. Julio Katinsky, Helio Penteado e Hélio Pasta. Usina Hidrelétrica de Xavantes. Rio Paranapanema [divisa geográfica entre os estados de São Paulo e do Paraná], 1968 [Fonte: arquivo Julio Katinsky]. 
Na elaboração de todo esse discurso, há uma sutil, mas decisiva diferença entre o postulado da HfG de Ulm e o ideal defendido por Katinsky. Na Escola de Ulm, o arquiteto perde esse seu status de artista construído pela tradição do ofício, e é rebatizado como um técnico que atua dentro de um setor da indústria, que é especificamente de edificações industrializadas. Para Katinsky, não. O arquiteto estaria muito mais próximo do paradigma de Argan, segundo o exemplo da parede de alvenaria, de que o arquiteto opera com elementos que lhe chegam prontos a priori, os tijolos, e que dentro desta atuação é que contribui para modificálo. Para Katinsky, o arquiteto opera com os equipamentos, materiais e técnicas industriais, mas como arquiteto num sentido clássico de definição da profissão. É um ponto de vista inclusive que o tempo se encarregou de comprovar a tese, no entendimento de Katinsky:

34. Depoimento ao autor em 05 de março de 2009.

\begin{abstract}
Uma das coisas que mais se falava era que a Arquitetura iria acabar (...). Até agora não aconteceu isso. (...) Aconteceu exatamente o contrário. Aconteceu que hoje tem mais arquitetos no mundo do que no tempo em que eu era estudante, inclusive em São Paulo. Tem muito mais arquitetos hoje do que no meu tempo. ${ }^{34}$
\end{abstract}

Mesmo que alguns dos elementos do debate possam ser outros, esta polêmica entre esses dois modelos reacende um pouco as discussões entre Lucio Costa e Max Bill, quando da passagem do designer suíço pelo Brasil em 1953, por ocasião da II Bienal de São Paulo. Nesta situação Max Bill lança, na imprensa nacional, severas críticas à arquitetura moderna brasileira, sobretudo à produção de Niemeyer e ao Ministério da Educação e Saúde do Rio de Janeiro. Conforme destaca Nobre (2008, p.20), Max Bill condenou o edifício-sede do Ministério da Educação pela falta de sentido e proporção humana, o partido 
35. Para maiores detalhes sobre este debate, ver NOBRE (2008). adotado no projeto e os azulejos ditos inúteis (...). Max Bill não deixa de criticar, também, em tom negativo os pilotis de formas barrocas dos projetos de Niemeyer. Sua crítica irá incidir, entre outras questões, nos elementos que Costa afirma como pertencentes à nossa tradição cultural arquitetônica e à construção ideológica do arquiteto carioca de que estes sejam incorporados à nossa arquitetura moderna. O desprezo pela elaborada incorporação de uma tradição à arquitetura moderna brasileira, nos moldes como defende Costa, é o que, por outro lado, fará Max Bill valorizar iniciativas como a Bienal de São Paulo e a revista Habitat, espaços privilegiados de entrada da Arte Concreta no Brasil. As críticas de Max Bill seriam rebatidas na imprensa por Lucio Costa e vários outros arquitetos modernos cariocas e paulistas daquele período. O empenho de Costa nesse sentido busca desautorizar a arte concreta e, em consequência, defender a produção de artistas integrados ao seu projeto de modernização, como é o caso dos pintores Portinari e Di Cavalcanti. ${ }^{35}$

Em consequência dessas diferenças de pontos de vista, ocorrerão também diferentes abordagens do ensino de desenho industrial. Pode-se caracterizar historicamente a defesa de uma vertente ligada à matriz do ensino de Belas Artes, centrada em uma formação artística e, outra, a uma base mais tecnicista, ligada a Ulm. Esses dois polos de disputa se estabeleceram durante o processo de implantação dos cursos de Desenho Industrial tanto da ESDI quanto da FAU USP.

$\mathrm{Na}$ linha esdiana, principalmente, mas não apenas, Alexandre Wollner e Karl Heinz Bergmiller se colocaram na defesa pela adoção da visão da HfG de Ulm. De outro lado, na defesa dessa formação baseada em uma matriz mais artística, estavam Carmem Portinho (diretora da ESDI a partir de 1968), os arquitetos modernos ligados ao MAM RJ (como, por exemplo, Maurício Roberto, que 
foi o primeiro diretor da ESDI até 1964) ou o designer gráfico Aloísio Magalhães. De acordo com o depoimento de Wollner, prevaleceria na ESDI o ponto de vista de seu grupo:

36. Wollner, 2003, p.147.

O projeto pedagógico aprovado da escola foi praticamente uma vitória minha e do Bergmiller, pois conseguimos manter a ideia original do Maldonado, ligeiramente adaptada à realidade de nossa cultura. ${ }^{36}$

Reforçando o exposto acima de uma disputa entre duas possíveis orientações para a futura ESDI, assim Wollner descreve o processo de aprovação de criação da Escola:

Além de Maldonado, a comissão convidou, para dar parecer e recomendações, os ingleses Mischa Black e Robin Darwin, do Royal College of Art de Londres, Jay Doblin, do Pratt Institute, e Joseph Carrero, da Philadelphia Art Scholl. Embora o RCA fosse mais técnico e focado seriamente no ensino do design, também era orientado para artes, como as instituições americanas. Aloísio, que tinha vínculos com Joseph Carrero era favorável ao ensino acadêmico estético de belas artes -, repudiou juntamente com os americanos o programa baseado na HfG. Como Bergmiller e eu mostrássemos firmeza nos conceitos elaborados pela HfG, o programa foi aprovado pela comissão. (Wollner, 2003, pp.147-148)

A opção por esse modelo originário de Ulm implicaria na adoção de um método de ensino introdutório ao curso que abandonaria certos métodos de aprendizagem como desenho de observação, modelo vivo, teoria de sombras e etc. e que estão na base do modelo Belas Artes. 0 ensino do desenho, ou melhor, o curso introdutório, teria outro caráter. Ele se dedicaria a disciplinas com bases mais técnicas e científicas, como o estudo de sistemas 
geométricos, geometria descritiva, análise combinatória, matemática, etc.

No caso da FAU USP, dentro da instituição, este mesmo impasse parece se fazer presente também de maneira clara. Onde de um lado está o grupo de História da Arquitetura, que se empenhou pela descoberta e assimilação de uma tradição no ensino da arquitetura e do desenho industrial e, de outro, alguns professores do Departamento de Projeto, na Sequencia de Desenho Industrial, com uma visão mais próxima de Ulm. E existiam ainda outros que se posicionaram construindo um discurso e uma ação híbrida entre essas duas visões.

Para explicar o primeiro grupo, constituído, sobretudo pelos professores do Departamento de História da Arquitetura, vale aqui mais uma vez retomar o ponto de vista do professor Flávio Motta quanto ao caminho a ser trilhado para a criação de um curso de Desenho Industrial, a partir do Museu de Arte Moderna em 1949:

37. Escola Livre de Artes Plásticas. São Paulo, abril de 1949. (Folheto de propaganda).
Além dos cursos permanentes de Escultura, Pintura e Desenho, que já se acham em funcionamento, a Escola programou uma série de cursos para os alunos que demonstrarem aptidão para as chamadas artes aplicadas: Publicidade, Tecelagem, Fotografia, Cerâmica, Cenografia, Tapeçaria, Mobiliário, etc. ${ }^{37}$

Esta iniciativa do MAM-SP se coloca a poucos anos de antecedência do desenvolvimento do pensamento de Ulm, mas, mesmo após a divulgação deste, como se viu, continuará a orientar o pensamento de boa parte do Departamento de História da FAU USP. Com certeza sofrerá algumas modificações, mas a gênese desta visão, como se vê no texto de Motta, se dá no enquadramento do desenho industrial como uma evolução das artes aplicadas. Na matriz fixada em Ulm, a opção é outra. 0 
surgimento do desenho industrial não carrega tal herança, nasce mesmo como resposta para organização de uma nova produção possibilitada por uma técnica moderna, a indústria.

Por outro lado, como demonstrado no capítulo anterior, as influências do modelo de ensino, estabelecido pela HfG de Ulm dentro da FAU USP, ocorrem principalmente a partir dos professores de projeto ligados à Sequencia de Desenho Industrial. Vários são os esforços no sentido de construir esta aproximação direta ou indireta. E, com certeza, o mais importante de todos eles é a aproximação com Andries van Onck, ex-aluno de Ulm, e a adoção de seu curso de Metadesign dentro do ensino de Desenho Industrial da FAU USP, caracterizando uma metodologia de projeto com bases científicas e técnicas.

Mas enfim, em resumo, o que postula esse grupo de professores do Departamento de História da FAU USP com relação ao ensino de Desenho Industrial? Em primeiro lugar que existe uma herança que deve ser investigada e resgatada com a construção de uma história da técnica, e pelo reconhecimento de uma tradição baseada na cultura popular, isto é, o folclore. E que essas duas heranças devem ser assumidas pelos desenhistas industriais ou arquitetos como meio de conferir identidade própria aos produtos da indústria nacional. E o ponto de vista adotado para essa aproximação com a tradição é o de uma intermediação da mesma pela arte, e a arquitetura moderna que tomam de empréstimo o mesmo modelo teórico gestado por Mário de Andrade, nas artes e na literatura, e Lucio Costa, na arquitetura, respectivamente. Com relação ao método de ensino, propunha-se um aprendizado que não significaria uma ruptura total com o modelo acadêmico, o padrão Belas Artes, pois considerava que o desenho industrial fosse uma evolução natural das artes aplicadas e do seu ensino. E, como uma importante influência desta tradição de ensino que não deve ser abandonada, está 
a manutenção do ideal do arquiteto como um artista, muito mais que como um técnico a ser integrado nos quadros profissionais da indústria. Esta visão defende a manutenção do exercício da arquitetura como atividade de criação, ainda que mude a sua forma de produção com a indústria. E nesse contexto, inclusive caracteriza o desenho industrial como algo muito mais amplo e complexo que o seu entendimento de que projeta objetos para a produção seriada apenas. 



\section{Desenho Industrial e Arquitetura na FAU USP}

Entre a criação da FAU USP e a implantação de sua Reforma de 1962, ao longo dos anos que seguem de 1948 até 1962, conforme demonstrado no Capítulo 1 , a conceituação e o ensino de arquitetura na instituição passam por um processo evolutivo cuja marca principal seria o abandono gradual do ensino tradicional nas matrizes das Escolas Politécnica e da Belas Artes. Esse gradual distanciamento se desenvolve na afirmação de uma orientação do ensino ligada aos pressupostos da arquitetura moderna. Essa evolução dentro da Escola, como visto anteriormente, terá o seu paralelo, no mesmo período, na organização da regulamentação profissional no que diz respeito à garantia da exclusividade do exercício profissional e das áreas delimitadas.

O próprio nascimento da FAU USP é marcado pela orientação modernista de seu criador e primeiro diretor, o professor Anhaia Mello. Pois, como foi indicado neste trabalho, quando da criação da Escola, para complementar o quadro de professores, além dos catedráticos da Escola Politécnica que foram incorporados ao quadro docente da FAU USP, Anhaia procurou contar com arquitetos de orientação moderna, sobretudo, formados na Escola Nacional de Belas Artes, a ENBA, do Rio de Janeiro, no contexto da reforma do seu ensino, proposta pelo arquiteto Lucio Costa, quando assume a direção da Escola a partir de 1930. 
Mas também é necessário considerar que entre os catedráticos da Politécnica incorporados à FAU USP, pelas próprias bases do ensino politécnico, a importância conferida à técnica constitui boa parte da orientação teórica desses professores. E, assim sendo, ao contrário dos antigos docentes da ENBA, os professores da Politécnica não se opuseram radicalmente a esse processo de identificação do curso de arquitetura com a orientação moderna. Antes, estabeleceram pontes entre a importância da técnica para o engenheiro e a ênfase na construção, mais que sobre a ideia de composição, aproximando-se assim da orientação moderna adotada para a nova escola de arquitetura. É a condição de professores como José Maria da Silva Neves e Caetano Fraccaroli.

Além desse grupo, houve aqueles que iniciaram suas carreiras como projetistas ou como docentes em São Paulo já dentro de uma adesão completa aos postulados

1. De acordo com Anelli (2001), Rino Levi foi professor na FAU USP até 1959. da arquitetura moderna. Entre esses, cabe indicar como exemplos mais emblemáticos, pela repercussão de seus trabalhos e discussões, os arquitetos João Batista Vilanova Artigas, Rino Levi ${ }^{1}$ e Zenon Lotufo. Mas houve também outros.

Quando se afirma um processo de construção do ensino na FAU USP identificado com a arquitetura moderna, obviamente tem-se uma necessidade de caracterizar o que está se querendo dizer com a expressão arquitetura moderna, pois que a mesma, ao longo do tempo e dos lugares, recebeu as mais distintas nuances. Mesmo dentro da própria FAU USP, a sua compreensão nunca foi uma só. Mas aqui, por arquitetura moderna interessam dois de seus princípios de fundamentação básica que percorre a história da FAU USP. O primeiro deles, a utilização de um novo meio para a sua produção, isto é, a máquina, ou a indústria. O segundo, o seu direcionamento ao atendimento das expectativas geradas para a profissão por 
um novo cliente: as demandas das sociedades urbanas de massa. $\mathrm{O}$ atendimento a esses dois requisitos está interrelacionado.

Assim sendo, em decorrência dessa aproximação com a arquitetura moderna, a FAU USP irá processar uma aproximação entre os tradicionais métodos de projeto em arquitetura e os novos métodos de projeto em desenho industrial. Na verdade, para se entender esta aproximação com o desenho industrial, é preciso considerar uma definição do mesmo não enquanto uma escala de operação, isto é, a escala do objeto, que excluiria a escala da arquitetura e do urbanismo. É necessário entender o desenho industrial como um método e não mais como escala de projeto. E pelo uso desse método é que a arquitetura cumpriria os dois pré-requisitos indicados acima como definidores da arquitetura moderna: a sua industrialização e o atendimento às demandas das sociedades urbanas de massa. Argan (1992, p.270) explica esse novo sentido desejado para a arquitetura:

\begin{abstract}
A racionalidade deve enquadrar as grandes e pequenas ações da vida: racionais devem ser a cidade em que se vive, a casa em que se mora, a mobília e os utensílios que se empregam, a roupa que se veste. Apenas um método de construção ou, mais precisamente, de projeto deve determinar a forma racional de tudo o que serve à vida e a condiciona; como tudo é ou será produzido pela indústria, tudo se reduz a projetar para a indústria: o plano urbanístico de uma grande cidade é o desenho industrial, da mesma forma que o projeto de uma colher.
\end{abstract}

A partir do exposto pelo crítico italiano, e conforme apontado no Capítulo 02, a experiência de ensino de arquitetura proposta pela HfG de Ulm provavelmente foi aquela que mais se empenhou na realização deste postulado indicado por Argan, transportando a 
2. Como foi demonstrado no

Capítulo 3, e conforme consta na listagem de exercícios de DI dos alunos entre 1962 e 1968 , entre os anexos deste trabalho. arquitetura para um método de projeto, onde tudo se reduz a projetar para a indústria. São exemplos de tal empenho da HfG de Ulm, entre tantas outras iniciativas, a adoção, para a denominação do curso, da expressão Edificações Industrializadas, em substituição à Arquitetura ou mesmo a concepção de um ensino teórico de história da arquitetura que começa nos conteúdos da arquitetura moderna e relacionada ao máximo possível com situações práticas do futuro exercício profissional, e tendo em alto valor as novas técnicas industriais de produção da arquitetura.

A realização desse mesmo pressuposto será objetivada dentro de todo o Departamento de Projeto da FAU USP, e não apenas dentro de sua Sequencia de Desenho Industrial. Como afirmado, dentro da Sequencia de DI, o estudante da FAU USP estava sendo preparado com exercícios de projeto de objetos para atuarem como projetistas de bens de consumo dentro desse setor da indústria². Mas também a FAU USP, desde 1962, procurou caracterizar o seu entendimento de arquitetura e o seu ensino a partir das possibilidades de sua industrialização, ensinando e pesquisando no campo da industrialização da construção civil.

A respeito desse novo método de projeto de arquitetura teorizado por Argan e exemplificado com a prática de ensino da HfG de Ulm, a sua transposição para uma escola brasileira, quer dizer, no caso da FAU USP, haveria de enfrentar os problemas particulares da realidade do país.

O contexto político, econômico e social sob o qual ocorre o processo de evolução do ensino na FAU USP que é focado neste trabalho pode ser definido como um período que se inicia a partir de 1945, e cujas marcas fortes seriam o de um acelerado processo de crescimento urbano e de industrialização do país. $\mathrm{E}$ a efetivação total desse processo de desenvolvimento é diagnosticada por um 
3. Fausto (2001, pp.447 e 448) identifica a discussão dessas reformas, definidas como Reformas de Base, no governo de João Goulart (196-1964), na procura por solucionar as seguintes questões: com relação à Reforma Agrária, tinha como objetivo eliminar os conflitos pela posse da terra e garantir o acesso à propriedade de milhões de trabalhadores do campo; e sobre a Reforma Urbana o objetivo principal consistia em criar condições pelas quais os inquilinos poderiam se tornar proprietários das casas alugadas. Como se sabe, algumas dessas questões até hoje não foram totalmente equacionadas.

4. Ver: FAU USP. Relatório sobre o Ensino de Arquitetura no Brasil, UIA UNESCO. Revista Sinopses. Edição Especial, 1993 (pp. 144-154). discurso quase consensual da necessidade de superação de uma noção de atraso, sendo não consensual o meio para se atingi-la. Para se ter uma ideia, tanto no Período Democrático (1945-1964), quanto durante o Regime Militar (1964-1985), ainda que por vias distintas, entre esses dois momentos políticos do país, havia uma consciência de que, para a concretização ampla desse desenvolvimento econômico buscado, seria necessário um conjunto de reformas, cuja importância estava indicada nos discursos de defesa daqueles empenhados para que as mudanças em curso se processassem integralmente, abandonando de vez resquícios de um país atrasado economicamente e socialmente. Quer dizer, a ideia de reforma se estabelece como um ideal de superação de uma condição de convívio de condições arcaicas e modernas dentro da sociedade brasileira e em prol da sobrevivência apenas da segunda condição. Assim se estabeleceram os conflitos ao redor de temas como o da Reforma Agrária, da Reforma Urbana, da Reforma Universitária, etc. A tensão que estes conflitos constituem é o que leva, por exemplo, à própria dissolução do período democrático e ao início do regime militar em $1964^{3}$. No caso da Reforma Universitária e a sua relação com a Reforma de 1962 da FAU USP, vale aqui pontuar algumas questões. A Reforma Universitária ocorre apenas em 1969, proposta pelo Governo Federal sob o regime autoritário militar e tendo como justificativa a expansão do ensino universitário brasileiro com o aumento do número de vagas. $\mathrm{E}$, como medidas adotadas para realizar tal objetivo, a Reforma de 1969 propõe: a departamentalização das faculdades; a matrícula por disciplina (regime de créditos e criação de disciplinas obrigatórias e optativas); a instituição do curso básico; a unificação do vestibular por região e o ingresso por classificação; e a fragmentação do grau acadêmico de graduação ${ }^{4}$. 
A estruturação interna das Faculdades por Departamentos e a supressão das cátedras, ainda que ocorram oficialmente apenas em 1969, com a Reforma Universitária do Ministério da Educação, é uma condição que a FAU USP já conseguira implantar no campo da prática com a Reforma de 1962, quando estabelece a estrutura das Sequências de Disciplinas. No caso da FAU USP, a criação das Sequências objetivava outra dinâmica de funcionamento da Escola e a modernização do ensino por meio da diminuição do poder daqueles professores detentores das cátedras vitalícias.

Entre a Reforma da FAU USP de 1962 e a Reforma Universitária do Governo Federal de 1969, ainda que os objetivos possam aparentemente ser semelhantes, pois desejavam uma atualização do ensino, e para isso, conforme indicado, as duas preconizavam em comum o fim das cátedras, existem diferenças fundamentais entre ambas. A primeira destas diferenças é que, no caso de 1962, trata-se de uma proposta que surgiu de dentro

5. A Reforma de 1969 foi elaborada pelo Grupo de Trabalho do Ministério da Educação e Cultura, do Governo Federal, por meio de um Convênio MEC-USAID (United States Agency for International Development). Neste sentido, o governo militar optou por essa assessoria e auxílio norteamericanos para impor um novo modelo de universidade com os objetivos de expandir o ensino superior e modernizar a estrutura da universidade brasileira.

6. Composta pelos arquitetos professores Rino Levi, Vilanova Artigas, Abelardo de Souza e Hélio de Queiroz Duarte (ver Capítulo 2). da própria universidade, enquanto a segunda tratase de uma comissão técnica que a elabora e a impõe à universidade ${ }^{5}$. Outra diferença está no processo de gestação das mesmas, em que uma segue na contramão da outra. A Reforma de 1962, realizada dentro do Período Democrático, criou condições de ensino a partir de um caráter experimental, colocando o funcionamento prático da FAU USP como um caminho que seguia em paralelo à estrutura engessada oficial da universidade. Desenvolveu-se como um processo coletivo, desde a sua primeira Comissão de Reestruturação de $1957^{6}$ até o Fórum de 1968, tendo significado este último, sob a liderança de Artigas, às vésperas de 1969, um processo de avaliação ampla do que havia sido implantado em 1962. Na contramão desse processo, a Reforma de 1969 era consequência de um conjunto de fatos que expressam a imposição de um pensamento autoritário à sociedade 
7. Ver ADUSP. O Livro Negro da USP: O Controle Ideológico na Universidade. (1979). Inclusive este livro informa que o reitor Gama e Silva depois desenvolveu carreira dentro do Ministério da Educação durante o regime militar. brasileira no geral, e no caso particular em apreço, às universidades públicas do país. Essas características autoritárias de que é tributária a Reforma de 1969 se iniciam a partir de 1964, com o Golpe Militar. A Reforma de 1969 se efetiva sob a égide do autoritarismo do governo militar, recrudescido com a edição do Ato Institucional no 5, o Al-5, em 13 de dezembro de 1968. $\mathrm{E}$, é importante considerar que, mesmo antes do Al-5, a universidade brasileira já havia sofrido toda uma série de intervenções arbitrárias impostas pelo regime autoritário. No caso da USP, assim como das outras universidades brasileiras, os quadros dirigentes são substituídos por aqueles alinhados com o regime militar, como é o caso do reitor da USP nesse período, o professor Gama e Silva. Ele foi eleito inicialmente em 1963, como candidato de conciliação entre os professores de visão progressista e outros, vinculados à defesa da cátedra e opositores de possíveis reformas dentro do ensino universitário da USP. Em 1966, o professor Gama e Silva permanece por mais um mandato como reitor da USP, agora alinhado com a visão do regime militar para os destinos da universidade pública brasileira7 ${ }^{7}$ No período que decorre entre a experiência democrática da Reforma de 1962 da FAU USP e a imposição da Reforma Universitária do regime militar em 1969, a história da universidade brasileira será marcada negativamente, a partir de 1964, pela instalação de um aparato militar de investigação das atividades de professores, alunos e funcionários. Este processo de investigação se realizou a partir da criação pelo governo militar dos Inquéritos Policiais Militares, os IPMs. De acordo com a publicação de O Livro Negro da USP (1979), essas investigações, apesar do clima de policiamento que criou, muito pouco conseguiram provar, e as delações que foram investigadas, muitas vezes, eram denúncias entre professores por motivos de disputa profissional dentro do ambiente universitário, feitas, sobretudo, por aqueles de pensamento mais retrógrado. 
8. ADUSP. O Livro Negro da USP: O Controle Ideológico na Universidade. (1979. pp. 26 e 27).

9. SCHWARZ, Roberto. (1978, p. 62).
Nesse contexto de investigação dos IPMs, entre os professores acusados, vale apontar o ocorrido na FAU USP:

Na FAU USP, também se instalou um IPM, tendo sido indiciados os dois professores acusados no documento da comissão da USP: João Batista Vilanova Artigas e Abelardo Riedy de Souza. Particularmente foi chocante a prisão do primeiro que teve lugar no próprio recinto da faculdade, durante o período de aulas e na presença dos alunos. Processados mais tarde, foram ambos absolvidos ${ }^{8}$.

Ainda a respeito desse período militar logo após o golpe de 1964 e tendo em vista, não apenas as universidades, mas a sociedade como um todo, assim Schwarz (1978) caracteriza a situação do país:

Em 1964, instalou-se no Brasil o regime militar, a fim de garantir o capital e o continente contra o socialismo. (...) Em seguida sofreu as consequências: intervenção e terror nos sindicatos, terror na zona rural, rebaixamento geral de salários, expurgo especialmente nos escalões baixos das Forças Armadas, inquérito militar na Universidade, invasão de igrejas, dissolução das organizações estudantis, censura, suspensão do Habeas Corpus, etc. ${ }^{~}$.

Posteriormente, a esta primeira fase, isto é, após o golpe e ao fim do governo do presidente general Humberto de Alencar Castelo Branco (1964-1967), o substitui o general Artur da Costa e Silva (1967-1969). Durante apenas o início do governo Costa e Silva, o regime militar pode ser caracterizado com um autoritarismo, em certa medida, mais brando que o imposto pelo presidente antecessor, conforme indica Fausto (2001, p.477): 
10. FAUSTO (2001, p.477).

11. ADUSP. O Livro Negro da USP: O Controle Ideológico na Universidade. (1979. p.33).
Seria um erro supor, porém, que Costa e Silva tenha sido no poder um instrumento da linha-dura. Levando em conta as pressões existentes na sociedade, estabeleceu pontes com a oposição moderada e tratou de ouvir os discordantes. Ao mesmo tempo, iniciou uma ofensiva na área trabalhista, incentivando a formação de sindicatos e a formação de lideranças sindicais confiáveis. Os acontecimentos iriam atropelar essa política de liberação restrita ${ }^{10}$.

De fato, sob essa relativa abertura, a oposição começa a se rearticular na luta pelo retorno do país à democracia. $\mathrm{E}$, entre aquilo que interessa aqui deste contexto, no final de 1966 assim é caracterizada a situação das universidades públicas do país:

É somente a partir do final de 1966, com a absolvição dos acusados pelos IPMs, a relativa liberalização do regime e a reorganização das entidades estudantis, que começa a renascer o espírito universitário. Reinicia-se a discussão sobre o papel e a estrutura da universidade, discussão esta que começa com os problemas criados pelos chamados excedentes (aqueles que não conseguiam ingressar nas universidades pela falta de vagas) e desemboca na questão da reforma universitária.

Na verdade, o caráter arcaico da universidade brasileira e sua incapacidade de atender a uma demanda social explosiva preocupava também os órgãos federais. Já estava patente para todos a necessidade de expandir o ensino superior e a impossibilidade de organizar esta tarefa sem modernizar a estrutura da universidade. ${ }^{11}$.

Nesse contexto de relativa abertura do regime militar, Fausto (2001) indica um processo de rearticulação de vários extratos da sociedade contra o regime militar, que pode ser exemplificado com a Passeata dos 100 mil, ocorrida 
12. Fausto (2001, p.479) aponta entre os grupos surgidos pós 1968 e relacionados à luta armada: a Aliança de Libertação Nacional, ALN, criado por Carlos Marighella; o Movimento Revolucionário 8 de outubro, MR-8 e a Vanguarda Popular Revolucionária, VPR, com forte participação de militares de esquerda.

13. O Al-5, ao contrário dos outros Als, não foi uma medida de caráter excepcional transitório, pois durou até 1979. Por meio dele o presidente possuía poderes para: fechar provisoriamente o Congresso Nacional, intervir e indicar interventores nos estados e municípios, cassar mandatos e suspender direitos políticos, demitir ou aposentar funcionários públicos. O Al-5 suspendeu também o direito ao Habeas Corpus.

14. ADUSP. O Livro Negro da USP: O Controle Ideológico na Universidade. (1979. p.33). Como se percebe, o texto não deixa de relatar a arbitrariedade do Governo Federal ao intervir em três cargos profissionais estaduais.

15. Em 1979, a partir do processo de redemocratização do país, são reintegrados à FAU USP os professores Vilanova Artigas, Paulo Mendes da Rocha e Jon Maitrejean. Ver: Grêmio da FAU USP. Anistia na FAU USP (1998). em 25 de junho de 1968, pedindo a redemocratização do país. Outro aspecto que Fausto (2001) aponta dentro desse processo de relativa abertura é o início da luta armada contra a ditadura ${ }^{12}$. Esses são os acontecimentos que iriam atropelar essa política de liberação restrita, que Fausto indica acima. Em resposta a eles, o governo militar de Costa e Silva baixa o Ato Institucional no 5, o Al-5, em 13 de dezembro de 1968, fechando o Congresso Nacional e dando início ao período mais repressivo da ditadura militar $^{13}$. Esses acontecimentos teriam seus rebatimentos na vida das universidades brasileiras.

No caso da USP, a partir do Al-5, serão lançados dois decretos federais em que professores da USP, uma instituição estadual, são aposentados compulsoriamente:

Em 28 de abril de 1969, a USP é atingida. Um estranho decreto datado de 25 do mesmo mês resolve aposentar nos cargos que ocupam nos órgãos da Administração Pública Federal (grifo nosso) 42 pessoas, entre as quais diversos intelectuais $e$ três professores da USP: Florestan Fernandes, Jaime Tiomno e João Batista Vilanova Artigas ${ }^{14}$.

Pouco tempo depois, em 29 de abril de 1969, um segundo decreto aposenta também na USP o reitor em exercício e mais 23 professores, entre esses Jon Maitrejean e Paulo Mendes da Rocha, ambos docentes da FAU USP ${ }^{15}$.

Esse é o processo que se estende dentro da USP entre a inicial Reforma de 1962, proposta pela FAU USP e a Reforma Universitária de 1969, imposta pelo regime militar à universidade brasileira como um todo.

Entre as reformas sociais indicadas nesse período como necessárias para a efetivação de um processo pleno de 
16. Inaugurada em 21 de Abril de 1960 desenvolvimento econômico com seus rebatimentos positivos no plano social, a questão da Reforma Urbana, assim como a Reforma Universitária, tem um similar interesse a este trabalho, pois está vinculada às discussões de um processo de produção de arquitetura em larga escala, ligada a um processo de intensa expansão urbana entre as décadas de 1960 e 1970 no país. E, tal como ocorre no caso da Reforma Universitária, o início dos debates sobre a Reforma Urbana, entre os setores da sociedade e o governo, ocorreria no Período Democrático, mas com a real tomada de medidas para a sua efetivação apenas dentro do autoritarismo do regime militar.

Nessa primeira etapa de constituição do debate em torno da questão urbana no Período Democrático, a contribuição da arquitetura brasileira se colocaria pela defesa de um compromisso social dos arquitetos por meio de sua contribuição à industrialização da arquitetura, a fim de que se pudesse produzir uma arquitetura de boa qualidade em larga escala. Koury (2005) descreve o processo de construção de Brasília ${ }^{16}$, a despeito de todas as críticas recebidas, como uma importante oportunidade no sentido de realização de um debate sobre os caminhos e as possibilidades da industrialização da construção civil brasileira. A autora aponta que de fato a experiência da construção de Brasília não foi aproveitada como parte de uma política de desenvolvimento da indústria da construção civil, por meio de uma ação coordenada entre o Estado e a iniciativa privada, no sentido de constituir as bases produtivas do país para enfrentar as demandas de urbanização em escala nacional e o enorme déficit habitacional. Mas salienta que, de modo indireto, muitas empresas de engenharia que, na década seguinte à da construção da nova capital, atuaram em processos de industrialização da construção civil tiveram sua origem ligada à experiência de Brasília que se caracterizou como uma grande oportunidade de trabalho para profissionais 
da área, na época da construção da nova capital.

A mobilização para a construção de Brasília colaborou para se gerar uma consciência da contribuição específica da arquitetura para a solução dos problemas acima apontados, tanto entre arquitetos quanto na opinião pública. Mas a sua construção não influiu apenas nesta área. As próprias reformas do ensino de arquitetura consideraram a experiência da nova capital, partindo de um marco zero. Construída em um período de três anos e seis meses, a inauguração de Brasília, em 21 de abril de 1960, daria inclusive mais fôlego aos debates para a Reforma de 1962 da FAU USP, pois na consulta aos documentos não são poucas as vezes em que são evocadas as novas possibilidades de atuação que a construção desta nova cidade coloca para o profissional arquiteto. E mesmo no caso da ESDI, a escola criada em 1963 para o desenho industrial dedicado ao projeto de bens de consumo, o exemplo de Brasília, também significou a fé no alargamento de horizontes de atuação para os seus profissionais formados. E, mesmo antes disto, alguns dos que vieram para o Brasil e se envolveram com a realização da ESDI, aqui aportaram inicialmente vislumbrando as possibilidades de atuação profissional que significaria a construção da nova capital do país. É uma condição expressa, por exemplo, no depoimento de Alexandre Wollner: plano de desenvolvimento, cinquenta anos em cinco. Além de instalar a Volkswagen em São Paulo, deslocou a capital do Rio de Janeiro para Brasília, projeto dos arquitetos Lucio Costa e Oscar Niemeyer. Era o momento ideal para se começar uma escola de design. Voltei ao Brasil em agosto de $1958^{17}$. 
Apesar da declaração, num outro momento, Wollner lamentaria a oportunidade perdida que esse contexto da época depois passou a significar para ele e outros :

18. STOLARSKI (2005, p.49).

\begin{abstract}
Quando Juscelino Kubitschek declarou que ia fazer o país crescer cinquenta anos em cinco, quando trouxe as grandes indústrias automobilísticas, as metalúrgicas, tivemos a esperança que a coisa fosse estourar e que teríamos trabalho à vontade. Não aconteceu, não sei por quêt ${ }^{18}$.
\end{abstract}

Em que pese as decepções de Wollner, e que não foi uma voz única a criticar o processo sob o qual se realizou a construção da nova capital, não se pode negar um aspecto importante a respeito de sua construção. Este foi o de trazer para a ordem do dia o debate na sociedade e nos meios profissionais sobre a importante contribuição que a profissão e o ensino da arquitetura e do desenho industrial teriam a dar ao nosso processo de industrialização e, consequente, desenvolvimento econômico.

E nesse processo de debate e mobilização, Koury (2005) chama a atenção para uma importante iniciativa em torno da qual os arquitetos de São Paulo tiveram importante participação. Trata-se da realização do Seminário de Habitação e Reforma Urbana, o SHRU. O Seminário foi promovido, em 1963, por iniciativa do Instituto de Arquitetos do Brasil, IAB, e o Instituto de Aposentadoria e Pensão dos Servidores do Estado, IPASE. O mesmo foi desenvolvido em duas fases (uma em São Paulo e outra no Rio de Janeiro) e estruturou a sua discussão em quatro grupos de trabalho distintos, mas centrados na discussão de questões relacionadas à habitação e ao planejamento urbano, estruturados a partir dos seguintes temas: 
19. ARQUITETURA. Revista Oficial do IAB, número 14, setembro de 1963. Apud $\operatorname{KOURY}(2005$, p.78). condições atuais;

2. A habitação e o aglomerado humano;

3. A Reforma Urbana: medidas para o estabelecimento de uma política de planejamento urbano e de habitação;

4. Execução dos Programas de Planejamento Urbano e de Habitação. ${ }^{19}$

Sobre as propostas indicadas por esse Seminário de 1963, estabelecido como campo de debate e de proposição de ideias, estas se efetivariam apenas dentro do autoritarismo do regime militar e, principalmente, pela criação de dois órgãos do Governo Federal. Um deles, o Banco Nacional de Habitação, o BNH, criado em 21 de agosto de 1964. E, outro, o Serviço Federal de Arquitetura e Urbanismo, o SERFHAU, criado no mesmo ano, junto com o BNH.

Sobre a origem dessas duas instituições, o BNH e o SERFHAU, como órgãos do regime militar, mas tributários do Seminário de Habitação e Reforma Urbana, o SHRU, de 1963, assim Koury (2005, pp. 83-84) caracteriza essa dupla e contraditória condição:

As duas instituições, com outros nomes fizeram parte das propostas do Seminário ( $S H R U$ ) para a criação de instrumentos capazes de enfrentar os problemas habitacionais e urbanísticos delineados nos anos 1960.

$(\ldots)$

A criação do BNH e do SERFHAU realizaram, no âmbito de um regime conservador e de direita, as perspectivas progressistas dos arquitetos quanto à instituição de um órgão federal que centralizasse os recursos e as decisões sobre a implementação da Reforma Urbana e do Plano Nacional de Habitação.

Apesar das expectativas que foram geradas entre os 
20. O Canteiro Experimental de Narandiba, proposto pelo BNH, abriu às empresas privadas ligadas à construção civil a possibilidade de demonstrarem seus protótipos para habitação popular com a apresentação de seus possíveis níveis de desenvolvimento tecnológico para o setor. arquitetos, a criação do BNH e algumas das experiências propostas pelo banco no seu início e que de fato foram inovadoras, como o Canteiro Experimental de Narandiba $^{20}$, a atuação do BNH foi caracterizada por uma política populista de empregos. Dessa forma, o banco não realizou seu papel como indutor de um processo de industrialização da construção civil no país. Constatase, entre as propostas implementadas na prática, certo conservadorismo contrastante com a profícua experimentação social, tecnológica, arquitetônica e urbanística desejada quando da criação do BNH. De acordo com Koury (2005), nesse sentido a criação do $\mathrm{BNH}$, em 1964, representou um enorme retrocesso nas pesquisas desenvolvidas sobre habitação social no Brasil. Entretanto, a autora complementa que, embora a despeito da adoção de modelos mais conservadores, os projetos realizados constituíram um padrão bastante satisfatório para a moradia popular além de contemplarem, em vários projetos, espaços coletivos e equipamentos sociais.

Nesse contexto descrito, as ideias do Seminário de Habitação e Reforma Urbana, o SHRU, de 1963, realizadas com colaboração do IAB, motivaram a criação do $\mathrm{BNH}$, mas essas mesmas ideias e os arquitetos ligados ao IAB e ao SHRU foram excluídos, em sua maioria, das realizações do BNH, ao longo da existência desse banco. Todavia, é importante considerar, esses arquitetos preocupados com as questões ligadas ao déficit habitacional e às questões de urbanização do país desenvolveram, em paralelo à atuação do $\mathrm{BNH}$, uma colaboração própria e próspera principalmente por três possibilidades. Desse grupo de arquitetos fazem parte também aqueles atuantes no estado de São Paulo e ligados ao ensino na FAU USP. E as três formas de atuação desses arquitetos se fizeram por uma aproximação com as seguintes possibilidades: por meio de construtoras habilitadas para captarem recursos financeiros junto ao $\mathrm{BNH}$ para financiamento 
21. A argumentação foi baseada no ponto de vista sugerido pelo prof. Dr. Carlos Alberto Ferreira Martins, exposto em conversa informal durante intervalo da disciplina SAP5826-3: Teoria e História da Arquitetura Moderna no Brasil (primeiro semestre de 2005).

22. Conforme apontado no Capítulo 4, será em torno dessa concepção carioca que surgirá a polêmica entre o suíço Max Bill e os arquitetos cariocas, com a posterior adesão dos paulistas ao lado dos cariocas. Criticando a arquitetura moderna brasileira, a produção de Oscar Niemeyer e o edifício do Ministério da Educação e Saúde, no Rio de Janeiro, Bill afirma falta de sentido e proporção humana, critica o partido adotado no projeto e os azulejos que ele considera inúteis no edifício do Ministério da Educação e Saúde. da construção de moradias, aos empréstimos também do $\mathrm{BNH}$ para o financiamento individual da casa própria direto ao proprietário e aos fundos de origem estadual para o financiamento habitacional. Os dois primeiros destinados à classe média, e o último às famílias de baixa renda. Se o SHRU, de 1963, significou a reflexão e a indicação dos caminhos para sanar o déficit habitacional e realizar a reforma urbana, foi, ao longo das décadas de 1960 e 1970, pelas três possibilidades acima indicadas, que arquitetos paulistanos, ligados ao ensino na FAU USP, se empenharam na realização de uma arquitetura, considerando a necessidade de sua industrialização e assim conseguiram estabelecer, no campo da realização prática, a experimentação de suas propostas teóricas.

No caso particular dos arquitetos professores do Departamento de Projeto da FAU USP, para se entender o ideal de colaboração do desenho industrial para a industrialização da arquitetura, é necessário considerar dentro da Escola a possibilidade de desenvolvimento de dois caminhos. Um deles que previa a industrialização dos elementos de construção e, outro, a industrialização da estrutura ${ }^{21}$. Essas duas possibilidades distanciariam o pensamento de arquitetura da FAU USP da chamada Escola carioca, que pensava em acabamento em arquitetura, para o qual o pensamento da dita Escola paulista elaborou, em contraposição, a ideia de detalhamento. Por acabamento em arquitetura pode-se considerar, a título de exemplo, o uso do mármore no revestimento de planos-parede ou no revestimento de pilares, como é o caso dos pilares do térreo livre do Ministério da Educação e Saúde (193743) $)^{22}$. Esta defesa do detalhamento também ajuda a explicar a crítica do arquiteto Vilanova Artigas à produção do arquiteto Gregori Warchavchik. Artigas colocaria um limite aos aspectos inovadores das casas do arquiteto ucraniano, pois se conseguia realizar uma nova estética 
23. Para detalhes desse debate ver: BUZZAR (1996) e FARIAS (1990).

atrelada à arquitetura moderna, entretanto esta não era acompanhada no plano das soluções técnico-construtivas. Um exemplo desta condição está na impossibilidade de realização nas residências modernistas de Warchavchik, à época de sua construção, de lajes planas, sendo então realizadas as coberturas das suas casas com telhas de barro, escondidas por platibandas ${ }^{23}$.

Mas com relação a essas duas possibilidades em que se orientam os arquitetos professores da FAU USP, é importante entender que industrializar os elementos da construção significa, em outras palavras, se aproximar da industrialização leve da construção

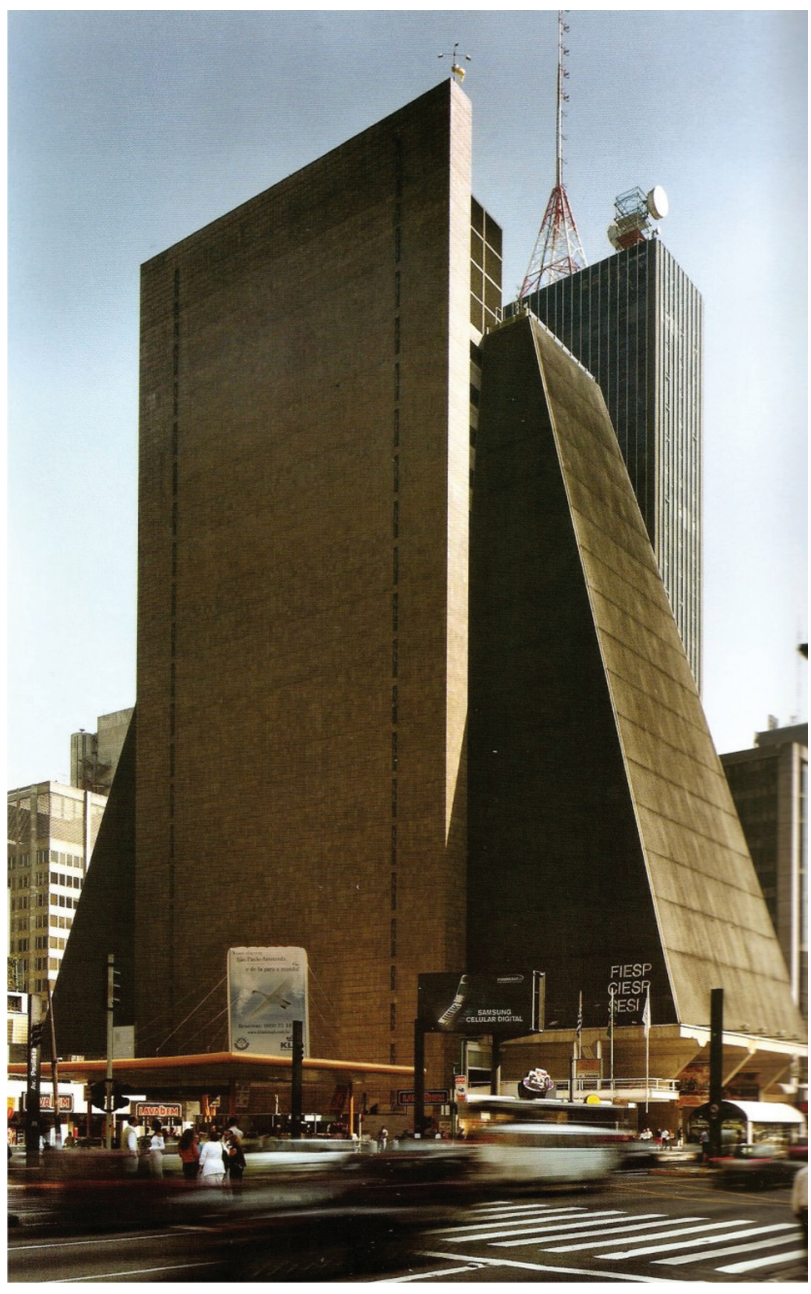

Fig.134. Escritório Rino Levi. Edifício FIESP / CIESP / SESI. Av. Paulista, São Paulo, SP. 1969. [Fonte: ANELLI, 2001]. civil, e industrializar a estrutura, concretizaria uma aproximação entre a arquitetura e a indústria pesada. Essas duas perspectivas de industrialização pelas quais a FAU USP se decide, a partir da década de 1960, estará presente no trabalho de vários arquitetos da Escola.

Entre uma e outra possibilidade de industrialização, Koury (2005), a partir de análise de um conjunto de artigos publicados entre os anos de 1950 e 1970, em revistas especializadas em arquitetura e engenharia, conceitua a préfabricação leve como sendo aquela que produz peças em que seu peso seja equivalente àquele suportado pelo trabalhador no processo de montagem sem necessidade de equipamentos especiais para a colocação das peças na posição de montagem. Os préfabricados pesados, ao contrário, requerem equipamentos de transporte e içamento das peças para a montagem no 
24. Nesses periódicos especializados, publicados entre 1950 e 1970, ainda são destacadas por Koury (2005, pp.100-101) mais outras duas categorias de classificação, a partir dos conceitos técnicos da pré-fabricação, e que são: pré-fabricação total, onde todo o conjunto da obra é produzido em uma usina e montado no local da obra, ou parcial, que se constitui por partes pré-fabricadas inseridas em um sistema tradicional de construção; e com relação ao processo de produção, podem ser pré-fabricados nos canteiros ou em usinas distantes do local da obra. Ver KOURY(2005).

canteiro $^{24}$.

O arquiteto Rino Levi e a equipe de seu escritório de projetos de arquitetura se empenharam em projetos que considerem um desenho voltado para a produção seriada dos elementos da construção, sejam estes painéis, elementos vazados, caixilhos, portas, algumas peças de mobiliário anexadas à arquitetura, etc. Esta atuação de Rino Levi, a partir de seu escritório de arquitetura, e não de dentro da indústria, entretanto, colocaria um limite inicial do alcance pretendido por essa industrialização. Rino Levi projetou peças que foram produzidas especificamente para cada obra, e o ideal da aproximação entre arquitetura e desenho industrial, com a produção repetida de um mesmo elemento da construção, ficou limitado ao uso de vários elementos iguais dentro de um único edifício, não se constituindo em uma possibilidade da

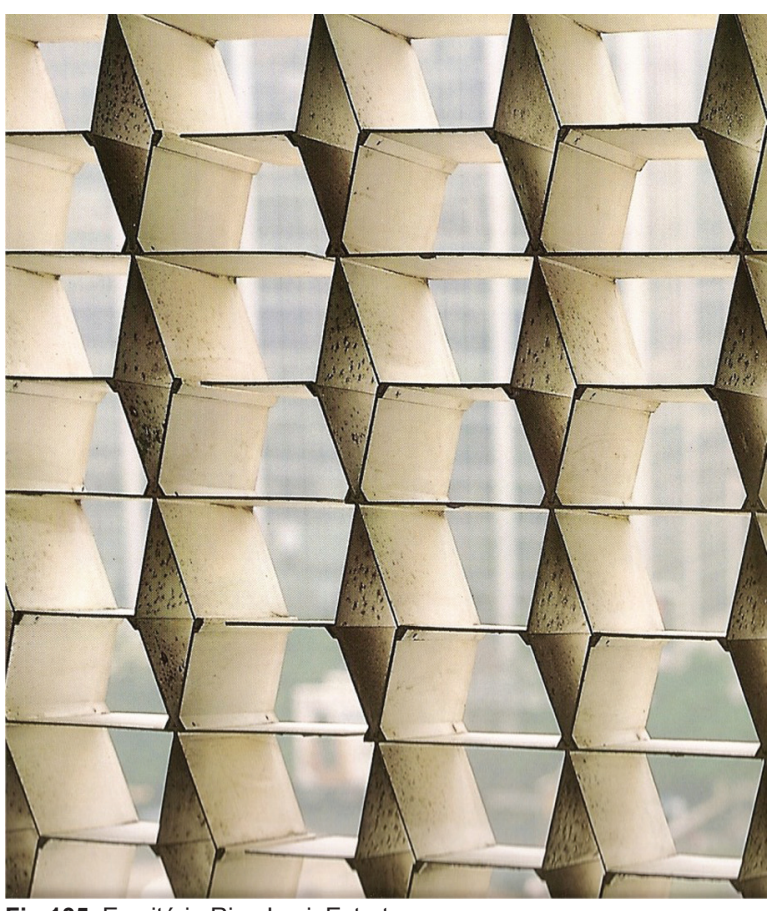

Fig.135. Escritório Rino Levi. Estrutura Metálica Geométrica. Fachada da FIESP. 1969. [Fonte: LEAL, 2002]. reprodutibilidade do próprio edifício. Dito em outras palavras, o elemento arquitetônico poderia ser produzido em série, mas não o edifício. Contudo vários pesquisadores são unânimes em apontar que muitas das soluções de Rino Levi e de seu escritório, para a produção de elementos seriados dentro de uma obra única, depois, pela sua eficiência, seriam incorporadas à indústria da construção civil, então atingindo esse objetivo mais amplo de Rino Levi. O conjunto da vasta produção arquitetônica do Escritório Rino Levi atesta esta busca, desde as suas primeiras encomendas de casas, os grandes cinemas de São Paulo ou outras obras de grande porte. Essa importância conferida ao elemento pré-fabricado para a construção civil e sua ligação com a arquitetura se dão em dois sentidos no trabalho de 
25. Ver ANELLI (2001).

Rino Levi. Ora aproveitando aquilo que o mercado disponibilizava, como telhas de fibrocimento, elementos vazados, entre outros. Ora projetando e executando os elementos não encontrados no mercado, como caixilhos para janelas, portas e painéis. No caso dos caixilhos desenvolvidos como painéis, entre tantos exemplos efetivados pelo Escritório Rino Levi, vale citar a pele de revestimento elaborada para o edifício sede da FIESP, CIESP e SESI, na Avenida Paulista, em São Paulo, no ano de $1969^{25}$. A grid metálica proposta para este edifício está para o desenho industrial enquanto multiplicação de um único microelemento de produção industrial seriada infinita, mas está também para a arquitetura e mesmo para o urbanismo na medida em que cumpre uma dimensão funcional para a arquitetura e outra dimensão plástica para a cidade.

A aposta do arquiteto Vilanova Artigas segue, sobretudo, pelo caminho da industrialização pesada e diz respeito a industrializar a estrutura do edifício. Entretanto é necessário pontuar que a arquitetura de Artigas quase sempre experimentou certo grau de artesanalidade em sua execução. Vários são os depoimentos daqueles que direta ou indiretamente estiveram ligados ao trabalho do mestre Artigas e confirmam esta condição. E este caráter artesanal é consequência de uma contingência da limitação tecnológica, onde o uso que o arquiteto fazia do concreto in loco requeria, por exemplo, todo um processo de montagem e desmontagem de fôrmas de madeira no canteiro, com grande utilização de mão de obra e a construção de soluções técnicas para determinados problemas construtivos, não previamente na prancheta, mas com um caráter experimental no próprio canteiro, e como um processo de driblagem de limitações de ordem técnica. 
Exemplo desse limite imposto pela situação tecnológica pode ser extraído do processo de construção da Estação Rodoviária de Jaú (1973), no interior do estado de São Paulo. O professor Lucio Gomes Machado conta, em depoimento, que a sua realização foi uma solicitação do prefeito da cidade ao arquiteto, e a sua construção seria feita coma mão de obra da própria prefeitura, sem contratar uma empresa especializada da área da construção civil. Primeiro limite tecnológico. Gomes Machado afirma que nesse contexto,

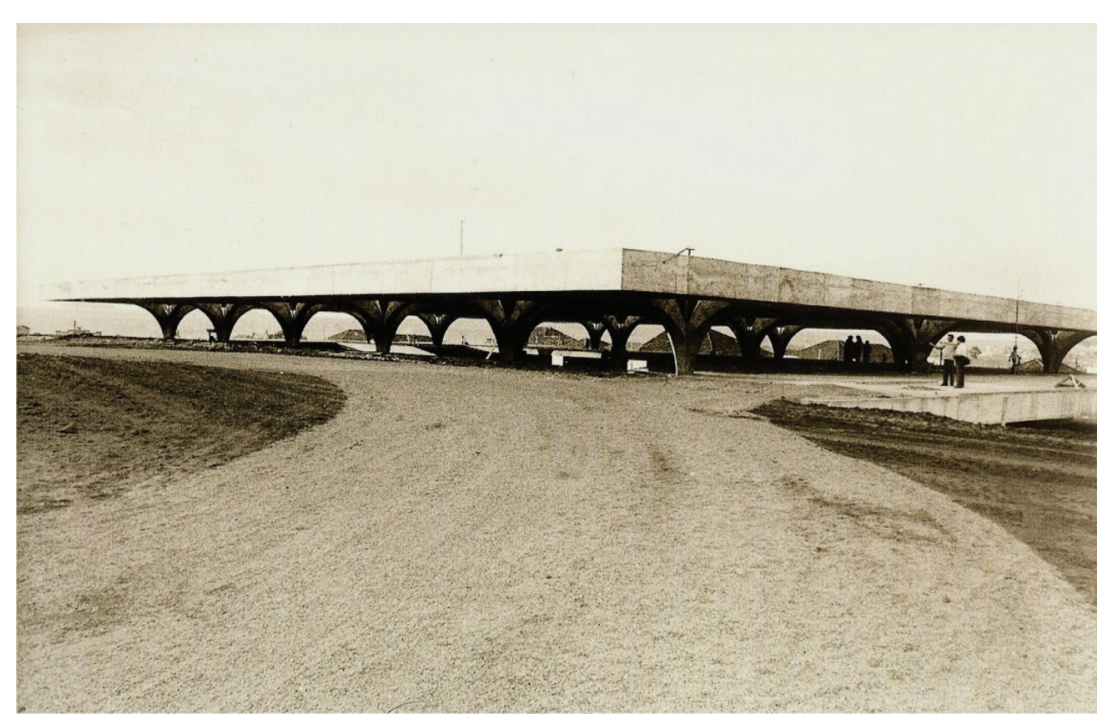
a intermediação entre o arquiteto e a construção da rodoviária era na verdade feita pelo mestre de obras da prefeitura. E, neste contexto de execução da obra in loco, ilustrando as condições de sua Rodoviária de Jaú. Jaú, SP, 1973. construção, destaca a dificuldade de execução da junção dos dezoito pilares com a laje de cobertura, onde cada um desses pilares, no seu topo, se dividia em quatro pétalas que receberiam as cargas de peso da laje. A execução deste detalhe incomum para a prática profissional do mestre de obras em questão seria um desafio a ser superado. De fato o projeto foi executado conforme o desenho indicado pelo arquiteto, todavia o processo de construção no canteiro é que seguiu outra lógica que não aquela esperada no âmbito de uma prática construtiva racionalizada. A partir de seu universo de conhecimento constituído na prática do ofício, o mestre de obras propôs e realizou artesanalmente primeiro um pilar de madeira, a partir deste pilar, realizou as fôrmas e com as fôrmas chegou ao pilar de concreto do edifício. 

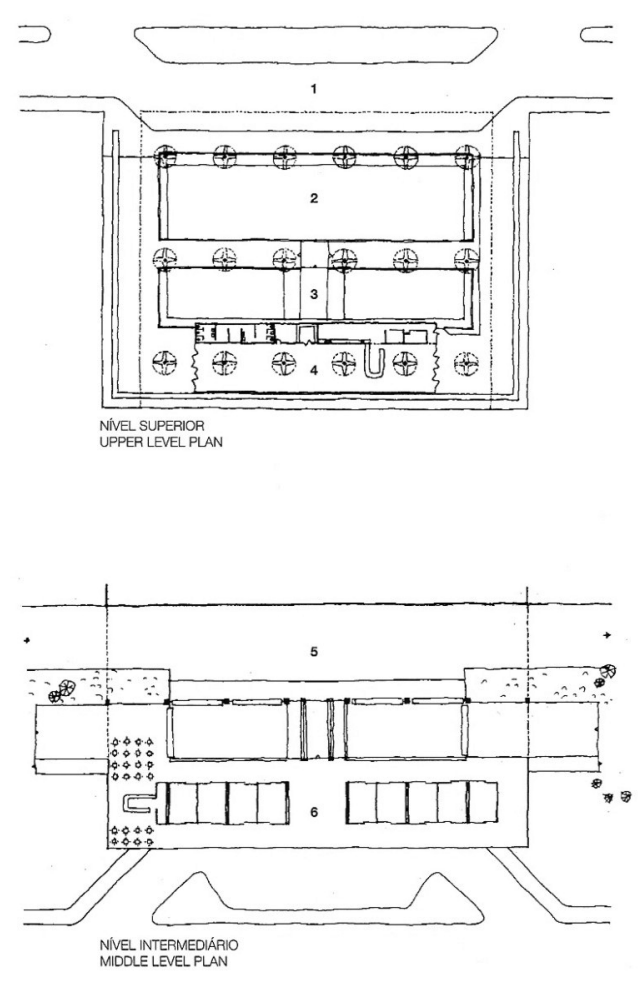

$\otimes$

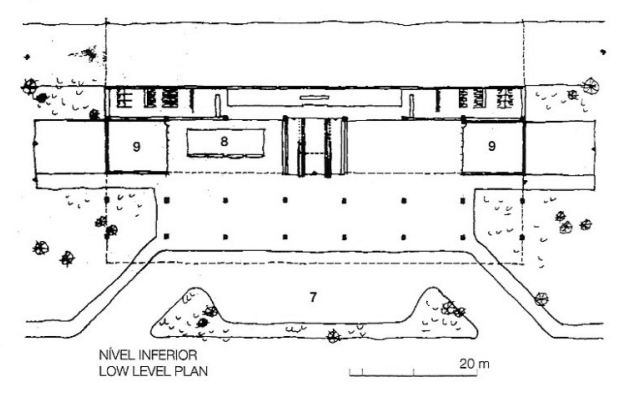

Fig.137. Vilanova Artigas. Estação Rodoviária de Jaú. Plantas. Jaú, SP, 1973. [Fonte: FERRAZ, 1999.]

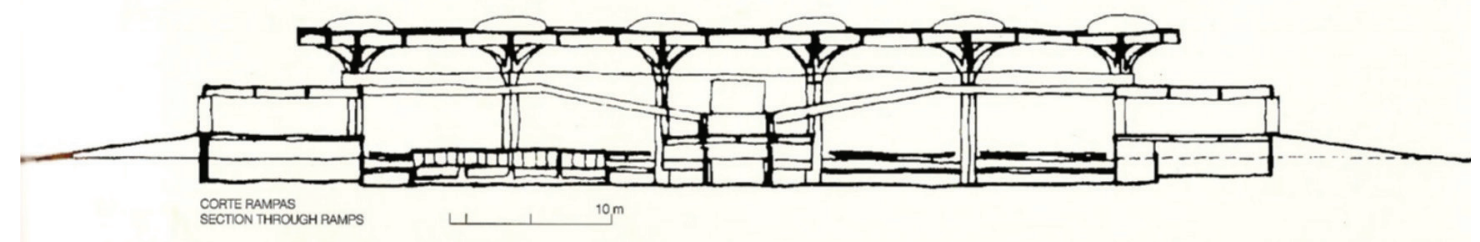

Fig.138. Vilanova Artigas. Estação Rodoviária de Jaú. Corte. Jaú, SP, 1973. [Fonte: FERRAZ, 1999.] 


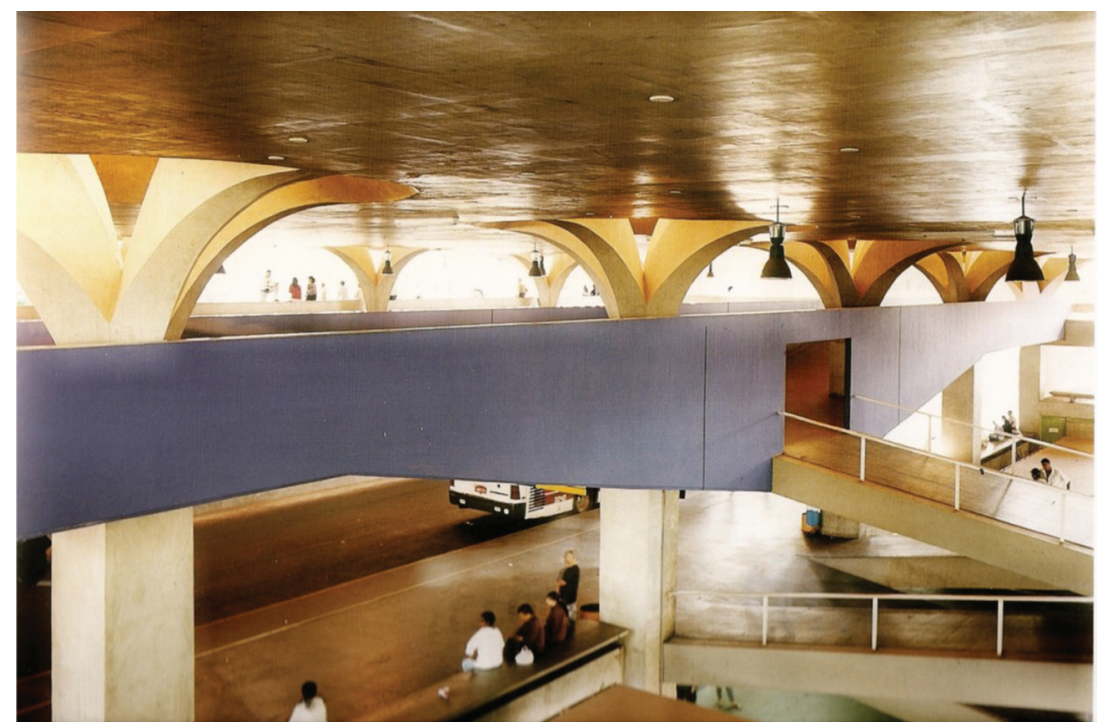

Fig.139. Vilanova Artigas. Estação Rodoviária de Jaú. Jaú, SP, 1973. Vista interna. [Fonte: FERRAZ, 1999.]

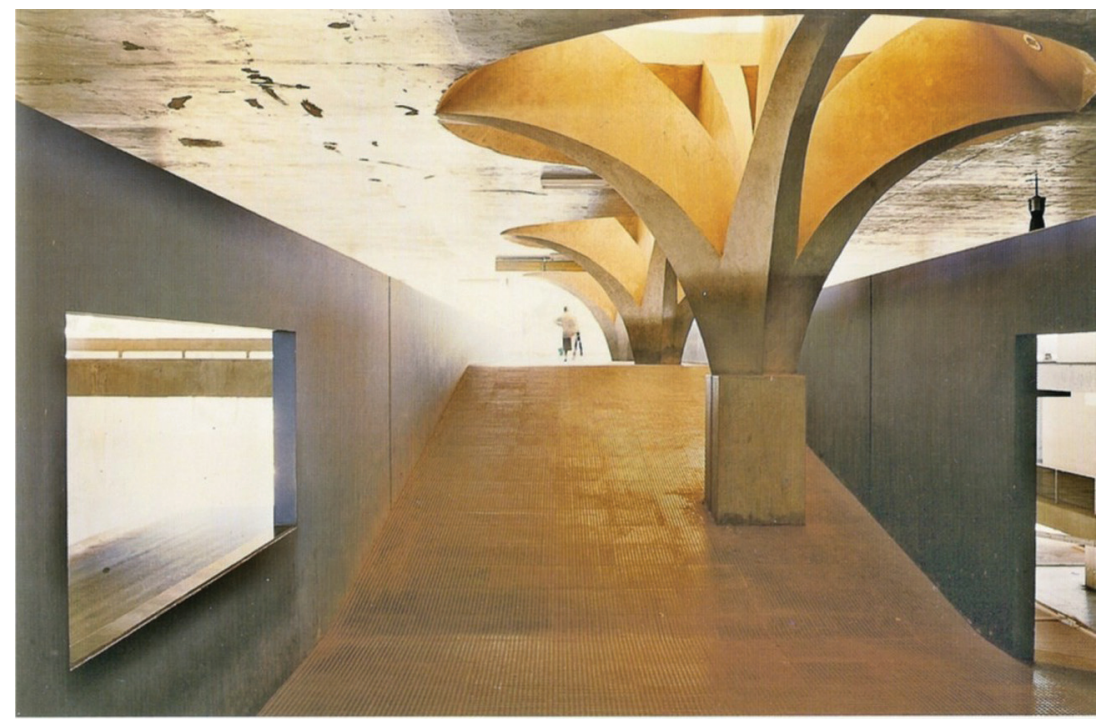

Fig.140. Vilanova Artigas. Estação Rodoviária de Jaú. Jaú, SP, 1973. Rampa. [Fonte: FERRAZ, 1999.] 
Esse grau de experimentalismo e de artesanato no canteiro de obras também pode ser verificado em outras situações da trajetória profissional de Artigas, colocando-se sempre em seu discurso como uma realidade a ser superada. Contudo, duas de suas obras, anteriores à realização da Estação Rodoviária de Jaú, conseguiram significar uma melhor experiência na busca pela industrialização da estrutura da arquitetura. Uma delas é o Ginásio de Utinga, e a outra, o Conjunto Habitacional Zezinho Magalhães Prado.

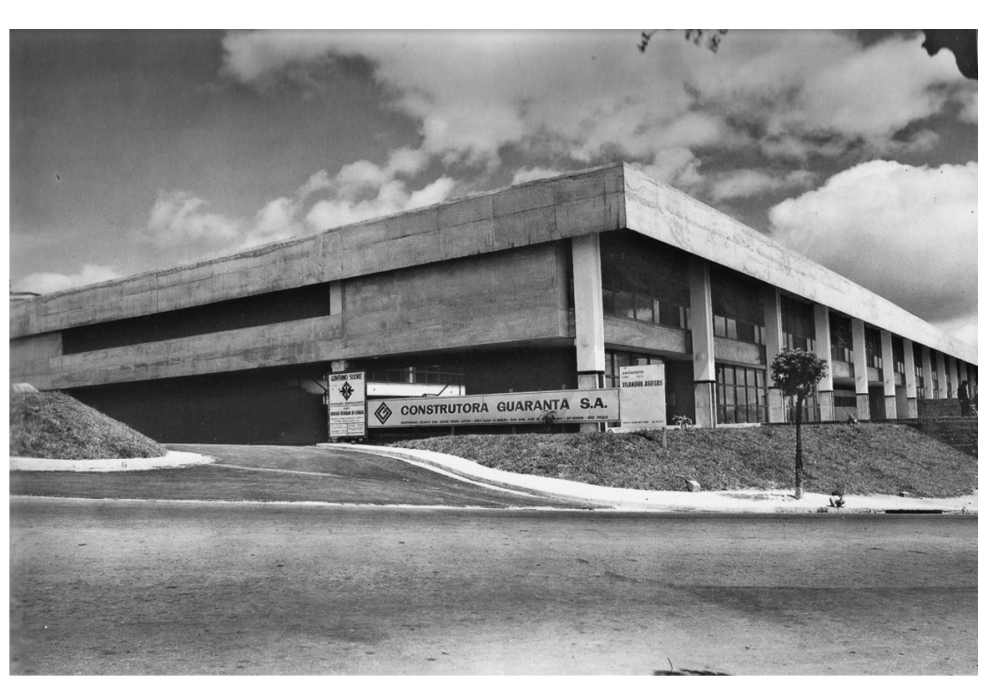

Fig.141. Vilanova Artigas e Carlos

Cascaldi. Ginásio de Utinga. Santo André, SP, 1962. Vista Externa. [Fonte: FERRAZ, 1999].
O Ginásio de Utinga foi projetado para a cidade de Santo André. $\mathrm{O}$ arquiteto Vilanova Artigas, associado ao arquiteto Carlos Cascaldi, realiza uma primeira versão do projeto em 1962. O projeto estabelecido inicialmente, contudo, entre os anos de 1966 e 1968, agora sem a colaboração de Cascaldi, foi modificado em algumas questões relacionadas ao programa arquitetônico e também com relação à substituição da prémoldagem por uma estrutura moldada in loco. De acordo com Seixas (2003), sobre a primeira versão, desenvolvida em 1962 para o projeto para a Escola em questão, esta tomava como ponto de partida projetual a utilização de uma estrutura pré-fabricada condicionando, inclusive, se comparada aos projetos anteriores dos dois arquitetos, algumas novas condições espaciais conferidas ao edifício, bem como, sobretudo, uma busca de outra relação com o canteiro de obras: 
26. SEIXAS (2003, pp. 91-92).
O Ginásio de Utinga é concebido prevendo a protensão e a pré-moldagem de seus elementos portantes, mantendo ainda as técnicas tradicionais na construção das paredes dos blocos que contém os setores funcionais e nos sub-sistemas de contenção de terras. Nessa perspectiva, alguns dos elementos característicos das outras escolas de Artigas e Cascaldi são adequados à nova lógica de produção. Ainda que em Utinga o sistema estrutural seja responsável pela modulação do espaço interno, o desenho dos apoios elaborados a partir de superfícies triangulares é substituído por pilares de seção quadrada. A opção pela protensão de vigas contínuas na cobertura, e não por uma estrutura porticada como em Guarulhos (Ginásio de Guarulhos, Vilanova Artigas e Carlos Cascaldi, 1960) e Itanhaem (Ginásio de Itanhaem, Vilanova Artigas e Carlos Cascaldi, 1959), transforma os esforços nos pilares, que passam a receber somente solicitações no sentido vertical. De fato, um sistema estrutural concebido à pré-moldagem em concreto dificilmente se adequaria ao engastamento necessário em estruturas porticadas ${ }^{26}$.

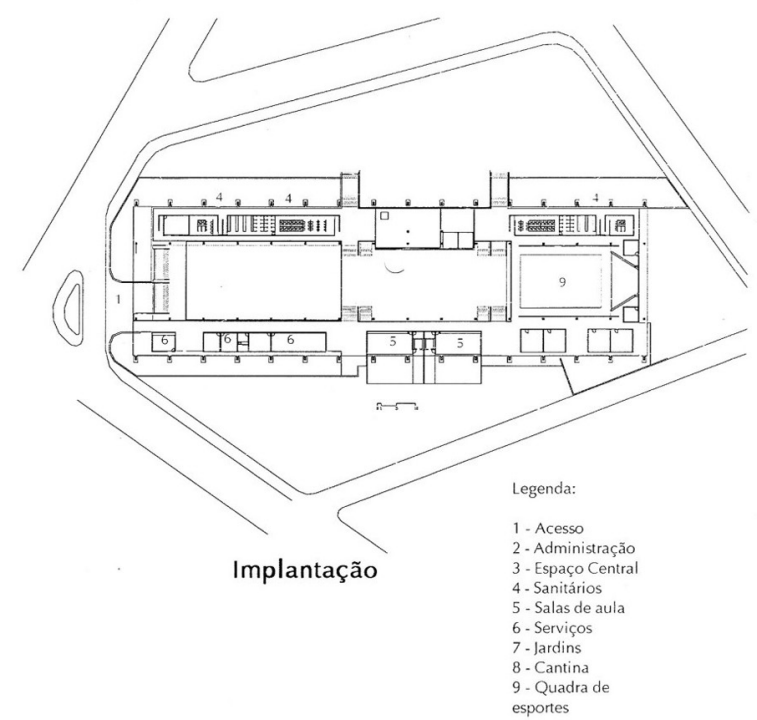

Fig.142. Vilanova Artigas e Carlos Cascaldi. Ginásio de Utinga. Santo André, SP, 1962. Implantação. [fonte: SEIXAS, 2003]. 


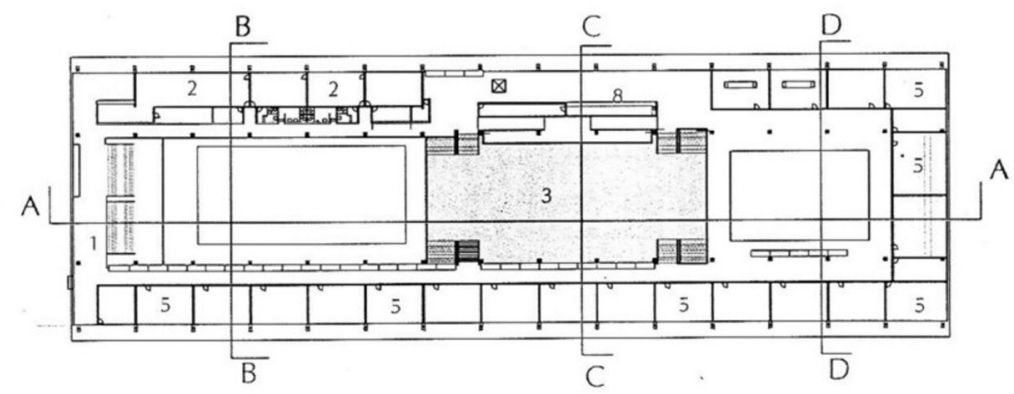

Pavimento Superior

Fig.143. Vilanova Artigas e Carlos Cascaldi. Ginásio de Utinga. Santo André, SP, 1962. Pavimento Superior. [fonte: SEIXAS, 2003].

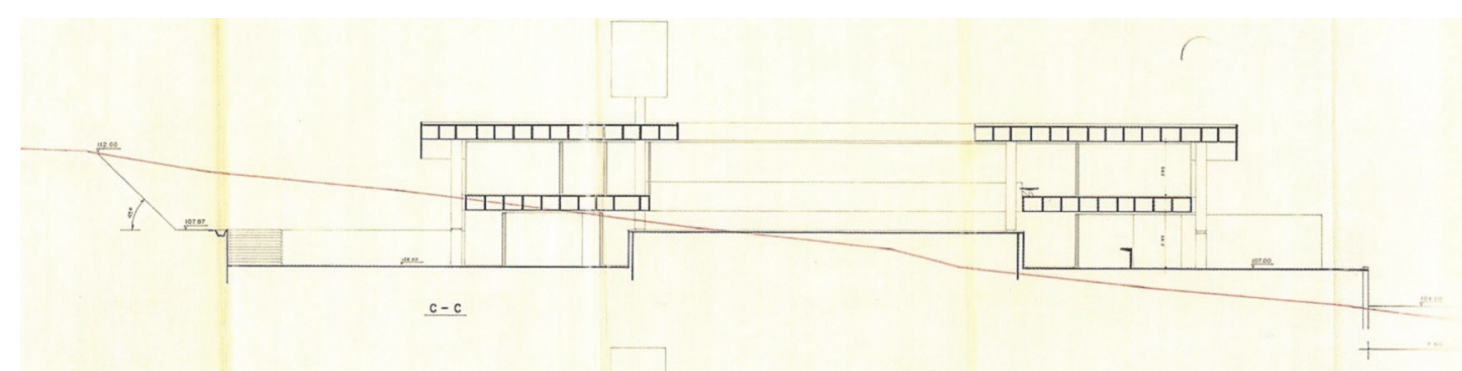

Fig.144. Vilanova Artigas e Carlos Cas-

caldi. Ginásio de Utinga. Santo André, SP,

1962. Corte. [fonte: FERRAZ, 1999]. 
Ainda sobre a qualificação espacial, comparativamente às obras anteriores dos dois arquitetos, Seixas (2003) apresenta a seguinte observação, afirmando que no Ginásio de Utinga:

(...) a relação entre arcabouço de sustentação e o espaço interno tende a ser menos intensa. A tensão expressiva focada na conexão entre laje e cobertura, que confere destaque aos espaços centrais de Guarulhos, Itanhaem e FAU USP (Vilanova Artigas e Carlos Cascaldi, 1961), cede lugar a uma configuração do espaço interno bem mais modesta, que procura agora marcar a diferença entre superfícies e pontos de apoio ${ }^{27}$.

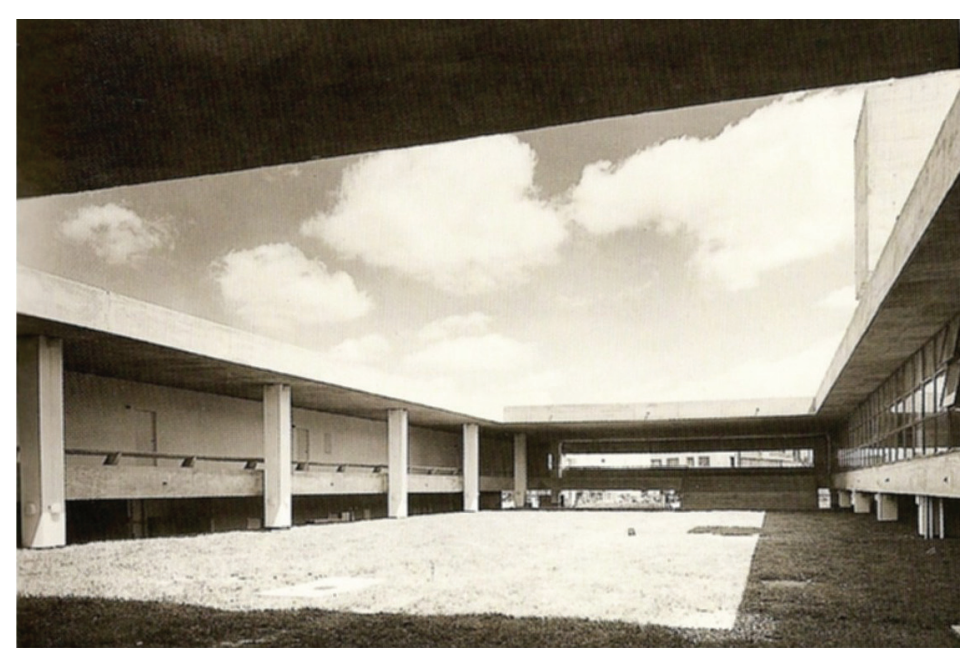

Fig.145. Vilanova Artigas e Carlos Cascaldi. Ginásio de Utinga. Santo André, SP, 1962. Pátio. [fonte: FERRAZ, 1999].

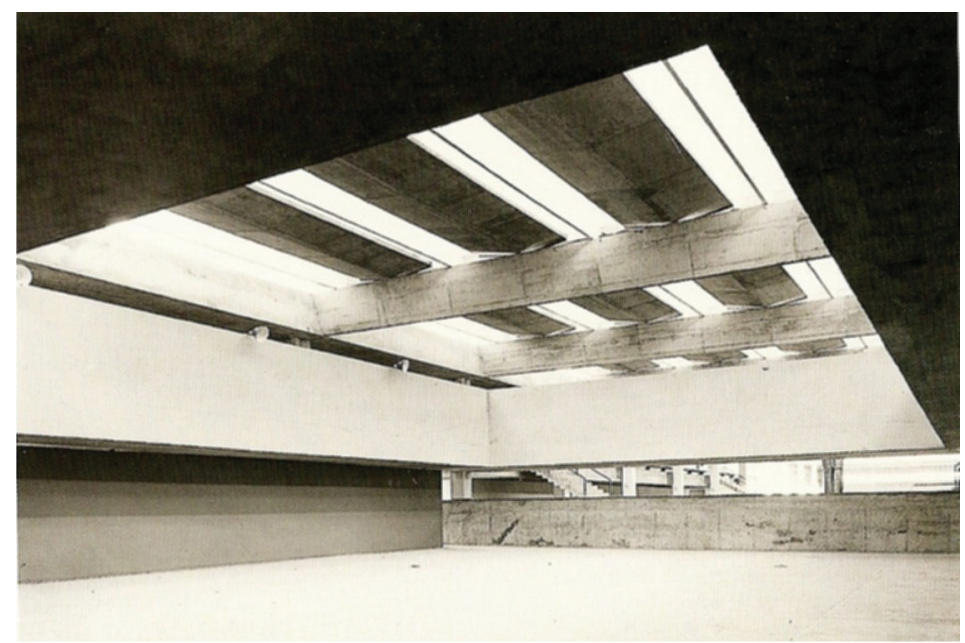

Fig.146. Vilanova Artigas e Carlos Cascaldi. Ginásio de Utinga. Santo André, SP, 1962. Detalhe da quadra de esportes. [fonte: FERRAZ, 1999]. 


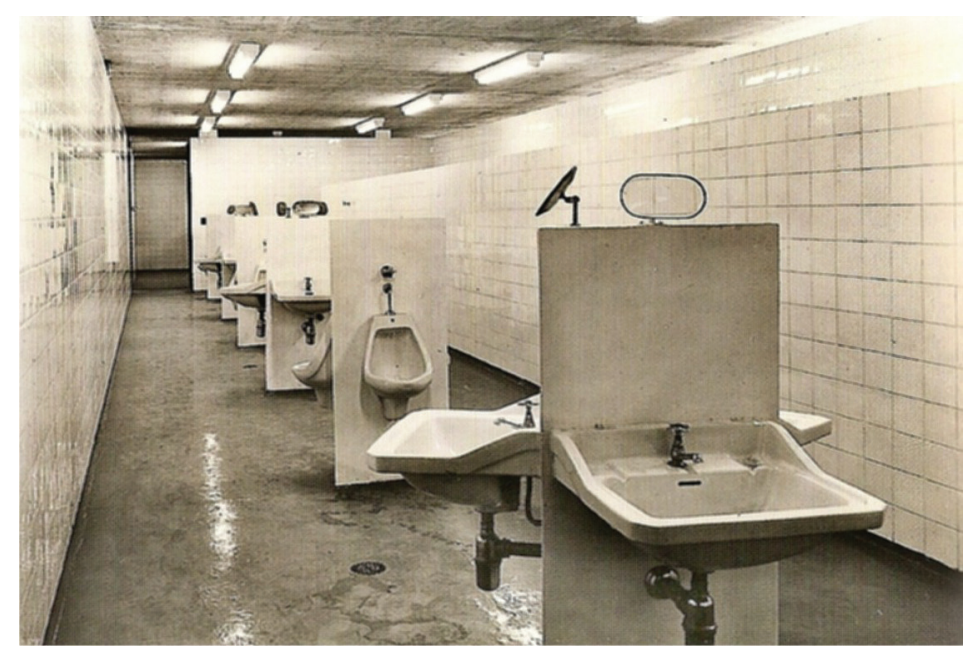

Fig.147. Vilanova Artigas e Carlos Cascaldi. Ginásio de Utinga. Santo André, SP, 1962 Banheiro masculino. [fonte: FERRAZ, 1999].

Esses pressupostos de industrialização da estrutura da arquitetura no Ginásio de Utinga, o que equivale a dizer, uma opção pela industrialização pesada da construção

28. A equipe completa era composta também pelos seguintes arquitetos colaboradores: Ruy Gama, Arnaldo Martino, Giselda Visconti, Geraldo Vespaziano Puntoni e Renato Nunes (Escritório Técnico CECAP). civil, são aqui pensados por Artigas como um recurso para suprir a escala territorial do país às demandas por equipamentos sociais, como escolas, hospitais, espaços de lazer, espaços de trabalho, habitação, etc. Nesse contexto descrito, trazer o pressuposto do desenho industrial ligado à produção em série para o campo de realização da arquitetura e, por que não dizer, do urbanismo, configurase como uma possibilidade da ocupação do território, como afirmam em vários momentos distintos de sua trajetória profissional, em seus discursos, os arquitetos Vilanova Artigas e também Paulo Mendes da Rocha.

Um outro projeto sob a liderança de Artigas que confere grande importância à industrialização da estrutura da arquitetura é o Conjunto Habitacional Zezinho Magalhães Prado (1967). Este foi projetado por Vilanova Artigas, Fabio Penteado e Paulo Mendes da Rocha ${ }^{28}$. Foi contratado pela Caixa Estadual de Casas para o Povo, CECAP, para o 
município de Guarulhos. Tratava-se de um plano dogoverno do estado de São Paulo junto às prefeituras das cidades do interior, para a criação de conjuntos habitacionais em locais onde houvesse facilidade de urbanização. Essa iniciativa objetivava controlar a expansão periférica das cidades. Ficher assim relata esse processo:

29. Ficher, s/d. apud KOURY (2005, p.211.)
A CECAP é uma autarquia do governo estadual criada em 1948, pelo Dr. Adhemar de Barros. Sua realização em 20 anos foi a construção de 18 casas. Em 1967 foi indicado para a superintendência o Dr. José Magalhães Prado, que resolveu dinamizar a autarquia e chamar os arquitetos João Batista Vilanova Artigas, Fabio Penteado e Paulo Mendes da Rocha, para formarem uma equipe de sociólogos e outros profissionais para a execução de um grande conjunto habitacional. Esta equipe constitui o escritório técnico do CECAP29.

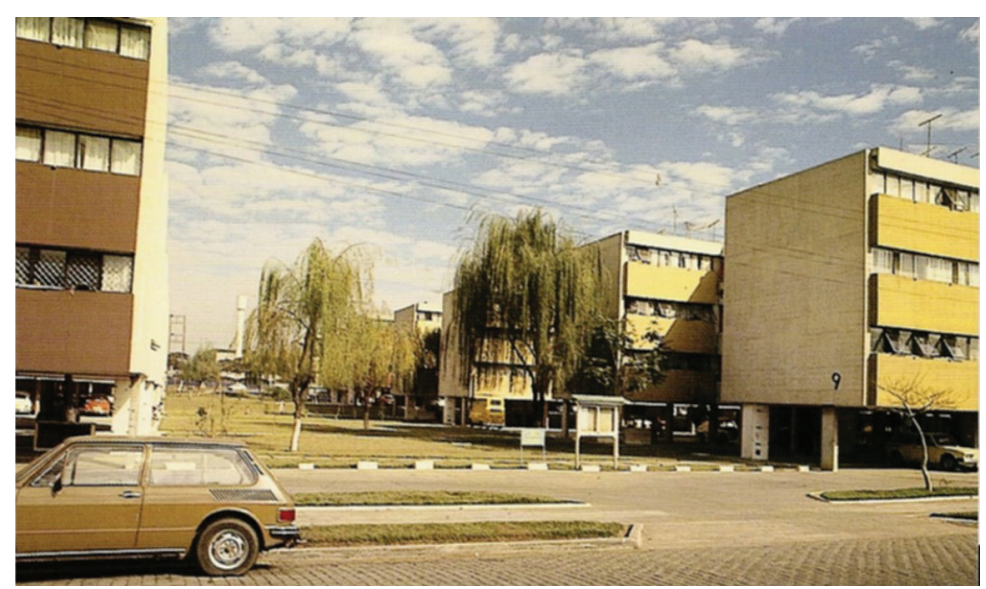

Fig. 148. Vilanova Artigas, Fabio Penteado, Paulo Mendes da Roche e Escritório Técnico CECAP. Conjunto Habitacional CECAP Zezinho Magalhães Prado. Guarulhos, SP, 1967. [Fonte: FERRAZ, 1999.] 


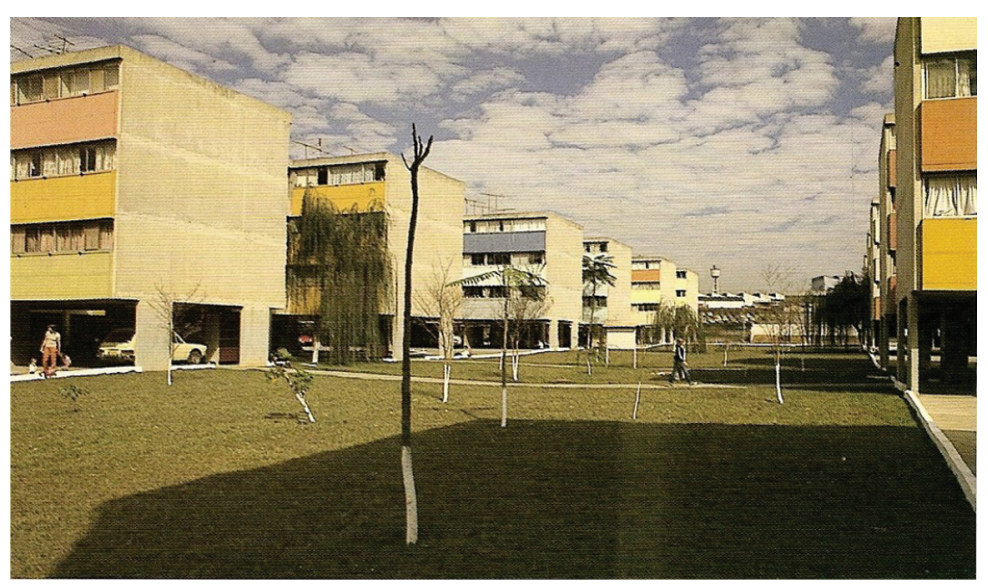

Fig.149. Vilanova Artigas, Fabio Penteado, Paulo Mendes da Roche e Escritório Técnico CECAP. Conjunto Habitacional CECAP Zezinho Magalhães Prado. Guarulhos, SP, 1967. [Fonte: FERRAZ, 1999.]

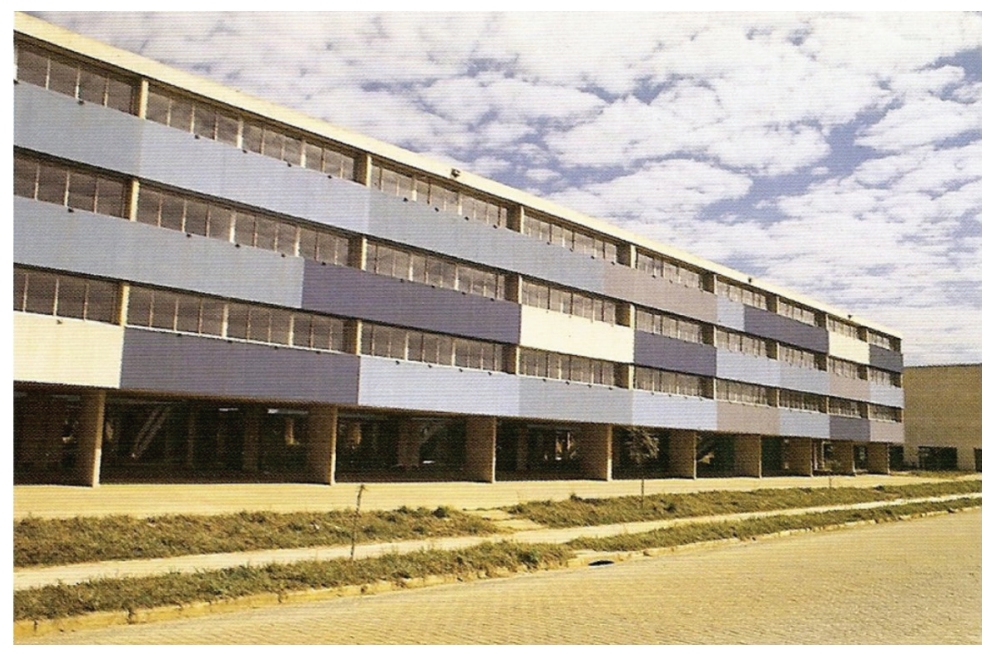

Flg.150. Vilanova Artigas, Fabio Penteado, Paulo Mendes da Roche e Escritório Técnico CECAP. Conjunto Habitacional CECAP Zezinho Magalhães Prado. Guarulhos, SP, 1967. [Fonte: FERRAZ, 1999.]

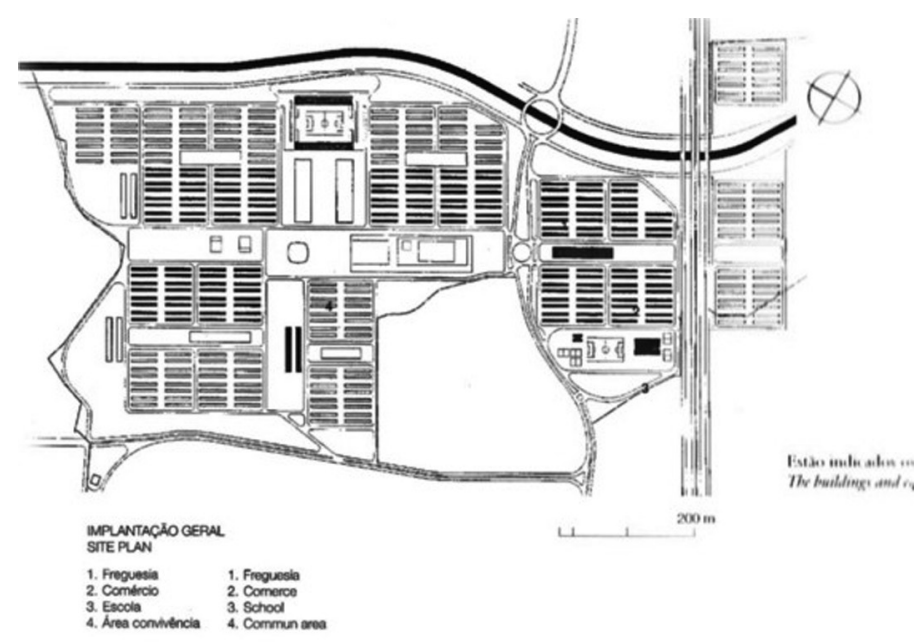

Fig.151. Vilanova Artigas, Fabio Penteado, Paulo Mendes da Roche e Escritório Técnico CECAP. Conjunto Habitacional CECAP Zezinho Magalhães Prado. Implantação Geral. Guarulhos, SP, 1967. [Fonte: FERRAZ, 1999.]. 
30. Ver FERRAZ (1997) e KOURY (2005).
O complexo habitacional a ser realizado foi determinado a partir de um conjunto de pesquisas sobre a população e as características da região. A proposta incluiria seis centros educacionais, um hospital, um estádio, áreas verdes a praças quantificadas para atender à população residente. O projeto foi estruturado em unidades chamadas freguesias, cada uma composta por 32 edifícios de três andares e também um edifício destinado a realizar um comércio local. A proposta previa também a realização de escolas, teatros, ginásio, igreja, clube e comércio central ${ }^{30}$.

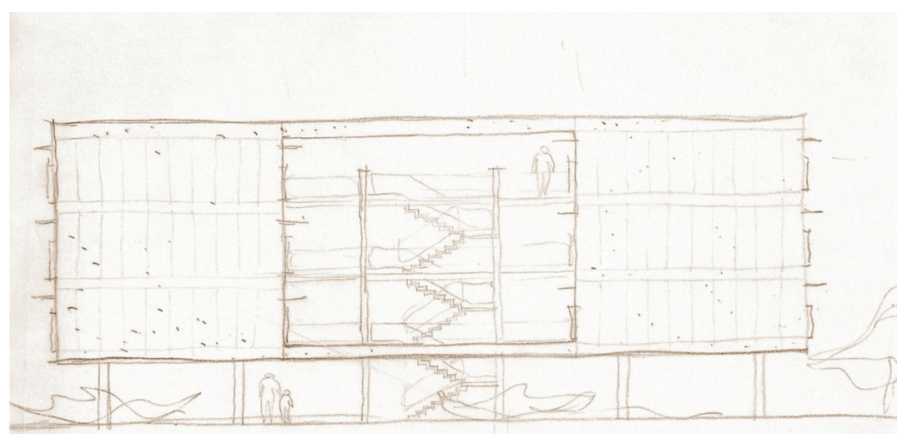

Fig.152. Vilanova Artigas, Fabio Penteado, Paulo Mendes da Roche e Escritório Técnico CECAP. Conjunto Habitacional CECAP Zezinho Magalhães Prado. Elevação do Bloco. Guarulhos, SP, 1967. [Fonte: FERRAZ, 1999.]Implantação Geral. Guarulhos, SP, 1967. [Fonte: FERRAZ, 1999.]

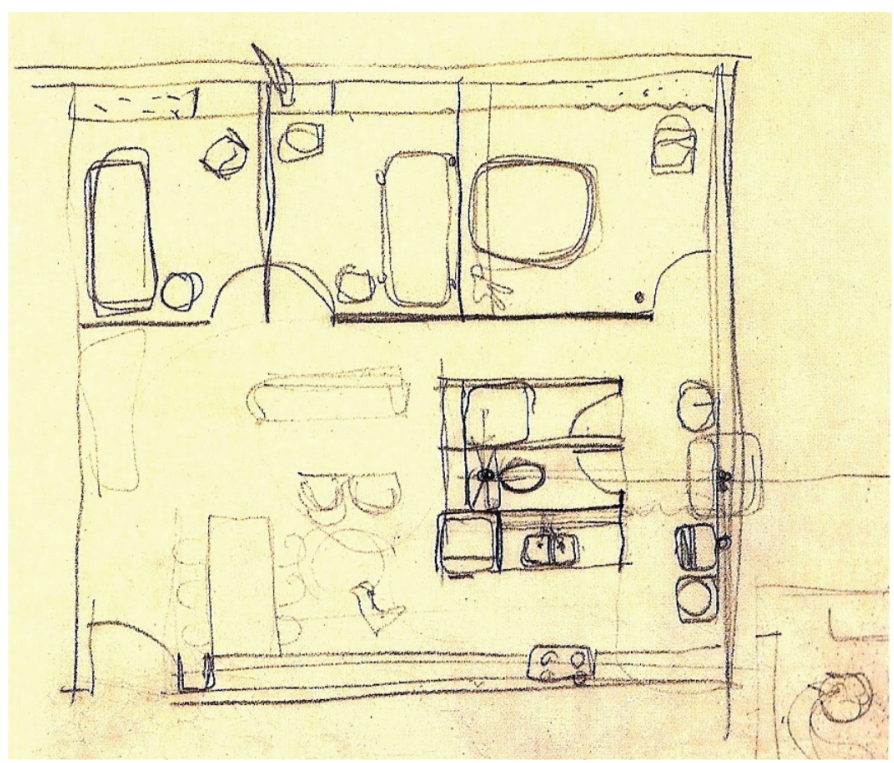

Fig.153. Vilanova Artigas, Fabio Penteado, Paulo Mendes da Roche e Escritório Técnico CECAP. Conjunto Habitacional CECAP Zezinho Magalhães Prado. Estudo da Unidade Habitacional. Guarulhos, SP, 1967. [Fonte: FERRAZ, 1999.] 
Para a realização dessa escala de projeto que significava o Conjunto Zezinho Magalhães, era previsto um processo de industrialização pesada que haveria de contar com o investimento inicial do Estado, arcando com os altos custos iniciais para a montagem de uma indústria que fosse capaz de produzir as estruturas necessárias para a construção do conjunto, reprodutível depois em outras regiões. Tal apoio não ocorreu na prática, e toda a concepção do conjunto pensado inicialmente para ser construído com peças pré-fabricadas acabou se realizando com uso dos métodos tradicionais da construção civil, à semelhança do que ocorrera com o Ginásio de Utinga.

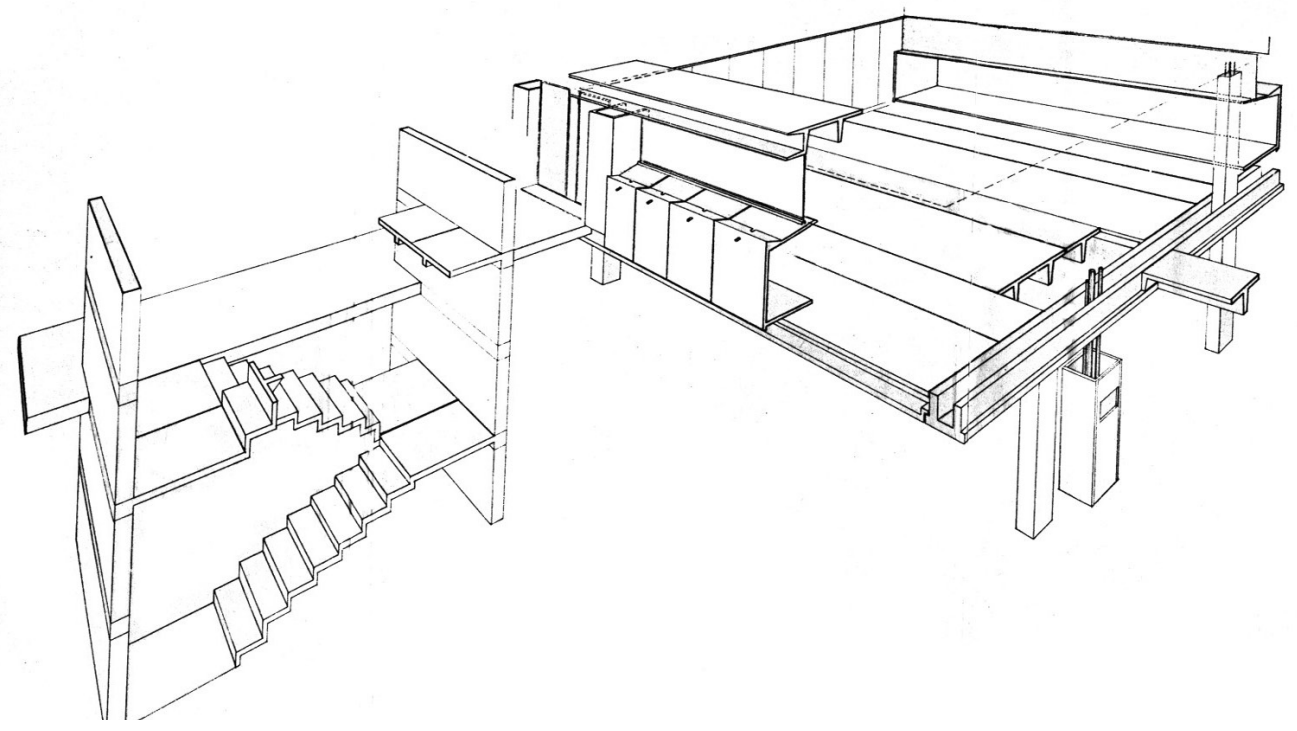

Fig.154. Perspectiva axonométrica demonstrando a montagem dos elementos pré-fabricados. Conjunto Habitacional Zezinho Magalhães Prado. Arquitetos: Vilanova Artigas, Fábio Penteado e Paulo Mendes da Rocha. Guarulhos, 1967, CECAP. [fonte: FICHER, Sylvia. Subsídios para um estudo do Conjunto Habitacional Zezinho Magalhães Prado. Pesquisa FAU USP, s/d.]

Com relação à amplitude desta proposição inicial de uma industrialização da construção por meio do uso de peças pré-fabricadas, o grupo envolvido com o Conjunto Zezinho Magalhães chegou a considerar também a possibilidade de desenvolvimento de equipamentos domésticos, como geladeiras, fogões e armários de cozinha, área de serviço ou dormitórios, que seriam produtos de um desenho industrial leve integrados à arquitetura. 


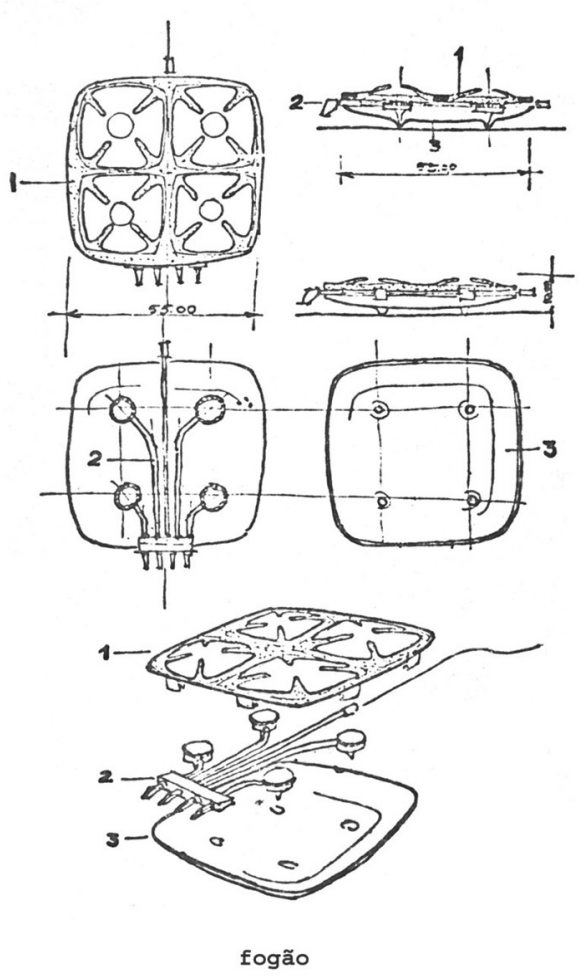

Fig.155. Fogão. Conjunto Habitacional Zezinho Magalhães Prado. Arquitetos: Vilanova Artigas, Fábio Penteado e Paulo Mendes da Rocha. Guarulhos, 1967, CECAP. [fonte: FICHER, Sylvia. Subsídios para um estudo do Conjunto Habitacional Zezinho Magalhães Prado. Pesquisa FAU USP, s/d.]

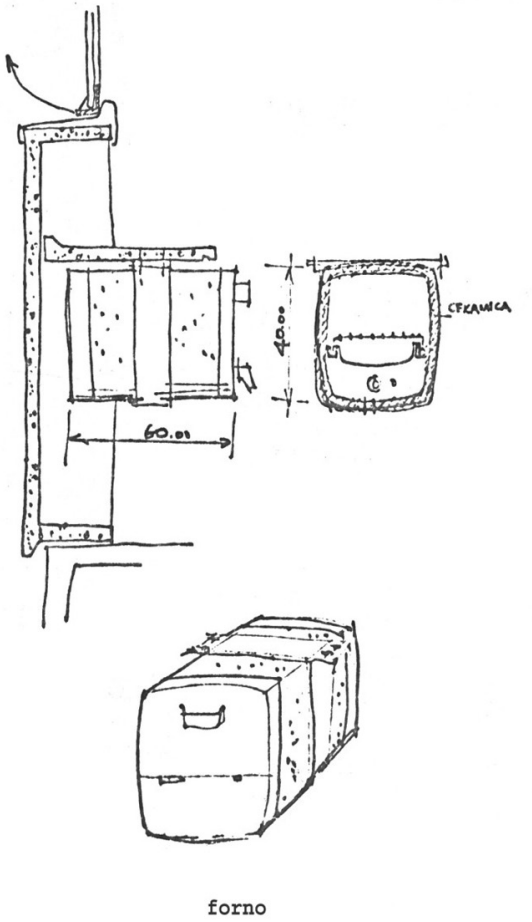

Fig.157. Forno. Conjunto Habitacional Zezinho Magalhães Prado. Arquitetos: Vilanova Artigas, Fábio Penteado e Paulo Mendes da Rocha. Guarulhos, 1967, CECAP. [fonte: FICHER, Sylvia. Subsídios para um estudo do Conjunto Habitacional Zezinho Magalhães Prado. Pesquisa FAU USP, s/d.]

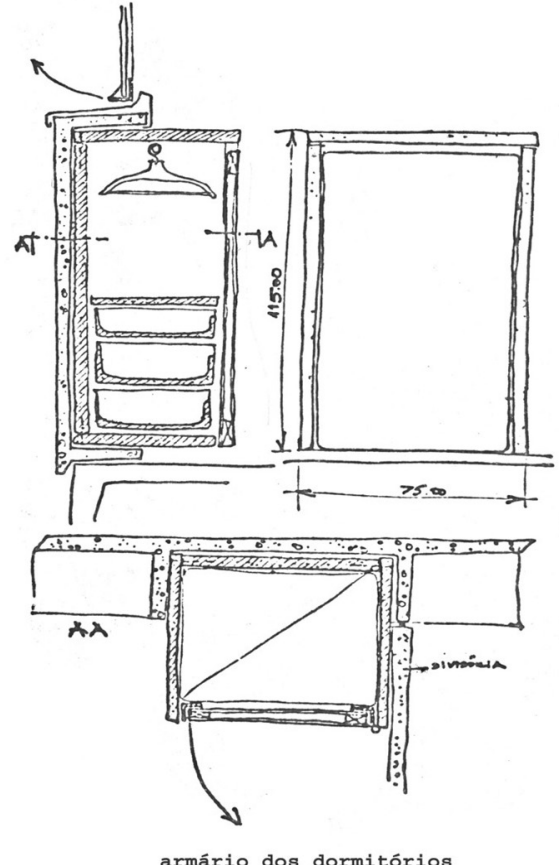

Fig.156. Armário dos dormitórios. Conjunto Habitacional Zezinho Magalhães Prado. Arquitetos: Vilanova Artigas, Fábio Penteado e Paulo Mendes da Rocha. Guarulhos, 1967, CECAP. [fonte: FICHER, Sylvia. Subsídios para um estudo do Conjunto Habitacional Zezinho Magalhães Prado. Pesquisa FAU USP, s/d.]

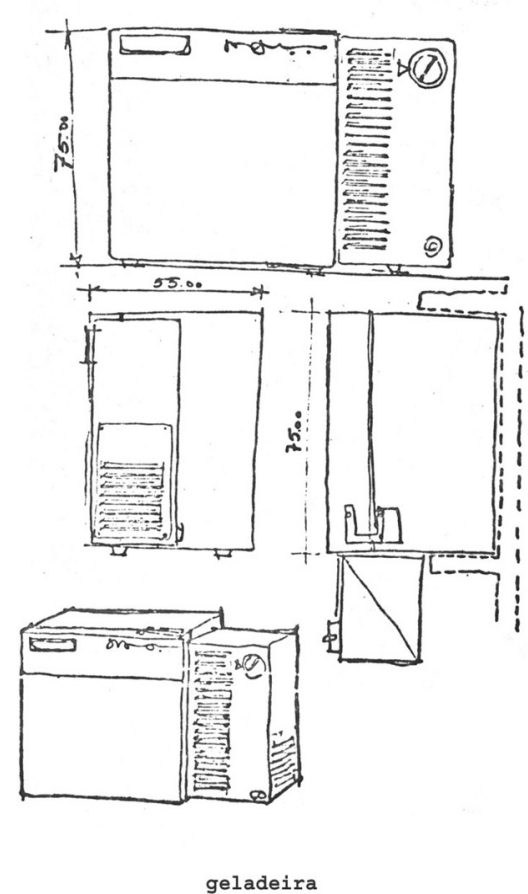

Fig.158. Geladeira. Conjunto Habitacional Zezinho Magalhães Prado. Arquitetos: Vilanova Artigas, Fábio Penteado e Paulo Mendes da Rocha. Guarulhos, 1967, CECAP. [fonte: FICHER, Sylvia. Subsídios para um estudo do Conjunto Habitacional Zezinho Magalhães Prado. Pesquisa FAU USP, s/d.] 


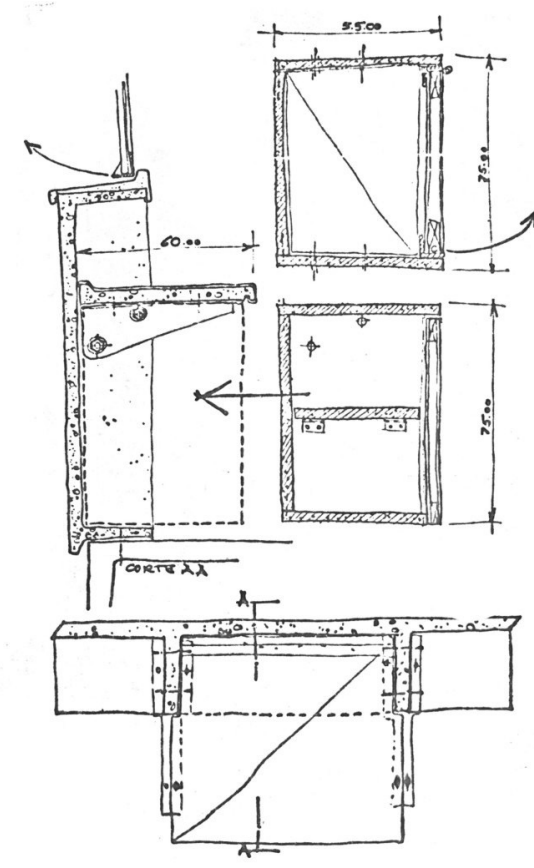

armários do balcão de serviços

Fig.159. Armário do balcão de serviços. Conjunto Habitacional Zezinho Magalhães Prado. Arquitetos: Vilanova Artigas, Fábio Penteado e Paulo Mendes da Rocha. Guarulhos, 1967, CECAP. [fonte: FICHER, Sylvia. Subsídios para um estudo do Conjunto Habitacional Zezinho Magalhães Prado. Pesquisa FAU USP, s/d.]

31. Ficher, s/d. apud KOURY (2005, pp.212 e 213.)
Apesar desses limites tecnológicos indicados e, em parte, consequentes da ausência da esperada participação do Estado no auxílio à montagem de um parque industrial brasileiro ligado ao setor da construção civil, no caso deste conjunto habitacional, muitas das soluções de pré-fabricação propostas depois foram incorporadas pela indústria da construção civil e mesmo o modelo de arquitetura para o conjunto passou depois a influenciar a realização de outros projetos nesta escala, como atesta o depoimento de Ficher:

Para todos os problemas técnicos levantados, desde as redes de infraestrutura até os projetos dos edifícios, foram propostas soluções inovadoras e é exatamente nas dificuldades de se implantar atitudes novas que se reflete o dinamismo que este projeto criou nos padrões de solução para o problema habitacional.

\section{(..)}

Hoje o escritório técnico, por sua experiência e pesquisa, é o único órgão apto a dar subsídios para uma política habitacional atuante, principalmente em nível federal. O Conjunto Zezinho Magalhães Prado representa o único exemplo de solução, tendo sensibilizado profundamente a orientação do BNH e se transformado em seu modelo.

A demanda de novas soluções junto às indústrias ligadas à construção nem sempre se vê frustrada. Constantemente novos materiais vêm sendo apresentados e recentemente foi examinado o primeiro módulo da geladeira proposta no projeto e que possibilitará a instalação de geladeira de baixo custo em todas as unidades ${ }^{31}$.

Ao longo desse processo que ocorre no Brasil, e em São Paulo com participação da FAU USP, dos arquitetos 
32. $O$ arquiteto João Filgueiras Lima, o Lelé, também realiza esse processo de síntese entre a industrialização pesada e a industrialização leve da arquitetura, atingindo assim a industrialização total da mesma. Inúmeras e exemplares são as experiências bem-sucedidas do arquiteto nessa área. Tratase de uma atuação em que o arquiteto está presente desde a etapa de constituição da indústria, ou usina, produtora dos elementos pré-fabricados. Nesse sentido, sua ação não se inicia apenas na prancheta ou no canteiro. A partir de seus princípios de préfabricação, realizou projetos de hospitais, escolas, habitação e equipamentos urbanos espalhados pelo território nacional. Para detalhes ver: FERRAZ, Marcelo Carvalho (org.). João Filgueiras Lima, Lelé. São Paulo: Instituto Lina Bo e PM Bardi; Editorial Blau, 1997. atribuírem uma importância decisiva à industrialização de nossa arquitetura, como forma de contribuição para suprir a demanda do país por habitação, equipamentos sociais e urbanização das cidades à escala de seu crescimento, conforme argumenta Carlos Martins, entre os arquitetos haveria ainda aqueles que somariam em sua obra a perspectiva de se industrializar tanto os elementos leves quanto a realização da indústria da estrutura pesada. $\mathrm{O}$ arquiteto Paulo Mendes da Rocha, professor da FAU USP inicialmente até 1969 , pode ser tomado como um exemplo de adoção deste ponto de vista ${ }^{32}$.

No caso de Paulo Mendes da Rocha e de sua contribuição acima indicada, um bom exemplo pode ser destacado do início de sua carreira profissional, em 1964. São as residências, para moradia de Paulo Mendes da Rocha e Luiz Gonzaga Cruz Secco, que foram construídas no bairro Butantã em São Paulo. As duas casas localizadas em terrenos contíguos possuem uma solução estrutural e volumétrica semelhante, com algumas pequenas diferenças em planta para se adequarem às necessidades específicas de cada uma das duas famílias. $O$ arquiteto Paulo Mendes da Rocha, que desenvolveu o projeto em coautoria com o arquiteto João Eduardo de Gennaro, informa que a realização dessas duas casas nasce a partir de um interesse pela pré-fabricação no campo da construção civil. Tal interesse é consequência de uma aposta na industrialização da construção como recurso para prover a arquitetura brasileira da qualidade na quantidade. Tudo isto, como o arquiteto mesmo afirma, com um ânimo novo em função da experiência que fora a construção de Brasília.

Ao longo da defesa de tal industrialização, Paulo Mendes da Rocha, em depoimento a Helio Piñón (2002), deixa clara a importância que atribui à industrialização tanto da estrutura pesada da construção quanto dos elementos leves que compõem tal residência. 
Consciente do processo de projeto e de construção das duas casas, Mendes da Rocha as caracteriza em realizações à semelhança de protótipos para a construção serial e industrializada. $\mathrm{O}$ arquiteto delimita a sua estrutura como consequência de um desenho rigoroso, coerente com uma visão de pré-fabricação. Uma condição que resulta em um sistema estrutural também rigoroso, de vão central com dois balanços bem equilibrados sobre quatro pilares. Na explicação da racionalidade de tal estrutura que, na verdade, é moldada in loco, o autor afirma que cada um dos pilares recebe cem toneladas de uma casa que pesa no total quatrocentas toneladas. Esse rigor na

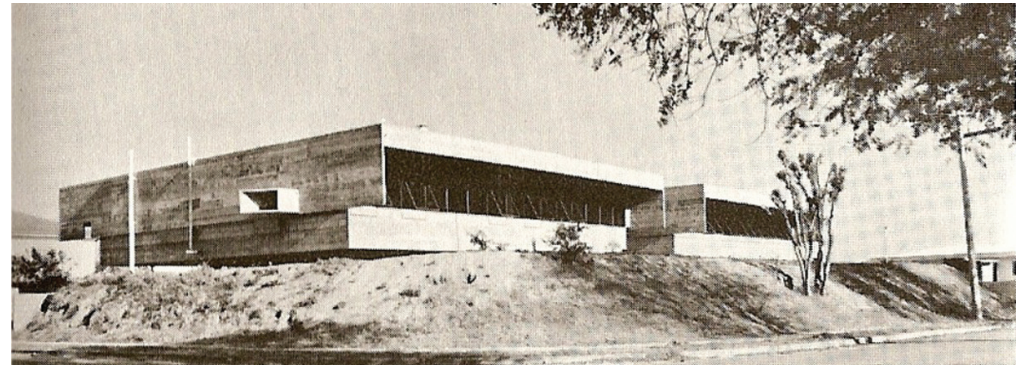

Fig.160. Paulo Mendes da Rocha. Residências Paulo Mendes da

Rocha e Luiz Gonzaga Cruz Secco.

São Paulo, 1964. [fonte: XAVIER, LEMOS E CORONA, 1983]. construção de uma estrutura de grande porte em função da obtenção de uma simplicidade de linhas estruturais é que coloca para a estrutura a indicada visão de pré-fabricação, que o autor afirma.

Como informado, entretanto, esse desejo de industrialização não se limita apenas à elaboração da estrutura. Ocorre, também, nos elementos leves das duas casas. Uma

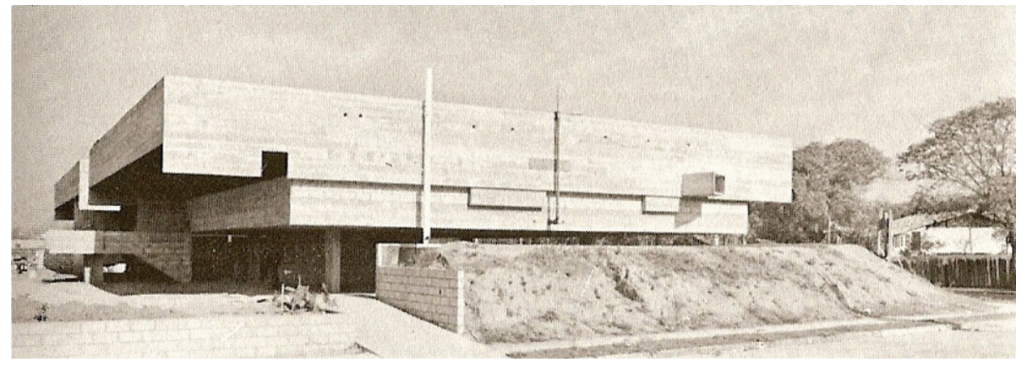

Fig.161. Paulo Mendes da Rocha. Residências Paulo Mendes da Rocha e Luiz Gonzaga Cruz Secco. São Paulo, 1964. [fonte: XAVIER, LEMOS E CORONA, 1983]. condição que, em seu depoimento a Piñón, Mendes da Rocha faz questão de deixar claro. Aponta, como exemplos, o ideal de concepção de um único caixilho capaz de resolver todas as aberturas da casa e ao mesmo tempo o desenvolvimento de um sistema hidráulico aparente, mas que por esta 
condição teria de ser resolvido tanto a partir de um ponto de vista funcional quanto poético. Essas características todas é que parecem colocar a casa do ponto de vista tecnológico, como o autor mesmo a enquadra, como um protótipo para a indústria.

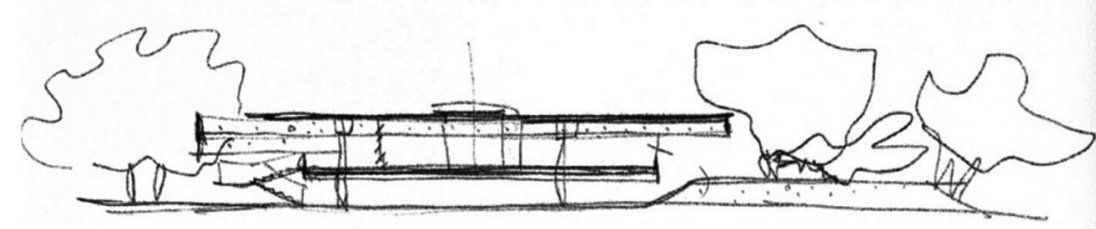

$P M R$

Fig.162. Paulo Mendes da Rocha. Residências Paulo Mendes da Rocha e Luiz Gonzaga Cruz Secco. São Paulo, 1964. [fonte: PIÑÓN, 2002].
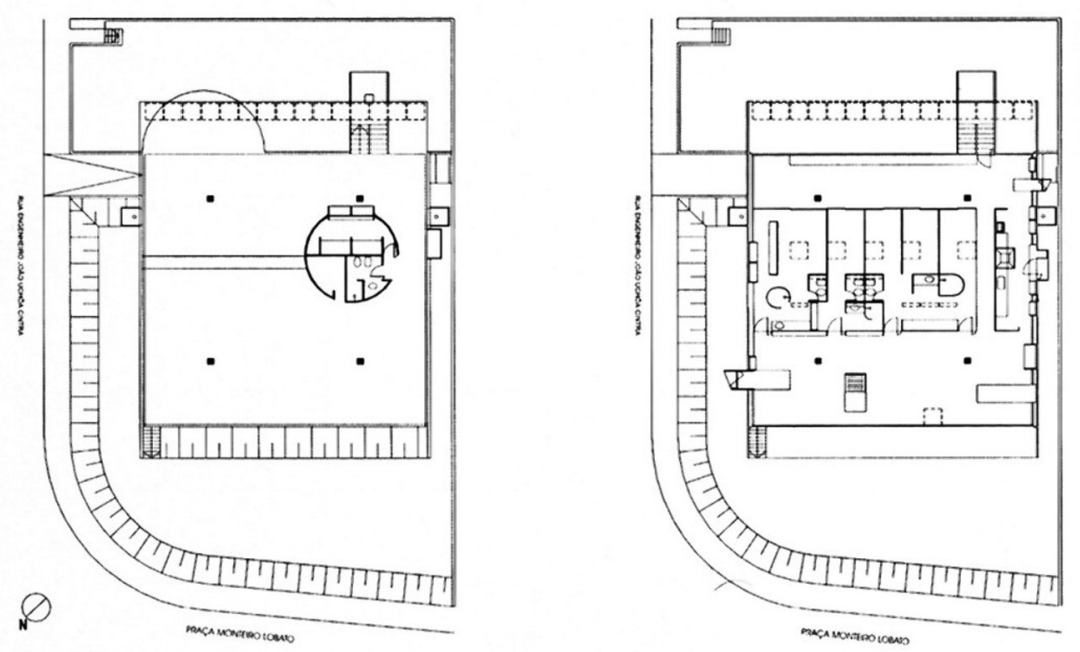

Fig.163. Paulo Mendes da Rocha. Residências Paulo Mendes da Rocha e Luiz Gonzaga Cruz Secco. São Paulo, 1964. [fonte: PIÑÓN, 2002]. 


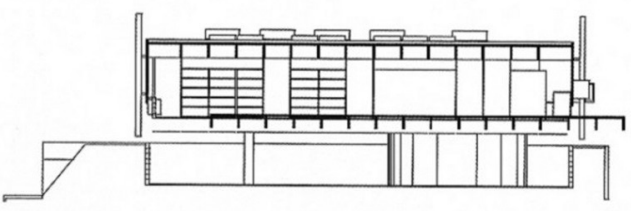

corte transversal

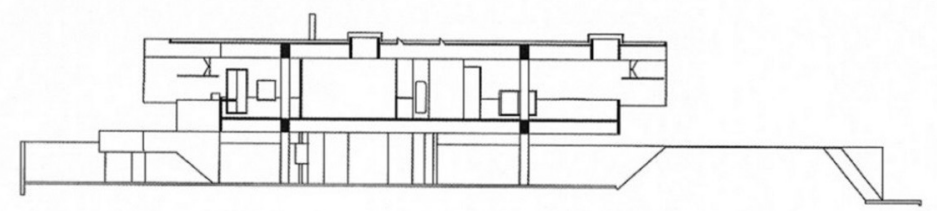

corte longitudinal

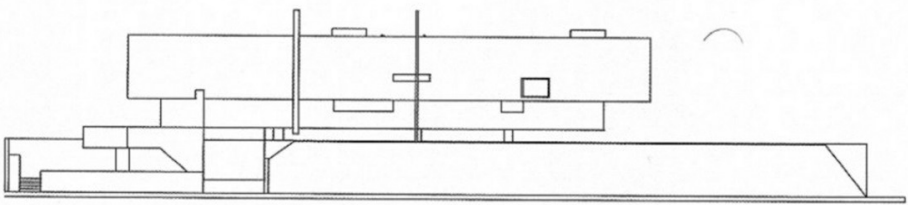

elevação leste

Fig.164. Paulo Mendes da Rocha. Residências Paulo Mendes da Rocha e Luiz Gonzaga Cruz Secco. São Paulo, 1964. [fonte: PIÑÓN, 2002]

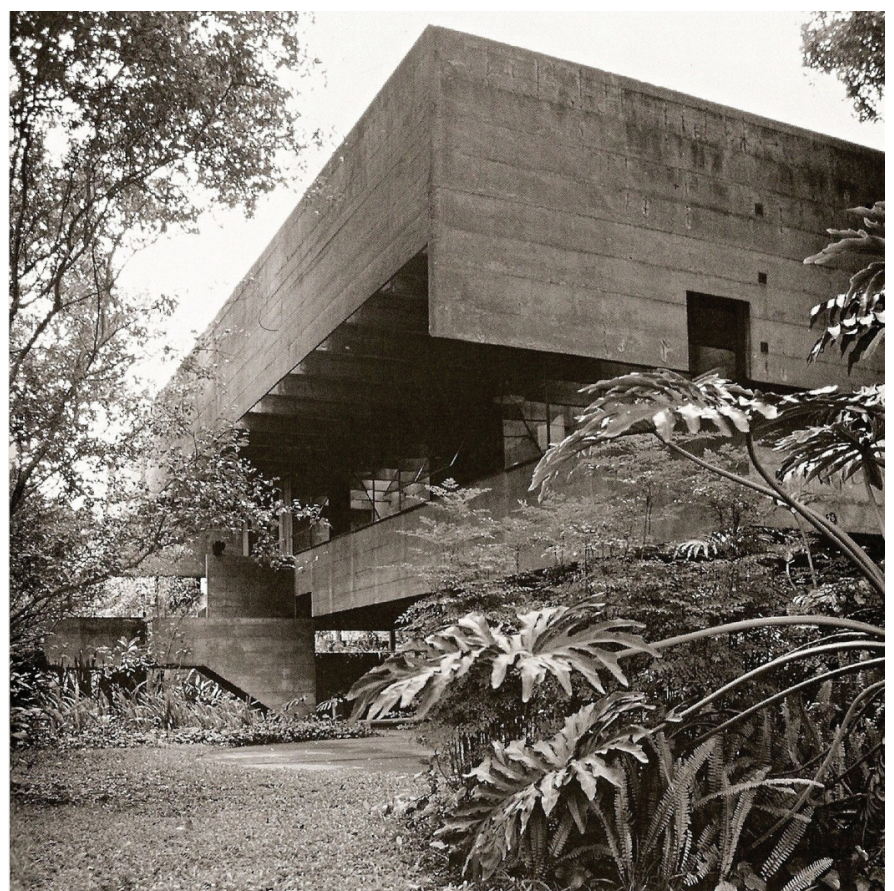

Fig.165. Paulo Mendes da Rocha. Residências Paulo Mendes da Rocha e Luiz Gonzaga Cruz Secco. São Paulo, 1964. [fonte: PIÑÓN, 2002]. 


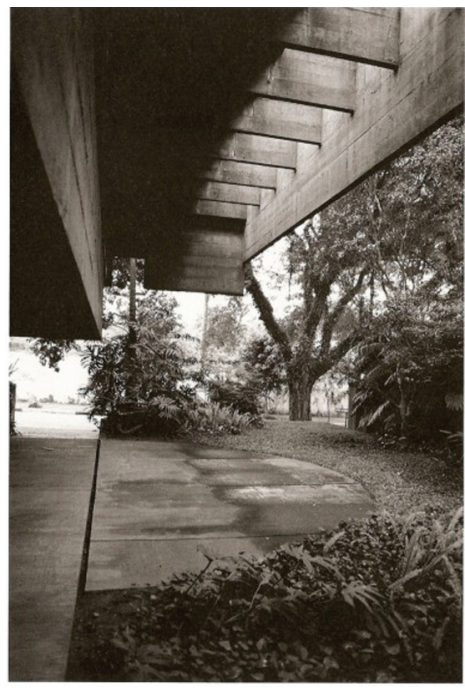

Fig.166. Paulo Mendes da Rocha. Residências Paulo Mendes da Rocha e Luiz Gonzaga Cruz Secco. São Paulo,

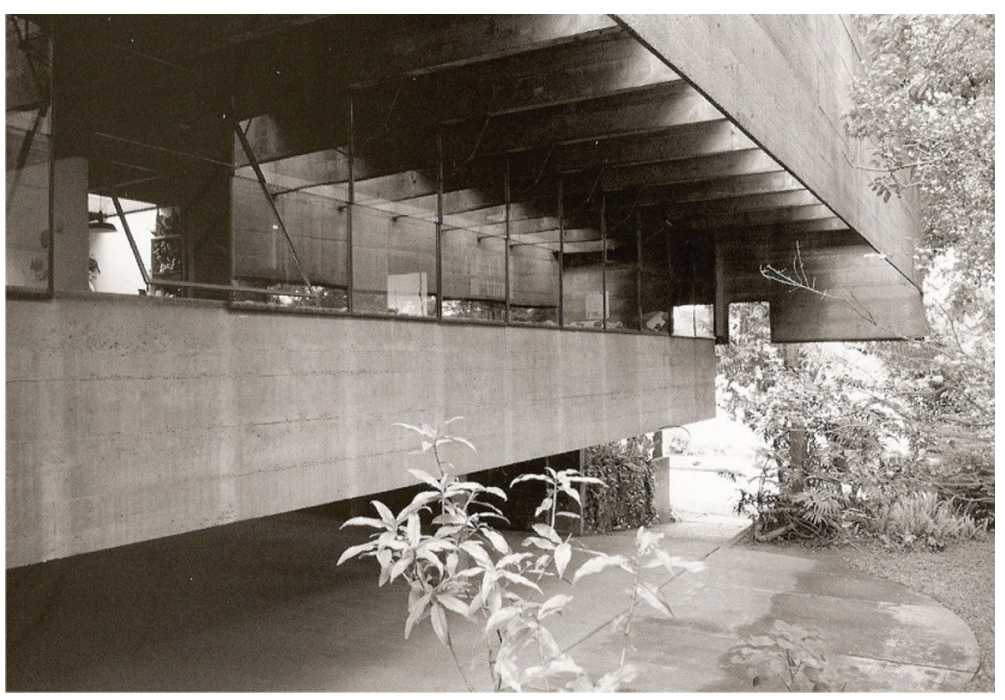

Fig.167. Paulo Mendes da Rocha. Residências Paulo Mendes da Rocha e Luiz Gonzaga Cruz Secco. São Paulo, 1964. [fonte: PIÑÓN, 2002].

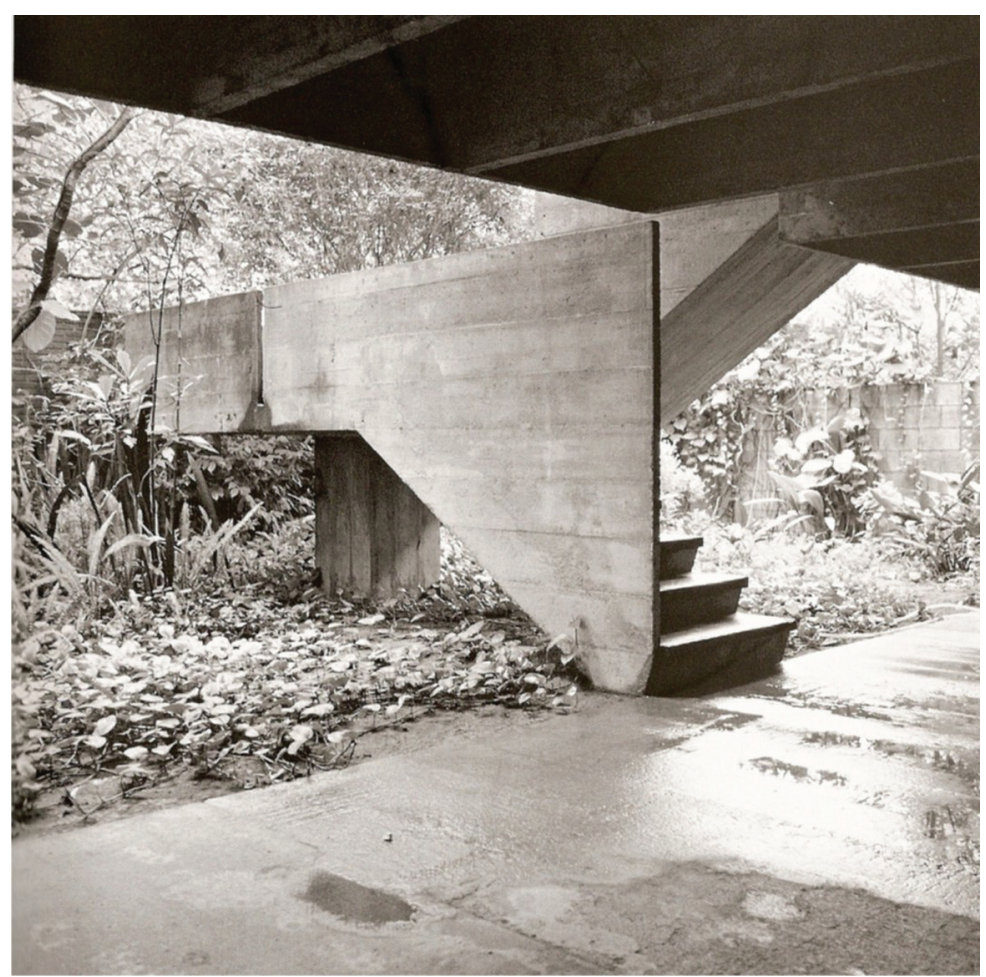

Fig.168. Paulo Mendes da Rocha. Residências Paulo Mendes da Rocha e Luiz Gonzaga Cruz Secco. São Paulo, 1964. [fonte: PIÑÓN, 2002]. 


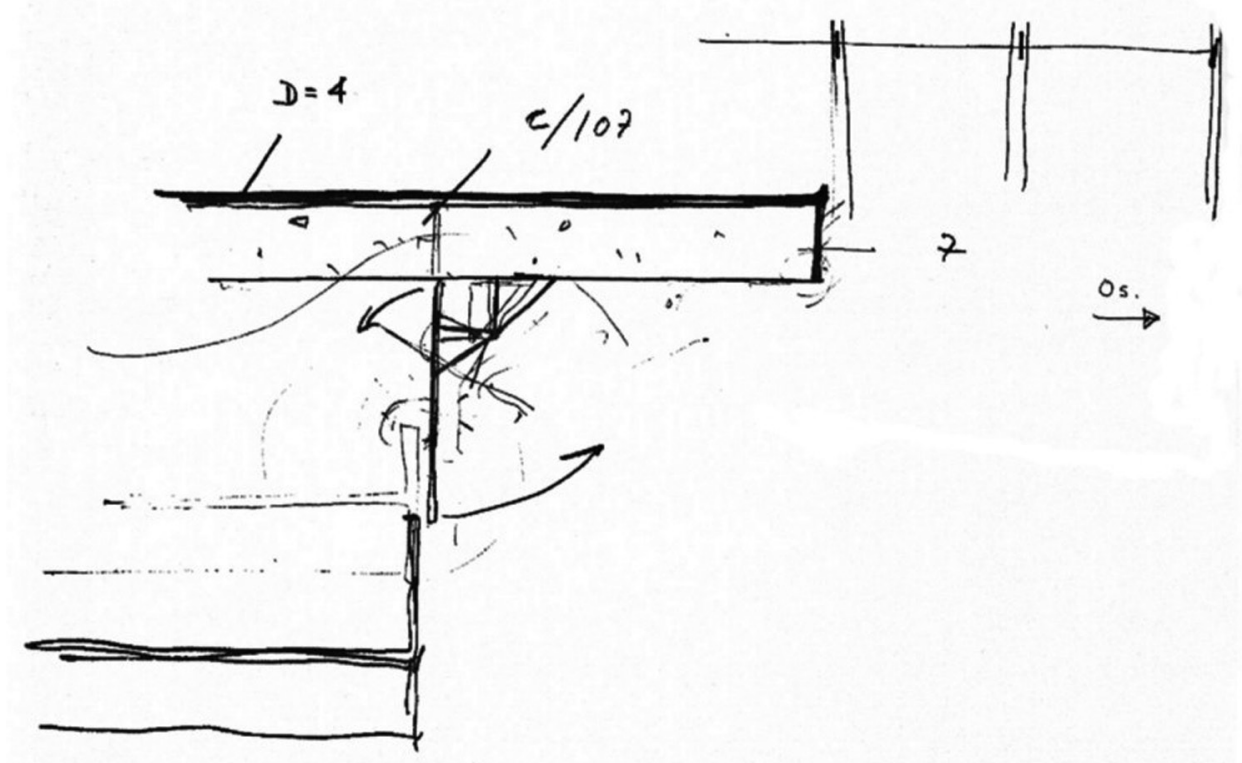

Fig.169. Paulo Mendes da Rocha. Residências Paulo Mendes da Rocha e Luiz Gonzaga Cruz Secco. São Paulo, 1964. [fonte: PIÑÓN, 2002].

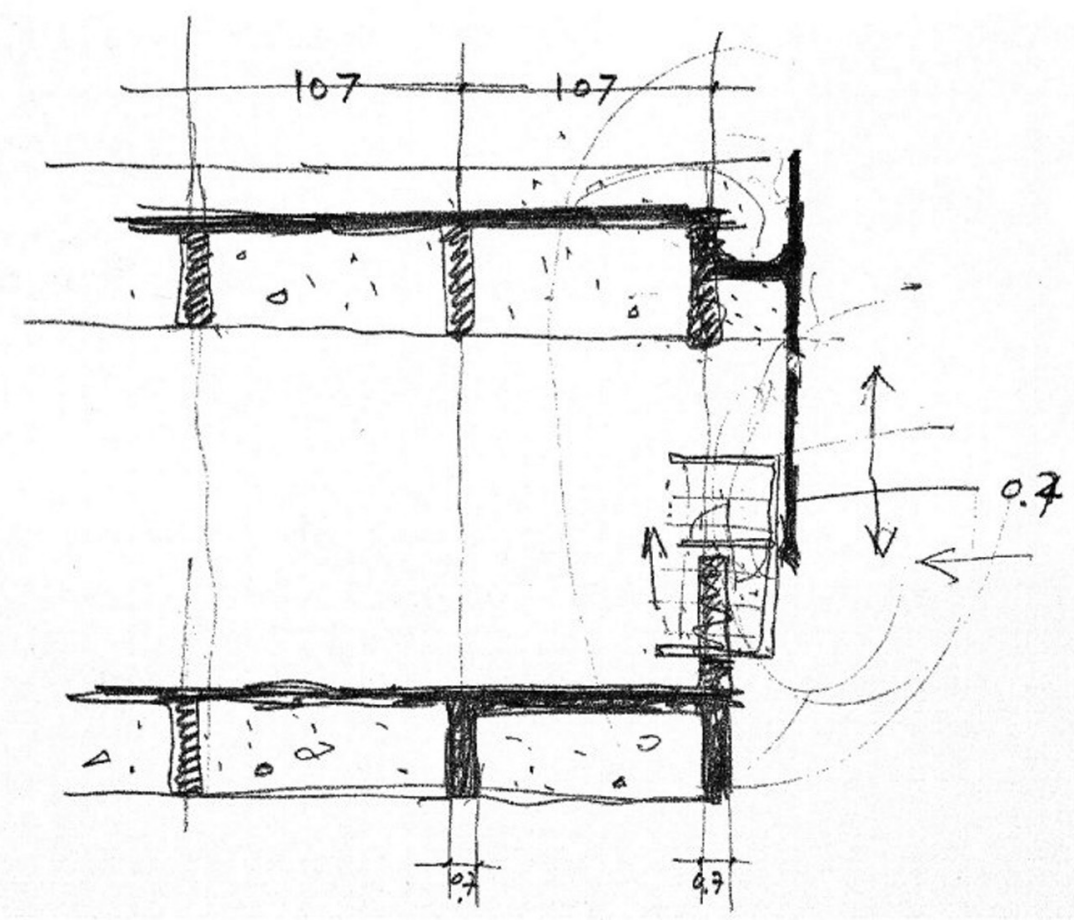

Fig.170. Paulo Mendes da Rocha. Residências Paulo Mendes da Rocha e Luiz Gonzaga Cruz Secco. São Paulo, 1964. [fonte: PIÑÓN, 2002] 


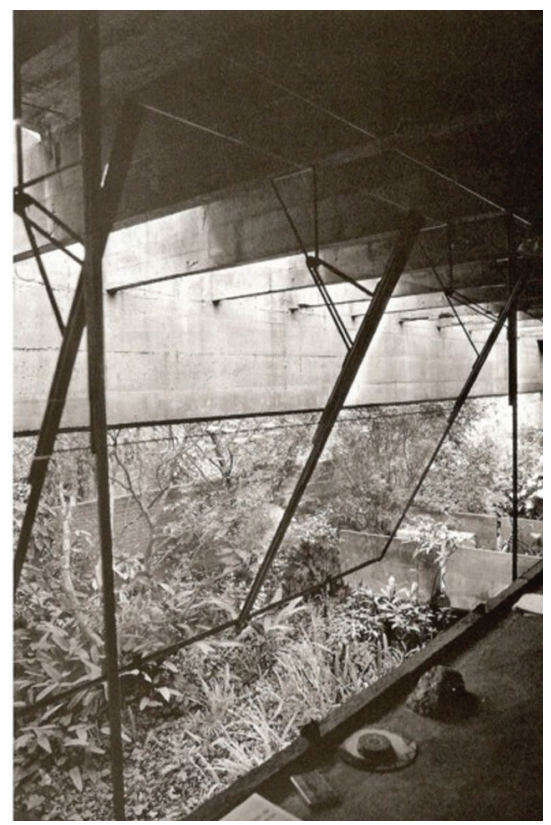

Fig.171. Paulo Mendes da Rocha. Residências

Paulo Mendes da Rocha e Luiz Gonzaga Cruz

Secco. São Paulo, 1964. [fonte: PIÑÓN, 2002]

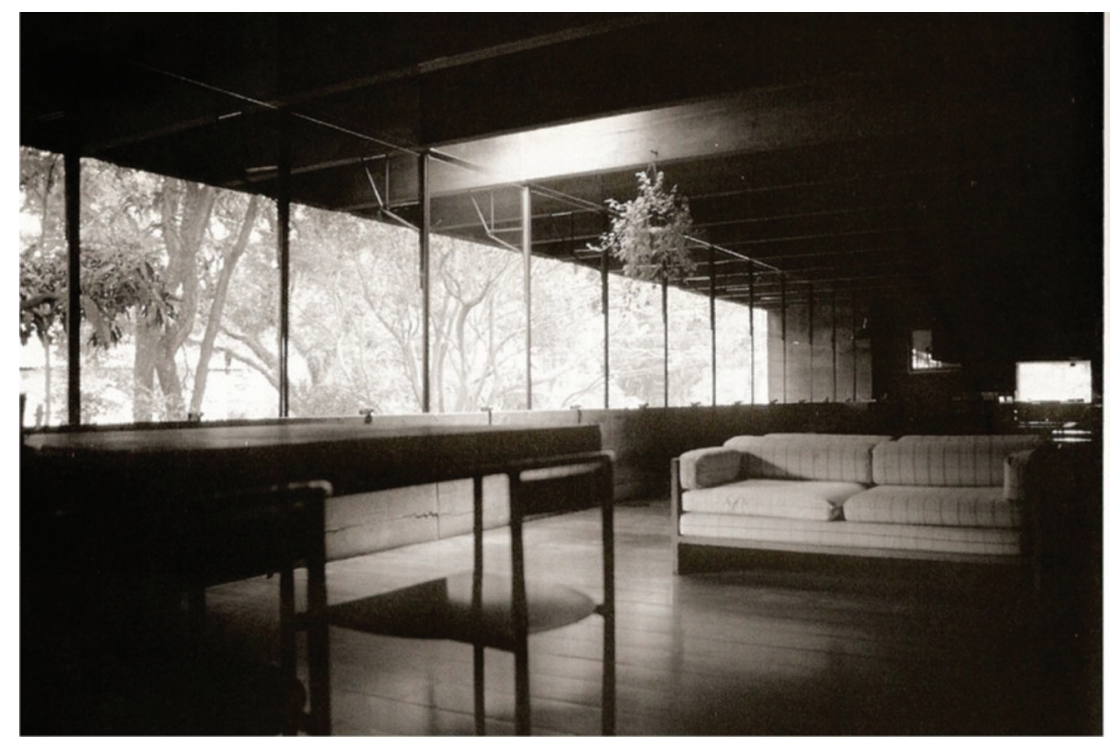

Fig.172. Paulo Mendes da Rocha. Residências Paulo Mendes da Rocha e Luiz Gonzaga Cruz Secco. São Paulo, 1964. [fonte: PIÑÓN, 2002].

Anos mais tarde, em 1988, a Casa Gerassi, também projetada pelo arquiteto Paulo Mendes da Rocha, na maior parte de suas características, parece se revelar como a possibilidade de industrializar o grau de manufatura que as duas casas do Butantã guardavam. 


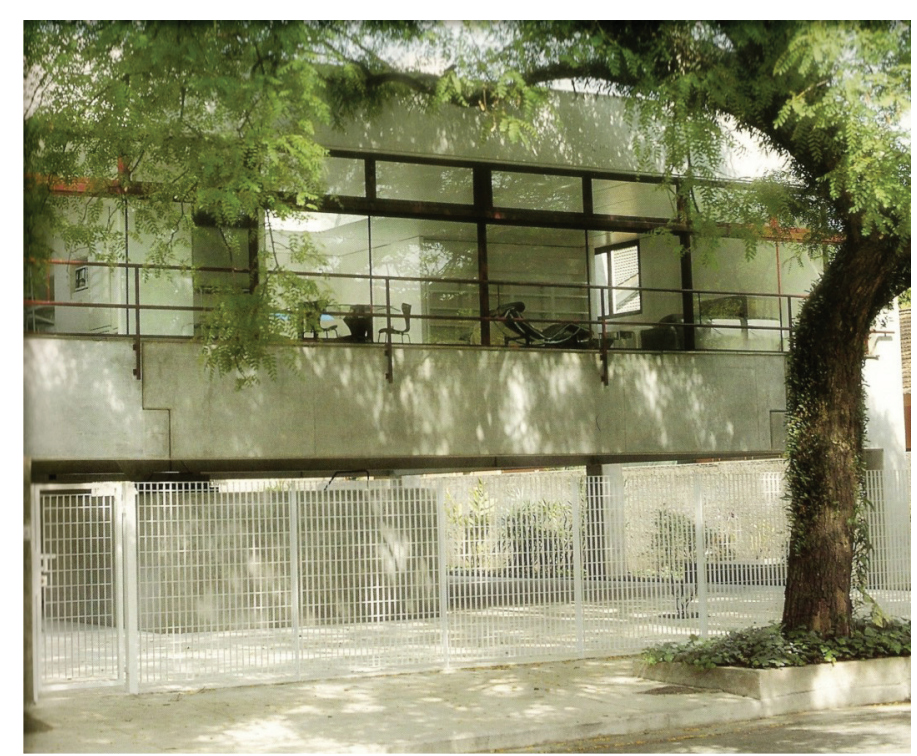

Fig.173. Paulo Mendes da Rocha. Residência Gerassi. São Paulo, 1988. [fonte: PIÑÓN, 2002]

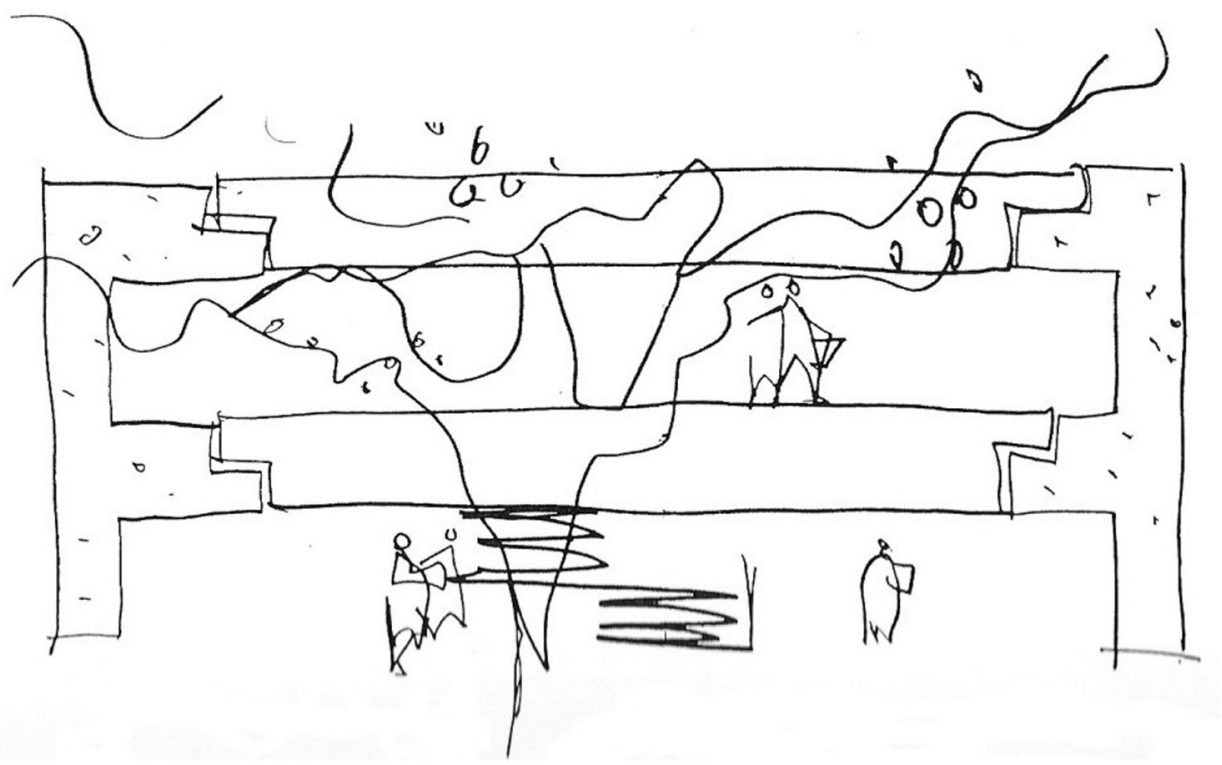

Fig.174. Paulo Mendes da Rocha.

Residência Gerassi. São Paulo,

1988. [fonte: ARTIGAS, Rosa;

2002]. 


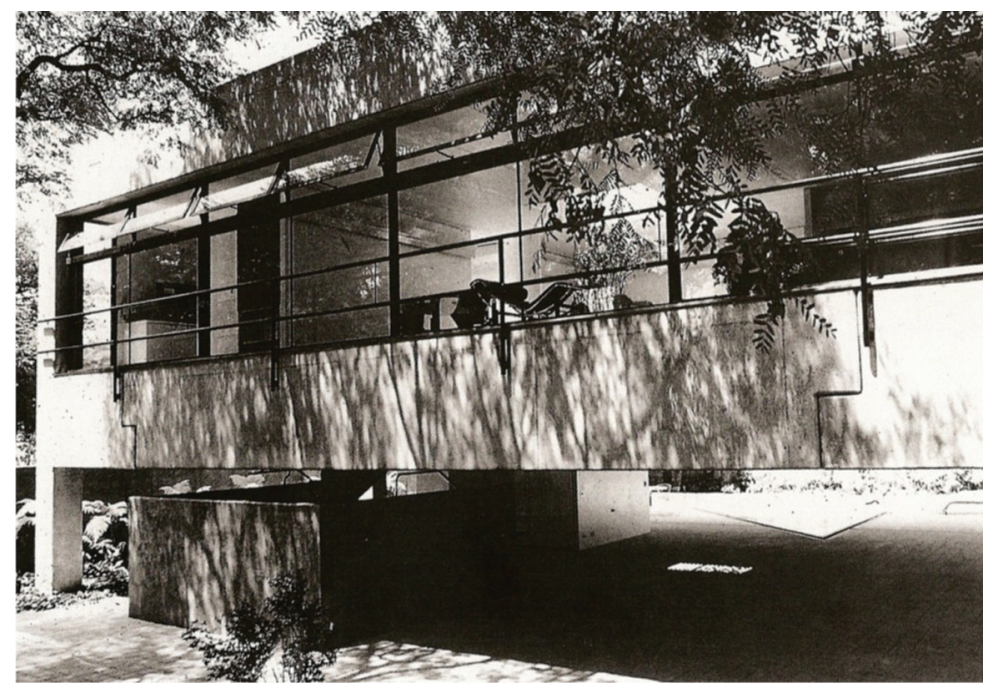

Fig.175. Paulo Mendes da Rocha. Residência Gerassi. São Paulo, 1988. [fonte: PIÑÓN, 2002].

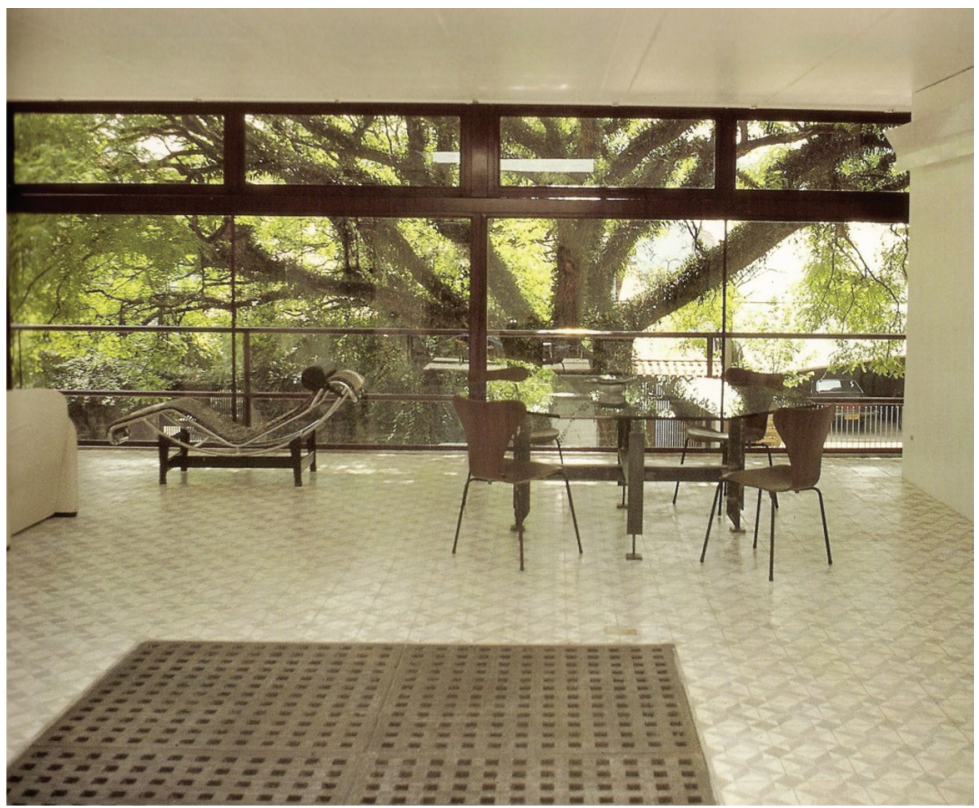

176. Paulo Mendes da Rocha. Residência Gerassi. São Paulo, 1988. [fonte: ARTIGAS, Rosa; 2002]. 

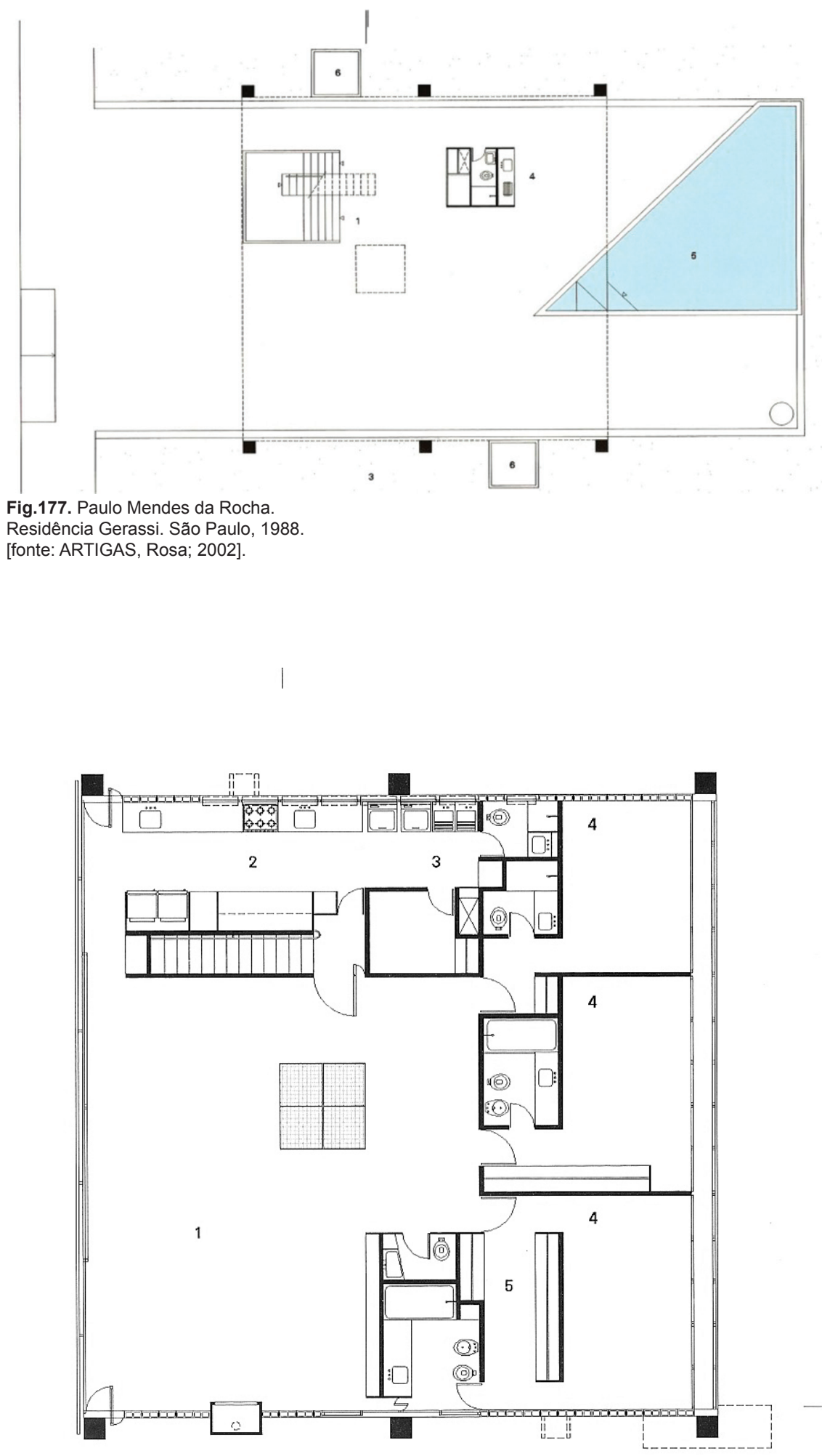

Fig.178. Paulo Mendes da Rocha.

Residência Gerassi. São Paulo, 1988.

[fonte: ARTIGAS, Rosa; 2002]. 


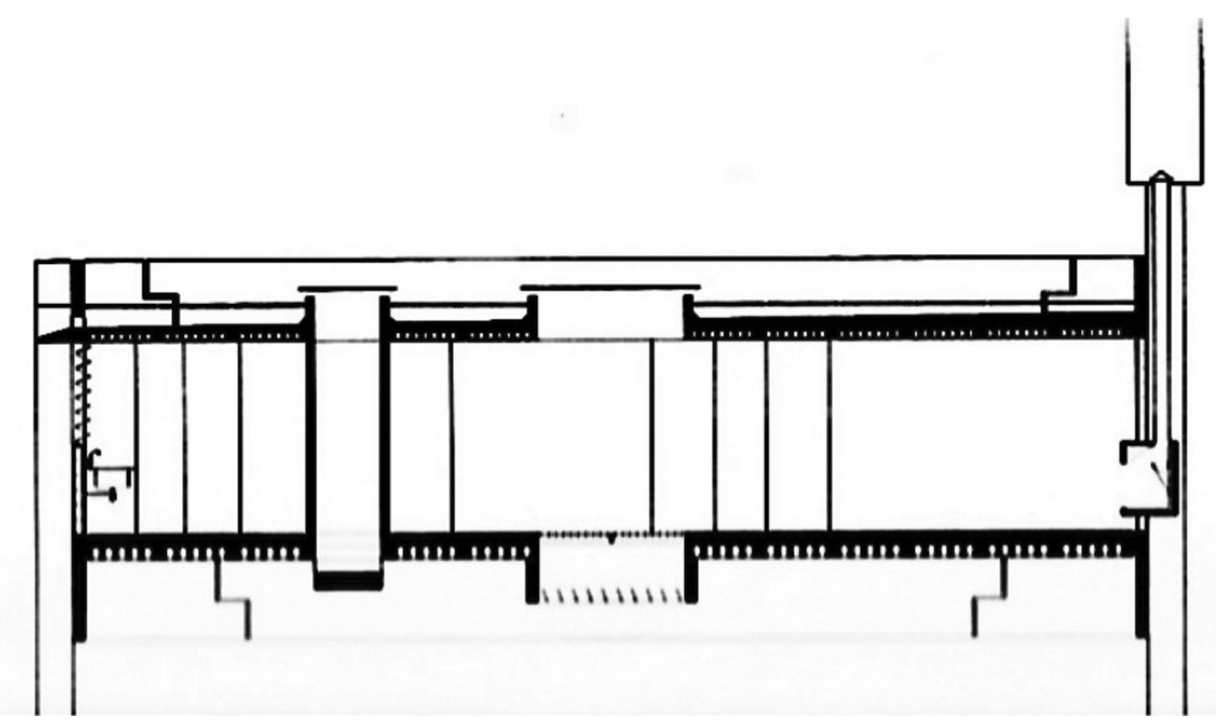

Fig.179. Paulo Mendes da

Rocha. Residência Gerassi. São

Paulo, 1988. [fonte: ARTIGAS

Rosa; 2002].

Fig.180. Paulo Mendes da Rocha.

Residência Gerassi. São Paulo, 1988.

[fonte: ARTIGAS, Rosa; 2002]. 


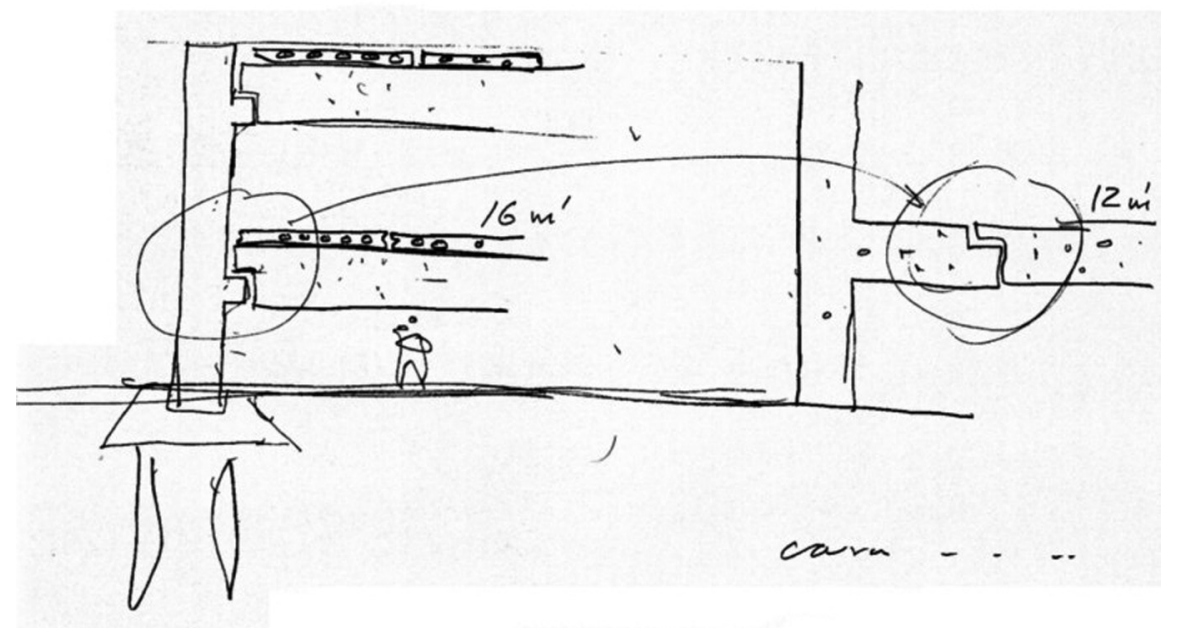

Fig.181. Paulo Mendes da Rocha

Residência Gerassi. São Paulo, 1988.

[fonte: PIÑÓN, 2002]

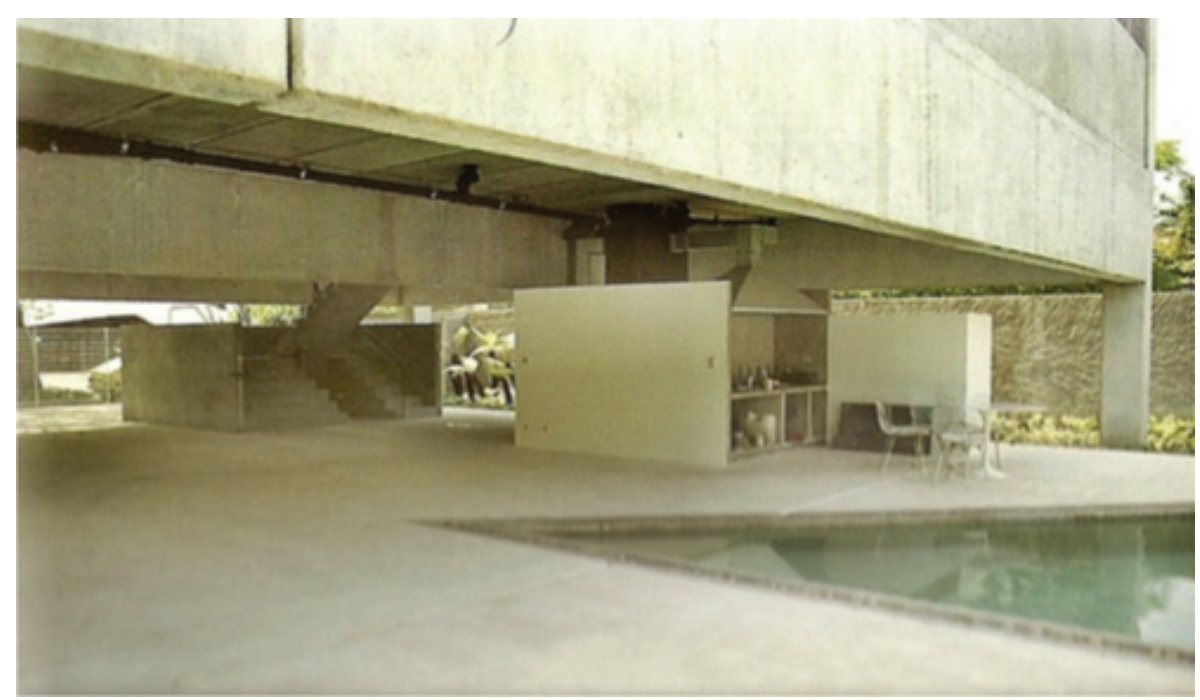

Fig.182. Paulo Mendes da Rocha.

Residência Gerassi. São Paulo,

1988. [fonte: ARTIGAS, Rosa;

2002]. 


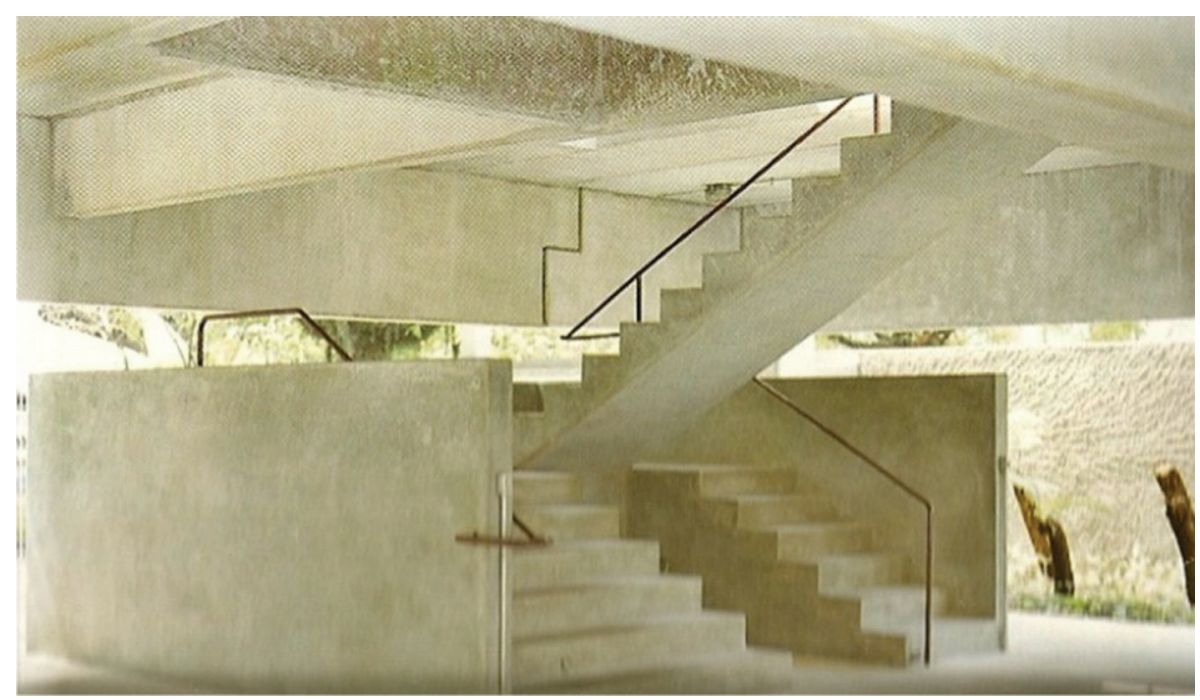

Fig.183. Paulo Mendes da Rocha.

Residência Gerassi. São Paulo,

1988. [fonte: ARTIGAS, Rosa;

2002].

A espacialidade e a qualidade arquitetônica da casa Gerassi é conseguida por meio de um projeto em que o arquiteto ou adota elementos disponíveis no mercado da pré-fabricação da construção civil, ou desenha ele mesmo elementos compatíveis com a execução industrial pretendida. A casa, elevada sobre seis pilares, utiliza peças pré-fabricadas pesadas de concreto armado e protendido, disponíveis no mercado comum e cuja lógica construtiva pode assim ser explicada:

O elenco de peças existentes, limitado sob a forma de arranjos ideais a que se obrigam a desenvolver os fabricantes, representa um desafio ao arquiteto, um ponto de partida para a criação de espaços interessantes e adequados aos 
33. WISNIK, Guilherme in: ARTIGAS, Rosa. Paulo Mendes da Rocha. São Paulo: Editora Cosac \& Naify, 2002 mais variados programas. Seu emprego representa um grande momento de encontro entre invenção formal e utilização de modernos recursos construtivos. Assim, a obra resultou fácil de executar em suas etapas de complementação, como as vedações de concreto e blocos de alvenaria, caixilhos de instalações elétricas ${ }^{33}$.

Na proposição e realização das Casas do Butantã e da Casa Gerassi, a industrialização pesada (estrutura) e a industrialização leve (caixilhos, vedação, instalações elétricas e hidráulicas, etc.) estão presentes. Mas entre uma e outra, uma diferença é fundamental: a primeira casa é uma contribuição da arquitetura para a indústria, e a segunda, de uma apropriação da indústria útil à arquitetura. Algo importante de se comentar aqui, e que deve ser entendido como um reflexo da distância temporal entre as duas experiências, uma em 1964 e outra em 1988, refletindo diferentes estágios da industrialização do país.

Essa possibilidade de leitura da produção arquitetônica de alguns professores da FAU USP, a partir dos seus focos sobre a relação entre a apropriação de tecnologias industriais para arquitetura e a consequente colaboração ao desenvolvimento do país, é uma situação que torna possível aproximar os seus métodos de projeto e execução em arquitetura àqueles que são característicos do desenho industrial. A análise desses condicionantes da arquitetura, produzida em e a partir de São Paulo nesse período, tem a importância de estabelecer uma possibilidade de compreensão da produção desses arquitetos com um sentido de reavaliar e superar prédenominações cristalizadas, como a ideia de escola paulista ou brutalismo. A pesquisadora Koury também afirma esse ponto de vista: 
34. KOURY (2005, pp. 226 e 232).
O rigor na adoção de um sistema de coordenação modular, a diminuição e a conseqüente repetição dos elementos construtivos adquirem importância para uma economia de escala. Marcam, principalmente, uma experiência de padronização de procedimentos projetuais voltados à produção em massa. Essa característica delineia um conjunto arquitetônico e constitui a riqueza e diversidade da produção paulistana do período e sua contribuição para o quadro da arquitetura contemporânea nacional. A possibilidade de organizar essas categorias de análise que representam os diversos vínculos estabelecidos entre projeto de arquitetura e o seu modo de execução contribui para o debate sobre a arquitetura contemporânea e para a constituição de instrumentos de análise mais representativos e substantivos do que chamada escola paulista ou brutalismo paulista ${ }^{34}$.

Para caracterizar os temas de discussão deste capítulo, foram tomadas algumas obras consideradas exemplares sobre os conceitos adotados. De acordo com os limites estabelecidos para o trabalho, privilegiaram-se alguns exemplos de arquitetos professores da FAU USP. Todavia essa é uma discussão ampla na qual pode-se dizer que toda uma geração de arquitetos se envolveu, discutindo e propondo soluções seja por meio de conceituações teóricas, em salas de aula, e das realizações nas pranchetas e nos canteiros, seja mesmo por meio de sua inserção dentro da indústria ou em laboratórios privados ou públicos de pesquisas tecnológicas. 


\section{Considerações Finais}

A evolução do ensino na FAU USP, no período considerado por este trabalho, contém três momentos decisivos para a sua estruturação. São estes: a sua criação em 1948, a sua primeira reforma em 1962 e, finalmente, uma segunda reforma em 1968.

O contexto do país dentro do qual se inscreve esta experiência da FAU USP tem, como tônicas de um discurso geral que perpassava a política, a necessidade de um desenvolvimento econômico, baseado na industrialização, e um empenho no campo social para a realização de reformas de base, como necessidade para a concretização de um desenvolvimento econômico capaz de atingir a todos os estratos sociais.

O nosso período de estudo sobre a FAU USP, conforme apontado, compreende os anos entre 1948 e 1968 que estão contidos dentro da história brasileira em dois de seus momentos mais importantes: o período democrático, entre 1945 e 1964, e o regime militar, entre 1964 e 1985. Entretanto, como considerar um recorte de estudo para a FAU USP, inserido ao mesmo tempo dentro de dois períodos da história brasileira com características políticas tão distintas entre si? Duas são as considerações necessárias a esse respeito.

No plano nacional, ainda que a política trilhasse caminhos totalmente opostos nesses dois momentos históricos, era comum aos dois períodos o empenho relacionado ao desenvolvimento econômico do país e as preocupações com suas consequências sociais. 
E dentro da FAU USP esse mesmo desafio será colocado, construindo-se um debate a respeito da contribuição específica que a arquitetura e o desenho industrial poderiam realizar para esse processo de desenvolvimento econômico e social. E como foi demonstrado, e isso justifica o recorte estabelecido, desde a criação da FAU USP em 1948, com a contratação de seus primeiros professores por Anhaia Mello, até a aposentadoria compulsória pelo regime militar em 1969, dos professores João Batista Vilanova Artigas, Paulo Mendes da Rocha e Jon Adoni Vergareche Maitrejean, dentro da FAU USP, oS atores sociais permaneceram os mesmos. O que mudou, na verdade, foi a receptividade de suas ações. Pois é necessário caracterizar que, no período democrático, o empenho desses professores em criar a FAU USP é aceito pelo Estado, sendo aprovado pelo Decreto Estadual $n$ o 104 , de 21 de junho de 1948. Ao mesmo tempo, dentro do período democrático acontece a Reforma de 1962, cujo período político de liberdade vivido no país permite esta condição de uma nova experimentação prática de estruturação de um curso e de seu método de ensino, ainda que, no plano formal burocrático, as regras da universidade permanecessem as mesmas. Quando da imposição do regime militar em 1964, continuariam esses mesmos professores em seu empenho de atualização de um ensino condizente com as necessidades da realidade do país. O que se alteraria seria a aceitação de seus pontos de vista. Assim é que parte dos nomes dos professores arquitetos da FAU USP está relacionada às listas de investigações internas da Universidade de São Paulo, sendo que depois tem suas ações docentes dentro da Universidade questionadas pelos Inquéritos Policiais Militares, IPMs, do governo militar, até serem compulsoriamente aposentados três de seus professores por decreto do Governo Federal, a despeito de serem funcionários públicos, mas atuantes na esfera estadual. A situação das trajetórias profissionais desses três 
professores dentro da USP, Artigas, Mendes da Rocha e Maitrejean, até as suas suspensões em seus cargos, tem em muito um caráter ilustrativo, por que não foram os únicos a vivenciarem esse processo. Entre outros acontecimentos, a própria Reforma Universitária de 1969, imposta pelo governo militar, atesta a amplitude da ação autoritária dentro da universidade pública brasileira.

De acordo com o apontado, para atender aos requisitos de um curso de arquitetura condizente com a realidade do país, o curso criado inicialmente em 1948 evoluiria dentro de um conjunto de transformações, cuja sublimação desse processo seria a Reforma de 1962. E nessa evolução abandonaria as noções tradicionais de compreensão e ensino de arquitetura. Em lugar dessas, procuraria considerar as experiências contemporâneas, no campo do ensino de arquitetura e de desenho industrial fora e dentro do país. Mas tudo isso captado por um viés crítico, capaz de filtrar pontos de vistas dessas Escolas, com uma apropriação apenas dos elementos capazes de contribuir para a particular forma de ensino de arquitetura e desenho industrial pretendida pela FAU USP. Nesse sentido é que se pode afirmar que a FAU USP, inclusive tudo foi comprovado pelos seus professores em depoimento, olhou para todos os modelos de ensino seja de arquitetura ou desenho industrial, aprendeu com todos eles, mas não reproduziu nenhum. Afirmou-se, também, como um modelo inédito.

Esse modelo, pela prática do ateliê, preconizava que o arquiteto pudesse ter competência profissional para realizar todas as escalas de projeto: arquitetura, urbanismo, design de produtos e design gráfico. O que corresponderia à constituição daquilo que alguns de seus professores definiram como a construção de uma universidade do projeto.

Nessa estruturação do curso da FAU USP, na condição de ter olhado criticamente para outros cursos contemporâneos de arquitetura e de desenho industrial, absorvendo alguns 
elementos, mas não a estrutura total de algum curso em particular, cumpre destacar algumas das diferenças, ou melhor, particularidades, que o ensino de desenho industrial e arquitetura na FAU USP determinou.

A primeira delas diz respeito a se ensinar desenho industrial amparando o estudante na amplitude da formação do profissional arquiteto. Por isto propôs não um curso de desenho industrial único. E sim, dentro do Departamento de Projeto, uma Sequência de Desenho Industrial, cujo funcionamento se objetivava solidário às demais Sequências dentro do Departamento de Projeto - Sequência de Arquitetura, Sequência de Urbanismo e Sequência de Programação Visual. E solidária também aos Departamentos de História e de Tecnologia.

Outro diferencial relaciona-se à contribuição que o Departamento de História constitui para o ensino de desenho industrial da FAU USP. Em muitos momentos do desenvolvimento da arquitetura moderna, na defesa da sua produção pela máquina, pela indústria, negou-se o valor da história ao ensino de arquitetura ou desenho industrial. Nesse contexto, o pressuposto defendido era que a capacidade da máquina de produzir objetos e arquitetura idênticos numa escala planetária levaria à superação de condições culturais particulares locais. Condições histórico-culturais ditadas pelo passado de cada região seriam superadas e uniformizadas pelo novo método de produção comum a todo o planeta. No Departamento de História da FAU USP, esta noção não foi adotada. Ao contrário, foi rebatida por uma série de críticas. E críticas não apenas a partir do campo da cultura e da arte, mas, sobretudo, no campo da política e da economia. Esse é o contexto da crítica do professor Julio Roberto Katinsky, do Departamento de História da FAU USP, endereçada à ESDI-RJ, quando esta Escola adota a experiência da Escola HfG de Ulm, na Alemanha, como um modelo a ser seguido no Brasil. No 
caso da FAU USP, ao contrário do ensino praticado em Ulm, em que o aprendizado de história da arquitetura era visto com reservas, e se iniciando no contexto das realizações da arquitetura moderna e privilegiando-se a sua aplicabilidade imediata ao projeto, na FAU USP, a contribuição do Departamento de História foi outro. O grupo de professores desse departamento sempre conferiu grande importância ao passado da técnica, seja na produção de artefatos, seja da arquitetura, sobretudo analisando as consequências culturais que essa técnica determinava ou em que era determinada. Nesse campo de ação se movimentaram, desde a criação da FAU USP, até no final da década de 1960 e início de 1970, quando institucionalizaram esse ponto de vista, criando uma disciplina específica para tratar da história da técnica na arquitetura, no desenho industrial e no urbanismo, com forte ênfase nos domínios tecnológicos de ocupação do território brasileiro desde o seu descobrimento.

Um terceiro ponto que singulariza o ensino na FAU USP diz respeito a uma reconceituação da arquitetura, aproximando-a dos métodos do desenho industrial. Nesse ponto, pode-se considerar que a FAU USP se aproxima do preconizado pela HfG de Ulm, em que a Escola alemã defendia que a arquitetura fosse transformada em desenho industrial e que a arquitetura se tornasse construções industrializadas. Os discursos das duas Escolas são próximos, ainda que nesse aspecto nenhum fato, documento ou depoimento comprove uma filiação direta da Escola brasileira à Escola alemã. Ainda há que se considerar, por outro lado, que esse pensamento na FAU USP se constrói com um diferencial da Escola alemã. Esse diferencial está relacionado à elaboração desse ponto de vista da FAU USP como uma contribuição ao processo de evolução das condições econômicas e sociais do país. Enquanto, na Alemanha, a HfG de Ulm está se constituindo dentro de uma nação em que já Ihe é familiar a cultura da indústria, mesmo que se considere que o surgimento 
da HfG ocorre após a Segunda Guerra Mundial. No caso do Brasil, a intenção de uma arquitetura industrializada, que a FAU USP defendia, não encontrava uma indústria da construção civil pronta para levá-la a cabo, nem na iniciativa privada, nem amparada pelo poder público. Tamanho é o limite da industrialização da construção civil brasileira no período, que as experiências da arquitetura nessa área são na maioria de pré-fabricação com o uso apenas do concreto. Assim sendo, como foi demonstrado nos exemplos do Capítulo 5 do trabalho, a maior parte das empreitadas de industrialização do canteiro de arquitetura pelos professores da FAU USP se viu limitada por não encontrarem uma indústria capaz de suprir suas demandas de elementos industrializados da construção civil. E várias dessas obras se limitaram às características de protótipos, no sentido de não absorver a indústria, mas sim de informar a sua ausência.

O limite proposto a este trabalho o encerra em 1968, pois objetiva dar conta de um momento que consideramos pioneiro pela estruturação e implantação de um novo ensino de desenho industrial e de arquitetura dentro da FAU USP, dentro de um contexto político, social e econômico com algumas características comuns e que giravam em torno da definição de um projeto de desenvolvimento econômico e social para o país. Como afirmamos, a maneira como a FAU USP conjuga o ensino de desenho industrial e de arquitetura é único no Brasil. $\mathrm{E}$ sobre suas consequências vale indicar duas constatações. As décadas seguintes a esse período, isto é, a partir de 1970, no Brasil houve uma proliferação enorme de novos cursos de Arquitetura e Urbanismo ou de Desenho Industrial. O modelo de ensino que a FAU USP determinou, no período de nosso estudo, serviu unanimemente de modelo para praticamente todos os demais cursos de Arquitetura e Urbanismo que vieram a partir de 1970, ou para as reformulações pelas quais passaram antigos cursos. Mas quanto ao ensino de desenho industrial, 
dentro do curso de arquitetura, esta foi uma ideia que não foi adotada, o que é comprovado pelos inúmeros cursos autônomos de desenho industrial que também surgiram no país, após a década de 1970. O limite desta discussão proposta pela FAU USP, nesses anos, de integrar em um só curso a formação do arquiteto e do designer, parece ser colocado pela própria Escola, quando cria em 2006 dentro da FAU USP, além da graduação em arquitetura e urbanismo, uma outra graduação exclusiva em design, com a possibilidade de uma dupla atuação: desenho industrial ou programação visual. Nesse contexto, a FAU USP passa a formar profissionais de desenho industrial que não são arquitetos, ainda que os formadores, isto é, os professores, sejam, na maioria, arquitetos. E isto se configura como uma ruptura do proposto à época de sua Reforma de 1962, ainda que alguns professores em depoimentos informem que se trata de um curso de design cujo diferencial seja estar dentro de uma escola de arquitetura e sendo ensinado, em boa parte, por arquitetos.

Entre as décadas que transcorreram entre 1968 e 2006, muitas mudanças de rumos se processaram no país e, em consequência, tiveram um rebatimento na compreensão do ensino de arquitetura e desenho industrial dentro da FAU USP. Após o período de nosso estudo, no caso do Brasil, são efetivadas determinadas características de um modelo de desenvolvimento econômico e social, em muito consequente das ações nesses campos estabelecidas durante o regime militar. O país vive, a partir de 1985, o seu processo de redemocratização política. No caso da FAU USP, também um quadro de mudanças se processou, a partir de 1968. Três de suas lideranças, Vilanova Artigas, Paulo Mendes da Rocha e Jon Maitrejean, são afastadas de suas atividades de ensino na Escola. Ainda no campo do ensino de desenho industrial e de arquitetura, a Escola passa a contar com novos professores com novas visões, como Décio Pignatari e Lucrecia Ferrara que, contratados 
em 1974, passam a relacionar dentro da FAU USP o ensino de desenho industrial com o ensino de semiótica. Esses são apenas alguns exemplos pontuais de toda uma série de mudanças pelas quais a Escola passaria, depois de 1968.

$\mathrm{Na}$ historiografia da arquitetura e do design brasileiros, quando a questão do ensino é colocada em foco, muito pouco há sobre o ensino de desenho industrial praticado pela FAU USP. O que não ocorre, com a mesma negligência, com a experiência contemporânea que foi a ESDI. Nesse sentido, com a produção deste trabalho julgamos realizar uma contribuição, não no sentido de dar conta de toda a amplitude da história do ensino de desenho industrial da FAU USP, mas sim de colaborar para a compreensão dos seus primeiros episódios, nos seus primeiros anos de existência (1962-1968).

Com um sentido complementar a este trabalho, novas pesquisas podem ser desenvolvidas com um olhar focado no desenvolvimento posterior as esses primeiros anos de ensino na FAU USP do Desenho Industrial e sua relação principalmente com a industrialização da arquitetura, do edifício, mas não somente. Ainda poderia ser importante uma abordagem da relação desta experiência de ensino de Desenho Industrial com as áreas de Programação Visual e Urbanismo, também abordados pela FAU USP.

A partir de 1968, como afirmado, os contextos político, econômico, social e cultural do país adotam um novo rumo. Este quadro de transformações tem seus rebatimentos no contexto do ensino universitário, no país. No caso da FAU USP, levaria a Escola a repensar alguns pontos de vistas sobre desenho industrial e arquitetura, gestados nos anos anteriores a 1968, quando se havia uma expectativa de mudanças econômicas, políticas, sociais que enveredaram depois por outro caminho, não esperado.

Uma avaliação do ensino do Desenho Industrial sob a 
forma de curso de pós-graduação na FAU USP, que se inicia a partir de 1974, e sua relação com o ensino de graduação, também pode ser muito importante para se compreender a posterior evolução da Sequencia de Desenho Industrial dentro do Curso de Arquitetura da FAU USP.

Ainda há que se acrescentar que, se como informamos, os primeiros anos de ensino de Desenho Industrial na FAU USP, e sua relação com a arquitetura, se faz num contexto de pioneirismo, pela existência de poucas outras instituições dedicadas a tal formação, após 1968 esse quadro se altera. Uma quantidade considerável de novas escolas de Desenho Industrial e de Arquitetura são estabelecidas no Brasil. Quais inter-relações neste contexto foram estabelecidas entre esse novo conjunto de escolas dedicadas ao ensino de projeto, seja em arquitetura ou desenho industrial e a FAU USP?

No ano de 1985 se inicia dentro da FAU USP, através de uma comissão de professores, a elaboração de uma proposta de se constituir um curso de Desenho Industrial independente do curso de Arquitetura Urbanismo. Proposta essa que se efetiva, como afirmado, em 2006, com a abertura do curso de Design dentro da Escola. Quais novos diálogos são construídos entre essas duas áreas de projeto, divididas agora entre dois cursos de graduação?

A pertinência de todas as discussões expostas através deste trabalho, bem como as novas pesquisas sugeridas, são construídas a partir de um conjunto de indagações como uma contribuição para se pensar sobre a importância atual de se relacionar o ensino de design, de arquitetura e de urbanismo como experiências comuns de uma mesma atividade: fazer o projeto. 

anexos 


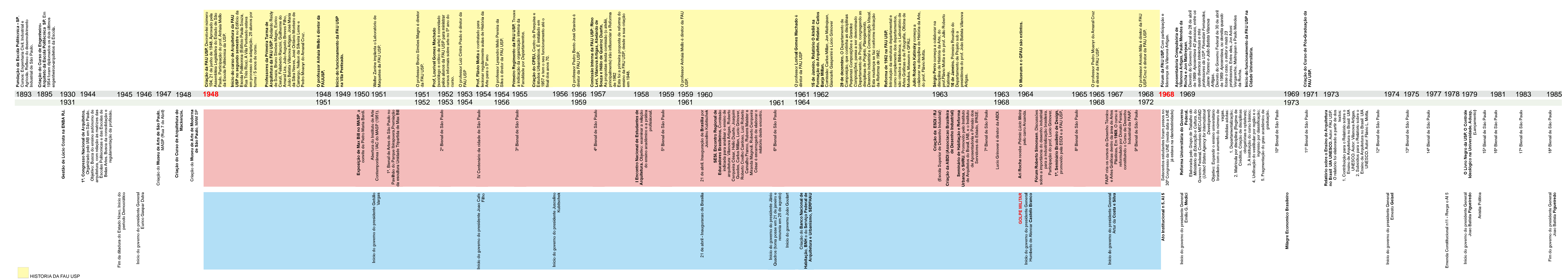


Entrevista: Prof. Lúcio Grinover

Data: 04 de março de 2009.

Local: Escritório do prof. Lúcio Grinover

L.G. - Lúcio Grinover

J.P. - Juliano Pereira

J.P. - O professor estudou na FAU USP entre os anos de 1954 e $1957 . .$.

L.G. - Entre 1953 e 1957. Entramos em 1953 e saímos em dezembro de 1957.

J.P. - Foi um período que antecede a reforma de 1962 e a implantação da centralidade do ateliê dentro do curso, e das Sequências, entre elas, a de desenho industrial. Eu gostaria de saber do professor como que era a FAU USP nesse período pré-1962? Havia alguma discussão relacionada a desenho industrial e industrialização da arquitetura? Esses temas já estavam presentes e de que forma?

L.G. - Mais desenho industrial do que a industrialização da arquitetura. Isso não tem a menor sombra de dúvida, tudo isso aí veio inclusive pelo fato de que alguns dos nossos colegas foram dar umas voltinhas pela Europa e trouxeram de lá uma série de conceitos e ideias relativas ao desenho industrial, e aí que em 1962. Realmente, em 1962 começaram as discussões mais interessantes. Mas nessa época se pensava muito pouco em termos de 
desenho industrial, quer dizer, em produto industrial brasileiro, com todas as características de um bom desenho. Não se pensava muito nessa época. Nessa época nós tínhamos a estrutura de cátedras ainda, como eram todas as estruturas das várias escolas da universidade. Então se tinha o catedrático e o assistente, e os programas eram desenvolvidos em função de certo tipo de complexidade que você ia acumulando conforme fosse $01^{\circ}, 2^{\circ}, 3^{\circ}, 4^{\circ}$ ano. Claro que todo mundo pensava, lia revistas, essas coisas todas, percebia que, pelo menos de início, um certo tipo de industrialização do produto, como da própria arquitetura, mas realmente as discussões dessa época, pelo menos que eu me lembre, não tinham muita profundidade.

J.P. - E sobre esse período, fiz uma pesquisa nos arquivos do Departamento de Projeto para ver o que tinha de ficha de disciplina que pudesse estar relacionado com essa questão da produção do objeto, e pude perceber que tinham as disciplinas de Composição...

L.G. - Que eram projetos de arquitetura...

J.P. -...mas que compreendia plástica também e, através do levantamento, me pareceu que a que chegava mais próximo a essa discussão da produção do objeto era...

L.G. -...era arquitetura de interiores...

J.P. - É o que era chamado de Composição Decorativa, que era do Prof. José Maria da Silva Neves, e que, me parece, ficava no meio termo, porque tinha preocupações de pensar a decoração na arquitetura, e, em outros, já tinha uma tentativa 
de entrar nessa discussão do desenho industrial.

L.G. - Isto aqui... De que ano é isso daqui? (apontando para a cópia da ficha da disciplina Composição Decorativa)

J.P. - É de 1959.

L.G. - 1959. Sim, porque você vê, por exemplo, que aqui já fala em organização e equipamentos de ambientes comerciais. Mas isso aqui já era aquilo que era decoração mesmo. Organização de ambientes religiosos, organização.... Quer dizer, o desenho industrial entrava, como início, numa discussão que poderia ter sido e que depois ficou muito mais ampla. Por exemplo, nós não pegamos mais, nem discutimos mais em relação a equipamentos de ambientes comerciais, a não ser em função de certos tipos de equipamentos que podiam ser produzidos industrialmente, isso foi a partir de 1962-63, que foi quando se implantou a questão do desenho industrial.

J.P. - E o prof. José Maria da Silva Neves era preocupado com essa discussão do desenho industrial?

L.G. - Eu não fui assistente dele nesse período todo. Ele era preocupado em termos, ele estava muito mais nessa composição decorativa dos ambientes, que propriamente no desenho do produto. Quem estava lá como assistente dele era justamente o Abrahão (Sanovics) e aquele outro rapaz... Como é que chama o... Que foi para São Carlos depois e morreu lá em São Carlos...

J.P. - O Gastão (Luiz Gastão de Castro Lima)? 
L.G. - Isso, o Gastão. Esses dois eram assistentes dele, quer dizer, o Abrahão, sobretudo. Nem tanto o Gastão, (o Abrahão) estava muito mais interessado na questão do desenho industrial, tanto que ele foi um dos primeiros a sair do Brasil para fazer um estágio lá na Europa. Lá, ele trabalhou com designers importantes, trouxe uma série de ideias para a Faculdade. Mas o projeto todo dessa disciplina (Composição Decorativa), até a Reforma (da FAU USP de 1962), era justamente mais organização de espaços religiosos, essa coisa toda. O desenho industrial entrava como algo que tentava quebrar um pouco as velhas estruturas.

J.P. - Temos esse quadro pré-1962, que o professor descreveu. Em 1962 nós temos o início da Sequência de Desenho Industrial...

L.G. - Se me lembro bem, a Sequência começou a funcionar mesmo em 1963... Se me lembro bem! Não sei se há algum documento aí que fala em 1962.

J.P. - Essa publicação data de 1963 e apresenta trabalhos de Desenho Industrial realizados pelos alunos no ano letivo de 1962. (apresentando a publicação: FAU USP. Desenho Industrial 1962. São Paulo: Departamento de Projeto FAU USP, 1963. 82p.)

L.G. - Bom, posso estar enganado... 1962, 1963, mas também não é muito mais nem muito menos.

J.P. - Dentro desse período, quando se pensou nessa Sequência de Desenho Industrial, ao que o professor se lembra, a FAU USP chegou a olhar para modelos estrangeiros, porque tivemos os VKhUTEMAS na 
União Soviética, depois a experiência da Bauhaus que vai até 33 , ou mesmo a experiência da HfG Ulm (Hochschule für Gestaltung / Escola Superior da Forma, Ulm - Alemanha), que se desenvolve de 1953 até 1968, ou seja, esta última escola, uma experiência de ensino de desenho industrial, que coexistiu junto com a Sequência de DI da FAU USP. Dentro desse processo de se preparar a Sequência de Desenho Industrial da FAU USP, qual era o olhar lançado sobre essas experiências estrangeiras?

L.G. - Um olhar de interesse, sobretudo, de ver como eles tinham introduzido essas questões no âmbito do ensino e como estava se desenvolvendo o ensino lá na Europa, particularmente. Não trouxemos e não implantamos modelos de ( $H f G$ ) Ulm ou uma coisa parecida. Quer dizer, se discutia ( $H f G$ ) UIm. Mesmo porque tinham algumas pessoas que foram para (HfG) Ulm. vieram dois, saíram de lá, um era o (Karl Heinz) Bergmiller que se formou mesmo em ( $H f G$ ) UIm, com diploma de desenhista industrial e o outro é o Wollner. Mas o Wollner não terminou o curso. Ele deve ter frequentado alguns anos e depois veio para cá. Wollner era um gráfico, artes gráficas. Então essas influências todas tiveram a sua consequência com relação à gente, particularmente no que dizia respeito à metodologia de projeto, tanto que no começo do desenho industrial na FAU USP, nós convidamos um, também formado em (HfG) UIm, o Andries van Onck, desenhista industrial formado em (HfG) Ulm. Se não me engano, contemporâneo de Bergmiller. Ele começou a trabalhar em diversas empresas italianas, tipo Rinasciente. E o van Onck veio para cá introduzindo, ou tentando introduzir uma metodologia para o projeto do desenho industrial. Tanto é que ele deu um curso chamado Metadesign. 
J.P. - Eu trouxe uma cópia da apostila desse curso. Eu gostaria que o professor pudesse falar um pouco desse curso de Metadesign e qual o rebatimento que ele teve de fato na FAU USP?

L.G. - Teve um rebatimento muito forte no instante em que nós começamos a projetar. Isso aqui (apontando para a apostila) é uma metodologia de trabalho no desenho industrial. Agora o que ele disse ou não disse, palavra que não me lembro, mas isso daqui quem foi que escreveu?

J.P. - São anotações sobre este assunto, são anotações de aula do van Onck.

L.G. - E quem anotou isso em aula?

J.P. - Estava numa apostila da professora Marlene Picarelli, datada de 1966.

L.G. - Tudo bem, tudo isso teve consequências muito fortes na parte de projeto, mas não só no projeto de produto. Também se começou por aí a fazer arquitetura industrializada, então essa mesma metodologia foi aplicada à arquitetura, em alguns aspectos ela se aplicava perfeitamente. Essa foi a importância dessa maneira de ver do Andries van Onck.

J.P. - Quando olhamos para as escolas europeias, seja a Bauhaus, a HfG de Ulm, ou os VKhUTEMAS, sempre havia um curso introdutório, e que era de grande importância, que era o que eles chamavam de Curso Básico. E, geralmente, depois desse Curso Básico, o aluno faria opção para a especialidade que ele gostaria de seguir. No caso das disciplinas de 
Desenho Industrial da FAU USP, pelo que pude ver pelos programas, me parecia que o primeiro ano do Curso de Desenho Industrial buscava cumprir essa função, de ter um caráter de curso básico.

L.G. - Uma espécie de propedêutico, digamos, de Desenho Industrial. Mais ou menos. A ideia inicial era dar uma consistência ao ensino de Desenho Industrial e, portanto, ao Desenho Industrial. Por isso fizemos, não me lembro exatamente quando, como de que jeito, mas fizemos uma espécie de introdução ao desenho industrial, daquilo que se fazia lá fora. Claro que as condições lá fora eram completamente diferentes das nossas, mesmo em nível de ensino. O que se fazia lá fora não se podia repetir aqui, nós não tínhamos as condições que eles tinham para realizar este tipo de trabalho, digamos assim, por isso nos baseamos naquilo que nós tínhamos e na nossa realidade. Nem tudo que veio de lá pode ser transferido para a situação brasileira, quer dizer, nós tentamos encontrar a nossa linha de Desenho Industrial, a nossa linha de produto, senão ficamos com produtos importados. E não valeria a pena se preocupar com desenho industrial aqui.

J.P. - E dentro dessa procura de um produto brasileiro, existia, já nesse período, a discussão de uma identidade desse produto?

L.G. - Sim. Sempre teve a preocupação de uma identidade de um produto brasileiro, o que eu acho que naquela época era extremamente difícil de encontrar, dando ideia de que a coisa podia ser identidade nacional, mas era difícil. A questão da identidade era uma questão extremamente delicada, como hoje também é uma questão delicada, até que ponto se podia pensar em um desenho industrial 
verdadeiramente brasileiro. Isso o que queria dizer? Ninguém de nós sabia realmente o que era, e você ia pela arte brasileira, pelo folclore brasileiro e por aí se tentava achar as raízes de um eventual desenho industrial brasileiro, mas nós tentamos discutir, acredito, contudo não me lembro de chegarmos a uma conclusão sobre a questão da identidade. Claro que você tinha materiais diferentes dos europeus, a exemplo dos grandes sucessos que tiveram lá fora, alguns desenhos nossos, como da Poltrona Mole do nosso amigo do Rio de Janeiro (arquiteto Sérgio Rodrigues). O que tinha de brasileiro? Antes de tudo tinha a madeira. Jacarandá da Bahia não era uma madeira europeia, nem norte-americana, ou africana, no caso era brasileira. $O$ fato de você ter um certo tipo de desenho que podia resumir um certo tipo de maneira de encarar o ócio, o descanso do brasileiro, está bom, você está forçando um pouco a barra. A cadeira mole é um desenho brasileiro, sim, é um desenho brasileiro, mas ele traduz essa identidade brasileira? Em termos, certo... digamos que você tentou, quer dizer, ele tentou, de forma a chegar próximo daquilo que poderia identificar um certo tipo de cultura brasileira, sim, sem dúvida nenhuma. Hoje estamos dizendo isso com muito mais clareza com que poderíamos ter dito, mas essa questão da identidade é uma questão extremamente delicada, mas com um valor muito forte a partir do instante em que você procura certo tipo de solução, certo tipo de raiz. Hoje estamos mais preparados para discutir esse assunto, embora faça anos que eu não discuta esse assunto em termos de desenho industrial. Discuto em termos de arquitetura, de planejamento urbano, em termos de desenho de cidade. Coisas desse tipo. Agora, essa questão cultural, digamos assim, ela é mais ou menos cosmopolita, quer dizer, você tem uma 
série de elementos de outros países que intervêm e ajudam a compreender melhor o teu ..., enfim, não é mais dizer: esse é um desenho brasileiro! Eu não sei até que ponto poderia defender umas coisas dessas, como, por exemplo, a questão do desenho italiano, o design italiano, todo mundo conhece o desenho italiano, o que era? Era o sucesso de alguns desenhistas industriais no campo de alguns móveis, eletrodomésticos, e particularmente no âmbito dos desenhos dos automóveis, fizeram com relação ao desenho de automóveis, e se destacavam em relação a todos os outros desenhos. Os norteamericanos não tinham esse desenho, os europeus depois começaram a ter. Inclusive muitos desses italianos aí foram desenhar na Alemanha, França, Inglaterra. Então digamos, se tentou descobrir e desenvolver um certo tipo de identidade brasileira, mas eu não sei até que ponto isso foi um sucesso. Mas ao que parece, apesar de tudo, por tudo que se lê desse período, existia essa busca pelo objeto com uma identidade brasileira... A gente sabia que estava à procura de alguma coisa em termos de uma identidade brasileira, isso sim é indiscutível. Se alguém de nós chegou, mostrou, criou algum produto, ou chegou perto dessa procura, talvez ele tenha sido mais feliz que os outros, mas fora alguns exemplos, me lembrei agora da Cadeira Mole do...

J.P. -... Sérgio Rodrigues...

L.G. -...do Sérgio Rodrigues lá do Rio de Janeiro, que foi idealmente um sucesso, de visão internacional inclusive. De fato pelos materiais, pela maneira de encarar, de sentar, digamos assim, era tipicamente brasileira. Um cara relaxado, com os pés em cima do braço da cadeira. Tudo bem, se procurou isso. Alguns chegaram perto, outros não. Se hoje você 
tem o desenho industrial brasileiro, eu juro que não sei.

J.P. - Talvez não exista um desenho exclusivamente brasileiro, talvez seja essa a questão.

L.G. - Por exemplo, você tem influência do mundo inteiro, em qualquer tipo de desenho, mesmo na arquitetura.

J.P. - Outra questão além desse olhar sobre as experiências fora do Brasil, devemos considerar no caso do Brasil, que além da Sequência de DI sendo implantada em 1962, temos também a experiência que a antecede, que é o MASP e o IAC, pois o MASP é criado em 1947 e depois o IAC em 1951.

L.G. - Mas são experiências relativas, certo? Inclusive não eram cursos sistematizados dentro de um contexto geral de ensino, eram mais cursos de, acho eu, de especialização, digamos. É você convidar algum tipo de desenhista que tinha feito móveis e ele, por exemplo, mostrar como ele tinha feito esses móveis. Mas não era nada organizado como sistema de ensino no sentido institucional.

J.P. - Na visão do professor, pensando nas pessoas que estavam envolvidas com o IAC e depois pensando no caso da FAU USP, o professor vê alguma continuidade, porque temos, por exemplo, o professor Flávio Motta, que foi assistente do Pietro Maria Bardi no MASP, depois ele esteve na FAAP e depois se torna professor da FAU USP.

L.G. - Ele foi professor da FAU USP em História da Arte, não História de Design ou coisa parecida. Ele podia discutir, como qualquer um podia discutir, 
o desenho industrial que estava surgindo, se manifestando mais na Europa do que aqui, mas que ele digamos, teve influência no desenho industrial... palavra de honra: não sei onde... A não ser nas discussões que ele talvez coordenasse ou se juntasse aos estudantes para discutir o assunto, mas todo mundo estava discutindo essas coisas do desenho industrial e da comunicação visual que estavam nascendo.

J.P. - Havia uma disciplina do Departamento de História, da FAU USP, que era a História da Técnica na Arquitetura...

L.G. - Sim, no desenho e nas artes gráficas, mas isto é posterior.

J.P. - Isto é começo dos anos de 1970.

L.G. - Sim, por aí.

J.P. - O professor Julio Katinsky participava também.

L.G. - Sim, o Katinsky.

J.P. - E até antes disso não tinha nenhuma conexão? Porque eu me lembro de ter lido, que se buscava sempre uma aproximação entre as áreas de ensino. Quando li as pranchas que o Artigas prepara para o Fórum de 1968, da FAU USP, ele fala que essa integração almejava desde 1962, mas que até então não se havia conseguido, e que era pensar os Departamentos de Tecnologia e o de História dando subsídios para o de Projeto.

L.G. - Isso tudo foi uma ideia que nos pareceu extremamente importante, só que depois 
esbarrou com aquilo que poderia ser considerado o engessamento do ensino no Brasil. A partir do instante em que você tem as suas disciplinas ou todas as disciplinas como sendo autônomas, não adianta dizer que elas estão interligadas. Cada dono da disciplina achava que era aquilo que ele desenvolvia por aí. Nós tentamos, dentro da Faculdade, fazer alguma coisa integrada, mas também não estava muito claro o que era integrado, certo? Como é que eu fazia o projeto de uma porta e colocava essa porta num projeto de edifício e chamava o desenhista industrial para desenhar a porta... E nesse sentido a visão estava completamente errada do que se tinha dos vários aspectos da integração. Você tem maneiras de projetar que podem ser semelhantes, embora o objeto desse projeto seja completamente diferente. A metodologia que você utilizou para projetar podia se aplicar, com algumas nuances diferentes, evidentemente, em cada uma dessas áreas, mas não era que daí surgia, como encanto, o projeto integrado brasileiro. Nós apanhávamos muito. Não somente porque não estávamos preparados, mas porque não se discutia, que eu saiba, na nossa área, não se discutia essa questão da identidade, coisa assim. A não ser de uma maneira extrema superficial, mas o que atrapalhava muito eram as disciplinas estanques que você tinha dentro da Universidade. Você tem compartimentalizado o ensino dentro da Universidade. Departamento disto, departamento daquilo, e mesmo dentro do departamento há várias disciplinas.

J.P. - Especializa-se cada vez mais.

L.G. - Esse foi o grande problema, a meu ver, por isso não deu certo como projeto integrado. E não adiante dizer: Ah, mas nós fizemos uma casa e 
participaram todas as disciplinas no projeto deste edifício. Eu tenho minhas dúvidas, eu nunca vi dentro da Faculdade um projeto integrado, naquela época. Hoje não sei, estou mais afastado, pode ser que haja realmente algum exemplo de projeto integrado, mas naquela época sinto muito, quem disser que tinha está...

J.P. - Considerando que a FAU USP faz a reforma de 1962 e que a ESDI começa a funcionar em 1963, duas questões: Existia alguma espécie de diálogo entre essas duas escolas pioneiras? E, segundo, apesar de termos essas duas experiências, eram apostas bem distintas, de certa forma, porque a ESDI pensava formar um profissional para o desenho do objeto, do produto, e a FAU USP, além de pensar este desenho do objeto pensava também em um desenhista industrial que pudesse realizar a industrialização da arquitetura...

L.G. - Certo, sem dúvida. As origens das duas Escolas são completamente distintas. Seja no desenho industrial aqui como no desenho industrial do Rio Janeiro. As grandes influências lá no Rio de Janeiro, naquela época, eram mais da Bauhaus e da escola de $(H f G)$ Ulm. Porque quando começou você tinha o (Karl Heinz) Bergmiller, você tinha o (Alexandre) Wollner que deram e começaram a dar aulas lá. Então realmente a origem da ESDI, no Rio de Janeiro, está mais relacionada com $(H f G)$ Ulm, do que a FAU USP. A ideia era completamente diferente. Lá queriam fazer desenho de produto e nós queríamos, pensávamos que, além do desenhista de produto, esse indivíduo que saía da FAU USP, era um indivíduo que podia projetar em diversas áreas, ele escolheria a área na qual se aprofundaria, por isso que tinha as quatro sequências: de projeto, desenho industrial, 
comunicação visual e urbanismo. A ideia da FAU USP era um pouco utópica, está certo, mas eu acho que continua uma ideia, ainda hoje, extremamente válida, de você ter praticamente uma universidade no projeto. Esse era o meu grande sonho quando garoto, de poder participar e colaborar na criação de uma universidade do projeto. Aí realmente as diferenças entre uma e outra geram nuanças. Certo, o que importava era você ter como básico todo o ensino, todo o desenvolvimento de ensino, seja teórico ou prático, num projeto. $\mathrm{E}$ isso daí, de vez em quando se tentava desenvolver alguma coisa que desse certo, mas até hoje não deu. Sempre, acho eu, que quem freou qualquer tipo de iniciativa, um ato mais ou menos inovador, era justamente a estrutura acadêmica da universidade, onde o que funcionam são as disciplinas, os donos das disciplinas e pronto, acabou, o resto era acessório... eu acho.

J.P. - E dentro disso que o professor comentou, fica bem clara essa filiação da ESDI, do Rio de Janeiro. E a FAU USP, ela está olhando para algum modelo, quando ela pensa, no sentido do que o professor falou: na universidade do projeto?

L.G. - Eu não sei se tinha algum modelo na época e alguma escola de projetos, não sei. Acho que isso foi mais uma consequência das discussões que nós tivemos dentro da escola. Discussões relacionadas a atividades de cada uma dessas áreas, certo, que estava lá dentro, embora não tivéssemos muito clara essa ideia, porque senão teríamos avançado muito, mas realmente começou a ter algum aspecto embrionário e depois foi cortado pelos assim chamados reacionários, os caras que não estavam querendo modificar as coisas, queriam deixá-las como estavam, porque aí eles se encontravam com 
uma certa facilidade e tinham um certo domínio daquilo.

J.P. - Eram professores ligados às cátedras?

L.G. - Não. Assistentes também, não somente professores das cátedras. A partir de 1962, 1963 quando se fez a Reforma na FAU, a cátedra realmente sumiu. Sumiu inclusive como significado, quer dizer, você tinha professor catedrático, mas o sentido, o espírito da cátedra realmente tinha saído da FAU USP.

J.P. - O que se fala é que ela deixa de existir oficialmente em 1969, na Universidade de São Paulo, mas com a Reforma de 62 e a criação das Sequências, elas são minimizadas.

L.G. - Na FAU USP começou antes essa questão de você acabar com a cátedra, porque na realidade não tinha mais sentido, se verificou que realmente não tinha sentido. Mas nós começamos antes de outras escolas. Tinha sim, outras escolas mais antigas, Medicina, Direito, Engenharia, que ainda sustentavam a questão da cátedra com unhas e dentes. Eu não sei hoje, mas desconfio que ainda tenha gente sustentando isso. A FAU USP, realmente nesse sentido, foi pioneira. O que não deu certo na FAU USP era que havia correntes que não prescindiam das suas ideias, então defendiam essas ideias em vez de estabelecer realmente um diálogo e poder ceder em alguns pontos para assumir ou incorporar as ideias de outros e tentar fazer assim alguma coisa que pudesse, aos poucos, se organizar e funcionar nesse sentido. Isso que vejo hoje. Aquela história da Universidade do Projeto tem muita gente que briga e diz: está maluco? Não existe isso daí! 
J.P. - Sobre essa questão da filiação da Universidade do Projeto que estamos falando, parece que é uma ideia do fundamento mesmo da arquitetura moderna, do arquiteto moderno e que é a própria visão que o (Giulio Carlo) Argan aponta em seu livro Arte Moderna, que é o profissional que realiza do desenho da colher à cidade.

L.G. - Sempre implicávamos com isso, evidentemente o Argan, na sua genialidade, tentava forçar um pouco a barra. Obviamente, se não forçar a barra, as coisas não andam. Mas realmente nossa ideia não era formar o indivíduo especialista em uma determinada área, quer dizer, nós queríamos que fosse um indivíduo que transitasse por todas as áreas e escolhesse a área onde quisesse se aprofundar, mas que ele passasse por todas essas áreas, tendo assim uma ideia de como realmente é um projeto. Projeto de caráter criativo se você quiser, de caráter administrativo, metodológico, mas um projeto. O que é um Projeto? Aí se discutia horrores nessa época, mas sempre tinha um cara que aparecia e dizia: Mas arquitetura é arte! Bom, tudo bem, arquitetura é arte, também. Não é que não seja arte, é arte também, mas o que precisava, não foi feito profundamente e esses fóruns que se fazia muito, não davam nenhum resultado, nesse sentido porque era uma baderna, mal se conseguia estabelecer um modus operandi, um critério, uma filosofia, digamos assim, que fosse como todas as outras áreas. Isso lamento! Se alguém disser que foi, está errado. Mas em todo caso a nossa origem é diferente da deles. Eles realmente eram a Escola de Desenho de Produto, do tipo (HfG) UIm. Produto gráfico, Produto Industrial, nós não. Nós achávamos que essas atividades podiam se integrar 
em benefício uma da outra. Quer dizer, não adianta pensar que posso fazer arquitetura sem pensar em desenho de algum produto que vá interferir ou ajudar. Enfim, colaborar com a arquitetura e que seja um produto industrial. Claro que a gente às vezes exagerava, está certo, em mostrar que ali tem maçaneta.... Maçaneta é um produto industrial, está bem, como também a torneira e assim por diante. São esses elementos que fazem a arquitetura, certo? Mas outros critérios, outras maneiras de encarar o mundo, que por certo poderiam ajudar essas várias áreas, não através de um simples objetinho.

J.P. - Me parece que um tema que era muito caro para o Desenho Industrial da FAU USP era essa própria perspectiva de pensar uma arquitetura brasileira que pudesse ser industrializada nos componentes, tanto que aqui nos trabalhos dos alunos... (apresentando imagens de trabalhos de DI da FAU USP relacionados ao desenvolvimento de componentes arquitetônicos.)

L.G. - Começa a aparecer alguma coisa...

J.P. - Essa ideia da produção do painel hidráulico aqui, essa outra situação também...

L.G. - Naquela época, quando na Europa se fabricavam esses painéis aqui, realmente, eram préfabricados e montados no local prontinho, só ligava os tubinhos, a energia elétrica e estava pronto, estava funcionando o banheiro e funcionando a cozinha. Pensava-se em alguma coisa desse tipo, mas pelo jeitão isso não foi adiante. Há uma série de condições sócio-econômico-culturais que se você não examina com certo tipo de cuidado, você não pode resolver. Era absolutamente impensável 
você fazer isso. Se fez muita coisa em termos de industrialização da arquitetura que redundou numa tremenda de uma exposição organizada pelo BNH (Banco Nacional de Habitação) na Bahia, Salvador, mas você vai ver que a situação...

J.P. - Isso foi nessa época?

L.G. - Sim, um pouquinho mais, digamos, mais adiantado. Por volta de 1971-72, não me lembro com certeza a data. Fez-se lá uma série de estudos de análise, se apresentou vários tipos de projeto, mas nós estamos longe disso, ainda hoje estamos longe disso.

J.P. - Infelizmente...

L.G. - Não sei se é felizmente ou infelizmente. Isso aqui é o tipo de cultura que não é nossa. Não é nossa cultura isso daí. Eu acho.

J.P. - Eu fico pensando numa parcela grande da construção brasileira que é atrasada tecnologicamente...

L.G. - Não sei se é tecnologicamente. Porque tem uma coisa que precisa ser resolvida. Do ponto de vista da técnica, indiscutivelmente, o Brasil domina a técnica. Pode não pôr em prática. Mas do ponto de vista teórico, digamos assim, não há técnica que nos é desconhecida, particularmente em termos de arquitetura. O que desenvolvemos adoidadamente foi a técnica do concreto armado. Agora a tecnologia do banheiro pré-fabricado, para dar certo, é muito relativa. Isso funciona quando você pensa numa produção do tipo que havia na Europa daquela época. Nós não tínhamos esse tipo de produção 
aqui, e qualquer tipo de tentativa que tenha sido feita, que não me lembro de ter sido feita, foi tudo por água abaixo. Por quê? Por causa dos aspectos culturais, econômicos e sociais que são diferentes dos países onde isso aqui deu certo.

J.P. - É o nosso próprio processo de urbanização...

L.G. - Inclusive, completamente diferente. Você tem uma porção de coisas que são absolutamente diferentes, pelo menos das europeias que não dá para você transpor esse tipo de ideia, de conceito aqui, no corpo, você tem que adaptar, está certo? Isso aqui (referindo-se à imagem de um banheiro pré-fabricado) eu não sei se alguém fez alguma tentativa nesse sentido, mas eu não me lembro de ter visto no mercado um banheiro feito assim dessa maneira. Não me lembro, pode ser que tenha existido. Então são coisas absolutamente diferentes que têm de ser encaradas com aqueles resguardos que são necessários para você julgar isso ou aquilo. Por exemplo, nós estamos cansados de saber que é antieconômico, anti qualquer coisa que você pense, você montar toda uma parede de tijolos e depois quebrá-la para pôr os fios, mas você continua fazendo isso. Será que isso daí não é um aspecto cultural? Econômico sem dúvida, porque você dá mão de obra para um monte de gente que não sabe fazer nada senão quebrar parede. Mas isso é relativo também, eu posso fazer uma coisa dessas, mas essa gente o que faço? Coloca-a para fora? Essa é uma grande questão a ser discutida. Questão de você tirar mão de obra pra colocar onde?

J.P. - É a discussão do canteiro já.

L.G. - Pois é, é a discussão do canteiro. Tudo 
bem o canteiro, você pode conduzir uma obra de uma maneira absolutamente tecnologicamente adequada a um mundo contemporâneo. Por exemplo, eu estava interessado em tudo isso e várias vezes fui visitar obras que são espetaculares, por exemplo, você deve lembrar o cubo que tem em Paris, aquele cubo que foi feito $100 \times 100$ metros com duas paredes laterais, uma cobertura ...

J.P. - Que possui uma estrutura tencionada?

L.G. - Isso. Essa estrutura somente serve para cobrir a entrada, nada mais. Bom, mas a construção daquilo lá se deu durante 5 anos. Era um negócio de se ficar parado olhando. Por exemplo, não tinha sujeira no chão. Nenhuma. Nós temos sujeira adoidado em qualquer tipo de obra. Onde quer que você vá há sujeira até dizer chega. Poderíamos nós, fazer uma obra como aquela? Duvido. Inclusive ela era feita, em cima, de todo um sistema de tráfego que existe embaixo dela, que é fabuloso naquele pedaço de Paris. Quer dizer, há formas de ver o mundo que é diferente da nossa. Graças a Deus, pois que se fôssemos todos do mesmo jeito... E isso daí foi discutido, se discutiu, mas eu não sei hoje como é que está. Hoje eu estou em outra área. Eu larguei um pouco o desenho industrial, talvez tenha largado momentaneamente, talvez retorne a ele, mas com outro espírito e com outra maneira de ver as coisas, mas enfim, isso era o que estava se discutindo naquela vez, e que hoje, digamos, muitos anos depois não se vê de outra maneira. Já se somam 50 anos.

J.P. - Já virou história.

L.G. - Já virou história mesmo. 
J.P. - Voltando um pouco, desde 1962, há uma questão que queria abordar. Nesse período, o Artigas já tem uma certa liderança dentro desse processo, ele está presente na Reforma de 1962.

L.G. - Ele foi um líder, sem dúvida nenhuma nessa Reforma.

J.P. - Pesquisando a pasta funcional dele, de professor da FAU USP, eu reproduzi um texto que está anotado a lápis e que é de 1962 ou 1963. E é um texto onde o Artigas fala sobre Desenho Industrial. Um texto de apresentação de uma exposição que seria organizada na FAAP, nesse período, como o apoio do IAB-SP (Instituto de Arquitetos do Brasil, núcleo São Paulo). Nesse texto, o Artigas vai se dirigir ao público em geral, e em particular aos desenhistas industriais e à própria camada dos industriais, falando da importância de se olhar para a construção de um desenho industrial brasileiro. $\mathrm{E}$ ele vai falar desta questão da identidade nacional. 0 Artigas usa palavras como folclore também.

L.G. - O folclore para você buscar uma identidade nacional, mas isso eu acho muito relativo.

J.P. - Sim. Mas dentro desse processo todo, qual era a importância que o Artigas dava para o Desenho Industrial, como estava presente o Desenho Industrial dentro do discurso dele?

L.G. - Eu somente posso lhe dizer, daquilo que posso me lembrar, daquilo que se discutiu 50 anos depois, 56 anos depois. O Artigas estava querendo dizer, acho eu, embora não tenha aparecido oficialmente em nenhum lugar, ele estava pensando também 
numa Universidade do Projeto, acho eu. Tudo me demonstra que ele estava pensando a mesma coisa. Talvez nós pensássemos maneiras diferentes para fazer isso, mas não me venham dizer que ele não tinha essa ideia, certo, de fazer alguma coisa, justamente uma ideia com várias possibilidades criativas e tecnológicas do arquiteto. Isso era aquilo que ele pregou durante muito tempo, sem dúvida nenhuma. Então, a importância dele, além de ser um carisma da arquitetura, a maneira de encarar os problemas todos... ele conduzia a turma para diversos lugares e nesse aspecto ele era muito bom e pioneiro. Depois disso, Artigas não faz mais nada que dissesse que ele estava apaixonado ou fizesse alguma coisa em termos de Desenho Industrial. Não, ele não fez. Ele desenvolveu algumas coisas em termos de arquitetura, depois ele ficou afastado devido ao 64 (ao Golpe Militar de 1964).

J.P. - Sobre este ponto, nós temos esse arco temporal, entre 1962 e 1968, onde temos todo esse processo dentro da FAU USP de implantar um novo método de ensino...

L.G. - Mas não somente dentro da FAU USP. Você tem de imaginar também, que dentro desse período foi criada a ABDI (Associação Brasileira de Desenho Industrial). E nós da ABDI estávamos brigando junto com a FAU USP nesses aspectos todos que estamos discutindo e conversando agora. Mas tinha uma espécie de rivalidade entre São Paulo e Rio de Janeiro, quer dizer, eles nunca poderiam aceitar e nunca aceitaram que um arquiteto pudesse fazer Desenho Industrial, quanto a nós, se quer fazer desenho industrial, faz. A única coisa é que dentro da faculdade de arquitetura, talvez você pudesse ter um preparo teórico melhor do que se não fosse. Nós 
admitíamos que outros pudessem fazer desenho industrial, não era exclusivo. Eles não. Achavam que era exclusivo.

J.P. - Dentro da ABDI, o senhor foi diretor de 1963 a 1968.

L.G. - Pois é. Eu tentava amenizar esse tipo de conversa de discussão entre os vários... Todo mundo... Tinha os caras do Rio de Janeiro, tinha os caras de São Paulo... Então eu tentava amenizar isso e mostrar que a coisa não era essa briga que ia resolver os problemas de uma Associação Brasileira de uma futura e eminente profissão de Desenho Industrial. Tanto que quando nós, na Faculdade de Arquitetura colocamos claramente para o CREA (Conselho Regional de Arquitetura e Urbanismo) a questão da profissão do Desenho Industrial, e durante certo período o CREA aceitou a nossa ideia. Portanto dava a quem fizesse um curso de Desenho Industrial a possibilidade de ser configurado um desenhista industrial do ponto de vista profissional, inclusive, as escolas de desenho industrial caíram em si e depois de um ano, um ano e meio ou dois não colocaram mais isso em discussão.

J.P. - O CREA alegava que havia um inchaço no currículo dentro da formação do arquiteto...

L.G. - Se o CREA achava isso, está certo... Desculpe, mas o CREA, estava influenciado por esses caras que não queriam esse tipo de situação. Se você cria uma coisa dessas, o pessoal vai tudo para uma faculdade de arquitetura, não vai para todas as escolas de desenho industrial que estavam saindo como cogumelo. Mas isso foi um erro clássico, inclusive nós não discutimos suficientemente esse tipo de 
posição, que poderia ter ido mais para frente e teria resolvido muitos problemas que continuam.

J.P. - A profissão até hoje não é regulamentada, ainda se coloca essa discussão.

L.G. - Sim, porque uns acham que deve ser somente os que se formam em uma escola de desenho industrial. Outros dizem: não, eu tenho todas as disciplinas de desenho industrial dentro do curso de arquitetura e tem a possibilidade de formação muito mais interessante do que os caras que estão se formando na escola de Desenho Industrial, é lógico, é um repartidarismo. Isso tudo foi um atraso que tivemos no Brasil em termos de esclarecimento de uma nova profissão que estava surgindo, seja do ponto de vista do desenho industrial como do ponto de vista da arquitetura que sofreu todas as influências do desenho industrial.

J.P. - Voltando ao Artigas, temos esse processo de 1962 a 1968 de inovação do ensino de arquitetura na FAU USP. Entretanto no meio disso acontece o Golpe de 1964 e as cassações dentro da Universidade. Isso de alguma forma vem desestabilizar o ensino de DI? Como fica?

L.G. - Todo esse processo da ditadura, digamos assim, engessou o processo de inovação a par dos esforços que fizemos para não sermos influenciados muito, mas sem dúvida engessou. Além do fato de que muitos deles foram cassados, foi um problema sério, mas nós estávamos engessados.

J.P. - Pensando na prática do ensino de DI no ateliê, como funcionava essa estrutura? Porque nas leituras que faço, vejo que havia certa dificuldade 
na operacionalidade dos laboratórios para poder fazer os protótipos, de experimentar coisas de fato. $E$, por outro lado, há fichas de disciplinas em que leio o desejo dos professores de colocarem o que é produzido como objeto de apreciação do industrial. Apresentar os objetos para serem avaliados por eles. Como era esse cotidiano de ateliê?

L.G. - O que se chamava de ateliê, nada mais era do que um espaço onde os estudantes e professores se reuniam e tentavam desenvolver os seus projetos, seja de arquitetura ou de desenho industrial, de programação visual, etc. A ideia do ateliê, isto é, que todo mundo discute o projeto tudo junto, eu acho furada. Existe um momento que você tem que se retirar disso, que você tem que assumir a responsabilidade da tua visão de mundo, portanto, do projeto que você coloca, você poderá, depois que você tem a sua ideia colocada, claro, digamos assim, você pode discutir com todo mundo, ver que influência você quer ter das discussões e que influências você pode dar aos outros, mas eu penso que essa história de fazer um projeto junto, ao meu ver, é utopia. Você não faz projeto junto, há certo momento em que há um líder, mas a ideia não é uma ideia que surge de milhões de ideias, às vezes, mas esses milhões de ideias têm de vir antes, têm de ser colocadas num papel, para lembrar, para você poder discutir. Portanto, a ideia de ateliê, para mim, foi uma ideia superada ...

J.P. - Do ateliê integrado?

L.G. - Quando se tentava fazer um projeto único, quando se juntavam todas as disciplinas. Nunca se discutia de maneira clara e precisa, a não ser do ponto de vista teórico, pois que na prática isso não 
funciona, não funcionou. Então algo estava errado ou incompleto, qualquer coisa assim, porque não funcionou. Não adianta dizer que funcionou, não funcionou e não funciona.

J.P. - Tem alguns professores importantes dentro da Sequência de DI da FAU USP, como, por exemplo, o Décio Pignatari que passou por lá...

L.G. - O Décio Pignatari e a Lucrecia Ferrara...

J.P. - ...de semiótica...

L.G. - Exato. Fui eu quem fiz que eles pudessem ser contratados. Nós achávamos que a semiótica, enquanto ciência, uns acham que sim, outros acham que não, mas vamos supor que seja ciência, podia dar alguma contribuição ao projeto. Eu acho e continuo achando que ela pode dar certa contribuição, mas até certo ponto, depois chega, parou. Para você analisar um certo tipo de comunicação não verbal, a semiótica é um instrumento fantástico, fabuloso. Então eles entraram lá dentro e discutiam os projetos sob um ponto de vista da semiótica. Tinha gente que seguia nessa discussão, e outros que achavam que era besteira, dizendo que o que contava era a criação do arquiteto. Mas eles tiveram importância sim, como não? Sem dúvida nenhuma.

J.P. - E o professor se lembra do período que eles entraram na FAU USP?

L.G. - Bom, nós já estávamos lá. Foi sem dúvida depois de 1969. Eu não me lembro precisamente, precisaria rever documentos da FAU USP, mas era na década de 1970-80, por aí. Entre fim de 1960 e começo de 1970 que eles entraram na Faculdade. 
E outra coisa que eu achava que era importante para a gente entender esse tipo de processo não só de projeto, mas de relacionamento de projeto com o consumidor, era o caso da psicologia. Eu fiz questão que uma psicóloga viesse para a aula, mas não deu certo. Ou ela não se adaptava ou o pessoal não estava se adaptando a ela, qualquer coisa assim, mas eu achava que se tivéssemos um psicólogo, nos ajudaria a compreender esse tipo de relacionamento, que não é feito somente pela obra do espírito santo: porque eu gosto. Agora se eu gosto ou não gosto depende de uma porção de coisas entre as quais certos aspectos de caráter psicológico.

J.P. - E que têm de serem descobertos pelo projeto...

L.G. - Descoberto, discutido, visto, analisado, dado novo valor, maior ou menor conforme o caso. Por isso que a gente introduziu a semiótica dentro da Faculdade. Essa professora que dava psicologia, deu psicologia durante certo tempo, não me lembro muito bem do resultado. E o van Onck que teve uma influência fantástica com essa história do metadesign, realmente do ponto de vista metodológico ele influenciou muito.

J.P. - O Humberto Eco também...

L.G. - O Humberto Eco foi do ponto de vista da cultura, dos aspectos socioantropológicos de qualquer tipo de manifestação, como no caso do Desenho Industrial, no caso da Arquitetura. Ele quem discutiu e traduziu o problema do código, da codificação da arquitetura, da codificação do objeto, da codificação do visual. Ele colocou isso muito bem, direitinho, ele teve influência sim, muito forte, 
sobretudo do ponto de vista cultural. Humberto Eco foi também uma daquelas coisas que, eu disse não, o Humberto Eco tem que vir pra São Paulo. Fui buscá-lo na Itália.

J.P. - Temos também o professor Abrahão (Sanovics) que foi para a Itália para estudar Desenho Industrial.

L.G. - Foram para lá o Abrahão e o (João Carlos) Cauduru.

J.P. - O professor Abrahão, parece-me, está desde 1962, como assistente do...

L.G. - Do Silva Neves

J.P. - Depois ele vai para a Itália estudar desenho industrial. Qual a contribuição do Sanovics e a visão que ele tinha do que poderia ser esse desenho industrial ensinado na FAU USP?

L.G. - Ele tinha evidentemente aprendido certo método de projeto, embora ele fosse um adepto da criação, da espontaneidade, essa coisa toda, mas ele indiscutivelmente, vamos dizer assim, tinha sofrido a influência desse outro tipo de maneira de encarar o projeto. Portanto ele teve uma boa influência, pois afinal das contas ele realizou projetos interessantes, embora talvez nem tanto de grande alcance, mas aqueles projetos de móveis que ele fez, tanto de concreto quanto de madeira, foram projetos limpos, claros, precisos, etc. Teve essa influência, afinal das contas, quando se falava em desenho industrial não era uma coisa utópica. O cara fez, o Lúcio fez, o Abrahão fez, o Cauduro. Então não era uma coisa absurdamente misteriosa. Concretamente era o resultado daquilo que a gente discutia. Podia não 
ser o melhor resultado, mas se tinha um resultado.

J.P. - Tinha uma concretude. Sobre o laboratório de maquetes e modelos da FAU USP, havia um auxílio ao desenvolvimento das disciplinas de DI?

L.G. - Prestavam. Prestavam porque, graças a Deus naquela época, tínhamos artesões fabulosos. Eram artesões, inclusive quem orientava tudo isso era o Fracarolli, Caetano Fracarolli, que foi professor de plástica, etc. Eles eram artesões fantásticos em uma série de materiais. Inclusive, as primeiras coisas em plástico que foram levadas lá para a Faculdade, foram levadas por esses artesões. Então, seja do ponto de vista do objeto em si, seja do ponto de vista gráfico também, havia artesões e havia professores gráficos fabulosos, que ajudaram os laboratórios, usaram os laboratórios e influenciaram outros trabalhos para o mesmo laboratório. Até 1986 eu posso dizer alguma coisa, depois disso eu não sei.

J.P. - E eram artesões ligados ao professor Fraccaroli?

L.G. - Sim. O Fracarolli trouxe alguns deles, outros não vieram via Fraccaroli, vieram por outro lado, por outros professores.

J.P. - Mas que estavam dentro da FAU USP trabalhando?

L.G. - Sim. Professores que estavam trabalhando dentro da FAU USP, conheciam aquele artesão, aquele técnico e fizeram tudo pra trazê-los para a FAU USP. Naturalmente que isso foi uma contribuição fantástica.

J.P. - E eles trabalhavam com que materiais? 
Madeira, metais...

L.G. - Com madeira, com metais, com gesso, com plástico. Mais tarde a Marlene (Picarelli) começou a fazer trabalhos em termos de elementos construtivos da arquitetura pré-fabricada, com concreto. Eram caras que estavam em bom momento. Estavam trabalhando, estavam contribuindo, ajudando de alguma maneira fantástica. Nesse ponto eu tiro o chapéu para aquela turma.

J.P. - E o Fracarolli, na década de 1960, foi responsável pelo laboratório?

L.G. - Eu acho que ele foi sim responsável pelo laboratório. O Fraccaroli era uma figura, de uma simpatia única, mas ele era adepto, o cara que divulgou a Gestalt feito um doido dentro da Faculdade. Tudo aquilo que se falava em termos de arte, para ele era Gestalt, mas ele era um técnico fabuloso. As coisas que se fazia e que se estava expondo por aí, ele fazia no laboratório dele. Então ele pegou esse grupo de pessoas, 1, 2 ou 3 que estavam no laboratório dele e trouxe para a Faculdade. Fraccaroli foi isso aí e a discussão toda em torno da Gestalt, uma maneira nova de compreender, de analisar a arte.

O problema do Desenho Industrial, pelo menos naquela época, foi uma coisa tipicamente clara, precisa. Primeiro, os industriais, em sua maioria, achavam que qualquer coisa que ele fosse propor em termos de alguém que desenhasse um produto era uma coisa supérflua. Houve um cara, que de vez em quando frequentava a $A B D I$, que um dia eu encontro ele no aeroporto, em Congonhas, e ele todo satisfeito dizia: - Oh Lúcio! - Com vinte aparelhos de iluminação que ele comprou lá (fora 
do Brasil) e vinha trazendo para produzir aqui. Era muito mais fácil, você ir lá, comprar e trazer, copiar, do que você contratar um cara para fazer o negócio. Havia outras experiências que não deram certo. Por exemplo, pessoalmente, tive uma experiência com uma indústria de refrigeradores, que era em São Carlos. Esses caras me disseram: Gostaria que você desenhasse uma geladeira. Nós temos essa geladeirazinha aqui, que está para ser lançada. Já tinha sido lançada, mas não estava vendendo. Porque não está vendendo, nós não sabemos. Levei para o escritório, sentei e começamos a fazer o desenho de uma nova geladeira a partir daquela geladeira. Eu me lembro que em discussão que os caras levantaram lá: - Por que é que você colocou a empunhadura na horizontal? Todas elas são verticais. Mas a moral da história era o seguinte, nós tínhamos estudado o interior da geladeira, e para que o espaço interno fosse possível de ser utilizado pelos produtos que você tinha no supermercado - era garrafa d'água, prato disso, prato daquilo -, fizemos esse desenho e venderam feito água, e continuei a fazer desenhos de geladeiras para essa empresa. Fizemos uma linha que se chamava linha de 120 litros até 440 litros. Também fez um sucesso grande. Depois eles abandonaram um pouco isso e entraram, em conjunto com a Westinghouse, no segmento de máquinas de lavar roupa. A única coisa que nós desenhamos foi um painel e não foi adiante o negócio. Depois retomamos de novo a história da geladeira, e a questão se havia colocado de uma maneira que eles aceitaram como discussão. Só para te dar uma ideia, eles utilizavam chapas de aço e eram 20 tipos com medidas diferentes de chapas de aço, para fazer uma linha de geladeira. Poxa, você vai ter problemas de estoque, você vai ter problema de corte, de produção, você tem saco 
de problemas. Por que não diminuímos o número dessas chapas? Chegamos à conclusão de que uma medida de chapa, talvez, pudesse servir para diversas geladeiras. Bom, fizemos até um protótipo e estávamos chegando a uma solução de qual era a dimensão de chapa que se deveria usar. Então se usava uma ou duas chapas, não me lembro. Sim, a chapa de fundo era diferente. Você tinha duas chapas, três: a que fazia o envoltório, a que fazia a porta e a que fazia o fundo, e não 20 chapas, porque cada uma era diferente da outra. E nós fizemos um protótipo, feito na martelada, mas se chegou à conclusão de que era viável. Os caras venderam a firma. Venderam a firma e nunca mais ninguém falou disso.

J.P. - E o professor sabe onde posso encontrar registro dessas geladeiras?

L.G. - Tem uma publicação. Foi publicada numa revista. Agora, qual revista? Eu não sei. Como te disse, eu abandonei o Desenho Industrial. Uma coisa muito simples, eu te confesso, não acreditava muito no desenho industrial brasileiro.

J.P. - Por quê?

L.G. - Porque o nosso desenho não servia pra nada. Os caras não faziam o nosso desenho, os caras estavam mais interessados em copiar, naquela época os desenhos que eles traziam da Europa. Projeto Geladeira Pereira Lopes (lembrando-se da empresa fabricante de geladeiras em São Carlos).

J.P. - Pereira Lopes! Outra questão importante, para esta minha investigação, é pensar em que medida esse desenho industrial da FAU USP está discutindo 
também uma industrialização do componente arquitetônico. Seja o painel de vedação, seja a produção industrial do caixilho.

L.G. - Naquela época foi, digamos assim, levado um pouco adiante. Marlene, sobretudo, foi quem colocou estudos sobre componentes de concreto armado. E todos esses experimentos com concreto armado foram feitos no laboratório da FAU USP. Agora eu não sei, os outros pensaram... Porque todo mundo falava: vamos pensar em caixilho, vamos pensar nisso, naquilo, naquilo outro. O que eles fizeram eu não sei. Não tenho registro de que eles tenham feito um trabalho sistemático sobre o problema do caixilho. A não ser como faz qualquer arquiteto quando faz um projeto: Vai lá e desenha o caixilho, como sendo a primeira vez em que o está desenhando. Depois você chama o cara que constrói o caixilho e discute com ele o caixilho.

J.P. - Como executar.

L.G. - Exato. O cara que sabe como executar hoje.

J.P. - Então a professora Marlene, foi ela quem desenvolveu esse trabalho dentro da área de DI de pensar o desenho industrial do componente arquitetônico?

L.G. - Sim. Sem dúvida nenhuma.

J.P. - E ela começa a trabalhar com essa discussão a partir de quando?

L.G. - Mais ou menos na mesma época em que nós começamos com o desenho industrial. Alguns anos depois, quando você saía um pouco daquilo que era 
o produto industrial, e se começou a colocar isso dentro da arquitetura: Por que uma escada não pode ser pré-fabricada? Por que outros componentes não poderiam ser pré-fabricados? O Abrahão, com toda simpatia que ele tinha, montou toda uma história de produção de concreto armado, não sei o que, com os acentos que ele colocou na FAU USP, bem por aí. Mas ele estava entusiasmadíssimo com tudo isso aí. Muitas das ideias que tivemos naquela época foram ultrapassadas pelo tempo, pela experiência, pelo resultado dos trabalhos, e uma porção de outras coisas.

J.P. - Mas elas foram ultrapassadas, penso, porque elas foram propostas e depois evoluíram, dentro de um caminho natural das coisas.

L.G. - Não foi à toa que nós tentamos fazer naquela época. Agora hoje, como é que estão realmente essas questões do desenho industrial brasileiro?

J.P. - É outra discussão. 
Entrevista: Prof. Julio Katinsky

Data: 05 de março de 2009.

Local: Biblioteca da Pós-Graduação da FAU USP (Palacete Vila Penteado, rua Maranhão).

J.K. - Julio Katinsky

J.P. - Juliano Pereira

J.K. - O curso de Desenho Industrial da Faculdade, na realidade, começou como uma Sequência do Departamento de Projeto, porém com repercussões nos outros departamentos, porque o Ministério da Educação exigia que houvesse uma disciplina de História da Técnica no Curso de Design (início da década de1970). Então, para se enquadrar na legislação em vigor, e o curso de Design da FAU USP ser reconhecido, era preciso que essa disciplina fosse dada: História da Técnica. E eu fui encarregado de dar essa disciplina, e me recusei a dar uma disciplina típica brasileira, que é de leitura. Você lê, de preferência, meia dúzia de livros estrangeiros e fala para todo mundo aquilo que você leu. Quer dizer, as disciplinas no Brasil, até pouquíssimo tempo atrás, eram tão somente verborrágicas, eram de pura verborragia, os caras não tinham experiência nenhuma de nada e então eu propus uma disciplina dupla: História Geral da Técnica, claro, essa que existe nos livros de História da Técnica e que é uma disciplina que vem sendo feita pelos europeus desde meados do século XVIII, mas com sinais claros de organização nos séculos XVI e XVII. Essa é a grande proposta da Renascença. E eu propus uma segunda disciplina que seria História da Técnica no Brasil. 
Evidentemente, a História da Técnica no Brasil não podia ser dada como a tradição da História da Técnica Europeia. Porque a História da Técnica Europeia era baseada numa relação histórica, cronológica das invenções, e as invenções retornavam. Como então poderia haver uma História da Técnica brasileira? Isso pode parecer engraçado, mas essa pergunta me foi feita por um dos fundadores da Universidade de São Paulo, um professor importante, professor francês chamado August Bastide que veio a São Paulo para receber o título de professor emérito, se não me engano, na década de 1970. A essa altura já havia definido a disciplina História da Técnica no Brasil com bastante clareza, ao menos para mim. Disso resultou toda uma série de trabalhos de caráter crítico e histórico que foram em parte absorvidos pelos alunos e pelos professores. A característica fundamental da História da Técnica foi abandonar a ideia de invenção, mas fazer uma espécie de levantamento das técnicas que permitiram a ocupação territorial do Brasil. Esse foi um ponto de vista muito apoiado na Antropologia, na época, e na Economia e na Sociologia. Arcabouço teórico que serviu de ponto de apoio para montar a disciplina História da Técnica no Brasil. Na faculdade, nessa época, na década de 1960, havia certa, vamos dizer assim, rejeição da ideia de uma Escola específica de Design. Porque, ao que se verificava, é que as escolas de design existentes eram escolas que iam atender a um setor muito específico do mercado mundial, que eram das grandes corporações. Como aqui nós não tínhamos grandes corporações, porque nós íamos fazer uma escola específica para atender às grandes corporações? Só para dar um exemplo simples, um dos maiores designers americanos, não o único, mas um dos maiores designers americanos que era, nessa época, prestigiadíssimo, que era o Raymond Loewy, ele desenhava locomotivas. Nós não tínhamos nem fábrica de locomotivas, como é que iríamos desenhar locomotivas? Eles tinham um parque industrial de locomotivas que era 
imenso. Para você ter uma ideia, enquanto nós tínhamos $30.000 \mathrm{~km}$ de estrada de ferro, os americanos tinham $600.000 \mathrm{~km}$. Não eram 10 vezes mais, eram 20 vezes mais. Evidente que eles jogavam todo um avanço tecnológico nos equipamentos industriais das estradas de ferro que nós não tínhamos nenhuma condição de ter. Nós não fabricávamos aviões naquela época, aliás, fabricávamos: os aviõezinhos de pano chamados paulistinha. Madeira e lona, quase lona. Aviõezinhos assim muito vagabundos, e mesmo assim o motor nem era nacional, porque nós não fabricávamos o motor. Partimos então da ideia de que, na realidade, o Desenho Industrial ia se basear muito nos equipamentos que a própria Arquitetura iria exigir. Você está sentado num. Essa é uma cadeira, que eu considero uma pequena obra-prima, do Paulo Mendes da Rocha (Katinsky se refere à Cadeira Paulistano, 1957).

J.P. $-\operatorname{Sim}$.

J.K. - E o Paulo Mendes da Rocha fez essa cadeira para um clube, o Clube (Atlético) Paulistano. Essa cadeira (Poltrona para L'Atelier, 1959) em que eu estou sentado, fui eu quem desenhei, nessa época, década de 1960, final da década de 1950. Antes de começar o curso de Desenho Industrial, eu fui trabalhar num escritório de arquitetura que gostava de fazer decoração que era o escritório do Jorge Zalszupin. E eu trabalhei muito com ele porque ele era um artista, ele é um artista muito especial, ele dava toda a autoridade para a gente se desenvolver, entende? Uma figura que me é muito simpática até hoje. Então, nós achamos que o melhor era fazer um Curso de Design dentro do Curso de Arquitetura, e as pessoas que quisessem somente fazer design podiam fazer, como, aliás, a Faculdade de Arquitetura nesse período de 1948, quando ela se fundou e até 1978, mais ou menos, 1980, ela também formou pintores, gráficos..., mas pintores mesmo, pintor de cavalete. Quando eu era diretor, eu 
pensei em fazer uma exposição dos artistas, dos pintores brasileiros formados na FAU USP, só os pintores formados na FAU USP. Eram uns 80. Claro, num universo de 4.500, isso é muito pouco, mas tudo bem. Dentro do universo de pintores brasileiros, alguns fazem parte hoje da história da pintura brasileira, como o Cláudio Tozzi e vários deles. Há pintores formados na FAU USP que foram para Alemanha e ficaram lá trabalhando na Alemanha e viveram de pintura na Alemanha. Então a coisa se caracterizou desse jeito, enquanto que o pessoal do Rio de Janeiro, seguindo uma linha bem colonizada, eles inventaram de fazer uma escola de design específica, que era a ESDI, que acabou se transformando numa coisa diferente do que eles imaginavam, porque a Escola da ESDI era cópia de Ulm (Hochschule für Gestaltung - Escola Superior da Forma -, HfG Ulm, na Alemanha) que foi pensada num universo industrial completamente diferente, além de ser uma política torta. E que existia naquela época, da Guerra Fria, e que queria caracterizar todo o trabalho criativo através do produto de mercado. Uma das coisas que mais se falava era que a Arquitetura ia acabar, porque as pessoas iam poder fazer as suas casas como (brinquedo de montar) lego: pegar pedaços de coisas produzidas e cada um ia ser arquiteto de si mesmo. Até agora não aconteceu isso, mas era uma ideia de que o futuro da Arquitetura seria esse. Aconteceu exatamente o contrário. Aconteceu que hoje tem mais arquitetos no mundo do que no tempo em que eu era estudante, inclusive em São Paulo. Tem muito mais arquitetos hoje do que no meu tempo. O pessoal diz assim: Nós estamos numa dificuldade! Que dificuldade, o que? Precisava ver no nosso tempo, dificuldade tínhamos no nosso tempo! Nós nem éramos apresentados como arquiteto porque isso aí não era profissão. Profissão era engenheiro. Nós éramos apresentados como engenheiros. Por delicadeza, não por má fé. Por delicadeza. Por que o que era arquiteto? Arquiteto era o cara que fazia túmulo no cemitério ou monumento nacional. Essa ideia de 
arquiteto, atendendo a planos sociais, era uma ideia do século XIX, basicamente, porque começam a surgir os programas da sociedade burguesa: bancos, indústrias, escolas, bolsas, mercados, tudo isso vai ser feito por arquitetos. Às vezes, arquitetos pouco conhecidos, mas por vezes por arquitetos de grande envergadura. Por exemplo, as bibliotecas de Paris foram feitas por um dos maiores arquitetos do século XIX. E ele usou todos os recursos industriais que existiam na época, quer dizer, não é que eles recusavam a indústria da época, de jeito nenhum, se tentava adaptar dentro das ideias culturais da época. O que eu acho que houve, logo após a Segunda Guerra Mundial, foi uma polarização ideológica que foi profundamente negativa. De um lado os americanos queriam caracterizar o socialismo como atraso, a União Soviética era o atraso e eles eram o progresso e o futuro, mas o futuro está ali. Nós estamos vendo o futuro. Por outro lado, os socialistas batiam na tecla de que tudo era produto do imperialismo e o imperialismo era um mal em si, o que também era uma grave distorção, porque eles mesmos praticavam os grandes conglomerados industriais. Isso é engraçado, porque eles falavam contra o imperialismo americano, mas eles aplicavam o sistema americano dentro da antiga União Soviética. Aliás, certas áreas de produção na União Soviética seriam inviáveis se não fossem desse jeito. Por exemplo, pra você explorar o xisto betuminoso, que tem um resíduo muito grande de matéria mineral, se você não tiver uma indústria que aproveite isso, não dá, nunca vai acontecer de você poder explorar o xisto betuminoso que tem três grandes jazidas no mundo. Uma na Rússia, outra nos Estados Unidos e a terceira no Brasil. No Brasil não dá para explorar. Tentou-se na época da ditadura, a ditadura que nós sofremos, que o pessoal diz que foi militar, mas não é verdade. A ditadura foi dos bancos, eles é que estabeleceram uma ferocidade muito grande nas relações sociais e, esse sim, era um modelo americano, total. Incentivaram toda essa indústria de informática e 
nós mesmos assim chegamos atrasados, pois que não temos uma indústria ainda mecânica e siderúrgica à altura das necessidades brasileiras. Então essa coisa foi evoluindo para uma, vamos dizer assim, uma ambição em que a maior parte dos designers, que se formaram na FAU USP e no Mackenzie, que mais ou menos acompanharam muito a contragosto, porque os arquitetos paulistas que fizeram a FAU USP eram participantes de uma ideia, que é muito anterior à Guerra Fria, que é a ideia de que o progresso industrial traria a democracia para todos. Evidente. Inegavelmente, hoje, uma pessoa não precisa ser rica para escovar os dentes. Só pode escovar os dentes quem tem uma escova de dentes, que custa muito pouco. Por outro lado, esse processo também teve os seus vícios, por exemplo, a indústria automobilística, um verdadeiro câncer na sociedade moderna. Num certo sentido, nós, a FAU USP, denunciamos isso. Tanto que os concursos inventados pelos grupos interessados em implantar a indústria automobilística no Brasil; eles fizeram um concurso de carro, o Prêmio Lucio Meira. Todos foram ganhos pela FAU USP, todos os primeiros lugares foram ganhos pela FAU USP. Todos. Por quê? Porque eram carros propostos corretamente. Anteciparam, num certo sentido, o que está acontecendo hoje. Apesar de na época os grandes carros ainda serem os americanos, Cadillac, principalmente os carros da Ford, enormes, gigantescos, todo mundo queria ter porque eram carros de 6 metros de comprimento, verdadeiros bêbados de gasolina, bebiam gasolina, a cada $6 \mathrm{~km}$ era um litro de gasolina.

J.P. - São os carros caudas de peixe.

J.K. - Eram os rabos de peixe. Além desses havia outros carros da Ford gigantescos, etc. Nós fizemos o contrário, em função de uma visão urbanística, todos os carros que o prêmio Lucio Meira concedeu eram todos carros pequenos, carros muito adequados. Inclusive alguns 
têm circulado por aí, não iguais, mas projetos muito semelhantes àqueles que nós pensamos naquela época, porque aliávamos, não necessidades da indústria, da produção capitalista, mas as necessidades da própria cidade. Até certo ponto eu acredito que o curso proposto pela FAU USP, agora, de um curso específico de Desenho Industrial (a recém-criada graduação em Design pela FAU USP), ele possa ter essa característica, considerando que a indústria brasileira hoje é uma indústria que se desenvolveu muito, como, aliás, toda a ciência brasileira se desenvolveu muito, mas nós temos ainda um gargalo que é a baixíssima atividade tecnológica no Brasil, porque a tecnologia não dá para ser feita somente com inteligência e com poucos recursos, é preciso investir muito, e o nosso empresariado prefere esperar que os outros façam para depois tentar...

J.P. -...copiar.

J.K. -...copiar. Eu tenho até vários textos sobre Desenho Industrial, te recomendo a leitura de três textos que estão publicados hoje na revista do Portal Vitruvius. Um na revista Agitprop, que publicou o meu texto, que estava esgotado há muitos anos que é: Uma História do Design Brasileiro. Um segundo texto, que é sobre o Artesanato Moderno e um terceiro texto, por enquanto, que é o Artesanato Revisitado. São textos onde analiso esse problema do Artesanato Moderno, não como resíduo do passado, mas ao contrário, como fenômeno provocado pelo desenvolvimento capitalista.

J.P. - Ok, vou pesquisar.

J.K. - E há finalmente outro texto, de que gosto muito, porque foram as minhas aulas de 1971, onde previa uma coisa que aconteceu, não como eu previa, mas aconteceu, que é (o texto sobre) a invenção da máquina a vapor. Um 
texto que fiz na FAU USP, mas que está esgotado, onde previa que o grande desenvolvimento que iria acontecer seria o desenvolvimento das máquinas de calcular. Hoje chamamos computadores, que no fundo são uma extensão das máquinas de calcular. Eu gozava pra burro a ideia dos americanos. Eles para dizerem besteira, não há país igual. Vários cientistas, da mais alta respeitabilidade, cientistas mesmo, escrevendo que no futuro haveria máquinas que iriam criar outras máquinas diretamente, isso ah!

J.P. - Não é ciência, é ficção científica.

J.K. - Ficção científica (risos). Então eles diziam o seguinte: Como nós fomos criados por Deus e matamos Deus, as máquinas, que são nossa criação, vão nos matar. É loucura total! Inclusive até o Pascal, que foi o primeiro homem a fazer uma máquina de calcular, bonita por sinal, ele fez cinco. Pensei que ele tivesse feito uma, mas não, ele fez cinco. Uma ou duas estão na Biblioteca Nacional. Ele então gozou essa ideia de que as máquinas poderiam um dia substituir os homens, isso é uma bobagem, isso não existe, é impossível. E nesse texto eu comentava em primeiro lugar essa bobagem toda e a segunda, que obrigatoriamente nós iríamos ter um grande desenvolvimento de máquinas, de, digamos assim, computadores. Naquele tempo, os computadores todos eram máquinas enormes, somente a IBM fazia. Ainda não havia surgido, e isso é uma coisa que eu nunca poderia prever; o PC, o Personal Computer, que era um negócio de estudantes de engenharia. Tinha um moleque lá, professor de Escola de Engenharia, que dizia: "Oh, podemos fazer um troço pequeninho!" E foi o que o pessoal chamou de a Grande Revolução. Isso não tem revolução nenhuma, mas na realidade abriu uma perspectiva, essa está escrita lá, que é o que aconteceu. Um dos maiores produtores de software são a Índia, nem Japão nem Estados Unidos, é a Índia. E aparecem essas novas potências: Índia, China, que estão jogando tudo 
no desenvolvimento científico-tecnológico, com dinheiro firme. Você vê a parcela do produto bruto nacional que cada um desses países joga na pesquisa científica e tecnológica é duas a três vezes maior que a brasileira e é evidente que eles vão passar na nossa frente, porque não há mistério. Isso que acho. A minha opinião está expressa nesses três textos. Melhor você pegar o texto original, que tem aqui na biblioteca e que está na História da Arte no Brasil do Walter Zanini.

J.P. - Sim, eu o conheço.

J.K. - Você tem?

J.P. - Eu tenho uma cópia dele. Professor, voltando um pouco a essa questão dos anos de 1960, sobre o início do Curso de Desenho Industrial, o professor menciona inicialmente uma diferença de industrialização nos Estados Unidos com relação ao Brasil e de um atraso aqui, para o qual teríamos que pensar num desenhista industrial....

J.K. - Adequado.

J.P. - Adequado para o nosso contexto...

J.K. - Foi um pouco do que aconteceu, porque o Desenho Industrial em São Paulo, enquanto possível, foi feito, pelo Oswaldo Arthur Bratke, pelo Rino Levi, pelo Artigas, pelo Jacob Ruchti, pelo Walter Zanini, e por nós também, pelo Ateliê, pelo Jorge Zalszupin e tudo mais. O que significa o quê? Que a indústria brasileira, o industrial brasileiro, nem naquilo que ele poderia ter aplicado os recursos do desenho industrial no Brasil, ele não aplicou. Tanto que, por exemplo, uma pessoa que estudou na ( $H f G)$ Ulm, dois desenhistas industriais que estudaram na ( $H f G) \mathrm{UIm}$, um foi o Alexandre Wollner e o outro foi o (Karl Heinz) Bergmiller. Eles vieram para o Brasil, eles voltaram para 
o Brasil, e foram ser professores da ESDI. O Vollner ainda chegou a ser chamado por uma indústria pequena de aparelhos elétricos. Mas, de uma maneira geral, o que o Vollner fez de respeitado, foi o que fez na Alemanha, porque aqui ele fez só coisas mais ou menos sem muita significação maior. Claro que ele fez coisa boa e tal, mas ele fez coisa boa como nós fizemos, nada excepcional, e o Alexandre Wollner fez gráfica. Ora, a gráfica é uma parte do desenvolvimento, aliás, uma coisa que eu chamei a atenção num texto meu, que é totalmente sobre arte e indústria, que você pode ler, de 1962. É belíssimo! Lá eu defino até uma série de coisas que o pessoal ficava perdido. Afinal de contas o que é projetar? O que é criar? Criar é o que fez o Picasso, pega um selim de bicicleta e um guidão e faz uma cabeça de boi.

J.P. - E que está na capa desta publicação.

J.K. - Mas o texto mais... talvez... além desse texto, que está na biblioteca também da FAU USP, que é o $A$ Invenção da Máquina a Vapor, há um texto... tem uma coisa que eu chamei atenção, o erro ideológico de todos os textos sobre Desenho Industrial, que separava, que só falava num Desenho Industrial como sendo objeto de consumo, quando na realidade o Desenho Industrial é um fenômeno muito maior, é o fenômeno da indústria de consumo e da indústria de bens de capital. Nisso, infelizmente, o texto ficou prejudicado, o texto do livro do Zanini ficou prejudicado porque não ficou muito claro. Eu falei nisso, mas não falei com a ênfase necessária, porque ele me cortou. $\mathrm{O}$ texto tinha 100 páginas e ele me obrigou a reduzir para 35. - Eu não vou publicar 100 páginas sobre uma coisa que não tem importância nenhuma, só faltou ele me dizer isso. Não tem importância nenhuma o Desenho Industrial, vou dar 100 páginas para falar sobre a arquitetura brasileira, coisa e tal, mas não sobre Desenho Industrial. Foi uma pena, porque eu chamei atenção sobre 
duas visões da produção industrial do século XIX. Uma feita pelos Estetas, que era uma visão profundamente negativa, e a outra, uma visão normal das pessoas que precisavam de produtos da indústria, visão esta extremamente positiva. Inclusive, até por ironia, peguei textos do Marx, mostrando o entusiasmo dele pela indústria do tempo dele, que são as prensas gigantescas pra época. Hoje é porcaria, mas na época, prensas de 200 toneladas, hoje isso aí, qualquer industriazinha vagabunda tem, mas naquele tempo era a maior prensa existente. Quer dizer, as máquinas operatrizes, que são o coração da produção industrial moderna, ficaram de fora desses textos todos de Desenho Industrial. Inclusive do Maldonado, ele não quis se arriscar, a própria ESDI sempre classificou como um produto em série, como eles diziam. Desenho Industrial é o graneleiro de 120.000 toneladas, que é um barco feito por encomenda. Eu até gozava, porque o avião 737, o Boeing, que é o avião mais difundido no mundo, tem um igual ao outro (risos). O fuso é igual, mas você entra dentro e é tudo diferente, porque no meio do caminho o banco muda, o puxador muda, aquele depósito de mala muda, vai mudando tudo, e as grandes obras de engenharia são tudo produto da indústria moderna, mas nenhuma delas é igual à outra. O Boeing é feito por encomenda, ninguém é louco de fazer um avião em série. Meu Deus, você vai fazer o que? Os americanos caíram nessa besteira, quando eles fizeram o módulo lunar. Eles fizeram 14, usaram 2. O resto serviu para que fizessem exposição no mundo. Nunca foram usados, eu vi um módulo lunar, nunca usado, numa exposição em Londres. Eu acho uma estupidez, não precisa. Módulo lunar, pô!, faz um.

J.P. - E nem pelo fato de ser desenvolvido individualmente, não faz com que ele deixe de ser um produto industrial.

J.K. - Exatamente. Você veja, todas as nossas usinas hidrelétricas são todas puro produto da indústria moderna. 
Aliás, Itaipu. Itaipu foi uma besteira fazer, porque foi um risco muito grande, porque a coluna d'água tem 120 metros de altura, e os congressos de engenharia recomendam que a altura máxima da coluna d'água chegue por volta de 80 metros. Veja que aconteceu um grande desastre na China por conta de uma brincadeira dessas. A nossa, tem 120 metros, ainda não aconteceu nada, e espero que não aconteça, mas é um risco desgraçado. Agora, cada uma delas, daqueles rotores, é uma coisa imensa, e os caras estavam fazendo pela primeira vez. Por exemplo, eu fiz a arquitetura de uma usina, que, aliás, eu considero minha, a Xavantes. Era uma das maiores usinas na época. E houve uma concorrência internacional para produzir um gerador. E esse gerador é enorme, tem 5 metros de diâmetro. Nunca ninguém tinha feito um gerador desse tamanho, o rotor. Quem ganhou foi uma firma japonesa, que pegou um rotor da Westinghouse, que tinha dois metros e pouco e simplesmente ampliou para cinco. Só que os problemas que surgem, quando você amplia, são gigantescos, e de fato houve uma pequena excentricidade nesse roteiro. Isso eu acompanhei bem porque os japoneses fizeram a gente pagar. Eles é que tinham que pagar, mas quem pagou fomos nós. Com essa pequena excentricidade o que acontece? A água formou uns redemoinhos, que os engenheiros hidráulicos chamam de cavitações, devido a essa pequena excentricidade. Como a água não é pura, você tem um pouquinho de areia, abriu um buraco nas pás do rotor, que eram de aço inox. Teve que parar, tirar, corrigir a excentricidade, que era mínima, mas teve que corrigir, cimentar de novo, com aço inox, os buracos feitos e depois alisar muito bem. Um trabalho, realmente, de alta especialização. Também os 4 rotores de Xavantes foram feitos especialmente, só que milhares de peças que entram nesses rotores foram feitas em série, claro. Você para entrar num navio de vela, você tem o mesmo interruptor que você tem na sua casa. Esse problema, infelizmente, está carregado de falsas, vamos dizer assim, 
proposições. Diante de todo problema do Desenho Industrial, devido a esse problema de luta de mercado, etc., é muito difícil de distinguir o que é avanço real e o que não passa de propaganda fraudulenta.

J.P. - O senhor apontou uma definição de Desenho Industrial que vai muito além do entendimento do Desenho Industrial como uma produção seriada de um mesmo objeto. O professor falava sobre a produção de arquitetos como Bratke, Rino Levi, e o Artigas que foram arquitetos...

J.K. - Mas não só. Outros arquitetos também colaboraram. Por exemplo, os do Rio de Janeiro: Lucio Costa, Oscar Niemeyer, (Affonso Eduardo) Reidy, Sérgio Bernardes, tem um monte deles lá do Rio que também tiveram essa preocupação com a indústria.

J.P. - Mas considerando esses arquitetos e a abordagem do Desenho Industrial na FAU USP, tudo isso parece ter um diferencial que é pensar um Desenho Industrial que pudesse industrializar a nossa arquitetura também...

J.K. - Também.

J.P. - Se compararmos com outras experiências de ensino de Desenho Industrial, a FAU USP era muito particular no sentido de pensar o Desenho Industrial do componente arquitetônico, seja o painel de vedação, seja o caixilho, ou mobiliários acoplados como armários, esse tipo de coisa. E temas como esses, como eram tratados dentro desse ensino de Desenho Industrial da FAU USP?

J.K. - Agora eu não sei como ele é levado, mas se você não tiver o apoio da Federação das Indústrias, para que essas experiências sejam levadas à prática, você não consegue fazer grandes progressos. Vou dar um exemplo 
simples, por exemplo, uma das coisas que sempre pensamos, foi em pré-fabricar edifícios. Não pré-fabricar projetos, pré-fabricar elementos que pudessem ser acoplados de maneira a produzir até obras diferentes. Isso em parte está sendo feito pela FDE (Fundação para o Desenvolvimento da Educação), mas com um processo industrial muito modesto, que é viga e pilar, sem fazer outra coisa. E isso mostra o atraso da indústria em não dar condições experimentais para, vamos dizer assim, novas proposições. E isso vale para todo o parque industrial paulista. Não há o mínimo de apoio à pesquisa de projeto e pesquisa tecnológica que são duas coisas diferentes. Por exemplo, você pode fazer um projeto que poderá ser industrializado e que não signifique, automaticamente, um avanço tecnológico. Você está sentado num caso desses (referindo-se à Cadeira Paulistano, de 1957, do arquiteto Paulo Mendes da Rocha). Essa proposta surgiu na Alemanha, 1900 e, até antes, surgiu na Holanda em 1926. Foi um arquiteto holandês Mart Stam que fez a primeira cadeira chamada de suspensão elástica, que depende de uma tecnologia extremamente desenvolvida, de aços especiais, como, aliás, a cadeira do Mies van der Rohe, aquela cadeira Barcelona, que parece muito frágil, mas não é. Aquilo lá tem um aço especial para poder resistir ao movimento contínuo, porque aquilo lá é um balanço gigantesco. E essa cadeira (cadeira Paulistano), do ponto de vista tecnológico, não representa nenhum avanço. Porém, ela representa um progresso no sentido de uma concepção arquitetônica ou artística, que se adapta perfeitamente a um processo industrial.

J.P. - É uma maneira de se apropriar de uma tecnologia existente, sem, entretanto, produzir um novo avanço tecnológico.

J.K. - Exato, exato. Agora, nós não podemos viver pirateando a tecnologia internacional, nós temos que ter 
um projeto tecnológico nacional e nós não temos. Não temos porque não se pensou nisso. Pesquisa tecnológica não pode ser localizada, esse é o grande erro desses empresários brasileiros. Eles querem uma pesquisa que vá beneficiar, imediatamente, a sua indústria. Isso não existe. É preciso haver um projeto tecnológico maior.

J.P. - Existe essa visão tecnológica que o professor está se referindo agora e que é importante considerar, mas há também outra questão que o professor apontava anteriormente, comparando o modelo da ESDI com o da FAU USP, e definindo a ESDI como importadora de uma visão externa, essa dimensão do colonizado, como o senhor se referiu, e dentro disso talvez poderíamos falar um pouco também da questão da identidade nacional no produto industrial. Como era pensado isso na FAU USP desses anos de 1960?

J.K. - Bom, nós sempre fomos muito ligados, na FAU USP, em primeiro lugar à arquitetura do Le Corbusier, por que ele foi o arquiteto que mais definiu, no seu pensamento, a absorção da ciência moderna e da tecnologia moderna. Se você pegar a revista L'Esprit Noveau, você vai ver, em primeiro lugar, grandes cientistas colaborando com a revista. A revista chamava-se L'Esprit Noveau e não Art Noveau. Um dos grandes cientistas franceses era um colaborador da revista. E a revista, em 1925, fez uma homenagem ao Einstein, que nada tem a ver com arte diretamente. Tem a ver, porque no fundo o Einstein era um humanista muito grande, ele foi membro de uma Associação de Amigos da Bauhaus, enfim era um homem muito ligado a esses problemas da cultura, mas ele era um cientista. Você vê então que essa postura do Le Corbusier repercutiu muito favoravelmente nos arquitetos brasileiros que o admiravam. Não eram todos, mas os arquitetos que o admiravam, o Reidy, os MMM Roberto, o Lucio Costa, o Oscar Niemeyer, enfim, todo esse pessoal pegaram esse 
aspecto, tanto que esses grandes arquitetos favoreceram três grandes engenheiros cariocas, que não eram cariocas, mas viviam no Rio de Janeiro. Um era o (trecho inaudivel: 51:42), o outro era o Joaquim Cardoso e, o terceiro, o Noronha Santos. Todos os três grandes engenheiros. Eles fazem parte do livro do Vasconcellos: Concreto Armado no Brasil. Então você vê que esse é um aspecto que marcou a arquitetura brasileira. Essa preocupação com o avanço tecnológico. Isso não existe com essa força, na arquitetura norte-americana, por exemplo, essa coisa não existe na arquitetura francesa, de maneira geral e não existe na arquitetura alemã, por incrível que pareça. E muito menos na arquitetura italiana, isso é uma característica que se imprimiu não por uma natureza brasileira, mas por uma consciência num determinado instante do Brasil, dos intelectuais e dos arquitetos brasileiros. Outra coisa que foi muito marcante na arquitetura brasileira desse período, e até hoje é marcante, é o sentido de absorver um fenômeno que marca a arte americana, não só a arte brasileira - a arte americana, entendida a arte latinoamericana -, que é a cor. A cor forte é uma característica que os espanhóis e portugueses absorveram dos índios.

J.P. - Ainda com relação à discussão sobre identidade, eu localizei na pasta funcional do Artigas, na FAU USP, um texto que ele redige e que está assinalado a lápis, que é de 1962 ou 1963, cujo título é Desenho Industrial e que na verdade trata-se de um texto de abertura de uma exposição que iria acontecer na FAAP, nesse período.

J.K. - Eu não conheço esse texto.

J.P. - É um texto em que o Artigas vai se dirigir tanto aos desenhistas industriais, quanto aos próprios industriais, chamando a atenção para a necessidade de se criar uma indústria nacional e pensar para essa indústria nacional uma identidade nacional que nos diferenciasse 
de outras produções. É instigante porque ele fala sobre a necessidade de se descobrir nossas raízes culturais e ele afirma ser necessário estudar tanto a nossa erudita quanto nossa produção folclórica.

J.K. - Ou popular.

J.P. - Ou popular. Nesse sentido qual é a discussão, qual é esse olhar que a FAU USP, nesse período, estava lançando para esse nosso artesanato, por exemplo?

J.K. - Essa visão vem dos modernistas. Vem do Mário de Andrade, do Oswald de Andrade, etc. e por incrível que pareça, ela é muito incentivada por artistas que eram europeus, que tinham assim uma visão muito humanista da obra de arte. A exemplo de Blaise Cendrars que insistiu para os paulistas irem visitar Minas Gerais. Ele foi junto em 1924. Também o próprio Le Corbusier que recomendou que se colocasse azulejo no Ministério da Educação. Azulejo é um produto tradicional brasileiro. Então, esse problema da identidade tem o risco de se transformar num slogan comercial. Eu tenho muito medo disso. Eu acho que a identidade nacional tem que aflorar obrigatoriamente, porque é uma característica. Eu gostaria de ler o texto do Artigas, mas eu tenho algumas discordâncias em relação ao Artigas, porque às vezes ele era um pouco chauvinista. Ele era um pouco antiuniversalista. Isso eu pretendo deixar por escrito, porque é verdade mesmo, e nós tivemos discussões seríssimas, com grande veemência, porque eu o chamava de chauvinista e ele ficava furioso e dizia: sou mesmo e coisa e tal. Aquelas coisas do Artigas. Então eu acho que essa identidade nacional é quase uma fatalidade. Por quê? Nós não estamos falando qual língua? Nós estamos falando português, é uma fatalidade. Se eu tivesse nascido na Itália, eu estaria falando italiano e assim por diante. Há uma condição brasileira que é inescapável, e isso aparece em uma porção de coisas. 
Por exemplo, numa coisa que também foi absorvida dos índios, que é uma certa hospitalidade, que é uma característica indígena e não portuguesa. Se você vai a uma aldeia indígena hoje, não há 500 anos atrás, mas uma aldeia indígena hoje, e se eles te recebem, tudo que eles têm, você pode utilizar. E eles também acham que tudo que você tem eles podem utilizar. Faz parte dessa visão de grande hospitalidade que é uma característica que eu diria, não sei se é toda latino-americana, mas é bem caracteristicamente brasileira. Isso se reflete até no jeito com que você recebe um estrangeiro. Há uma porção de características que nós temos, que nem percebemos e que, no entanto, fazem parte do nosso cotidiano. Essa a gente não precisa se preocupar, ela vai aparecer nas coisas que a gente faz.

J.P. - Vou pedir licença para ler um parágrafo do texto do Artigas, intitulado Desenho Industrial, que acho que ele...

J.K. - define isso.

J.P. - É. Ele coloca os seguintes termos sobre essa discussão que estamos falando, ao afirmar: No Brasil, a caracterização dos produtos, segundo tendências estéticas nacionais, impõe-se ainda pelo vasto repositório formal, constituído por um largo passado de criação artística que se manifestou em todos os campos plásticos, desde o erudito ao folclórico. Essa caracterização do Artigas entre o erudito e o folclórico de que eu falava. E segue: ... e por um presente muito rico de inventividade estética de alto mérito, cujo valor é incontestável e fortemente demonstrado pelo apreço internacional de que tem sido alvo. Por esse motivo, não é admissível que a produção industrial brasileira consiga ser alheia a este vasto manancial de criações artísticas, passado e presente, erudito e folclórico. 
J.K. - Você vê isso na Lina Bardi, que era italiana. Ela faz várias exposições: A mão do (povo) brasileiro... Ela tem o Museu do Unhão... E isso, mais ou menos, começou a ser inventariado, já no século XIX, em poesia. Em poesia, começou cedo. Como sempre, porque no Brasil a arte que se desenvolveu foi a arte dos eruditos. A poesia é uma arte erudita. Arte popular, a poesia popular, só começa a ser valorizada no século XX e toda atividade artística não erudita só passa a ser valorizada a partir dos modernistas, basicamente.

J.P. - Uma coisa que acho importante, aqui nesse texto, é o fato do Artigas adotar essa palavra: folclore...

J.K. - É.

J.P. - Estamos falando da Lina, e ela se colocava contra o uso da palavra folclore porque, para ela, folclore é uma palavra criada por uma visão erudita sobre a visão popular.

J.K. - Isso. Ela via o folclore como uma opressão da classe dominante sobre a classe dominada. Porque ela era uma leitora bem marxista.

J.P. - E no caso do Artigas, que o professor conviveu com ele, qual era a visão que ele tinha?

J.K. - Ele tem a visão do folclore brasileiro, que era um folclore feito contra a classe dominante, a começar por Gonçalves Dias que era um preto. Entendeu? O Gonçalves Dias é um poeta, um homem ligado ao folclore, à pesquisa folclórica. Então o sentido do folclore no Brasil tomou um sentido democrático desde o século XIX, por isso que o Artigas não tem medo da palavra.

J.P. - Ah, entendi. 
J.K. - Agora a Dona Lina tinha razão, porque ela veio de outra cultura, ela tinha a sensibilidade de uma opressão da classe dominante sobre a classe dominada. E o Artigas não tinha.

J.P. - Para mim, com relação ao Artigas, esta é uma importante informação.

J.K. - Isso não é fácil, a gente vai descobrindo essas coisas aos poucos. A Lina se entusiasmou com o Augusto Rodrigues que descobriu aqueles bonequinhos de barro do Vitalino. Ela fez uma exposição, não me lembro muito bem, 1948-49. O Flávio Motta participou desse processo, mas ele era mocinho nessa época. Ele era um homem, evidentemente, ligado a esse movimento todo moderno brasileiro de valorização popular etc., mas isso a Lina já trouxe de lá da Europa. E ela, ao contrário, valorizou coisas que nós não daríamos valor, porque os primeiros bonecos de barro, inclusive do Vitalino, depois ele vai cozinhar, mas a maioria era de barro cru, seco ao sol e pintado com essas tintas esmalte. Não era pintado com requinte cerâmico, era uma coisa feita para, como se diz, presépio. Essa produção de bonecos de barro para presépio existe até hoje. Grosso modo falando, diminuiu bastante, mas existe até hoje. Existe bastante no Vale do Paraíba até hoje.

Eles souberam valorizar. Isso vem um pouco do Integralismo, mas vem muito do Movimento Modernista, porque os Integralistas eram ligados ao grupo Anta, que era um grupo dissidente dos modernistas. Eles tinham essa preocupação da arte brasileira, da arte popular brasileira. E isso também vai preocupar muito a Lina. A Lina vai se preocupar muito com uma arquitetura nitidamente popular, e isso vai repercutir em vários trabalhos que vão ser feitos aqui na FAU USP. Até minha tese de doutorado, sobre a Casa Bandeirista, é sobre isso. 
J.P. - O professor Flávio Motta é auxiliar do Pietro Maria Bardi no IAC (Instituto de Arte Contemporânea) do MASP, e depois participa na FAAP, também, do Curso de Artes onde se discutia Desenho Industrial...

J.K. - Ele bolou uma coisa muito bonita para a época. Formar artistas no Brasil não dá, não tem mercado. Então a ideia dele, que, aliás, foi a própria história dele, ele é um excelente pintor, era formar professores de desenho. Sendo professor de desenho, o que é que vai acontecer? Você vai... (instante de silêncio, Katinsky observa a cópia de um artigo publicado na revista Acrópole, de 1960, o qual eu havia selecionado para a entrevista). Essa mesa, acho que é minha (apontando para artigo).

J.P. - Sim, ela é. E eu trouxe para conversarmos sobre sua produção de mobiliário.

J.K. - Mas, a mais bonita minha não é essa não. Tem o meu nome aí?

J.P. - Tem. É um artigo da revista Acrópole, de 1960, que eu reproduzi. Todos os objetos são do professor.

J.K. - Mas aqui está com nome do Jorge Zalszupin, mas não é não, essa mesa é minha. Quer ver o que é meu aqui? (folheando as páginas do artigo).

J.P. - Essa mesa, eu a vi na casa do Roberto Portugal.

J.K. - É. O Roberto Portugal ganhou de presente. Isso aqui também fui eu quem desenhou. Essas duas outras obras aqui são do Jorge Zalszupin. Esse banco é meu, e eu tenho uma mesa que não está aqui. Uma mesa de que eu gosto muito, exposta há pouco tempo no Museu de Arte Moderna, numa exposição. Essa mesa não é do Jorge não, essa mesa é minha. Essa mesa de centro aí é minha. 
J.P. - Olha só! E então, é um artigo da revista Acrópole publicado em 1960.

J.K. - Mas esses móveis foram todos criados antes, 195859.

J.P. - Essa era uma das questões, porque eu trouxe esse artigo e gostaria de ouvir um pouco como era esse processo de trabalho...

J.K. - O processo de trabalho era muito simples. O Jorge era um cara muito ligado à arte europeia, ela adorava a arquitetura, aliás, ele tem um depoimento dessa época em que ele diz isso. Ele adorava a arquitetura italiana e o design italiano e do norte da Europa, que naquele momento era a última palavra para nós todos. Eram todos artistas, como Alvar Aalto e outros artistas finlandeses. Outro artista muito querido naquela época, no nosso escritório, era o Arne Jacobsen, dinamarquês. Eu e o Abrahão (Sanovics) propusemos para o Oswaldo dar o prêmio de 1961, prêmio máximo de arquitetura, para o Arne Jacobsen. Mas a Dona Iolanda inventou, porque foi passear na Finlândia e ficou apaixonada pelo Alvar Aalto, de dar o prêmio a ele. Era uma bobagem, o Alvar Aalto não precisa do prêmio da Bienal. Agora, se tivesse dado para o Arne Jacobsen seria o primeiro prêmio internacional dele. Burrice é burrice, o que fazer, não é? Ah, outro cara que era muito admirado por nós todos naquela época era o Sérgio Rodrigues, e o Sérgio Rodrigues era muito influenciado por esses arquitetos, desenhistas industriais nórdicos que eram, perto da grande indústria norteamericana, pequeníssimas indústrias. Eles, quase todos, eram arquitetos, não eram designers. Uns eram, mas muito raro, entendeu? O maior design naquela época para nós era o Charles Eames. Era arquiteto também, não era designer. Nós nos sentíamos então, muito seguros 
em relação a essa ideia de um país pobre como o nosso, com uma indústria muito pequena, dedicar uma parte da preocupação com o design em projetos técnicos. $\mathrm{Na}$ realidade, o design dessa época foi feito por teimosia dos arquitetos, porque ninguém pagava. Desenhava-se esse móvel, fazia-se esse móvel e daí fazia-se meia dúzia. Tudo produção de 10, 15, 20 exemplares. Não mais que isso. Não era uma grande produção, sempre uma produção pequena.

J.P. - A produção acabava então esbarrando no limite de uma produção com certa artesanalidade?

J.K. - Sim.

J.P. - E que não era absorvida pela indústria?

J.K. - Não.

J.P. - Mas havia esse desejo...

J.K. - Nós queríamos, mas o que adianta? Não bastava querer. Precisava a outra parte querer.

J.P. - Sim, teria que haver essa incorporação.

J.K. - Designers brasileiros somente vão surgir, sem contar o Sérgio Rodrigues, depois da década de 1980-90, aí começam a aparecer designers no sentido pleno da palavra: só designer. Tinha também o (Carlo Benvenuto) Fongaro, que era arquiteto. Fongaro trabalhava para a loja Ambiente do Leo Seincman. Ele era designer exclusivo da firma do Leo Seincman, que era um cara que começou como vendedor de móveis, depois se associou a um italiano, fez a loja Ambiente e depois da loja ele fez uma fábrica de móveis que produziu durante muito tempo a cadeira do Arne Jacobsen. 
J.P. - Apesar desse limite industrial da produção seriada, me parece que todo discurso dentro da FAU USP, da Sequência de DI, era pensar um arquiteto que pudesse se inserir dentro da indústria, não é?

J.K. - Rarissimamente. Teve um estudante da FAU USP que foi trabalhar para a Walita. A Walita era tão ordinária, como empresa, que nunca publicou os trabalhos desse rapaz. Vale a pena até procurar, porque depois a Walita foi vendida para a General Eletric, e aí não sei que fim levou, não sei se ele se aposentou. Seria interessante procurar e saber. Um depoimento dele seria interessante.

J.P. - O professor se lembra o nome dele?

J.K. - Não lembro. Não lembro, mas tem gente que sabe. Outros professores de DI da FAU USP sabem. Uma das coisas que eu acho que deveria ser feita, eram os meninos do Desenho Industrial (referindo-se ao novo curso de graduação em Design da FAU USP) que quisessem fazer arquitetura, não precisassem fazer novo vestibular, é automático, faz tudo. Quer ser Desenhista Industrial? Tudo bem! Quer ir mais pra frente? Tudo bem! Aliás, na Inglaterra é assim. Tem um curso de designer que tinha um rapaz tão bom que os caras pegaram e disseram: Você vai para a escola de arquitetura.

J.P. - Nesse período também, tem a questão do professor Abrahão Sanovicz que ele vai para a Itália estudar o designer italiano...

J.K. - Era dentro daquele sonho nosso. Ele era meu sócio nessa época.

J.P. - E o professor recorda desse período em que ele foi para a Itália e qual a visão que ele trouxe de lá? 
J.K. - Ele voltou todo entusiasmado com o (Marcello) Nizzoli, com o Enzo Mari, com os designers italianos. Agora eu acho que o Abrahão não trouxe uma visão especial não, ele ficou meio... como todo mundo que foi para a Itália, naquela época, nós não tínhamos distanciamento crítico para absorver tudo aquilo. A Itália tem uma cultura solidíssima, é diferente de nós. Outro dia estava comentando isso, a propósito, lá no hospital e um dos médicos disse assim: Você estudou na FAU USP? Você é professor da FAU USP? Meu pai também foi professor da FAU USP. Ele era um engenheiro italiano, um judeu italiano chamado Mário Franco. Aí eu disse: Eu conheci bem o Mário Franco. O Mário Franco era um engenheiro italiano, tipicamente italiano... que cultura! Nenhum engenheiro tem a cultura que ele tem, e não só da engenharia. Ele era excelente engenheiro, um dos maiores engenheiros de São Paulo, mas não é isso não. Ele tem uma cultura geral que é um negócio muito sólido. Eu tive oportunidade de ver isso em banca, junto com ele. Isso nós não temos, é tudo meio improvisado, tudo sem arquivo. Nós nem sabemos o que é arquivo. Acabaram de acabar com o arquivo do Departamento de História. Pegaram, encheram um monte de caixotes e jogaram fora, quer dizer, todo o arquivo do Departamento de História acabou. Ele estava ocupando espaço.

J.P. - O senhor me dizia, voltando um pouco no tempo, sobre esse passado da FAU USP, quando se fala da Reforma de 1962, uma bandeira que é muito defendida, é essa de tentar criar uma Escola de Arquitetura que pudesse se distanciar, tanto do ensino da Politécnica...

J.K. - Quanto da Escola de Belas Artes.

J.P. - Quanto da Escola de Belas Artes, e o que se fala é de ter a aprendizagem dentro do ateliê, como uma nova 
possibilidade de ensino que se distanciasse dessas duas matrizes antigas. O senhor estudou na FAU USP de 1952 até 1957, que é um período pré-reforma de $1962 \ldots$

J.K. - Que prepara. Porque na realidade, apesar de se falar que nós não queríamos nem curso da Poli nem o curso da Belas Artes, historicamente, as duas grandes escolas que existiam e que existiram, foram a Escola de Belas Artes, que é uma criação renascentista, que baseava todo o ensino no desenho, e a escola Politécnica que centrava todo seu ensino no desenvolvimento da ciência da tecnologia. Então o que a FAU USP fez, na realidade, nesse período, que vai de 1957, digamos, antes de se corporificar em 1958...

J.P. - Em 1957, foi montada uma primeira comissão para tentar discutir uma nova forma de ensino de arquitetura.

J.K. - Então, o que na realidade a Faculdade de Arquitetura fez foi a síntese das duas Escolas, e para mim, quem fez a síntese das duas escolas, não foi o Artigas, foi um antropólogo chamado Mário Wagner Vieira da Cunha, que é antropólogo reconhecido pelo pai da antropologia paulista que é o Claude Lévi-Strauss. Você pega o livro dele Tristes Trópicos, está lá o nome dele, Mário Wagner. Um aluno reconhecido pelo mestre. Ele reconhece como alunos dele o Antônio Cândido, o Florestan Fernandes, a Gioconda Mussolini e o Mário Wagner Vieira da Cunha.

J.P. - E o Mário Wagner estava dentro da FAU USP nesse período?

J.K. - Em 1955. Ele entra na FAU USP em 1955 e traz uma visão antropológica para a arquitetura, não mais uma visão exclusivamente urbanística e uma visão edificada, digamos assim, de edifícios. Ele traz uma visão global da sociedade para a compreensão da arquitetura, e ele consegue fazer 
uma síntese das duas escolas, da Politécnica e a da Belas Artes, que é o que caracteriza, grosseiramente, até hoje, a FAU USP. É que o Artigas era muito vivo, ele pegava tudo, depois, na Reforma de 1962. O Artigas ficou sempre com um resíduo politécnico.

J.P. - Que é a formação dele.

J.K. - É a formação dele. Ele tinha certo desprezo pelo Departamento de História e pelo Departamento de Tecnologia. Eu falo isso, mas como hipótese, eu não posso provar, mas eu sempre senti certo desprezo dele pelo Departamento de História. Ele insistia na importância do Departamento de Projetos. Num certo sentido eu concordo que uma Faculdade de Arquitetura não está aí para formar historiador, está aí para formar arquiteto e projetista, mas esse arquiteto não pode ser mais como no passado, um homem que atende o mercado, e isso ficou muito forte na época. Isso acho que vem desta visão do Mário Wagner e desta visão antropológica que pega o Antônio Cândido, pega o Florestan, principalmente. Há também o Flávio Motta que entra nesse processo e ajuda a formar essa síntese porque ele também, junto com o Pietro (Maria Bardi) que era muito inteligente, apesar de ser um fascista safado, e a Lina, ele traz também essa visão. O Pietro Maria Bardi era admirador do Jean Paul Sartre, quer dizer, o Pietro sempre foi um cara fascista, mas nunca entrou nas burradas fascistas, sempre foi um cara muito atento ao processo global da arquitetura e do que interessava.

Essa é uma coisa interessante que, na exaltação do Artigas, nós nos esquecemos da figura do Mário Wagner.

J.P. - Confesso que é uma pessoa da qual não havia ouvido falar, até então.

J.K. - Eu acho que ele está vivo. Se morreu, morreu há 
pouquíssimo tempo. Acho que você tem uma figura que pode lhe ajudar muito que é o Juarez Brandão Lopes, que foi assistente dele, mas é um sociólogo também, muito ligado a esse mundo antropológico, etc. O Juarez também faz parte desse processo.

J.P. - Dentro desse período em que o senhor foi aluno da FAU USP, nesse período pré-Reforma de 1962, de alguma forma, era discutida essa questão da indústria dentro da arquitetura? Ou a presença do desenho industrial na arquitetura? Existiam as disciplinas de Composição de Arquitetura, mas teve uma específica, que me chamou bastante a atenção, que é a Cadeira 22: Composição Decorativa, que era do professor José Maria da Silva Neves, que depois, na reforma de $1962 \ldots$

J.K. - Vai ser Desenho Industrial.

J.P. - Se torna Desenho Industrial. Me parece, pela ficha da disciplina, que ela está num meio termo. Existe na primeira parte do curso, a intenção de discutir arte decorativa e arquitetura, arquitetura de interiores, uso da cor na decoração e na arquitetura de interiores. Por outro lado, há outra discussão, num segundo momento da disciplina, que abordaria também a relação da arte decorativa e o setor industrial.

J.K. - Ele era professor da Poli.

J.P. - Ele era da Poli?

J.K. - Era. Ele é arquiteto. Ele fez diversas obras de arquitetura do período Art Deco. E ele já tinha preocupações marcadamente funcionalistas nas obras dele. Uma das escolas está aqui perto, aquela escola Marina Franco, que era uma escola que se chamava José de Anchieta, por isso tem aquele horrível azulejo do padre 
Anchieta com um indiozinho. Esse projeto é dele. Ele fez vários projetos. Você pode pegar um livro da FDE sobre o Convênio Escolar. Há uma série de projetos que são dele. Os que antecedem o Convênio Escolar. Preocupação com o ensino, com a construção de edifícios escolares, foi uma preocupação constante da República Paulista, desde 1890, e o José Maria da Silva Neves era um arquiteto, um engenheiro-arquiteto muito respeitado. Eu fui aluno dele. Ele era muito simpático, ele nos deixava fazer tudo que queríamos, uma beleza! Nós trabalhávamos muito com ele.

J.P. - Ele era um professor preocupado com a discussão sobre a presença da indústria na arquitetura?

J.K. - Sim, porque essa era uma preocupação permanente da Poli. A Poli é quem traz essa ideia da indústria da construção. É o cavalo de batalha da Poli. São eles que fazem o Laboratório de Ensaios de Materiais que vai se transformar no futuro em IPT (Instituto de Pesquisas Tecnológicas). O pessoal diz que o IPT tem 100 anos. Tem porque eles incorporam o Laboratório de Ensaios de Materiais que era dirigido pelo próprio Paula Souza, que é o fundador da Poli, e depois vai ser dirigido pelo Pujol, que é o arquiteto que fez o prédio do Banco do Brasil, que hoje não é mais usado pelo banco e sim pela Associação Cultural Banco do Brasil, lá no centro. É interessante porque é um prédio meio misturado, com uns elementos Art Noveau, uns elementos neoclássicos, um troço assim bem eclético.

J.P. - Há também outro profissional, que é o Walter Zanini, que participa da maquetaria da FAU USP.

J.K. - É. Ele veio aqui como maquetista, mas ele tinha uma firma, logo que ele veio para cá, ele fez uma firma, móveis $Z$, e ele também fazia jardins. O Zanini é outra figura 
interessante, porque ele não era professor, nunca foi. Ele fez jardins, fez muitos jardins. Fez também vasos, desenhou vasos. O Zanini era um cara muito criativo. Ele começou como maquetista no Rio de Janeiro. Ele fazia as maquetes para os arquitetos modernos e inventava materiais. Por exemplo, uma chapa de cobre ele transformava num elemento vazado. Era muito criativo. O pessoal gostava muito dele. O pessoal do Rio gostava muito dele. Quando foi feita a FAU USP, a FAU USP foi feita com um grande apoio do pessoal do Rio. Porque o Anhaia Mello queria fazer a melhor escola do mundo. Isso é verdade, ele queria mesmo era fazer a melhor escola do mundo. Pintou tudo aqui de branco (se referindo às paredes do Palacete Vila Penteado, sede da FAU Maranhão).

J.P. - Então foi nessa época que foi pintado?

J.K. - Ele então se apoiou muito em alguns arquitetos do Rio de Janeiro, mas aí começa a Guerra Fria, e é um negócio que perturbou o mundo, mas o José Maria ( $d a$ Silva Neves) era muito preocupado com esses aspectos artísticos e ao mesmo tempo industriais, que marcavam a Politécnica. É isso aí, mais ou menos essa é a minha visão.

J.P. - Além do Zanini na maquetaria da FAU USP, fala-se também da presença do professor Fracarolli que...

J.K. - O Fracarolli veio da Poli, também. O Fracarolli já é um caso diferente, ele é um artista, sabia fazer, acadêmico, e que foi apanhado de repente por essa bruta transformação do Ministério da Educação, Arte Moderna, etc. Ele então tentou se...

J.P. - ...adequar.

J.K. -...se adequar. Se aggiornare, como dizem os italianos, e então ele introduziu várias propostas de 
ensino. Uma delas foi, todo mundo, durante certo tempo, fazer Mondrian, depois ele passou para a Gestalt, estudo da Gestalt. Uma pessoa que pode falar sobre ele, com bastante propriedade, é a Vera Palamini que foi assistente dele muito tempo. Ele era um homem difícil, porque ele era, a visão dele era uma visão meio fascista, mas ele foi um apaixonado pela Faculdade de Arquitetura, e ele morreu na Faculdade de Arquitetura. Ele tem busto espalhado por aí, tem busto até aqui na FAU USP. Ele fazia todos os bustos, enfim, ele nunca foi bem tratado, aliás, como nunca as pessoas são bem tratadas no Brasil. Ele não foi bem tratado porque brigou com muita gente. Ele era muito... ele se considerava o maior artista do mundo, claro, mas isso não tinha muita importância. Ele acabou um pouco solitário, mas a Vera sempre deu apoio a ele, e é quem cuida, ainda hoje, do ateliê dele. Eu até defendi, no fim da vida, defendi muito ele, apesar de saber que ele era um tremendo fascista. Ele brigava feio. Acabei defendendo tanto o Fracarolli que ele me deu de presente uma escultura dele, por sinal muito bonita, uma figura de Moébius, uma fita de Moébius. Mas ele sempre foi um homem, na realidade, muito ligado ao ensino acadêmico. É isso aí.

J.P. - Para terminar, estávamos falando sobre aquela disciplina de História da Técnica e eu fiz uma cópia da ficha da disciplina, e o registro mais antigo que eu encontrei, na FAU USP, foi de 1972.

J.K. - É inicial.

J.P. - Ela se inicia em 1972?

J.K. - É. Aí que foi instalado.

J.P. - E é a partir daquele processo que o professor falou de tentar adequar o currículo da FAU a uma exigência 
do MEC de um currículo mínimo para a formação do Desenhista Industrial?

J.K. - Isso. Aí nós começamos fazendo uma bibliografia inicial da História da Técnica no Brasil. Isso foi trabalho desse ano, 1972. A partir de 1973, nós começamos a fazer um levantamento das fazendas de açúcar e café de Itu, que era pertinho. Os alunos da FAU USP sempre foram bem abonados. Eles iam de carro, nós íamos de carro, passávamos o dia inteiro do sábado lá. Almoçávamos em Itu e depois eles iam, por conta própria, fazer o levantamento das fazendas. Pediam licença e fizeram levantamentos preciosos. E eles lembram, o que é gostoso, que eles aprenderam alguma coisa. Porque eles deixaram de aprender em livro. Eles começaram a ver engenho de açúcar, é esse troço que está aí diante de nós.

J.P. - Imagino que não deva ter muito registro disso nos livros.

J.K. - Não, eles estavam pesquisando e dando uma contribuição definitiva para a Universidade, e o trabalho deles aparece depois em trabalhos de outros pesquisadores e em trabalhos de mestrado e doutorado. Outro dia, eu entrei no escritório de um importante arquiteto que é importante e vi lá o trabalho que ele fez para mim.

J.P. - Isso deve ser muito bom!

J.K. - Acho que sim. Eles aprenderam a aprender. O que é fundamental. Está bom?

J.P. - Muito obrigado. 
Entrevista: Prof. Alessandro Ventura

Data: 19 de fevereiro de 2009.

Local: FAU USP - LABINDUS - Laboratório de Industrialização da Construção

A.V. - Alessandro Ventura

J.P. - Juliano Pereira

J.P. - O professor começou a estudar na FAU USP, em 1958, e se formou em 1962. Eu acredito que em um período de muita transição sobre a maneira de se ensinar arquitetura, se nós pensarmos que, em 1957, é estabelecida a primeira comissão para uma reforma curricular desde a criação da FAU USP, em 1948, que é aquela comissão de que o Vilanova Artigas faz parte, referida depois no relatório do Atelier na Formação do Arquiteto do Carlos Millan, e em que ele retoma os princípios defendidos por esse primeiro grupo de trabalho. Então o professor entra um ano após esta primeira comissão na FAU USP e se forma em 1962 que é o ano em que é feita a Reforma de 62 na Escola e que é o momento em que se estabelece a Sequência de Projeto e dentro desta, a Sequência de Desenho Industrial. Então eu queria saber, inicialmente, do professor como era a FAU USP nesse período de sua formação, antes de 1962. Nesse período em que o professor estudou, o que se discutia sobre projeto de arquitetura e qual a relevância que o desenho industrial tinha dentro do ensino da FAU USP nesse momento e quais professores chamavam a atenção para essa importância do desenho industrial e sua possível relação com a arquitetura? 
A.V. - Eu me formei em 1962. Em 1962, eu era presidente do grêmio da FAU USP e participei dessas reuniões de modificação do curso como presidente do grêmio e naturalmente eu não tive participação nenhuma porque estudante é estudante. Então a gente podia ouvir, mas não tinha... nessa época eu era presidente do DCE da USP e já era em 1962, mas nessa comissão além do Artigas tinha o Hélio Duarte que era um personagem importante, não sei se você conhece o Hélio Duarte, ele foi professor há uns não sei quantos anos da FAU USP, foi meu professor inclusive, e ele era uma pessoa influente, quer dizer, tinha, vamos dizer assim, uma ideologia diferente da ideologia do Artigas. Então, ah... a tua pergunta era sobre como era a Escola, não é? Eu diria que o desenho industrial não existia no meu ponto de vista, provavelmente você vai falar com o Julio Katinsky e ele vai te dar uma versão, uma visão diferente da minha, mas a meu ver não se discutia o problema de desenho industrial, não me lembro de ter ouvido discussões sobre a indústria ou coisa que o valha.... então, o que acontece... você perguntou também o que se discutia muito, se discutia muito a obra do arquiteto Frank Lloyd Wright, do arquiteto Le Corbusier... existiam uns grupos que eram a favor do Frank Lloyd Wright e do Le Corbusier. Então existia muita discussão entre os alunos, e participação, me lembro que existiam alguns colegas nossos que ainda estão ativos e que defendiam o Frank Lloyd Wright, existia o grupo do Sérgio Ferro, do Flávio Império que era contra, enfim, existia toda uma discussão, mas nem me lembro muito direito porque já faz quarenta e tantos anos... e.... mas o que acontece, o meu entendimento do que foi a Reforma (de 1962) foi que eu acho que teve a liderança do Artigas, que teve uma influência muito 
forte dele, mas eu acho que ele tinha uma visão ideológica do Construtivismo Russo, que o arquiteto devia participar de todas as atividades, a arte estava em tudo, então o profissional, ele via como uma abertura de mercados, inclusive para o arquiteto poder trabalhar na comunicação visual, no desenho industrial, mas no fundo isso tudo era uma visão muito próxima do Construtivismo Russo. E então eu acho, pelo que eu me lembro, a discussão começou nesse ponto, quer dizer apareceu o problema do desenho industrial; eram quatro divisões: o desenho industrial, a comunicação visual, o urbanismo e a arquitetura. Eram os quatro grupos que depois, anos depois, se acrescentou também o paisagismo.

J.P. - Entendi.

A.V. - Mas o problema é que quando se discutiu isso, como é que se montava esse curso, esse curso então se pegava algumas disciplinas que eu agora não sei te dizer o nome delas, mas você vai encontrar isso em documentos, mas era Composição Decorativa, eu não sei, tinha algumas coisas assim. Então resolveram pegar e juntar essas disciplinas pra fazer o curso. Você tem a relação...

J.P. - (apresentando ficha da disciplina ao Alessandro Ventura) Eu trouxe uma que é Composição Decorativa que era o Prof. José Maria da Silva Neves quem lecionava, e essa disciplina foi a que eu vi mais próxima desse assunto que eu estou tratando, que é o Desenho Industrial, mas que eu imagino que não abordavam em profundidade os temas do desenho industrial.

A.V. - Eu acho que houve, vamos dizer assim, é sempre a minha visão, certamente não vai coincidir 
com a do Julio Katinsky, nós temos visões um pouco diferentes, mas eu me lembro que Lúcio Grinover começou a dar aula em 1962 ou em 1963. Não me lembro. E ele veio para entrar numa dessas disciplinas chamadas do Curso de Desenho Industrial, e eu me lembro que a turma reclamava porque dizia ah, nós vamos ficar detalhando caixilhos, nós vamos ficar detalhando isso... Então, a visão que se tinha era uma visão muito do desenho dos componentes da arquitetura, não tinha nada, nenhuma ligação com a indústria, e também não existiam escritórios de desenho industrial, propriamente no Brasil. Então eu acho que esses primeiros anos foram assim mais ou menos anos de incompreensão do que seria... de que se entendia que o desenho industrial iria trabalhar com os objetos pequenos da arquitetura. Mas não se examinava isso como um componente importante no desenvolvimento industrial do país, nunca vi essa discussão. Aí, na verdade, você pega, por exemplo, o João Carlos Cauduro que é um arquiteto que eu acho que se formou dois anos antes do que eu, ou três no máximo, por aí. E ele fazia arquitetura, depois ele se dedicou à Comunicação Visual, junto com Martino etc., e até hoje ainda trabalha ...mas nessa época não existia isso...entende, quer dizer... você pega por exemplo o Abrahão (Velvu Sanovicz), o Abrahão desenhava muito bem, fazia cartazes, isso se fazia, era comunicação visual, mas não se entendia como sendo comunicação visual, era muito mais um viés do arquiteto que sabia desenhar. $\mathrm{E}$ eu, eu acho que em 1964 houve um pouco de rompimento com isso tudo porque o Artigas foi embora, e eu trabalhava com o Artigas, no escritório do Artigas, depois de formado, e eu também fui embora. Então, nesse período, não me lembro muito, eu não participei muito, não tenho muitas informações. Agora eu 
em 1966, num rescaldo desse período, um período meio indefinido, eu tinha uma bolsa para ir para a França.

J.P. - Professor, antes de entrarmos nesse assunto, o senhor, no começo da entrevista, apontou uma diferença existente entre a visão do Hélio Duarte e a do Artigas. Poderia me explicar um pouco melhor, em que sentido era esta diferença?

A.V. - Bom, ideologicamente eu não saberia avaliar muito bem o Hélio Duarte, mas o Artigas era Partidão (Partido Comunista Brasileiro/PCB), tinha uma visão do Partido Comunista, o Hélio Duarte não era comunista. O Hélio Duarte era um educador, um homem que trabalhou, com o ...como é que chama o grande educador brasileiro?

J.P. - O Anísio Teixeira.

A.V. - Anísio Teixeira, e que fez muita coisa na área educacional, em termos de edifícios e que ele (Hélio Duarte) também introduziu, quer dizer, o modernismo no edifício público. Então ele teve uma importância genial. Era arquiteto, mas não era ideologicamente ligado às visões da esquerda, mas eu também não saberia te dizer aonde ele se situa, sei que eram diferentes, mas eu não saberia te identificar o que seria uma ideologia dele, a não ser que ele era um grande educador, um homem voltado para a educação, sempre teve isso. Já como professor aqui, tive contato com ele e eu sei disso, que ele tinha muita preocupação com esses aspectos e certamente ele não era um comunista. É isso, não saberia te dizer muito mais.

J.P. - Entre 1966 e 1968, o professor foi para os 
Estados Unidos fazer especializações na área de desenho industrial...

A.V. - O que acontece é que houve nesse período, ou nesse intervalo de 1964, de meados de 1964 até meados de 1966, em que existia uma indefinição, eu fiquei fora bastante tempo, fiquei no Brasil, mas fora de circulação e no fim eu não tinha uma estrutura de trabalho, então eu resolvi estudar na França. Já tinha bolsa, já tinha tudo, estava até treinando o meu francês, porque eu conhecia francês de criança, mas eu não tinha praticado e se você não pratica a língua, fica algum tempo sem praticar, você perde a fluência. Estava eu fazendo conversação já, me preparando para ir para a França e aí eu conheci minha mulher. Resolvemos casar no espaço de um mês, não que tivesse qualquer problema, foi uma decisão apenas madura e acontece que minha mulher estava fazendo doutoramento na Columbia em Nova lorque e ela tinha vindo para o Brasil para o casamento da irmã e aí eu encontrei com ela nessa ocasião e começamos a sair e resolvemos casar. E surgiu o impasse, porque eu vou pra a França e ela estava terminando o doutoramento na Columbia, então decidi ir para os EUA e larguei a bolsa. Eu disse que tudo bem, mas ir para os EUA, eu até esse ponto estava fazendo Arquitetura, não tinha nenhum interesse, nenhuma proximidade, nada com desenho industrial nem comunicação visual nada, eu iria fazer arquitetura na França, mas quando surgiu esse.... vamos chamar assim inconveniente (risos), eu estou casado há 43 anos com ela, e eu disse: não, eu acho que eu não vou prejudicar você terminar o seu doutoramento, então vamos para os EUA, mas nos EUA eu não tenho o menor interesse na arquitetura, então a única coisa que poderia me interessar lá seriam os aspectos industriais. Minha 
mulher era, era porque ele morreu, era sobrinha do Henrique Mindlin - irmão do José Mindlin-, que é arquiteto, que morava no Rio. $\mathrm{O}$ Henrique Mindlin (arquiteto) era muito amigo do Jorge Nelson, de Nova lorque, que tinha escritório em Nova lorque. Então através... e eu também disse para a minha mulher: eu não tenho interesse de ir pra lá para estudar, só vou lá para trabalhar, mas tem que ser nessa área . Então, através do Henrique Mindlin, eu tive o contato com Jorge Nelson, eles eram muito amigos, e eu fui pra lá pra trabalhar com o Jorge Nelson que era um arquiteto que fazia não só arquitetura, mas fazia comunicação visual, fazia desenho industrial, decoração também e ele fez todos os móveis da (trecho inaudivel). Enfim, ele já faleceu há muitos anos, mas ele tinha muito prestígio nos EUA. Então eu fui trabalhar com ele e fiquei lá, não me lembro, um ano, um ano e meio, não me lembro, não sei, uma coisa assim, e nos EUA existe uma divisão muito grande em termos de trabalho, os trabalhos são muito segmentados, divididos, então eu me ressentia de uma falta de visão do conjunto. Eu estava trabalhando numa área, mas, entende muito especializada. Então eu falei com o Jorge Nelson que eu tinha intenção de fazer um curso na Pratt Institute, e eu fiz este curso na Pratt Institute em Nova lorque. Eu saí justamente para poder ter uma visão mais ampla do que eu estava simplesmente tendo no trabalho. Então eu voltei para o Brasil, e quando eu voltei para o Brasil, resolvi me dedicar a essa área, mas que não era meu objetivo de três anos antes, nem passava pela minha cabeça. Então, quando eu voltei, resolvi começar a trabalhar aqui e por coincidência o meu sogro era velho industrial e ele foi fundador da Deca, torneiras e, enfim, e ele foi sócio do Olavo Setúbal durante 50 anos e ele tinha a Deca, e depois ele tinha a Duratex e assim por 
diante. Então eu tinha alguma facilidade, ou algum protecionismo, vamos dizer, por parte do meu sogro, no sentido de poder ter clientes. E eu resolvi me dedicar a esse setor de produtos industriais. Continuei fazendo alguma coisa de arquitetura, mas principalmente desenho industrial... diga!

J.P. - Ainda sobre sua passagem pelos Estados Unidos, o professor foi orientado pelo Moholy-Nagy em seu curso de pós-graduação...

A.V. - Não, era a viúva dele, ele já havia morrido, eu tive aulas com ela, na Pratt Institute, acho que ela já morreu também, mas enfim era outro curso, eu tive contato, não foi minha orientadora de tese. Se você me perguntar agora quais são os meus orientadores não me lembro, precisaria procurar, não me lembro os nomes.

J.P. - O professor se lembra um pouco do conteúdo dos cursos de desenho industrial?

A.V. - O desenho industrial, podemos falar um pouco sobre isso. Eu era arquiteto e quando você chega aos Estados Unidos dizendo: Eu quero fazer desenho industrial, todo mundo te olha com espanto, como quem diz: Você é arquiteto, arquitetura está acima disso. Tanto que, quando eu resolvi estudar no Pratt Institute, dizendo que era arquiteto da USP, eu fui aprovado na oficina, sem grandes problemas e, não só isso, eu recebi uma bolsa de estudos da própria Escola, o que é muito difícil de conseguir. Então o pessoal achava estranho que você, um arquiteto, quisesse trabalhar com um negócio que teoricamente seria um nível, não digo inferior, mas mais simples. Então eu sentia esse preconceito, mas tudo bem. Agora, eu aprendi muito lá. Eu não posso 
falar sobre o curso em si, porque eu me lembro vagamente, faz muito tempo, mas me lembro, por exemplo, de aulas de escultura, eu aprendi muito sobre escultura, que é uma coisa que você usa, você pode usar até na arquitetura, mas certos conceitos, certos critérios de como construir uma escultura. Isto foi muito importante para mim, foi uma coisa marcante. Nós tínhamos disciplinas de tecnologia, de materiais, uma coisa assim. $E$ isso tudo é nos anos de 1960, que tinha efervescência muito grande, e tinha a Guerra do Vietnã, muita gente morreu, tinha muita gente que eu conhecia, toda semana saía no jornal o nome das pessoas. Era uma época de muita atividade cultural, de muita agitação cultural. Era muito importante aprender certas disciplinas de como desenvolver a sua criatividade em relação às coisas. E você tinha que fazer um recipiente para perfume, mas não usar o perfume, usar outros conceitos. Eu acho que foi interessante, eu não diria que foi assim marcante, a não ser estas coisas que eu não tinha feito aqui, eu tinha feito desenho, mas escultura eu nunca tinha feito. Eu diria que foi um convívio muito grande com esse pessoal, isso foi importante de ser feito.

Então eu voltei para o Brasil, e voltei para o Brasil e comecei a trabalhar na área industrial, eu continuava a fazer edifícios, mas eu percebi que o que não tinha no Brasil era equipe, não existia infraestrutura para desenvolver o produto. Eu tinha visto no escritório do Jorge Nelson uma oficina de modelos, uma oficina de protótipos. Aqui não se tinha nada disto, você não tinha sequer projetista. Os que existiam eram de arquitetura ou mecânica, não tinham projetistas da parte industrial. Então se você pegar a produção desse período, dos anos de 1970, você vai ver que a grande maioria dos produtos feitos pela indústria, quando não eram copiados literalmente, eles eram 
projetados por estes projetistas mecânicos, então você vê coisas que são absurdas. Era isso que você tinha. Enquanto que na arquitetura você tinha projetista, desenhista. Então eu resolvi montar uma estrutura, um escritório, aonde eu treinei gente para fazer este tipo de trabalho. Então eu tinha desde alunos da FAU USP que depois viraram professores...

J.P. - E quem eram esses alunos?

A.V. - O Júlio Maia, que ainda está aqui, tem um professor que está, acho, que no Paraná que era o ... agora não me lembro o nome, enfim tinham algumas pessoas, mas eu tinha projetistas que eu treinei para trabalhar nesta área de modelistas, porque existiam modelistas de fundição, aquele que trabalha em madeira e prepara os moldes para serem mandados para a fundição, mas não existiam modelistas de produtos, aqueles que são capazes de construir um modelo que é igual, ou quase igual a um verdadeiro, como fazer um protótipo. Então este pessoal todo eu treinei durante anos, e era uma estrutura que eu não poderia dispensar ninguém, porque se eu dispensasse, estaria mandando embora e não tinha substituição. Esse era um dos problemas que eu tinha, sustentar uma estrutura cara no escritório, enfim, eu me lembro que uma vez, em contato com o Artigas - talvez isto seja interessante para você -, eu passei a me dedicar à indústria, e ele me disse, poxa, eu nunca pensei que fôssemos chegar a este ponto, de ver alguém trabalhando na indústria. Porque a visão dele era outra, ele ficou surpreso em ter um profissional, um arquiteto, voltado para os problemas industriais. Ele não achou que fosse fazer isso, muito provavelmente achou que fosse ser outra coisa, mas ele achou surpreendente ter chegado a este ponto, quer dizer, tão longe, acho 
que o alcance que ele previa era mais curto.

J.P. - No Fórum de 1968, quando o Artigas elabora os croquis das pranchas de discussão, ele tem algumas considerações sobre desenho industrial, sobre a Sequência de Desenho Industrial e o professor me falou que ele não imaginava que o arquiteto chegasse até esse ponto. Mas o professor imagina qual a expectativa de formação que ele pensava para o arquiteto na área de desenho industrial?

A.V. - Eu não sei te dizer isso, na verdade eu não explorei esta observação dele, eu poderia ter explorado, mas a sensação que me ficou foi ele dizer que não imaginava que alguém pudesse ter avançado tanto neste setor. Talvez ele visse o desenho industrial, como a maior parte dos arquitetos, como uma atividade secundária e auxiliar do arquiteto. Talvez ele visse o arquiteto trabalhando para a indústria, com produtos da indústria da construção civil e não para a indústria como um todo. Mas é uma visão muito limitada, porque na verdade, o problema da produção industrial é fundamental e muito mais importante, porque todo o desenvolvimento, todo o progresso do país está ligado a isso: ao sistema de produção, então você tem que ter gente trabalhando nisso, e essa é a grande diferença quando nós formamos o curso aqui em 2003, porque o programa que eu propus é um programa de criação de um curso de vanguarda, porque o desenho industrial é estratégico, e não é estratégico porque eu penso, se você pegar os programas governamentais: CNPq, o Ministério da Indústria, você vai ver que ele é prioritário lá. Então o sistema de governo percebe que essa participação do desenho industrial na indústria é crucial. Se você pegar alguns dados 
internacionais, de comércio entre as nações, você vai ver que no fim do ano, próximo do ano 2000, $50 \%$ dos produtos, do intercâmbio de produtos, era de produtos inteligentes. O que, o que eram produtos inteligentes? Produto inteligente é aquele que contém dentro dele alguma coisa que não é direta, não é automática, não é uma modificação. É um processador, um processador que processa as informações e dá os resultados, por exemplo, quando você tem o automóvel que incorpora um controle de velocidade, um piloto automático, isso é uma introdução a um sistema inteligente, não é a mesma coisa que você controlar pelo velocímetro. Então, 50\% do comércio internacional, no início deste século, eram de produtos que continham alguma contribuição de inteligência, ora, quem introduz a inteligência? Porque o Desenho Industrial, ele é amplo, ele não só vê os problemas da tecnologia, mas vê os problemas da cultura, ele interpreta o que você precisa: o que é adequado, o que é futuramente adequado, e usa a tecnologia para fazer isso. É um instrumento típico de criação da inteligência dos produtos, de modificação da inteligência dos produtos, por isso que ele é estratégico. Isso que o pessoal não enxergou até hoje. Quando nós, quando eu fiz a proposta, minha proposta era fazer um curso de desenho Industrial que fosse de vanguarda e dirigido, justamente, à criação de uma base sólida, num sistema de criação de bens de capital. É um setor fundamental do desenvolvimento, é um setor muito sensível, então nós temos que nos preparar para isto. Se a Faculdade prepara o desenho industrial para isso, nós temos que montar laboratórios... Houve uma reação muito grande, porque o corpo docente que existia até 2003 aqui na FAU USP, era de um pessoal ligado ao desenho da arquitetura: desenho da maçaneta, do 
caixilho, etc.. Essa proposta que eu fazia, era uma proposta que punha em xeque todo esse pessoal, toda a cultura que eles tinham. Então qual era a grande divisão nesse momento? A minha proposta era fazer um curso desvinculado da arquitetura, que fosse de vanguarda e que com isso atraísse a arquitetura e a fizesse se tornar tecnologicamente mais avançada. Qual foi a proposta do outro grupo e que acabou sendo implantada? Não, nós vamos fazer um curso de desenho industrial que incorpore a cultura da arquitetura - todos os vícios da arquitetura, por que então ninguém vai para frente -, porque você está pegando um negócio que é novo e está colocando em nível de um negócio que está em crise. Mas é a visão deles, da maioria, então fica. Agora eu acho que o desenho industrial nessa época toda, dos anos de 1962 para cá, ele não tinha esta visão do problema da indústria, hoje você tem vários cursos que formam gente, existe um corpo de pessoas que enxerga isso com clareza, mas na escola não se via isso e não era essa a intenção.

J.P. - No momento em que falávamos do Artigas, o professor comentou um pouco da visão que o Artigas tinha sobre essa relação do desenho industrial. Ainda tenho uma questão que é a seguinte: o Artigas participa da Reforma de 1962, como um dos grandes articuladores, mas depois em 1964 tem o Golpe Militar, e em 1968 o regime militar fica ainda mais pesado com o Al-5, e Artigas acaba, em 1969 , sendo afastado desse processo e temos uma série de outros professores que continuam dando aulas na FAU USP e que acabam participando do desenvolvimento desse curso de desenho industrial entre 1962 e $1968 \ldots$

A.V. - Um deles é o Lúcio Grinover, é isso que você 
quis dizer?

J.P. - Sim. O senhor entra aqui na FAU em 1970, mas antes, entre 1962 até 1968-70, que professores trabalhavam com Desenho Industrial na escola e qual a visão que eles tinham?

A.V. - Eu na verdade, como eu disse pra você, eu de 1964 em diante, até 1968, estava ou fora (da FAU USP) aqui (no Brasil) ou fora lá (Estados Unidos), e não acompanhei. Eu voltei no 2ㅇ. semestre de 1968, bem no final da década, então os professores que tinham aqui eram professores que eram arquitetos que trabalhavam com isso. Quando eu chego, foi o próprio Lúcio quem me convidou para vir para cá. Eu venho com uma visão diferente, das experiências que eu tive fora, embora não tivesse ainda uma experiência industrial mais encorpada, vamos dizer assim, mas enfim, eu tinha uma visão um pouco diferente. O que, o que faz o Lúcio? Ele entra numa... Isso não é em 1970, é ao longo dessa década de 1970. Ele traz para cá uma série de linguistas: Décio Pignatari, Lucrécia Borges (Ferrara). Enfim, não me lembro quem mais, mas era uma visão do Desenho Industrial muito mais intelectualizada, muito mais europeia, eu diria, do que a que eu tinha, que era uma visão mais direta, industrial. Eles - eu não me lembro mais em que ano, entre 1970 e 1980 - entraram aqui e trouxeram esse discurso, um discurso teórico, mais intelectual, sobre Desenho Industrial, mas não operativo, sem operação nenhuma. Nós tínhamos divergência. Eu acho, existem ainda professores aqui que são seguidores dessas ideias, ainda existem. No meu ponto de vista isto foi um retrocesso, não pela discussão, porque eu acho que a discussão poderia existir, mas não num Departamento de Projetos, 
e sim num Departamento de História. Mas você querer trazer os problemas linguísticos para a produção é falar grego ou japonês, porque não dá para entender. Se você fosse falar qualquer coisa que esse pessoal falasse, para um empresário, um industrial, ele iria colocar-Ihe para fora e diria: O que você está querendo comigo? Quer dizer, um pessoal que não entendia o problema industrial. Não sei, eu não me lembro agora, pode ser que não houvesse esse clima de discussão de políticas industriais no país, eu não me lembro muito bem, mas dentro da Escola eu entendo isto como um retrocesso: um curso de projeto baseado num discurso, baseado totalmente num discurso, num texto da semiótica, isso tem uma importância relativa, porque senão ele desvirtua o caminho, e acho que desvirtuou. O Lúcio (Grinover) depois saiu da Escola, acho que ele saiu depois desse pessoal. O pessoal saiu antes, depois saiu ele, e continuaram alguns também seguidores do Lúcio.

J.P. - O professor me descrevia a dificuldade que era, naquele período em que voltou para o Brasil, para se encontrarem profissionais aptos a atuarem nesta área do desenho industrial. Mas havia outro problema na época também, que era esse de conscientizar o empresário da importância do Desenho Industrial, na qualificação do produto. Nesse período, em 1963, é fundada a Associação Brasileira de Desenho Industrial / ABDI, em que o próprio professor Lúcio Grinover participa como diretor até 1968.

A.V. - A ABDI é uma associação que eu participei também, depois que eu voltei, e era uma associação, eu vou usar um termo talvez impróprio, mas, uma associação triste, porque nós éramos no máximo 10 
pessoas e entre estas 10 pessoas tínhamos, sei lá, 2, 3 empresários de peso...

J.P. - O professor se recorda quem eram os empresários?

A.V. - Bom, um deles era o dono dos Elevadores Villares, o Luiz Villares. Depois tinha o... dos móveis, era o... Eu to com ele na minha frente... quando o assunto é nomes, a idade não ajuda. Daqui a pouco eu me lembro. Mas enfim, era uma associação que se reunia, onde alguns entendiam dos problemas, que gostariam de poder ajudar, mas não existia muita repercussão. Discutia-se o que podemos fazer, o que não podemos e era uma luta insana. $\mathrm{Na}$ verdade não se avançou muito. Acho que o último presidente foi o Sérgio Kell. Depois ela acabou, depois surgiram outras associações, mas no fundo o que acontecia é que não existiam escritórios, existiam pouquíssimos. Existiam, sei lá, se contava com uma palma de uma mão.

J.P. - Dentro da ABDI como é que funcionava essa perspectiva de tentar conscientizar o industrial da importância do Desenho Industrial?

A.V. - Eu diria que eram tentativas muito voluntariosas. A ABDI funcionava no escritório do presidente. O Lúcio (Grinover), foi ele que a fundou, seria muito interessante você descobrir o que ele pensava, como é que ele via, que certamente era de uma maneira diferente da minha. Mas enfim, eu acho que ele foi presidente durante dois mandatos. Mas enfim, eu acho que eram tentativas meio... eu participei recentemente, talvez um ano atrás, da Associação Brasileira dos Designers, um nome assim, não me lembro, inclusive me puseram no 
conselho e eu fui numa reunião, ou duas, mas eu não vejo muita diferença entre o pessoal discutindo hoje e o pessoal daquela época. No fundo é um bando de desesperados, porque eles querem reunir, eles querem fazer avançar, mas é muito difícil. Na verdade, o que mais faz avançar são os programas governamentais. Você tem o Programa Brasileiro de Design, onde fazem muitas coisas, isto em Brasília, no Ministério do Desenvolvimento. E esses organismos governamentais funcionam muito melhor que as associações, embora eles usem as associações.

J.P. - Mas ainda com relação à $A B D I$, nesse período dos anos de 1960, pelo que eu...

A.V. - Eu estou me lembrando agora, mas se você quiser falar sobre a $A B D I$, você poderia falar com o Vollner, o Alexandre Vollner, conhece?

J.P. - Sim, o conheço.

A.V. - Ele é grande amigo meu. O Alexandre, eu não me lembro se ele chegou a ser presidente, mas ele conhece a história da ABDI bem melhor do que eu. Deixa-me ver até se eu tenho o telefone dele! Bom, mas vamos falando enquanto eu procuro... Então, eu acho que seria muito bom você falar como Vollner, ele é da área de Comunicação Visual, não de Desenho Industrial. Nós convivemos muito ao longo desses anos, embora a gente se encontre muito raramente e more a duas quadras de distância um do outro. Ele certamente vai falar um monte de coisas, mas eu acho que é uma pessoa que - daqui a pouco eu vejo este telefone -, mas acho que é importante, principalmente esta parte da ABDI, eu acho que ele vai poder falar muito. Ele é professor, 
ele está aposentado porque ele é mais velho do que eu, deve ter uns 80 anos, parece. Ele era professor da ESDI (Escola Superior de Desenho Industrial, Rio de Janeiro).

J.P. - Este é um ponto que eu gostaria de abordar também, porque parece que a $A B D I$, quem participava dela, eram pessoas ligadas, havia professores ligados à FAU USP e havia professores ligados também à ESDI.

A.V. - Sim, mas o pessoal da ESDI era pouca gente, o Wollner era um deles, porque na verdade, o pessoal morava no Rio, o Wollner é que era uma exceção, mas enfim... Está aqui, você quer tomar nota?

(o professor Alessandro Ventura me passa o telefone do designer Alexandre Wollner)

A.V. - Se não for mais este, você me telefona que eu procuro. Você pode falar em meu nome para ele que ele vai te atender.

J.P. - Nesse período do início dos anos de 1960, no Brasil, existiram duas experiências que são pioneiras de ensino de Desenho Industrial: a FAU USP e a ESDI e que, de certa forma, eram visões distintas sobre o Desenho Industrial.

A.V. - Não, não são, o que acontece é que a ESDI foi criada, eu diria, baseada no modelo alemão. 0 próprio Wollner estudou na Alemanha. Eles seguem o modelo alemão e desenvolveram, se ligaram muito às escolas alemãs que têm convênios com outros países e sempre se arvoraram como sendo os donos do Desenho Industrial e nós sempre rejeitamos isso e eles nos qualificaram como os arquitetos que 
tentam fazer Desenho Industrial. Na verdade, o curso de Desenho Industrial da FAU USP começou antes deles. Mas existe uma rivalidade muito grande porque são visões diferentes. Mas aqui nesse curso (sobre o recém-criado curso de graduação em Design da FAU USP), eu fiz força pra trazer dois (professores) deles, um é o Marcos Braga que está no Departamento de História e o outro é o Cláudio Portugal que está no Departamento de Projeto. Eles são de origem de lá, e eu achei importante trazê-los para cá. Mas existe uma rivalidade grande, eles não gostam da gente, e a gente talvez não goste deles. Mas é uma diferença de formação. O Bergmiller, ele estudou em (HfG) UIm e foi uma pessoa muito importante lá (na ESDI). Eu o visitei na ESDI, na época em que a Carmem Portinho era diretora. Mas enfim, o Bergmiller, o Vollner, e tem mais alguns que eram alunos deles (da HfG UIm) e que levaram sempre esse lado europeu e alemão.

J.P. - Uma condição que me parece clara quando pensamos na ESDI, é que nela existe uma filiação à Escola de Ulm e, sobretudo através da presença do Max Bill que passa pelo Brasil primeiro a convite do professor Pietro Maria Bardi para fazer exposição no MASP. Mas se essa filiação do Desenho Industrial da ESDI à vertente alemã, isto é, à Escola de Ulm, é clara; no caso da FAU USP... talvez esta seja a pergunta mais cara do meu trabalho: Qual a referência da FAU?

A.V. - Para onde vai...

J.P. - Para onde está olhando, quais modelos a FAU USP toma como referência?

A.V. - Eu diria que ela não está olhando para 
modelo nenhum. Tirando... não sei até que ponto você vai usar este tipo de coisa, mas eu acho que a FAU USP ainda continua atrelada à arquitetura, ela não é ligada nem à Itália nem a coisa nenhuma, talvez até o Lúcio tenha tentado fazer essa ligação, mas eu acho que a FAU USP não tem, eu não sei para que lado vai esse curso (o recém-criado curso de Design da FAU USP), como é que ele vai se organizar ao longo dos anos ou que rumo vai tomar. Em 2007, eu era presidente da Comissão de Pesquisa, fui quatro anos presidente da Comissão de Pesquisa da Escola, e o diretor me chamou e me disse: O curso de Desenho Industrial está muito ruim e nós precisamos levantá-lo. E eu disse a ele o seguinte: Eu não mexeria no curso, porque se eu disser qualquer coisa, eles vão cair em cima de mim dizendo que é um absurdo, eu acho que eu não vou fazer um trabalho por aí, eu vou fazer um trabalho paralelo. Se eu continuar como presidente da Comissão, porque iria terminar o meu mandato da Comissão de Pesquisa, eu posso montar um grande grupo de pesquisa sobre bens de capitais. E eu tinha organizado, tinha chamado gente da UNICAMP, gente de materiais, de micromateriais. Enfim, tinha uma equipe grande que nós conseguimos trazer. A ideia era montar esse grande centro de pesquisas e com ele atrair os professores. Numa influência direta, de uma estrutura de curso que é muito complicada porque existem outros interesses em volta, não são puramente pedagógicos, educativos. Fora a questão de as pessoas acharem que estávamos nos atrelando muito à indústria. Eu tenho essa visão por que eu fui industrial. A gente tem que ter uma visão ampla, livre, entende? Então estas coisas atrapalham e eu acabei não fazendo isso, não levando adiante por razões políticas outras daqui, e eu saí da Comissão de Pesquisa, eu não fiquei um terceiro mandato, eu 
fiquei até o segundo. Eu disse: agora o problema é da Comissão de Pesquisa fazer esse trabalho, então, eu acho que aqui na FAU USP não existe este tipo de definição (sobre uma possível visão unitária do Desenho Industrial), não tem um viés claro, nós não temos, eu acho que a FAU USP está em busca. A grande oportunidade que a FAU USP tinha de criar isso foi quando foi criado o curso (de Design) e que foi deixado de lado: Não, vamos trazer isso pra baixo do nível da arquitetura e fica tudo no mesmo nível. Eu acho que não existe, cara, até agora.

J.P. - Uma impressão que eu tenho, a partir do que eu tenho lido sobre o ensino de Desenho Industrial na FAU USP, considerando a estruturação do Departamento de Projeto e as quatro Sequências de Projeto (edifício, urbanismo, programação visual e desenho industrial), é que a visão da FAU USP está muito próxima àquela de uma definição da própria Arquitetura Moderna, que o (Giulio Carlo) Argan vai caracterizar, e que é a de pensar o arquiteto como um profissional apto para desenhar da colher até a cidade...

A.V. - E essa é a visão do Artigas também...

J.P. - A visão do Artigas, e ele chegava a formulá-la?

A.V. - Ele tinha a visão de que ele poderia desenhar. A mudança, que eu não queria chegar nesse ponto, porque eu estava envolvido com a indústria. Quando você desenha a colher, nem sempre você está envolvido com a indústria, você pode estar vendendo a colher, se você quiser, mas com a visão cultural do que é a colher e não com a visão estratégica do que é a indústria. Essa é a diferença. 


\section{J.P. - Entendo.}

A.V. - Eu acho que aqui o pessoal vê de uma forma mais livre, do ponto de vista cultural da discussão: A colher é importante para os pobres, então nós temos que fazer isso assim, assim... Sem se preocupar quem é que fabrica isso, qual é o custo disso, qual é o estado da arte para fabricar isso, é importante, não é importante... Por exemplo, eu tive durante quinze anos escritório de desenho industrial, eu nunca fiz mobiliário, não é que eu não fiz porque eu não tive oportunidade, eu não quis, eu não quis trabalhar com madeira, eu quis trabalhar com técnicas mais sofisticadas, e a madeira, apesar de ser um material nobre, ela tem uma limitação tecnológica, então a minha visão era de que aquilo não ia... só um minuto... (pausa para conversa com secretário). A gente estava falando sobre...

J.P. - ... a questão da madeira e...

A.V. - Quer dizer, eu queria ter uma participação mais importante junto à indústria, eu achei que a indústria da madeira é uma indústria importante sim, mas ela não significa avanço, eu queria avançar, com tecnologias novas, são opções estratégicas que você faz, é a tua visão. Eu, por exemplo, trabalhei na área de informática, na primeira geração de informática. Com exceção do patinho feio aqui da Poli (Escola Politécnica da USP), eu participei de quase todos os projetos: os primeiros computadores feitos no Brasil e periféricos, até talvez, a metade da segunda fase, então isso é uma opção. Eu já projetei louça sanitária e é um negócio aparentemente ultra-artesanal, e é artesanal, mas de difícil controle de desenho, então era um desafio, porque a forma de produção dessas peças era por tentativa, porque você faz um molde, 
põe a argila, a mistura de argila e gesso, espera o gesso absorver a umidade e vai para um forno a 500 graus e você vai ver o que aconteceu do outro lado, porque quando ela entra no forno ela sofre retrações, mas como é uma peça extremamente complexa construtiva e esculturalmente, ela tem paredes duplas, mais simples, mais grossas, então cada uma dessas vai entrar de uma forma. Umas retraem $5 \%$, outras $6 \%$, outras $3 \%$, e quando chega do outro lado não tem nada a ver com o que entrou, então o desafio que eu sentia era: Como é que eu vou controlar esse processo, como é que eu vou fazer um desenho tal que eu saiba o que vai sair lá do outro lado? Eu fiz um projeto, que foi a linha original Vogue da Deca que ficou 15 anos como líder de mercado. E essa linha tinha uma definição geométrica muito clara. Ela tinha um círculo e para sair o círculo, e para descobrir como fazer esse círculo antes, para chegar lá e sair um círculo. Então é um trabalho que é muito diferente de você fazer um móvel de madeira, onde você vai usar, produzir técnicas e equipamentos, principalmente equipamentos mais do que conhecidos, a evolução é muito pequena. Enquanto que num produto como esse, por exemplo, você... Eu vou te dar um outro exemplo, um projeto que eu fiz para a antiga Semp, que hoje é Semp Toshiba, na época era só Semp. Eu fiz um dos primeiros rádios portáteis de plástico. Qual era a tradição da Semp naquela época? Eles construíam rádios de madeira imensos. Porque existia o conceito, no interior do Brasil, de que quanto maior o rádio mais longe ele pegava. Não tinha nada a ver com nada, mas era isso que...

J.P. - Era o folclore.

A.V. - Era o folclore. Eles faziam essas caixas 
enormes e colocavam um negocinho lá dentro, que era o radinho. Então eles me chamaram para fazer um rádio portátil. Os rádios ainda eram com válvulas e ia fazer um para transistor, para ver como é antigo. Eles tinham feito já um primeiro protótipo que existiu na base de alumínio, que se usava para colocar válvula, porque a válvula tinha que fazer força para colocar, tirar, então tinha um chassi de alumínio. Eles tinham feito o rádio para pôr dentro da caixa de plástico e o chassi de alumínio e tinha o transistor. Eu disse: Por que o chassi? Não precisa do chassi, precisava lá, aqui você pode usar outro tipo de material. Segunda coisa, o apoio não precisa ser mais um chassi, o próprio plástico é capaz de suportar. Então foi uma simplificação tremenda feita através de um projeto. Quer dizer, você tem a capacidade, quando você tem projetos deste tipo, de realmente encontrar avanços. Aquilo foi um avanço para a empresa, ela percebeu coisas que ela não estava percebendo antes. Por quê? Porque quando você está dentro de uma empresa, existem vícios, formas de fazer que são difíceis, estão arraigadas, é difícil de você modificar, tem que chegar uma pessoa de fora, e essa é a função do consultor. Chegar de fora e apontar outra forma de fazer aquilo. Em muitos casos, o desenho industrial funciona desta forma, é o consultor: está errado aqui, ali... E eles podem até eles mesmos resolverem os problemas através dessas críticas. Então, o projeto de desenho industrial muitas vezes é estratégico nesse sentido, ele provoca o avanço, ele provoca a intromissão de coisas inteligentes... E então a indústria precisa dele. A indústria não precisa só de um desenho bonito, precisa também, mas o desenho bonito tem uma vida muito curta, ele tem que ter ... (pausa, conversa ao celular) Desculpe... Onde nós estávamos? 
J.P. - Falando da questão de um desenho como expressão de domínio tecnológico dentro da indústria...

A.V. - Eu acho que esse é um problema que nós temos aqui, o pessoal não enxerga isso. Talvez tentem enxergar porque entrou muita gente nova, entrou gente da Poli, da FEA - da economia -, então pode ser que isso mude na visão do pessoal, mas até este momento, eu diria, nós estamos com esse problema. Enquanto que lá no Rio eles têm essa visão alemã das coisas, eles estão ligados à indústria. Não sei até que ponto eles têm um envolvimento com a indústria nacional, mas talvez tenham, eu não sei, eu não tenho acompanhado bem de perto.

J.P. - Nós estamos falando sobre essa ênfase na FAU USP de industrialização da arquitetura, como um objetivo buscado pelas disciplinas de DI. Mas temos também outro pessoal ou grupo de professores que estão pensando, desde o começo de 1962, por aí, sobre a questão do projeto do produto, porque eu pude ver, através dos exercícios solicitados aos alunos, várias situações de exercícios de projetos de produto mesmo. Inclusive essa revista de 1966, que é o Dirigente Industrial, que consta um depoimento do professor Lúcio Grinover... (apresento cópia do artigo)

A.V. - Sei...

J.P. - E neste momento o Grinover está falando para os industriais sobre a importância do desenho industrial. E ele mostra alguns trabalhos de alunos da FAU USP, que são desenhos de produto e que ...

A.V. - Eu acho que existe, o que não existe, eu 
acho, é aquele envolvimento... Isso aqui é encarado com o um produto em si, não existe a ligação com os problemas industriais efetivamente. Talvez eu tenha uma visão um pouco rígida, pelo fato de ter sido industrial. Porque eu vi todo o outro lado, quer dizer, a minha experiência envolve o projeto, mas envolve também a administração da empresa, da indústria, como é que ela opera... E depois de ter feito isto, eu percebo com muita clareza que o projeto é muito relativo. Na verdade, você pode ter uma indústria extremamente eficaz e você pode até nem ter produto, porque você pode ter equipamentos e a administração dos equipamentos... funcionalmente, etc. Um exemplo, você teve durante muito tempo uma indústria que apoiava toda a indústria automobilística. Essas indústrias não têm produto próprio, muitas delas são, por assim falando, para terceiros, e você pode ter indústrias muito eficientes, você tem indústrias que estão voltadas para o grande volume e outras que estão voltadas para o pequeno volume. Eles são mercados diferentes, estratégias diferentes. Você vê, se você é um industrial que não tem produto ou serviços, isso não tem importância. Eu posso ter uma indústria que tem produtos e eles podem não ser o melhor produto, não responder às melhores necessidades, mas o que é importante na indústria é tua rede de vendas, de suporte, de mercado. Você tem mercado, você pode ter produtos medíocres, mas se você tem um controle eficaz do mercado, você tem sucesso, você funciona, você regenera o capital. Porque no fundo o que é a indústria? É a regeneração do capital. Porque ao invés de você aplicar na bolsa ou aplicar nos CDBs, você aposta numa ideia e fabrica esta ideia. Então você tem que ter um retorno equivalente, senão você vai aplicar num CDB que ao menos tem garantia. 
Enquanto que na indústria você tem um risco. Meu sogro costumava dizer que ter uma empresa é como pedalar bicicleta: parou, cai. Então eu diria que o produto em si pode ou não ter importância. Então o que importa para nós em termos de estratégia para o país é: Que tipo de indústria nós queremos ter, que tipo de força nós queremos ter? Se nós continuarmos com o sistema antigo e não incorporarmos inteligência, nós vamos continuar fabricando geladeiras, fogões, etc. e tal, enquanto os outros fazem produtos inteligentes que são muito mais valorizados e que rendem muito mais e geram rentabilidade e capital muito maior. Quem esteve do outro lado do balcão, sabe que esse desenho é bom, ele é ótimo, pode ser bonito, mas eu não sei se ele é importante para uma estrutura industrial ou não. Talvez até um mais convencional, que este seja melhor, consiga regenerar meu capital com mais velocidade. E regenerar meu capital significa me equipar melhor. Então como eu estava falando antes, eu não aplico em CDB, eu aplico em uma indústria porque eu acho que em vez de receber $1 \%$ ao mês, eu vou receber $10 \%$ ao mês. Eu vou ter um lucro de $10 \%$. Isso me atrai mais recursos. Você tem riscos, mas... Se eu tiver um ventilador como este (apontando para o ventilador portátil em sua mesa), eu vou penar para vender, porque eu vou ter que convencer as pessoas de que isto é um ventilador e não uma caixa de bombons. Se eu tiver um ventilador com cara de ventilador, eu vou vender mais rápido, vou repor minhas máquinas. $\mathrm{Na}$ medida em que eu tenho retorno do capital, eu posso atualizar minha máquina e tornar eficiente, produzir mais barato, mesmo fazendo um produto que não é os olhos da cara do projetista industrial. Então, no fundo, no fundo, o desenho industrial é importante como alavanca, ele pode ser importante se trouxer 
benefícios concretos, mas ele não é essencial e sobreviveu-se sem ele durante muitos anos. Ele tem que ser eficaz, tem que ser bom. Outro negócio que eu não entendia: Quando tinha escritório, eu dizia para o meu sogro que meu escritório tem toda infraestrutura, pode desenvolver produtos, oferecer produtos, não preciso ficar esperando o industrial vir me procurar pra prestar um serviço. E ele me dizia: Não, não é assim. Eu não entendia. Somente depois que eu tive uma indústria, eu entendi. O que é? A indústria tem a sua estratégia, ela tem seus objetivos, onde tem de ir, o que ela tem que saber, aonde está apertando o sapato. Eu posso ser fabricante de ventilador, mas você vai chegar com um projeto belíssimo de ventilador e ele tem que estar dentro da minha estratégia. Por exemplo, seu ventilador é mais econômico que o meu? Vai fazer eu vender mais, mas se em compensação eu tenho que substituir minhas máquinas, aí eu não faço, eu não posso fazer, então eu descarto. Então é muito difícil você vir com um produto que vai atender justamente o que eu estou precisando. Não, meu problema hoje não é produzir ventilador, é pessoal, é a mão de obra que possui um nível técnico muito baixo. Eu não consigo ir ao mercado, então eu tenho que desenvolver um programa de aprimoramento profissional para eles. Pouco me interessa ter um produto melhor ou não. Quer dizer, a visão empresarial é diferente da visão do usuário. O usuário vai querer ter, mas eu não ponho em risco o capital que eu investi para fazer um negócio que não vem de encontro ao que eu estou precisando hoje. Você se encaixar nas necessidades específicas da estratégia industrial é muito difícil, então não dá para você criar um produto e oferecer...

J.P. - Talvez seja o contrário, olhar primeiro para a 
possibilidade de produção, para depois enxergar o produto.

A.V. - E isso é outra dificuldade, mas admitindo que você pudesse fazer isso, você estaria certo. Mas o que acontece, você não tem acesso a essa informação, porque nenhuma empresa vai abrir as suas portas para te dizer o que faz e o que deixa de fazer, o que está errado e o que está certo. Como eu faço o meu ventilador, eu não divulgo. Porque para fazer este ventilador eu apanhei muito, eu fiz uma caixinha de plástico assim e ela rachava naquele lugar. Porque rachava naquele lugar? Isto demanda tempo, recurso, desenvolvimento, testes, aplicações, investimentos em modelos diferentes e isso eu não conto para você. Essa é a dificuldade quando você tem uma Escola, porque numa Escola o ideal seria que você pudesse ensinar para o aluno como realmente se faz um ventilador, mas você não tem acesso às informações. A não ser, excepcionalmente, que você seja o homem que trabalhou nisso, você não terá, porque nenhuma empresa te permitiu isto.

J.P. - Mas voltando um pouco à questão do ensino, nesse período em que estamos focando, outra preocupação que é sempre relatada nos documentos, nos textos dos professores que são publicados, é de uma necessidade de um ensino que pudesse integrar as várias disciplinas, de pensar o ensino de Projeto próximo ao ensino de História e também próximo ao ensino de Tecnologia. E dentro desta questão da industrialização, da discussão tecnológica, nesse período de 1962 até a entrada do professor na FAU USP, quando o senhor começa a lecionar, qual a participação do Departamento de Tecnologia dentro desta Sequência de DI? Eles 
se integram de alguma forma? Como que isso acontece?

A.V.-Eu acho que não. Hoje, com o curso (de Design), que até 2003 não tinha o curso. Antes, eu diria que era quase nulo, hoje existe talvez alguma integração no curso ou comece a ter alguma discussão, eu acho que existe isso. Agora, até então (antes da existência do curso de graduação em Design) eu acho que não. Existe um problema de entendimento, quer dizer, normalmente os departamentos têm as suas pesquisas que podem ser totalmente adequadas a eles, mas eles muitas vezes não entendem o que o outro precisa.

J.P. - A partir da entrada do professor nos anos de 1970 para o quadro docente da FAU USP, que disciplinas o professor lecionou e como funcionava o conteúdo delas? Como eram as disciplinas dentro da Sequência de Desenho Industrial?

A.V. - Eu vou falar, mas sem saber os temas, porque eu já não me lembro, porque era na década de 1970. Eu posso te assegurar que eram todos projetos. Projetos de produtos. Agora quais eram, eu não sei. Nos últimos tempos eu tinha dado inclusive junto com Julio Maia, sobre mobiliário, cadeiras em particular. Mas eu dei também um curso, mas aí já era na parte de edificações e que era sobre modularidade. Como funcionam os módulos. Mas sempre foram produtos. Agora eu não me lembro, mas sempre eram projetos.

J.P. - E esses produtos dentro da disciplina chegavam até que nível de desenvolvimento? Tinha protótipo?

A.V. - Existe uma diferença entre protótipo e 
modelo. O que existia eram modelos, protótipo já é uma peça funcionando. Nunca se chegou a isso, os modelos mesmo eram ruins. Hoje talvez até estejam melhorando porque mudou a oficina, mudou as pessoas, mas aqui não se consegue fazer modelos de muito boa qualidade. Eu tinha modelos em que uma vez eu enganei o meu cunhado, não que eu quisesse, mas estava em cima da mesa e ele veio para ligar o rádio... mas isso é madeira... era tão bem feito que ele pensou que fosse real. Mas a gente não chega a fazer (protótipos), inclusive por falta de pessoal técnico que oriente adequadamente. É muito difícil, no serviço público, você ter funcionários realmente envolvidos, capacitados. Eles vão encostando, às vezes até sabem, podem fazer, mas fazem de conta que não sabem. Então é difícil. Os alunos eu acho que não têm muito apoio nesse sentido.

J.P. - No caso da FAU USP, se fala muito, com relação aos anos de 1960, da participação do José Zanini Caldas no laboratório de maquetes e modelos...

A.V. - O laboratório de maquetes era aqui onde você está sentado, nesta sala, antes da reforma. Mas ele (Zanini) foi anterior à minha vinda para cá, eu não conheço bem a participação dele. Quem cuidava daqui, que nós chamamos de Lame até hoje, que é Laboratório de Ensaios e Modelos, era o Fraccaroli.

J.P. - O Caetano Fracarolli?

A.V. - Que era escultor, e já morreu...

J.P. - Até que período que ele ficou no laboratório?

A.V. - O que acontece é que eu fiquei de 1970 a 1980 e depois eu saí, porque eu tinha a fábrica e voltei 
em 1998, quando eu vendi tudo. E o Fraccaroli acho que ainda era em 1980, mas eu não sei em que ano ele saiu, mas isso não é difícil de conseguir saber, pode perguntar, que o pessoal deve saber aí. Eu não sei. Mas o Fraccaroli era um escultor, quer dizer, ele realizava peças do ponto de vista da escultura lá no seu ateliê. Mas é isso, acho que não ajudei muito você.

J.P. - Não, me ajudou bastante. 


\section{Desenho Industrial ${ }^{1}$}

\section{2}

\section{Apresentação de Vilanova Artigas}

1. O presente texto, do arquiteto Vilanova Artigas, foi reproduzido de sua Pasta Funcional de Professor da FAU USP, pertencente à sessão de obras raras da biblioteca da FAU USP. Foi produzido como apresentação de uma exposição de Desenho Industrial que se realizaria na Fundação Armando Álvares Penteado, FAAP, em 1962. Esta exposição foi uma iniciativa de uma Comissão de Desenho Industrial do IAB SP em colaboração com a FAAP.
A fase que o Brasil atravessa em sua evolução industrial é a mais crítica e a que assume maior importância na história de nossa industrialização. É que já atravessou a produção manufatureira nacional o período de implantação dos processos mecânicos de fabricação, para ingressar num estágio em que a técnica do fabrico e a forma plástica dos produtos têm que ser plasmado pela nossa gente. Daí, o duplo esforço que se faz necessário presentemente, para tornar efetivamente nacional os processos industriais de produção e entranhadamente brasileiros os produtos de nossas manufaturas: primeiro, o aprimoramento científico e técnico dos que trabalham no campo manufatureiro, em particular dos jovens que ingressam e ingressarão dentro em pouco nas atividades produtoras, a fim de que se possa atingir uma ciência e uma técnica nacionais de produção; e, segundo, a elaboração, para os nossos produtos, de uma forma plástica genuinamente brasileira, de modo a dar caráter próprio aos artigos que produzimos. A primeira resolve-se pela pesquisa e pelo ensino científico, a segunda pelo congrassamento de todos que labutam no campo (da produção) das artes plásticas, a fim de imprimir aos nossos produtos uma forma que os caracteriza como brasileiros.

A Fundação Armando Álvares Penteado e o Instituto de Arquitetos do Brasil, entidades visceralmente ligadas ao ensino, à difusão, à caracterização e à produção de formas plásticas tipicamente nacionais, sentindo a importância dos problemas plásticos na produção nacional, resolveram iniciar uma campanha, junto aos industriais e aos artistas, para iniciarem um movimento de criação e produção de artigos, - cujas formas sejam plasticamente nossas, 
em outras palavras, para constituição de um desenho industrial caracteristicamente brasileiro. Não fazem, porém, as duas instituições esse movimento com intenção demagogicamente nacionalista, mas porque entendem que as formas plásticas dos produtos constituem veículo importante de educação artística, assumindo assim relevante aspecto social.

Além disso, em todos os países, as formas plásticas dos produtos refletem os aspectos culturais de seu povo, - particularmente as tendências estéticas que o gosto artístico aliados aos usos e costumes compuseram. Estes aspectos culturais não sintetizam apenas a tradição, mas resumem também a etnologia dentro das quais o povo se formou.

A forma plástica dos produtos industriais fabricados no Brasil em sua grande maioria vem de fora. Isto porque, de um lado, os nossos produtores preocuparam-se, em virtude do rápido desenvolvimento industrial, antes com o reequipamento para atingir a expansão e a melhoria técnica requeridas pelo crescimento acelerado da produção manufatureira, do que com a forma plástica do objeto a produzir, de outro lado, as indústrias estrangeiras que aqui se instalaram, trouxeram conjuntamente com os equipamentos, o que é natural, o desenho dos produtos que iam produzir em nosso país. O resultado dessa dupla atitude, aliás muito compreensível, frustrou o desabrochamento do desenho industrial brasileiro e prejudicou a continuidade da inspiração de nossa anterior insipiente manufatura, que era em grande parte (palavra ilegível) no artesanato popular. Por esse motivo, nas formas plásticas de nossos produtos industrializados seguem os aspectos culturais dos países de onde provinham. Acham-se desse modo divorciadas das tendências estéticas genuinamente brasileiras. Esse divórcio não é aconselhável, nem em termos de cultura, nem em termos econômicos.

Não é aconselhável em termos de cultura, em primeiro 
lugar, porque desvirtua a própria orientação estética do país, pelo entrechoque de gostos e tendências artísticas, que leva a um atordoamento no campo criativo das formas plásticas. Em segundo lugar, porque se a indústria pode promover cultura, o desenvolvimento da cultura por seu turno contribui para a afirmação e o progresso da indústria. No campo das formas plásticas, a nossa indústria não promoveu e nem utilizou da cultura brasileira. Falta-nos assim aquela experiência coletiva, que em outros países transformou um gosto nacional em produtos industriais típicos de uma cultura. Daí, a quase ausência entre nós de bons desenhos industriais. Se bem existem bons exemplos, testemunhos eloqüentes do que podemos fazer neste campo.

Não é aconselhável em termos econômicos, uma vez que, na competição entre produtos, as indústrias que orientam as formas plásticas de seus artigos segundo as tendências estéticas tipicamente brasileiras terão obtido um forte elemento de combate, para enfrentarem os produtos de derivados de formas plásticas estrangeiras. É que entre artigos similares, a diferenciação para atrair compradores não se faz apenas nos preços, mas também, e, sobretudo, na personalização das formas plásticas segundo as tendências estéticas nacionais. $E$ agora que a indústria nacional se prepara para entrar nos mercados internacionais, essa personalização das formas plásticas de nossos produtos faz-se ainda mais necessária, para atrair pela originalidade e beleza de suas formas plásticas os compradores estrangeiros. Há a lembrar ainda o escoamento de divisas que o pagamento de "royalties" obriga. Esse escoamento se estancaria ou diminuiria caso os produtos nacionais fossem realizados segundo desenhos também nacionais.

No Brasil, a caracterização dos produtos segundo tendências estéticas nacionais impõe-se ainda pelo vasto repositório formal, constituído por um largo passado de criação artística, que se manifestou em todos os campos 
plásticos, desde o erudito ao folclórico, e por um presente muito rico de inventividade estética de alto mérito, cujo valor incontestável é fortemente demonstrado pelo apreço internacional de que tem sido alvo. Por esse motivo, não é admissível que a produção industrial brasileira conservese alheia a este vasto manancial de criações artísticas, passado e presente, erudito e folclórico.

Para que esse manancial de criações artísticas sirva de elemento orientador da produção industrial, é preciso que os artistas nacionais, responsáveis pela formação de nossa cultura artística, passado e presente, tenham a oportunidade de contribuir no sentido de afirmação plástica dos nossos produtos manufaturados. Dandose a eles essa oportunidade, abre-se de novo campo profissional de grande importância cultural e econômica - a do desenhista industrial. É para a criação desta nova atividade artística e produtora, que os artistas e os industriais devem dirigir seus esforços.

A Fundação Armando Álvares Penteado e o Instituto de Arquitetos do Brasil entendem que o processo mais eficiente para criar o debate em torno da criação de formas plásticas, genuinamente nacionais, para os artigos manufaturados brasileiros, é promover uma exposição sobre a arte na indústria, tendo como tema o desenho industrial. A exposição destina-se, primeiro, a iniciar uma campanha de esclarecimento e de colocação do desenho industrial junto aos produtores, aos artistas e ao público. Para tal, a exposição terá como preâmbulo uma parte didática, em que as questões em torno do desenho industrial serão formuladas, ao mesmo tempo em que terão apresentadas as linhas estéticas gerais de uma possível solução para o caso brasileiro. O corpo central da exposição constituir-se-á da apresentação de produtos industriais cujos desenhos já são brasileiros. Para isto, far-se-á uma pesquisa, a fim de se conhecer o que nossa indústria já produz utilizando desenho tipicamente nacional. Esse levantamento será de enorme utilidade, 
pois revelará aos incrédulos e pessimistas o absurdo das suas posições, enquanto revigorará a fé daqueles que acreditam e trabalham para um Brasil maior e melhor.

Para alcançar o objetivo que se propõe - o desenho industrial caracteristicamente brasileiro, a formação e o desenvolvimento do desenhista industrial - as duas instituições estão convencidas de que será necessário continuidade na campanha que ora encetam. Por esse motivo, acordam que as exposições do gênero que ora realizam devem ser periódicas. 

lista de exercícios das disciplinas de desenho industrial da FAU USP entre 1965 e 1968 


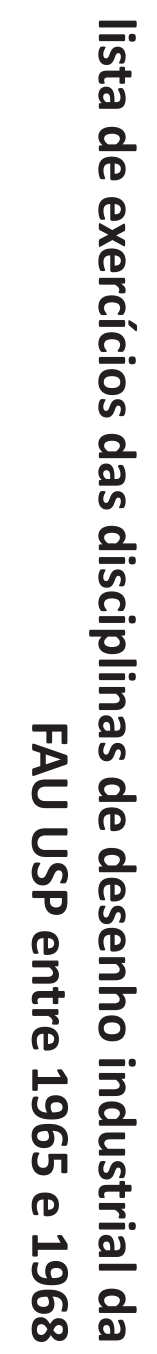





\begin{tabular}{|c|c|c|c|}
\hline disciplina & exercício & tema & descrição: programa, conteúdo teórico, exercícios práticos, professores e instrutores, etc. \\
\hline $\begin{array}{l}\text { Disciplina } \\
\text { Autônoma } \\
\text { 131: } \\
\text { Desenho } \\
\text { Industrial I }\end{array}$ & T.02 & Simetria & $\begin{array}{l}\text { - Decompor uma estrutura dada a partir da análise de seus órgãos de simetria, tais que: } \\
\text { 1. O número de elementos resultantes da decomposição seja 4; } \\
\text { 2. Que pelo menos } 3 \text { desses elementos sejam desiguais; } \\
\text { 3. Que a estrutura resultante seja estável; } \\
\text { - A estrutura será escolhida dentre os seguintes sólidos geométricos ( } V \text { aprox. = } 4.000 \text { centímetros cúbicos): tetraedro, } \\
\text { octaedro, cubo, icosaedro, dodecaedro, prisma reto de base triangular, prisma reto de base quadrada, pirâmide } \\
\text { regular de base triangular, pirâmide regular de base quadrada, cubotaedro, cubotaedro tronco, prisma torto. }\end{array}$ \\
\hline $\begin{array}{l}\text { Disciplina } \\
\text { Autônoma } \\
\text { 131: } \\
\text { Desenho } \\
\text { Industrial I }\end{array}$ & T.04 & $\begin{array}{l}\text { Coordenação } \\
\text { Modular. } \\
\text { Sistema de } \\
\text { Elementos } \\
\text { Componíveis }\end{array}$ & $\begin{array}{l}\text { - Projetar um sistema de elementos componíveis tais que: } \\
\text { 1. O número máximo de elementos seja } 9 \text {; } \\
\text { 2. Os elementos sejam bidimensionais e geometricamente definidos; } \\
\text { 3. O sistema possibilite a construção de figuras geométricas (triângulos, quadrados, retângulos, etc.) }\end{array}$ \\
\hline $\begin{array}{l}\text { Disciplina } \\
\text { Autônoma } \\
\text { 131: } \\
\text { Desenho } \\
\text { Industrial I }\end{array}$ & $n / c$ & $\mathrm{n} / \mathrm{c}$ & $\begin{array}{l}\text { - Os primeiros trabalhos não são condicionados pela relação homem-objeto, mas sim por certas relações geométricas } \\
\text { ou abstratas, conduzindo gradativamente para uma coordenação de determinados parâmetros que intervêm nos } \\
\text { problemas de "design". } \\
\text { - A programação para o ano de } 1965 \text { obedece ao seguinte esquema: } \\
\text { 1. Construção de curvas geradoras de figuras planas e espaciais; } \\
\text { 2. Decomposição de elementos; } \\
\text { 3. Sistemas de elementos componíveis; } \\
\text { 4. Agrupamento de elementos bidimensionais no plano; } \\
\text { 5. Agrupamento de elementos bidimensionais no espaço; } \\
\text { 6. Agrupamento de elementos tridimensionais; } \\
\text { 7. Projeto de um jogo (brinquedo) para armar ou construir. } \\
\text { - PROGRAMA: Fundamenta-se o curso sobre elementos básicos da comunicação gráfica do desenho industrial e sobre } \\
\text { análises conceituais, gráficas e construtivas das formas. }\end{array}$ \\
\hline
\end{tabular}




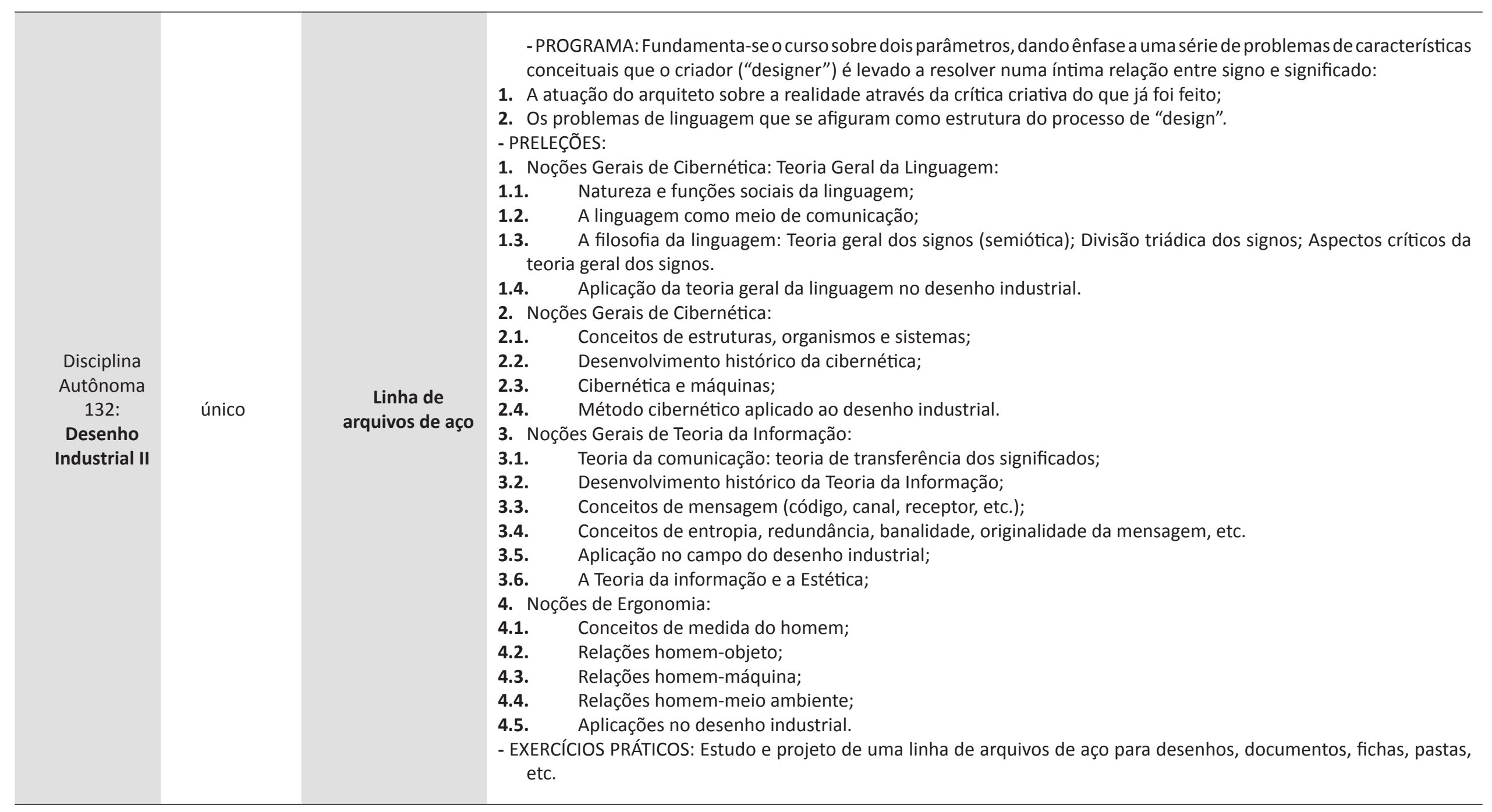




\begin{tabular}{|c|c|c|c|}
\hline $\begin{array}{c}\text { Cátedra 13: } \\
\text { Desenho } \\
\text { Industrial } \\
\text { III }\end{array}$ & único & $\begin{array}{l}\text { Equipamentos } \\
\text { para Habitação }\end{array}$ & $\begin{array}{l}\text { - INTRODUÇÃO: Considerando os conhecimentos teóricos e práticos adquiridos pelos alunos durante os três primeiros } \\
\text { anos do curso de arquitetos, passando por uma fase de introdução e preparação, no 3o ano do referido curso passam } \\
\text { por uma fase de execução. } \\
\text { Nesse sentido são estudados os diversos equipamentos da habitação, sempre ligados a uma mesma diretriz, } \\
\text { mantendo o princípio de estabelecer um conceito de linha de produção consoante com as necessidades do homem } \\
\text { e o progresso industrial no país. } \\
\text { Procura-se ainda uma colaboração íntima com as outras seqüências de Ateliê no sentido de completar a formação } \\
\text { profissional dos futuros arquitetos. } \\
\text { - PROGRAMA: Fundamenta-se o curso sobre as implicações do desenho industrial nos equipamentos da habitação. } \\
\text { O equipamento da habitação é estudado com o espírito de estabelecer um conceito de linha de produção consoante } \\
\text { com as necessidades do homem. } \\
\text { - PRELEÇÕES: } \\
\text { 1. Características gerais do equipamento da habitação: aspectos fisiológicos, sociais, econômicos e culturais; } \\
\text { 2. Noções de tecnologia adequada: aspectos gerais, escolha dos materiais, a tecnologia do mobiliário, noções de } \\
\text { elementos de pré-fabricação (painéis divisórios, forros, etc.) } \\
\text { 3. Funções humanas na habitação: permanência diurna, permanência noturna, higiene, alimentação e serviços gerais. } \\
\text { - EXERCíCIOS PRÁTICOS: Projeto de uma linha de objetos, dentro da orientação geral acima exposta, execução de } \\
\text { desenhos, modelos e detalhes construtivos. }\end{array}$ \\
\hline
\end{tabular}




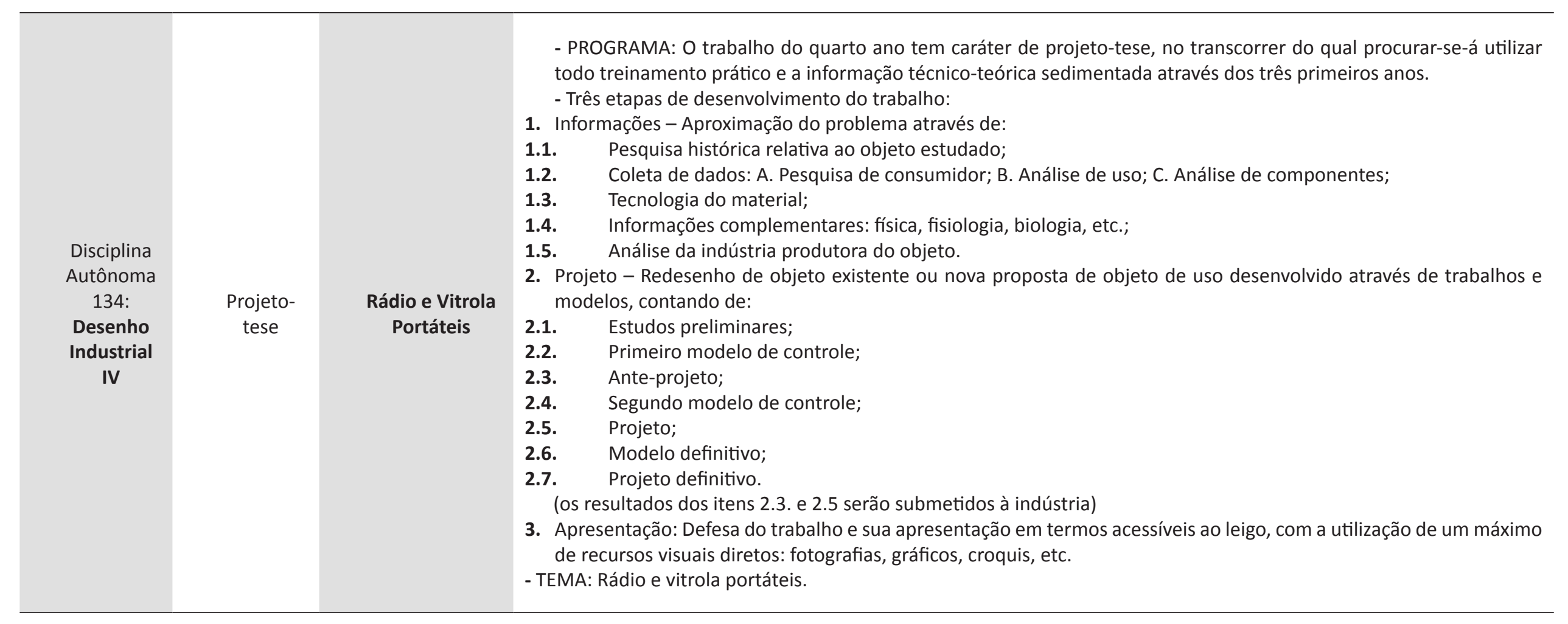




\begin{tabular}{|c|c|c|c|}
\hline disciplina & exercício & tema & descrição: programa, conteúdo teórico, exercícios práticos, professores e instrutores, etc. \\
\hline $\begin{array}{c}\text { Disciplina } \\
\text { Autônoma } \\
\text { 131: } \\
\text { Desenho } \\
\text { Industrial I }\end{array}$ & $\mathrm{n} / \mathrm{p}$ & $n / p$ & $\begin{array}{l}\text { - Os primeiros trabalhos não são condicionados pela relação homem-objeto, mas sim por certas relações geométricas } \\
\text { ou abstratas, conduzindo gradativamente para uma coordenação de determinados parâmetros que intervêm nos } \\
\text { - A programação para o ano de } 1966 \text { obedece ao seguinte esquema: } \\
\text { 1. Construção de curvas geradoras de figuras planas e espaciais; } \\
\text { 2. Decomposição de elementos; } \\
\text { 3. Sistemas de elementos componíveis; } \\
\text { 4. Agrupamento de elementos bidimensionais no plano; } \\
\text { 5. Agrupamento de elementos bidimensionais no espaço; } \\
\text { 6. Agrupamento de elementos tridimensionais; } \\
\text { 7. Projeto de um jogo (brinquedo) de armar ou construir. } \\
\text { - PROGRAMA: Fundamenta-se o curso sobre elementos básicos da comunicação gráfica do desenho industrial e sobre } \\
\text { análises conceituais, gráficas e construtivas das formas }\end{array}$ \\
\hline
\end{tabular}




\begin{tabular}{|c|c|c|}
\hline $\begin{array}{c}\text { Disciplina } \\
\text { Autônoma } \\
\text { 132: } \\
\text { Desenho } \\
\text { Industrial } \\
\text { II }\end{array}$ & $\mathrm{n} / \mathrm{p}$ & 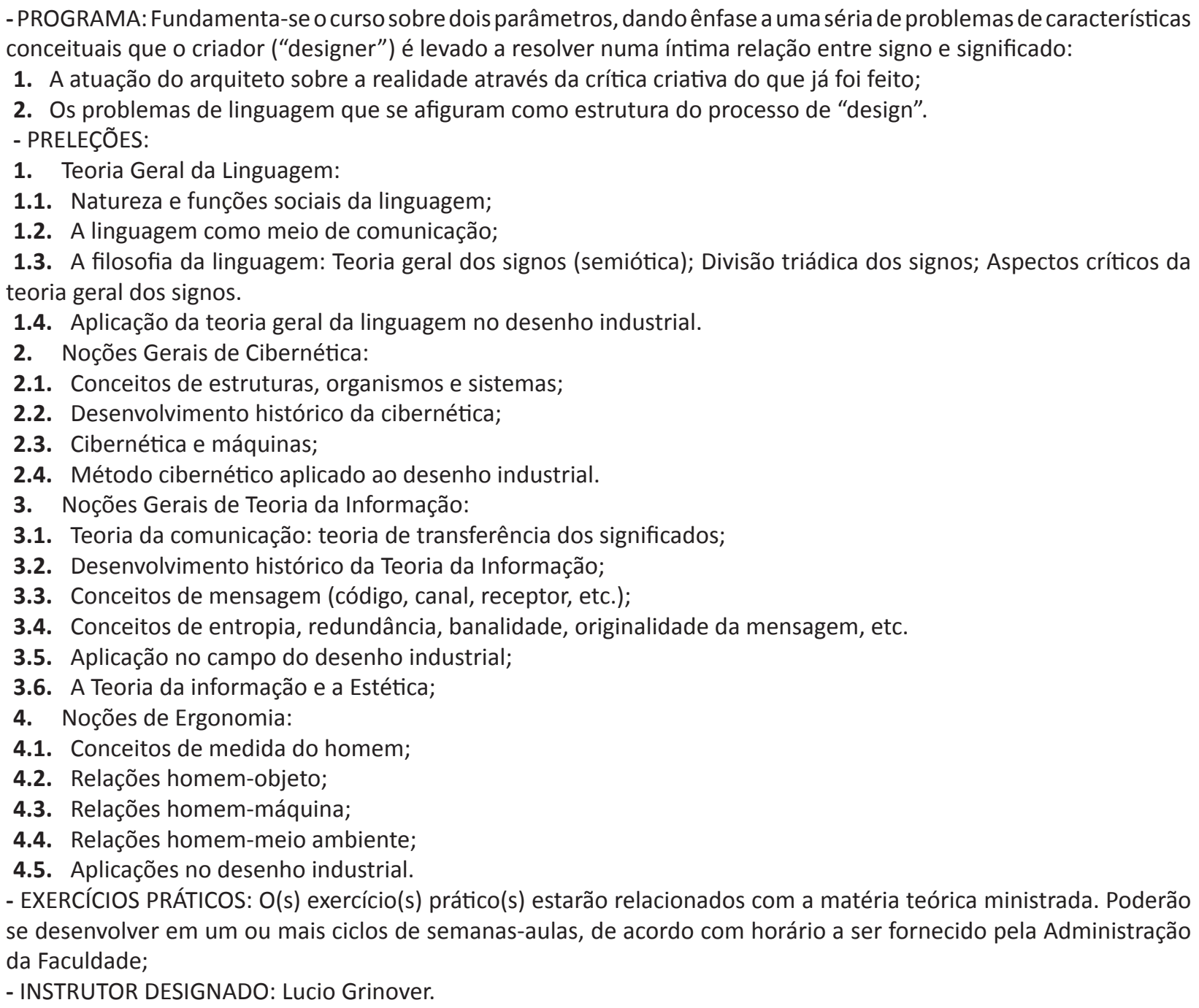 \\
\hline
\end{tabular}




\begin{tabular}{|c|c|c|c|}
\hline $\begin{array}{l}\text { Cátedra 13: } \\
\text { Desenho } \\
\text { Industrial } \\
\text { III }\end{array}$ & único & $\begin{array}{c}\text { Equipamentos } \\
\text { para } \\
\text { Habitação }\end{array}$ & $\begin{array}{l}\text { - Implicações do desenho industrial nos equipamentos da habitação; } \\
\text { - O equipamento da habitação é estudado com o espírito de estabelecer um conceito de linha de produção consoante } \\
\text { com as necessidades do homem; } \\
\text { - EXERCíCIOS PRÁTICOS: Projeto de uma linha de objetos (...), execução de desenhos, modelos e detalhes construtivos; } \\
\text { - TEMA proposto: Estudos das zonas de habitação que compreende as atividades de higiene, cocção e serviços gerais } \\
\text { (estas três partes completam o estudo do uso das diferentes zonas das habitações iniciadas no ano anterior). }\end{array}$ \\
\hline $\begin{array}{l}\text { Disciplina } \\
\text { Autônoma } \\
\text { 134: } \\
\text { Desenho } \\
\text { Industrial } \\
\quad \text { IV }\end{array}$ & $\begin{array}{l}\text { Projeto- } \\
\text { tese }\end{array}$ & $\begin{array}{l}\text { Escolhido no } \\
\text { início do ano } \\
\text { letivo }\end{array}$ & $\begin{array}{l}\text { - INTRODUÇÃO: O trabalho do quarto ano procura colocar o aluno em contato com um problema tanto quanto } \\
\text { possível real, onde a utilização das informações sedimentadas através dos anos anteriores possa sofrer o primeiro } \\
\text { contato mais íntimo com a realidade onde ele, futuramente, vai procurar intervir como criador. Assim, o trabalho é } \\
\text { sempre desenvolvido em colaboração com uma indústria; } \\
\text { - PROGRAMA: O trabalho do 40 ano tem caráter de projeto-tese, no transcorrer do qual procurar-se-á utilizar todo } \\
\text { o treinamento prático e a informação técnico-teórica sedimentada através dos } 3 \text { primeiros anos. Será desenvolvido } \\
\text { em } 3 \text { etapas: Informações, Projeto, Apresentação. } \\
\text { - Observação do programa: Os resultados serão submetidos á apreciação da indústria. } \\
\text { - INSTRUTOR DESIGNADO: Luiz Roberto Carvalho Franco. }\end{array}$ \\
\hline
\end{tabular}




\begin{tabular}{|c|c|c|c|}
\hline disciplina & exercício & tema & descrição: programa, conteúdo teórico, exercícios práticos, professores e instrutores, etc. \\
\hline $\begin{array}{l}\text { Disciplina } \\
\text { Autônoma } \\
\text { 131: } \\
\text { Desenho } \\
\text { Industrial I }\end{array}$ & $\begin{array}{c}\text { T.05 } \\
\text { (maio) }\end{array}$ & $\begin{array}{l}\text { Fosforeira de } \\
\text { mesa }\end{array}$ & $\begin{array}{l}\text { - Projetar uma fosforeira de mesa contendo as seguintes características: } \\
\text { 1. Conter palitos de fósforo do tipo e tamanho existentes no mercado; } \\
\text { 2. Sistema de armazenamento dos palitos em gavetas; } \\
\text { 3. Conter no mínimo três e no máximo vinte gavetas. } \\
\text { - Material de confeç̧ão: cartão. }\end{array}$ \\
\hline $\begin{array}{l}\text { Disciplina } \\
\text { Autônoma } \\
\text { 131: } \\
\text { Desenho } \\
\text { Industrial I }\end{array}$ & $\begin{array}{c}\text { T.05 } \\
\text { (agosto) }\end{array}$ & $\begin{array}{l}\text { Decomposi-ção } \\
\text { e agrupamen- } \\
\text { to espacial } \\
\text { de elementos } \\
\text { tridimensio-nais } \\
\text { Decomposi-ção } \\
\text { e agrupamen- } \\
\text { to espacial } \\
\text { de elementos } \\
\text { tridimensionais }\end{array}$ & $\begin{array}{l}\text { - Decompor um sólido geométrico em elementos, os quais reagrupados, poderão compor novo(s) elemento(s), tais que: } \\
\text { 1. Associado a outro(s) iguais possibilitem a formação de agrupamentos tridimensionais; } \\
\text { 2. Organizem agrupamentos através de encaixes ou justaposição; } \\
\text { 3. Apresentem características, tais que permitam grande flexibilidade nos agrupamentos; } \\
\text { - Definir a quantidade de elementos necessária para o bom funcionamento do sistema; } \\
\text { - Definir um tipo de organização cromática a ser utilizado que tenha por finalidade valorizar o sistema; } \\
\text { - Projetar a embalagem; } \\
\text { - A execução será em cartão duplex revestido de papéis coloridos. }\end{array}$ \\
\hline
\end{tabular}

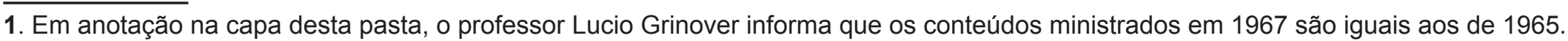




\begin{tabular}{|c|c|c|c|}
\hline $\begin{array}{c}\text { Disciplina } \\
\text { Autônoma } \\
\text { 131: } \\
\text { Desenho } \\
\text { Industrial I }\end{array}$ & $\begin{array}{c}\text { T.07 } \\
\text { (outubro) }\end{array}$ & $\begin{array}{l}\text { Coordenação } \\
\text { Modular }\end{array}$ & $\begin{array}{l}\text { - Projetar e construir um conjunto de caixas. Estas caixas serão produzidas industrialmente com placas de madeira. } \\
\text { Estas placas de madeira deverão constituir um sistema de elementos componíveis. } \\
\text { - Estes elementos deverão: } \\
\text { 1. Ser dimensionados a partir de uma série numérica (a ser definida); } \\
\text { 2. Ser no máximo } 8 \text { e no mínimo 4; } \\
\text { 3. Ser o mais flexível possível, isto é, com o mínimo de elementos obter o maior número de caixas; } \\
\text { - Definir um sistema de fixação entre as placas, levando em consideração a espessura do material; } \\
\text { - Deverão ser apresentados todos os protótipos das caixas. }\end{array}$ \\
\hline $\begin{array}{l}\text { Disciplina } \\
\text { Autônoma } \\
\text { 131: } \\
\text { Desenho } \\
\text { Industrial I } \\
\quad+ \\
\text { Cátedra 12: } \\
\text { Comunica- } \\
\text { ção Visual I }\end{array}$ & $\begin{array}{c}\text { Trabalho } \\
\text { Final }\end{array}$ & $\begin{array}{l}\text { Equipamento de } \\
\text { Recreação Infantil }\end{array}$ & $\begin{array}{l}\text { - Projeto e construção de equipamento de recreação infantil ao ar livre; } \\
\text {-Características gerais: } \\
\text { 1. Faixa etária: de } 6 \text { a } 10 \text { anos; } \\
\text { 2. Versatilidade no agrupamento e na utilização; } \\
\text { 3. Possibilidade de montagem e desmontagem através de operações simples; } \\
\text { 4. Possibilidade de transporte manual. } \\
\text { - Características visuais: } \\
\text { 1. Linguagem visual integrada ao projeto; } \\
\text { 2. Organização de conjunto de sinais visuais a serem vinculados aos elementos do equipamento, estruturando mensagens } \\
\text { visuais. }\end{array}$ \\
\hline $\begin{array}{c}\text { Disciplina } \\
\text { Autônoma } \\
\text { 132: } \\
\text { Desenho } \\
\text { Industrial II }\end{array}$ & Т.01 & Ergonomia & $\begin{array}{l}\text { - Levantamento das funções ergonômicas de um veículo; } \\
\text { Modelos adotados: } \\
\text { 1. Sedan volkswagen; } \\
\text { 2. Perua volkswagen; } \\
\text { 3. Ônibus mercedez-benz (da Faculdade); } \\
\text { - INSTRUTORES: Marlene Picarelli e Manoel Kosciuszko Corrêa. }\end{array}$ \\
\hline
\end{tabular}




\begin{tabular}{|c|c|c|c|}
\hline $\begin{array}{c}\text { Disciplina } \\
\text { Autônoma } \\
\text { 132: } \\
\text { Desenho } \\
\text { Industrial II }\end{array}$ & Т.02 & $\begin{array}{l}\text { Coordenação } \\
\text { Modular }\end{array}$ & $\begin{array}{l}\text { - Projeto de uma família de mesas para produção em série; } \\
\text { - Materiais: madeira compensada e cola; } \\
\text { - Equipamentos: disponíveis na Faculdade; } \\
\text { - INSTRUTORES: Marlene Picarelli e Manoel Kosciuszko Corrêa. }\end{array}$ \\
\hline $\begin{array}{c}\text { Disciplina } \\
\text { Autônoma } \\
\text { 132: } \\
\text { Desenho } \\
\text { Industrial II }\end{array}$ & Т.04 & Trabalho Final & $\begin{array}{l}\text { - Sistema estrutural para exposição itinerante; } \\
\text { - INSTRUTORES: Marlene Picarelli. }\end{array}$ \\
\hline $\begin{array}{l}\text { Cátedra 13: } \\
\text { Desenho } \\
\text { Industrial III }\end{array}$ & $\begin{array}{l}\text { 20 Tema } \\
\text { do Ano }\end{array}$ & $\begin{array}{l}\text { Equipamen-tos } \\
\text { para Supermer- } \\
\text { cado }\end{array}$ & $\begin{array}{l}\text { - Projetar um dos equipamentos de um supermercado, à escolha de cada equipe de alunos; } \\
\text { - A relação destes equipamentos para escolha, compreende desde o caixa de entrada, gôndola para exposição de } \\
\text { produtos, terminais de gôndola, displays e carrinhos para transporte de compras. Exclui-se deste trabalho as partes que } \\
\text { servem à alimentação refrigerada. } \\
\text { - PROFESSOR LIVRE-DOCENTE: Lúcio Grinover; } \\
\text { - INSTRUTOR: Abrahão Sanovicz. }\end{array}$ \\
\hline $\begin{array}{l}\text { Disciplina } \\
\text { Autônoma } \\
\text { 134: } \\
\text { Desenho } \\
\text { Industrial } \\
\text { IV }\end{array}$ & $\begin{array}{l}2 \text { o } \\
\text { Trabalho } \\
1 \text { o Ciclo } \\
\text { (outubro) }\end{array}$ & livre & $\begin{array}{l}\text { - Projeto de um objeto que utilize única ou predominantemente a madeira compensada. A escolha do objeto ficará a } \\
\text { cargo do aluno, dependendo apenas da aprovação dos instrutores. O trabalho constará de desenhos e de modelo. } \\
\text { - Luiz Gastão de Castro Lima e João Carlos Rodolpho Stroeter assinam a ficha de disciplina, mas não constam informações } \\
\text { sobre o cargo que ocupam. }\end{array}$ \\
\hline $\begin{array}{l}\text { Disciplina } \\
\text { Autônoma } \\
\text { 134: } \\
\text { Desenho } \\
\text { Industrial } \\
\text { IV }\end{array}$ & $\begin{array}{l}2 \text { o } \\
\text { Trabalho } \\
2 \text { o Ciclo } \\
\text { (outubro) }\end{array}$ & livre & $\begin{array}{l}\text { - O segundo ciclo de aulas do mês de outubro será dedicado à construção do modelo, em compensado (ou qualquer } \\
\text { outro material que se julgar mais adequado a cada caso particular), em escala a ser decidida pelo aluno; } \\
\text { - Luiz Gastão de Castro Lima e João Carlos Rodolpho Stroeter assinam a ficha de disciplina, mas não constam informações } \\
\text { sobre o cargo que ocupam. }\end{array}$ \\
\hline
\end{tabular}




\begin{tabular}{|c|c|c|c|}
\hline disciplina & exercício & tema & descrição: programa, conteúdo teórico, exercícios práticos, professores e instrutores, etc. \\
\hline $\begin{array}{c}\text { Disciplina } \\
\text { Autônoma } \\
\text { 131: } \\
\text { Desenho } \\
\text { Industrial I }\end{array}$ & T.02 & $\begin{array}{l}\text { Agrupamento } \\
\text { Bidimensional } \\
\text { de Elementos. } \\
\text { Simetria }\end{array}$ & $\begin{array}{l}\text { - Projetar um conjunto de elementos tais que associados entre si, com grande flexibilidade organizem uma estrutura } \\
\text { definida através das seguintes invariantes: } \\
\text { 1. Base da estrutura: quadrado de } 20 \mathrm{~cm} \times 20 \mathrm{~cm} \text {; } \\
\text { 2. Número de elementos: tais que quando agrupados ocupem a base sem deixar vazios; } \\
\text { 3. Forma dos elementos: estrutura a partir de um quadrado (os elementos poderão ser iguais ou diferentes e deverão } \\
\text { ter espessura); } \\
\text { - Projetar a embalagem para conter os elementos; } \\
\text { - Material para a confecção do conjunto de elementos e embalagem: cartão, balsa, cortiça, linóleo ou similares. }\end{array}$ \\
\hline $\begin{array}{c}\text { Disciplina } \\
\text { Autônoma } \\
\text { 131: } \\
\text { Desenho } \\
\text { Industrial I }\end{array}$ & T.02 & $\begin{array}{c}\text { Coordenação } \\
\text { Modular. } \\
\text { Projeto de } \\
\text { um Sistema } \\
\text { Componível }\end{array}$ & $\begin{array}{l}\text { - Projeto de um sistema componível (estante, armários, etc.) destinado ao armazenamento ou sustentação de } \\
\text { objetos e materiais, dentro de um dos seguintes campos (a escolha do aluno): } \\
\text { 1. Habitação; } \\
\text { 2. Comércio; } \\
\text { 3. Educação. } \\
\text { - Material: Madeira maciça e compensado; } \\
\text { - Objetivo: introduzir nos métodos de projeto, teorias normativas e exposição sistemática dos instrumentos matemáticos } \\
\text { próprios da coordenação modular, visando em justo grau de equilíbrio na eficiência das componentes funcionais, } \\
\text { figurativas,tecnológicas e econômicas dos produtos; } \\
\text { - INSTRUTORA: Marlene Picarelli }\end{array}$ \\
\hline $\begin{array}{c}\text { Disciplina } \\
\text { Autônoma } \\
\text { 131: } \\
\text { Desenho } \\
\text { Industrial I }\end{array}$ & T.03 & $\begin{array}{c}\text { Desenho } \\
\text { Técnico }\end{array}$ & $\begin{array}{l}\text { - Execução do desenho Técnico do T.02: Agrupamento Bidimensional de elementos (Disciplina Autônoma 131: } \\
\text { Desenho Industrial I/ 1968); } \\
\text { - Representação do(s) elemento(s) componente(s) do sistema; } \\
\text { - Representação do conjunto. }\end{array}$ \\
\hline
\end{tabular}




\begin{tabular}{|c|c|c|c|}
\hline $\begin{array}{c}\text { Disciplina } \\
\text { Autônoma } \\
\text { 131: } \\
\text { Desenho } \\
\text { Industrial I }\end{array}$ & Т.04 & $\begin{array}{l}\text { Simetria. } \\
\text { Coordenação } \\
\text { Modular }\end{array}$ & $\begin{array}{l}\text { - Projetar e construir uma família de objetos (recipientes) que tenha por função receber ou conter elementos } \\
\text { - Exemplos de famílias de elementos: } \\
\text { 1. Porta sal e pimenta, galhetas e paliteiro; } \\
\text { 2. Porta lápis, porta clips, porta papel para anotações, porta cigarros (?); } \\
\text { 3. Conjunto de vasos grande, médio, pequeno; } \\
\text { 4. Embalagens; } \\
\text { 5. Garrafas para bebidas grande, média, pequena; } \\
\text { 6. Copos; } \\
\text { 7. Latas de mantimentos; } \\
\text { 8. Bandejas; } \\
\text { 9. Serviço de chá e café: bule para leite, bule para café, bule para chá, açucareiro, manteigueira e recipiente para geléia; } \\
\text { 10. Conjunto de potes para casa. }\end{array}$ \\
\hline $\begin{array}{c}\text { Disciplina } \\
\text { Autônoma } \\
\text { 131: } \\
\text { Desenho } \\
\text { Industrial I }\end{array}$ & T.04.B & $\begin{array}{l}\text { Simetria. } \\
\text { Coordenação } \\
\text { Modular }\end{array}$ & $\begin{array}{l}\text { - Projetar e construir com conjunto de recipientes; } \\
\text { - Os elementos componentes do conjunto deverão manter a mesma estrutura formal a apresentar as seguintes } \\
\text { características: } \\
\text { 1. Número de elementos: três ou mais; } \\
\text { 2. Dimensões variáveis de acordo com a sua utilização. } \\
\text { - INSTRUTORES: João Cauduro e Eduardo de Almeida. }\end{array}$ \\
\hline $\begin{array}{c}\text { Disciplina } \\
\text { Autônoma } \\
\text { 132: } \\
\text { Desenho } \\
\text { Industrial II }\end{array}$ & T.01 & $\begin{array}{l}\text { Ergonomia. } \\
\text { Análise } \\
\text { Ergonômica } \\
\text { de um Veículo } \\
\text { Nacional e } \\
\text { Propostas }\end{array}$ & $\begin{array}{l}\text { - Levantamento ergonômico de um dos seguintes sistemas de um veículo: } \\
\text { 1. Sistema de indicação (qualitativos, quantitativos, leitura de verificação, pictóricos, etc.); } \\
\text { 2. Sistema de controle (botões, pedais, alavancas, etc.); } \\
\text { 3. Sistema de relações espaciais (relação espaço físico - usuário); } \\
\text { 4. Sistema de visão (externo, interno, etc.). } \\
\text { - Objetivos: Preparar o aluno para o desenvolvimento das relações homem-objeto que influenciam a criação de } \\
\text { equipamento, que explicam a natureza de estudos de adaptação dos objetos ao homem, que indicam o método } \\
\text { mais conveniente para sua utilização e melhor eficiência. }\end{array}$ \\
\hline
\end{tabular}




\begin{tabular}{|c|c|c|c|}
\hline $\begin{array}{l}\text { Cátedra 13: } \\
\text { Desenho } \\
\text { Industrial } \\
\text { III }\end{array}$ & $\begin{array}{c}10 \\
\text { semestre } \\
\text { (tema A) }\end{array}$ & $\begin{array}{l}\text { Família de } \\
\text { Luminárias }\end{array}$ & $\begin{array}{l}\text { - Projetar uma família (linha) de luminárias; } \\
\text { - Projetar o plug ou plugs, ou canoplas; } \\
\text { 1. Lâmpadas de "x" watts; } \\
\text { 2. Soquetes; } \\
\text { 3. Fios número; } \\
\text { 4. Tomada; } \\
\text { 5. Caixinha de embutir no forro. } \\
\text { - Dados a determinar: } \\
\text { 1. Voltagem; } \\
\text { 2. Área iluminada ou a iluminar; } \\
\text { 3. Superfície iluminante ou luminosa. } \\
\text { - Complexidade funcional: } \\
\text { 1. Elenco das diversas funções (usos) da(s) luminária(s); } \\
\text { 2. Espaço no qual é inserido o produto; } \\
\text { 3. Espaços conflitantes (opcional) com o produto. } \\
\text { - Complexidade estrutural: } \\
\text { 1. Materiais a serem usados; } \\
\text { 2. Cores aplicadas ao produto; } \\
\text { 3. Processos. }\end{array}$ \\
\hline $\begin{array}{l}\text { Cátedra 13: } \\
\text { Desenho } \\
\text { Industrial } \\
\text { III }\end{array}$ & $\begin{array}{c}20 \\
\text { semestre } \\
\text { (tema B) }\end{array}$ & Embalagem & $\begin{array}{l}\text { - Projetar a embalagem do produto resolvido no exercício anterior (Cátedra 13: Desenho Industrial III / } 1968 \text { / } 1 \text { o } \\
\text { semestre / Tema A - Família de Luminárias); } \\
\text { - Projetar a embalagem de uma quantidade " } x \text { " para expedição; } \\
\text { - Projetar a comunicação visual da embalagem; } \\
\text { - Estudar o uso da embalagem de expedição para servir de stand de exposição do produto nos locais de venda } \\
\text { (definir os locais de venda). }\end{array}$ \\
\hline
\end{tabular}




\begin{tabular}{|c|c|c|c|}
\hline $\begin{array}{l}\text { Cátedra 13: } \\
\text { Desenho } \\
\text { Industrial } \\
\text { III }\end{array}$ & $\mathrm{n} / \mathrm{c}$ & $\begin{array}{l}\text { Análise de } \\
\text { Produto } \\
\text { Industrial }\end{array}$ & $\begin{array}{l}\text { - Análise de suportes mecânicos de lentes para correção ótica ou cromática da visão; } \\
\text { - Excluem-se deste enunciado as chamadas lentes de contato; } \\
\text { - Três categorias para a análise: } \\
\text { 1. Ergonomia: Diz respeito às relações entre as dimensões (medidas lineares, superfícies, peso), do objeto e as } \\
\text { dimensões padrão do crânio humano. Dentro desta categoria, aluno deverá investigar tudo que puder sobre estas } \\
\text { relações. Verificar aspectos como apoio do nariz, nas orelhas, a relação possível entre a largura dos óculos e o } \\
\text { comprimento das hastes, a movimentação dos olhos e a variação de seu eixo ótico, etc. } \\
\text { 2. Uso: As relações desta categoria com as anteriores são evidentes. Porém aqui se pesquisa a dinâmica de uma relação } \\
\text { homem-objeto. Devem ser levantados todos os problemas que aparecem no uso deste objeto, ou seja, elementos } \\
\text { como, tirar e por os óculos, limpar as lentes, abaixar a cabeça, guardar no estojo, etc. Levantar também os tipos } \\
\text { existentes (óculos de sol, leitura, etc.). } \\
\text { 3. Tecnologia: Esta categoria investiga os elementos industriais da execução dos óculos. O produto compõe-se de } \\
\text { diversos materiais (plástico, metal, vidro, etc.) - Como é resolvida a integração destes? Por outro lado, certas } \\
\text { operações de corte e ajuste, tanto das lentes como da armação exigem graus diferentes de simplificação que devem } \\
\text { ser lembrados, e assim por diante. }\end{array}$ \\
\hline $\begin{array}{l}\text { Cátedra 13: } \\
\text { Desenho } \\
\text { Industrial } \\
\text { III }\end{array}$ & $\mathrm{n} / \mathrm{c}$ & $\begin{array}{c}\text { Lanterna de } \\
\text { Pequeno } \\
\text { Porte }\end{array}$ & $\begin{array}{l}\text { - Análise e projeto de lanterna de pequeno porte para iluminação de emergência; } \\
\text { - Dados fixos do problema - elementos construtivos: } \\
\text { 1. Duas pilhas tipo lapiseira } 1,5 \mathrm{v} \text {; } \\
\text { 2. Uma lâmpada } 3 \mathrm{v} ; \\
\text { 3. Um soquete; } \\
\text { 4. Um refletor (opcional); } \\
\text { 5. Um interruptor; } \\
\text { 6. Invólucro; } \\
\text { 7. Mola. } \\
\text { - Dados fixos do problema - esquema elétrico; } \\
\text { Fatores determinantes: ergonômicos, tecnológicos, etc. }\end{array}$ \\
\hline
\end{tabular}




\begin{tabular}{|c|c|c|c|}
\hline $\begin{array}{l}\text { Cátedra 13: } \\
\text { Desenho } \\
\text { Industrial } \\
\text { III Unidade } \\
\text { de Ensino } \\
\text { Alternativo }\end{array}$ & $\begin{array}{c}20 \\
\text { semestre }\end{array}$ & $\begin{array}{c}\text { Sinalização } \\
\text { Urbana }\end{array}$ & $\begin{array}{l}\text { - Sinalização do Parque Ibirapuera ou de Nova Igaratá: } \\
\text { 1. O significado sociológico do Parque Ibirapuera no contesto metropolitano; } \\
\text { 2. Análise da "estrutura" do Parque Ibirapuera; } \\
\text { 3. Limites do projeto. } \\
\text { - PROFESSOR LIVRE-DOCENTE: Lucio Grinover. }\end{array}$ \\
\hline $\begin{array}{c}\text { Cátedra 13: } \\
\text { Desenho } \\
\text { Industrial } \\
\text { III } \\
\text { Unidade } \\
\text { de Ensino } \\
\text { Alternativo }\end{array}$ & $\begin{array}{c}20 \\
\text { semestre }\end{array}$ & $\begin{array}{c}\text { Equipamento } \\
\text { Urbano }\end{array}$ & $\begin{array}{l}\text { - Equipamentos urbanos (mobiliário de rua), para produção em série. } \\
\text { 1. Banuns dos itens que podem ser desenvolvidos: } \\
\text { 2. Postes de iluminação (sistema de iluminação); } \\
\text { 3. Cabines telefônicas; } \\
\text { 4. Suportes para placas de ruas; } \\
\text { 5. Suportes para cartazes; } \\
\text { 6. Bancas de jornal; } \\
\text { 7. Jardineira; } \\
\text { 8. Caixa postal; } \\
\text { 9. Cestas de lixo; } \\
\text { 10. Quiosques para frutas, etc. } \\
\text { - INSTRUTORES: Abrahão Sanovicz, João Carlos Rodolpho Stroeter, Ludovico Antonio Martino. }\end{array}$ \\
\hline
\end{tabular}


ano letivo não indicado

\begin{tabular}{|c|c|c|c|}
\hline disciplina & exercício & tema & descrição: programa, conteúdo teórico, exercícios práticos, professores e instrutores, etc. \\
\hline $\mathrm{n} / \mathrm{c}$ & $\begin{array}{c}\text { Exercício } \\
\text { nํ. } 5\end{array}$ & $\begin{array}{c}\text { Painel de } \\
\text { Informações }\end{array}$ & $\begin{array}{l}\text { - Projetar um painel de informações sobre o centro da cidade de São Paulo, para ser colocado em logradouros } \\
\text { públicos; } \\
\text { - O projeto deve constar de: } \\
\text { 1. O mapa do centro da cidade, nas dimensões do mapa fornecido pelo Departamento de Cadastro da Prefeitura } \\
\text { sobre o qual deverão ser assinalados com símbolos, acompanhados de seus nomes próprios os principais pontos } \\
\text { de interesse e utilidade pública, como por exemplo: transportes, cinemas e teatros, hotéis, bancos, restaurantes, } \\
\text { parques, mãos de direção de trânsito, hospitais, escolas, igrejas, etc.; } \\
\text { 2. Uma legenda que facilite a decodificação dos símbolos usados na planta; } \\
\text { 3. Um invólucro para proteger o painel, que permita a fixação nos logradouros públicos; } \\
\text { 4. Iluminação do painel. } \\
\text { - Apresentação: em forma de protótipo. }\end{array}$ \\
\hline
\end{tabular}





\section{BIBLIOGRAFIA}

Livros:

ACAYABA, Marlene Milan. Branco \& Preto: uma história de design brasileiro nos anos 50. São Paulo: Instituto Lina Bo e PM Bardi, 1994.

ANELLI, Renato. Rino Levi. Arquitetura e Cidade. São Paulo: Editora Romano Guerra, 2001.

ARTIGAS, Rosa; LIRA, José Tavares Correia de. Caminhos da Arquitetura. Vilanova Artigas. São Paulo, Cosac Naify, 2004

ADUSP. $O$ Livro Negro da USP: O Controle Ideológico na Universidade. São Paulo: ADUSP, 1979.

AICHER, Otl. El mundo como proyecto. Barcelona: Gustavo Gili, 1994.

ALBUQUERQUE, Roberto Portugal (coordenação). Caderno dos Riscos Originais: Projeto do Edifício da FAU USP na Cidade Universitária. João Batista Vilanova Artigas. São Paulo, FAU USP, 1998.

ARGAN, Giulio Carlo. Arte Moderna. Do Iluminismo aos movimentos contemporâneos. São Paulo: Companhia das Letras, 1993.

ARGAN, Giulio Carlo. Projeto e Destino. São Paulo, Editora Ática, 2000. 334p. (Trad. Marcos Bagno).

ARNHEIM, Rudolf. Arte e Percepção Visual: Uma psicologia da visão criadora. São Paulo: Pioneira, Editora 
da Universidade de São Paulo, 1986.

ARTIGAS, Rosa. Paulo Mendes da Rocha. São Paulo: Editora Cosac \& Naify, 2002.

BARDI, Pietro Maria. Excursão ao Território do Design. São Paulo: Banco Sudameris Brasil S.A., 1986.

BENEVIDES, Maria Victória. O governo Kubitschek. Desenvolvimento econômio e estabilidade política. 3ạ. ed. Rio de Janeiro: Paz e Terra,1979.

BIELSCHOWSKY, Ricardo. Pensamento Econômico Brasileiro. O Ciclo Ideológico do desenvolvimentismo. Rio de Janeiro, Contrapondo, 2000.

BRANDÃO, Gildo Marçal. As duas Almas do Partido Comunista. São Paulo, Editora Hucitec, 1997.

BRUNA, Paulo J. V. Arquitetura, industrialização e desenvolvimento. São Paulo: Editora Perspectiva, 2002.

BRUAND, Yves. Arquitetura Contemporânea no Brasil. São Paulo: Editora Perspectiva, 1991 (2a . Ed.).

CARDOSO, Rafael. Uma introdução à história do design. São Paulo: Editora Edgard Blücher, 2004.

CLARO, Mauro. Unilabor: Desenho Industrial, Arte Moderna e Autogestão Operária. São Paulo: Editora SENAC São Paulo, 2004.

DROSTE, Magdalena. Bauhaus. 1919-1933. Alemanha: Taschen, 2001.

FARO, Clovis \& SILVA, Salomão L. Quadros. A década de 50 e o Programa de Metas. In: GOMES, Ângela de Castro (org.). O Brasil de JK. Rio de Janeiro: Editora da FGV / CPDOC, 1989.

FAUSTO, Boris. História Concisa do Brasil. São Paulo: Imprensa Oficial do Estado de SP / Edusp, 2001.

FAUSTO, Boris. História do Brasil. São Paulo: Edusp, 2008.

FAUSTO, Boris. O pensamento Nacionalista Autoritário (1920 -1949). Rio de Janeiro: Jorge Zahar Editor Ltda., 
2001.

FERRAZ, Marcelo Carvalho (org.). João Filgueiras Lima, Lelé. São Paulo: Instituto Lina Bo e PM Bardi; Editorial Blau, 1997.

FERRAZ, Marcelo Carvalho (org.). Vilanova Artigas. São Paulo: Instituto Lina Bo e PM Bardi; Fundação Vilanova Artigas, 1999.

FERREIRA, Jorge \& DELGADO, Lucília de Almeida Neves (orgs.). O Brasil republicano. 0 tempo da experiência democrática. Rio de Janeiro: Civilização Brasileira, 2003.

FICHER, Sylvia. Os Arquitetos da Poli: Ensino e Profissão em São Paulo. São Paulo, FAPESP, Edusp, 2005.

FRAMPTON, Kenneth. História crítica da Arquitetura Moderna. São Paulo: Martins Fontes, 1997 (trad. CAMARGO, Jefferson Luiz).

FURTADO, Celso. Formação Econômica do Brasil. São Paulo: Companhia das Letras, 2007.

FURTADO, Celso. O Brasil Pós-“Milagre”. Rio de Janeiro: Paz e Terra, 1983.

Grêmio da FAU USP. Anistia na FAU USP: A Reintegração dos Professores Cassados pelo AI-5. São Paulo: FAU USP, 1998.

HOUAISS, Antônio; VILLAR, Mauro deSalles. Minidicionário Houaiss de Língua Portuguesa. Rio de Janeiro: Objetiva, 2009.

LEAL, Joice Joppert. Um olhar sobre o design brasileiro. São Paulo: Objeto Brasil; Instituto Uniemp; Imprensa Oficial do Estado de São Paulo, 2002.

MALDONADO, Tomás. El Diseño Industrial Reconsiderado. México: Gustavo Gili, 1993.

MORAES, Reginaldo; ANTUNES, Ricardo; FERRANTE, Vera B. (orgs). Inteligência Brasileira. São Paulo, Editora Brasiliense, 1986.

MOTTA, Flávio. Desenho e Emancipação. In: Desenho 
Industrial e Comunicação Visual / Exposição. São Paulo: FAUUSP, 1970.

NAPOLITANO, Marcos. Cultura brasileira: utopia e massificação (1950-1980). São Paulo: Contexto, 2001.

NIEMEYER, Lucy. Design no Brasil, Origens e Instalação. Rio de Janeiro: Editora 2AB, 1998.

PEDROSA, Mário. Dos murais de Portinari aos murais de Brasília. São Paulo: Perspectiva, 1981.

PEREIRA, Miguel Alves (coordenação geral). Sobre Arquitetura Brasileira e Ensino na Virada do Século: Depoimentos de Professores Arquitetos da FAU USP. São Paulo: FAU USP, 2008. Volume 01.

PEREIRA, Miguel Alves (coordenação geral). Sobre Arquitetura Brasileira e Ensino na Virada do Século: Depoimentos de Professores Arquitetos da FAU USP. São Paulo: FAU USP, 2008. Volume 02.

PEREIRA, Juliano A. Lina Bo Bardi, Bahia, 1958-1964. Uberlândia: EDUFU, 2008.

PEVSNER, Nikolaus. Os Pioneiros do Desenho Moderno / de Willian Morris a Walter Gropius. São Paulo: Martins Fontes, 1995. (trad. MONTEIRO, João Paulo).

PIÑóN, Helio. Paulo Mendes da Rocha. São Paulo: Romano Guerra Editora, 2002.

SANTOS, Maria Cecília Loschiavo dos. Escola Politécnica (1894-1984). São Paulo: Universidade de São Paulo, 1985.

SANTOS, Maria Cecília Loschiavo dos. Móvel Moderno no Brasil. São Paulo: Studio Nobel; FAPESP; Editora da Universidade de São Paulo, 1995.

SCHWARZ, Roberto. O Pai de Família e Outros Estudos. Rio de Janeiro: Paz e Terra, 1978.

SODRÉ, Nelson Werneck. Introdução à Revolução Brasileira. São Paulo, Livraria Editora Ciências Humanas Ltda., 1978.

SODRÉ, Nelson Werneck. Síntese da História da Cultura 
Brasileira. Rio de Janeiro, Editora Civilização Brasileira SA, 1994.

STOLARSKI, André. Alexandre Wollner e a formação do Design Moderno no Brasil: Depoimentos sobre o design visual brasileiro. São Paulo: Cosac \& Naify, 2005.

SOUZA, Pedro Luiz Pereira de. ESDI: biografia de uma idéia. Rio de Janeiro: EDUERJ, 1996.

TOLEDO, Caio Navarro de. ISEB: fábrica de ideologias. 2ª . ed. São Paulo: Ática,1982.

WISNIK, Guilherme. Lúcio Costa. São Paulo: Cosac Naify, 2001.

WOLLNER, Alexandre. Alexandre Wollner: Design Visual 50 anos. São Paulo, Cosac \& Naify, 2003.

XAVIER, Alberto (org.). Depoimento de uma Geração / Arquitetura Moderna Brasileira. São Paulo: Cosac \& Naify, 2003.

XAVIER, Alberto; LEMOS, Carlos; CORONA, Eduardo. Arquitetura Moderna Paulistana. São Paulo: PINI, 1983.

ZANINI, Walter. História Geral da Arte no Brasil. São Paulo: Instituto Walther Moreira Salles, 1983. (2 volumes)

Teses, Dissertações e Trabalhos Acadêmicos:

ALBUQUERQUE, Roberto Portugal. Uma Escola de Arquitetura - FAU USP: Edifícios e ensino. Dissertação (Mestrado). São Paulo: FAU USP, 2004.

BERNARDI, Cristiane Kröling Pinheiro Borges. Luiz Gastão de Castro Lima: Trajetória e obra de um arquiteto. Dissertação (Mestrado). São Carlos: EESC-USP, 2008.

BUZZAR, Miguel Antônio. João Batista Vilanova Artigas / Elementos para a compreensão de um caminho da Arquitetura Brasileira / 1938-1967. 1996. Dissertação (Mestrado). São Paulo: FAU USP, 1996. 
FARIA, Agnaldo Caldas. A arquitetura eclipsada: notas sobre história e arquitetura a propósito da obra de Gregori Warchavchik, introdutor da arquitetura moderna no Brasil. Dissertação (Mestrado). Campinas: UNICAMP, 1990.

FICHER, Sylvia. Subsídios para um estudo do Conjunto Habitacional Zezinho Magalhães Prado. Pesquisa FAU USP, s/d.

GARCIA, Hernan Carlos W. S. VKhUTEMAS/VKhUTEIN, Bauhaus, Hochschule für Gestaltung Ulm: Experiências Didáticas Comparadas. Dissertação (Mestrado). São Paulo: FAU-USP, 2001.

GRINOVER, Lucio. As Implicações da Ciência e do Pensamento Lógico no Desenho Industrial. Tese (Livre Docência). São Paulo: FAU USP, 1964.

IAFIGLIOLA, Leandro Giamas. 40 anos de Desenho Industrial na FAU-USP. São Paulo: FAU-USP, 2002. (Trabalho Final de Graduação/TFG. Orientadora: SANTOS, Maria Cecília Loschiavo dos).

KOURY, Ana Paula. Arquitetura Construtiva. Proposições para a produção material da arquitetura contemporânea no Brasil. Tese (Doutorado). São Paulo: FAU-USP, 2005.

LEON, Ethel. IAC Instituto de Arte Contemporânea, Escola de Desenho Industrial do MASP (1951-1953): Primeiros Estudos. Dissertação (Mestrado). São Paulo: FAU-USP, 2006.

NOBRE, Ana Luiza de Souza. Fios Cortantes: Projeto e Produto, Arquitetura e Design no rio de Janeiro (19501979). Tese (Doutorado). Rio de Janeiro: PUC-RJ, 2008.

PEREIRA, Juliano Aparecido. A ação cultural de Lina Bo Bardi na Bahia e no Nordeste (1958-1964). Dissertação (mestrado). São Carlos: EESC-USP, 2001.

PICARELLI, Marlene. Desenho Industrial na Edificação: Ensino e Pesquisa. São Paulo: FAPESP, 1983.

SEIXAS, Alexandre Rodrigues. Arquitetura Escolar de Vilanova Artigas e Carlos Cascaldi: 1959-1962. Dissertação (Mestrado). São Carlos: EESC-USP, 2003. 
Periódicos:

ACRÓPOLE. Poltronas e Mesinhas. Móveis de l'Atelier. São Paulo: 1960, № 265.

BARDI, Pietro Maria. O que é decoração? Revista Casa

Vogue. p.40.

BRESSER-PEREIRA, Luiz Carlos. Seis Interpretações sobre o Brasil. Revista Ciências Sociais, 5(3), 1982, pp. 269-306.

BRAVO: 100 objetos essenciais do design mundial. São Paulo: 2008, número especial.

CARAMELO. São Paulo: FAU USP, 1998.

DIAS, Caio Benjamin. A estrutura da Universidade de Brasília. Revista Acrópole, São Paulo, ano XXXI, no. 369/370, p.13-17, jan-fev.1970.

FICHER, Silvia. O Ensino da Construção no Domínio da Arquitetura. São Paulo, Revista Projeto, número 112, 1988, pp. 129-130.

GRINOVER, Lúcio. Definição de Desenho e Desenho Industrial. In: Enciclopédia Abril v.4. São Paulo: Abril, 1972.

GRINOVER, Lúcio. Desenho atende ao mercado em termos de produção. O Dirigente Industrial. (revista) São Paulo, agosto de 1966. Número 12, vol.7.

KATINSKY, Julio Roberto. Onde há vida há sonho. Revista Arc Design, São Paulo, no. 10, p. 48-53, 1999.

RUCHTI, Jacob. Instituto de Arte Contemporânea. Revista Habitat no 3. São Paulo, 1951.

SINOPSES: Memória. São Paulo: FAU USP, 1993. ISSN: 0101-7225.

PEREIRA, Miguel Alves. Ensino de Arte e Arquitetura. Revista Acrópole, São Paulo, ano XXXI, no. 369/370, p.4550, jan-fev.1970.

PRODUTO E LINGUAGEM. São Paulo: Associação Brasileira 
de Desenho Industrial, 1․ trimestre de 1965. Ano 1, número 1.

PRODUTO E LINGUAGEM. São Paulo: Associação Brasileira de Desenho Industrial, 2‥ trimestre de 1965. Ano 1, número 2.

PRODUTO E LINGUAGEM. São Paulo: Associação Brasileira de Desenho Industrial, 1‥ trimestre de 1966. Ano 1, número 3.

Projeto Design. Cinquentenário da FAUUSP. Edição Especial. Revista Projeto Design no. 228, 1999.

SANTOS, Maria Cecília Loschiavo dos. A importância do ensino da história da cultura material na formação do arquiteto. In: Pós - Número especial/Anais do seminário Nacional $O$ estudo da História na formação do Arquiteto. São Paulo: FAUUSP, 1995.

WILHEIM, Jorge. Arquitetura para quê? 0 Dirigente Industrial, São Paulo, p. 76, jul.1966.

\section{Catálogos:}

Escola Livre de Artes Plásticas. São Paulo, abril de 1949. (Folheto de propaganda).

FUNDAÇÃO BIENAL DE SÃO PAULO; FEDERAÇÃO E CENTRO DAS INDÚSTRIAS DO ESTADO DE SÃO PAULO. Departamento de Tecnologia / Núcleo de Desenho Industrial (São Paulo, SP). Desenho Industrial: Exposição Tradição e Ruptura. Catálogo. [São Paulo]. Fundação Bienal de são Paulo; Federação e Centro das Indústrias do Estado de são Paulo, [1984]. 64p. Catálogo de Exposição.

BRAUN DO BRASIL (São Paulo, SP). A Idéia Braun. Catálogo. [São Paulo]. Braun do Brasil, [sem data]. 12p. Catálogo de Produtos.

MUSEU DE ARTE MODERNA (São Paulo, SP). Concreta '56: A raiz da forma. Catálogo. Museu de Arte Moderna, 2006. 311p. Catálogo da Exposição Concreta '56: A raiz da 
forma.

MUSEU DE ARTE MODERNA (São Paulo, SP). Escola Livre de Artes Plásticas. Catálogo. Museu de Arte Moderna, [1949]. 4p. Catálogo de Propaganda dos Cursos.

Relatórios e Monografias:

ALEXANDRE, Carlos Alberto Inácio; ANDRADE, Julio Maia de; PERRONE, Rafael Antônio Cunha. Desenho Industrial. Atividades e trabalhos didáticos. AUP 438 - Desenho Industrial III - 10. Projeto. São Paulo, FAU USP, 1981.

ARTIGAS, Vilanova. Desenho Industrial. São Paulo, FAU USP (Pasta Funcional de Professor), 1962/1963 (mimeo).

ARTIGAS, Vilanova. Proposta para organização da Faculdade de Arquitetura e Urbanismo de Jaú / Prefeitura Municipal de Jaú. São Paulo, FAU USP (Pasta Funcional de Professor), setembro de 1978 (mimeo).

ARTIGAS, Vilanova. Rumos para o Ensino da Arquitetura. São Paulo, FAU USP (Pasta Funcional de Professor), setembro de 1956 (mimeo).

BLACK, Misha. Desenho Industrial: Arte ou Tecnologia. São Paulo, 1963. (Traduzido por Maria Celina Junqueira). 3p. (mimeo).

BONSIEPE, Gui. Desenho Industrial, Tecnologia e Subdesenvolvimento. São Paulo: Departamento de Projeto FAU USP, 1974. 26p. (publicação para uso do Grupo de Disciplinas de Desenho Industrial, FAU USP) (Tradução: Nicolau A. Guida Neto) (mimeo)

BONSIEPE, Gui. Metodologia experimental - Desenho Industrial. Brasília: CNPq, 1984.

BONSIEPE, Gui. Vivissecção do Desenho Industrial. São Paulo, FAU USP, 1972. 19p. (publicação para uso do Grupo de Disciplinas de Desenho Industrial, FAU USP) (mimeo) 
CAMPOS, Cândido Malta Filho; CAUDURO, João Carlos. Seqüência de Desenho Industrial: Desenho Industrial I. São Paulo: Departamento de Projeto - Museum - FAU USP, 1964. 5p. (mimeo).

CAUDURO, João Carlos. Design e ambiente. Apostila do curso de Desenho Industrial. São Paulo: FAUUSP, 1978.

CONSELHO do Museu da FAU USP. Fórum 69 / FAUUSP / Documentos e Conclusões. São Paulo, FAU USP, 1969.

FAU USP. Atelier no 10. Ano. Projeto de Edificações / Desenho Industrial - 1977 / 20. Semestre. Apostila. São Paulo: FAUUSP, 1978.

FAU USP. Atelier Desenho Industrial. Atividades e Trabalhos Didáticos. AUP438 - Desenho Industrial III 10. Projeto. Mar-jun / 1981. São Paulo: FAUUSP, 1982.

FAU USP. Desenho Industrial e Comunicação Visual: Exposição, Debates - 12 a 13 de outubro. São Paulo: FAU USP, 1970. 34p. (coletânea de textos para a exposição de Desenho Industrial e Programação Visual programada pela FAU USP para os meses de outubro-novembro de 1970). (mimeo).

FAU USP. Desenho Industrial 1962. São Paulo: Departamento de Projeto FAU USP, 1963.

FAU USP. Fórum 1969 / Relatório Museu FAU. São Paulo, FAU USP, 1969.

FAU USP. Forum de Debates 1968: Documentos e Relatórios das Comissões e Sub-Comissões. São Paulo, FAU USP, 1968.

FAU USP. I Encontro de Ensino de Projeto Depto. de Projeto. São Paulo: FAUUSP, 1975.

FAU USP. Informações Gerais \& Programas de Graduação. São Paulo: FAUUSP, 2000.

FAU USP. Relatório das Atividades de 1962. São Paulo: FAUUSP, 1963.

GRINOVER, Lucio. As bases filosóficas do metadesign. 
Estudos Ambientais 3. São Paulo: Departamento de Projeto da FAU USP, 1971. P 1-14.

GRINOVER, Lúcio. Problemas de ensino e pesquisa em Desenho Industrial: anotações para uma política de desenvolvimento. São Paulo: FAUUSP, 1982.

GULLAR, Ferreira. As artes na cidade. In: Desenho Industrial e Comunicação Visual/Exposição. São Paulo: FAUUSP, 1970.

INSTITUTO de Arquitetos do Brasil / Departamento de São Paulo. Relatório do Encontro de Especialistas sobre o Ensino de Arquitetura. / Organizado pela UNESCO / Zurich / Suíça / Junho de 1970. São Paulo, IAB, 1971.

INSTITUTO de Arquitetos do Brasil / Departamento de São Paulo. Resumo da Palestra sobre o encontro de Zurich proferida pelo professor João Batista Vilanova Artigas no IAB-SP. São Paulo, IAB, 1971.

KATINSKY, Julio Roberto. Apontamentos sobre Arte e Indústria. São Paulo: Departamento de História, FAU USP, 1963. 64p.

KATINSKY, Júlio (colab.). Contribuição para o Ensino de Arquitetura e Urbanismo. Brasília: MEC-INEP, 1999.

MILLAN, Carlos Barjas (relator). O Ateliê na formação do arquiteto / 1962 / Relatório. São Paulo, FAU USP, 1962.

MOHOLY-NAGY, Làzlo. As possibilidades do Desenho Industrial. São Paulo, sem data. 9p. (mimeo).

O Desenho Industrial no Brasil: Ensino e Mercado de Trabalho. Rio de Janeiro: Instituto Latino Americano de Relações Internacionais / ILARI e Movimento Universitário de Desenvolvimento Econômico e Social / MUDES, 1970. $104 p$.

ONCK, Andries Van. Metadesign. São Paulo: PósGraduação FAU USP, 1965 (Traduzido por Lucio Grinover de Edilízia Moderna, número 85). 16p. (mimeo).

PICARELLI, Marlene (organização e coordenação). 
Desenho Industrial na Edificação: Ensino e Pesquisa. São Paulo: Grupo de Disciplinas de Desenho Industrial, Departamento de Projeto, FAU USP; FAPESP, 1983. 127P.

PICARELLI, Marlene. Introdução a Teoria dos Grupos, Introdução a Simetria, Introdução a Teoria Combinatória. São Paulo: FAU USP, 1966. 18p. (apontamentos de aula) (mimeo)

REIS FILHO, Nestor Goulart; BICUDO, Vicente de Paula Borges. Fórum da Faculdade de Arquitetura e Urbanismo a realizar-se no período de 12 a 14 de novembro de 1963. São Paulo, FAU USP, 1963 (mimeo).

SANOVICZ, Abrahão; KATINSKY, Julio Roberto. Desenho Industrial / Programação Visual. São Paulo, 1976 (Proposta para organização das disciplinas de Desenho Industrial e Programação Visual para o Instituto de Arquitetura e Urbanismo da Universidade de Brasília). 45 p.

SANOVICZ, Abrahão; KATINSKY, Julio Roberto. Desenho Industrial e Programação Visual para Escolas de Arquitetura. São Paulo: Associação Brasileira de Escolas de Arquitetura / ABEA, 1977.48p.

Vários Autores. Fórum de Debates 1968 / Documentos e Relatórios das Comissões e Subcomissões. São Paulo, FAU USP, 1968.

Vários Autores. O histórico Brasileiro e a Faculdade de Arquitetura e Urbanismo da Universidade de São Paulo. São Paulo, FAU USP, data: n/c. 